\title{
SLAWOMR ZAPLATA
}

\section{WPLYW WEWNĘTRZNYCH CZYNNNKÓW}

NA SUKCES PROJAKOŚCIOWEGO

ZARZADZANA W ORGANZACII

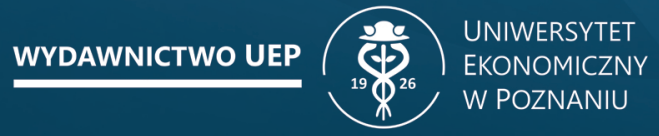


SLAWOMR ZAPLATA

WPLYW WEWNĘTRZNYCH CZYNNIKÓW

NA SUKCES PROJAKOŚCIOWEGO

ZARZADZANIA W ORGANIZACJI

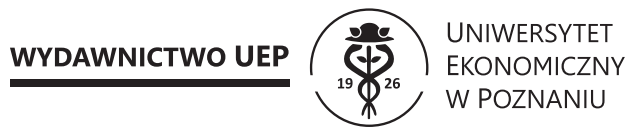

Poznań 2018 
KOMITET REDAKCYJNY

Szymon Cyfert, Elżbieta Gołata (przewodniczaca), Jacek Lisowski, Ewa Małuszyńska, Jerzy Schroeder (sekretarz), Krzysztof Walczak, Ryszard Zieliński

\section{RECENZENCI}

Piotr Jedynak, Krystyna Lisiecka

PROJEKT OKŁADKI

Boobry Group

Marta Brzóstowicz

REDAKCJA I KOREKTA

Anna Grześ

\section{ISBN 978-83-7417-960-7 \\ e-ISBN 978-83-66199-40-8 \\ https://doi.org/10.18559/978-83-66199-40-8}

(C) Copyright by Uniwersytet Ekonomiczny w Poznaniu

Poznań 2018

\section{(c) $(1) \Theta \Theta$}

Ta książka jest udostępniana na licencji Creative Commons - Uznanie autorstwa-Użycie niekomercyjne-Bez utworów zależnych 4.0 Międzynarodowe

WYDAWNICTWO UNIWERSYTETU EKONOMICZNEGO W POZNANIU ul. Powstańców Wielkopolskich 16, 61-895 Poznań

tel. 618543154,618543155

www.wydawnictwo-ue.pl, e-mail: wydawnictwo@ue.poznan.pl adres do korespondencji: al. Niepodległości 10, 61-875 Poznań

Skład: Wydawnictwo eMPi ${ }^{2}$

Druk: Zakład Graficzny Uniwersytetu Ekonomicznego w Poznaniu

ul. Towarowa 53, 61-896 Poznań, tel. 6185438 06, 618543803 


\section{SPIS TREŚCI}

Wstęp

\section{Rozdział I}

Projakościowe zarządzanie w organizacji ............................................................. 13

1. Aspekty zarządzania jakością .......................................................................... 13

2. Systemowe zarządzanie jakością ...................................................................... 26

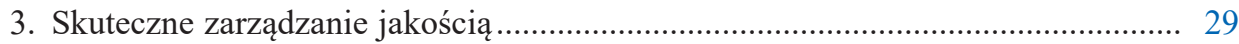

4. Zarządzanie ryzykiem jakości ........................................................................ 37

\section{Rozdział II}

Organizacyjne elementy skutecznego zarządzania jakością ................................... 45

1. Wewnętrzne czynniki sukcesu zarządzania jakością........................................... 47

1.1. Stan dotychczasowych badań na świecie.................................................... 51

1.2. Problematyka badań w Polsce.................................................................... 60

2. Rezultaty projakościowego zarządzania w organizacji ...................................... 67

3. Aspekt ryzyka w osiąganiu celów dotyczących jakości ...................................... 74

Rozdział III

Metodyka badań empirycznych...................................................................... 85

1. Cel i zakres badań..................................................................................... 85

2. Charakterystyka procesu badawczego .............................................................. 87

3. Dobór i charakterystyka próby badawczej ....................................................... 90

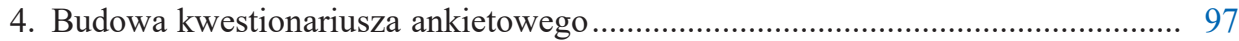

5. Przetwarzanie i analiza danych.................................................................... 98

\section{Rozdział IV}

Ocena ważności wewnętrznych czynników projakościowego zarządzania w organizacji.

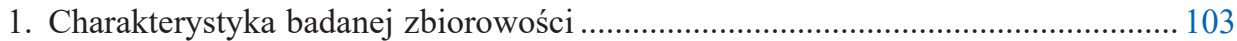

2. Zarządzanie jakością $\mathrm{w}$ badanych organizacjach ................................................... 110

2.1. Ważność głównych wewnętrznych czynników zarządzania jakością .............. 110

2.2. Ocena rezultatów zarządzania jakością.......................................................... 120

2.3. Ważność elementów konstytuujących główne wewnętrzne czynniki zarządzania jakością w organizacji 
2.4. Współzmienność pomiędzy głównymi wewnętrznymi czynnikami oraz rezultatami zarządzania jakością.

3. Eksploracyjna analiza czynnikowa aspektów zarządzania jakością ....................... 153

3.1. Identyfikacja wewnętrznych czynników zarządzania jakością........................ 157

3.2. Grupowanie rezultatów projakościowego zarządzania w organizacji .............. 173

3.3. Oddziaływanie wewnętrznych czynników na rezultaty zarządzania jakością 179

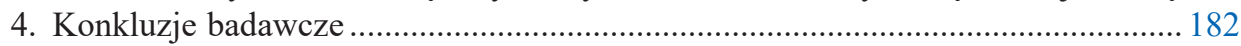

\section{Rozdział V}

Kluczowe zagadnienia w osiąganiu sukcesu w zarządzaniu jakością........................ 187

1. Analiza skupień w zarządzaniu jakością ............................................................. 187

2. Optymalizacja zarządzania jakością w organizacji ................................................ 195

2.1. Krytyczne wewnętrzne czynniki zarządzania jakością.................................203

2.2. Priorytetowe elementy konstytuujące wewnętrzne czynniki zarządzania

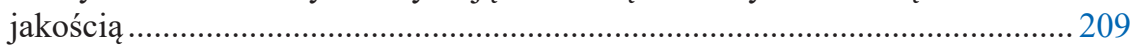

2.3. Newralgiczne relacje między wewnętrznymi czynnikami i rezultatami zarządzania jakością ............................................................................... 213

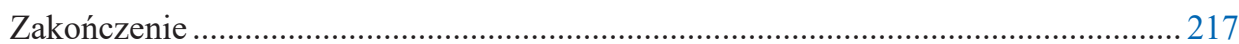

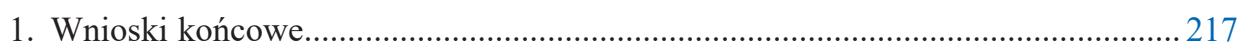

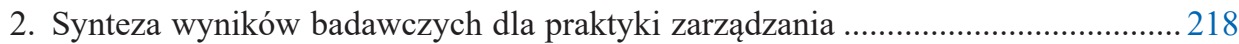

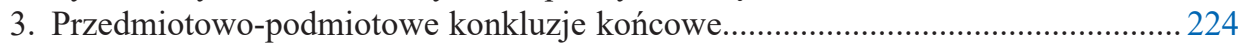

4. Ograniczenia i kierunki przyszłych badań ....................................................... 230

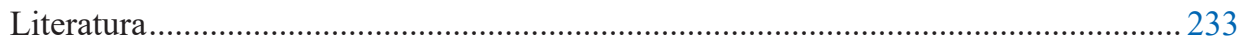

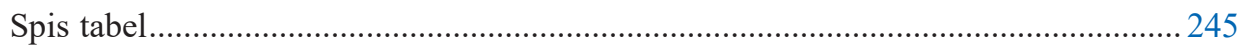

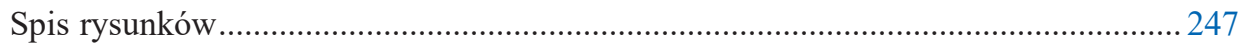

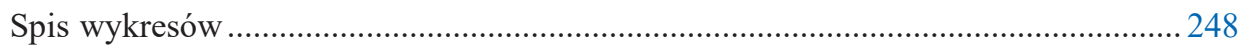




\section{WSTĘP}

Jakość jest przymiotem (właściwością, atrybutem) otaczającego nas świata, stanowiąc kryterium wyboru $\mathrm{w}$ podejmowaniu różnorodnych decyzji. Z perspektywy organizacji oferujących produkty zapewnienie powtarzalnej jakości (utrzymania za każdym razem właściwości na zaplanowanym poziomie) stanowi podstawę funkcjonowania na rynku. Wszystko, co może być oferowane na rynku dla zaspokojenia pragnienia lub potrzeby, jest produktem, w tym: dobrem fizycznym (towarem), usługą, doznaniem, wydarzeniem, osobą, miejscem, nieruchomością, organizacją, informacją i ideą [Kotler i Keller 2012, s. 349]. Działania organizacyjne skoncentrowane wokół różnorodnych techniczno-organizacyjnych aspektów jakości mieszczą się w ramach koncepcji zarządzania jakością. Przez wiele lat podejście do zarządzania jakością ewoluowało, lecz zawsze było ukierunkowane na spełnianie wymagań i oczekiwań klientów. Jakość to znaczący czynnik sukcesu rynkowego każdej organizacji [Jakubiec 2013, s. 36]. Wysoka jakość oferowanych produktów jest uważana za jeden z podstawowych elementów wzrostu konkurencyjności przedsiębiorstw [Zimon i Sikora 2012, s. 21]. Zmieniające się rynkowe warunki gospodarowania wymuszają proces ciągłego dostosowywania wewnętrznych działań w organizacji w imię osiągania zaplanowanych celów. To powoduje, że organizacje, przy uwzględnianiu wpływów otoczenia, poszukują informacji o wewnętrznych czynnikach, których kształtowanie poprzez własne decyzje wpływa na efekty projakościowego zarządzania $\mathrm{w}$ organizacji. $\mathrm{Z}$ uwagi na zmieniające się okoliczności rynkowe jest to proces ciągły, a identyfikacja wewnętrznych czynników sukcesu zarządzania jakością jest tematem aktualnym zarówno wśród środowisk naukowych, jak i w różnorodnych organizacjach, tym bardziej że sukces działań organizacyjnych może być różnorodnie, indywidualnie postrzegany.

Pojęciu sukcesu, podobnie jak pojęciu jakości, z natury rzeczy powszechnie nadawane jest pozytywne znaczenie [Niedzielski 2016, s. 285]. Aczkolwiek uniknięcie porażki również może być traktowane jako sukces, podobnie jak bylejakość, a nie tylko doskonałość, jest przejawem jakości, zatem postrzeganie sukcesu ma charakter subiektywny i sytuacyjny [Niedzielski 2016, s. 285]. Kategorie „sukces” i „porażka” są bardzo często wykorzystywane 
w języku potocznym dla podkreślenia pozytywnych lub negatywnych skutków działań człowieka, nie są to jednak kategorie precyzyjne i często nabierają różnych odcieni w zależności od wykorzystywanego kontekstu [Garbarski 2016, s. 57].

Projakościowe zarządzanie jest realizowane w każdej organizacji, aczkolwiek w różny sposób - intuicyjny lub systemowy. Intuicja menedżerów stanowi ogólny klimat dla podejmowania decyzji oraz uwzględniania priorytetów i zagrożeń w prowadzonej działalności gospodarczej. Jednak aby osiągać cele organizacyjne, działania nie mogą wynikać jedynie z intuicji decydentów, lecz powinny być podejmowane w sposób zorganizowany, systemowy. Jednym ze sposobów systemowego zarządzania jakością jest spełnienie adekwatnych wymagań normatywnych. Implementacja znormalizowanego systemu zarządzania jakością jest działaniem dobrowolnym i z różnych przyczyn (nie)podejmowanym w organizacjach. Dlatego istotne jest posiadanie informacji o wewnętrznych czynnikach sukcesu projakościowego zarządzania w organizacji, niezależnie od podstaw systemowego podejścia. Organizacje posiadające informacje o zbiorze takich czynników oraz zależnościach występujących pomiędzy nimi i ich wpływie na efekty organizacji jako całości mają możliwość kształtowania tych elementów poprzez wewnętrzne decyzje pracowników na rzecz sukcesu zarządzania jakością w organizacji.

Powyższe zagadnienia znajdują się w kręgu zainteresowań naukowych autora i wskazują na obszar tematyczny niniejszej monografii. Obszar badawczy dotyczy ogólnie zarząazzania jakością w organizacji (nazywanego również projakościowym zarządzaniem $\mathrm{w}$ organizacji) i został skoncentrowany na czynnikach wewnętrznych, ich ważności i oddziaływaniu na rezultaty zarządzania jakością, które parametryzują sukces podejmowanych działań organizacyjnych w tym obszarze zarządzania.

Analiza literatury, obserwacje rynkowe oraz doświadczenia własne autora wpłynęły na zdefiniowanie następujących przesłanek badawczych:

1. Globalizacja i zmieniające się okoliczności gospodarowania sprawiają, że konkurencja pomiędzy organizacjami sprowadza się do minimalnych techniczno-organizacyjnych wyróżników jakościowych (wyrobów, procesów organizacyjnych), mających wpływ na pozyskanie i utrzymanie klientów. Organizacje chcące się wyróżnić na rynku uwzględniają, w ramach projakościowego zarządzania $\mathrm{w}$ organizacji, aspekty ryzyka w celu minimalizacji zagrożeń i wykorzystywania szans.

2. Tematyka zarządzania jakością $\mathrm{w}$ organizacji jest cały czas aktualna $\mathrm{z}$ uwagi na podejmowane $\mathrm{w}$ organizacjach działania, które są ukierunkowane na jakość końcowych produktów (wyrobów i usług). Zmieniające się wymagania i oczekiwania klientów co do jakości produktów oraz „wachlarza” dostępnego asortymentu na rynku wysoko pozycjonują, w przekonaniu autora, 
zagadnienia zarządzania jakością jako priorytet w działaniu każdej organizacji. Poszukiwanie wewnątrzorganizacyjnych czynników oraz relacji pomiędzy nimi i siły ich wpływu na rezultaty zarządzania jakością będzie zawsze aktualne i ekonomicznie uzasadnione.

Istnieją różnorodne opracowania teoretyczne i empiryczne w obszarze systemowego zarządzania jakością. Brak jest jednak empirycznych badań ukazujących wewnętrzne czynniki wpływające na sukces projakościowego zarządzania w organizacji przy ukazaniu zależności pomiędzy aspektami jakości i ryzyka. Dlatego też dotychczasowy brak publikacji zestawiających wyniki badań z obszaru wewnętrznych czynników zarządzania jakością z elementami uwzględniającymi ryzyko stanowi lukę badawczą wartą, w przekonaniu autora, przeanalizowania oraz uzupełnienia wynikami badań empirycznych. W literaturze przedmiotu wskazywane jest łączenie zagadnień zarządzania jakością z ryzykiem ich realizacji. Jednak brak jest systemowego powiązania tych elementów w zbiór wewnętrznych działań organizacyjnych ze wskazaniem ważności czynników wewnętrznych zarządzania jakością uwzględniających ryzyko. Luka badawcza dotyczy wzbogacenia wewnętrznych czynników projakościowego zarządzania $\mathrm{w}$ organizacji poprzez uwzględnienie elementów składowych poszczególnych czynników w aspekcie ryzyka. Dlatego analizy i badania czynników wewnętrznych zarządzania jakością wzbogacone o ryzyko stanowią, zdaniem autora, wypełnienie luki badawczej istniejącej w obszarze naukowym. W dzisiejszych czasach szanse na sukces mają jedynie te przedsiębiorstwa, które potrafią w pełni zaspokoić potrzeby nabywców. Zatem muszą być one najlepsze przynajmniej pod jakimś względem, by pozyskać klientów. Szanse na sukces daje skoncentrowanie się na kluczowych czynnikach sukcesu i osiągnięcie perfekcji w określonej dziedzinie [Nieżurawski, Duarte i Nieżurawska 2016, s. 240]. Wybór wskazanej tematyki badawczej i przeprowadzenie tematycznych analiz oraz empirycznych badań z obszaru działań zarządzania jakością, które są podejmowane w każdej organizacji, pozwoli na uzupełnienie wiedzy w zakresie wewnętrznych czynników sukcesu projakościowego zarządzania w organizacji. Wiedza o ważności wewnętrznych czynników wpływających na sukces zarządzania jakością, w zestawieniu działań w aspekcie jakości podejmowanych z uwzględnieniem aspektu ryzyka, pozwoli organizacjom na podejmowanie adekwatnych decyzji, ukierunkowanych na osiąganie sukcesu projakościowego zarządzania $\mathrm{w}$ organizacji.

W związku z powyższym problem badawczy został zdefiniowany w formie pytania: Jakimi wewnętrznymi czynnikami można wpływać na sukces projakościowego zarządzania $\mathrm{w}$ organizacji?

Analiza literatury z zakresu zarządzania jakością w ukierunkowaniu na czynniki i rezultaty tego obszaru zarządzania w organizacji stanowiła podstawę dla 
podjętych prac badawczych. Jako zagadnienia kluczowe dla całości opracowania można wskazać: jakość, zarządzanie jakością, wewnętrzne czynniki (składowe, elementy, elementy konstytuujące ${ }^{1}$ zarządzania jakością, sukces zarządzania jakością, wpływ zarządzania jakością na rezultaty organizacji. Również skuteczność zarządzania jakością oraz podejście oparte na ryzyku w działaniach z obszaru zarządzania jakością stanowią zakres problematyki rozważanej w niniejszym opracowaniu. Powyższe kwestie zostały naświetlone przez autora w pierwszym rozdziale monografii jako ukazanie obszaru badawczego i wprowadzenie do dalszych analiz i badań empirycznych.

Badania empiryczne zostały przeprowadzone $\mathrm{w}$ grupie autoryzowanych salonów sprzedaży i serwisu samochodów osobowych w Polsce z perspektywy osób zarządzających w poszczególnych lokalizacjach bądź bezpośrednio nadzorujących zagadnienia zarządzania jakością. Dobór takiego zakresu podmiotowego opracowania, a jednocześnie próby badawczej, wynika z przyjęcia przez autora założenia o uregulowanym stopniu zaawansowania działań z zakresu zarządzania jakością $\mathrm{w}$ tejże grupie organizacji. Jest to efektem autoryzacji przyznawanej poszczególnym dealerom przez importerów i producentów samochodów danej marki. Tym samym dane jednostki, wytypowane do badania, są zobligowane do spełnienia wymagań autoryzacyjnych, które wkomponowują się w zarządzanie jakością niezależnie od funkcjonowania znormalizowanego systemu zarządzania jakością. Analiza tych zagadnień była realizowana przez autora wielopłaszczyznowo, przez wiele lat:

- od strony teoretycznej (poprzez analizę literatury, co zaowocowało na przykład współautorstwem monografii [Zapłata i Kaźmierczak 2011] dotyczącej m.in. ryzyka i ciągłości biznesu w aspekcie zarządzania jakością, wydanej w renomowanym wydawnictwie);

- na płaszczyźnie szkoleniowej (poprzez udział w charakterze uczestnika w szkoleniach największych audytorów znormalizowanych systemów zarządzania w jednostkach certyfikujących systemy zarządzania oraz prowadzenie szkoleń jako wykładowca w różnych organizacjach gospodarczych);

- z perspektywy dydaktycznej (prowadzenie wykładów, ćwiczeń i seminariów na Uniwersytecie Ekonomicznym w Poznaniu w ramach m.in. przedmiotów: zarządzanie jakością, zarządzanie jakością i bezpieczeństwem, ekonomiczne aspekty jakości, zarządzanie projektami, zarządzanie sytuacjami kryzysowymi, systemowe zarządzanie ciągłością działania oraz jako opiekun grup studenckich w ramach projektów badawczych Koła Naukowego QUALITAS);

- w ujęciu normalizacyjnym (praca jako członek Komitetu Technicznego nr 6 ds. Systemów Zarządzania przy Polskim Komitecie Normalizacyjnym,

\footnotetext{
${ }^{1}$ Konstytuować - tworzyć lub kształtować coś [Dubisz 2008].
} 
w szczególności w zespole roboczym przy tworzeniu polskich wersji dokumentów normalizacyjnych PN-ISO 31000 oraz PN-ISO Guide 73);

- w sferze badawczej (poprzez realizację grantu własnego (finansowanego przez Narodowe Centrum Nauki) dotyczącego systemowego zarządzania ciągłością działania w polskich organizacjach oraz udział w sześciomiesięcznym stażu naukowo-badawczym (finansowanym przez Poznański Akademicki Inkubator Przedsiębiorczości) ukierunkowanym na wdrożenie znormalizowanego systemu zarządzania ciągłością działania);

- w wymiarze praktycznym (jako audytor procesów biznesowych w sieciach sprzedaży i serwisu samochodów, koordynator testów tajemniczego klienta w branży motoryzacyjnej, współtwórca portali do wspomagania zarządzania w salonach sprzedaży i serwisu samochodów oraz doradca i konsultant w licznych projektach wdrażania i utrzymania znormalizowanych systemów zarządzania w jednostkach z różnych branż).

Dla zdefiniowanego problemu badawczego i zakresów pracy sformułowane zostały cele. Głównym celem pracy była identyfikacja i ocena ważności wewnętrznych czynników oraz ich oddziaływania na sukces projakościowego zarządzania w organizacji. Dla tak zdefiniowanego głównego celu pracy zostały określone, na trzech płaszczyznach, cele szczegółowe:

I. Na płaszczyźnie teoriopoznawczej:

1. Zidentyfikowanie głównych wewnętrznych czynników zarządzania jakością po szczegółowej analizie literatury przedmiotu.

2. Zidentyfikowanie elementów konstytuujących główne wewnętrzne czynniki projakościowego zarządzania $\mathrm{w}$ organizacji w aspekcie jakości.

3. Określenie obszarów wpływu zarządzania jakością na sukces w organizacji poprzez identyfikację grup rezultatów projakościowego zarządzania w organizacji.

4. Zidentyfikowanie elementów konstytuujących główne wewnętrzne czynniki zarządzania jakością $\mathrm{w}$ organizacji w aspekcie ryzyka.

II. W obszarze empirycznym można wskazać na cele, które zostały zrealizowane w ramach analiz wyników badania ankietowego:

1. Ocena ważności elementów konstytuujących poszczególne wewnętrzne czynniki projakościowego zarządzania w organizacji oraz relacji pomiędzy tymi elementami.

2. Ocena ważności wewnętrznych czynników zarządzania jakością w organizacji oraz zależności zachodzących pomiędzy nimi.

3. Ocena ważności oraz hierarchizacja rezultatów projakościowego zarządzania $\mathrm{w}$ organizacji.

4. Identyfikacja relacji i ocena oddziaływania pomiędzy wewnętrznymi czynnikami a rezultatami projakościowego zarządzania w organizacji. 
III. Cele utylitarne są związane z wykorzystaniem wyników uzyskanych podczas realizacji pracy:

1. Dostarczenie decydentom z autoryzowanych salonów sprzedaży i serwisu samochodów osobowych w Polsce informacji o ważności wewnętrznych czynników i ich oddziaływaniu na rezultaty projakościowego zarządzania w organizacji. Informacje te mogą stanowić podstawę podejmowania decyzji biznesowych.

2. Z uwagi na charakter projakościowego zarządzania, jako działań mających miejsce w każdej organizacji, dostarczenie różnym organizacjom zorientowanym na klienta informacji o hierarchizacji wewnętrznych czynników zarządzania jakością i relacjach pomiędzy nimi oraz wpływie na osiągane wyniki (ich ważności).

3. Informacje pozyskane w wyniku realizacji teoretycznych analiz i empirycznych badań mogą być przydatne organizacjom doradczo-szkoleniowym, środowisku akademickiemu i innym zainteresowanym stronom w analizowaniu działań ukierunkowanych na sukces zarządzania jakością.

Realizacja celów empirycznych wymagała weryfikacji hipotez badawczych.

Pierwsza hipoteza badawcza (H1) brzmi: Zaangażowanie kierownictwa i pracowników $w$ jakość oraz orientacja na klientów stanowiq najważniejsze wewnętrzne czynniki sukcesu projakościowego zarządzania w organizacji.

Druga hipoteza badawcza (H2) zawiera przypuszczenie, że: Elementy konstytuujące wewnętrzne czynniki zarządzania jakościa $w$ aspekcie ryzyka maja mniejsze znaczenie $w$ oddziatywaniu na sukces zarządzania jakościa niż elementy $w$ aspekcie jakości.

Trzecia hipoteza badawcza (H3) brzmi: Wewnętrzne czynniki zarządzania jakościa w największym stopniu wpływaja na niefinansowe mierniki sukcesu projakościowego zarzadzania w organizacji.

W celu zweryfikowania postawionych hipotez badawczych i realizacji celów pracy przeprowadzone zostały badania empiryczne. Badanie właściwe przeprowadzono metodą pośrednich badań ankietowych. Dane empiryczne zostały zgromadzone przy użyciu kwestionariusza ankiety internetowej. Badanie ankietowe przeprowadzono wśród reprezentantów autoryzowanych salonów sprzedaży i serwisu samochodów osobowych w Polsce. W ramach procedury badawczej skorzystano m.in. z następujących metod badawczych: badania źródeł wtórnych, obserwacji oraz metod statystycznych (eksploracyjna analiza czynnikowa, korelacja, analiza skupień).

Praca ma charakter teoretyczno-empiryczny i składa się z pięciu rozdziałów. Pierwsze dwa rozdziały monografii mają charakter teoretyczno-poznawczy. W rozdziale trzecim przedstawiono metodykę badań oraz charakterystykę próby badawczej. Rozdział czwarty to prezentacja oraz interpretacja wyników badania 
empirycznego. Rozdział ostatni zawiera syntetyczne podsumowanie wyników i weryfikacji hipotez badawczych.

Pierwszy rozdział przedstawia problematykę projakościowego zarządzania w organizacji oraz ogólnych zagadnień związanych z ryzykiem jakości. Teoretyczna analiza obszaru badawczego została skoncentrowana na aspektach rynkowych i ewolucyjnych w systemowym zarządzaniu jakością. Ważną kwestię stanowiło odróżnienie czynników jakości, jako atrybutów związanych z produktami, od wewnętrznych czynników zarządzania jakością, jako elementów działań organizacyjnych kształtujących ostateczne wyniki podejmowanych aktywności. Problematyka skutecznego zarządzania jakością stanowiła dalszą treść w tym rozdziale, gdzie ukazane zostały działania od planowania do oceny skuteczności wraz z dylematami dotyczącymi wpływu zarządzania jakością na rezultaty organizacji. W ostatnim punkcie pierwszego rozdziału przedstawione zostały wyniki literaturowych analiz aspektu ryzyka uwzględnianego w projakościowym zarządzaniu w organizacji. Rozdział pierwszy został zakończony przedstawieniem wniosków z analiz obszaru badawczego.

Obszar badawczy niniejszej monografii został skoncentrowany na wewnętrznych czynnikach wpływających na sukces projakościowego zarządzania w organizacji. Czynniki wewnętrzne zostały przedstawione w drugim rozdziale monografii, co stanowi wynik przeprowadzonej literaturowej analizy obszaru badawczego. W rozdziale zidentyfikowano zbiór głównych wewnętrznych czynników zarządzania jakością wpływających na różne aspekty funkcjonowania tego obszaru zarządzania wraz z elementami składowymi. Wyniki te uzyskano $\mathrm{w}$ efekcie analizy literatury anglojęzycznej oraz publikacji polskojęzycznych. Następnie została poruszona problematyka sukcesu projakościowego zarządzania $\mathrm{w}$ organizacji z perspektywy wpływu działań z tego obszaru na funkcjonowanie i wyniki uzyskiwanie w organizacji. W części rozdziału drugiego zaprezentowane zostało podejście oparte na ryzyku jako koncept minimalizujący zagrożenia i maksymalizujący wykorzystywanie szans w zarządzaniu jakością. Ostatecznie zaprezentowano elementy z obszaru podejścia opartego na ryzyku, uzupełniające aspekty jakości głównych wewnętrznych czynników zarządzania jakością.

Metodyka badań empirycznych stanowi tytuł, i jednocześnie wskazuje na zawartość, rozdziału trzeciego. W tej części pracy został opisany cel i zakres badań. Uzasadniono dobór zakresu podmiotowego pracy oraz opisano procedurę zrealizowanego procesu badawczego. Scharakteryzowano również zawartość kwestionariusza ankietowego oraz przedstawione zostały zagadnienia przetwarzania i analizy danych uzyskanych w badaniu ankietowym.

Uzyskane wyniki badania ankietowego zostały zaprezentowane w czwartym rozdziale, który zatytułowany został Ocena ważności wewnętrznych czynników projakościowego zarzadzania $w$ organizacji. W rozdziale tym zostały 
przedstawione wyniki przeprowadzonych badań. Ujęto w nim różnorodne analizy statystyczne, opatrzone komentarzami autora.

Interpretacja wyników i zależności pomiędzy szeregiem elementów zawartych w kwestionariuszu ankietowym pozwoliła na zidentyfikowanie różnorodnych relacji, które umożliwiły weryfikację postawionych hipotez badawczych. Treści związane z weryfikacją przypuszczeń naukowych oraz konkluzje z tym związane zapełniły strony piątego rozdziału monografii.

W Zakończeniu zostały przedstawione syntetyczne wnioski, zarówno poznawcze, jak i praktyczne implikacje, dla organizacji stanowiących zakres podmiotowy opracowania. Została również zwrócona uwaga na możliwe dalsze kierunki badań będące kontynuacją rozważań, od strony teoretycznej i praktycznej, na rzecz pogłębienia wiedzy o funkcjonowaniu obszaru zarządzania jakością w kierunku pozytywnego wpływu na wyniki organizacji.

Tytułowy w niniejszej monografii wpływ wewnętrznych czynników na sukces projakościowego zarządzania $\mathrm{w}$ organizacji dotyczy szerokiej problematyki teoretycznej przekładającej się na wymierne efekty w rzeczywistości gospodarczej. Koncentracja działań organizacyjnych na wybranych wewnętrznych czynnikach zarządzania jakością pozwala wpływać na sukces podejmowanych działań. 


\section{Rozdział I \\ PROJAKOŚCIOWE ZARZĄDZANIE W ORGANIZACJI}

Jakość jest uwzględniana w podejmowaniu różnorodnych decyzji. Projakościowe zarządzanie $\mathrm{w}$ organizacji jest ukierunkowane na spełnianie różnych wymagań, jak również oczekiwań klientów. Jeśli podejmuje się działania ukierunkowane na trwały sukces ${ }^{2}$ zarządzania jakością, konieczna jest wiedza o aspektach występujących w tym obszarze organizacyjnym oraz mechanizmach funkcjonowania adekwatnych rozwiązań systemowych.

\section{Aspekty zarządzania jakością}

Jakość w języku potocznym dotyczy najczęściej oceny, w jakim stopniu dany przedmiot lub usługa odpowiada wymaganiom oceniającego [Łańcucki 2010, s. 12]. Jakość w ujęciu filozoficznym to istotne cechy przedmiotu wyróżniające go spośród innych i stanowiące o jego swoistości pod każdym względem [Dubisz 2008, t. I, s. 1263]. Właściwości ocenianego elementu mogą być dwojakie: inherentne (tkwiące $\mathrm{w}$ istocie rzeczy) lub przypisane (subiektywnie postrzegane) [Łańcucki 2010, s. 32-33]. Zarówno właściwości inherentne, jak $\mathrm{i}$ - w większym stopniu - przypisane podlegają subiektywnej ocenie różnych podmiotów, co jest uwarunkowane ${ }^{3}$ wieloma czynnikami ${ }^{4}$. Generalnie każdy

\footnotetext{
2 Sukces to:
}

- osiągnięcie celu, pomyślny wynik jakichś starań, działań [Dubisz 2008, t. III, s. 1447],

- osiągnięcie celu [PN-EN ISO 9000 2015-10, pkt 3.7.3, s. 25].

Trwały sukces to sukces trwający nieprzerwanie [PN-EN ISO 9000 2015-10, pkt 3.7.4, s. 25].

3 Uwarunkować (uwarunkowywać) - uzależnić (uzależniać) od określonych warunków [Dubisz 2008, t. IV, s. 309].

Uwarunkowanie - okoliczność mająca wpływ na coś, czynnik określający charakter czegoś [Dubisz 2008, t. IV, s. 309].

${ }^{4}$ Czynnik - jedna z przyczyn wywołujących skutek; jeden ze składników warunkujących coś, rozstrzygających o czymś [Dubisz 2008, t. I, s. 538]. 
z podmiotów oceniających produkty zwraca uwagę na ich zgodność z wymaganiami oraz oczekiwaniami. Kwestia minimalizacji wad produktowych oraz niezgodności organizacyjnych (związanych z tokiem produkcji i świadczeniem usługi) dotyczy podejścia do jakości w każdej organizacji. Pojęcie jakości jest wielowymiarowe, ponieważ odnosi się do wszystkich aspektów życia i przez to może być postrzegane w wielu wymiarach [Karaszewski i Skrzypczyńska 2013, s. 13]. Na jakość końcowych produktów wpływ mają różne uwarunkowania, co jest uzależnione m.in. od rodzaju i zakresu prowadzonej działalności gospodarczej, oferowanego asortymentu, charakterystyki klientów.

Istotę jakości ukazuje normatywna definicja przyjęta w niniejszej pracy, że jakość to stopień, w jakim zbiór inherentnych właściwości (cech) obiektu spełnia wymagania [PN-EN ISO 9000:2015-10, pkt 3.6.2]. Wymaganie jest określone jako potrzeba lub oczekiwanie, które zostały ustalone, przyjęte zwyczajowo lub są obowiązkowe [PN-EN ISO 9000:2015-10, pkt 3.6.4]. Warto również zwrócić uwagę, że jakość - jako pojęcie towarzyszące każdej osobie i podmiotowi na rynku - jest $\mathrm{w}$ dużej mierze związana $\mathrm{z}$ indywidualnym charakterem występującym po stronie popytowej. Tym samym w odpowiedzi na popyt istnieją rozliczne uwarunkowania jakości po stronie podażowej. Z perspektywy organizacji prowadzących działalność gospodarczą te jakościowe interakcje są zindywidualizowane $\mathrm{z}$ uwagi na różnorodne uwarunkowania. W tym kontekście warto zwrócić uwagę na dwa aspekty wpływające na jakość i jej postrzeganie: efekt końcowy działań (wyrób, usługa) oraz rynkowy obszar działalności (rynek przemysłowy, konsumpcyjny).

Rodzaj działań podejmowanych $\mathrm{w}$ organizacjach jest związany $\mathrm{z}$ oferowanymi produktami. Wyroby mają materialny charakter i mogą zostać wyprodukowane „na stan magazynowy”, celem dalszej dystrybucji i sprzedaży, bądź na konkretne zamówienia ze strony klientów. W jednym i drugim przypadku potencjalni klienci mają możliwość oceny wyrobów przed podjęciem decyzji zakupowej, na podstawie dóbr dotąd wytwarzanych. W przypadku usług, które mają niematerialny charakter, ocena przed zakupem jest ograniczona do sfery dotychczasowych realizacji usługodawcy i ocen wcześniejszych klientów. $\mathrm{Z}$ perspektywy potencjalnego klienta przy zakupie usługi występuje większa niepewnośćs , niż w przypadku materialnych wyrobów, co do efektu końcowego, postrzeganego przez pryzmat potrzeb i oczekiwań.

\footnotetext{
${ }^{5}$ Niepewność:
}

- ważna siła wynikająca ze zmienności i złożoności, która wpływa na wiele działań organizacyjnych [Griffin 2013, s. 90],

- w ujęciu teoretycznym o niepewności mówimy wówczas, gdy nie możemy powiązać prawdopodobieństwa z możliwym zdarzeniem lub nie wiemy, co może nas spotkać i jakie może to mieć konsekwencje, natomiast o ryzyku mówimy zawsze wtedy, gdy losowość daje się wyrazić w ścisłym liczbowym prawdopodobieństwie [Zawiła-Niedźwiecki 2013, s. 14]. 
Cechy wyrobów to pewne jego właściwości mające spełniać potrzeby klientów, czyli ich wymagania i oczekiwania [Karaszewski i Skrzypczyńska 2013, s. 42]. W ujęciu technicznym wyrób jest opisany przez zbiór właściwości fizycznych, z których wynikają jego właściwości użytkowe. Wartości (stany) cechy jakościowej są obrazami obiektów. Cechy te mogą być werbalne lub liczbowe, mierzalne albo niemierzalne, stałe, zmienne lub ciągłe, jedno- lub wielowymiarowe [Borys i Sudoł 1992, s. 13]. Ważność cech wyrobu wynika z tego, że odnoszą się do wymagań i oczekiwań klientów, kształtując satysfakcję z dostarczanych wyrobów [Karaszewski i Skrzypczyńska 2013, s. 42].

Cechy charakterystyczne usług, w porównaniu do wyrobów, to m.in. [Gronroos 2000, s. 47-48]: niematerialność (brak możliwości oceny przed dokonaniem zakupu), nierozłączność (równoczesność produkcji i konsumpcji), różnorodność (wynik jest wypadkową kooperacji pomiędzy usługodawcą a usługobiorcą), brak możliwości magazynowania, niemożność przywłaszczenia (brak transferu własności usługi), indywidualizacja (oczekiwania i potrzeby klientów nawet względem tej samej usługi mogą się różnić właśnie z uwagi na indywidualizm klientów). Ciężar gatunkowy poszczególnych atrybutów (cech) jest różny, w zależności od charakteru usługi. To powoduje, że jakość usług jest znacznie bardziej skomplikowana w definiowaniu niż jakość wyrobów [Karaszewski i Skrzypczyńska 2013, s. 20].

Jako usługę można traktować wynik procesu z przynajmniej jednym działaniem nieodzownie przeprowadzonym między organizacją a klientem [PN-EN ISO 9000:2015-10, pkt 3.7.7, s. 25]. Takie zdefiniowanie wpisuje się w ujęcie wskazywane w literaturze, gdzie przez pojęcie usługi rozumie się najczęściej te wszystkie przejawy ekonomicznej aktywności człowieka, które mają charakter niematerialny i charakteryzują się interaktywnością pomiędzy świadczącym usługi podmiotem a usługobiorcą [Łańcucki 2002, s. 12]. Elementem dominującym wyrobu jest zwykle jego materialność [PN-EN ISO 9000:2015-10, pkt 3.7.6, Uwaga 2, s. 25]. Jednak wyprodukowanie wyrobu często może obejmować element usługi, np. na etapie dostawy do klienta [PN-EN ISO 9000:2015-10, pkt 3.7.6, Uwaga 1, s. 25]. Dla zobrazowania relacji materialno-niematerialnych można wskazać (z perspektywy zakresu podmiotowego opracowania) na usługi serwisowe, które są przeprowadzane na materialnym samochodzie dostarczonym przez klienta. Z kolei w obszarze sprzedaży nowych samochodów $\mathrm{w}$ autoryzowanych salonach ${ }^{6}$ klient może się zdecydować na zakup modelu samochodu dostępnego „od ręki”, w danym salonie sprzedaży, jak

${ }^{6}$ W niniejszej pracy w odniesieniu do autoryzowanych salonów sprzedaży i serwisu samochodów osobowych w Polsce używane będą dwa terminy:

- organizacja jako podmiot prowadzących ww. działalność,

- lokalizacja jako salon sprzedaży i (lub) serwisu, dana organizacja może mieć kilka lokalizacji (punktów dealerskich i (lub) serwisowych). 
również może zdecydować o zamówieniu pojazdu według własnej konfiguracji. W drugiej sytuacji samochód będzie dopasowany do indywidualnych potrzeb klienta, ale równocześnie wydłuży to czas oczekiwania na odbiór zamówionego pojazdu. W jednym i drugim przykładzie interakcja pomiędzy kupującym a sprzedającym, w ramach transakcji kupna-sprzedaży, jest ukierunkowana na materialny wyrób, przy różnym natężeniu działań usługowych. Różnorodność interakcji pomiędzy usługami a materialnymi rezultatami prac wytwórczych sprawia, że ocena jakości usług jest wielowymiarowa i w procesie jej oceny można korzystać z pięciu wymiarów jakości, stanowiących kryteria jej oceny [Karaszewski i Skrzypczyńska 2013, s. 23]:

- wymiar materialny, rozumiany jako wygląd pomieszczeń, wyposażenia, personelu;

- niezawodność usług - zdolność dostawcy do zrealizowania usługi w sposób niezawodny i solidny;

- reakcja na oczekiwania klienta obejmująca chęć udzielenia mu pomocy, szybkość działań i reagowania na wymogi stawiane przez odbiorcę usług;

- fachowość i zaufanie odnoszące się do wiedzy merytorycznej personelu oraz ogólnego jego zachowania, umiejętności zdobywania zaufania klienta;

- empatia, czyli umiejętność zrozumienia oczekiwań klienta, zindywidualizowanego potraktowania jego potrzeb przez usługodawcę.

Organizacje $^{7}$ oferujące wyroby i usługi identyfikują te różnorodne zagadnienia, tworząc asortyment $\mathrm{w}$ celu dotarcia do grup docelowych i generowania przychodów ze sprzedaży. Ten nieustanny dwukierunkowy ruch rynkowy w dopasowaniu stron podażowej i popytowej stanowi rdzeń działań gospodarczych. Klienci, w swoich decyzjach zakupowych i późniejszej ocenie jakości, uwzględniają powiązane $\mathrm{z}$ wyrobami i usługami czynniki ich jakości. Zatem dla dalszych rozważań i ukazania późniejszych zależności konieczne jest, zdaniem autora, zdefiniowanie terminu „czynnik jakości”. Skoro jakość oznacza zbiór inherentnych właściwości obiektu, a czynnik to jedna z przyczyn ${ }^{8}$ wywołująca skutek, to za czynniki jakości należy uznać wszystkie właściwości, które decydują o wyborze danego produktu oraz wynikowo - o ocenie jakości. Jednak

\footnotetext{
7 Organizacja to:

- grupa ludzi, którzy współpracują ze sobą w sposób uporządkowany i skoordynowany, aby osiągnąc pewien zestaw celów [Griffin 2013, s. 5];

- osoba lub grupa osób, pełniąca funkcje z przypisaniem odpowiedzialności, uprawnień i powiązań, do osiągnięcia swoich celów [PN-EN ISO 9000 2015-10, pkt 3.2.1, s. 15].

Pojęcie „organizacja” jest używane w niniejszej pracy w zawężonym, podmiotowym znaczeniu jako termin ogólny (pomimo występujących praktycznych różnic w znaczeniach), wskazujący na przedsiębiorstwo, spółkę, korporację, organ władzy państwowej, organizację non profit, działalność gospodarczą, instytucję, niezależnie od osobowości prawnej bądź formy własności.

8 Przyczyna to czynnik wywołujący jakieś zjawisko jako swój skutek; zespół warunków wywołujących jakieś zjawisko; powód [Dubisz 2008, t. III, s. 777].
} 
klienci kierują się w swoich decyzjach zakupowych nie tylko cechami tkwiącymi w obiekcie, ale również przypisanymi. W tym kontekście można wskazać na poziomy produktu - na każdym poziomie wartość dla klienta jest coraz większa, a wszystkie pięć poziomów stanowi hierarchię wartości dla klienta [Kotler i Keller 2012, s. 350]:

- korzyść podstawowa (rdzeń produktu), usługa lub pożytek, które klient w istocie kupuje,

- produkt rzeczywisty (materialny wymiar),

- produkt oczekiwany - zbiór cech i warunków, jakich nabywca zwykle oczekuje, kupując dany produkt,

- produkt ulepszony - wykracza poza oczekiwania klienta,

- produkt potencjalny - obejmuje wszystkie możliwe ulepszenia i przekształcenia, którym produkt lub oferta może podlegać w przyszłości.

Za czynniki jakości należy zatem uznać wszystkie właściwości wyrobów i usług, zarówno inherentne, jak i przypisane, które mają znaczenie w procesie podejmowania przez klienta decyzji o zakupie i w późniejszym czasie, czyli podczas oceny jakości produktów (wyrobów i usług). Kompleksowość relacji pomiędzy czynnikami jakości wynika z różnorodności klientów i indywidualnych przesłanek podejmowanych przez nich decyzji. Ocena jakości jest oparta na doświadczeniach klienta wynikających z użytkowania produktu. Miarą jakości jest stosunek postrzeganego stanu faktycznego wyrobu i usługi do oczekiwań klienta - jawnych albo niejawnych, świadomych albo jedynie wyczuwalnych zmysłami, realizowanych technicznie lub całkowicie subiektywnych [Karaszewski i Skrzypczyńska, 2013, s. 34]. Klienci mogą być indywidualni bądź instytucjonalni, w zależności od rynku, co jednocześnie wpływa na postrzeganie jakości. Dlatego też rynkowy obszar działalności (rynek przemysłowy - b2b business to business, konsumpcyjny - b2c business to consumer) został wyróżniony jako drugi aspekt $\mathrm{w}$ analizie podejścia do jakości. Jakość produktów można określać z punktu widzenia producenta i konsumenta. Jakość z punktu widzenia konsumenta odnosi się do potrzeb funkcjonalnych (co dotyczy bezpośredniej eksploatacji produktu oraz dyspozycyjności) i niefunkcjonalnych (image, potrzeby estetyczne), natomiast na jakość z punktu widzenia producenta można spojrzeć przez pryzmat zyskowności i konkurencyjności [Karaszewski i Skrzypczyńska 2013, s. 36], co oczywiście wynika z cech samego produktu, na które uwagę zwracają klienci. Można wskazać, że czynniki jakości na rynku b2b są w większym stopniu zobiektywizowane niż na rynku b2c. Na rynku konsumpcyjnym $\mathrm{w}$ większym stopniu niż $\mathrm{w}$ relacjach pomiędzy organizacjami ${ }^{9}$ mają znaczenie elementy subiektywne i cechy niefunkcjonalne. Jednak granice pomiędzy wskazanymi rynkami zacierają się i nie zawsze jest możliwe jednoznaczne ich

9 Choć należy spojrzeć na poziom personalizacji relacji, ponieważ w usługach b2b nie spotykają się instytucje, ale konkretni ludzie je reprezentujący [Rogoziński 2016, s. 54]. 
rozdzielenie. Samochody osobowe sprzedawane klientom mogą być zakupione wyłącznie na użytek prywatny, jak również do prowadzenia działalności gospodarczej. Co więcej, pojazd może być wykorzystywany wyłącznie służbowo, ale też może być używany w celach zarówno służbowych, jak i prywatnych ${ }^{10}$. Powstaje zatem pytanie odnośnie do podmiotu dokonującego zakupu. W przypadku transakcji dokonywanej przez klienta prowadzącego jednoosobową działalność gospodarczą kupujący pojazd uwzględnia swoje potrzeby i oczekiwania jako klient i następnie użytkownik pojazdu. Jednak nabywcą może być również podmiot gospodarczy dokonujący zakupu samochodów dla swoich pracowników i wówczas indywidualne wymagania i oczekiwania użytkowników będą miały mniejsze znaczenie, a priorytety prawdopodobnie wyznaczają decydenci w danej organizacji. Zatem podział na rynek dóbr konsumpcyjnych oraz przemysłowych w mikroekonomicznej perspektywie nie jest jednoznaczny, lecz jest uwarunkowany indywidualnym charakterem pojedynczych transakcji, a to ma wpływ na podejście do jakości po obydwu stronach rynkowej relacji - popytowej i podażowej.

Z powyższych rozważań wyłania się koncepcja jakości jako zagadnienia o szerokim znaczeniu i dopasowywanego w sposób indywidualny do wyrobów i usług stanowiących rdzeń transakcji zakupowo-sprzedażowych. Atrybuty związane z wyrobami i usługami, jako cechy powiązane oraz przypisane, tworzą zbiór czynników jakości. Hierarchizacja czynników jakości (ważność w podejmowaniu decyzji zakupowych klientów) dotyczy obszaru badań rynkowych z zakresu preferencji konsumentów. Zakres zainteresowań naukowych autora $\mathrm{w}$ niniejszej pracy dotyczy sfery działań organizacyjnych prowadzących do wytworzenia wyrobów i usług, przy uwzględnieniu indywidualnej w każdej organizacji wiedzy o czynnikach kształtujących określony poziom jakości.

Rynkowe i sformalizowane wymagania dla produktów dotyczą nie tylko dokumentacji technicznych charakterystyk, ale również odnoszą się do zarządzania organizacją, co w znacznej mierze decyduje o klęsce lub sukcesie na rynku danej organizacji [Łańcucki 2006, s. 11]. Zarządzanie to zestaw działań obejmujący planowanie i podejmowanie decyzji, organizowanie, przewodzenie (kierowanie ludźmi) i kontrolowanie aktywności skierowanych na zasoby organizacji i wykonywanych z zamiarem osiągnięcia celów organizacji w sposób sprawny i skuteczny ${ }^{11}$ [Griffin 2013, s. 6]. Celem zarządzania jest zapewnienie ${ }^{12}$

${ }^{10}$ Znajduje to odzwierciedlenie $\mathrm{np}$. w przepisach podatkowych: Ustawa $\mathrm{z}$ dnia 11 marca 2004 r. o podatku od towarów i usług (Dz.U. 2004 Nr 54 poz. 535 z późn. zm., art. 86), gdzie istnieje rozróżnienie w użytkowaniu pojazdu wyłącznie służbowo bądź w celach służbowo-prywatnych, $\mathrm{z}$ adekwatnymi zasadami rozliczania podatku VAT.

${ }^{11}$ Skuteczność to stopień, w jakim planowane działania są zrealizowane i planowane wyniki osiągnięte [PN-EN ISO 9000 2015-10, pkt 3.7.11, s. 26].

${ }^{12}$ Zapewnić = zapewniać, co oznacza oświadczenie, że coś będzie na pewno, uczynić coś pewnym [Dubisz 2008, t. IV, s. 848-849]. 
oczekiwanych rezultatów wynikających z działalności danej organizacji. Zarządzanie jest niejako narzędziem, które ma zapewnić instytucji, niezależnie od tego, czy będzie nią przedsiębiorstwo, kościół, uniwersytet czy szpital, możliwość osiągnięcia zamierzonych wyników w otoczeniu, w którym działa [Drucker 2000, s. 39].

Jakość jest ważna [Vasileios i Odysseas 2015, s. 150], ponieważ jakość funkcjonowania każdej organizacji jest pierwotna w procesie sprzedaży wyrobów i usług, a wynik tego procesu wpływa na bieżącą działalność i długookresowe funkcjonowanie organizacji na rynku. Dlatego w funkcjonowaniu organizacji ważne jest odpowiednie zarządzanie jakością. Każda organizacja prowadzi działania w zakresie zarządzania jakością, niezależnie od tego, czy zostały one formalnie zaplanowane, czy nie [PN-EN ISO 9000:2015-10, pkt 2.4.2, s. 13]. System $^{13}$ zarządzania jakością stanowi jeden $\mathrm{z}$ wielu podsystemów w systemie zarządzania organizacją i jest to część systemu zarządzania dotycząca jakości [PN-EN ISO 9000:2015-10, pkt 3.5.4, s. 21]. System zarządzania jakością funkcjonuje $\mathrm{w}$ organizacji jako podsystem zarządzania obok np. zarządzania finansami, zarządzania środowiskowego, zarządzania bezpieczeństwem i higieną pracy oraz zarządzania ryzykiem [Łańcucki 2006, s. 12]. Odpowiednie zarządzanie jakością oznacza działania dopasowane do specyfiki danej organizacji, przy uwzględnieniu zasygnalizowanego postrzegania jakości. Słowo „odpowiednie” w ukierunkowaniu na jakość oznacza, po pierwsze, dopasowanie poziomu jakości wyrobów i usług do wymagań oraz oczekiwań klientów. Po drugie, dotyczy powtarzalności jakości (utrzymania właściwości na zaplanowanym poziomie za każdym razem). Potoczne sformułowanie, że ,jedyną stałą rzeczą jest zmiana” oddaje istotę gospodarowania, zmieniających się wymagań i oczekiwań klientów, zmian uwarunkowań prowadzenia działalności i konieczności doskonalenia działań organizacyjnych.

Projakościowe zarządzanie w organizacji jest dynamicznym obszarem działań w każdej organizacji i ewoluuje w czasie. Przez lata, wraz z rozwojem przemysłowym i związanym z tym wzrostem jakości życia, podejście do jakości ewoluowało od kontroli, sterowania, poprzez zapewnienie do zarządzania jakością [Łańcucki 2006, s. 21]. Środek ciężkości zmieniał się w czasie, ewoluując z obszaru technicznego wyrobów w kierunku działań organizacyjnych ukierunkowanych na wytworzenie wyrobu i uwzględniających również sferę usług, z uwagi na zmiany rynkowe, bogacenie się społeczeństw i zmianę struktury konsumpcji. To nawiązuje do zagadnień społecznych, a w ujęciu rynkowym ewolucja działań podejmowanych $\mathrm{w}$ ramach zarządzania jakością wynikała m.in. z rosnącej konkurencyjności oraz zmieniających się wymagań klientów [Weckenmann, Akkasoglu i Werner 2015, s. 281]. Jednocześnie konkurencyjność oraz wymagania

${ }^{13}$ System to zestaw wzajemnie powiązanych elementów funkcjonujących jako całość [Griffin 2013, s. 54]. 
klientów wzajemnie się napędzają, bowiem organizacje, oferując podobne asortymenty, próbują się wyróżnić na tle konkurencji atrybutami mającymi zachęcić klientów do decyzji zakupowych. Konsumenci przyzwyczajają się do coraz to nowszych produktów i wynikające $\mathrm{z}$ tego rosnące wymagania klientów wpływają na kolejne działania podejmowane przez podmioty reprezentujące stronę podażową. Zagadnienia te przyczyniają się do ewolucji w podejściu do jakości. Ta ewolucja ${ }^{14} \mathrm{w}$ skali ogólnej jest efektem działań podejmowanych w skali szczegółowej, w poszczególnych organizacjach, gdzie jest związana z procesem ciągłego doskonalenia ${ }^{15}$. Powtarzające się działania doskonalące są powiązane $\mathrm{z}$ działaniami wewnętrznymi oraz $\mathrm{z}$ otoczeniem $\mathrm{z}$ uwagi na nieustanne zmiany i potrzebę dostosowywania się właśnie do zmieniających się okoliczności gospodarowania. Różnorodne koncepcje w zakresie zarządzania jakością były dopasowywane do aktualnej w danym momencie sytuacji rynkowej. Zmieniające się podejście do jakości nie było rewolucyjne, nie polegało na gwałtownych zmianach zasad w zakresie zarządzania jakością. Zmiany w obszarze zarządzania jakością są ewolucyjne. Powszechną koncepcją zarządzania jakością jest kompleksowe zarządzanie organizacją przez jakość (TQM). Jest to filozofia zarządzania wykorzystywana przy realizacji wszystkich przedsięwzięć i procesów w przedsiębiorstwie, opierająca się na przywódczej roli kierownictwa oraz zaangażowaniu każdego pracownika współpracującego z zespołem ze swego środowiska pracy [Wasilewski 1999, s, 26]. Koncepcja TQM polega na tym, aby główna uwaga kadry zarządzającej i personelu wykonawczego była skupiona na możliwie wysokim poziomie jakości pracy, przebiegu procesów, produktów, przy respektowaniu postulatów gospodarności we wszystkich obszarach działań [Lichtarski 2015, s. 30]. W wyniku przeglądu różnorodnych definicji kompleksowego zarządzania jakością [Szczepańska 2013, s. 26-30] można wskazać na składowe tworzące akronim TQM - Total Quality Management, gdzie:

- T oznacza kompleksowość zarządzania jakością, co dotyczy jej przenikania przez wszystkie aspekty działań, funkcji, obszarów i poziomów w organizacji;

- Q oznacza jakość jako wartość organizacji związaną z identyfikacją wymagań i oczekiwań i dążeniem do spełnienia wymagań i zidentyfikowanych potrzeb;

- M oznacza przyjęcie jakości jako parametru w procesie zarządzania, podejmowanych decyzjach i wykonywanych zadaniach, dla osiągnięcia zamierzonych celów.

${ }^{14}$ Więcej o definiowaniu i ewolucji w podejściu do jakości: [Łańcucki 2006, s. 18-21; Urbaniak 2010a, s. 494-512; Hawrysz 2014a, s. 27-34; Hys 2015a, s. 17-30, 36-59; Łukasiński 2016a, s. 41-51] oraz istocie i definicjach TQM w: [Łańcucki 2006, s. 21-27; Karaszewski i Skrzypczyńska 2013, s. 105-135].

${ }^{15}$ Ciągłe doskonalenie to powtarzające się działanie mające na celu poprawę efektów działania [PN-EN ISO 9000 2015-10, pkt 3.3.2, s. 17]. 
Zasadniczo we wszystkich koncepcjach podejścia do jakości występują zagadnienia, które można przedstawić $\mathrm{w}$ trzech płaszczyznach [Karaszewski i Skrzypczyńska 2013, s. 106-135 $\left.{ }^{16}\right]$ : zmienne rdzeniowe (np. przywództwo, skupienie uwagi na kliencie), zmienne wewnętrznego (planowanie, podejście zespołowe) i zewnętrznego (środowisko infrastruktura, przełomowe zmiany) pierścienia. W literaturze przedmiotu wskazuje się, że mode ${ }^{17}$ kompleksowego zarządzania jakością posiada sześć zdefiniowanych filarów, które jednoznacznie tworzą zasady TQM [Hys 2015a, s. 43]: orientacja na klienta (Total), przywództwo, podmiotowość (Management), proces ciągłego doskonalenia, eliminację marnotrawstwa (Quality) oraz pomiary poziomu jakości. Kompleksowe zarządzanie jakością jest również wskazywane jako bieżąca koncepcja zarządzania, która jest szerszym spojrzeniem niż systemowe zarządzanie jakością zgodne z wymaganiami zawartymi w normie ISO 9001 [Weckenmann, Akkasoglu i Werner 2015], ale równocześnie jest kolejną koncepcją w ewolucji. Takie rozdzielenie i ukazanie następstwa czasowego nie jest jednak w przekonaniu autora niniejszego opracowania poprawne. Koncepcja kompleksowego zarządzania jakością została zapoczątkowana zdecydowanie wcześniej niż znormalizowane podejście do obszaru zarządzania jakością. Z kolei system zarządzania jakością jest wskazywany jako etap w dążeniu do kompleksowego zarządzania jakością ${ }^{18}$ [Wielicki 2000, s. 46-62]. Właśnie z uwagi na trudności w określaniu zakresu kompleksowego zarząazania jakością oraz wykazania praktycznego wdrożenia tej idei powstała sfera normalizacyjna obszaru zarządzania jakością. Spełnienie wymagań normatywnych można poddać ocenie jednostki certyfikującej, a certyfikat stanowi obiektywny dowód i uwiarygodnienie podejmowanych projakościowych działań w organizacji, co w przypadku koncepcji TQM nie ma miejsca [Jedynak 2007, s. 29]. Kompleksowe zarządzanie jakością jako filozofia zarządzania - jest wciąż aktualne, choć zakres działań w dużym stopniu jest uzależniony od indywidualnych preferencji kierownictwa dla podejmowania szeregu działań organizacyjnych. Cały czas jednak pozostanie problem w zewnętrznym potwierdzeniu podejmowanych działań. Certyfikacja jest jedynie wykazaniem zgodności w odniesieniu do wymagań normatywnych, w ściśle określonym zakresie. Gdyby jednak była potrzeba jedynie certyfikatu w tej materii, to liczba certyfikowanych systemów zarządzania jakością byłaby równa liczbie organizacji na świecie. Tymczasem każda organizacja, działając w ramach swojego otoczenia, podejmuje działania, które uznaje za uzasadnione

${ }^{16}$ Autorzy analizowali różnorodne koncepcje z zakresu zarządzania jakością, w szczególności kluczowe aspekty kompleksowego zarządzania jakością w świetle koncepcji Crosby’ego, Deminga i Jurana.

${ }^{17}$ Model - konstrukcja, schemat lub opis ukazujący działanie, budowę, cechy zależności jakiegoś zjawiska lub obiektu [Dubisz 2008, t. II, s. 696].

${ }^{18}$ Substytucyjność obu podejść do zarządzania jakością była rozpatrywana m.in. w: [Pełka i Pełka 2000, s. 34-36; Rogala 2012, s. 66-67]. 
gospodarczo. Jednocześnie wprowadzenie w przedsiębiorstwie systemu zarządzania jakością zgodnego z wymaganiami normy ISO 9001 to o wiele za mało, aby mówić o obecności koncepcji TQM w przedsiębiorstwie. Choć oczywiście norma ISO 9001 to konkretny i jasny zbiór kryteriów dotyczących systemu zarządzania jakością i przyczyniła się do rozpowszechnienia kultury jakości [Konarzewska-Gubała i Barcewicz 2013, s. 170]. Z uwagi na certyfikowalność systemu zarządzania jakością zgodnego z wymaganiami normy ISO 9001 koncepcja ta jest wskazywana jako statyczne podejście do zarządzania. Postrzeganie znormalizowanego systemu zarządzania jakością jako raczej statycznego niż dynamicznego systemu wynika $\mathrm{z}$ faktu, że wymagania normatywne pozwalają na nadzorowanie procesów w celu osiągnięcia zaplanowanych rezultatów [Urbaniak 2010a, s. 510]. Jednak w normie ISO 9001 zawarte są m.in. wymagania dotyczące doskonalenia i są one weryfikowane przez jednostkę certyfikującą, zatem element doskonalenia jest wpisany w znormalizowany system zarządzania jakością.

Różnorodne definicje i charakterystyki kompleksowego zarządzania jakością wynikają między innymi z przenikania się teorii i praktyki. Naturą praktyki gospodarczej jest różnorodność - z uwagi na rodzaj działalności, zasobów, rynków, pracowników, celów czy metod i narzędzi wykorzystywanych dla realizacji planów [Karaszewski i Skrzypczyńska 2013, s. 143]. Kompleksowe zarządzanie jakością odzwierciedla taki poziom rozwoju jakości, który jest definiowany i realizowany na wszystkich poziomach struktury organizacyjnej, uwzględnia istniejące funkcje zarządzania [Hys 2015a, s. 38]. Pozorna mnogość różnych koncepcji opisujących ten sam obszar TQM może zatem wynikać z używania różnych słów do opisu tych samych zjawisk i procesów [Łańcucki 2006, s. 27]. Podsumowując należy stwierdzić, że TQM jest filozofią zarządzania, która przyjmując perspektywę ciągłego usprawniania jakości, kształtuje kulturę organizacyjną umożliwiającą rozpoczęcie wędrówki ku doskonałości [Karaszewski i Skrzypczyńska 2013, s. 144].

Z określaniem zarządzania jakością jako części zarządzania odnoszącej się do jakości wiąże się jednak pewien problem [Rogala 2012, s. 63]. Wprawdzie jest to podejście intuicyjnie zrozumiałe, ale nie tworzy ono precyzyjnych kryteriów do wskazania tego, co w praktyce mieści się w ramach zarządzania jakością. Przy współczesnym, szerokim rozumieniu jakości oraz w sytuacji, gdy uwzględni się perspektywę klienta wewnętrznego, właściwie każde działanie w organizacji może być uznane za element zarządzania jakością [Rogala 2012, s. 64].

Wśród różnych rozwiązań w zakresie zarządzania, nazywanych także „receptami”, można wymienić trzy różniące się pod względem szczegółowości kategorie [Jagoda i Lichtarski 2010, s. 3-6]: koncepcje, metody ogólne, metody szczegółowe. W skład każdej koncepcji wchodzą ogólne (ideowe) założenia oraz dowolna i zmienna w czasie liczba metod [Rogala 2012, s. 62-63]. Jako 
przykład koncepcji zarządzania można wskazać np. marketing, który biorąc początek z jakiejś określonej funkcji, w wyniku rozwoju obejmuje także inne funkcje zarządzania, np. marketing jako rozwinięcie funkcji sprzedaży [Rogala 2012, s. 63]. Bazując na tym, proponuje się, by zarządzanie jakością mogło być traktowane zarówno jako koncepcja zarządzania, jak i jako funkcja rodzajowa organizacji (podobnie jak to ma miejsce np. w marketingu) [Rogala 2012, s. 66]. Ponadto w praktyce funkcjonowania organizacji pojawiły się bądź umocniły liczne zrutynizowane działania z zakresu zarządzania jakością, takie jak: kontrola jakości (dostaw, procesów, produktów gotowych), certyfikacja, wprowadzanie ujednoliconych procedur działania, zwiększanie zaangażowania pracowników, poszukiwanie możliwości i wprowadzanie działań doskonalących. Są one na tyle powszechne, że upoważniają do wyodrębnienia funkcji zarządzania jakością [Rogala 2012, s. 66]. Przyjmując takie ujęcie, zarządzanie jakością można rozumieć jako wszystkie skoordynowane czynności, które ustalają politykę jakości, zapewniają jej realizację oraz prowadzą do zapewnienia odpowiedniego poziomu jakości [Rogala 2012, s. 66].

Operacjonalizacja orientacji i koncepcji zarządzania, dokonywana w celach aplikacyjnych, prowadzi do ukształtowania odpowiedniego instrumentarium metodyczno-narzędziowego zarządzania, w tym zasad (fundamenty, reguły, podstawy), które wspóltworzą podstawowe założenia i wytyczne dla metod i narzędzi zarządzania w różnych jego obszarach i na różnych poziomach [Lichtarski 2015, s. 37]. Identyfikacja zasad oraz ich standaryzacja w najbardziej chyba wyrazistej postaci wystąiła w powszechnie znanym i stosowanym systemie norm serii 9000 w obszarze zarządzania jakością [Lichtarski 2015, s. 39]. Do rangi zasad podniesione zostały całe podejścia (orientacje): na klienta, procesowe, systemowe, których podstawowe założenia można opisać m.in. także za pomocą właściwych im zasad. Widać tu, jak złożone i wymagające pogłębionej refleksji relacje mogą występować między różnymi zasadami i ich zbiorami [Lichtarski 2015, s. 38]. Konfiguracja (architektura) systemu zarządzania organizacją powinna tworzyć kompozycję wielu różnych orientacji opartych na określonych ideach. Powinna stanowić odpowiedź na konfigurację licznych czynników, których oddziaływanie należy brać pod uwagę w kształtowaniu owych orientacji i ich kompozycji. Rolę tych czynników powinny pełnić określone właściwości (cechy) potencjału organizacji i jego relacji z otoczeniem, istotne dla osiągania ważnych celów, a jednocześnie pozostające w polu oddziaływania (skutkowania) zastosowań poszczególnych orientacji w zarządzaniu [Lichtarski 2015, s. 102]. W ramach projakościowego zarządzania w organizacji są uwzględniane m.in. dwa obszary czynników wpływających na różne aspekty funkcjonowania tego obszaru w organizacji - czynniki jakości oraz czynniki zarządzania jakością. Działania organizacyjne w ramach projakościowego zarządzania systematyzują procedury postępowania, a te są bezpośrednio ukierunkowane na jakość 
efektu końcowego działań - produktu. Klienci oceniają w pierwszej kolejności użyteczność wyrobów i usług w odniesieniu do celu ich zakupu, a następnie wszystkie inne okoliczne zagadnienia, czyli pośrednio dokonują oceny zarządzania jakością w organizacji.

Należy zatem wskazać na dwa zagadnienia konieczne do uwzględnienia w ramach projakościowego zarządzania w organizacji - czynniki jakości oraz czynniki zarządzania jakością. Czynniki jakości dotyczą cech poszczególnych poziomów produktu, które klienci uwzględniają w swoich decyzjach zakupowych i które podlegają bezpośredniej ocenie przez klientów. Natomiast czynniki zarządzania jakością są to działania (elementy proceduralne) występujące w organizacjach i w ich otoczeniu, które są ukierunkowane na zapewnienie „odpowiedniej” jakości efektu końcowego. Dla przykładu nabywcy samochodów osobowych, dokonując zakupu, kierują się różnorodnymi czynnikami jakości, jak np. model i marka pojazdu, kolor, wyposażenie, gabaryty i inne elementy, które dopasowują do swoich potrzeb i oczekiwań. W każdej marce samochodów, grupach zawodowych, lokalizacjach klienci będą decydować o zakupie, kierując się różnorodnymi czynnikami jakości ${ }^{19}$. Każdy salon sprzedaży (dealer), w celu uzyskania jak najlepszych efektów swoich działań, powinien te czynniki jakości identyfikować i uwzględniać w działaniach organizacyjnych (np. zamawiając odpowiednio wyposażone samochody demonstracyjne). I właśnie szereg działań organizacyjnych, które w poszczególnych organizacjach uwzględniają czynniki jakości, można zgrupować jako czynniki zarządzania jakością. Zamawianie samochodów demonstracyjnych jako proces występuje u każdego dealera, ale różne będzie ukierunkowanie tych działań i wewnętrzne procedury w poszczególnych salonach sprzedaży.

Analizując obszar zarządzania jakością, poza sferą czynników jakości oraz czynników zarządzania jakością, konieczne jest uwzględnianie otoczenia organizacji. Globalizacja i związana z tym ogromna liczba interakcji pomiędzy podmiotami gospodarowania rozmieszczonymi terytorialnie sprawia, że jakość nie dotyczy już tylko aspektów technicznych oraz wymagań klientów powiązanych z wyrobami i usługami. Obecnie na jakość spogląda się szerzej i konieczne jest uwzględnianie zagadnień odpowiedzialności społecznej oraz zrównoważonego rozwoju [Weckenmann i in. 2015, s. 288]. Kompleksowość działań podejmowanych $\mathrm{w}$ poszczególnych organizacjach, wynikająca $\mathrm{z}$ indywidualnych uwarunkowań i okoliczności zarówno wewnętrznych, jak i zewnętrznych (oraz wzajemnych interakcji pomiędzy nimi), wpływa na zindywidualizowanie celów i towarzyszących im zadań. Ta różnorodność stanowi podstawę działań zarządczych we wszystkich organizacjach na poszczególnych jej poziomach.

${ }^{19}$ Dla przykładu, nabywcy samochodów na terenach górskich w większym stopniu wybierają napęd $4 \times 4$, co jest związane z uwarunkowaniami geograficznymi terenu i możliwościami użytkowania w pełni pojazdu np. w okresie zimowym. 
Każda organizacja poszukuje „swojej ścieżki” działania po to, aby wyróżnić się na rynku i pozyskiwać nowych klientów oraz utrzymywać relacje z obecnymi. Te działania składają się na proces zarządzania, a ich ukierunkowanie na zagadnienia jakościowe tworzy system zarządzania jakością. Zarządzanie jakością ma zatem dwojakie zadania [Weckenmann, Akkasoglu i Werner 2015, s. 292]. Z jednej strony ma służyć identyfikowaniu i znajdowaniu rozwiązań dla bieżących problemów, co jest związane $\mathrm{z}$ operacyjną (codzienną) redukcją ryzyka. $Z$ drugiej strony ma umożliwiać diagnozowanie i przewidywanie przyszłych problemów w kierunku osiągania zaplanowanych wyników działania. Dlatego zarządzanie jakością pozostanie kluczowym ${ }^{20}$ czynnikiem sukcesu w każdej organizacji, ponieważ jako jedno z narzędzi doskonalenia organizacji wpływa na osiąganie pożądanych rezultatów [Tickle, Mann i Adebanjo 2016, s. 354]. U podstaw orientacji na jakość, nazywanej również orientacją projakościową, leży idea dążenia do doskonałości procesów i produktów [Lichtarski 2015, s. 34]. Uwzględnianie orientacji na jakość w zarządzaniu organizacją jest określane mianem projakościowego zarządzania w organizacji i zamiennie stosowane ze sformułowaniem zarządzanie jakością w organizacji lub ogólnie zarząazzanie jakością [Łukasiński 2013, 2016a, 2016b; Jakubiec 2017].

Reasumując, w kontekście działań ukierunkowanych na odpowiednie zarządzanie jakością można wyróżnić trzy zagadnienia stanowiące przedmiot dalszych analiz:

1. Zarządzanie jakością w kontekście określenia zakresu działań organizacyjnych i systemowego podejścia. Pożądana jest wiedza o czynnikach zarządzania jakością w organizacji, co do natężenia ich występowania i stopnia oddziaływania na rezultaty działań decydujące o sukcesie na rynku.

2. Uwzględnianie jakości jako przymiotu m.in. działań organizacyjnych oraz produktów wpływającego na sukces w organizacji. Jakość występuje w każdej działalności gospodarczej i dotyczy różnorodnych aspektów funkcjonowania. Zapewnienie odpowiedniej jakości procesów w organizacji wpływa na osiągnięcie zaplanowanej jakości produktów, co implikuje wynik finansowy. Kategoria jakości jest zatem kluczowa dla sukcesu organizacji.

3. Redukcja bieżącego ryzyka ${ }^{21}$. Każda działalność jest obarczona niepewnością co do uzyskania założonych wyników. Różnorodne zagrożenia ${ }^{22}$ mogą powodować problemy w działaniach i odchylenia w realizacji celów, szanse natomiast mogą wspierać ich osiągnięcie.

${ }^{20}$ Kluczowy oznacza istotny, podstawowy, główny, najważniejszy [Dubisz 2008, t. II, s. 131].

${ }^{21}$ Termin „ryzyko” jest używany zarówno w liczbie pojedynczej, jak i mnogiej. Używanie w liczbie pojedynczej wynika z pierwotnego znaczenia jako poczucie niepewności, odnośnie do liczby mnogiej wskazuje się, że współczesne ryzyko coraz częściej odnosi się do różnorodnych zdarzeń, które tworzą zbiór różnych ryzyk [Hadyniak i Monkiewicz 2010, s. 13].

${ }^{22}$ Zagrożenie to sytuacja lub stan, które komuś lub czemuś zagrażają [Dubisz 2008, t. IV, s. 784]. 


\section{Systemowe zarządzanie jakością}

Podejście w zarządzaniu organizacją, w którym jest uwzględniany zestaw wzajemnie powiązanych elementów funkcjonujących jako całość, jest określany mianem systemu [Griffin 2013, s. 54] jako zbioru podsystemów. W ramach prowadzenia działalności gospodarczej zachodzą różnokierunkowe interakcje pomiędzy podsystemami, a to oznacza, że zmiany w jednym obszarze mogą wpływać na zmiany w pozostałych. Jednocześnie działania w ramach podsystemów powinny wpływać pozytywnie na wyniki organizacji jako całości. Z uwagi jednak na zachodzące w organizacji interakcje trudno jest wydzielić spośród rezultatów organizacji wyniki wyłącznie danego podsystemu zarządzania.

Różnorodność organizacji i aspekt jakości występujący w każdej z nich sprawia, że działania w obszarze zarządzania jakością są podejmowane w każdej działalności gospodarczej. Projakościowe zarządzanie w organizacji jest ukierunkowane na zapewnienie odpowiedniej jakości końcowego efektu działań organizacji - jej wyrobów i usług. Natężenie tych działań może być różne, w zależności od koncentracji na podsystemie zarządzania jakością i świadomego podejmowania działań regulujących ten obszar. Analizując zagadnienia zarządzania jakością, w szczególności w systemowym ujęciu, należałoby w pierwszej kolejności wskazać na elementy składowe tworzące system zarządzania jakością. Następnie w ujęciu procesowym (następstw działań) konieczne jest przybliżenie barier wdrożenia zarządzania jakością, zarówno od strony organizacyjnej (jako zagadnienia problematyczne w ustanowieniu działań z zakresu zarządzania jakością), jak i od strony barier w kontekście ograniczania pozytywnego wpływu zarządzania jakością na wyniki organizacji.

Określając elementy zarządzania jakością, najprościej sięgnąć po już ustalony zakres. Dokumentem wskazującym na elementy zarządzania jakością jest norma ISO 9001, zawierająca wymagania dla znormalizowanego systemu zarządzania jakością. Jednak taki system stanowi jedno z narzędzi, które może być wykorzystywane w procesie zarządzania organizacją w aspekcie jakości. Systemy te sprzyjają ustanowieniu niezbędnego, minimalnego zestawu wymagań, których spełnienie powinno umożliwić osiągnięcie zaplanowanych wyników, zgodnych z wymaganiami klientów [Łańcucki 2010, s. 16]. Chcąc zatem analizować systemowe zarządzanie jakością, należy zadać pytanie, czy analiza w ujęciu normatywnym tego podsystemu zarządzania $\mathrm{w}$ organizacji jest wystarczająca. Zdaniem autora niniejszej monografii, wskazane jest wyjście poza zakres wymagań normatywnych, których spełnienie pozwala na uzyskanie certyfikatu potwierdzającego zgodność wdrożonego systemu zarządzania jakością z wymaganiami normatywnymi. Znormalizowane systemy zarządzania to pewien minimalny zestaw wymagań dla określenia istoty zarządzania jakością w sposób systemowy. W organizacji 
mogą mieć miejsce różnorodne działania wchodzące w skład zarządzania jakością, zarówno zawężające wymagania normatywne, jak i je rozszerzające, których stosowanie jest uwarunkowane podejściem organizacji do zarządzania jakością. Co więcej, historia norm z zakresu zarządzania jakością jest zdecydowanie krótsza niż historia koncepcji zarządzania jakością. Zatem wskazane jest szersze spojrzenie na elementy tworzące zarządzanie jakością niż tylko tematyka wymagań normatywnych. Niemniej jednak nie można zaprzeczyć ważnej roli norm z zakresu zarządzania jakością ponieważ ich stworzenie i okresowe aktualizowanie niweluje braki wiedzy co do wdrażania elementów z zakresu zarządzania jakością. Brak ram dla działań z zakresu zarządzania jakością spowodował w ewolucji podejścia do zarządzania jakością publikację norm zawierających wymagania dla systemowego podejścia. Analizując sferę normalizacyjną, nie można nie zauważyć rosnącej liczby certyfikatów ISO 9001 wydanych organizacjom na całym świecie, których na koniec 2016 roku było $1106356^{23}$ [ISO Survey 2017, s. 1]. Również duża liczba publikacji nawiązujących do znormalizowanego systemu zarządzania jakością sprawiła, że w „masowym odczuciu” zarządzanie jakością kojarzy się często właśnie z „ISO 9001”, tym samym ograniczając w praktyce działania do ich przyporządkowania względem wymagań normatywnych. Oczywiście istnieją organizacje, które wykraczają poza ustaloną liczbę wymagań stanowiących podstawę certyfikacji znormalizowanego systemu zarządzania jakością. W obszarze normalizacyjnym zostały uwzględnione wytyczne opublikowane w normie ISO 9004, wskazujące na podejście do zarządzania jakością w ukierunkowaniu na trwały sukces organizacji.

Możliwość poszukiwania czynników zapewniających odpowiednią jakość efektu końcowego zarówno w otoczeniu, jak i wnętrzu organizacji jest naturalna, bowiem zarządzanie jakością jest skupione w organizacji, która z kolei funkcjonuje w pewnym otoczeniu. Otoczenie zewnętrzne to wszystko poza granicami organizacji, co może na nią oddziaływać [Griffin 2013, s. 75]. Z kolei środowisko wewnętrzne to warunki panujące i siły działające wewnątrz organizacji [Griffin 2013, s. 75]. Z perspektywy organizacji czynniki mogą być zatem zewnętrzne i wewnętrzne ${ }^{24}$ i można wskazać na trzy źródła ich identyfikacji [Yusof i Aspinwall 2000, s. 283]:

- koncepcje zarządzania jakością przedstawiane przez guru jakości,

- modele doskonałości i nagrody jakości,

- przeglądy teoretyczne oraz badania praktyczne.

${ }^{23} \mathrm{~W}$ tym 80.596 certyfikatów zgodności systemu zarządzania jakością z wymaganiami normy ISO 9001:2015. Warto również wskazać, że certyfikaty „SZJ ISO 9001”, wskazujące na zgodność SZJ - systemu zarządzania jakością - z wymaganiami normy ISO 9001:2008 utracą ważność po trzech latach od publikacji najnowszego standardu.

${ }^{24}$ Więcej o relacjach pomiędzy czynnikami zewnętrznymi a wewnętrznymi w zarządzaniu jakością m.in. w: [Zapłata 2009, s. 70-105]. 
W wyniku analizy i własnych obserwacji autora warto uszczegółowić ostatnie źródło informacji, które obecnie odgrywa najistotniejszą rolę z uwagi na liczbę publikacji odnoszących się do systemowego zarządzania jakością. Przywoływanie $\mathrm{w}$ literaturze przedmiotu pierwszych dwóch koncepcji jest coraz rzadsze z racji ewolucji podejścia do jakości. Jednak elementy występujące wcześniej w ewolucji są bezpośrednio i pośrednio uwzględniane w następnych publikowanych materiałach.

Różnorodne działania organizacyjne powinny być ukierunkowane na jakość końcową wyrobów i usług. Rezultat końcowy jest zatem uzależniony od jakości zarządzania, czyli podejmowania działan organizacyjnych, które mogą napotkać bariery w założonym zrealizowaniu celów, np. dotyczących jakości. Na podstawie analizy literatury można wskazać trzy główne grupy barier skutecznego wdrożenia kompleksowego zarządzania jakością [Mosadeghrad 2014, s. 160-187]:

- nieskuteczny albo niewłaściwy model TQM (czyli dobór składowych zarządzania jakością, nieodpowiednich dla danej organizacji ${ }^{25}$ ),

- nieskuteczne albo niewłaściwe metody wdrożenia kompleksowego zarządzania jakością,

- niewłaściwe środowisko dla wdrożenia TQM (zaangażowanie, kultura jakości, co nawiązuje do miękkich elementów zarządzania).

Wskazane obszary dotyczą barier w sensie ogólnym, szczegółowe ich wyróżnienie wymagałoby powiązania ze specyfiką danej organizacji. To samo działanie może stanowić w jednej organizacji czynnik sukcesu, a w innej tworzyć największą barierę dla sukcesu projakościowego zarządzania w organizacji. Dla przykładu zaangażowanie kierownictwa w jednej organizacji może pozytywnie motywować pracowników do działań, a w innej wpływać na niezadowolenie pracowników.

Czynniki, które przeszkadzają w podejmowaniu inicjatyw doskonalących w obszarze zarządzania jakością, określane jako bariery, mają większe znaczenie w organizacjach średniej wielkości niż w małych [Mendes i Lourenco 2014]. Jako najistotniejsze bariery w podejmowaniu inicjatyw jakościowych wskazywane są: priorytety najwyższego kierownictwa, koszty i aktualne wyniki działalności, brak wsparcia ze strony zewnętrznych konsultantów, przeciążenie ludzi, niechęć do zmian, brak zasobów [Mendes i Lourenco 2014]. W branżach usługowych trzy najważniejsze bariery kompleksowego zarządzania jakością

${ }^{25}$ Można zauważyć, że w tym obszarze umiejscowiona jest niniejsza praca. Pożądanym efektem analiz i badań jest wskazanie wewnętrznych czynników z elementami składowymi, według ich ważności w oddziaływaniu na sukces projakościowego zarządzania w organizacji. To pozwoli na wpływanie decyzjami wewnątrzorganizacyjnymi na rezultaty działań z zakresu zarządzania. Finalnie wiedza o tych zagadnieniach powinna zredukować właśnie bariery dotyczące projakościowego zarządzania w organizacji. 
stanowią: zagadnienia kierownicze, orientacja na ludzi, sprawy organizacyjne [Talib i Rahman 2015].

Zagadnienia barier zarządzania jakością są hasłowo zbieżne z czynnikami zarządzania jakością, bowiem podobny jest charakter obydwu grup - czynnościowy oraz wewnętrzny bądź zewnętrzny. Zatem ten sam element rzeczywistości gospodarczej w organizacji może pozytywnie bądź negatywnie wpływać na efekty działań, co jest uzależnione od wielu zmiennych charakterystycznych dla poszczególnych organizacji. W systemowym zarządzaniu jakością ważna jest koordynacja różnorodnych aktywności. Działania w ramach systemu zarządzania jakością mogą wpłynąć na uzyskanie rezultatów zamierzonych (zaplanowanych), ale również i niezamierzonych (nieujętych w celach dotyczących jakości). Uzyskiwane efekty nie mogą być wynikiem przysłowiowego szczęścia, ponieważ w systemowym zarządzaniu jakością, w ukierunkowaniu na powtarzalność jakości, konieczne jest wyznaczenie celów, aby można następnie mówić o skuteczności zarządzania jakością.

\section{Skuteczne zarządzanie jakością}

Stopień, w jakim zrealizowane zostały zidentyfikowane i formalnie ustanowione cele, jest określany mianem skuteczności stanowiącej warunek sukcesu organizacji. Aby działania można było poddać ocenie skuteczności, konieczne jest porównanie uzyskanych rezultatów do zaplanowanych celów. Aby zapewnić skuteczność działań, konieczne jest podejmowanie bieżących decyzji i działań ukierunkowanych nie tylko na zrealizowanie planów, ale również identyfikację i minimalizację zagrożeń mogących negatywnie wpłynąć na pożądane wyniki. Tym samym, ukierunkowując działania z zakresu zarządzania jakością na skuteczność, konieczne jest uwzględnienie czynników zarządzania jakością, barier oraz efektów działań w tym obszarze zarządzania. Uwzględnienie tych zagadnień powinno być dokonywane przez pryzmat systemowego podejścia do zarządzania i umiejscowienia ich względem siebie w celu optymalizacji ${ }^{26}$ działań organizacyjnych. W tym kontekście można się posłużyć cyklem Deminga $(\mathrm{PDCA})^{27}$, wskazującym w prosty sposób na następstwo poszczególnych działań na etapach „PWSD” (Planuj-Wykonaj-Sprawdź-Działaj). Warunkiem sukcesu organizacji jest sprawne zarządzanie, które można oceniać w odniesieniu do prakseologicznych kryteriów skuteczności, ekonomiczności i korzystności

\footnotetext{
${ }^{26}$ Optymalizacja - uzyskanie najlepszych wyników, wybór najlepszego wariantu [Dubisz 2008 , t. II, s. 1286].

${ }^{27}$ Cykl Deminga $=$ PDCA (ang. Plan-Do-Check-Act) $=$ PWSD (pol. Planuj-Wykonaj-Sprawdź-Działaj).
} 
[Niedzielski 2016, s. 286]. Przejawem skuteczności systemów zarządzania jakością może być realizacja celów jakości, wysokość i wskaźniki kosztów złej jakości lub kosztów braku jakości; ekonomiczna zaś ocena systemów zarządzania nie jest łatwa [Lisiecka 2017, s. 12]. Równocześnie jednak wymóg racjonalności gospodarowania wymaga zwrócenia uwagi na zachowanie gospodarności w toku realizacji celu, z czym związana jest potrzeba uwzględniania relacji w jakiej pozostają względem siebie z jednej strony ponoszone nakłady, $\mathrm{z}$ drugiej zaś uzyskane dzięki nim efekty [Borowiecki 2014, s, 91].

Zarządzanie jest zatem w sposób immanentny powiązane z problemem celów działalności przedsiębiorstwa, które to cele stanowią ex ante istotny wyznacznik decyzji podejmowanych w toku zarządzania oraz służą ukierunkowaniu wszelkich podejmowanych działań, natomiast ocena stopnia ich realizacji umożliwia ex post weryfikację efektywności i skuteczności samego zarządzania [Borowiecki 2014, s. 84]. Problem zróżnicowanych celów działalności przedsiębiorstwa jest obecny $\mathrm{w}$ funkcjonalnym wymiarze zarządzania, w ramach planowania, które obok organizowania, motywowania, kontroli i koordynowania jest wymieniane jako jedna z funkcji zarządzania [Borowiecki 2014, s, 84]. Rozpatrując kategorię efektywności na gruncie nauk o zarządzaniu, należy w pierwszej kolejności zwrócić uwagę na jej ścisłe powiązanie z realizacją celów organizacji [Borowiecki 2014, s, 90]. Z pojęciem celu jest bowiem związany przedmiotowo i podmiotowo zdefiniowany przyszły, pożądany stan lub rezultat działania organizacji, który uznaje się za możliwy i przewidziany do osiągnięcia w założonym terminie [Godziszewski i in. 2011, s. 122; Krzyżanowski 1994, s. 180]. Poziom efektywności organizacji jest w tej sytuacji odzwierciedleniem jej zdolności do realizacji przyjętych celów [Borowiecki 2014, s, 91]. Brak powiązania stopnia realizacji celów organizacji ze stopniem jej efektywności skutkowałby bowiem w skrajnych przypadkach kreowaniem postaw opartych na dążeniach do osiągnięcia założonego celu za wszelką cenę, co pozostawałoby w sprzeczności z podstawowymi zasadami rachunku ekonomicznego i zagrażałoby dalszemu istnieniu organizacji [Grzesiak 1996, s. 177].

Pierwotnym procesem w ocenie skuteczności podejmowanych działań gospodarczych jest planowanie. Planowanie jest etapem wytyczania celów organizacji i określenia, jak można je najlepiej osiągnąć [Griffin 2013, s. 9]. Częścią procesu planowania jest podejmowanie decyzji, co obejmuje wybór trybu działania spośród zestawu dostępnych możliwości [Griffin 2013, s. 9]. Proces planowania jest kaskadowy, początkowym etapem jest zidentyfikowanie celów strategicznych, które następnie są uszczegóławiane na poziomie taktycznym, i ostatecznie formułowane są cele operacyjne. Cele strategiczne (uwzględniając ramy czasowe - długookresowe) to cele ustalone na najwyższym szczeblu przez najwyższe kierownictwo organizacji, cele taktyczne (średniookresowe) są ustalane na średnim szczeblu i dla menedżerów tego poziomu organizacyjnego, a cele operacyjne 
(krótkookresowe) - na kolejnym poziomie i dla menedżerów niższego szczebla [Griffin 2013, ss. 212]. Zidentyfikowane cele, stanowiące efekt planowania, pełnią ważne funkcje w organizacji m.in.: dostarczają wskazówek i wyznaczają kierunek działań, mogą być źródłem motywacji dla pracowników organizacji oraz odniesieniem w mechanizmie oceny i kontroli [Griffin 2013, s. 213].

$\mathrm{W}$ ramach projakościowego zarządzania $\mathrm{w}$ organizacji definiowane są cele jakościowe. Cele dotyczące jakości w poszczególnych organizacjach są dopasowane do specyfiki danej organizacji, co oznacza uwzględnianie indywidualnych uwarunkowań przy ich definiowaniu. Tym samym późniejsza ocena skuteczności działań w obszarze zarządzania jakością w organizacji automatycznie zawiera w sobie rezultat ściśle powiązany z charakterem danej organizacji. To sprawia, że możliwe jest sterowanie skutecznością systemu zarządzania jakością już na etapie planowania poprzez definiowanie celów dotyczących jakości „z góry zdanych na sukces". Powstaje zatem pytanie o powody takiego potencjalnego podejścia. Jednym $\mathrm{z}$ nich są kwestie normatywne, w których wymagania dla systemu zarządzania jakością w normie ISO 9001 wskazują na skuteczność jako cel tego systemu [PN-EN ISO 9001:2015-10, pkt 5.1.1, s. 12]. Taka interpretacja wymagań normatywnych nie jest właściwa. Ukierunkowanie celów na działania, które z pewnością pozwolą na ich osiągnięcie, prowadzi jedynie do wykazania zgodności z danym wymaganiem normatywnym. Jest to jednak spojrzenie krótkowzroczne, aczkolwiek zauważalne niestety w praktyce $\mathrm{z}$ obszarów znormalizowanych systemów zarządzania. Takie podejście nie ma jednak nic wspólnego z długookresowym wpływem zarządzania jakością na rezultaty organizacji. Dlatego też w przekonaniu autora analizy związane $\mathrm{z}$ realizacją celów dotyczących jakości w poszczególnych organizacjach nie mają ogólnej wartości poznawczej (na poziomie analitycznym i porównawczym danych pochodzących z różnych organizacji) właśnie z uwagi na ograniczoną możliwość uwzględnienia indywidualnej ważności celów i ich rzeczywistego poziomu wyznaczonego do osiągnięcia. Na zarządzanie jakością należy zatem spojrzeć jak na zbiór działań wykonywanych w każdej organizacji, które w ukierunkowaniu na jakość końcowych produktów (wyrobów i usług) mają pozytywnie wpływać na rezultaty całej organizacji. W tym kontekście można wskazać na trzy generalne cele systemu zarządzania jakością: zapobieganie niezgodnościom, ciągłe doskonalenie oraz skoncentrowanie na satysfakcji klientów [Psomas, Pantouvakis i Kafetzopoulos 2013, s. 151].

Na kolejnym etapie cyklu PDCA podejmowane są działania ukierunkowane na osiągnięcie sformułowanych celów. Działania w organizacji można pogrupować $\mathrm{w}$ procesy ${ }^{28}$, które obejmują wszystkie działania podejmowane $\mathrm{w}$ organi-

${ }^{28}$ Proces to zbiór działań wzajemnie powiązanych lub wzajemnie oddziałujących, w których wykorzystuje się wejścia procesu (dane wejściowe procesu) do dostarczenia zamierzonego rezultatu [PN-EN ISO 9000 2016, pkt 3.4.1, s. 19]. 
zacji i stanowią faktyczne jej funkcjonowanie [Skrzypek 2012, s. 172]. Łącznie zarządzanie wszystkimi procesami tworzy podejście systemowe do zarządzania ${ }^{29}$. Zarządzanie procesami może wpływać na jakość zarządzania w organizacji, rozumianą jako stopień spełnienia potrzeb i wymagań jej stron zainteresowanych (np. akcjonariuszy, dostawców, klientów, pracowników) [Szczepańska i Bugdol 2016, s. 11]. Sposób podejmowania działań oraz całe instrumentarium wykorzystywane w ukierunkowaniu na realizację zaplanowanych celów jest szerokie, dostosowane do zindywidualizowanych celów i możliwości organizacyjnych każdej jednostki.

Po etapie realizacji działań $\mathrm{w}$ ramach realnej sfery zarządzania w organizacji przeprowadzane są działania sprawdzające. Mierzenie stanowi podstawę zarządzania procesami i organizacją, natomiast pomiar jest elementem infrastruktury koniecznej do ciągłego doskonalenia procesów [Skrzypek 2012, s. 177]. Na tym etapie następuje identyfikacja efektów podejmowanych aktywności gospodarczych oraz ich zestawienie z planami, co stanowi przedmiot oceny skuteczności. Monitorowanie procesów oraz pomiarowe punkty kontrolne, stanowiące elementy niezbędne do nadzorowania, są specyficzne dla każdego procesu i różnią się w zależności od związanego ryzyka [PN-EN ISO 9001:2015-10, pkt 0.3.1, s. 6]. Na problematykę skuteczności działań organizacyjnych można spojrzeć wielopłaszczyznowo. Definicyjnie odnosi się ją do zidentyfikowanych celów, do których porównuje się uzyskane rezultaty i tym samym otrzymuje informacje o skuteczności działań. Jak to zostało powyżej zasygnalizowane, odnoszenie się do indywidualnych celów może zniekształcać rzeczywisty poziom działań realizowanych w organizacji, ukazywać za każdym razem wynik skuteczności w subiektywnym świetle, co jest związane $\mathrm{z}$ indywidualizmem w formułowaniu planów. Abstrahując od płaszczyzn planowania $\mathrm{w}$ organizacji $\mathrm{w}$ ramach zarządzania jakością i powiązanych $\mathrm{z}$ tym poziomów w ocenie skuteczności, można spojrzeć na ogólną ocenę skuteczności zarządzania jakością przez pryzmat celów, dla których podejmowane są w organizacji działania w obszarze projakościowego zarządzania. Ocena może być dokonywana poprzez wpływ zarządzania jakością na rezultaty funkcjonowania organizacji na rynku. Dlatego też rezultaty zarządzania jakością w organizacji są określane w niniejszej monografii wpływem tych działań na wyniki organizacji jako całości, co znajduje odzwierciedlenie w literaturze przedmiotu.

29 „Podejście systemowe do zarządzania” stanowiło zasadę w ramach systemowego zarządzania jakością zgodnego z wymaganiami ISO 9001:2008. W ramach standardu ISO 9001:2015 zasada ta nie występuje, co jest naturalne z uwagi na funkcjonowanie systemu bazującego na wielu wymaganiach, w ramach cyklu PDCA, czyli podejście systemowe występuje „samo w sobie”, co zostało opisane m.in. w książce zatytułowanej Podejście systemowe do zarządzania jakościa w organizacji [Ligarski 2010]. 
„Definicja sukcesu jako osiągnięcie celu wskazuje na jednorazowy rezultat i nie uwzględnia perspektywy czasu, która w przypadku działalności organizacji jest niezwykle istotna, bowiem to, co dzisiaj można nazwać sukcesem, już w krótkim czasie może przestać nim być" [Grabowska i Drygas 2010, s. 515]. „Dlatego też w odniesieniu do organizacji bardziej właściwe wydaje się utożsamianie sukcesu z procesem, działaniem na najwyższym poziomie możliwości zmierzającym do realizacji wyznaczonych celów" [Majewska-Opiełka 2007]. W tym kontekście, po analizie literatury przedmiotu, dokonano ujęcia rezultatów projakościowego zarządzania w organizacji w sposób dynamiczny, poprzez ukazanie pozytywnego wpływu wewnętrznych czynników (i poszczególnych elementów składowych) na rezultaty ukazane jako miary tytułowego w pracy sukcesu projakościowego zarządzania w organizacji.

Doskonalenie działalności przedsiębiorstwa jest możliwe tylko wtedy, gdy podejmowane w nim decyzje wynikają z analizy działalności operacyjnej, która jest oparta na miernikach umożliwiających monitorowanie aktualnego stanu realizacji procesów [Urbaniak 2010b, s. 280]. Współczesne organizacje, chcąc sprostać wymaganiom konkurencyjnego otoczenia, powinny, spoglądając w przyszłość, szybko odpowiadać na zmiany zachodzące w otoczeniu, przewidywać te zmiany i w związku z tym ukierunkowywać działania na doskonalenie produktów, procesów, umiejętności pracowników oraz systemów zarządzania [Brajer-Marczak 2015, s. 11]. W tym ostatnim obszarze można wskazać na podsystem zarządzania $\mathrm{w}$ organizacji ukierunkowany na jakość, czyli system zarządzania jakością, który właśnie w ramach idei cyklu PDCA powinien być doskonalony. Doskonalenie jest formą rozwoju, ponieważ zmiana jest cechą konstruktywną zarówno rozwoju, jak i doskonalenia [Borys i Rogala 2011, s. 19]. Doskonalenie jakości to zespół przedsięwzięć podejmowanych w celu uzyskania dodatkowych korzyści przez organizację, jej klientów oraz ogólnie interesariuszy [Brajer-Marczak 2015, s. 15]. Doskonalenie dotyczy wszystkich aspektów prowadzonej działalności gospodarczej, zarówno wyrobów i usług, jak i otoczenia oraz poszczególnych składowych wewnętrznych $\mathrm{w}$ organizacji. Z perspektywy zarządzania jakością jako zbioru działań organizacyjnych można wskazać na doskonalenie procesów celem dążenia do poprawy ich funkcjonowania w ukierunkowaniu na osiągnięcie lepszych efektów oraz wynikowo powodujących wyższy poziom satysfakcji klienta [Nowosielski 2008, s. 41]. Reasumując, zarządzanie jakością w organizacji odgrywa kluczową rolę w procesie ciągłego doskonalenia procesów, wyrobów i usług [Teixeira i in. 2015, s. 16].

Jakość jest jedną z podstawowych kategorii decydujących o stopniu konkurencyjności organizacji i projakościowe zarządzanie stanowi determinantę trwałego sukcesu organizacji [Łukasiński 2013, s. 73]. Sukces jest związany z osiąganiem zaplanowanych celów, czyli zbiorem działań realizowanych w ramach zarządzania jakością i uszeregowanych w cyklu PDCA. Organizacje dążą 
do osiągania zaplanowanych celów na poszczególnych poziomach organizacyjnych, aczkolwiek trwały sukces organizacji dotyczy kwestii ogólnego wpływu zarządzania jakością na wyniki zarządzania organizacją. Realizacja celów operacyjnych jest związana z bieżącym funkcjonowaniem organizacji, co oznacza osiąganie celów dla procesów zarządzania jakością i implikuje osiąganie celów strategicznych (długookresowych). Cykliczne działania w ramach cyklu PDCA w zarządzaniu jakością systematyzują bieżące działania oraz długookresowy proces doskonalenia w celu pozytywnego wpływu zarządzania jakością na rezultaty organizacji. W perspektywie długookresowej zarządzanie jakością wpływa stabilnie (trwale, bez gwałtownych odchyleń) na funkcjonowanie organizacji na rynku. Zależność ta znalazła odzwierciedlenie w normie ISO 9004. W tejże normie trwały sukces organizacji został określony jako wynik zdolności organizacji do osiągnięcia i utrzymania swoich celów w długim czasie [PN-EN ISO 9004 2010, s. 11]. Nawiązuje to do definicji z normy terminologicznej, gdzie użyte słowo „nieprzerwanie” nawiązuje do realizacji celów w długim czasie, czyli właśnie oddziaływania zarządzania jakością na rezultaty zarządzania organizacją cały czas, każdego dnia. Organizacja osiąga trwały sukces dzięki zdolności do zaspokajania potrzeb i oczekiwań klientów i innych zainteresowanych stron w długim czasie i w zrównoważony sposób [PN-EN ISO 9004 2010, s. 7]. Organizacje dążą do długookresowego funkcjonowania na rynku, co jest związane $\mathrm{z}$ wieloma aktywnościami organizacyjnymi, na różnych poziomach organizacyjnych, z różnym horyzontem czasowym. Mimo że rzadko zdarza się dokładnie przewidzieć przyszłość przedsiębiorstwa, a czynniki zewnętrzne mogą przeszkadzać w realizacji nawet najlepiej sformułowanych planów, zdarzenia nieplanowane byłyby pozostawione losowi [Koźmiński i Piotrowski 2005, s. 215]. Dlatego $\mathrm{w}$ ramach zarządzania organizacją podejmowane są różnorodne działania dla osiągnięcia zaplanowanych celów. Działania te mogą mieć dwojaki charakter - prewencyjny oraz reakcyjny. Działania prewencyjne są związane z przewidywaniem różnego rodzaju sytuacji i podejmowaniem działań mających na celu niedopuszczenie do zidentyfikowanych, negatywnych zdarzeń. Z perspektywy systemowej dotyczy to identyfikacji zagrożeń, oceny możliwości ich zaistnienia (prawdopodobieństwa) oraz oszacowania potencjalnych skutków dla zaistnienia danej sytuacji. Płaszczyzna reakcyjna dotyczy działań mających miejsce po rzeczywistym zaistnieniu zagrożeń i ukierunkowanych na minimalizację skutków oraz jak najszybszy powrót do normalnego stanu funkcjonowania organizacji. W ujęciu systemowym działania podejmowane jako reakcja na zaistnienie niepożądanej sytuacji wymagają wcześniejszego zaplanowania w ramach procesu zarządzania ryzykiem ${ }^{30}$. Natomiast działania podejmowane już po zaistnieniu niepożądanej sytuacji dotyczą zagadnień ciągłości działania.

\footnotetext{
${ }^{30}$ Proces zarządzania ryzykiem jest definiowany jako systematyczne stosowanie polityki, procedur i praktyk zarządzania do działań w zakresie komunikacji, konsultacji, ustanawiania
} 
Ogólnie ciągłość działania to zdolność organizacji do reagowania na zakłócenia $^{31}$ normalnego, bieżącego funkcjonowania w celu szybkiego przywrócenia normalnych warunków, a tam, gdzie jest to niemożliwe, przejścia do zaplanowanego sposobu zastępczego działań [Staniec i Zawiła Niedźwiecki 2015, s. 281]. Wdrożenie i utrzymywanie planów ciągłości działania podwyższa bezpieczeństwo i wzmacnia stopień niezawodności funkcjonowania organizacji poprzez zagwarantowanie płynności procesów biznesowych w trakcie zakłóceń i po ich wystąpieniu [Mitkow i Leszczyńska 2016, s. 13]. Ciągłość działania, jako postępowanie organizatorskie, tworzy zdolność organizacji do skutecznego reagowania w sytuacji zaistnienia zakłócenia i w takim ujęciu jest przedmiotem zarządzania operacyjnego, stanowiąc ostatnie ogniwo zarządzania ryzykiem operacyjnym [Staniec i Zawiła-Niedźwiecki 2015, s. 281]. Podejście operacyjne wynika ze strategicznych decyzji organizacji, a kwestia zapewnienia ciągłości stanowi jedną z kluczowych odpowiedzialności najwyższego kierownictwa [Musgrave i Woodman 2013, s. 4]. Podejście do ciągłości działania powinno być racjonalne i równoważyć oczekiwany stopień pewności działania względem kosztów jego uzyskania, co oznacza przyjęcie założenia o rezygnacji z kolejnych elementów normalnego prowadzenia działalności w zależności od zmieniających się rozmiarów sytuacji krytycznej [Staniec i Zawiła Niedźwiecki 2015, s. 283-284].

Zarządzanie ciągłością działania ma swoje korzenie w obszarze ochrony systemów informatycznych, lecz przez lata ewoluuje $\mathrm{e}^{32} \mathrm{w}$ kierunku uwzględniania działań ze wszystkich obszarów organizacji [Elliott, Swartz i Herbane 2010, s. 3]. Zarządzanie ciągłością działania stanowi odpowiedź praktyków zarządzania na pojawiające się ryzyko w turbulentnym otoczeniu [Jedynak 2013, s. 85]. Ta koncepcja zarządzania wkracza w różnorodne obszary i podsystemy w zarządzaniu organizacją. Nie oznacza to jednak, że zarządzanie ciągłością działania dąży do objęcia swoim zakresem całej działalności organizacji. Jest to po prostu niemożliwe $\mathrm{z}$ uwagi na wskazane powyżej zagadnienie równowagi działań względem finansów, ale i fizycznych możliwości prowadzenia działalności gospodarczej w przypadku zakłócenia normalnego jej funkcjonowania. Pojawienie się zakłóceń wymaga skoncentrowania działań na wybranym obszarze działalności, który jest chroniony w przypadku pojawiających się problemów. Ten wybór obszaru szczególnego zainteresowania, w ramach zarządzania ciągłością działania, stanowi wynik systemowego podejścia do zarządzania i jego wyznaczenia na wcześniejszym etapie. Takie podejście powoduje, że w przypadku pojawienia się

kontekstu, oraz identyfikowania, analizowania, ewaluacji, postępowania z ryzykiem, monitorowania przeglądu ryzyka [PN-ISO 31000 2012, pkt 2.8, s. 17].

${ }^{31}$ Zakłócenie to naruszenie ustalonego porządku, biegu spraw, procesów [Dubisz 2008, t. IV, s. 800].

${ }^{32}$ Więcej o ewolucji w ramach zarządzania ciągłością działania (BCM - Business Continuity Management) w: [Elliott, Swartz i Herbane 2010, s. 14-15] oraz interpretacje i rozważania w: [Jedynak 2013, s. 85-96]. 
zakłócenia pracownicy nie podejmują panicznych działań, lecz działają zgodnie z wypracowanymi wcześniej procedurami na wypadek sytuacji awaryjnych. Nie jest możliwe przewidzenie wszystkich negatywnych zdarzeń wpływających na funkcjonowanie organizacji, jednak brak jakichkolwiek planów generuje większe ryzyko niezrealizowania zaplanowanych celów. Jednocześnie tworzenie takich planów samo w sobie podnosi ogólną świadomość pracowników co do zagrożeń i odpowiednich działań w organizacji [Lindström 2012, s. 274]. Wzrost wielkości organizacji powoduje wzrost liczby zagrożeń dla jej funkcjonowania, co oznacza, że duże organizacje są w większym stopniu zainteresowane zarządzaniem ciągłością działania [Musgrave i Woodman 2013, s. 11].

Analizując kwestie systemowego zarządzania ciągłością działania w organizacji, warto zauważyć, że wskazana powyżej koncentracja na wybranym zakresie znajduje odzwierciedlenie w wymaganiach normatywnych tego obszaru zarządzania $^{33}$. W normie ISO 22301 zawierającej wymagania dla systemu zarządzania jakością istnieje konieczność ustalenia zakresu systemowego podejścia i zadeklarowania tego, co dotyczy identyfikacji kluczowych produktów [ISO 22301 2012, pkt 3.23, s. 4]. Kluczowe wyroby i usługi stanowią dla organizacji istotne pozycje asortymentowe. Ich ważność może wynikać z różnych przesłanek, w zależności od przyjętych kryteriów analizy dla wyznaczenia zakresu systemowego podejścia do zarządzania ciągłością działania. Aczkolwiek z perspektywy praktycznej to raczej decyzja o wdrożeniu i ewentualnej certyfikacji systemu zarządzania ciągłością działania podejmowana jest po określeniu właśnie kluczowych produktów. Natomiast samo wyznaczenie tego zakresu jest wynikiem interakcji rynkowych, np. oferowania usług dostępnych 24 godziny przez 7 dni w tygodniu (np. usługi e-bankowości) lub ochrona procesów wytwarzania towarów zakontraktowanych w danym okresie. Następuje zatem koncentracja na istotnych procesach dla długookresowego funkcjonowania organizacji w kontekście wytwarzania wyrobów i świadczenia usług dla klientów, jak i wytycznych ze strony pozostałych interesariuszy (np. udziałowców).

Reasumując, celem zarządzania ciągłością działania jest wykonywanie działań produkcyjnych i usługowych w stosunku do kluczowych produktów, na założonym poziomie $\mathrm{w}$ odpowiedzi na zidentyfikowane zakłócenia. Jest to zatem zestaw działań wspierających realizację celów w organizacji, w tym dotyczących jakości. Uwzględnienie tych zagadnień w ramach projakościowego zarządzania w organizacji stanowi uzupełnienie elementów uszczegóławiających główne wewnętrzne czynniki ${ }^{34}$ wpływające na sukces zarządzania jakością. Takie działania

${ }^{33}$ Historia normalizacji w zakresie zarządzania ciągłością działania w połączeniu również z obszarem zarządzania ryzykiem ukazana została m.in. w: [Elliott, Swartz i Herbane 2010, s. 5257; Zapłata i Kaźmierczak 2011, s. 95-102].

${ }^{34} \mathrm{~W}$ pracy sformułowanie „wewnętrzne czynniki” jest używane zamiennie ze sformułowaniem „czynniki wewnętrzne”. 
mają wpływać na zwiększenie możliwości realizacji zaplanowanych celów, czyli doskonalić skuteczność zarządzania jakością. To prowadzi do stwierdzenia, że działania z zakresu zarządzania ciągłością działania mogą się przyczyniać do odpowiedniego funkcjonowania procesów. Zapewnienie elastyczności procesów w warunkach zmienności otoczenia dotyczy właśnie ciągłości działania i wymaga od organizacji zarządzania ryzykiem tych procesów [Karkoszka 2013, s. 147]. Jednak aby ta pozytywna relacja pomiędzy czynnikami zarządzania jakością a rezultatami miała miejsce w rzeczywistości gospodarczej, konieczne jest podejmowanie systemowych działań, $\mathrm{w}$ tym identyfikacji zagrożeń mogących zniekształcać funkcjonowanie procesów i wpływać negatywnie na osiąganie założonych celów. Tym samym warto $\mathrm{w}$ ramach projakościowego zarządzania w organizacji uwzględniać aspekt ryzyka, co zostało przedstawione w kolejnym punkcie niniejszego rozdziału monografii.

\section{Zarządzanie ryzykiem jakości}

W ramach zarządzania organizacją występują różnorodne podsystemy zarządzania, w tym system dotyczący zarządzania jakością ukierunkowanego na odpowiednią jakość końcowego rezultatu działań. Nie ma zatem zarządzania bez zarządzania jakością. Niepewność gospodarowania sprawia, że każda decyzja i bieżące działania są obarczone ryzykiem, czyli wpływem niepewności na cele [PN-ISO 31000 2012, pkt 2.1, s. 15]. Identyfikacja zagrożeń i szans wpływających na realizację zaplanowanych celów stanowi zadanie nie tylko kadry zarządzającej, ale wszystkich pracowników, z uwagi na efekt końcowy będący pochodną pracy właśnie wszystkich pracowników w organizacji. Nie ma zatem „zarządzania bez zarządzania ryzykiem” [Staniec i Zawiła-Niedźwiecki 2015, s. 13]. Jeżeli zestawimy obydwa obszary zarządzania w organizacji - zarządzanie jakością oraz zarządzanie ryzykiem - to można wskazać, że realizacja zaplanowanych celów dotyczących jakości wymaga podejścia systemowego, w celu zwiększenia skuteczności ich osiągnięcia, przy uwzględnieniu elementów z obszaru zarządzania ryzykiem. Nie ma zatem zarządzania bez zarządzania jakością i ryzykiem. Można by mnożyć kolejne takie sformułowania, jednak skoro jakość wyrobów i usług stanowi priorytet w działaniach organizacji, z uwagi na istotę dla klientów i byt rynkowy, to konieczne jest właśnie zarządzanie ryzykiem jakości ${ }^{35}$. Jednocześnie jakość produktów jest wynikiem podejmowanych

${ }^{35}$ Terminu ,zarządzanie ryzykiem jakości” autor użył po raz pierwszy w materiale opublikowanym na początku 2016 roku [Zapłata 2016b, s. 109-113] jako wskazanie na potrzebę zarządzania ryzykiem w obszarze jakościowym, na przykładzie branży motoryzacyjnej. Nie jest 
działań organizacyjnych w obszarze zarządzania jakością, co nawiązuje do zasygnalizowanych czynników zarządzania jakością. Jakość nie dotyczy zatem tylko końcowego efektu działań, ale również (jako potrzeba spełnienia wymagań i oczekiwań stron zainteresowanych w ukierunkowaniu na efekt końcowy) dotyczy kwestii organizacyjnych. Można zatem wskazać, że zarządzanie ryzykiem jest kluczowym aspektem wpływania na jakość zarządzania organizacjami [Lisiecka 2012b, s. 557].

Jedną z miar jakości zarządzania $\mathrm{w}$ organizacji, w tym realizowania działań $\mathrm{z}$ zakresu zarządzania ryzykiem, jest równowaga $\mathrm{w}$ działalności gospodarczej związana z minimalizacją sytuacji kryzysowych. Sytuacja kryzysowa jest zespołem okoliczności zewnętrznych i wewnętrznych wywołanych zmianami w danym układzie. Rezultatem tych zmian może być jakościowo nowy układ lub powstanie nowej struktury bądź funkcji w układzie istniejącym [Stabryła 2015, s. 515-516]. Możliwość powstania kryzysu jest uwarunkowana ryzykiem funkcjonowania i rozwoju, które wyraża się prawdopodobieństwem powstania sytuacji kryzysowych [Cyfert i Krzakiewicz 2010, s. 62]. Proces funkcjonowania stabilizuje działalność organizacji i stanowi jednocześnie podstawę procesu rozwoju. Rozwój narusza równowagę dynamiczną systemu organizacyjnego i kształtuje równocześnie warunki stabilizacji jego funkcjonowania. W ten sposób powstają cykliczne tendencje rozwoju, które oznaczają potencjalne możliwości wystąpienia kryzysów [Cyfert i Krzakiewicz 2010, s. 69].

Istota kryzysu w zarządzaniu polega na tym, że konkretne lub potencjalne zdarzenie może wywołać istotne zagrożenie dla funkcjonowania przedsiębiorstwa i negatywnie wpływać na jego wartość [Cyfert i Krzakiewicz 2010, s. 62]. Dla przedsiębiorstwa istotne jest zatem zaprojektowanie odpowiedniego systemu zarządzania kryzysowego, który pozwoliłby kierownictwu na podjęcie skutecznych kroków w momencie wykrycia symptomów sytuacji kryzysowej bądź zastosowania efektywnej strategii zwalczania zaistniałego już kryzysu i likwidacji jego skutków [Stabryła 2015, s. 515-516]. Pierwsze pojawiające się pytanie dotyczy tego, co rozumiane jest przez kryzys. Kryzys to sytuacja mogąca zagrażać bieżącemu funkcjonowaniu, a niekiedy także przetrwaniu organizacji, charakteryzująca się niepewnością w sferze przyczyn i trudnymi do przewidzenia konsekwencjami, wymagająca podjęcia szybkich decyzji [Krzakiewicz 2008, s. 7]. Kryzys to sytuacja, w której przedsiębiorstwo nie jest w stanie osiągnąć założonych celów za pomocą własnych środków i wymaga

to oczywiście nic odkrywczego z uwagi na istnienie zarządzania ryzykiem zarówno w praktyce gospodarczej w obszarze zarządzaniu jakością, jak i teorii uwidocznionej w publikacjach i najnowszym standardzie ISO 9001:2015. Jednak stanowi to, w przekonaniu autora, podkreślenie roli zarządzania ryzykiem w zarządzaniu jakością, podczas gdy „podejście oparte na ryzyku” z normy ISO 9001:2015 wskazuje to w sposób elastyczny, że „nie ma wymagań w zakresie formalnych metod lub udokumentowanych procesów zarządzania ryzykiem” [PN-EN ISO 9001 2015-10, pkt A.4, s. 31]. 
zewnętrznej siły i osób trzecich, aby tę sytuację przezwyciężyć [Stabryła 2015, s. 516]. Jednak w przekonaniu autora nie każdy kryzys wymaga wsparcia ze strony osób trzecich czy podmiotów zewnętrznych. Jeżeli przyjąć, że kryzys jest sytuacją, w której następuje trwałe zakłócenie działalności, to właśnie trwałość zakłócenia jest elementem wymagającym przeanalizowania, co dotyczy skali tego zakłócenia oraz czasu jego trwania. To powoduje, że można skalować kryzys i dopiero wówczas należy stwierdzić, czy organizacja sama sobie z nim poradzi, czy też konieczny będzie udział osób (podmiotów) spoza organizacji. Kwestia „trwałości” kryzysu jest zagadnieniem indywidualnym dla każdej organizacji i sytuacji, dlatego można wskazać, że zarządzanie ciągłością działania jest uruchamiane, gdy incydent przechodzi w kryzys [Gołąb 2009, s. 34].

Kryzysy można klasyfikować, posługując się różnymi kryteriami ${ }^{36}$ : zdolnością przystosowania się do zmian wywołanych kryzysem, procesowym charakterem zarządzania kryzysowego, czasem ostrzegania (pomiędzy pierwszym symptomem a wystąpieniem kryzysu), przyczynami, sferą organizacji, na którą kryzys oddziałuje [Stabryła 2015, s. 518-519]. Przy definiowaniu kryzysów można również uwzględnić kryteria: tempo przebiegu i czasu trwania, miejsca powstania przyczyn, skutków, jakie kryzys wywołuje, przyczyn wywołujących kryzys [Barczak i Bartusik 2010, s.15]. Według miejsc powstawania przyczyn ${ }^{37}$ można wskazać na kryzysy w przedsiębiorstwie: wewnętrzne (np. brak elastyczności i otwartości na zmiany, niewłaściwe kompetencje pracowników) lub zewnętrzne (np. spadek popytu) [Barczak i Bartusik 2010, s.15]. Brak jednej, powszechnie akceptowanej definicji kryzysu jest związany z odnoszeniem tego terminu do różnych dziedzin życia [Stabryła 2015, s. 516]. Z kolei zarządzanie (anty)kryzysowe ${ }^{38}$ to proces, w którym przewiduje się niebezpieczeństwo kryzysu, dokonuje się analizy jego symptomów, przedsięwzięć ograniczających negatywne konsekwencje kryzysu i wykorzystuje się jego czynniki w celu kontynuacji procesu rozwoju [Krzakiewicz 2008, s. 32].

${ }^{36}$ Różnorodne klasyfikacje kryzysów zostały przedstawione m.in.. w: [Krzakiewicz 2008, s. 21-23], przegląd literatury $\mathrm{z}$ lat 1980-2006 nt. disaster management $\mathrm{w}$ : [Lettieri, Masella i Radaelli 2009, s. 117-136], typy sytuacji kryzysowych w: [Cyfert i Krzakiewicz 2010, s. 63-64], badania nad ważnością czynników zewnętrznych i wewnętrznych na wystąpienie kryzysu w przedsiębiorstwie m.in. w: [Starosta 2014, s. 607-614], strategie zarządzania antykryzysowego m.in. w: [Walas-Trębacz i Borek 2015, s. 111-129].

${ }^{37}$ Ukazanie zewnętrznych i wewnętrznych przyczyn kryzysu w organizacji m.in. w: [Staniec i Zawiła-Niedźwiecki 2015, s. 95-102].

${ }^{38}$ Ogólnie terminy ,zarządzanie kryzysowe” oraz „zarządzanie antykryzysowe” używane są jako synonimy, a drugie sformułowanie służy podkreśleniu idei działań w ramach zarządzania ryzykiem, czyli zapobiegawczego ich charakteru $\mathrm{w}$ ukierunkowaniu na niedopuszczenie do materializacji ryzyka [Zapłata i Kaźmierczak 2011, s. 47]. 
Obok zarządzana kryzysowego występuje wiele różnych terminów dotyczących sfery przewidywania i zapobiegania zakłóceniom w działalności gospodarczej [Hiles 2011, s. 98-103], ale wszystkie wkomponowują się w ogólny termin zarządzania ryzykiem. $Z$ perspektywy organizacji konieczna jest jednak identyfikacja różnorodnych elementów zarządzania ryzykiem i dobór właściwych. To oznacza dopasowanie tych elementów do specyfiki organizacji w celu wspomagania działań na różnych poziomach struktury organizacyjnej i w różnej perspektywie czasowej. Zebranie różnorodnych zagadnień dotyczących ryzyka $\mathrm{w}$ jeden zbiór $\mathrm{w}$ organizacji jest określane mianem enterprise risk management (ERM) [Hiles 2011, s. 19-20]. Takie podejście wpisuje się w tendencję, zauważalną $\mathrm{w}$ długim okresie ${ }^{39}$, łączenia zarządzania ryzykiem finansowym z ryzykiem niefinansowym pod nazwą właśnie ERM, określaną w wersji polskojęzycznej jako zintegrowane zarzadzanie ryzykiem [Staniec i Zawiła-Niedźwiecki 2015, s. 13]. Takie podejście było już sygnalizowane kilkanaście lat temu [Bizon-Górecka 2002, s. 19-26] w ramach kompleksowego systemu zarządzania ryzykiem w przedsiębiorstwie (TRM-E - total risk management in the enterprise) opartego właśnie na znormalizowanym systemie zarządzania jakością, jako fundamencie $\mathrm{w}$ budowaniu bezpiecznej kultury organizacji. Z drugiej strony niektórzy autorzy [Williams i in. 2006, s. 77] wskazują na pewną sprzeczność idei skutecznego zarządzania jakością z zarządzaniem ryzykiem. Systemowe zarządzanie jakością jest ukierunkowane na powtarzalność procesów w celu zapewnienia powtarzalnego poziomu jakościowego wyrobów i usług. Z kolei w podejściu do zarządzania ryzykiem uwzględnia się zmienności otoczenia i w głównej mierze stara się przewidywać i minimalizować materializację ry$\mathrm{zyk}^{40}$. Proces postępowania z ryzykiem jest ciągły, bowiem otoczenie organizacji jest zmienne. Jednak nieodłączną cechą wszystkich rzeczywistych systemów jest zmienność, która wprowadza do systemu niepewność. Zarządzanie powinno umieć tworzyć i uruchamiać mechanizmy ograniczania zmienności - źródła niepewności determinującej ryzyko w podejmowaniu decyzji. Zmienność w otoczeniu systemu zarządzanego przez ograniczanie zmienności wewnątrz systemu to szansa uzyskania korzyści z działań doskonalących [Lisiecka 2012a, s. 149]. Zmiany wpływają również na zarządzanie jakością. Mogą one wpływać negatywnie na powtarzalność procesów, lecz z drugiej strony stanowią przyczynek

${ }^{39}$ Historia badań nad ryzykiem została przedstawiona m.in. w: [Kaczmarek 2010, s. 29-51]. Analiza porównawcza współczesnych koncepcji zarządzania ryzykiem została ukazana m.in. w: [Staniec 2014, s. 601-606].

${ }^{40}$ Materializowanie ryzyka $=$ sytuacja spełniania się zagrożeń [Kosieradzka i Zawiła-Niedźwiecki 2016, s. 38].

Materializacja ryzyka jest terminem określającym zaistnienie w rzeczywistości zdarzenia negatywnie wpływającego na funkcjonowanie organizacji. Inne terminy związane z tym obszarem i stosowane w niniejszej pracy to m.in.: zmaterializowanie się ryzyka, zaistnienie niepożądanych zdarzeń (wydarzeń, sytuacji), zaistnienie, pojawienie się zagrożenia. 
do doskonalenia jakości. Zdaniem autora, nie można mówić o sprzeczności tych koncepcji zarządzania, raczej należy podkreślić wzajemne uzupełnianie się i poszerzanie zakresu działań z obszaru zarządzania ryzykiem na różne obszary organizacyjne. Właśnie komplementarność tych koncepcji jest widoczna w budowie najnowszej normy ISO 9001 i wkomponowaniu podejścia opartego na ryzyku do działań w obszarze zarządzania jakością. Podejście oparte na ryzyku umożliwia organizacji określenie czynników, które mogą powodować odchylenia od zaplanowanych wyników dotyczących procesów i systemu zarządzania jakością, wprowadzenie zapobiegawczych środków nadzoru, aby minimalizować negatywne skutki oraz maksymalnie wykorzystać pojawiające się szanse [PN-EN ISO 9001:2015-10, pkt 0.1, s. 5]. Wpływ zmienności i niepewności jest uzależniony od podejmowania adekwatnych działań w organizacji. Właśnie dla kształtowania efektów działań w obszarze jakościowym warto identyfikować wewnętrzne czynniki zarządzania jakością i uwzględniać, obok aspektów jakości, również i aspekty ryzyka.

Zarządzanie ryzykiem ${ }^{41}$ jest częścią składową procesu kierowania organizacją w różnych obszarach i coraz częściej zarząazanie ryzykiem uznaje się za podsystem zarządzania organizacją [Kaczmarek 2010, s. 149]. Ryzyko określone zostało jako wpływ niepewności na cele. Określenie celów pozwala na identyfikację zagrożeń i ocenę ryzyka mogącego zagrozić ich osiągnięciu [Staniec 2011, s. 37]. Oczywiście, aby mówić o skuteczności działań, konieczne jest udokumentowanie celów, aby stanowiły obiektywną podstawę oceny uzyskanych wyników. Mając to na względzie, można wskazać, że zarządzanie ryzykiem jest zbiorem działań realizowanych w organizacji cały czas, w ramach każdej decyzji. Ideą zarządzania ryzykiem jest podejście prewencyjne mające identyfikować zagrożenia i minimalizować ryzyko ${ }^{42}$. Jednak podejście ideowe do zarządzania ryzykiem miało miejsce $\mathrm{w}$ momentach zaistnienia negatywnych skutków określonego ryzyka, a bieżące zarządzanie ryzykiem zostało sprowadzone do funkcji służebnych wobec celu głównego komercyjnej działalności gospodarczej - maksymalizacji zysku [Łańcucki 2013, s. 3].

${ }^{41}$ Zagadnienia zarządzania ryzykiem są bardzo rozległe, a na potrzeby niniejszej pracy analiza tego obszaru zarządzania w organizacji została ukierunkowana na uwzględnienie elementów związanych z jakością, minimalizacją zagrożeń oraz maksymalizacją wykorzystywania szans w realizacji celów dotyczących jakości. Warto jednak zasygnalizować i mieć na uwadze, że:

- zarządzanie ryzykiem ma swoje źródło w ochronie ubezpieczeniowej [Wieteska 2011, s. 11],

- wytyczne, zasady i akty prawne z zakresu zarządzania ryzykiem regulują działalność w szczególności w obszarach finansowo-ubezpieczeniowych [Kaczmarek i Ćwiek 2009, s. 33-48],

- koncepcje podejścia do zarządzania ryzykiem ewoluowały przez lata [Monkiewicz 2010, s. 6273].

${ }^{42}$ Więcej o rodzajach i kategoriach ryzyka m.in. w: [Hiles 2011, s. 9; Staniec 2011, ss. 18-33; Zawiła-Niedźwiecki 2013, s. 23; Staniec i Zawiła-Niedźwiecki 2015, s. 24]. 
Zarządzanie ryzykiem przenika działalność każdej organizacji w dwóch nurtach (płaszczyznach). W pierwszym, ogólnym, zarządzanie ryzykiem jest trudną do wydzielonej obserwacji częścią zarządzania bieżącego. Na tej płaszczyźnie działania zarządcze mają charakter rutynowych reakcji, których skuteczność jest tym większa, im bardziej jest rozbudowany drugi nurt zarządzania - ryzykiem operacyjnym. Drugi nurt ma charakter autonomiczny, związany wyłącznie z danym rodzajem ryzyka, jest oparty na strukturach zadaniowych bądź interwałowo. Pierwszy nurt jest oparty w większym stopniu na działaniach intuicyjnych i sytuacyjnych, a drugi jest ukierunkowany na pogłębioną analizę i wypracowywanie rozwiązań precyzyjnie odnoszących się do ryzyka [Zawiła-Niedźwiecki 2013, s. 70].

W obszarze naukowo-badawczych zainteresowań autora znajduje się drugi nurt zarządzania ryzykiem operacyjnym $\mathrm{w}$ ramach projakościowego zarządzania w organizacji. Działania gospodarcze są podejmowane każdego dnia i na bieżąco towarzyszy im ryzyko. To codzienne ryzyko określane jest mianem ryzyka operacyjnego ${ }^{43}$ i definiuje się je jako ryzyko strat materialnych i reputacyjnych oraz odpowiedzialności prawnej wynikającej z niedostosowania lub zawodności procesów i niezbędnych dla nich zasobów (osobowych, materialnych, informacyjnych i finansowych) powstających w wyniku zakłóceń będących następstwem oddziaływania zagrożeń wewnętrznych i zewnętrznych [Zawiła-Niedźwiecki 2013, s. 62]. Oddziaływanie wobec zdarzeń krytycznych jako przejawów ryzyka może się odnosić do przyczyn tych zdarzeń (prewencja jako postępowanie ex ante) lub do ich skutków (terapia jako postępowanie ex post), gdzie [Zawiła-Niedźwiecki 2013, s. 85]:

- oddziaływanie na przyczyny określa się zapewnianiem bezpieczeństwa operacyjnego $\mathrm{i} \mathrm{w}$ ten nurt, zdaniem autora niniejszej monografii, wpisuje się problematyka zarządzania jakością,

- oddziaływanie na skutki to zapewnianie ciągłości działania.

Od strony organizacyjnej problematyka zarządzania ryzykiem i zapewnianiem ciągłości działania zbiega się m.in. z zarządzaniem jakością i innymi znormalizowanymi systemami zarządzania [Zawiła-Niedźwiecki 2013, s. 98].

W wyniku przeprowadzonej analizy literatury i opisanych zagadnień przybliżających kwestie projakościowego zarządzania w organizacji oraz działań organizacyjnych ukierunkowanych na zapewnienie odpowiedniej jakości w zmieniającym się otoczeniu można wskazać na kilka istotnych kwestii.

Po pierwsze, jakość zarówno od strony produktów, jak i od strony procesowej została ukazana jako element istotny w funkcjonowaniu każdej organizacji, a jednocześnie bardzo zindywidualizowany po stronie organizacji oferującej

${ }^{43}$ Więcej o ryzyku operacyjnym m.in. w: [Karkoszka 2013, s. 35; Zawiła-Niedźwiecki 2013, tabela 3.3, s. 64; Staniec i Zawiła-Niedźwiecki 2015, s. 35-50]. 
wyroby i usługi oraz kupujących. Istotę jakości ujmuje normatywna definicja, przyjęta do dalszych rozważań, która wskazuje, że jakość to stopień, w jakim zbiór inherentnych właściwości obiektu spełnia wymagania, a działania podejmowane w odniesieniu do jakości w ramach zarządzania to zarządzanie jakością określane również jako projakościowe zarządzanie w organizacji.

Po drugie, dla realizacji celów jakościowych konieczne jest odpowiednie zarządzanie jakością w organizacji. Dotyczy to trzech zagadnień. Pierwszym jest dopasowanie poziomu jakości wyrobów i usług do wymagań oraz oczekiwań klientów, co jest kwestią indywidualną nawiązującą do poszczególnych poziomów produktu. Drugie dotyczy powtarzalności jakości, czyli utrzymania właściwości wyrobów na zaplanowanym poziomie za każdym razem. Trzecie zagadnienie dotyczy ukierunkowania działań na skuteczność systemu zarządzania jakością i wymaga szczególnej uwagi z perspektywy indywidualnych celów planowanych w każdej organizacji.

Po trzecie, skuteczność systemu zarządzania jakością definiowana jako osiągnięcie celu, łączy się z sukcesem.

Po czwarte, aby zrealizować powyższe działania, konieczne jest w zarządzaniu jakością uwzględnianie czynników jakości oraz czynników zarządzania jakością. Czynniki jakości są to atrybuty wyrobów (produktów i usług), które podlegają bezpośredniej ocenie przez klientów i użytkowników. Natomiast czynniki zarządzania jakością to działania (elementy proceduralne) występujące w organizacjach i w jej otoczeniu, które są ukierunkowane na zapewnienie „odpowiedniej” jakości efektu końcowego.

Nie ma zarządzania bez zarządzania jakością i ryzykiem. Jakość wyrobów i usług stanowi priorytet $\mathrm{w}$ działaniach biznesowych $\mathrm{z}$ uwagi na istotę dla klientów i rynkowy byt organizacji. Jednocześnie jakość produktów jest wynikiem podejmowanych działań organizacyjnych, co jest związane z kształtowaniem wewnętrznych czynników zarządzania jakością. Jakość dotyczy zatem zarówno końcowego efektu działań, jak i kwestii organizacyjnych. W celu minimalizowania negatywnych skutków oraz wykorzystywania pojawiających się szans można zastosować podejście oparte na ryzyku. Podejście to jest związane z określeniem czynników, które mogą powodować odchylenia od zaplanowanych wyników dotyczących procesów projakościowego zarządzania w organizacji. Dlatego jest uzasadnione, zdaniem autora, uwzględnienie - obok aspektów jakości - aspektów ryzyka w wewnętrznych czynnikach zarządzania jakością, i spojrzenie na ich wzajemne relacje w zakresie wpływu na sukces projakościowego zarządzania $\mathrm{w}$ organizacji.

Przedstawione $\mathrm{w}$ niniejszym rozdziale pracy zagadnienia projakościowego zarządzania $\mathrm{w}$ organizacji zostaną rozwinięte $\mathrm{w}$ kolejnych rozdziałach monografii. W drugim rozdziale przedstawiono schemat i wyniki przeprowadzonej 
analizy teoretycznej z zakresu czynników zarządzania jakością w organizacji, rezultatów projakościowego zarządzania $\mathrm{w}$ organizacji oraz podejścia opartego na ryzyku. Wynikowo zidentyfikowane zostały główne wewnętrzne czynniki projakościowego zarządzania $\mathrm{w}$ organizacji wraz z elementami uszczegóławiającymi $\mathrm{w}$ aspekcie jakości oraz ryzyka. Wyniki prac analitycznych zostały uwzględnione w kwestionariuszu ankietowym i zagadnienia te objęte zostały badaniem empirycznym. 


\section{Rozdział II \\ ORGANIZACYJNE ELEMENTY SKUTECZNEGO ZARZĄDZANIA JAKOŚCIĄ}

Układ treści niniejszego rozdziału pracy odpowiada analizie literatury przedmiotu, która dotyczyła trzech obszarów: wewnętrznych czynników projakościowego zarządzania w organizacji, grupy rezultatów jako miary sukcesu zarządzania jakością w organizacji, podejścia opartego na ryzyku.

W każdym obszarze teoretycznej analizy uwzględniono ogólne zagadnienia literaturowe oraz kwestie normalizacyjne, mające praktyczne zastosowanie w organizacjach. Pierwszy z analizowanych obszarów tematycznych jest najszerszy tematycznie i z uwagi na zakres przedmiotowy niniejszego opracowania dotyczy głównie wewnętrznych czynników zarządzania jakością. Analiza czynników zarządzania jakością została przeprowadzona na podstawie przeglądu literatury, z wyszczególnieniem dorobku zagranicznych (punkt $1.1 \mathrm{w}$ niniejszym rozdziale) oraz polskich badaczy (punkt 1.2). W rezultacie opracowana została lista głównych wewnętrznych czynników zarządzania jakością (szczegółowy cel nr 1) na płaszczyźnie teoriopoznawczej i tworzących je elementów składowych (w aspekcie jakości), co stanowi kolejny szczegółowy cel pracy (nr 2). Grupy rezultatów zarządzania jakością (punkt 2 tegoż rozdziału) zostały zidentyfikowane na podstawie analizy literatury i przedstawione w sposób ogólny, bez podziału na anglojęzyczne oraz polskie publikacje, z uwagi na powiazanie tego obszaru tematycznego z kolejnym celem szczegółowym pracy (nr 3) dotyczącym identyfikacji grup rezultatów zarządzania jakością występujących w poszczególnych organizacjach. Ostatnia część niniejszego rozdziału została poświęcona zidentyfikowaniu, przez pryzmat podejścia opartego na ryzyku, elementów składowych głównych wewnętrznych czynników zarządzania jakością (cel szczegółowy nr 4 na płaszczyźnie teoriopoznawczej). Lista głównych wewnętrznych czynników zarządzania jakością w organizacji została opracowana z uwzględnieniem elementów uszczegóławiających w dwóch aspektach - jakości i ryzyka. Ideą w stworzeniu listy tychże czynników była kwestia identyfikacji kluczowych czynników, które odpowiadają na pytanie: „Na czym musimy się skupić, aby urzeczywistnić 
wizję i uzyskać satysfakcjonujące wyniki i sukces całej organizacji? Kluczowymi czynnikami sukcesu są te działania, cechy, kompetencje i umiejętności, które są postrzegane jako krytyczne (niezbędne) warunki wstępne dla sukcesu organizacji w swojej branży w danym momencie” [Niemiec 2015, s. 565]. „Do głównych metod stosowanych w identyfikacji kluczowych czynników sukcesu zalicza się: analizę literatury, metodę indywidualnych przypadków i historii sukcesu, wywiad" [Niemiec 2016, s. 66]. W niniejszej pracy przyjęto analizę literatury jako metodę identyfikacji czynników projakościowego zarządzania jakością.

Podczas kwerendy i analizy literatury wykorzystane zostały następujące bazy danych:

- anglojęzyczne: Emerald, EBSCO, ScienceDirect, SAGE Journals, ProQuest, Scopus, SpringerLink, Wiley Online Library;

- polskojęzyczne: Katalog BG UEP, BazEkon, BazTech, IBUK Libra.

Przy wyszukiwaniu pozycji literaturowych adekwatnych do zakresu badawczego przyjęto następujące sformułowania:

- w bazach anglojęzycznych: quality, quality management, TQM, quality management system, QMS, ISO 9001, quality factors, quality management factors, quality performance, quality results, risk, risk management, ISO 31000, quality risk, business continuity, continuity management, business continuity management system, BS 25599, ISO 22301, risk-based thinking;

- w bazach polskojęzycznych: jakość, zarządzanie jakością, TQM, system zarządzania jakością, ISO 9001, czynniki jakości, czynniki zarządzania jakością, wyniki jakości, rezultaty jakości, ryzyko, zarządzanie ryzykiem, ISO 31000, ryzyko jakości, ciągłość działania, ciągłość biznesu, ciągłość działalności, zarządzanie ciągłością, system zarządzania ciągłością działania, BS 25999, ISO 22301, podejście oparte na ryzyku.

W ramach ścieżki analitycznej zastosowano procedurę ukierunkowaną na zapoznanie się z jak najpełniejszą listą odpowiednich pozycji bibliograficznych (w bazach anglojęzycznych oraz polskich) poprzez:

- wyszukiwanie publikacji we wskazanych bazach danych przy użyciu wylistowanych sformułowań jako: słów kluczowych, słów w tytułach, słów w streszczeniach;

- po analizie poszczególnych materiałów (po uprzednim uszeregowaniu od pozycji najnowszych) poszukiwanie kolejnych, które były cytowane i do których następowały odwołania w treści, a dotyczące wskazanych sformułowań;

- wyróżnienie nazwisk autorów pozycji literaturowych powiązanych z obszarem badawczym i poszukiwanie kolejnych artykułów tychże autorów;

- uzupełnienie procedury o analizę najnowszych publikacji książkowych oraz czasopism z obszaru zarządzania dostępnych w Bibliotece Głównej UEP i poszukiwanie kolejnych cytowanych pozycji w analizowanej tematyce; 
- ostatecznie, w ramach identyfikacji szerokiego spektrum publikacji, skoncentrowane poszukiwania również na rozprawach doktorskich i habilitacyjnych, co uczyniono na dwóch płaszczyznach:

- przeanalizowanie ogólnopolskiego wykazu osób, którym nadano stopień doktora lub doktora habilitowanego (polon.nauka.gov.pl) według obszaru, dziedziny, dyscypliny, specjalności;

○ przeanalizowanie portalu, „Nauka Polska” (nauka-polska.pl) w dwóch obszarach:

- według prac badawczych (praca doktorska, praca habilitacyjna) oraz po dodaniu w kolejnych wyszukiwaniach słów kluczowych: jakość, zarządzanie jakością, zarządzanie ryzykiem, zarządzanie ciągłością działania;

- według specjalności „zarządzanie jakością” w zakładce „Ludzie nauki”.

W ramach zastosowanych metod badawczych można wskazać na:

- metodę analizy i krytyki piśmiennictwa, która została zastosowana w punkcie 1 niniejszego rozdziału, w obszarze identyfikacji dotychczasowych badań literaturowych, jako tło dla ukazania oryginalności podjętego do badań problemu badawczego;

- metodę analizy i konstrukcji logicznej, która została zastosowana w analizie elementów składowych ujętych w problemie naukowym, oraz syntezy, jako połączenia analizowanych elementów w nową całość.

Powyższa procedura analityczna prezentuje schemat działań, jednak w praktyce poszczególne etapy były realizowane naprzemiennie w trakcie zapoznawania się z poszczególnymi publikacjami, zagłębiania się $\mathrm{w}$ problematykę zarządzania jakością oraz tworzenia kolejnych przybliżeń prezentacji wyników analizy.

\section{Wewnętrzne czynniki sukcesu zarządzania jakością}

W pierwszym rozdziale pracy termin „czynniki zarządzania jakością” został zdefiniowany jako działania (elementy proceduralne) występujące w organizacjach i w otoczeniu, które są ukierunkowane na zapewnienie „odpowiedniej” jakości końcowego produktu. Wskazane zostało również, że czynniki zarządzania jakością mogą być zewnętrzne i wewnętrzne. Pierwsze mają swoje źródło w otoczeniu organizacji, drugie - jako czynniki wewnątrzorganizacyjne - mają swoje źródło w samej organizacji. Jednocześnie analizę skoncentrowano na identyfikacji czynników zarządzania jakością, ze wskazaniem na ich wewnętrzny charakter. Jako czynniki wewnętrzne można je bowiem kształtować poprzez wewnętrzne decyzje w organizacji, oddziałując wynikowo na sukces projakościowego zarządzania w organizacji. 
Klasyczny sposób definiowania sukcesu odnoszony do każdego człowieka sprowadza sukces do rezultatu określonego działania na najwyższym poziomie możliwości danej jednostki, oznaczając osiągnięcie zamierzonego stanu w założonym czasie [Garbarski 2016, s. 58]. Różnorodność charakterów ludzi, hierarchii wartości oraz doświadczeń oznacza, że sukces może być postrzegany w różny sposób. Kategoria sukcesu może być również rozpatrywana w odniesieniu do działań organizacji. W tym kontekście osiąganie sukcesu może być rozpatrywane w wielu różnych wymiarach [Garbarski 2016, s. 59], np. w wymiarze sukcesu finansowego, rynkowego, wizerunkowego czy wręcz sukcesu marketingowego. Sukces rynkowy przedsiębiorstwa może mieć swoje źródło w różnego typu działaniach wewnętrznych, podejmowanych w odniesieniu do interakcji z otoczeniem [Garbarski 2016, s. 59]. Dlatego też czynniki sukcesu organizacji można podzielić na trzy grupy [Bieńkowska 2004, s. 155]: czynniki związane z osobą przedsiębiorcy, czynniki związane z organizacją, czynniki zewnętrzne zawierające element niepewności i ryzyka. Otoczenie konkurencyjne (branżowe) przedsiębiorstwa określa warunki funkcjonowania i rozwoju przedsiębiorstwa $\mathrm{w}$ danym sektorze i na danym geograficznie rynku [Gierszewska i Romanowska 2017, s. 75]. Wartość poznawcza wszystkich analiz jest uzależniona od możliwości praktycznego zastosowania tych wyników w praktyce gospodarczej i taki wymiar ma kształtowanie czynników poprzez decyzje wewnątrzorganizacyjne w celu regulowania wpływu na rezultaty projakościowego zarządzania $\mathrm{w}$ organizacji.

Przeprowadzona analiza literatury pozwala na stwierdzenie, że czynniki zarządzania jakością badane były przez lata. Wyróżnia się wiele czynników zarządzania jakością, ponieważ jakość produktów oraz procesów jest zagadnieniem występującym w każdej organizacji i tym samym okoliczności prowadzenia danej działalności, na danym terytorium, wpływają na ich rodzaj (liczebność) oraz hierarchizację według stopnia oddziaływania na rezultaty działań. W 1989 roku został opublikowany pierwszy artykuł [Saraph, Benson i Schroeder 1989] przedstawiający analizę elementów składowych zarządzania jakością przez pryzmat czynników wpływających na kompleksowe zarządzanie jakością. Już w tym miejscu, przed zaprezentowaniem wyników analizy, można stwierdzić, że w literaturze przedmiotu od wskazanego czasu do obecnego dnia nie można zidentyfikować przełomowych zmian odnośnie do metodyki identyfikacji czynników wpływających na zarządzanie jakością. Zasadniczo składowe elementy zarządzania jakością są do siebie zbliżone, niezależnie od podstaw i zakresu działań w obszarze zarządzania jakością. Dlatego też czynniki zarządzania jakością są do siebie podobne. Czy jest zatem zasadne identyfikowanie i analizowanie czynników wewnętrznych wpływających na sukces zarządzania jakością? Odpowiedź autora niniejszej monografii jest w pełni twierdząca. Zakres zarządzania jakością jest zasadniczo stały, zatem i analiza czynników wewnętrznych 
pozostaje niezmienna co do grup - czyli zbioru głównych czynników wewnętrznych. Zmianie natomiast ulega ich ważność, wynikająca $\mathrm{z}$ indywidualnego (w poszczególnych organizacjach, branżach, obszarach terytorialnych) wpływu na różne aspekty zarządzania jakością, co jest widoczne w publikacjach. Jednocześnie zmianie ulega zakres głównych czynników, a dokładniej elementy składowe opisujące i uszczegóławiające główne czynniki wewnętrzne. Te zmiany wynikają z dostosowywania działań w każdej organizacji do zmieniających się okoliczności gospodarowania. I właśnie tutaj jest, zdaniem autora niniejszej pracy, miejsce na wypełnienie luki badawczej dotyczącej wzbogacenia wewnętrznych czynników projakościowego zarządzania w organizacji poprzez uwzględnienie elementów składowych poszczególnych czynników o aspekty ryzyka. Skoro właśnie widoczna jest zmienność elementów składowych, to i obecnie zasadne jest ich uzupełnienie o działania podejmowane w praktyce przez organizacje, a mające znaczenie dla osiągania sukcesu zarządzania jakością, tym bardziej że organizacje na bieżąco dostosowują się do rzeczywistości i możliwości gospodarowania, zatem informacje pozyskane w badaniach empirycznych ukazują aktualny stan działań i ważność poszczególnych elementów w oddziaływaniu na sukces podejmowanych aktywności z obszaru zarządzania jakością. W tym znaczeniu kolejne badania, koncentrujące się na organizacjach w Polsce, stanowią nowość. $Z$ drugiej strony, skoro od tylu lat w literaturze światowej zagadnienia czynników sukcesu zarządzania jakością stanowią aktualny temat badań, to należy uznać, że wpływ różnorodnych czynników na rezultaty projakościowego zarządzania $\mathrm{w}$ organizacji ma cały czas praktyczny wymiar. Zdaniem autora, stanowi to przesłankę do podjęcia tej tematyki, ponieważ zarządzanie jakością jako zbiór działań realizowanych w każdej organizacji jest dopasowywany do zmieniających się okoliczności, powiązanych ze zmianą otoczenia oraz warunków gospodarowania. Zatem szereg publikacji na temat kompleksowego zarządzania jakością i czynników sukcesu działań z tego obszaru obrazuje duże znaczenie zarządzania jakością i elementów, na które należy zwracać uwagę i które należy wewnątrzorganizacyjnie moderować na rzecz sukcesu zarządzania jakością.

W literaturze przedmiotu pojawia się wiele sformułowań związanych z elementami konstytuującymi ${ }^{44}$ zarządzanie jakością $\mathrm{w}$ organizacji, na które trzeba zwrócić uwagę przy uzyskiwaniu pożądanych efektów podejmowanych działań. Często pojawia się termin CSF (critical success factors - krytyczne czynni-

${ }^{44}$ W 2014 roku opublikowana została książka pt. Niematerialne czynniki konstytuujące systemy zarządzania [Hawrysz 2014b], która wskazuje na to sformułowanie w kontekście poziomu czynników jako elementów w organizacji. Autor niniejszej pracy używa tego sformułowania również w kolejnym poziomie analizy czynników zarządzania jakością, czyli ich konstytuowania elementami składowymi, czyli uszczegółowieniami, które w pracy są rozważane w aspekcie jakości i ryzyka. 
ki sukcesu) definiowane jako kluczowe [Kutlu i Kadaifci 2014], decydujące, istotne elementy, które wymagają analizy i kategoryzacji (grupowania) w celu zapewnienia skutecznego zarządzania jakością [Oakland 1995]. Kluczowe czynniki sukcesu mogą być również zdefiniowane jako krytyczne obszary, w których organizacja musi podjąć działania w celu oceny ich wpływu [Oakland 1995]. Czynniki wskazywane są również jako elementy wpływające na wzrost jakości [Chin i in. 2002] bądź kluczowe elementy zawarte w skutecznym kompleksowym zarządzaniu jakością (TQM) [Kutlu i Kadaifci 2014, s. 562]. Krytyczne czynniki sukcesu są również wskazywane jako najlepsze praktyki [Hassan i in. 2012; Hietschold, Reinhardt i Gurtner 2014], aktywatory bądź klucze prowadzące do sukcesu organizacji [Sila i Ebrahimpour 2002]. Krytyczne czynniki sukcesu stanowią początkowe dane wejściowe $\mathrm{w}$ działaniach $\mathrm{z}$ zakresu zarządzania jakością, które oddziałują na funkcjonowanie i rezultaty zarządzania jakością w ważny, istotny, krytyczny sposób [Salaheldin 2009]. Pomimo wielu czynników, które wpływają w każdej organizacji na wyniki zarządzania jakością, można wskazać na te najczęściej występujące, co jest widoczne w literaturze przedmiotu i wynika z roli systemów zarządzania. Celem systemów zarządzania jest wsparcie organizacji $\mathrm{w}$ dostosowywaniu się do zmieniających się potrzeb i oczekiwań klientów i pomocne są w tym czynniki bezpośrednie, powiązane ze skutecznością wdrażania systemów zarządzania jakością, a w literaturze przedmiotu nazywane właśnie kluczowymi czynnikami sukcesu [Hawrysz 2014a, s. 35].

Analizując różnorodne podejścia do wskazywanych zagadnień, można uznać, że krytyczne czynniki sukcesu stanowią ramy dla kompleksowego zarządzania jakością (TQM) nawiązujące do krytycznych obszarów, na które konieczny jest nacisk w celu osiągnięcia sukcesu [Fatemi, Wei i Moayeryfard 2016]. Istnieje wiele różnorodnych czynników, które wpływają na sukces bądź porażkę działań z zakresu zarządzania jakością [Salaheldin 2009].

Mając na uwadze problematykę zarządzania jakością w praktyce gospodarczej oraz różnorodność podejść do nazewnictwa na płaszczyźnie teoretycznej, autor niniejszej pracy przyjął po analizach, że czynniki główne to zbiory elementów uszczegóławiających dany czynnik, tematycznie powiązanych w danym obszarze. Główne wewnętrzne czynniki zarządzania jakością to te, które mają swoje źródło w organizacji i tym samym można je kształtować poprzez wewnętrzne decyzje w ukierunkowaniu na sukces zarządzania jakością.

Nie sposób jednak pominąć różnorodności analizowanych pojęć i tym samym nie stosować nazw używanych przez lata. W literaturze pojawiają się terminy czynników wpływających, oddziałujących, kształtujących, determinujących różne aspekty zarządzania jakością. W ramach różnych aspektów zarządzania jakością można zwrócić uwagę na: funkcjonowanie tego obszaru, wdrożenie (implementację) systemu zarządzania jakością i jego późniejsze funkcjonowanie oraz 
sukces, w tym skuteczność zarządzania jakością. Różnorodność pojęć na płaszczyźnie teoretycznej w analizowanej materii zarządzania jakością ma wspólny mianownik - cel zarządzania jakością, jakim jest realizacja działań na rzecz zapewnienia powtarzalnej jakości (utrzymania za każdym razem właściwości produktów na zaplanowanym poziomie). Autor skoncentrował swoje rozważania na zagadnieniach wpływu wewnętrznych czynników na sukces projakościowego zarządzania $\mathrm{w}$ organizacji przy uwzględnieniu różnorodności pojęć, w świetle powyżej wskazanego celu zarządzania jakością.

\subsection{Stan dotychczasowych badań na świecie}

Dla uściślenia stosowanych terminów konieczne jest przejście do szczegółowych analiz teoretycznych. Pierwsze zagadnienie wymagające ustalenia to pytanie, jaką przyjąć ścieżkę analityczną dla zidentyfikowania listy głównych czynników wewnętrznych zarządzania jakością, która w dalszej kolejności zostanie uzupełniona o elementy konstytuujące poszczególne główne wewnętrzne czynniki zarządzania jakością.

Po analizie różnorodnych materiałów z obszaru czynników zarządzania jakością można wskazać, że główne czynniki wewnętrzne wpływające na rezultaty zarządzania jakością są do siebie podobne, niezależnie od przyjętego źródła ich identyfikacji [Tarí 2005]. W ramach tych najczęściej wskazywanych czynników zarządzania jakością istnieje generalnie grupa czynników, które pojawiają się zawsze w badaniach (z ewentualnymi drobnymi modyfikacjami nazw), jak również dodatkowe. W celu zidentyfikowania jak najpełniejszej listy głównych wewnętrznych czynników zarządzania jakością dokonano w pierwszej kolejności analizy literatury anglojęzycznej, a następnie uzupełniono publikacjami polskojęzycznymi.

Rozwój analiz z zakresu zarządzania jakością w organizacji w kontekście czynników w tym obszarze zarządzania został zapoczątkowany w 1989 roku artykułem An instrument for measuring the critical factors of quality management [Saraph, Benson i Schroeder 1989], który jest wskazywany w późniejszych publikacjach jako pierwszy poruszający sferę czynników w zarządzaniu jakością. Następnie publikowano w literaturze anglojęzycznej szereg materiałów z tego zakresu. Po analizie fragmentu literatury dotyczącego właśnie zagadnień czynników wpływających na różne aspekty projakościowego zarząazzania w organizacji autor niniejszej publikacji wskazałby na dwa typy publikacji. Pierwszy stanowi przeglądowe artykuły teoretyczne oraz praktyczne badania poprzedzone analizą literatury. Ich główną ideą jest pokazanie dotychczasowych badań, opracowanie listy czynników wpływających na różne aspekty zarządzania jakością i poddawanie ich badaniom empirycznym w różnorodnych podmiotowo 
i terytorialnie próbach badawczych. Druga grupa publikacji to artykuły wskazujące na odbiegające od dotychczasowych podejścia do kwestii czynników zarządzania jakością, w których przedstawiono szczegółowe analizy dotyczące grupowania czynników oraz ukazywania zależności przyczynowo-skutkowych pomiędzy samymi czynnikami.

Wyniki analizy literatury anglojęzycznej zostały zaprezentowane $\mathrm{w}$ tabeli 1, w której ujęto artykuły odnoszące się do wieloletnich badań, od pierwszego artykułu [Saraph, Benson i Schroeder 1989] aż do czasów obecnych. Dane dotyczące czynników zarządzania jakością z lat 1989-2000 zostały opublikowane w 2002 roku w artykule [Sila i Ebrahimpour 2002] często przywoływanym w późniejszych publikacjach. W materiale tym została przedstawiona lista 25 czynników (kolumna A w tabeli 1) wpływających na różne aspekty zarządzania jakością, którą opracowano na podstawie przeanalizowania 347 badań z tego obszaru zarządzania w organizacji. Od 2006 roku dostępny jest artykuł [Karuppusami i Gandhinathan 2006], w którym autorzy objęli badaniem liczne materiały z zakresu czynników zarządzania jakością z lat 1989-2003 i zastosowali analizę Pareto-Lorenza w celu wyłonienia wąskiej grupy czynników w największym stopniu odpowiadających za rezultaty zarządzania jakością (kolumna B w tabeli 1). W rezultacie autorzy zidentyfikowali łącznie 56 czynników zarządzania jakością i wyłonili spośród nich 14 najczęściej występujących (25\%). Kolejny artykuł (wskazany w kolumnie C tabeli 1) prezentował dłuższy okres analizy od poprzednich, bowiem dokonano w nim prezentacji dorobku literatury z okresu 18 lat. W ramach tej publikacji [Kutlu i Kadaifci 2014] zidentyfikowano występowanie w literaturze 18 czynników zarządzania jakością i wynikowo wskazano na 9 czynników mających silny wpływ na rezultaty zarządzania jakością, dodatkowo wskazując na dwa najistotniejsze. W tym artykule autorzy podkreślili, że jako pierwsi podjęli się tematu analizy interakcji pomiędzy czynnikami ${ }^{45}$ zarządzania jakością i stąd ukazanie dwóch najistotniejszych, które mają decydujące oddziaływanie na pozostałe. W analizowanej grupie artykułów (kolumna D w tabeli 1) można jeszcze umiejscowić pozycję [Hassan $\mathrm{i}$ in. 2012], która prezentuje analizy z zakresu czynników zarządzania jakością z lat późniejszych niż ww., bowiem z okresu 2001-2012. W tym artykule odniesiono się szczegółowo do 21 badań z zakresu elementów zarządzania jakością, identyfikując 12 czynników i wyróżniając spośród nich siedem najczęściej występujących. Jako ostatni artykuł z analizy (kolumna E w tabeli 1) ujęty został artykuł [Kharub i Sharma 2016] zawierający wyniki przeglądu artykułów do 2015 roku.

Przyjęty tryb analizy literatury anglojęzycznej został skoncentrowany na zapewnieniu pokrycia czasowego dla publikowanych informacji o czynnikach

${ }^{45}$ Jednak po analizie anglojęzycznej literatury przedmiotu można wskazać na dwa artykuły [Singh 2011; Tritos, Pei-Lee i Dotun 2013] opublikowane wcześniej od powyższego, które nawiązywały już do tych zależności. 
zarządzania jakością. Analiza nie była konkretnie ukierunkowana na poszukiwanie tylko wewnętrznych czynników zarządzania jakością, jednak można zwrócić uwagę, że charakter publikowanych czynników jest właśnie wewnątrzorganizacyjny. Wydaje się to naturalne $\mathrm{z}$ uwagi na poszukiwanie przez organizacje informacji o elementach działań gospodarczych, które można regulować własnymi decyzjami w ukierunkowaniu na sukces projakościowego zarządzania w organizacji.

Z uwagi na poszukiwanie „kluczowych” czynników wewnętrznych zarządzania jakością w organizacji zastosowanym kryterium identyfikacji była częstotliwość i powtarzalność ich występowania w badaniach opisywanych w literaturze.

Czynniki zarządzania jakością wskazywane w literaturze przedmiotu zostały przeanalizowane z perspektywy ich zmian (aktualności) w czasie. Po przestudiowaniu wskazanych w tabeli 1 artykułów przyjęto własną listę głównych czynników wewnętrznych zarządzania jakością (kolumna F tabeli 1), przeznaczoną do dalszych rozważań. Podczas analizy wskazano w niektórych wierszach „TAK” oraz „NIE”, co oznacza, że dane pozycje zostały uwzględnione bądź nieuwzględnione we własnej liście głównych czynników zarządzania jakością.

W ramach selekcji zidentyfikowanych literaturowo czynników projakościowego zarządzania $\mathrm{w}$ organizacji dokonano:

- oceny przynależności danego zagadnienia do zakresu zarządzania jakością, według kryterium składowych koncepcji zarządzania jakością przedstawionych w I rozdziale monografii;

- oceny adekwatności do zakresu podmiotowego według kryterium rodzaju działalności autoryzowanych salonów sprzedaży i serwisu samochodów osobowych w Polsce (np. projektowanie wyrobów);

- zaszeregowania czynników jako wewnętrzne według kryterium możliwości oddziaływania na poszczególne czynniki decyzjami wewnątrzorganizacyjnymi.

Następujących elementów nie uwzględniono jako główne czynniki wewnętrzne (zaznaczając w tabeli 1, w kolumnie F „NIE”):

1. Odpowiedzialność społeczna, jako szeroka koncepcja zarządzania, łącząca się również z zagadnieniami zarządzania jakością i wyłączona z zakresu niniejszej monografii.

2. Benchmarking, jako zagadnienie porównywania swoich działań do innych. Nie jest to element zakresu przedmiotowego pracy, chociaż można wskazać na zagadnienia sieciowości w próbie do badań empirycznych. Salony samochodowe działające $\mathrm{w}$ ramach autoryzacji powinny spełniać wymagania autoryzacyjne i podlegają okresowej weryfikacji przez importera. Jednak to porównywanie ma miejsce właśnie na poziomie podmiotu nadającego autoryzację i dotyczy raczej kwestii wyników i porównywalności poszczególnych 


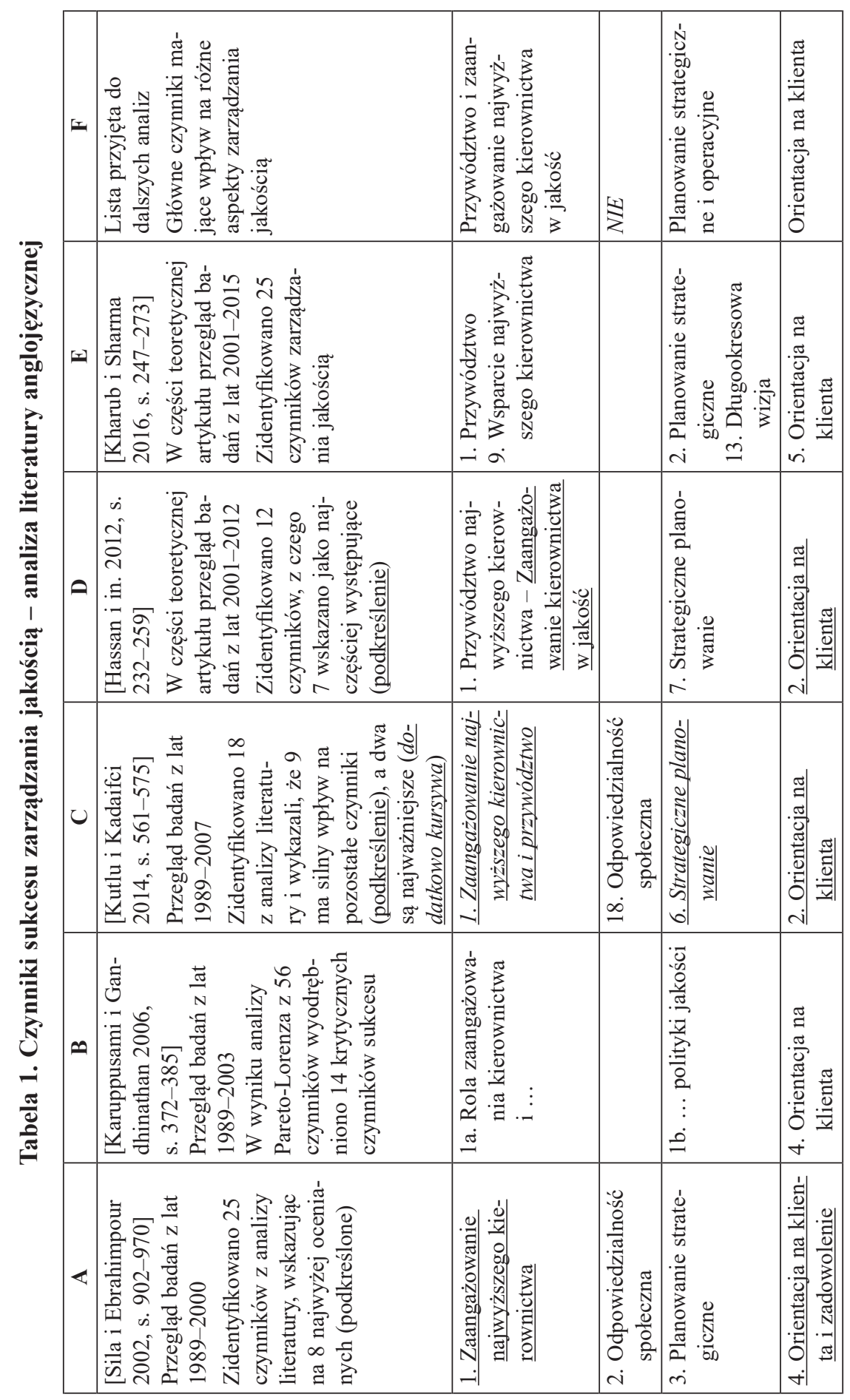

[54] 


\begin{tabular}{|c|c|c|c|c|c|c|c|}
\hline 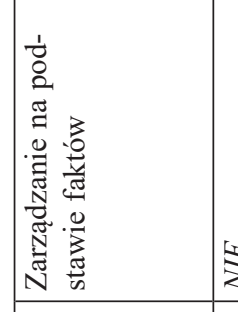 & 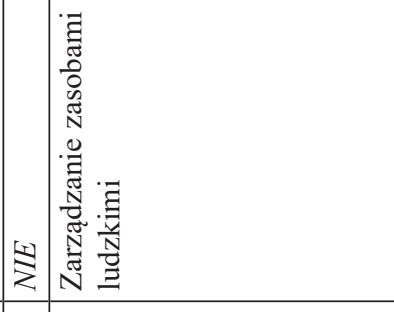 & $\mathbb{\sharp}$ & 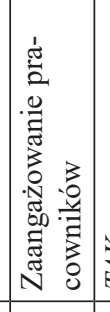 & İ & ঊ & $\mathbb{\sharp}$ & 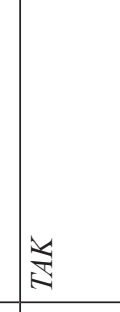 \\
\hline 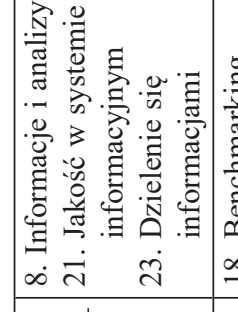 & 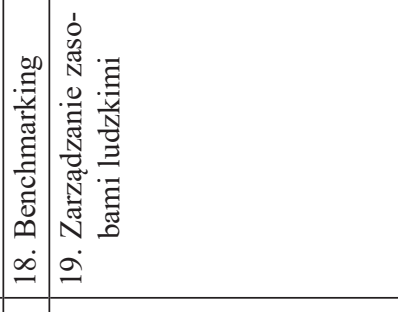 & 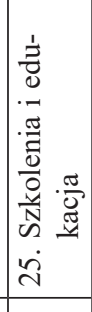 & 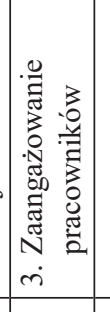 & & & & 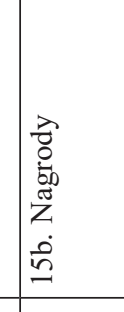 \\
\hline 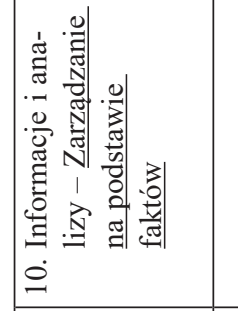 & 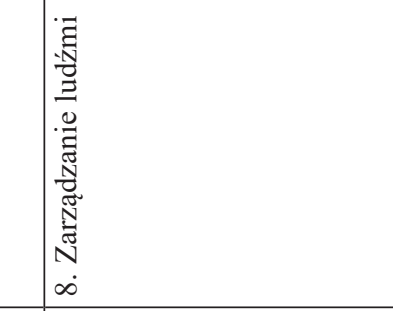 & 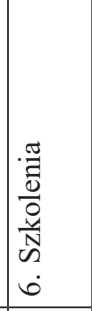 & 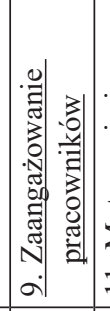 & 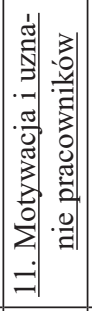 & & 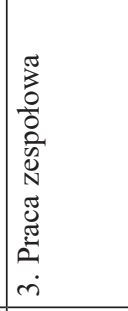 & \\
\hline 㺃 & 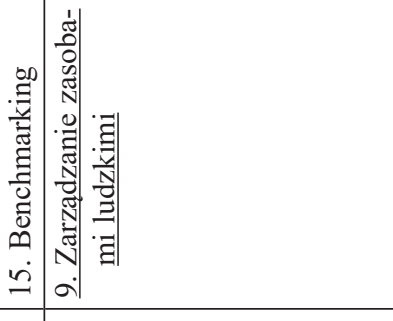 & 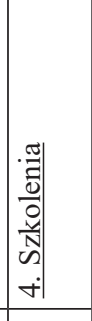 & 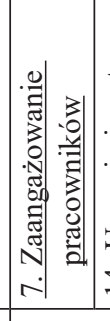 & 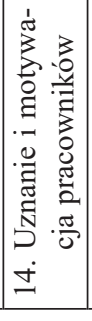 & 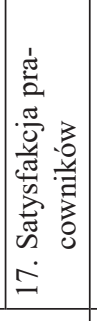 & 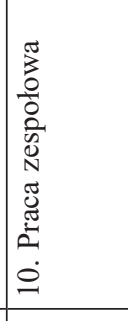 & \\
\hline 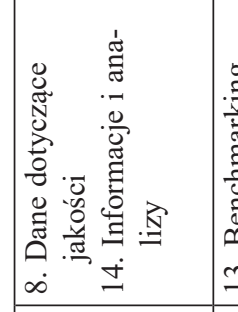 & 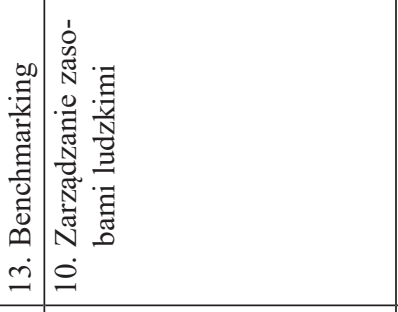 & 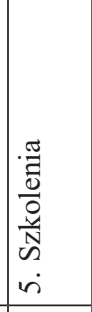 & 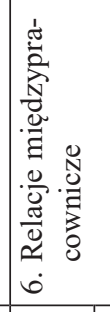 & & & 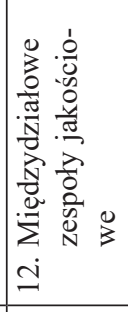 & 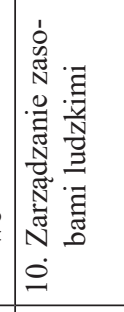 \\
\hline 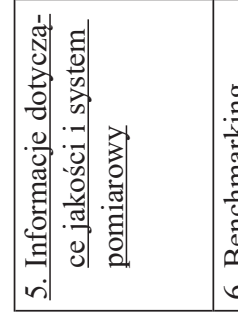 & 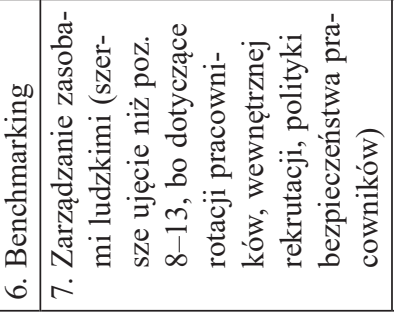 & 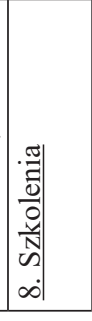 & 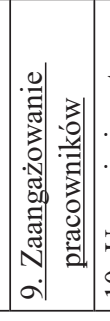 & 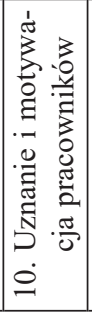 & 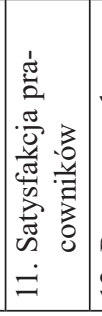 & $\mid$ & 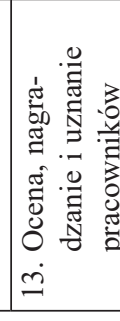 \\
\hline
\end{tabular}




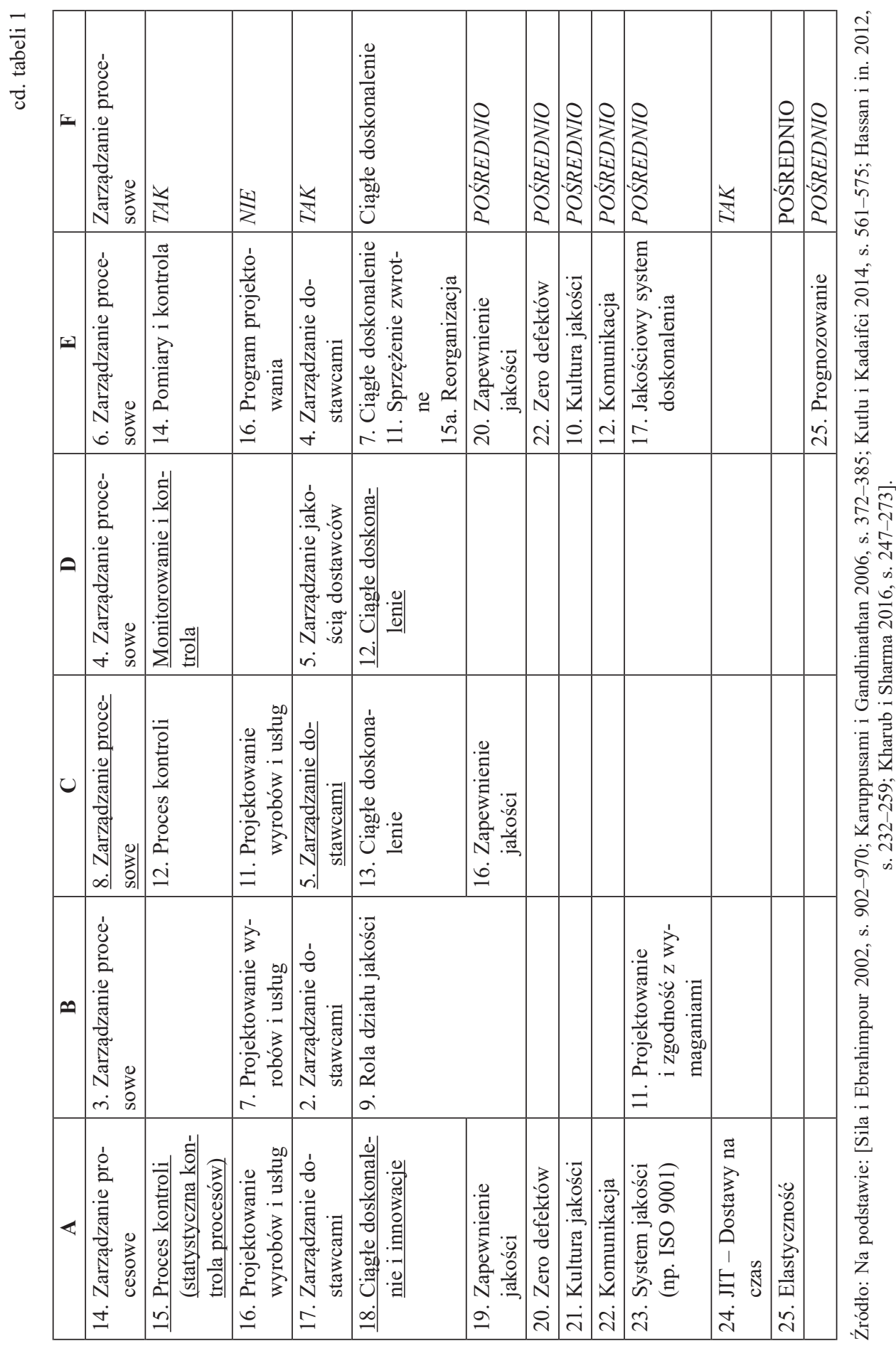

[56] 
lokalizacji w sieci salonów danej marki aniżeli poszczególnych salonów do innych.

3. Projektowanie wyrobów i usług. W perspektywie próby badawczej projektowanie wyrobów nie ma miejsca, ponieważ jest to zakres działalności producentów samochodów. Projektowanie usług zasadniczo również nie ma miejsca w salonach sprzedaży i serwisu samochodów osobowych, ponieważ zakres autoryzacji jest ustalony umownie pomiędzy daną organizacją a przedstawicielem producenta (określanym najczęściej jako importer).

Dla elementów wskazanych jako uwzględnione, ale nie jako główny czynnik zarządzania jakością, lecz jako element uszczegóławiający, przypisano „TAK”:

1. W ramach „Zarząadzania zasobami ludzkimi” oraz „Zaangażowanie pracowników" uwzględniono elementy: szkolenia ( $\mathrm{nr} 8 \mathrm{w}$ kolumnie A), uznanie i motywacja pracowników (10A), satysfakcja pracowników (11A), praca zespołowa (12A), Ocena, nagradzanie i uznanie pracowników (13A).

2. Tematyka monitorowania i kontrolna (15A) została uwzględniona w ramach elementów uszczegóławiających głównego czynnika wewnętrznego „Zarządzanie na podstawie faktów".

3. Zagadnienia terminowości dostaw (24A) zostały uwzględnione w ramach „Zarządzania procesowego”.

Siedmiu czynnikom (wskazanych w kolumnie A tabeli 1) przypisano w ostatniej kolumnie oznaczenie „POŚREDNIO”. Są to elementy stanowiące zagadnienia ogólne i przenikające różnorodne działania gospodarcze:

- zapewnienie jakości (19A) wraz z systemem jakości (23A) - zagadnienia wpisujące się w ogólną ideę systemowego zarządzania jakością, co w badaniu empirycznym zostało uwzględnione, lecz nie jako czynnik, a uwarunkowanie (poprzez pytanie respondentów o posiadanie certyfikowanego systemu zarządzania jakością);

- zero defektów (20A), kultura jakości (21A), komunikacja (22A), elastyczność (25A) wraz z prognozowaniem (numer 25, w kolumnie E analizowanej tabeli) - elementy występujące w każdym z poszczególnych głównych czynników wewnętrznych, a jednocześnie dotyczące działań w całej organizacji.

Analizując różnorodne pozycje literatury anglojęzycznej dotyczące analizowanej tematyki, można dostrzec podobieństwo komponentów zarządzania jakością [Talib, Rahman i Qureshi 2011; Mosadeghrad 2014]. Generalnie lista czynników zarząazzania jakością nie zmienia się w czasie. Jest to naturalne z uwagi na cel zarządzania jakością, jakim jest spełnienie różnorodnych wymagań w celu oferowania klientom wyrobów i usług na powtarzalnym poziomie jakościowym. W anglojęzycznej literaturze przedmiotu zauważalne jest uszczegóławianie badań dotyczących czynników zarządzania jakością po 2009 roku. Pierwszym artykułem wyróżniającym się takim podejściem była pozycja z 2009 roku [Salahedin 2009], w której oprócz tradycyjnej analizy ważności czynników 
zgrupowano czynniki zarządzania jakością w większe zbiory. Z kolei w 2011 roku został opublikowany artykuł [Singh 2011], w którym stworzono klastry czynników według ich ważności i autonomiczności w oddziaływaniu pomiędzy sobą. Czynnik „Zaangażowanie najwyższego kierownictwa” zidentyfikowany został jako niezależny od innych (autonomiczny), a jednocześnie mający największą siłę oddziaływania na pozostałe czynniki. Z kolei czynniki „Zadowolenie klientów” oraz „Jakość produktów” zostały wskazane jako dwa czynniki bardzo zależne od pozostałych, a jednocześnie o małej sile oddziaływania na pozostałe [Singh 2011, s. 15]. Te dwa ostatnie wskazania wydają się logiczne, ponieważ jakość produktów jest efektem działań organizacyjnych odnoszących się oczywiście do materialnych elementów wykorzystywanych w procesach produkcyjnych i świadczenia usług, a w następnej kolejności wpływa to na zadowolenie klientów. Jednocześnie te dane są uwzględniane w procesie doskonalenia działań, ale przy założeniu, że działania planujemy i realizujemy w sposób ukierunkowany na osiągnięcie założonych wyników, to informacje zwrotne z rynku nie powinny wskazywać na potrzebę rewolucyjnych zmian, co tłumaczy stosunkowo niską wartość oddziaływania tych czynników na pozostałe. Wzajemne interakcje były również analizowane w ramach relacyjności czynników w publikacji z 2013 roku [Tritos, Pei-Lee i Dotun 2013]. Generalnie w ramach tych wyróżniających się pozycji literaturowych można wskazać na dwie kwestie: grupowanie czynników oraz ukazywanie interakcji pomiędzy nimi. W ramach pierwszego obszaru dokonywane są podziały czynników na „miękkie i twarde” oraz na czynniki strategiczne, taktyczne i operacyjne. W drugiej płaszczyźnie są analizowane i badane zależności pomiędzy czynnikami prowadzące do identyfikacji zależności oraz określenia ich bezpośredniego bądź pośredniego wpływu na rezultaty zarządzania jakością.

Podział na „miękkie i twarde” czynniki zarządzania jakością oraz ich pozytywny wpływ na rezultaty zarządzania jakością zaprezentowano w 2013 roku [Calvo-Mora i in. 2013]. Czynniki miękkie dotyczyły zagadnień społecznych, związane były z zachowaniami ludzi. Z kolei czynniki twarde dotyczyły zagadnień technicznych oraz działań związanych z wdrożeniem i doskonaleniem aktywności z obszaru zarządzania jakością. Przyjmując jednak, że w różnych pozycjach literatury czynniki zarządzania jakością są synonimem elementów, składowych, praktyk w zarządzaniu jakością, trzeba by wskazać na artykuły, które już dokonywały wcześniej takich podziałów zagadnień zarządzania jakością [Wilkinson 1992; Black and Porter 1996; Prajogo i McDermott 2005; Bou-Llusar $i$ in. 2009]. Jednak w cytowanym materiale [Calvo-Mora $i$ in. 2013] różnicowanie czynników na miękkie i twarde nastąpiło na podstawie analizy literatury, bez badań empirycznych, a takie podejście już wcześniej było przedstawiane jako niejednoznaczne z uwagi na nieostre kryteria podziału [Zairi i Alsughayir 2011]. Istotniejsze z praktycznego punktu widzenia jest uszeregowanie 
czynników od najsilniej wpływających na rezultaty zarządzania jakością, a nie dokonywanie podziałów czynników na miękkie i twarde czy też inne grupy. Aczkolwiek wartość poznawcza wszystkich analiz jest uzależniona od możliwości praktycznego zastosowania tych wyników w praktyce gospodarczej i, zgodnie z ideą, kształtowania czynników poprzez wewnętrzne decyzje w celu regulowania wpływu na wyniki organizacji.

Podział na czynniki strategiczne, taktyczne i operacyjne można zidentyfikować w różnych artykułach [Salaheldin 2009; Kharub i Sharma 2016]. Podział ten odzwierciedla wpływ poszczególnych czynników na wyniki zarządzania jakością, bowiem podziały zostały dokonane w efekcie przeprowadzonych badań empirycznych.

Czynniki strategiczne to te, które są szerokie w swojej naturze (można w nich wskazać wiele elementów uszczegóławiających) i wpływają w długim okresie na skuteczność organizacji. Jednocześnie czynniki strategiczne wymagają zmiany w sposobie prowadzenia biznesu i są to czynniki dominujące i odgrywające kluczową rolę w trwałym sukcesie zarządzania jakością [Turban, McLean i Wetherbe 1999]. W tym kontekście można wyróżnić: zaangażowanie najwyższego kierownictwa, kulturę organizacyjną i politykę jakości, przywództwo, ciągłe doskonalenie.

Czynniki taktyczne mają mniej krytyczny wpływ od strategicznych na rezultaty zarządzania jakością. Jednak znaczenie tych czynników jest istotne, ponieważ wspomagają metody oraz aktywności, dzięki którym osiągane są oczekiwane korzyści z podejmowania zaplanowanych działań z obszaru kompleksowego zarządzania jakością. Są to zatem czynniki, które wpływają na decyzje podejmowane przez menedżerów średniego szczebla zarządczego [Turban, McLean i Wetherbe 1999] i można tutaj wskazać na: zaangażowanie i motywowanie pracowników, pracę zespołową (w ukierunkowaniu na rozwiązywanie problemów), korzystanie z technologii w celu analizowania danych jakościowych, zarządzanie jakością dostaw, relacje z dostawcami.

Czynniki operacyjne są najmniej krytyczne we wpływie na długookresową skuteczność działań z obszaru zarządzania jakością, niemniej jednak w bieżącym funkcjonowaniu mają bezpośredni wpływ na efekt w postaci wyrobów i usług [Turban, McLean i Wetherbe 1999]. W tej grupie znajdują się elementy, które tworzą właśnie dostrzegalne rezultaty w krótkim okresie, takie jak: projektowanie wyrobów i usług, proces kontroli, zarządzanie relacjami z dostawcami, orientacja na klientów, wiedza o rynku i klientach, utrzymanie ruchu, kontrola jakości i związany z tym system pomiarowy.

Powyższy podział na czynniki strategiczne, operacyjne i taktyczne wskazuje na wagę danego czynnika we wpływie na długookresowe rezultaty zarządzania jakością. Jednocześnie ten podział uwidacznia kwestię kaskadowości oddziaływania, zgodnie ze stwierdzeniem, że czynniki strategiczne wpływają w długim 
okresie na skuteczność w organizacji, czyli oddziałują na pozostałe grupy czynników.

Główne czynniki zarządzania jakością są niezależne od branż, wielkości organizacji, lokalizacji prowadzonej działalności, co wynika z czynnościowego charakteru zarządzania jakością. Aczkolwiek można w literaturze przedmiotu zaobserwować różnicowanie wyników badań ważności czynników zarządzania jakością w zależności od branży i wielkości organizacji [Desai, Antony i Patel 2012]. Listy czynników zarządzania jakością są podobne - różnice dotyczą najczęściej ocen dokonywanych przez reprezentantów w badaniach empirycznych w danych zakresach podmiotowych (branżowych) czy terytorialnych.

Czynniki projakościowego zarządzania w organizacji zostały nazwane głównymi wewnętrznymi czynnikami wpływającymi na różne aspekty zarządzania jakością. Określenie „główne” oznacza, że są to hasła, które występują często w literaturze i wynikach badań empirycznych, a jednocześnie zawierają w sobie zakresy, które są określone elementami składowymi. W tabeli 1 (kolumna F) wskazana została lista czynników jako wynik przeglądu anglojęzycznej literatury przedmiotu. Wykaz ten został oznaczony jako „lista przyjęta do dalszych analiz", która została poddana weryfikacji w ramach dalszych badań.

\subsection{Problematyka badań w Polsce}

Analizowanie „czynników sukcesu” w polskojęzycznych bazach danych prowadzi w dużej mierze do publikacji wskazujących na kluczowe czynniki sukcesu w działalności organizacji jako całości. Koncepcja kluczowych czynników sukcesu jest integralną częścią zarządzania strategicznego [Nieżurawski, Duarte i Nieżurawska 2016, s. 245]. Na sukces organizacji wpływ ma wiele różnych czynników występujących zarówno wewnątrz danego podmiotu, jak i poza nim, w jego otoczeniu. Poszczególne czynniki sukcesu organizacji są ze sobą powiązane i nie można ich rozpatrywać w odosobnieniu. Dlatego też przyjmuje się, że o sukcesie organizacji na rynku decyduje pewien zestaw czynników współdziałających ze sobą na zasadzie synergii [Nieżurawski, Duarte i Nieżurawska 2016, s. 243]. Zarówno zagadnienia czynników sukcesu, jak i sam sukces organizacji są rozpatrywane $\mathrm{z}$ poziomu całej organizacji. Literatura przedmiotu ujmuje pojęcia sukcesu organizacji w wymiarze oceny sprawności działania, czyli badania skuteczności w osiągnięciu wyznaczonych celów oraz efektywności wykorzystywanych zasobów [Kałowski 2015, s. 520]. Ten ogólny obszar związany z sukcesem organizacji i czynnikami na niego wpływającymi tworzy bardzo szeroki zakres badawczy, wymagający podziału analitycznego. Działanie w myśl zasady wyodrębnienia z całości mniejszych obszarów jest sprawdzonym przez wieki kanonem sztuki organizatorskiej, a dobór kryteriów 
dyslokacji zasobów i działań realizacyjnych na mniejsze części pozostaje zagadnieniem ciągle aktualnym [Grajewski 2016, s. 17]. Tematyka niniejszej monografii została umiejscowiona w obszarze zarządzania jakością w organizacji. W ramach praktycznego nurtu badawczego w naukach o zarządzaniu można wskazać na podział według kryterium poziomów zarządzania: strategiczny, operacyjny, funkcjonalny. W ramach poziomu operacyjnego jedną z siedmiu subdyscyplin jest zarządzanie jakością o zakresie tematycznym: znormalizowanego systemy zarządzania, techniki i metody doskonalenia jakości produktów i procesów, rachunek kosztów jakości [Cyfert i in. 2014, s. 41-42]. Dalsza analiza koncentruje się na kwerendzie czynników projakościowego zarządzania w organizacji. Literatura polskojęzyczna dotycząca czynników zarządzania jakością nie jest tak bogata jak anglojęzyczna. Przede wszystkim należy wskazać na kwestie terytorialne. W literaturze anglojęzycznej są publikowane zagadnienia o różnych zakresach przestrzennych, a polskojęzyczna terytorialnie dotyczy najczęściej jednego kraju. Jednak różnica w dorobku piśmiennictwa nie wynika tylko z kwestii terytorialnych, lecz także z historii zarządzania jakością, która w perspektywie wolnorynkowej, ukierunkowanej na spełnienie potrzeb i oczekiwań klientów, ma dłuższy rodowód poza granicami Polski. Artykuły mające w tytule słowo „czynnik” dotyczą różnych czynników będących synonimem elementów, składowych, praktyk w zarządzaniu jakości, jak również motywów podjęcia decyzji o wdrożeniu systemu zarządzania jakością [Miara 2016]. Zasadniczo wszystkie polskojęzyczne pozycje literatury (m.in. wskazane w bibliografii niniejszej pracy) opisujące różne aspekty zarządzania jakością należy zaklasyfikować do tych traktujących właśnie o czynnikach projakościowego zarządzania w organizacji.

Jednak z perspektywy przyjętej ścieżki badawczej zaprezentowanej na początku niniejszego rozdziału konieczne jest wyszukanie pozycji ukazujących dokładnie identyfikację i podział czynników zarządzania jakością. Warto zwrócić uwagę na publikację, którą można umiejscowić pomiędzy ogólnymi materiałami a tymi dokładnie dotyczącymi czynników zarządzania jakością. Jest to publikacja opisująca zagadnienia zarządzania jakością z perspektywy zasad zarządzania jakością, stanowiących swoisty kręgosłup dla analiz wyników badawczych. Pozycja ta została opublikowana w 2011 roku [Wolniak 2011] i wskazano w niej, że brak hierarchizacji wymagań prowadzi do sytuacji, w której po przeprowadzeniu oceny poziomu dojrzałości systemu zarządzania jakością w organizacji, trudności sprawia określenie, co należy w pierwszej kolejności doskonalić, które aspekty funkcjonowania systemu zarządzania jakością wymagają szybkich działań, a którymi można się zająć w drugiej kolejności [Wolniak 2011, s. 10]. Publikacja ta została skoncentrowana na zbadaniu istotności kryteriów wykorzystywanych w procesie oceny poziomu dojrzałości systemów zarządzania jakością i ich parametryzacji właśnie w świetle zasad zarządzania 
jakością [Wolniak 2011, s. 11]. Chcąc zatem przywołać pozycje literatury, które w różnym ujęciu ukazują zagadnienia możliwe do zaklasyfikowania jako główne wewnętrzne czynniki zarządzania jakością, jak również i elementy szczegółowe tych czynników, można zasadniczo wskazać na wszystkie pozycje z obszaru zarządzania jakością. Jednak analiza została skoncentrowana właśnie na poszukiwaniu pozycji literatury dotyczących czynników zarządzania jakością w organizacji, które uwzględniono w dalszych pracach analitycznych, w ramach tworzenia list elementów uszczegóławiających poszczególne główne wewnętrzne czynniki zarządzania jakością w organizacji.

W docelowej sferze poszukiwań dorobku polskiej literatury przedmiotu warto wyróżnić trzy zwarte publikacje książkowe, porządkując ich przywołania od najbardziej aktualnych względem daty ich publikacji.

Pierwsza pozycja to monografia z 2015 roku, w której system zarządzania jakością stanowił część obszaru badawczego, obok koncepcji społecznej odpowiedzialności organizacji [Hys 2015a]. W ramach opisywania zagadnień poświęconych czynnikom procesu dyfuzji obydwu koncepcji został wskazany właśnie zbiór czynników charakterystycznych dla systemu zarządzania jakością. Czynniki te zostały pogrupowane według klucza: odpowiedzialności prawnej, ekonomiczno-finansowej, klucza społecznego oraz ekologicznego, w celu dalszych analiz porównawczych wskazanych koncepcji [Hys 2015a, s. 116-117]. Ten materiał posłużył autorowi niniejszej monografii jako element analiz dla zidentyfikowania szczegółowych elementów opisujących poszczególne główne, wewnętrzne czynniki zarządzania jakością.

W 2014 roku opublikowana została książka zatytułowana Niematerialne czynniki konstytuujące systemy zarządzania [Hawrysz 2014b]. Zgodnie z tytułem publikacji autorka skoncentrowała swoje analizy na czynnikach niematerialnych powiązanych $\mathrm{z}$ procesem wdrożenia systemu zarządzania jakością. Za cel badań przyjęto odpowiedź na pytanie: Jakie niematerialne czynniki odgrywają zasadniczą rolę w konstytuowaniu systemów zarządzania opartych na jakości w organizacjach sektora publicznego? W przywołanej monografii wskazane zostało także, że czynniki wewnętrzne wiążą się z zasobami organizacji niezbędnymi z punktu widzenia skutecznej implementacji mechanizmów projakościowych [Hawrysz 2014b, s. 8-9]. W wyniku analizy literatury autorka zidentyfikowała 99 kluczowych czynników sukcesu, które wynikają z zestawienia wybranych opracowań w tej materii [Hawrysz 2014b, tabela 6, s. 62-71]. Koncentracja treści analizowanej monografii na niematerialnych czynnikach zarządzania jakością nawiązuje do wskazanego w analizie literatury anglojęzycznej podziału na czynniki miękkie i twarde. Jednocześnie analizowana publikacja polskojęzyczna skoncentrowana została na jednostkach administracyjnych, czyli na sferze usług. 
Autorka przytoczonej monografii opublikowała dwa artykuły [Hawrysz 2014a, 2015] dotyczące tych samych zagadnień. W nowszej publikacji wskazała na najważniejsze niematerialne czynniki zarządzania jakością, do których należą: kultura organizacyjna, kadra menedżerska oraz komunikacja [Hawrysz 2015 , s. 42-52]. We wspomnianym artykule przywołano również prace dotyczące kluczowych czynników sukcesu wpływających na skuteczność wdrożenia różnych systemów zarządzania, wskazując, że w opracowaniu skoncentrowano się głównie na kluczowych czynnikach sukcesu w organizacjach usługowych, które z uwagi na charakter swojej działalności w sposób bardziej elastyczny reagują na rynkowe fluktuacje [Hawrysz 2014a, s. 35-40]. Warto zauważyć, że pod pojęciem systemu zarządzania jakością autorka przyjęła wszystkie systemy zarządzania jakością wymagające ciągłej poprawy jakości oaz podejmowania wysiłków na rzez zapewnienia wysokiej jakości wyrobów i usług, m.in: [Hawrysz 2014a, s. 36]: EFQM, TQM, Lean, ISO, Six Sigma. Zidentyfikowane czynniki uporząakowano według kryterium częstotliwości wskazań w analizowanych artykułach anglojęzycznych w siedem grup czynników: przywództwo, pracownicy, orientacja na klienta, strategia, kultura organizacyjna, komunikacja, pomiar jakości.

Ostatnia z trzech przywołanych polskich monografii została opublikowana w 2013 roku [Szczepańska 2013]. Autorka analizowała czynniki wdrożenia kompleksowego zarządzania jakością (TQM), dokonując syntezy z przeglądu badań z różnych pozycji anglojęzycznych w zakresie miękkich czynników TQM, nazywanych również czynnikami skutecznego wdrożenia TQM [Szczepańska 2013, s. 45-51]. W końcowej części rozważań zidentyfikowane czynniki przypisano do zasad zarządzania jakością [Szczepańska 2013, tab. 4.5, s. 57]. Ta pozycja została również uwzględniona w pracach ukierunkowanych na stworzenie szczegółowych opisów do poszczególnych głównych czynników wewnętrznych zarządzania jakością.

Następnym krokiem w analizie czynników wewnętrznych projakościowego zarządzania $\mathrm{w}$ organizacji była próba ich uporządkowania, pogrupowania (kategoryzacji) wynikająca z podziałów zaobserwowanych podczas analizy literatury przedmiotu, m.in. na: miękkie, twarde, strategiczne, operacyjne, taktyczne. Również wymiary strategicznej karty wyników służyły do grupowania kluczowych czynników sukcesu [Waśniewski 2016]. Kryteria możliwe do zastosowania zostały przeanalizowane w odniesieniu do Strategicznej Karty Wyników, modelu analizy SWOT, niematerialnych charakterystyk organizacji w modelu $7 \mathrm{~S}$, podziale procesów w organizacjach zakresu podmiotowego badań (w szczególności na sprzedaż i obsługę posprzedażną), kwestii ekonomiczno-finansowych poszczególnych obiektów wytypowanych do badania. Analizowana była również kwestia wymagań autoryzacyjnych dla salonów sprzedaży i serwisu samochodów osobowych w Polsce, te jednak są zróżnicowane dla poszczególnych 
marek, a koncentracja na ogólnych kategoriach (np. infrastruktura, procesy obsługi klienta) nie dodaje utylitarnych wartości w segregacji czynników. Na tym etapie teoretycznej analizy autor niniejszej pracy uznał, że istotniejsze z praktycznego punktu widzenia jest uszeregowanie czynników od najsilniej wpływających na rezultaty zarządzania jakością w organizacji, aniżeli dokonywanie podziałów czynników na grupy. Ostatecznie po analizie różnorodnych materiałów dotyczących zagadnień czynników projakościowego zarządzania w organizacji, w szczególności przywołanych trzech zwartych polskojęzycznych pozycji literaturowych, można wskazać, że rodzime pozycje literaturowe opierają się na przeglądach anglojęzycznych publikacji z zakresu czynników zarządzania jakością w organizacji. W wyniku przeprowadzonej analizy literatury przedmiotu, zarówno anglojęzycznej, jak i polskojęzycznej, przyjęto osiem grup głównych czynników wewnętrznych wpływających na sukces projakościowego zarządzania w organizacji. Są to czynniki wyszczególnione w wyniku analizy przeglądowych anglojęzycznych artykułów (kolumna F tabeli 1), które nie uległy zmianie, co do struktury, ani po analizie literatury rodzimej, ani po dalszej analizie zależności szczegółowych ${ }^{46}$. Tym samym, z uwagi na ich charakter, przyjęte zostały następujące główne wewnętrzne czynniki zarządzania jakością:

1. Przywództwo i zaangażowanie najwyższego kierownictwa w jakość.

2. Planowanie strategiczne i operacyjne.

3. Orientacja na klienta.

4. Zarządzanie na podstawie faktów.

5. Zarządzanie zasobami ludzkimi.

6. Zaangażowanie pracowników.

7. Zarządzanie procesowe.

8. Ciągłe doskonalenie.

Zidentyfikowanie głównych wewnętrznych czynników zarządzania jakością, po szczegółowej analizie literatury przedmiotu, stanowiło pierwszy teoretyczny cel pracy. Stworzenie listy ośmiu głównych wewnętrznych czynników zarządzania jakością stanowi zatem realizację założonego celu szczegółowego w obszarze teoriopoznawczym.

Reasumując, do poszczególnych głównych czynników wewnętrznych przypisano elementy składowe $\mathrm{w}$ aspekcie jakości wskazujące na podejmowane działania. Elementy te zostały ujęte czynnościowo i jednokierunkowo dla późniejszego ich przedstawienia $\mathrm{w}$ kwestionariuszu ankietowym.

${ }^{46}$ Analiza szczegółowa technicznie polegała na wypisywaniu na rozwieszonych na ścianach flipchartach elementów uszczegóławiających zidentyfikowanych w trakcie analizy poszczególnych pozycji literatury. Następowało łączenie podobnych zakresowo elementów i wynikowo przypisanie do poszczególnych głównych czynników wewnętrznych, co odbywało się etapowo i oznaczało zmiany kart, przepisywanie grup, wieszanie kolejnych i ich zapełnianie sukcesywne w czasie wraz z analizą kolejnych pozycji bibliograficznych. 
Dla czynnika wewnętrznego Przywództwo i zaangażowanie najwyższego kierownictwa w jakość wskazano na sześć elementów składowych:

1. Najwyższe kierownictwo kładzie nacisk na zagadnienia jakościowe.

2. Najwyższe kierownictwo w celach jakościowych uwzględnia trendy rynkowe.

3. Najwyższe kierownictwo demonstruje swoje zaangażowanie w jakość.

4. Najwyższe kierownictwo formalnie definiuje cele jakościowe i rozlicza $\mathrm{z}$ ich realizacji.

5. Najwyższe kierownictwo stworzyło, udokumentowało i zakomunikowało politykę jakości.

6. Najwyższe kierownictwo przeznacza wystarczające zasoby na rzecz doskonalenia jakości.

Do drugiego głównego czynnika wewnętrznego zarządzania jakością Planowanie strategiczne i operacyjne przypisano siedem elementów uszczegóławiających:

1. Cele jakościowe są planowane na poszczególnych poziomach w organizacji.

2. Cele jakościowe są mierzalne i jasno sprecyzowane.

3. Nasze cele jakościowe są w pełni dopasowane do specyfiki i zakresu naszej działalności.

4. Cele dotyczące jakości są komunikowane wszystkim pracownikom.

5. Cele są szczegółowo rozpisywane na zadania dla poszczególnych działów organizacyjnych.

6. Każdy z pracowników ma wyznaczone zadania dla realizacji zidentyfikowanych celów jakości.

7. Jakość stanowi priorytet w planowaniu celów. W ramach czynnika głównego zatytułowanego Orientacja na klienta ujętych zostało dziewięć sformułowań składających się na opis danego czynnika:

1. W działaniach najwyższego kierownictwa priorytetem są wymagania i oczekiwania klientów.

2. W działaniach każdego pracownika priorytetem są wymagania i oczekiwania klientów.

3. Aktywnie poszukujemy informacji zwrotnych od klientów.

4. Istnieje sformalizowany system identyfikacji potrzeb i oczekiwań klientów.

5. Wymagania klientów i informacje zwrotne są uwzględniane w procesie doskonalenia jakości.

6. Istnieje procedura przyjmowania uwag i reklamacji ze strony klientów.

7. W procesie obsługi klienta są uwzględniane dane $\mathrm{z}$ okresowych analiz rynku oraz konkurencji.

8. Istnieją udokumentowane procedury obsługi klientów.

9. Identyfikujemy tematy rynkowe mające wpływ na obsługę klientów. 
Czynnik czwarty Zarzązanie na podstawie faktów zawiera w sobie sześć zdań opisujących tenże czynnik w aspekcie jakości:

1. Okresowo są organizowane spotkania dotyczące analizy danych jakościowych.

2. Okresowo są przeprowadzane wewnętrzne audyty jakościowe.

3. Okresowo są przeprowadzane zewnętrzne audyty jakościowe.

4. Organizowane są doraźne spotkania w celu rozwiązywania problemów jakościowych w poszczególnych działach.

5. Organizowane są okresowe międzydziałowe spotkania na rzecz doskonalenia jakości.

6. Dane jakościowe są uwzględniane w podejmowaniu decyzji na wszystkich szczeblach organizacyjnych.

Zarzadzanie zasobami ludzkimi jest czynnikiem piątym uszczegółowionym przez pięć stwierdzeń:

1. Organizacja motywuje pracowników do działania i realizacji zdefiniowanych celów jakości.

2. Najwyższe kierownictwo organizacji zachęca i motywuje do pracy zespołowej.

3. Okresowo pracownicy biorą udział w szkoleniach z zakresu zarządzania jakością.

4. Elementy jakościowe są uwzględniane w premiowaniu pracowników.

5. Pracownicy swobodnie pozwalają sobie na wypowiadanie się o ich spojrzeniu, uwagach krytycznych i informacjach zwrotnych nt. osiąganych wyników przez organizację.

Główny czynnik zarządzania jakością Zaangażowanie pracowników zawiera następujące elementy konstytuujące:

1. Pracownicy dzielą się pomysłami i sugestiami z zakresu zarządzania jakością.

2. Pracownicy akceptują zagadnienia jakościowe jako główne wzmocnienie organizacji w osiąganiu przewagi konkurencyjnej.

3. Istnieje skuteczna komunikacja w organizacji dotycząca grupowego rozwiązywania problemów jakościowych.

Czynnik zatytułowany Zarzadzanie procesowe został opisany pięcioma elementami uszczegóławiającymi w aspekcie jakości:

1. W organizacji zostały zidentyfikowane procesy obejmujące całą działalność organizacji.

2. Działania w poszczególnych procesach zostały opisane w formie ,procedur".

3. Istniejące $w$ organizacji procedury postępowania uwzględniają aspekty jakościowe.

4. Pierwszorzędnym kryterium doboru dostawców/podwykonawców jest jakość. 
5. Budujemy długookresową współpracę ze stałymi dostawcami.

Ostatni czynnik, nazwany Ciągłe doskonalenie, został określony siedmioma składowymi elementami:

1. Kierownictwo kładzie nacisk na uwzględnianie jakości w doskonaleniu wszystkich procesów na wszystkich poziomach organizacyjnych.

2. Doskonalenie procesów jest działaniem zespołowym realizowanym pomiędzy działami w organizacji.

3. Organizacja przyjmuje ciągłe doskonalenie działań jako długookresową strategię doskonalenia jakości.

4. Identyfikujemy przyczyny niezgodności i podejmujemy działania doskonalące.

5. Okresowo dokonywana jest ocena zgodności z wymaganiami prawnymi.

6. Zmiany w organizacji są planowane i skutecznie wdrażane.

7. Priorytetem działań doskonalących jest zwiększenie zadowolenia klientów.

Za drugi szczegółowy cel pracy (na płaszczyźnie teoriopoznawczej) przyjęto zidentyfikowanie elementów konstytuujących główne wewnętrzne czynniki projakościowego zarządzania w organizacji w aspekcie jakości. Przedstawione w ośmiu poprzedzającch akapitach elementy konstytuujące poszczególne główne czynniki zarządzania jakością w organizacji stanowią efekt analizy literatury i tym samym zrealizowany został drugi teoretyczny, szczegółowy cel pracy.

Czynniki projakościowego zarządzania w organizacji oddziałują na różne rezultaty w organizacji. Kwestia określenia grup rezultatów projakościowego zarządzania w organizacji stanowi treść kolejnego punktu w niniejszym rozdziale.

\section{Rezultaty projakościowego zarządzania w organizacji}

„Definicja sukcesu jako osiągnięcie celu wskazuje na jednorazowy rezultat i nie uwzględnia perspektywy czasu, która w przypadku działalności organizacji jest niezwykle istotna, bowiem to, co dzisiaj można nazwać sukcesem, już w krótkim czasie może przestać nim być” [Grabowska i Drygas 2010, s. 515]. „Dlatego też w odniesieniu do organizacji bardziej właściwe wydaje się utożsamianie sukcesu z procesem, działaniem na najwyższym poziomie możliwości zmierzającym do realizacji wyznaczonych celów" [Majewska-Opiełka 2007].

W zależności od koncentracji działań organizacyjnych na poszczególnych wewnętrznych czynnikach zarządzania jakością uzyskiwane będą adekwatne do nich wyniki działań. Zarysowuje się zatem obszar indywidualizmu tych zagadnień $\mathrm{w}$ poszczególnych organizacjach z uwagi na planowanie dopasowanych celów dotyczących jakości, skorelowanych z posiadanymi zasobami i możliwościami wewnętrznymi organizacji. 
Kwestie subiektywizmu w rozpatrywaniu efektów zarządzania jakością w poszczególnych organizacjach zostały ukazane w pierwszym rozdziale pracy. Poruszone zostały także zagadnienia skuteczności systemu zarządzania jakością, czyli stopnia realizacji zaplanowanych celów. W ujęciu dokładnie oceniającym cele zaplanowane i udokumentowane na etapie planowania można wskazać, że wyniki tej oceny są bezpośrednio uzależnione właśnie od zaplanowanych wcześniej celów. Całość tego procesu „planowania-oceny” jest uzależniona od podejścia organizacji do oceny skuteczności - można jej dokonać w sposób obiektywny bądź subiektywny (przy definiowaniu celów np. mniej ambitnych i „z góry zdanych na sukces”). Dla zminimalizowania indywidualności w podejściu do oceny systemowego zarządzania jakością warto się opierać na analizie wpływu tych działań na rezultaty całej organizacji. Skuteczność zarządzania jakością rozumiana ogólnie, nie w odniesieniu do indywidualnych celów, lecz właśnie w perspektywie idei, odnosi się do trzech celów skutecznego zarządzania jakością [Kafetzopoulos, Psomas i Gotzmani 2015]: orientacji na zadowolenie klientów, zapobiegania niezgodnościom, ciągłego doskonalenia.

System zarządzania jakością jako podsystem zarządzania organizacją z założenia wpływa na rezultaty osiągane przez daną organizację w sposób pozytywny. Z uwagi właśnie na funkcjonowanie obok systemu zarządzania jakością również innych podsystemów (np. środowiskowego, finansowego) trudne jest wyodrębnienie $\mathrm{z}$ rezultatów funkcjonowania organizacji tylko tych osiągniętych działaniami z zakresu zarządzania jakością. Istnieje bowiem szereg różnorodnych wewnętrznych działań organizacyjnych, które wpływają na ostateczny wynik organizacji. Jednocześnie uwarunkowania zewnętrzne organizacji wpływają na te wyniki w różny sposób, zarówno na rezultaty operacyjne, jak i końcowo na wynik finansowy organizacji. Osiągane przez organizacje wyniki są determinowane przez wiele kwestii, do których należy m.in.: zakres przedmiotowy prowadzonej działalności (terytorialny czy czasowy), wewnętrzne okoliczności organizacyjne oraz interakcje $\mathrm{z}$ otoczeniem. Dlatego też porównywanie pomiędzy organizacjami nominalnych rezultatów (wyników w danej jednostce $\mathrm{w}$ danym czasie np. liczby reklamacji), bez analizy indywidualnych uwarunkowań, nie jest w pełni miarodajne (zobiektywizowane). W tym znaczeniu konieczne jest analizowanie wpływu działań na rezultaty w sposób subiektywny. Subiektywny, ponieważ oceniany przez reprezentantów organizacji, czyli osoby z jej wnętrza, co może zniekształcać rzeczywisty obraz sytuacji. Niemniej jednak w literaturze przedmiotu, przedstawiającej badania $\mathrm{z}$ obszaru zarządzania jakością właśnie takie podejście znajduje się u podstaw badań rzeczywistości gospodarczej. Pozytywny wpływ kompleksowego zarządzania jakością na działalność i rezultaty organizacji, w tym doskonalenie wyników, jest niezaprzeczalny [Huq 2005; Ronnback i Witell 2008; Mensah, Copuroglu i Fening 2012; Sampaio i in. 2012; Boulter, Bendell i Dahlgaard 2013; Psomas i Jaca 2016]. 
Zdecydowana większość autorów wskazuje na pozytywny, pośredni wpływ kompleksowego zarządzania jakością na rezultaty finansowe [Dick 2009; Shahin 2011]. Należy również pamiętać, że na rezultaty finansowe wpływ ma wiele różnych czynników i trudno wyodrębnić tylko te z podsystemu zarządzania jakością w organizacji, które decydują o wyniku finansowym. Taka tematyka jest podejmowana w badaniach [Wu i Chen 2011], gdzie autorzy analizowali wpływ zarządzania jakością na rezultaty organizacji w czterech perspektywach, zgodnie z wymiarami Strategicznej Karty Wyników ${ }^{47}$. W przywołanym artykule potwierdzono hipotezy zakładające pozytywny wpływ rezultatów ze wszystkich trzech operacyjnych perspektyw na finanse organizacji, zarówno dla organizacji posiadających certyfikowany system zarządzania jakością, jak i bez niego. Jednocześnie wskazano, że wpływ działań z zakresu zarządzania jakością jest pośredni na finansowe rezultaty organizacji właśnie poprzez rezultaty $\mathrm{w}$ perspektywach operacyjnych, które dopiero następnie oddziałują na rezultaty ze sfery finansowej [Wu i Chen 2011, s. 869]. Jednocześnie wyniki tego badania wskazały na silniejszy wpływ rezultatów z obszaru procesów wewnętrznych na finanse w organizacjach posiadających certyfikowany system zarządzania jakością, aniżeli w organizacjach nieposiadających „certyfikatu ISO 9001”. Jeżeli zarządzanie jakością wpływa pośrednio na rezultaty finansowe organizacji, to oznacza, że w sposób bezpośredni wpływa na osiąganie operacyjnych celów działalności [Baird, Jia Hu i Reeve 2011] lub inaczej ujmując, zarządzanie jakością oddziałuje bezpośrednio na wyniki dotyczące jakości produktów oraz operacyjne rezultaty, natomiast pośrednio - na biznesowe (finansowe) efekty [Kafetzopolulos, Psomas i Gotzamani 2015]. Potwierdzone to zostało zarówno na podstawie analizy literatury, jak i w badaniach wśród greckich organizacji [Ismyrlis i Moschidis 2015] - wskazano, że w obszarze jakości osiągane są cele operacyjne zarówno wewnętrzne (np. redukcja strat), jak i zewnętrzne (np. satysfakcja klientów). Stopień satysfakcji klientów stanowi jednak ostateczny efekt prowadzonych działań wewnątrz organizacji, zatem jej zewnętrzny wymiar wynika jedynie $\mathrm{z}$ faktu, że klienci zewnętrzni znajdują się $\mathrm{w}$ otoczeniu organizacji. Można również wydzielić pięć ukazywanych w literaturze przedmiotu obszarów identyfikowania rezultatów zarządzania jakością [Psomas i Kafetzopolulos 2014]:

1. Jakość wyrobów (wyniki jakościowe, zgodność ze specyfikacją, powtarzalność i niezawodność.

2. Wyniki operacyjne (produktywność, efektywność, skuteczność).

3. Zadowolenie klientów (z produktów, usług posprzedażnych, lojalność klientów).

${ }^{47}$ Przegląd efektów zarządzania jakością [Szczepańska 2013, pkt 4.2, s. 58-64] oraz korzyści z wdrożenia znormalizowanego systemu zarządzania jakością [Szczepańska 2013, s. 68-71] przedstawiono wynikowo w układzie czterech perspektyw Strategicznej Karty Wyników w: [Szczepańska 2013, s. 71]. 
4. Efekty rynkowe (wizerunek, udział w rynku, wejście na nowe rynki).

5. Rezultaty finansowe (przychody i ich zmienność, zysk, przepływy finansowe). Z kolei w 2016 roku na bazie przeglądu literatury zidentyfikowano [Jaeger i Adair 2016] pięć obszarów rezultatów zarządzania jakością: produktywność, jakość, klienci, koszty, konkurencyjność ${ }^{48}$.

Można zatem zauważyć podstawowy podział rezultatów zarządzania jakością na dwie grupy: finansowe oraz niefinansowe [Salaheldin 2009]. W odniesieniu do kwestii znormalizowanego systemu zarządzania jakością można na to spojrzeć z dwóch perspektyw. Pierwsza to porównanie rezultatów finansowych i pozafinansowych do koncepcji skuteczności i efektywności systemu zarządzania jakością. Druga to kwestia różnicowania grup rezultatów zarządzania jakością w zależności od (nie)posiadania „certyfikatu ISO 9001” wraz z powiązanymi motywami wdrożenia i certyfikacji systemu zarządzania jakością oraz zakresem działalności.

Pierwsza płaszczyzna dotyczy wskazanego już w niniejszej monografii aspektu skuteczności systemu zarządzania jakością. Z kolei efektywność systemu zarządzania jakością jest definiowana jako relacja między osiągniętymi wynikami a wykorzystanymi zasobami [PN-EN ISO 9000:2015-10, pkt 3.7.10, s. 26] ${ }^{49}$. Ocena efektywności systemu zarządzania jakością jest dobrowolna, w ramach funkcjonowania certyfikowanego systemu zarządzania jakością. Zestawiając kwestię obligatoryjnej oceny skuteczności i fakultatywnego podejścia do oceny efektywności, nie sposób nie porównać tego do bezpośredniego wpływu zarządzania jakością na rezultaty operacyjne (w aspekcie jakości) i pośredniego oddziaływania na rezultaty finansowe całej organizacji. Problematyka oceny na płaszczyźnie finansowej nie jest rozpatrywana w wymaganiach normatywnych dla systemu zarządzania jakością. W ramach znormalizowanego systemu zarządzania jakością konieczna jest ocena stopnia realizacji zaplanowanych celów, co dotyczy kwestii działań operacyjnych w ukierunkowaniu na jakość produktów. Jednak nie należy zapominać o wspomnianej problematyce indywidualizmu i możliwego subiektywizmu w ocenie skuteczności na płaszczyźnie normatywnej i odnoszenia tego do ogólnego wpływu zarządzania jakością, niezależnie od podstaw podejmowanych działań, na wyniki całej organizacji. Z perspektywy praktycznej rozważania nad skutecznością i efektywnością nie są tak pasjonujące jak na płaszczyźnie teoretycznej. W działalności gospodarczej konieczne jest generowanie zysków, w celu długookresowego funkcjonowania na rynku. W tym znaczeniu działania gospodarcze powinny być i skuteczne, i efektywne.

${ }^{48} \mathrm{~W}$ badaniach bezpośrednio ukierunkowanych na zbadanie zależności pomiędzy zarządzaniem jakością a konkurencyjnością potwierdzono pozytywną zależność w: [Elshaer i Augustyn 2016].

${ }^{49}$ Więcej o efektywności systemowego zarządzania jakością m.in. w: [Łańcucki 2004, Zapłata 2009, Kozuń-Cieślak 2013, Skrzypek 2014]. 
Potrzebę łącznej oceny skuteczności i efektywności uzasadniają między innymi związki zachodzące w obszarze pojęć: cele-efekty-nakłady. Pojęcie celu zwraca uwagę na skuteczność działania, rezultaty i nakłady dotyczą efektywności w znaczeniu ekonomicznym [Jedynak 2007, s. 74]. Skuteczne zarządzanie to takie, które z jednej strony prowadzi do realizacji celów przedsiębiorstwa, z drugiej zaś czyni to efektywnie [Borowiecki 2014, s, 84].

Druga płaszczyzna krótkich rozważań w tej części pracy dotyczy różnicowania grup rezultatów zarządzania jakością w zależności od (nie)posiadania „certyfikatu ISO 9001” wraz z powiązanymi motywami wdrożenia i certyfikacji systemu zarządzania jakością i zakresu działalności. Porównując wpływ znormalizowanego systemu zarządzania jakością na rezultaty finansowe (zwrot z aktywów, przychody ze sprzedaży) pomiędzy organizacjami posiadającymi „certyfikat ISO 9001” na terenie Portugalii, a tymi, które nie podeszły do procesu recertyfikacji systemu, po trzech latach nie wykazano znaczących różnic [Cândido, Coelho i Peixinho 2016]. Oczywiście nieprzedłużenie ważności „certyfikatu ISO 9001” oznacza, że system zarządzania jakością wcześniej funkcjonował i działania systemowe prawdopodobnie upowszechniły się w organizacji i fakt nieprzedłużenia ważności certyfikatu nie mógł wprowadzić istotnych różnić w ocenie realizacji działań. Gdyby wyniki w tym zakresie były mocno zróżnicowane, to wówczas należałoby się zastanowić nad przesłankami pierwszej certyfikacji i analizą działania konkretnej organizacji. Z kolei badania w USA wykazały istotne różnice $\mathrm{w}$ wynikach finansowych pomiędzy organizacjami z certyfikowanym systemem zarządzania jakością a tymi, które nie posiadają takiego certyfikatu, na korzyść tych pierwszych [Aba, Badar i Hayden 2016]. Podobne wyniki zaobserwowane zostały na terenie Grecji [Psomas i Kafetzopoulos 2014], również ze wskazaniem osiągania większych korzyści w organizacjach, które certyfikowały swoje znormalizowane systemy zarządzania jakością. W świetle tych kwestii należy zwrócić uwagę na aspekt „certyfikacji ISO 9001”, która jest podejmowana z różnych powodów. Zatem to nie sam certyfikat powoduje, że organizacja ma lepsze bądź gorsze wyniki od innych, lecz wewnętrznie podejmowane działania. Oczywiście w ramach funkcjonowania certyfikowanego systemu zarządzania jakością konieczne jest spełnianie wymagań normatywnych, jednak, jak to już zostało wskazane, to ludzie, ich postawy i zachowania mają wpływ na funkcjonowanie systemów [Lisiecka i Czyż-Gwiazda 2014, s. 31-32]. W literaturze przedmiotu twierdzi się, że wdrożenie znormalizowanego systemu zarządzania jakością $\mathrm{w}$ przypadku wewnętrznej motywacji prowadzi do lepszych rezultatów aniżeli zewnętrzne powody wdrożenia i certyfikacji tego systemu [Denton i Maatgi 2016]. Generalnie podkreśla się różne natężenie działań podejmowanych $\mathrm{w}$ ramach projakościowego zarządzania $\mathrm{w}$ organizacji w zależności od motywów [Ismyrlis i Moschidis 2015]. Działania z zakresu zarządzania jakością implikują jakość 
końcowych produktów (wyrobów i usług). Można zatem spojrzeć na ewentualne różnicowanie rezultatów zarządzania jakością właśnie z perspektywy zakresu przedmiotowego działalności organizacji. Jednak z perspektywy grup rezultatów nie ma to znaczenia ani w działalności produkcyjnej [Psomas i Kafetzopoloulos 2014], ani usługowej [Psomas i Jaca 2016], ani przy zbiorczych analizach [Ismyrlis i Moschidis 2015]. Działania z zakresu zarządzania jakością są podejmowane w danej organizacji, w odniesieniu do jej specyfiki, w ukierunkowaniu na efekt końcowy (wyroby i usługi), a różnicowanie wyników będzie uzależnione m.in. od indywidualnych celów, działań i klientów. Przyjęto zatem podział rezultatów projakościowych w organizacji na finansowe i niefinansowe efekty. Dodatkowo w trakcie analizy ukierunkowanej na identyfikację zbiorów rezultatów, celem dalszego ich ujęcia w kwestionariuszu ankietowym, postanowiono wyodrębnić grupę rezultatów ogólnych. Podczas analizy literatury przedmiotu zaobserwowano, że te ogólne rezultaty są wskazywane jako uzależnione od dużej liczby działań, jednym słowem „kompleksowo” oddają efekt zbioru różnorodnych działań projakościowego zarządzania w organizacji. Wynikowo zatem przyjęte zostały trzy grupy rezultatów zarządzania jakością: ogólne, niefinansowe oraz finansowe.

Określenie obszarów wpływu zarządzania jakością na sukces w organizacji, poprzez identyfikację grup rezultatów projakościowego zarządzania w organizacji, przyjęte zostało jako trzeci, szczegółowy cel pracy, a przyjęcie w efekcie analizy literatury trzech grup rezultatów pozwala stwierdzić, że tenże teoretyczny cel pracy został zrealizowany. Po wyznaczeniu wskazanych grup, w których są umiejscowione konkretne rezultaty zarządzania jakością, nastąpiło zebranie właśnie tych rezultatów z analizowanych pozycji literatury. Działanie to było ukierunkowane na uwzględnienie $\mathrm{w}$ kwestionariuszu ankietowym stwierdzeń ukazujących wpływ działań z zakresu zarządzania jakością na rezultaty ${ }^{50}$ organizacji, operacjonalizujących tytułowy sukces zarządzania jakością.

W ramach artykułów przywoływanych bezpośrednio w pierwszym punkcie niniejszego rozdziału autorzy wskazywali również na efekty działań w obszarze zarządzania jakością. Wśród zbioru analizowanych artykułów warto wskazać, z uwagi na zakres zawartych informacji, na publikację z 2013 roku [Ebrahimi i Sadeghi 2013], w której przedstawiona została szeroka analiza literatury zestawiająca wyniki badań z okresu 17 lat (1995-2012) w układzie praktyk

${ }^{50}$ Rezultat to bezpośrednia korzyść z danego produktu (wyrób, usługa) bądź działania. Wpływ rezultatu w czasie (oddziaływanie) na różne aspekty funkcjonowania organizacji jest określany mianem efektu. W niniejszej pracy dla uproszczenia prowadzonych analiz zamiennie stosowane są słowa: rezultat, efekt, wynik. Wskazano jednocześnie, że rezultaty projakościowego zarządzania w organizacji stanowią mierniki sukcesu zarządzania jakością w organizacji. Stanowi to pewne uproszczenie względem problematyki tego obszaru w zarządzaniu jakością, bowiem rezultaty, efekty, wyniki danych działań dopiero w zestawieniu z zaplanowanymi celami umożliwiają ocenę ich osiągnięcia, czyli definicyjnej skuteczności. 
zarządzania jakością (224 elementów organizacyjnych z zakresu zarządzania jakością) z miarami rezultatów (co do grup i szczegółów). W efekcie działań analitycznych zidentyfikowano $\mathrm{w}$ niniejszej pracy łącznie siedemnaście jednokierunkowych stwierdzeń zakładających pozytywny wpływ zarządzania jakością na rezultaty organizacji. Stwierdzenia umiejscowiono w wyznaczonych grupach rezultatów. W grupie ogólnych rezultatów zawarte zostały cztery stwierdzenia (nr 1-4), w grupie niefinansowych jedenaście (nr 5-15) oraz dwa w finansowej (nr 16-17).

W ramach grupy ogólnych rezultatów zarządzania jakością zawarto cztery stwierdzenia, poddane następnie w badaniu ankietowym ocenie respondentów:

1. Klienci są usatysfakcjonowani naszymi wyrobami.

2. Klienci są usatysfakcjonowani naszymi usługami.

3. Osiągamy zaplanowane cele jakościowe.

4. Osiągamy zaplanowane rezultaty finansowe.

$\mathrm{W}$ grupie niefinansowych rezultatów projakościowego zarząadzania w organizacji zawartych zostało łącznie jedenaście stwierdzeń:

5. Zarządzanie jakością pozytywnie wpływa na zwiększenie zaangażowania pracowników.

6. Zarządzanie jakością pozytywnie wpływa na minimalizację fluktuacji pracowników.

7. Zarządzanie jakością pozytywnie wpływa na zwiększenie współpracy pomiędzy działami w organizacji.

8. Zarządzanie jakością pozytywnie wpływa na pozyskanie nowych klientów.

9. Zarządzanie jakością pozytywnie wpływa na utrzymanie obecnych klientów.

10. Zarządzanie jakością pozytywnie wpływa na doskonalenie naszych działań organizacyjnych.

11. Zarządzanie jakością wpływa na minimalizację czasu obsługi klientów.

12. Zarządzanie jakością wpływa na zmniejszenie reklamacji dotyczących wyrobów.

13. Zarządzanie jakością wpływa na zmniejszenie reklamacji na świadczone usługi.

14. Zarządzanie jakością wpływa na zmniejszenie reklamacji dotyczących procesu obsługi klientów.

15. Zarządzanie jakością wpływa na zmniejszenie niezgodności wewnętrznych.

Ostatnią kategorię tworzą rezultaty ukazujące wpływ zarządzania jakością na finansowe wyniki działalności organizacji:

16. Zarządzanie jakością wpływa na minimalizację kosztów działalności.

17. Zarządzanie jakością wpływa na maksymalizację przychodów ze sprzedaży.

Zmieniające się okoliczności gospodarowania implikują zmiany w procesach wewnętrznych organizacji i tym samym modyfikują stan ryzyka, co potwierdza konieczność elastycznego podejścia do zarządzania jakością. Miarą skuteczności 
systemu zarządzania jest skuteczność procesów tym systemem objętych, a więc również działań związanych z ograniczeniem zagrożeń i ich skutków. Sposobem na doskonalenie tego systemu jest zarządzanie ryzykiem, które bezpośrednio odzwierciedla wagę potencjalnych skutków zagrożeń i prawdopodobieństwo ich występowania [Karkoszka 2013, s. 14]. Tym samym skuteczność zarządzania ryzykiem jest dostosowywana do indywidualnych uwarunkowań każdej organizacji i jest uzależniona od czynników występujących zarówno wewnątrz, jak i na zewnątrz [Staniec 2011, s. 5]. Dlatego też zapewnienie sukcesu projakościowego zarządzania $\mathrm{w}$ organizacji wymaga podejmowania działań w aspekcie ryzyka, którym to zagadnieniom poświęcony został ostatni punkt niniejszego rozdziału pracy.

\section{Aspekt ryzyka w osiąganiu celów dotyczących jakości}

Charakterystyczną cechą gospodarki rynkowej jest to, że kryzysowe sytuacje mogą powstawać w dowolnym stadium cyklu życia organizacji, ale krótkookresowe sytuacje kryzysowe nie zmieniają istoty przedsiębiorstwa jako wytwórcy wartości i mogą być zlikwidowane za pomocą operatywnych działań [Krzakiewicz 2008, s. 6]. Identyfikując źródło, istotę i określając zarysy sytuacji kryzysowej oraz analizując potencjalne konsekwencje kryzysów, można stworzyć bardziej niezawodny system zarządzania antykryzysowego dzięki ograniczeniu poziomu ryzyka i realizacji odpowiednich przedsięwzięć [Krzakiewicz 2008, s. 31]. Przedmiotem właściwego zarządzania ryzykiem jest jego identyfikacja oraz właściwe z nim postępowanie, a celem - zapewnienie maksymalnych trwałych korzyści we wszystkich dziedzinach działalności [Łańcucki 2013, s. 12]. Właściwe postępowanie z ryzykiem oznacza kompleksowe podejście do uwzględniania ryzyka i postępowania z nim w całej organizacji, na poszczególnych jej poziomach organizacyjnych, w odniesieniu zarówno do zagrożeń, jak i szans, i to w sposób systemowy, udokumentowany. Tymczasem działania z obszaru zarządzania ryzykiem są podejmowane często $\mathrm{w}$ organizacjach w sposób wybiórczy i intuicyjny [Bezpieczna Firma 2010], są kojarzone z podejściem niewłaściwym, mniej skutecznym od działań podejmowanych w sposób systemowy i dokumentowany. Nie można jednak automatycznie zakładać, że to podejście jest złe, ponieważ ta intuicyjność, wykorzystywana każdego dnia, stanowi know-how poszczególnych organizacji [Zapłata 2016a, s. 81]. Zgodnie $\mathrm{z}$ tradycyjną koncepcją ryzyko jest postrzegane jako zjawisko negatywne, sprawiające, że faktycznie osiągnięte rezultaty okazują się mniej korzystne niż zakładano. W tym nurcie ryzyko jest niebezpieczeństwem 
poniesienia strat w zarządzaniu jakością [Szkoda 2012, s. 69]. Takie podejście to, niestety, powszechne postrzeganie ryzyka jako negatywnego aspektu w działalności gospodarczej. Konieczne jest jednak całościowe ujęcie zagadnień zarządzania ryzykiem (systemowe), ponieważ fragmentaryczne podejście (silosowe) jest samo w sobie ryzykowne [Conti 2010, ss. 355]. W zorganizowaniu działań z tego obszaru pomocna może być norma zawierająca wymagania dla systemowego zarządzania jakością ISO 9001, opublikowana w 2015 roku. Norma ta zawiera nowe w stosunku do wcześniejszych edycji wymagania dotyczące podejścia opartego na ryzyku. Wymagania normatywne w tym zakresie stanowią nowość, ale samo praktyczne podejście już nie. Podejście to jest bowiem automatycznie uwzględniane w codziennych działaniach z zakresu zarządzania jakością [ISO/TC 176/SC2/N1284 2015, s. 1]. Zmiany mogą wpłynąć pozytywnie na osiągane rezultaty zarządzania jakością, co prawdopodobnie stanowiło przesłankę wprowadzenia wymagań z obszaru zarząadzania ryzykiem do normy ISO 9001 [PN-EN ISO 9001:2015-10]. Należy jednak podkreślić, że tematyka podejścia opartego na ryzyku zasadniczo zawsze była uwzględniania, również w sposób systemowy, chociażby w ramach działań zapobiegawczych, które w swej istocie służyły przewidywaniu i zapobieganiu niezgodnościom, co również stanowi zagadnienie przedstawione w normie ISO 31000 [Klimczak 2014, ss. 16-20]. Organizacja powinna planować działania z uwzględnieniem ryzyka zarówno pozytywnego (szans), jak i negatywnego (zagrożeń), nie ma jednak wymagań w zakresie stosowania formalnych metod lub udokumentowanych procesów zarządzania ryzykiem w ramach systemowego zarządzania jakością [PN-EN ISO 9001:2015-10, pkt A.4]. Na tę ogólność można spojrzeć dwojako. Z jednej strony dowodzi to elastycznego podejścia do zarządzania ryzykiem i indywidualnego dopasowania wymagań do specyfiki organizacji. Z drugiej jednak strony można uznać, że brak ostrych wymagań dotyczących procesu i metod zarządzania ryzykiem $^{51}$ ugruntowuje niestety wybiórcze podejście do tych ważnych zagadnień w działalności gospodarczej. Autor niniejszego opracowania uważa, że ugruntowanie ogólnego, intuicyjnego ${ }^{52}$ podejścia do zarządzania ryzykiem w obszarze jakościowym jest słuszne, zgodnie z linią znormalizowanych systemów zarządzania, których zamiarem nie jest ujednolicanie struktury tych

${ }^{51}$ Metody i narzędzia zarządzania ryzykiem zostały przedstawione w dokumencie normalizacyjnym IEC/ISO 31010.

${ }_{52}$ Intuicja rozumiana jako twórcza wyobraźnia i przekonanie o danym działaniu bez pomocy doświadczenia [Dubisz 2008, t. I, s. 1237]; ISO/TC 176/SC2/N1284 „Risk-based thinking in ISO 9001:2015”, www.iso.org/tc176/sc02/public: „Risk is inherent in all aspects of quality management system”. Uwzględnienie w systemowym zarządzaniu jakością podejścia opartego na ryzyku i usunięcie, względem poprzednich edycji normy, osobnego wymagania dotyczącego działań prewencyjnych sprawia, że w obszarze zapobiegania zagrożeniom większy nacisk jest położony na podejście proaktywne niż reaktywne. 
systemów [PN-EN ISO 9001:2015-10, pkt 0.1, s. 5], ponieważ, jak już to zostało $\mathrm{w}$ niniejszej pracy podkreślone, każda organizacja jest indywidualna, a dopasowywanie działań do wzorca nie będzie jednoznaczne z uzyskiwaniem pozytywnych rezultatów we wszystkich organizacjach.

Ryzyko dotyczy zdarzeń możliwych do przeanalizowania wówczas, gdy niepewność jest mierzalna (poziom A na rysunku 1) [Urbanowska-Sojkin 2013a, s. 14]. Kiedy odnosimy to do sfery pojedynczych organizacji, możemy mówić o płaszczyźnie mikroekonomicznej (poziom B na rysunku 1). W tym kontekście można wskazać na ryzyko wyboru działalności oraz, po określeniu tego profilu, na ryzyko prowadzenia danej działalności, nazywane ryzykiem operacyjnym (poziom C na rysunku 1). To ryzyko dotyczy bieżących działań organizacji, jednak występuje niuans w nazewnictwie dotyczący właśnie bieżącego czasu działań [Zapłata 2016a, s. 82]. W organizacji działania są realizowane w różnym horyzoncie, co implikuje perspektywę czasową (poziom D na rysunku 1) dla wyznaczanych celów i przyporządkowanych im zadań. W ramach najkrótszego okresu („,codzienności”) w prowadzonej działalności gospodarczej następuje powielenie $\mathrm{w}$ nazewnictwie ryzyka, ponownie mamy do czynienia z ryzykiem operacyjnym. Na tym etapie dotyczy to bieżących operacji gospodarczych, które w dłuższym czasie przekładają się na osiąganie celów taktycznych, a te z kolei wpływają na realizację planów strategicznych. Spoglądając na jedną z wielu definicji ryzyka operacyjnego, pasuje ona do dualnego spojrzenia na ryzyko. Ryzyko operacyjne jest uważane za ryzyko niedostatecznej skuteczności działania z perspektywy celu operacyjnego (bieżącego) tego działania. Stanowi więc o tym, na ile procesy organizacyjne są dość skuteczne, w tym odporne na zakłócenia, aby organizacje mogły realizować swoje cele [Kosieradzka i Zawiła-Niedźwiecki 2016, s. 39]. Jednak dla rozróżnienia słownego tych poziomów autor niniejszej monografii dokonał modyfikacji w nazewnictwie ryzyka operacyjnego w perspektywie wybranego zakresu działalności i określił je jako całościowe ryzyko działalności organizacji.

Z perspektywy jakości wytwarzanych wyrobów i świadczonych usług najważniejsza jest perspektywa operacyjna zarządzania ryzykiem, dotycząca celów bieżących, w tym jakościowych. Jednocześnie rozpatrując działania z zakresu zarządzania jakością, można wskazać na procesy podstawowe oraz poboczne (poziom E na rysunku 1). Te pierwsze dotyczą głównego celu działalności, a poboczne są związane z działaniami pomocniczymi oraz marginesowym profilem działalności. Na końcu tej kaskadowej analizy zarządzania ryzykiem występuje ryzyko pozytywne oraz negatywne (poziom $F$ na rysunku 1), co jest związane z postrzeganiem ryzyka ${ }^{53}$. Ten poziom zarządzania ryzykiem jest kojarzony $\mathrm{z}$ analizowaniem strat, czyli negatywną sferą, co uznaje się za powód braku jed-

${ }^{53}$ Postrzeganie ryzyka to opinia interesariusza dotycząca ryzyka [PKN-ISO Guide 732012 , pkt 3.2.1.2, s. 13]. 
nolitego i spójnego ,podejścia” do problemu ryzyka [Kaczmarek 2010, s. 48]. Jednak końcowo każde zidentyfikowane ryzyko można rozpatrywać w sposób pozytywny (jako szanse), jak i negatywny (jako zagrożenia), a na postrzeganie ryzyka istotny wpływ ma kontekst sytuacyjny i subiektywne nastawienie decydentów [Jajuga 2007, s. 7]. Ten kontekst nie ogranicza się jedynie do kwestii optymistyczno-negatywistycznego postrzegania ryzyka, ale całościowo dotyczy

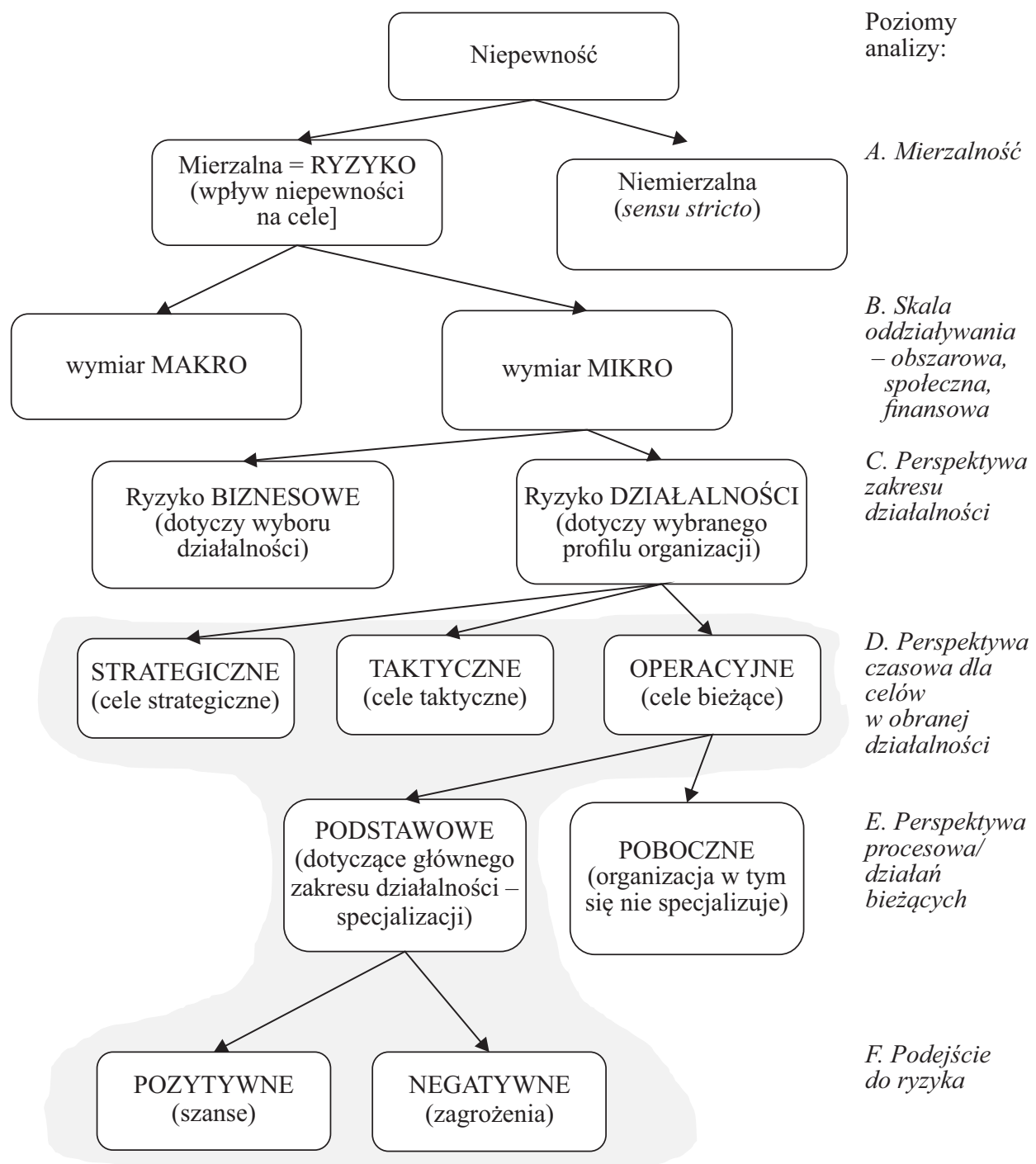

Rysunek 1. Organizacyjne poziomy w zarządzaniu ryzykiem

Źródło: Na podstawie: [Zapłata 2016a, s. 83] 
podejmowania wszystkich działań na różnych szczeblach organizacyjnych, co wpisuje się w szeroko rozumianą ,atmosferę ryzyka” [Urbanowska-Sojkin 2013a, s. 9].

Na rysunku 1 obszar dotyczący trzech ostatnich poziomów organizacyjnych został objęty szarym tłem jako wskazanie wspólnego obszaru zarządzania ryzykiem i jakością, uwzględnianego w dalszej analizie. Pamiętając, że celem zarządzania ryzykiem jest wspomaganie realizacji m.in. celów dotyczących jakości, to działania organizacyjne podejmowane są właśnie przez pryzmat trzech perspektyw czasowych: strategicznej, taktycznej oraz operacyjnej (dla wybranego profilu działalności), również w ramach zarządzania jakością.

Samo posiadanie znormalizowanego, certyfikowanego systemu zarządzania jakością zgodnego z wymaganiami normy ISO 9001 stanowi narzędzie zarządzania ryzykiem jakościowym na dwóch płaszczyznach - pierwszej ogólnej (rynkowej), związanej z posiadaniem certyfikatu i uzewnętrznianiem tego w ramach działań promocyjnych; drugiej operacyjnej, związanej z bieżącym funkcjonowaniem systemu i minimalizacją ryzyka jakościowego w procesach wytwórczych. Różnorodność uwarunkowań każdej organizacji jest uwzględniana podczas procesu wdrożenia systemu zarządzania jakością. Interpretacja wymagań normatywnych oraz dopasowanie rozwiązań organizacyjnych są ukierunkowane na minimalizację zdarzeń mogących negatywnie wpływać na bieżące zadania i osiąganie zaplanowanych celów. Potwierdzenie zgodności systemu zarządzania jakością z wymaganiami normatywnymi jest dokonywane przez zewnętrzną jednostkę certyfikującą, a certyfikacja systemów zarządzania powinna być postrzegana właśnie jako integralna część strategii zarządzania ryzykiem [Maatta 2009, s. 19]. Jednak jakość samego systemu jest uzależniona od motywów jego wdrożenia i celów funkcjonowania, a jednocześnie oddziałuje na osiągane rezultaty w obszarze zarządzania jakością, co zostało zasygnalizowane $\mathrm{w}$ poprzednim punkcie pracy. W przypadku potrzeby posiadania jedynie certyfikatu jako warunku koniecznego dla współpracy z kontrahentami można wskazać, że jest to element zarządzania ryzykiem z perspektywy danej organizacji, a mniej dla kolejnych potencjalnych klientów. W przypadku ukierunkowania działań na stworzenie dopasowanego systemu zarządzania jakością ma to szerszy, ideowy kontekst działań w ramach zarządzania ryzykiem. W tym nurcie rozważań można wskazać na wewnętrzną kulturę organizacji. W ramach zbioru różnorodnych postaw ludzkich, które tworzą charakterystyczną pajęczynę dla każdej organizacji, istnieje kultura jakości, która jest elementem całościowego zbioru postaw i podejść do różnorodnych działań w organizacji. Istotą kultury jakości jest właściwe oddziaływanie na postawy i zachowania ludzi. To oni potrafią sprawić, że nawet kiepski operacyjny system będzie działał, a dobry upadnie [Lisiecka i Czyż-Gwiazda 2014, s. 31-32]. Istnieje zatem wiele uwarunkowań dotyczących budowy systemu zarządzania jakością, niezależnie od 
podstaw i certyfikowalności, a jednocześnie wiele różnorodnych czynników, które wpływają na efekty jego funkcjonowania, co należy uwzględniać w ramach podejścia opartego na ryzyku, aby system był skuteczny i osiągał sukces zarządzania jakością.

Podejście oparte na ryzyku wywodzi się z zagadnień zarządzania ryzykiem, które stanowi narzędzie wspomagania realizacji zaplanowanych celów. To wspomaganie jest rozumiane jako minimalizacja zagrożeń mogących negatywnie wpłynąć na osiągnięcie zaplanowanych celów oraz jako maksymalizacja efektów poprzez wykorzystywanie szans rynkowych. Podejście oparte na zarządzaniu ryzykiem nie jest bynajmniej nowe w praktyce funkcjonowania systemów jakości, których celem zawsze było zapewnienie jakości wyrobów i procesów (poprzez unikanie niezgodności) [Urbaniak 2016, s. 16]. Wpisanie tej koncepcji w wytyczne najczęściej wykorzystywane w międzynarodowych standardach zarządzania w jeszcze większym stopniu powinno uwrażliwić organizacje na podejmowanie wysiłków, których celem jest ograniczenie zagrożeń (wewnętrznych i zewnętrznych), a także spełnianie w coraz większym stopniu oczekiwań interesariuszy (klientów, właścicieli, pracowników, dostawców, jak i społeczeństwa) [Urbaniak 2016, s. 16]. Coraz częściej działania przedsiębiorstw w zakresie zarządzania ryzykiem przybierają charakter systemowy i są oparte na koncepcji ciągłego doskonalenia, obejmując następujące etapy [Urbaniak 2016, s. 12]:

- określenie celów organizacji,

- identyfikacja ryzyka i jego źródeł (przyczyn),

- analiza ryzyka (identyfikacja obszarów i miejsc występowania potencjalnych zagrożeń, ich opis oraz pomiar),

- ocena ryzyka (prawdopodobieństwo i skutki),

- zdefiniowanie celów ukierunkowanych na ograniczenie ryzyka oraz zapewnienie zasobów,

- zdefiniowanie planów na wypadek sytuacji awaryjnej,

- informowanie o ryzyku pracowników i kształtowanie świadomości,

- realizacja celów poprzez działania operacyjne ukierunkowane na ograniczenie ryzyka - koncentracja na minimalizacji znanego ryzyka oraz identyfikacja nowego.

Głównymi etapami zarządzania ciągłością w ujęciu systemowym ${ }^{54}$ są następujące działania: zrozumienie organizacji, w tym analiza wpływu poszczególnych działań na prowadzenie działalności, określenie strategii przetrwania, opracowanie procedur składających się na plan ciągłości działania oraz testowanie i utrzymywanie planów [Gołąb 2009, s. 14]. Zarządzanie ciągłością działania

${ }^{54}$ Różne były w organizacjach motywy implementacji systemu zarządzania ciągłością działania (zgodnego z poprzednim standardem BS 25999-2), np. podtrzymanie zaufania do firmy czy pokazanie stronom zainteresowanym proaktywnego stosunku do kwestii bezpieczeństwa [Jedynak 2007, s. 72]. 
należy traktować nie jako wąską dyscyplinę uprawianą jedynie przez profesjonalistów, ale jako szerokie spektrum działań zawierających w sobie zarządzanie ryzykiem, zarządzanie kryzysowe i zarządzanie bezpieczeństwem. Jest ono częścią zarządzania organizacją i jest ukierunkowane na takie przeprojektowanie procesów wytwarzania wyrobów i świadczenia usług, aby zwiększyć odporność organizacji na występowanie szkodliwych zakłóceń przerwania procesów i poniesienia strat [Gołąb 2009, s. 23].

Działania w ramach zarządzania ryzykiem można kształtować poprzez decyzje wewnątrzorganizacyjne, podobnie jak w projakościowym zarządzaniu w organizacji. W zarządzaniu jakością decyduje to o wyniku końcowym z perspektywy czynników jakości. W zarządzaniu ryzykiem decyduje to o (nie)zmaterializowaniu się ryzyka. Obydwie koncepcje zatem łączą się i zarządzanie ryzykiem stanowi proces wspierający zarządzanie jakością, w ukierunkowaniu na efekt końcowy działań organizacyjnych. W przypadku jednak zmaterializowania się ryzyka konieczne jest uruchomienie procedur dotyczących ciągłości działania, polegających na ochronie kluczowych wyrobów i usług.

Organizacyjne poziomy w zarządzaniu ryzykiem (rysunek 1) wyznaczają granice dla identyfikacji elementów uszczegóławiających główne czynniki zarządzania jakością dzięki składowym w aspekcie ryzyka. W ramach dalszych działań analitycznych ukierunkowanych na zrealizowanie piątego szczegółowego celu pracy przyjęto następujące podstawy normatywne dla wyłonienia wskazanych składowych:

- norma PN-EN ISO 9001:2015-10, zawierającą wymagania dla systemu zarządzania jakością,

- norma PN-ISO 31000:2012, zawierająca zasady i wytyczne dla zarządzania ryzykiem,

- ISO 22301:2012, zawierająca wymagania dla systemu zarządzania ciągłością działania.

Normy organizacyjne przyjęto jako zbiór wymagań dla danego systemu zarządzania. W ramach technicznej procedury przyjęto szereg analizowanych artykułów, w szczególności dotyczących wyników systematycznego przeglądu literatury z obszaru zarządzania ryzykiem w podmiotach sektora mikro oraz małych i średnich [Falkner i Hiebl 2015].

Końcowo przypisano do poszczególnych głównych wewnętrznych czynników projakościowego zarządzania w organizacji elementy składowe, wskazujące na podejmowane działania $\mathrm{w}$ aspekcie ryzyka. Elementy te zostały ujęte czynnościowo i jednokierunkowo, dla późniejszego ujęcia w kwestionariuszu ankietowym. Jednocześnie zastosowana numeracja jest kontynuacją wcześniejszych elementów konstytuujących główne wewnętrzne czynniki zarządzania jakością $\mathrm{w}$ aspekcie jakości, z uwagi na łączne uwzględnianie różnorodnych aspektów w podejmowaniu decyzji, w tym łączenie aspektu jakości z ryzykiem. 
Dla czynnika wewnętrznego Przywództwo i zaangażowanie najwyższego kierownictwa $w$ jakość wskazano na siedem elementów składowych:

7. Najwyższe kierownictwo identyfikuje zagrożenia wpływające na realizację zidentyfikowanych celów jakościowych.

8. Najwyższe kierownictwo identyfikuje szanse wpływające na maksymalizację osiąganych efektów jakościowych.

9. Najwyższe kierownictwo identyfikuje potencjalne skutki dla zagrożeń wpływających na realizację celów jakościowych.

10. Najwyższe kierownictwo identyfikuje potencjalne skutki dla szans dotyczących maksymalizacji efektów jakościowych.

11. Najwyższe kierownictwo określa prawdopodobieństwo wystąpienia zagrożeń i szans związanych z realizacją celów dotyczących jakości.

12. Najwyższe kierownictwo identyfikuje zagrożenia i (lub) szanse w obszarze zarządzania jakością w sposób udokumentowany.

13. Najwyższe kierownictwo zidentyfikowało kluczowe produkty, które chronimy i do których realizacji dążymy nawet w sytuacjach kryzysowych (jak np. brak prądu, choroby pracowników).

Do drugiego głównego czynnika wewnętrznego zarządzania jakością Planowanie strategiczne i operacyjne przypisano sześć elementów uszczegóławiających:

8. Dla zidentyfikowanych zagrożeń w realizacji celów tworzone są prewencyjne plany zarządzania ryzykiem, mające zminimalizować prawdopodobieństwo zaistnienia zagrożeń.

9. Powyższe plany są dokumentowane oraz komunikowane wewnętrznie w organizacji.

10. Dla zidentyfikowanych szans realizacji celów tworzone są plany zarządzania ryzykiem mające maksymalizować prawdopodobieństwo wykorzystania szans.

11. Dla zidentyfikowanych zagrożeń w realizacji celów tworzone są plany na wypadek rzeczywistego zaistnienia zagrożenia, mające zminimalizować skutki sytuacji kryzysowej.

12. Powyższe plany są dokumentowane oraz komunikowane wewnętrznie w organizacji.

13. Okresowo są realizowane ćwiczenia/testowanie planów na wypadek sytuacji awaryjnych.

W ramach czynnika głównego zatytułowanego Orientacja na klienta ujęte zostały trzy sformułowania składające się na charakterystykę danego czynnika:

10. Jesteśmy świadomi potrzeby identyfikacji i postępowania z ryzykiem w obszarze obsługi klientów.

11. Klienci stanowią źródło największych zagrożeń w działalności. 
12. Wszystkie dane dotyczące obsługi klientów są uzupełniane w systemie komputerowym.

Czynnik czwarty Zarzadzanie na podstawie faktów zawiera w sobie cztery zdania opisujące tenże czynnik w aspekcie ryzyka:

7. Ograniczamy podejmowanie decyzji przy niepełnym posiadaniu danych.

8. Przy podejmowaniu decyzji identyfikujemy zagrożenia dla sukcesu podejmowanych działan.

9. Przy podejmowaniu działań rozważamy szanse ich realizacji.

10. Zagrożenia i szanse związane z podejmowaniem decyzji są dokumentowane. Zarządzanie zasobami ludzkimi jest czynnikiem piątym uszczegółowionym przez pięć stwierdzeń:

6. Elementem w rozliczaniu pracowników jest zapobieganie zagrożeniom w realizacji celów.

7. Elementem w rozliczaniu pracowników jest wykorzystywanie szans dla zwiększenia osiąganych efektów.

8. Pracownicy mają odpowiednie kompetencje w zakresie zarządzania ryzykiem w obszarach swoich obowiązków.

9. Świadomość jakościowa potencjalnych pracowników stanowi ważne kryterium $\mathrm{w}$ procesie rekrutacji.

10. Skuteczność naszych selekcji i rekrutacji można określić sformułowaniem „właściwy człowiek na właściwym miejscu”.

Główny czynnik zarządzania jakością, Zaangażowanie pracowników, zawiera następujące trzy elementy konstytuujące $\mathrm{w}$ aspekcie ryzyka:

4. Pracownicy są świadomi zagrożeń związanych z wykonywanymi działaniami i realizacją celów jakościowych.

5. Pracownicy w swoich działaniach prezentują postawę „lepiej zapobiegać niż leczyć".

6. Pracownicy dzielą się z najwyższym kierownictwem swoimi spostrzeżeniami dotyczącymi zagrożeń i szans związanych z realizacją celów jakościowych.

Czynnik zatytułowany Zarzadzanie procesowe został opisany trzema elementami uszczegóławiającymi wzbogacającymi dotychczasowe składowe o aspekt ryzyka:

6. Procesy mają przypisanych właścicieli, którzy są odpowiedzialni za zarządzanie ryzykiem tych procesów.

7. Zarządzanie ryzykiem jest częścią zarządzania każdym procesem.

8. Reklamacji do dostawców jest stosunkowo niewiele.

Ostatni czynnik, nazwany Ciagłe doskonalenie, został określony trzema składowymi elementami w perspektywie podejścia opartego na ryzyku:

8. Priorytetem w doskonaleniu są działania zapobiegawcze (ukierunkowanych na przyczyny potencjalnych niezgodności). 
9. Priorytetem w doskonaleniu są korekty (naprawa niezgodności).

10. Priorytetem w doskonaleniu są działania korygujące (ukierunkowane na przyczyny zaistniałych niezgodności).

Zidentyfikowanie elementów konstytuujących główne wewnętrzne czynniki zarządzania jakością $\mathrm{w}$ organizacji $\mathrm{w}$ aspekcie ryzyka stanowiło czwarty teoretyczny szczegółowy cel pracy. Stworzenie listy elementów konstytuujących główne czynniki wewnętrzne projakościowego zarządzania w organizacji, a dotyczących podejścia opartego na ryzyku, potwierdza realizację powyższego celu.

Treść rozdziału drugiego niniejszej monografii, związana $\mathrm{z}$ analizami teoretycznymi, była ukierunkowana na realizację czterech szczegółowych celów pracy. Wszystkie teoretyczne cele zostały osiągnięte w ramach treści poszczególnych punktów tegoż rozdziału:

1. W wyniku analizy literatury przedmiotu (anglojęzycznej oraz polskojęzycznej) zidentyfikowano osiem głównych wewnętrznych czynników zarządzania jakością.

2. Zidentyfikowano elementy konstytuujące główne czynniki wewnętrzne zarządzania jakością, w aspekcie jakości, w łącznej liczbie 48 składowych.

3. Określono obszary wpływu zarządzania jakością na rezultaty osiągane w organizacji, poprzez identyfikację trzech grup efektów zarządzania jakością, umiejscawiając $\mathrm{w}$ nich siedemnaście rezultatów zarządzania jakością.

4. Zidentyfikowano 34 elementy konstytuujące główne wewnętrzne czynniki projakościowego zarządzania $\mathrm{w}$ organizacji w aspekcie ryzyka.

Efekty realizacji szczegółowych celów pracy zostały wkomponowane w kwestionariusz ankietowy, którego konstrukcja została przedstawiona w kolejnym rozdziale pracy.

W obliczu powyższych kwestii konieczne jest dokonanie syntetycznego podsumowania najważniejszych treści:

1. Różnorodność pojęć na płaszczyźnie teoretycznej zarządzania jakością i czynników wpływających na różne aspekty w tym obszarze działań organizacji ma wspólny mianownik - cel zarządzania jakością, jakim jest realizacja działań na rzecz zapewnienia odpowiednej i powtarzalnej jakości produktów (wyrobów i usług). „Odpowiedniej” oznacza na ustalonym poziomie, a „powtarzalnej" dotyczy utrzymania właściwości na zaplanowanym poziomie za każdym razem.

2. Czynniki zarządzania jakością opisywane w literaturze przedmiotu mają zazwyczaj swoje źródło w organizacji i dlatego automatycznie są uznawane za wewnętrzne czynniki projakościowego zarządzania w organizacji, bez podawania ich wewnętrznego charakteru w nazewnictwie. Wewnętrzna natura czynników zarządzania jakością oznacza, że można je kształtować poprzez autonomiczne decyzje $\mathrm{w}$ organizacji, w ukierunkowaniu na sukces projakościowego zarządzania. 
3. Wewnętrzne czynniki zarządzania jakością dotyczą obszarów działań w organizacji, które mogą się odnosić do różnych aktywności. Zasadniczo zbiory te należy nazwać głównymi czynnikami wewnętrznymi zarządzania jakością, ponieważ zawierają w sobie zakresy określone jako elementy składowe.

4. Elementy składowe konstytuujące główne wewnętrzne czynniki zarządzania jakością można analizować w dwóch aspektach - jakości i ryzyka.

5. Istnieją różnorodne efekty zarządzania jakością, które w sposób bezpośredni bądź pośredni oddziałują na wyniki organizacji jako całości. Efekty zarządzania jakością można umiejscawiać w różnych grupach rezultatów, które operacjonalizują sukces projakościowego zarządzania w organizacji.

Ogólnie projakościowe zarządzanie w organizacji pozytywnie wpływa na wyniki jej funkcjonowania na rynku. Szczegółowo w efektach końcowych ma swój współudział zbiór różnorodnych wewnętrznych czynników zarządzania poprzez swoje elementy składowe. Charakter wewnętrznych czynników zarządzania jakością oraz zależności pomiędzy elementami je konstytuującymi jest wielowątkowy i różne czynniki w różny sposób oddziałują na rezultaty w różnych organizacjach. Ocena relacyjności pomiędzy wewnętrznymi czynnikami zarządzania jakością i ich wpływ na sukces projakościowego zarządzania w organizacji została przeprowadzona $\mathrm{w}$ badaniach empirycznych. Wyniki badań zebrano, przeanalizowano i zinterpretowano w celu weryfikacji postawionych hipotez badawczych oraz w kolejnych rozdziałach niniejszej monografii przedstawiono wnioski i rekomendacje. 


\section{Rozdział III METODYKA BADAŃ EMPIRYCZNYCH}

\section{Cel i zakres badań}

Działania ukierunkowane na realizację celów pracy oraz weryfikację postawionych hipotez badawczych zostały przeprowadzone w ramach określonej procedury badawczej. Planując procedurę, uwzględniono poszczególne etapy działań w celu zapewnienia rzetelności badań oraz trafności wnioskowania. W ramach procedury badawczej można wskazać na dwie płaszczyzny - teoretyczną (skoncentrowaną na kwerendzie i analizie literatury przedmiotu) oraz empiryczną (dotyczącą realizacji badań empirycznych).

Główny cel pracy zdefiniowano jako: Identyfikacja i ocena ważności wewnętrznych czynników oraz ich oddziaływania na sukces projakościowego zarządzania $\mathrm{w}$ organizacji. Wyznaczenie celu pracy zostało poprzedzone zdefiniowaniem problemu badawczego w formie pytania badawczego: Jakimi wewnętrznymi czynnikami można wpływać na sukces projakościowego zarządzania $\mathrm{w}$ organizacji?

W ramach zarządzania jakością $\mathrm{w}$ organizacji znajdują się działania, które mogą mieć różnorodną naturę, w rozumieniu ukierunkowania tych działań. Mogą to być aktywności tradycyjnie jakościowe, ukierunkowane na spełnienie potrzeb i oczekiwań klientów. Mogą to być działania podejmowane w aspekcie ryzyka, a zatem uwzględniające minimalizację zagrożeń i maksymalizację szans w realizacji celów zarządzania jakością. Działania te wchodzą ze sobą we wzajemne interakcje oraz łączą się w zbiory o podobnym charakterzee. Te zbiory nazwane zostały w niniejszej monografii wewnętrznymi czynnikami zarządzania jakością. Relacje pomiędzy wewnętrznymi czynnikami zarządzania jakością stanowią obszar sformułowania pierwszej hipotezy badawczej (H1). Działania stanowiące zawartość tych zbiorów zostały nazwane elementami konstytuującymi wewnętrzne czynniki zarządzania jakością. Relacje pomiędzy dwoma obszarami (naturą) elementów składowych analizowanych zbiorów stanowią obszar dla sformułowania drugiej hipotezy badawczej (H2). Czynniki wewnętrzne 
wpływają ostatecznie na rezultaty zarządzania jakością. Oddziaływanie czynników wewnętrznych na rezultaty zarządzania jakością stanowi płaszczyznę dla trzeciej hipotezy badawczej (H3). Zweryfikowanie hipotez badawczych, odnoszących się do wskazanych obszarów, pozwoliło na pozyskanie informacji o wewnętrznych czynnikach zarządzania jakością oraz elementach składowych, których kształtowanie poprzez decyzje w organizacji pozwala oddziaływać na sukces zarządzania jakością.

Pierwsza hipoteza badawcza (H1) brzmi: Zaangażowanie kierownictwa i pracowników $w$ jakość oraz orientacja na klientów stanowia najważniejsze wewnętrzne czynniki sukcesu projakościowego zarzadzania w organizacji.

Druga hipoteza badawcza (H2) zawiera przypuszczenie, że: Elementy konstytuujace wewnętrzne czynniki zarzadzania jakościa $w$ aspekcie ryzyka maja mniejsze znaczenie w oddziaływaniu na sukces zarzadzania jakościa niż elementy $w$ aspekcie jakości.

Trzecia hipoteza badawcza (H3) brzmi: Wewnętrzne czynniki zarządzania jakościa w największym stopniu wplywaja na niefinansowe mierniki sukcesu projakościowego zarządzania w organizacji.

Przyjęto, że podmiot badań empirycznych stanowi grupa autoryzowanych salonów sprzedaży i serwisu ${ }^{55}$ samochodów osobowych w Polsce, $\mathrm{z}$ racji jednorodności cech umiejscowiona w podobnym otoczeniu. Każda organizacja jest zindywidualizowana $z$ uwagi na interakcje w mikrootoczeniu i wnętrzu organizacji, co jest wynikiem złożonych procesów gospodarowania w danej lokalizacji i w danym momencie stanowiących efekt działań historycznych. Uwzględniając zatem podobieństwo otoczenia (zarówno bliższego, jak i dalszego) dla przyjętego zakresu podmiotowego, a jednocześnie różne oddziaływania $\mathrm{z}$ zewnątrz na decyzje poszczególnych menedżerów, należy stwierdzić, że to właśnie wewnętrzne czynniki można kształtować poprzez podejmowanie decyzji w każdej organizacji. Dlatego też wewnętrzne czynniki, w zestawieniu z zarządzaniem jakością, czyli zbiorem działań jakościowych ukierunkowanych na zadowolenie klientów, zostały uwzględnione w ramach obszaru badawczego. Decydenci w organizacjach podejmują każdego dnia decyzje, które składają się na efekt końcowy działalności. W badanych podmiotach jest to ukierunkowanie działań na sprzedaż klientom samochodów osobowych wraz z obsługą posprzedażną, co implikuje zadowolenie klientów i w dłuższym czasie wpływa na funkcjonowanie organizacji na rynku. Jednocześnie w codzienne działania menedżerskie

\footnotetext{
${ }^{55}$ Serwis jest najczęściej używaną nazwą w odniesieniu do obszaru napraw związanych $z$ samochodami. Jednak w ramach struktur organizacyjnych tych organizacji stosunkowo często nazywa się ten obszar szerzej - „obsługą posprzedażną”. Taka nazwa wskazuje nie tylko na naprawczy charakter działań podejmowanych wobec samochodów klientów, ale również przeglądowy, utrzymaniowy charakter usług oraz oferowanie sprzedaży części zamiennych, akcesoriów.
} 
wkomponowane są mechanizmy ukierunkowane na minimalizację zagrożeń oraz maksymalizację szans, co towarzyszy podejmowaniu decyzji po rozpatrzeniu różnych możliwości działania.

Reasumując, jako poszczególne zakresy niniejszej monografii można wskazać:

- zakres podmiotowy: autoryzowane salony sprzedaży i serwisu samochodów osobowych,

- zakres przedmiotowy: zarządzanie jakością, wewnętrzne czynniki zarządzania jakością,

- przestrzenny: Polska,

- czasowy: 2016 rok.

\section{Charakterystyka procesu badawczego}

W procesie badawczym można wyróżnić fazy: przygotowawczą badań, badania i analizy jakościowe oraz ilościowe, weryfikację badań.

$\mathrm{W}$ fazie przygotowawczej zostały zapoczątkowane działania dotyczące analizy literatury w kontekście naukowego opisania obszaru zainteresowań autora. W efekcie tych działań zidentyfikowano lukę badawczą i zdefiniowano problem badawczy. Sfera doświadczeń praktycznych autora miała znaczenie w zdefiniowaniu celów pracy, przy których tworzeniu przyświecała potrzeba utylitarności wyników oraz możliwości ich zastosowania w praktyce gospodarczej. Dlatego też w fazie przygotowawczej można wskazać na [Apanowicz 2003]:

- metodę badania dokumentów (sukcesywnie gromadzono materiały dotyczące obszaru badawczego, identyfikowano w poszczególnych publikacjach obszary dotyczące problematyki badawczej oraz łączono zagadnienia w poszczególne grupy tematyczne, do późniejszego wykorzystania przy pisaniu poszczególnych części monografii);

- metodę obserwacji (identyfikowanie różnorodnych zdarzeń rzeczywistych i publikowanych faktów następowało z przypisywaniem do obszaru badawczego oraz kolejnymi przybliżeniami relacji przyczynowo-skutkowych);

- metodę analizy i konstrukcji logicznej (analiza dostępnych materiałów i informacji w zestawieniu z obserwacjami własnymi autora zarówno na płaszczyźnie teoretycznej, jak i w ramach praktyki gospodarczej pozwoliła na zsyntetyzowanie faktów i relacji w formie problemu badawczego).

W fazie przygotowawczej analizowano obszar tematyczny pod względem jego zakresów, celów oraz hipotez badawczych. Te działania (od stycznia 2016 roku do kwietnia 2017 roku) zostały ujęte w tabeli 2. 
Tabela 2. Ramowy harmonogram prac badawczych

\begin{tabular}{|c|c|c|c|c|c|c|c|c|c|c|}
\hline \multirow{4}{*}{ Fazy procedury badawczej } & \multicolumn{10}{|c|}{ Następstwo czasowe dzialań } \\
\hline & \multicolumn{6}{|c|}{2016} & \multicolumn{4}{|c|}{2017} \\
\hline & \multicolumn{10}{|c|}{ miesiące } \\
\hline & 1-3 & $4-6$ & $7-9$ & 10 & 11 & 12 & 1 & 2 & 3 & 4 \\
\hline \multicolumn{11}{|c|}{ I. FAZA PRZYGOTOWAWCZA } \\
\hline \multicolumn{11}{|c|}{\begin{tabular}{l|l|l} 
Analiza obszarów tematycznych & &
\end{tabular}} \\
\hline \multicolumn{11}{|l|}{$\begin{array}{l}\text { Ostateczne sformułowanie proble- } \\
\text { mu badawczego }\end{array}$} \\
\hline \multicolumn{11}{|l|}{$\begin{array}{l}\text { Ostateczne określenie celów i hipo- } \\
\text { tez badawczych }\end{array}$} \\
\hline \multicolumn{11}{|l|}{$\begin{array}{l}\text { Analiza literatury - czytanie stresz- } \\
\text { czeń i pełnych wersji }\end{array}$} \\
\hline \multicolumn{11}{|l|}{$\begin{array}{l}\text { Szczegółowa analiza kluczowych } \\
\text { publikacji }\end{array}$} \\
\hline \multicolumn{11}{|c|}{\begin{tabular}{l|l|l|} 
Aktualizacja wykazu badanych & & \\
organizacji & &
\end{tabular}} \\
\hline \multicolumn{11}{|c|}{ II. BADANIA I ANALIZY JAKOŚCIOWE } \\
\hline \multicolumn{11}{|l|}{ Wywiady } \\
\hline \multicolumn{11}{|l|}{ Spotkania z ekspertami } \\
\hline \multicolumn{11}{|c|}{ III. BADANIA I ANALIZY ILOŚCIOWE } \\
\hline \multicolumn{11}{|l|}{ Badanie pilotażowe } \\
\hline \multicolumn{11}{|l|}{ Badanie właściwe } \\
\hline \multicolumn{11}{|c|}{ IV. FAZA WERYFIKACJI BADAŃ } \\
\hline \multicolumn{11}{|c|}{\begin{tabular}{|l|l} 
Opracowanie statystyczne wyników & \\
\end{tabular}} \\
\hline \multicolumn{11}{|l|}{ Analiza i interpretacja wyników } \\
\hline \multicolumn{11}{|l|}{$\begin{array}{l}\text { Opracowanie wyników z badania } \\
\text { ankietowego }\end{array}$} \\
\hline Wyjaśnienie problemu badawczego & & & & & & & & & & \\
\hline
\end{tabular}

Źródło: Na podstawie: [Hys 2015a, s. 133].

W ramach badań jakościowych zostały przeprowadzone wywiady oraz spotkania z ekspertami. Pogłębione wywiady indywidualne z kierownictwem autoryzowanych salonów sprzedaży i serwisu samochodów osobowych w Polsce zostały przeprowadzone (w okresie kwiecień - czerwiec 2016 roku) w grupie 16 organizacji, w ramach sieci jednej marki samochodów, po jednej organizacji z każdego województwa. Taki dobór podmiotowy był podyktowany przede wszystkim powiązaniem respondentów z tematem badań oraz możliwościami współpracy $\mathrm{z}$ tą autoryzowaną siecią oraz zgodą tych podmiotów na udział w badaniu. W każdej lokalizacji badanie trwało cały dzień ( 8 godzin). Celem tego badania było pozyskanie ogólnych informacji o działaniach z zakresu 
zarządzania jakością, czynnikach wpływających na realizację celów, podstawach dokumentacyjnych bieżących działań oraz aktywnościach podejmowanych z obszaru minimalizacji ryzyka i maksymalizacji szans. Wywiady były realizowane w sposób niestrukturyzowany, ukierunkowany na pozyskanie informacji o kaskadowym działaniu w obszarze zarządzania jakością. Rozmowy były prowadzone $\mathrm{w}$ pierwszej kolejności $\mathrm{z}$ osobami zarządzającymi w danej lokalizacji, a następnie z pracownikami nadzorującymi poszczególne obszary sprzedaż oraz serwis.

W ramach empirycznych badań jakościowych zostały przeprowadzone dwa spotkania z grupą praktyków, wieloletnich ekspertów z obszaru motoryzacji. Obydwa spotkania miały miejsce w Warszawie (pierwsze w lipcu, drugie w sierpniu 2016 roku). Spotkania odbyły się w centrali grupy dealerskiej posiadającej 11 autoryzowanych salonów sprzedaży i serwisu samochodów osobowych w Polsce, które posiadają autoryzację pięciu różnych producenckich marek samochodowych. Wykorzystano comiesięczne „zjazdy” dyrektorów zarządzających poszczególnymi lokalizacjami, które odbywały się w centrali tejże grupy dealerskiej. Pierwsze spotkanie z dyrektorami miało formę dyskusji o zagadnieniach zarządzania jakością w organizacji, w szczególności działaniach wpływających na realizację celów biznesowych. Spotkanie drugie skoncentrowane było na wewnętrznych czynnikach wpływających na rezultaty podejmowanych działań w poszczególnych lokalizacjach. Podstawę tej rozmowy stanowiła lista głównych czynników zarządzania jakością oraz elementów je konstytuujących. Celem drugiego spotkania z ekspertami było doprecyzowanie czynników zarządzania jakością względem czynników jakości (które stanową element rozważań w pierwszym rozdziale pracy) oraz wyjaśnienie różnorodnych wątpliwości wpływających na ostateczny kształt listy wewnętrznych czynników zarządzania jakością i elementów składowych.

Badania i analizy ilościowe dotyczyły badania pilotażowego oraz badania właściwego.

Metody zbierania danych $\mathrm{w}$ badaniach uwarunkowań wewnętrznych należą głównie do metod ilościowych, a do najczęściej stosowanych zalicza się wywiad osobisty oraz ankietę pocztową [Kaczmarczyk 2007, s. 201]. Ankietę wybrano na potrzeby badania empirycznego. Z uwagi na rozproszenie terytorialne respondentów [Kaniewska-Sęba, Leszczyński i Pilarczyk 2006, s. 122] narzędziem badawczym służącym realizacji zastosowanej techniki badań [Pilch i Bauman 2001, s. 71] był kwestionariusz ankietowy. Biorąc pod uwagę sposób dystrybucji kwestionariusza ankietowego wśród respondentów, zdecydowano się na ankietę internetową [Kaniewska-Sęba, Leszczyński i Pilarczyk 2006, s. 122] wspomaganą komputerowo - CAWI (Computer Assisted Web Interviews). Technikę badawczą wybrano ze względu na liczebność próby badawczej (i jej rozproszenie terytorialne), jak również powszechne wykorzystywanie 
internetu w próbie badawczej oraz minimalizację kosztów badania [Habrzyk 2013, s. 36].

Badanie pilotażowe miało miejsce na początku listopada 2016 roku. Przy wyborze jednostek do badania pilotażowego wykorzystano kontakty osobiste. Otrzymano 14 wypełnionych ankiet, co stanowiło zwrotność na poziomie 100\%. Badanie to posłużyło do weryfikacji kwestionariusza ankietowego, jak również od strony technicznej - do weryfikacji ankiety internetowej. Nie stwierdzono konieczności merytorycznej modyfikacji kwestionariusza ankietowego. Dokonano jedynie zmian graficznych oraz wprowadzono wymóg udzielenia odpowiedzi na wszystkie pytania (respondent dopiero wówczas mógł przejść do kolejnego punktu $\mathrm{w}$ ankiecie). Tym samym wyeliminowano problem uzyskania niepełnych ankiet, co zagwarantowało, że wszystkie 219 wypełnionych ankiet $\mathrm{z}$ badania właściwego było kompletnych ${ }^{56}$.

Właściwe badanie empiryczne zostało przeprowadzone jako pośrednie badanie sondażowe $\mathrm{z}$ wykorzystaniem metody badań ankietowych $\mathrm{w}$ formie ankiety internetowej ${ }^{57} \mathrm{w}$ grudniu 2016 roku. Taka forma badania empirycznego została wybrana $\mathrm{z}$ uwagi na rozproszenie terytorialne respondentów oraz możliwość dotarcia do dużej zbiorowości w stosunkowo krótkim czasie przez jedną osobę [Kaczmarczyk 2011, s. 227; Churchill 2002, s. 232]. W badaniu właściwym posłużono się kwestionariuszem ankietowym, którego zawartość stanowiła efekt analiz przedstawionych w II rozdziale niniejszej monografii.

Ankieta internetowa bez udziału ankietera jest zaliczana do metod ilościowych, a otrzymane dane są analizowane metodami statystycznymi [Kaczmarczyk 2011, s. 236]. W fazie weryfikacji badań przeprowadzono analizę i interpretację wyników uzyskanych w badaniu ankietowym. Dane zebrane zostały na dzień 31 grudnia 2016 roku.

\section{Dobór i charakterystyka próby badawczej}

Jako próbę badawczą do empirycznego badania właściwego przyjęto autoryzowane salony sprzedaży i serwisu samochodów osobowych w Polsce. Dobór celowy w badaniu ankietowym był efektem wieloletnich analiz autora związanych

${ }^{56}$ Choć zidentyfikowano 11 wejść na internetową stronę z kwestionariuszem ankiety i po udzieleniu odpowiedzi na część pytań strona z ankietą została przez danego użytkownika zamknięta.

${ }^{57}$ Ankieta, od strony technicznej, została przygotowana przez firmę informatyczną i umieszczona pod adresem domeny www.kzsz-uep-ankieta.pl, specjalnie wykupionej na potrzeby badania właściwego. W wiadomości mailowej przesyłanej do potencjalnych respondentów, po scharakteryzowaniu badania, został umieszczony link przekierowujący na stronę z ankietą. 
z obszarem badawczym. Doświadczenia teoretyczno-praktyczne autora można ująć w dwóch grupach. Grupa pierwsza to doświadczenia koncentrujące się na zagadnieniach zarządzania ciągłością działania w sferze normalizacyjnej. Drugi zbiór działań jest związany z nurtem umiejscowionym w zarządzaniu jakością, przy uwzględnianiu podejścia opartego na ryzyku.

W pierwszej grupie doświadczeń można wskazać na zainteresowanie sferą normalizacyjną zarządzania ciągłością działania i zagadnieniami wkomponowania ryzyka $\mathrm{w}$ znormalizowane systemy zarządzania. Jedną z pierwszych aktywności był udział autora w charakterze uczestnika $\mathrm{w}$ audytorskich szkoleniach organizowanych przez jednostki certyfikujące z zakresu zarządzania bezpieczeństwem informacji (organizatorem był SGS), zarządzania ciągłością działania (BSI), zarządzania bezpieczeństwem łańcucha dostaw (LRQA). Zainteresowania natury teoretycznej spotkały się z możliwością praktycznej weryfikacji w ramach projektu „SSN - Staż Sukcesem Naukowca” (11.2010 - 04.2011). Organizatorem projektu stażowego był PAIP (Poznański Akademicki Inkubator Przedsiębiorczości), a sam staż miał miejsce w drukarni opakowań dla przemysłu farmaceutycznego. Celem sześciomiesięcznego stażu była ocena możliwości praktycznego wdrożenia systemu zarządzania ciągłością działania zgodnie z wymaganiami brytyjskiej normy BS 25999-2. W ramach prac z tym związanych przeprowadzono proces oceny ryzyka, korzystając z zasad i wytycznych normy ISO 31000. Przeprowadzono również analizę ryzyka, wykorzystując metody przedstawione w dokumencie normalizacyjnym IEC/ISO 31010. Kolejnym działaniem w tej grupie doświadczeń było wydanie, we współautorstwie, monografii zatytułowanej Ryzyko, ciagłość biznesu, odpowiedzialność społeczna. Nowoczesne koncepcje zarzadzania [Zapłata i Kaźmierczak 2011], w której przedstawiono teoretyczne spektrum zagadnień zarządzania ciągłością działania. Analizy dotyczące możliwości rozwoju systemowego zarządzania ciągłością działania były ukierunkowane na poszukiwanie zakresu podmiotowego badań empirycznych. Można tutaj wskazać na płaszczyzny analizy: zagrożenia i uwarunkowania związane z wielkością organizacji, a w szczególności aspektami ludzkimi, lokalizację działalności gospodarczej, posiadaną infrastrukturę [Zapłata i Kaźmierczak 2011, s. 131-135]. Autor uzyskał pozytywną opinię wniosku o dofinansowanie projektu badawczego własnego ${ }^{58}$ zatytułowanego „System zarządzania ciągłością działania BS 25999-2: motywy, bariery oraz efekty funkcjonowania - wykorzystanie doświadczeń systemowego zarządzania bezpieczeństwem informacji". W ramach tego projektu zostały przeprowadzone badania ankietowe wśród organizacji w Polsce posiadających certyfikowany, znormalizowany system zarządzania bezpieczeństwem informacji ISO/IEC 27001. Celem badania było pozyskanie informacji o możliwości rozwoju syste-

${ }^{58}$ Projekt finansowany przez Narodowe Centrum Nauki, realizowany w okresie 05.2011 08.2012, nr umowy 4106/B/H03/2011/40. 
mowego zarządzania ciągłością działania właśnie wśród organizacji, które z racji posiadanego już systemu były predysponowanego do wdrożenia kolejnego, dotyczącego ciągłości działania.

Podejmowane działania, składające się na pierwszą grupę doświadczeń, wpłynęły na sformułowanie wniosków, że zagadnienia ciągłości działania i zarządzania ryzykiem są realizowane w organizacjach w różny sposób. Dalsza obserwacja rynku w obszarze znormalizowanych systemów zarządzania ugruntowała przekonanie autora, że certyfikacja systemów zarządzania w obszarach ciągłości działania i zarządzania ryzykiem nie stanowi determinanty sukcesu organizacji ogólnie na rynku, tak jak to ma chociażby miejsce w obszarze systemowego zarządzania jakością.

Dalsze analizy zostały ukierunkowane na zagadnienia zarządzania jakością, przy uwzględnieniu podejścia opartego na ryzyku. Ten kierunek został wybrany z uwagi na powszechność zarządzania jakością jako zagadnień występujących w działalności każdej organizacji, a mającej wpływ na końcowy efekt działań - produkt (wyrób i usługę). Zagadnienia podejścia opartego na ryzyku są bowiem wkomponowane w bieżące działania w każdej organizacji. Naturalne wydawało się skoncentrowanie aktywności badawczych na znormalizowanym systemie zarządzania jakością. Tym bardziej że był to czas rozpoczynających się prac nad nowelizacją normy ISO 9001 i informacji o prawdopodobnym uwzględnieniu elementów zarządzania ryzykiem w modyfikacji treści wymagań normatywnych. Pozyskanie praktycznej wiedzy o zarządzaniu jakością było możliwe dzięki pracy doradczo-szkoleniowej autora w salonach sprzedaży i serwisu samochodów osobowych w Polsce. Najistotniejszym doświadczeniem jest realizowanie audytów procesowych $\mathrm{w}$ autoryzowanej sieci sprzedaży i serwisu samochodów osobowych, dostawczych oraz ciężarowych. Projekt audytowy został ukierunkowany na ocenę zgodności działań, w obszarze sprzedaży i obsługi posprzedażnej samochodów osobowych, z wymaganiami autoryzacyjnymi dotyczącymi realizacji procesów biznesowych. Obszarem szczególnego zainteresowania była identyfikacja zagrożeń występujących w prowadzonej działalności wraz z możliwościami minimalizacji ryzyka w całej sieci dealerskiej danej marki. Podejście to zostało roboczo nazwane „SZR ISO 9001+" 59 i dotyczyło systemowego zarządzania ryzykiem, bazującego na wymaganiach z normy ISO 9001, właśnie $z$ dodatkiem elementów minimalizacji ryzyka i maksymalizacji szans jako zagadnień wpływających na unifikację działań w poszczególnych lokalizacjach danej sieci sprzedażowo-serwisowej. Praktyczny kontakt z badania-

${ }^{59}$ Takie podejście autor zaprezentował w referacie plenarnym [Zapłata 2012] pt. Zarzadzanie ryzykiem, ciagłość działania, znormalizowane systemy zarzadzania - praktyczne zastosowanie teorii, zaprezentowanym podczas seminarium „Zarządzanie ryzykiem - 2. Ryzyko w działaniach biznesowych, praktyczne podejście", zorganizowanym przez Polskie Forum ISO 9000 w Ciechocinku 15-17 października 2012 roku. 
mi realizowanymi metodą tajemniczego klienta ${ }^{60} \mathrm{w}$ działach sprzedaży i obsługi posprzedażnej w różnych lokalizacjach samochodowych w Polsce wpłynął na pozyskiwanie informacji o zagadnieniach procesowych dotyczących realizacji zaplanowanych celów jakościowych.

Powyższe ostatecznie wpłynęło na:

- ujęcie zarządzania jakością w organizacji w sposób nieznormalizowany, ale nadzorowany w wyniku autoryzacji poszczególnych lokalizacji;

- utylitarność wyników, z uwagi na łączenie zagadnień naukowych z doświadczeniami praktycznymi;

- przyjęcie, że podejście oparte na ryzyku występuje w każdej organizacji w ukierunkowaniu na realizację zaplanowanych celów.

Warto zwrócić uwagę na fakt, że w całym 2016 roku zarejestrowano w Polsce ponad 416 tys. samochodów osobowych [Branża motoryzacyjna 2017, s. 4]. Jest to imponująca liczba, jak na polskie warunki, a był to wynik o 17,21 proc. (61 118 sztuk) lepszy w porównaniu z 2015 rokiem [IBRM Samar 2017]. Było to zarazem najlepszych dwanaście miesięcy od 2000 roku, kiedy to na krajowym rynku sprzedało się ponad 468 tys. aut. Potem - gdy po wejściu do Unii Polacy zaczęli sprowadzać używane samochody z Niemiec czy Holandii, liczba rejestracji nowych aut zaczęła gwałtownie spadać. Najgorszy wynik rynek zanotował w 2005 roku, gdy w Polsce zarejestrowano jedynie nieco ponad 235 tys. sztuk [IBRM Samar 2017].

Właściwe badanie ankietowe zostało przeprowadzone w grudniu 2016 roku, a zatem w najlepszym (pod względem wolumenu sprzedaży) miesiącu ze wszystkich ostatnich szesnastu lat. Wzrost sprzedaży oznacza wzrost wewnętrznych działań w organizacji, a to implikuje wzrost zagrożeń i końcowo wzrost ryzyka. $Z$ perspektywy zakresu przedmiotowego pracy umiejscowienie czasowe badań $\mathrm{w}$ tym miesiącu było sprzyjającym momentem, z uwagi na realizację celów pracy.

Organizacje wytypowane do badania stanowią zbiorowość o następujących cechach [Ignatczyk i Chromińska 2004, s. 14-16]:

1. Grupa jest jednorodna z uwagi na zakres działalności - sprzedaż i serwis samochodów osobowych w autoryzowanych lokalizacjach na terenie Polski.

2. Grupa tworzy zbiór liczbowo zamknięty (jest skończona) z uwagi na zamkniętą listę autoryzowanych lokalizacji, w ramach poszczególnych marek motoryzacyjnych.

3. Organizacje wytypowane do badań empirycznych tworzą zbiorowość dynamiczną, z uwagi na możliwą zmienną liczebność, choć w przypadku uzyskiwania autoryzacji i budowy nowych salonów nie jest to proces

${ }^{60}$ Realizacja testów tajemniczego klienta w sprzedaży i serwisie pojazdów osobowych została wskazana przez autora jako praktyczny przykład zarządzania ryzykiem w obszarze zarządzania jakością, w: [Zapłata 2016a]. 
„jednodniowy”. Lista autoryzowanych salonów sprzedaży i serwisu samochodów osobowych w Polsce została stworzona na dzień 25 listopada 2016 roku.

Populacja generalna (zbiorowość statystyczna) przyjęta przy zastosowaniu wskazanych powyżej kryteriów jest homogeniczna; wszystkie te organizacje mają ten sam zakres działalności - sprzedaż i serwis samochodów osobowych ${ }^{61}$.

W kwestii sprecyzowania zakresu podmiotowego badań konieczne jest doprecyzowanie kwestii branży. Na branżę motoryzacyjną składa się przemysł motoryzacyjny (produkcja pojazdów samochodowych) oraz handel i usługi motoryzacyjne (handel hurtowy i detaliczny pojazdami samochodowymi, częściami i akcesoriami oraz naprawa pojazdów samochodowych); natomiast jako sektory powiązane można wskazać m.in. usługi finansowe i ubezpieczeniowe [Misztal 2015, s. 14]. Z kolei w kwartalnych raportach bieżących trendów w branży motoryzacyjnej $\mathrm{w}$ Polsce branża jest rozumiana zarówno jako rynek motoryzacyjny (sprzedaż i obsługa posprzedażna pojazdów), jak i produkcja przemysłowa (przemysł motoryzacyjny jako produkcja i eksport) oraz motoryzacyjne usługi finansowe (leasing, ubezpieczenia) [Branża motoryzacyjna 2017, s. 2]. $\mathrm{W}$ ramach branży motoryzacyjnej są zatem ujmowane podmioty produkujące pojazdy oraz sprzedające i prowadzące obsługę posprzedażną, które w ww. raporcie są ujmowane pod nazwą ,rynek motoryzacyjny”. Z uwagi na powiązanie zakresu podmiotowego monografii, autoryzowanych salonów sprzedaży i serwisu samochodów osobowych w Polsce z producentami pojazdów (poprzez autoryzację z ich przedstawicielami bądź importerami) grupę badanych organizacji nazywano w niniejszej monografii „branżą motoryzacyjną”.

Lista autoryzowanych salonów sprzedaży i serwisu samochodów osobowych w Polsce została przygotowana we własnym zakresie. Baza danych zawierająca listę poszczególnych lokalizacji była tworzona na bieżąco od lipca 2016 roku, a ostateczna jej aktualizacja nastąpiła w listopadzie tego samego roku. Stworzona baza zawierała wykaz ilościowy lokalizacji danej marki w danym województwie. Łącznie zidentyfikowano w Polsce 1585 lokalizacji ${ }^{62}$

${ }^{61} \mathrm{~W}$ samej ankiecie jest również pytanie o zakres, ponieważ w Polsce występują autoryzowane stacje serwisowe, w których nie jest prowadzona sprzedaż nowych samochodów. Aczkolwiek doświadczenia praktyczne autora wskazują na dwa rodzaje lokalizacji wyłącznie serwisowych. Pierwsze to pojedyncze lokalizacje serwisowe należące do jednego właściciela, który nie prowadzi dodatkowo działalności w innych lokalizacjach. Drugie to lokalizacje z autoryzacją serwisową, ale w grupie dealerskiej, która w innych lokalizacjach prowadzi również sprzedaż samochodów. Obserwacje własne wskazują, że często taka serwisowa lokalizacja stanowi stacjonarny punkt dla „mobilnych handlowców”, którzy penetrują rynek w poszukiwaniu klientów, w danym regionie.

${ }^{62}$ Jako lokalizacja traktowane jest terytorialne miejsce, gdzie można dokonać zakupu pojazdu lub pozostawić samochodów w celu skorzystania z obsługi serwisowej. Istnieją w Polsce obiekty, które łączą w danym miejscu sprzedaż i serwis różnych marek, np. Mazda i Jeep, i wówczas w zestawieniu, pomimo jednego obiektu, ujęte zostały w bazie danych jako dwie odrębne lokalizacje i pozyskane zostały osobne adresy mailowe. 
związanych ze sprzedażą i serwisem samochodów osobowych, które podlegają autoryzacji producentów samochodów, co przedstawiono w ujęciu terytorialnym na wykresie 1 .

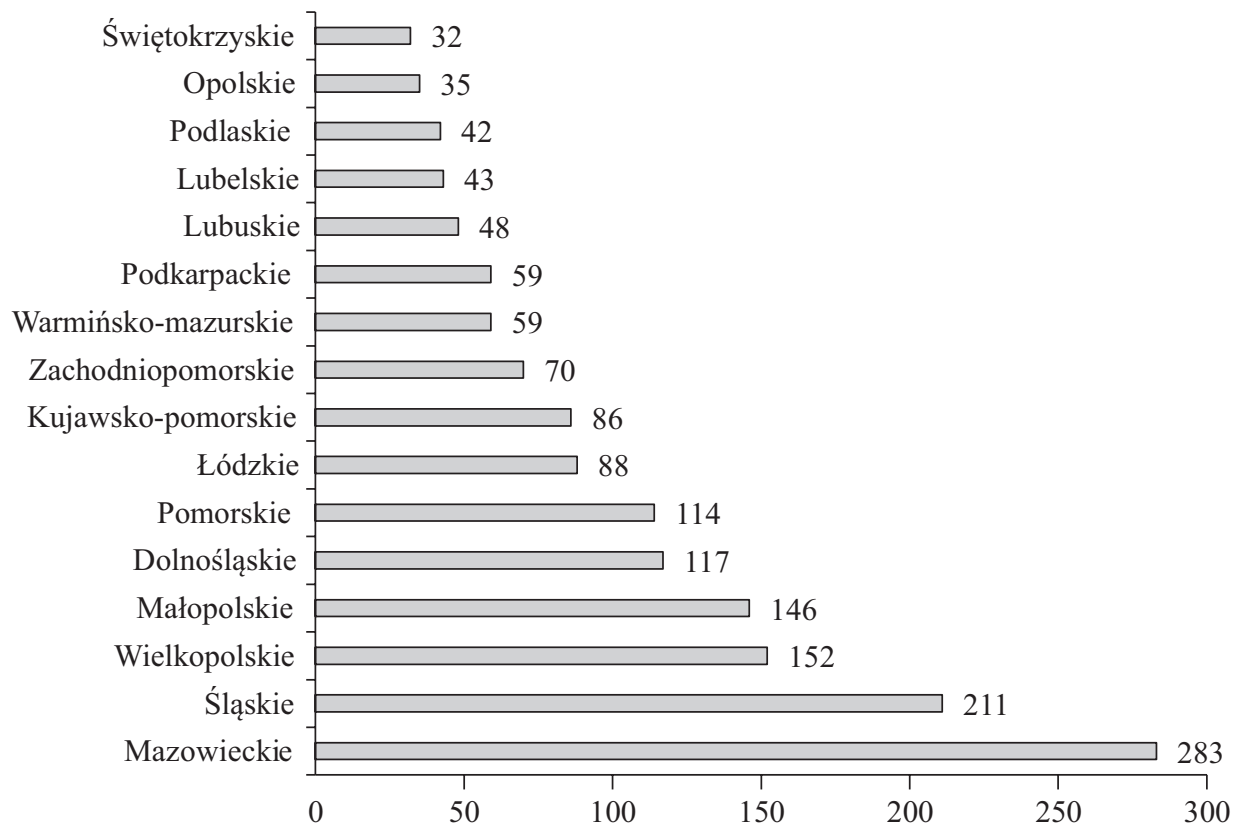

Wykres 1. Lokalizacje autoryzowanych salonów sprzedaży i serwisu samochodów osobowych w Polsce - ujęcie terytorialne

W procesie tworzenia i aktualizacji bazy priorytetowym kryterium, dla zapewnienia jej kompletności, był wykaz marek samochodów. Pierwszym działaniem było zatem opracowanie tabeli z markami samochodów, a następnie ilościowe ujęcie lokalizacji według województw. Za podstawę pozyskania danych posłużyła strona internetowa Instytutu Badań Rynku Motoryzacyjnego SAMAR $^{63}$ i ilościowy wykaz liczby lokalizacji poszczególnych marek pojazdów, co zostało przedstawione na wykresie 2 .

Wskazana baza posłużyła do identyfikacji autoryzowanych salonów sprzedaży i serwisu samochodów osobowych poszczególnych marek w Polsce. Ostatecznie opracowano grupy adresów mailowych, uporządkowanych według marek samochodów, celem ich wykorzystania do wysyłki wiadomości informującej o badaniu ankietowym oraz zawierającej link do strony z ankietą.

${ }^{63} \mathrm{http}: / /$ www.samar.pl/katalog-nowych-samochodow i zakładka ,samochody osobowe” oraz dla weryfikacji wykaz marek samochodów na stronie z ogłoszeniami www.otomoto.pl. 


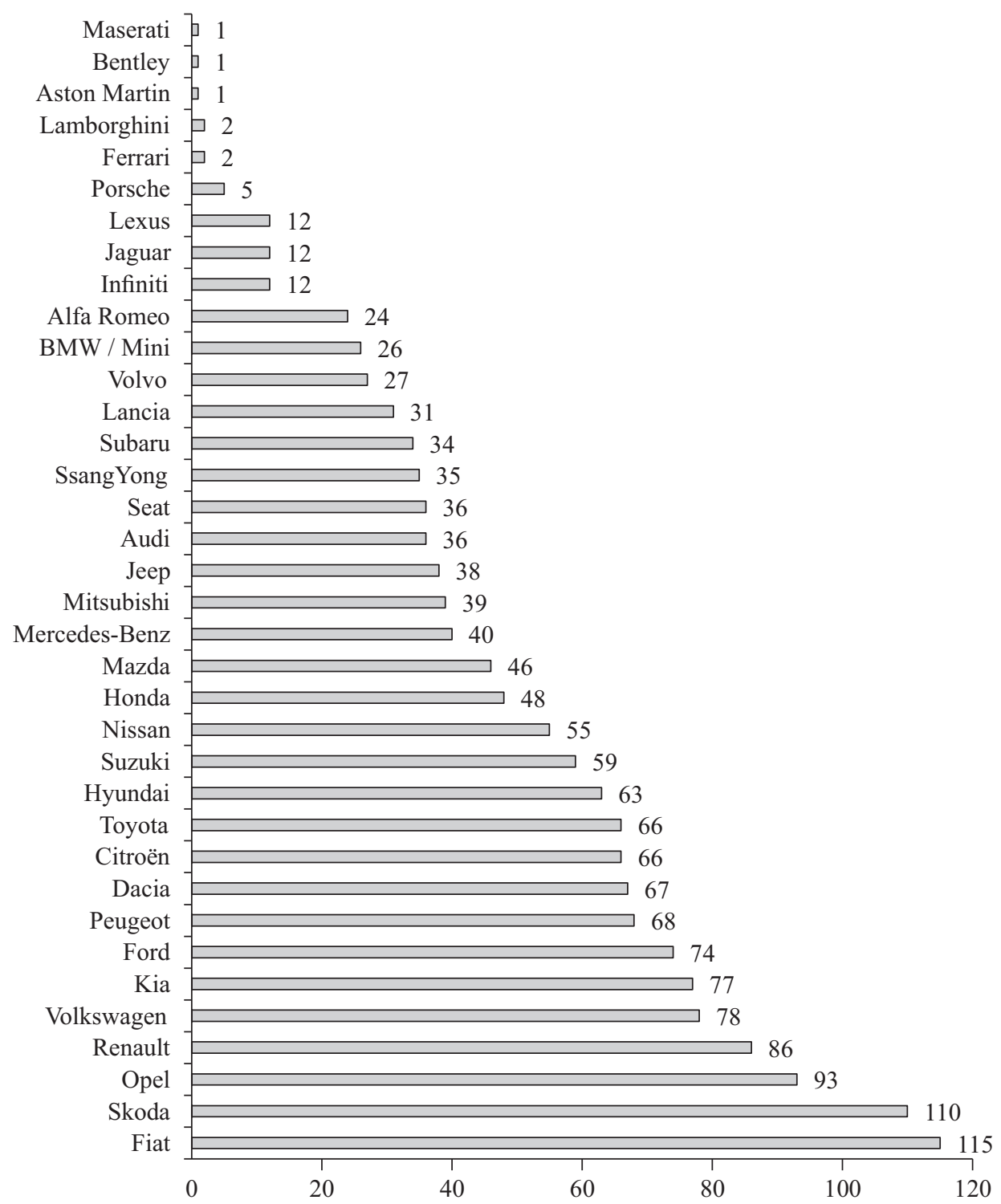

Wykres 2. Autoryzowane salony sprzedaży i serwisu samochodów osobowych w Polsce - ujęcie według marek pojazdów 


\section{Budowa kwestionariusza ankietowego}

Przy ustalaniu kolejności pytań w kwestionariuszu ankietowym uwzględniono wyniki analizy literatury oraz próbę formułowania jak najprostszych pytań, w ukierunkowaniu na pozyskanie informacji umożliwiających weryfikację hipotez badawczych oraz realizację celów pracy. Kwestionariusz ankietowy składał się z trzech części:

1. Wstępnej (zawierającej informacje o badaniu oraz zapewnieniu anonimowości respondentom).

2. Zasadniczej, podzielonej na trzy odpowiednio zatytułowane części (powiązane ze szczegółowymi, teoretycznymi celami pracy):

- czynniki sukcesu zarządzania jakością (gdzie umiejscowiono osiem głównych wewnętrznych czynników zarządzania jakością);

- elementy zarządzania jakością (w tej części osiem głównych wewnętrznych czynników zarządzania jakością uszczegółowiono elementami składowymi w aspekcie jakości oraz ryzyka);

- rezultaty zarządzania jakością (w tym obszarze w ramach trzech grup rezultatów zarządzania jakością umiejscowiono efekty obrazujące wpływ zarządzania jakością na wyniki organizacji).

3. Końcowej - informacje o respondencie.

$\mathrm{W}$ celu ograniczenia błędu pomiaru badawczego zunifikowano kwestionariusz ankietowy poprzez ten sam sposób skalowania odpowiedzi oraz tę samą liczbę odpowiedzi w poszczególnych pytaniach. W kwestionariuszu zastosowano siedmiostopniową, przedziałową skalę Likerta [Churchill 2002, s. 423]. W poszczególnych częściach ankiety znalazło się sformułowanie: „Proszę o ustosunkowanie się do poniższych stwierdzeń, w odniesieniu do Państwa lokalizacji, przy zastosowaniu siedmiostopniowej skali odpowiedzi, gdzie: 1 oznacza zdecydowanie nie, 2 - nie, 3 - raczej nie, 4 - nie mam zdania, 5 - raczej tak, 6 - tak, 7 - zdecydowanie tak".

W badaniach ankietowych z zakresu zarządzania jakością zastosowanie mają obydwie skale Likerta, zarówno siedmiostopniowa [Wu i Chen 2011; Psomas i Kafetzopoulos 2014; Kafetzopoulos, Psomas i Gotzamani 2015; Psomas i Jaca 2016], jak i pięciostopniowa [Salaheldin 2009; Baird, Jia i Reeve 2011; Hassan i in. 2012; Talib, Rahman i Qureshi 2013; Gambi i in. 2015; Ismyrlis, Moschidis i Tsiotras 2015]. W literaturze podawane są wady ${ }^{64}$ stosowania skali pięciopunktowej (w stosunku do siedmiopunktowej) [Finstad 2010, s. 104-110]. W bada-

${ }^{64}$ Najczęściej wymienianymi wadami są niewystarczająca czułość skali pięciopunktowej, częstsze stosowania interpolacji przez respondentów odpowiadających na skali pięciopunktowej - u sporego odsetka respondentów występowały wątpliwości i chęć zaznaczenia odpowiedzi „pomiędzy" - najczęściej dotyczyło to opcji 2,5 oraz 3,5 (czyli nieco powyżej oraz nieco poniżej 
niu empirycznym, na potrzeby realizacji celów niniejszej pracy, zdecydowano ostatecznie o zastosowaniu siedmiopunktowej skali Likerta jako umożliwiającej większe zróżnicowanie odpowiedzi respondentów niż skala pięciostopniowa. Przyczynowo-skutkową zależność pomiędzy wewnętrznymi czynnikami a rezultatami stanowiącymi opomiarowanie tytułowego w monografii sukcesu projakościowego zarządzania $\mathrm{w}$ organizacji respondenci oceniali w badaniu empirycznym przy zastosowaniu siedmiostopniowej skali odpowiedzi. Przypisanie przez respondentów wyższej skali w ocenie oznacza większy wpływ ocenianego czynnika na powiązane w badaniach statystycznych rezultaty projakościowego zarządzania $\mathrm{w}$ organizacji. Większy wpływ poszczególnych wewnętrznych czynników na przyjęte $\mathrm{w}$ badaniu rezultaty zarządzania jakością $\mathrm{w}$ organizacji utożsamiany jest z wyższą ważnością danego analizowanego czynnika.

Zebrane w badaniu ankietowym dane poddano analizie rzetelności skali przy zastosowaniu testu Alfa-Cronbacha, który dla wszystkich pozycji wyniósł 0,975. Przeprowadzono również analizę rzetelności dla poszczególnych grup pytań ujętych w kwestionariuszu i najniższy wynik wyniósł 0,723 , a kolejne znalazły się w przedziale od 0,812 do 0,975 . Wyniki powyższego testu świadczą o dużej spójności i rzetelności zastosowanego narzędzia badawczego. Analizy ukierunkowane na zmienność współczynnika Alfa-Cronbacha, w zależności od usuwania pozycji zaniżających rzetelność (pojedynczych pytań), wykazały, że nie można było uzyskać poprawy statystyk nawet o 0,001 .

\section{Przetwarzanie i analiza danych}

Uzyskane w badaniu ankietowym wyniki poddano obróbce statystycznej ${ }^{65}$. $\mathrm{W}$ analizach zastosowano analizę czynnikową, korelację, jak również analizę skupień.

Analiza czynnikowa została wykorzystana do zbadania wzajemnych relacji pomiędzy dużą liczbą zmiennych, które w badaniu dotyczyły elementów ujętych w drugiej i trzeciej części kwestionariusza ankietowego. Analiza czynnikowa służy do agregacji zmiennych oraz analizy struktury wzajemnych zależności, co pozwala na wykrycie ukrytych zależności. Interpretacja tych zależności pozwala na wyjaśnienie relacji przyczynowo-skutkowych, co jest związane z celami pracy i odpowiedzią na postawione pytanie ukazujące problem badawczy.

Różnorodność elementów konstytuujących główne wewnętrzne czynniki zarządzania jakością, z perspektywy użyteczności i praktycznej możliwości

poziomu neutralnego). Skala siedmiopunktowa nie ma tych ograniczeń, natomiast rozwinięcie skali do 9 punktów sprawia, że odpowiedzi respondentów nie są powtarzalne.

${ }^{65}$ Analizy dokonano przy użyciu pakietu statystycznego IBM SPSS STATISTICS 23. 
zastosowania, wymaga ich pogrupowania, czyli wyodrębnienia tzw. składowych (abstrakcyjnych czynników), które zachowując w sobie pierwotne elementy, pozwalają na wyjaśnienie interesujących zjawisk. Analiza czynnikowa została przeprowadzona w kilku etapach. Najpierw uwzględniono drugą część ankiety, obejmującą osiem głównych wewnętrznych czynników zarządzania jakością wraz z elementami je opisującymi, i w wyniku analizy czynnikowej zidentyfikowano osiem składowych. Następnie skoncentrowano działania na analizie rezultatów zarządzania jakością ujętych w trzeciej części kwestionariusza i zidentyfikowano trzy składowe. Zastosowaną metodą wyodrębniania czynników była metoda głównych składowych (PCA - Principal Component Analysis) [Podolec i Zając 1978]. Polega ona na tym, że każdy wieloelementowy zbiór zmiennych można przedstawić jako liniową kombinację tych czynników (oraz składnika reprezentującego oddziaływanie charakterystyczne dla zmiennej faktycznej) [Malarska 2005]. Umożliwia to maksymalizację różnic pomiędzy czynnikami oraz charakterystykę rozproszenia poszczególnych wymiarów w przestrzeni. W celu oceny zasadności zastosowania analizy czynnikowej przeprowadzono ocenę istotności statystycznej macierzy korelacji, przeprowadzając test sferyczności Barletta. Następnie dokonano oceny adekwatności macierzy korelacji za pomocą współczynnika Kaisera-Mayera-Olkina (KMO), którego wartość powinna wynosić co najmniej 0,5 , aby istniały silne podstawy do zastosowania analizy czynnikowej [Field 2005].

Kolejnym aspektem wymagającym uwzględnienia był sposób wyznaczania głównych składowych oraz ocena wyników. Określenie optymalnej (racjonalnej) liczby składników określa się na podstawie: testu osypiska Cattella, kryterium Kaisera oraz sumarycznie kryterium minimum. Każde z kryteriów dotyczy wartości własnych. Według kryterium Kaisera należy uwzględniać tylko wartości własne większe od 1 (jeśli składowa wyjaśnia mniej niż jedną zmienną, to stosowanie jej jest bezcelowe). Według testu osypiska Cattella należy zidentyfikować, gdzie na wykresie zaczyna się łagodny spadek wartości własnych [Malarska 2005]. Jest to kryterium znacznie bardziej niejednoznaczne niż kryterium Kaisera, ale pozwalające uwzględniać optymalną liczbę składowych w przypad$\mathrm{ku}$, gdy ma się do czynienia z dużą liczbą zmiennych i potencjalnie dużą liczbą składowych. Sumaryczne kryterium minimum zakłada, że przyjmuje się taką liczbę składowych, jaka wyjaśni założony wcześniej odsetek wariancji (zwykle jest to od 0,7 do 0,9 ). W celu poprawy czytelności rozwiązania (ponieważ początkowe rozwiązania modelu czynnikowego zazwyczaj są nieinterpretowalne) dokonuje się rotacji osi. Dzięki nowemu położeniu pierwotnie duże ładunki stają się jeszcze większe, a mniejsze - jeszcze mniejsze. W analizie wykorzystano rotację Varimax, która była wykorzystywana także przez innych badaczy obszaru zarządzania jakością [Fotopoulos i Psomas 2010] oraz jest wskazywana przez statystyków jako najczęściej stosowana metoda rotacji [Abdi 2003; Thompson 
2004; Kline 1999; Hair i in. 2009]. W analizie poszczególnych czynników wzięto pod uwagę te, przy których zmienne były skorelowane ze składowymi wysoko $(>0,6)$ lub umiarkowanie $(>0,3)$ [Balicki 2013]. Wszystkie obliczenia wykonano w analizie czynnikowej na danych zestandaryzowanych [Kline 1994; Hair i in. 2009; Malarska 2005].

Po wykonaniu analizy czynnikowej policzono wartości ładunków czynnikowych dla każdej obserwacji (każdego autoryzowanego salonu sprzedaży i serwisu samochodów osobowych w Polsce). W tym celu wykorzystano jedną z trzech najpopularniejszych metod (regresji, Bartletta i Andersona-Rubina) [Malarska 2005]. Sprawdzono następnie, czy fakt posiadania certyfikowanego systemu zarządzania wpływa na wartości ładunków czynnikowych. Zbadano także wpływ wielkości organizacji oraz czasu funkcjonowania na rynku. Każdorazowo podzielono przy tym populację na dwie grupy, w zależności od posiadania certyfikowanego systemu zarządzania jakością, wielkość zatrudnienia oraz czas funkcjonowania na rynku. Przeprowadzono następnie test $\mathrm{t}$ Studenta dla dwóch prób niezależnych, przy zastosowaniu poprawki w przypadku niespełnienia założenia o równości wariancji (test Levene’a). Wykorzystano test t mimo braku spełnienia założenia o normalności - założenie to nie wpływa na wyniki testu, ponieważ test $\mathrm{t}$ jest dość odporny na niespełnienie założenia o normalności rozkładu. W przypadku grup o dużej liczebności (powyżej 30 elementów) odchylenia od normalności, o ile nie występują skrajne asymetrie, nie wpływają na wynik testu [Ferguson i Takane 2009].

Drugą zastosowaną $\mathrm{w}$ pracy grupą metod statystycznych była analiza korelacji pomiędzy zmiennymi, tak jak $\mathrm{w}$ innych badaniach $\mathrm{z}$ obszaru zarządzania jakością [Salaheldin 2009; Valmohammadi 2011]. Wykorzystano w tym celu współczynnik korelacji liniowej Pearsona oraz współczynnik korelacji rang R Spearmana [Sobczyk 2002]. Współczynnik korelacji rang R Spearmana można stosować do siły korelacji dwóch cech, szczególnie w przypadku, gdy mają one charakter jakościowy, jak i dla cech ilościowych w przypadku niewielkiej liczby obserwacji. Interpretacja współczynnika korelacji liniowej Pearsona i Spearmana (przyjmującego wartości od -1 do 1) jest identyczna. Dodatni znak współczynnika korelacji wskazuje na istnienie współzależności dodatniej, a ujemny - ujemnej; korelacja jest wyraźna, gdy współczynnik przekracza 0,5, a średnia - gdy współczynnik korelacji jest pomiędzy 0,3 do 0,5 [Sobczyk 2002]. Oprócz tych dwóch współczynników w literaturze podaje się także współczynnik zbieżności Czuprowa i stosunki korelacyjne Pearsona, jednak są one wykorzystywane niezbyt często. Porównując wartości i istotności współczynników korelacji liniowej Pearsona oraz korelacji rang R Spearmana, można zauważyć, że w przypadku gdy nie występują wartości odstające i skrajne, przyjmują one zbliżone wartości (niezależnie od tego, czy występuje rozkład normalny, czy też nie). Występowanie rozkładu normalnego jest podawane czasami jako warunek 
stosowania współczynnika korelacji liniowej Pearsona, ale nie zawsze [Aczel 2000; Sobczyk 2002; Rószkiewicz 2012].

Trzecią zastosowaną $\mathrm{w}$ niniejszej pracy metodą statystyczną była analiza skupień. Tak jak w analizie czynnikowej wszystkie obliczenia wykonywane w ramach analizy skupień odbywały się na danych zestandaryzowanych [Kline 1994; Hair i in. 2009; Malarska 2005]. Podstawowym zadaniem analizy skupień jest identyfikacja homogenicznych grup obiektów oraz identyfikacja obiektów nienależących do żadnej z grup, czyli tzw. obiektów odstających [Anderberg 1973]. W analizie skupień wykorzystuje się różne miary podobieństwa i zróżnicowania. Te drugie są najczęściej kojarzone z odległościami pomiędzy obiektami. Ze względu na fakt, że w analizie wzięto pod uwagę dużą liczbę zmiennych, istotny jest wybór metod pomiaru odległości. Literatura wyróżnia kilka podstawowych miar odległości - klasyczną odległość euklidesową lub kwadrat z niej, odległość miejską (metrykę miejską), odległość Mahalanobisa, odległość Czebyszewa, odległość Minkowskiego, metrykę Canberra, odległość Czekanowskiego, metrykę minimum czy też miary odległości Matusity, Gowera, czy Lance'a i Williamsa [Balicki 2013]. Najczęściej jest używana miara odległości euklidesowej lub jej kwadrat. Inne miary są wykorzystywane rzadziej (odległość miejska) lub prawie w ogóle. W pierwszym kroku zastosowania tej metody konieczne jest zestandaryzowanie wszystkich zmiennych, ponieważ zmiana rzędu wielkości może prowadzić do różnych wyników [Everitt, Landau i Leese 1993]. Drugim etapem w analizie skupień jest wybór metody pomiaru podobieństwa - najprostszym jest współczynnik korelacji Pearsona jednak jest on stosunkowo rzadko stosowany w praktyce, chociaż niektórzy badacze podają przykłady badań, gdzie z powodzeniem wykorzystano współczynnik korelacji Pearsona [Everitt, Landau i Leese 1993]. Drugą popularną miarą jest miara podobieństwa Braya i Curtisa, która najczęściej jest stosowana w ekologii.

W analizie skupień są wykorzystywane metody grupowania hierarchicznego, gdzie proces grupowania rozpoczyna się od pojedynczych obiektów, a kończy na grupie skupiającej wszystkie obserwacje. Wszystkie metody mają pewien wspólny zestaw własności określany w literaturze akronimem SAHN (sequelntial, agglomerative, hierarchic, nonoverlapping), co bardzo dobrze oddaje istotę wszystkich hierarchicznych metod aglomeracyjnych. Wśród najczęściej stosowanych metod grupowania hierarchicznego należy wymienić metodę najbliższego sąsiada (przeliczanie odległości między obiektami jednego skupienia a obiektami innego skupienia według kryterium najmniejszej odległości), metodę najdalszego sąsiada (czyli kierujemy się największą odległością pomiędzy skupieniami), metodę średniej grupowej/średniego połączenia (jest to średnia odległość pomiędzy wszystkimi parami obiektów należących do dwóch porównywalnych grup), metodę centroidalną (wykorzystującą środki ciężkości skupień), metodę mediany (podobną do metody średniego połączenia, ale zamiast 
średniej wykorzystującą medianę), a także najczęściej wykorzystywaną metodę Warda, która całkowicie różni się od pozostałych metod zarówno jeśli chodzi o miary podobieństwa, jak i metody łączenia skupień [Balicki 2013]. Na każdym etapie łączenia obiektów minimalizuje się wewnątrzgrupową sumę kwadratów odchyleń wszystkich zmiennych dla każdego obiektu od ich średnich grupowych. Dodatkowo dokonuje się oceny grupowania na podstawie dendrogramu, tak by liczba wydzielonych grup nie była zbyt mała (obiekty w ramach jednej grupy mogą się wtedy cechować bardzo dużą różnorodnością), ale też zbyt duża (pojawia się wtedy niebezpieczeństwo tworzenia się grup o bardzo małej liczbie elementów, a nawet grup jednoelementowych składających się z obiektów, które potencjalnie mogłyby być wartościami odstającymi). W analizie danych w niniejszej pracy wykorzystano metodę hierarchiczną (metodę Warda), a jako miarę odległości wykorzystano najczęściej stosowany kwadrat odległości euklidesowej [Gatnar i Walesiak 2004].

Reasumując przedstawione w niniejszym rozdziale rozważania badawcze należy wskazać na przyjęcie procedury ukierunkowanej na weryfikację hipotez badawczych oraz realizację celów pracy. Na podstawie wieloletnich analiz związanych z obszarem badawczym określono zakres podmiotowy pracy - autoryzowane salony sprzedaży i serwisu samochodów osobowych w Polsce. We właściwym badaniu empirycznym wykorzystano zatem ankietę internetową wspomaganą komputerowo. Uzyskane wyniki badawcze zostały poddane analizom statystycznym, a ich interpretacja została przedstawiona w kolejnych rozdziałach niniejszej monografii. 


\section{Rozdział IV \\ OCENA WAŻNOŚCI WEWNĘTRZNYCH CZYNNIKÓW PROJAKOŚCIOWEGO ZARZĄDZANIA W ORGANIZACJI}

\section{Charakterystyka badanej zbiorowości}

W przeprowadzonym badaniu ankietowym uzyskano 219 ankiet wypełnionych przez respondentów z autoryzowanych salonów sprzedaży i serwisu samochodów osobowych w Polsce. W odniesieniu do sporządzonej bazy danych, zawierającej 1585 lokalizacji, oznacza to zwrotność na poziomie 13,82\%.

Analiza terytorialna respondentów zobrazowana została na wykresie 3.

Średnia zwrotność według województw ukształtowała się na poziomie ponad 14\%. Najmniej reprezentowanym obszarem geograficznym jest województwo warmińsko-mazurskie (10,17\%), a największą zwrotność uzyskano z lokalizacji z województwa świętokrzyskiego $(21,88 \%)$ oraz z województwa podlaskiego $(21,43 \%)$. Województwo mazowieckie, najliczniejsze pod względem zlokalizowanych autoryzowanych salonów sprzedaży i serwisu pojazdów w Polsce, jest reprezentowane przez $13,78 \%$ lokalizacji.

$\mathrm{Na} 36$ marek samochodów osobowych posiadających w Polsce autoryzowane salony sprzedaży i serwisu odpowiedzi otrzymano z lokalizacji reprezentujących 29 marek (wykres 4).

Najwięcej autoryzowanych salonów sprzedaży i serwisu samochodów osobowych w Polsce posiada sieć Fiata i niewiele mniej Skoda. Zwrotność z autoryzowanych lokalizacji marki Fiat ukształtowała się na poziomie ponad 18\%, a z sieci Skody - powyżej 19\%. W całym badaniu ankietowym tylko dla sieci trzech marek samochodów zwrotność, liczona pod kątem lokalizacji, ukształtowała się powyżej $20 \%$. Najwięcej respondentów, aż z $65 \%$ lokalizacji, wypełniło ankietę z sieci Mercedes-Benz. Z salonów Porsche odpowiedzi udzieliło $40 \%$ i prawie $27 \%$ autoryzowanych lokalizacji sprzedających i serwisujących pojazdy marek BMW i Mini. 


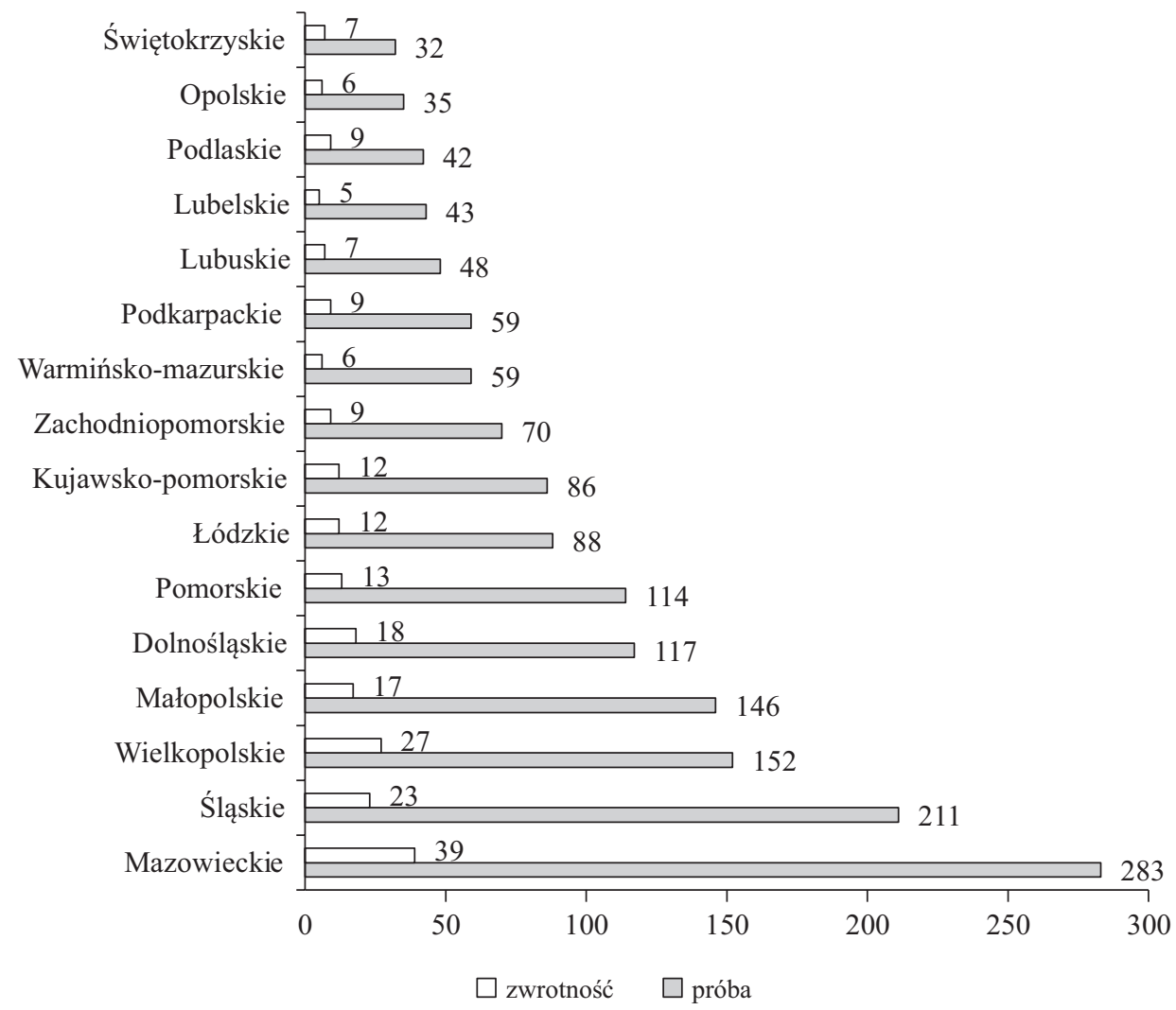

Wykres 3. Badane autoryzowane salony sprzedaży i serwisu samochodów osobowych w Polsce w podziale na województwa

Ankiety zostały wypełnione przez przedstawicieli salonów sprzedaży i serwisu samochodów osobowych w Polsce, którzy na podstawie wpisów w metryczce kwestionariusza reprezentowali 22 służbowe stanowiska. Na podstawie nazwy stanowiska służbowego zaszeregowano respondentów do dwóch grup, co zostało przedstawione w tabeli 3.

Wszystkich respondentów, którzy wzięli udział w badaniu ankietowym, przyporządkowano na podstawie nazwy stanowiska do dwóch grup: „Kierownictwo” oraz „Służby jakości”. Jest to podział porządkowy i autorytarny, na potrzeby różnicowania wyników badania w zależności od grupy udzielającej odpowiedzi. Jednak przy dalszych analizach należy pamiętać o dwóch ograniczeniach związanych z zastosowanym pogrupowaniem.

Pierwsze ograniczenie jest związane $\mathrm{z}$ nazewnictwem danego stanowiska względem zakresu obowiązków i uprawnień wykonywanych przez danego pracownika. Analiza nazw stanowisk osób wypełniających ankietę nasuwa 


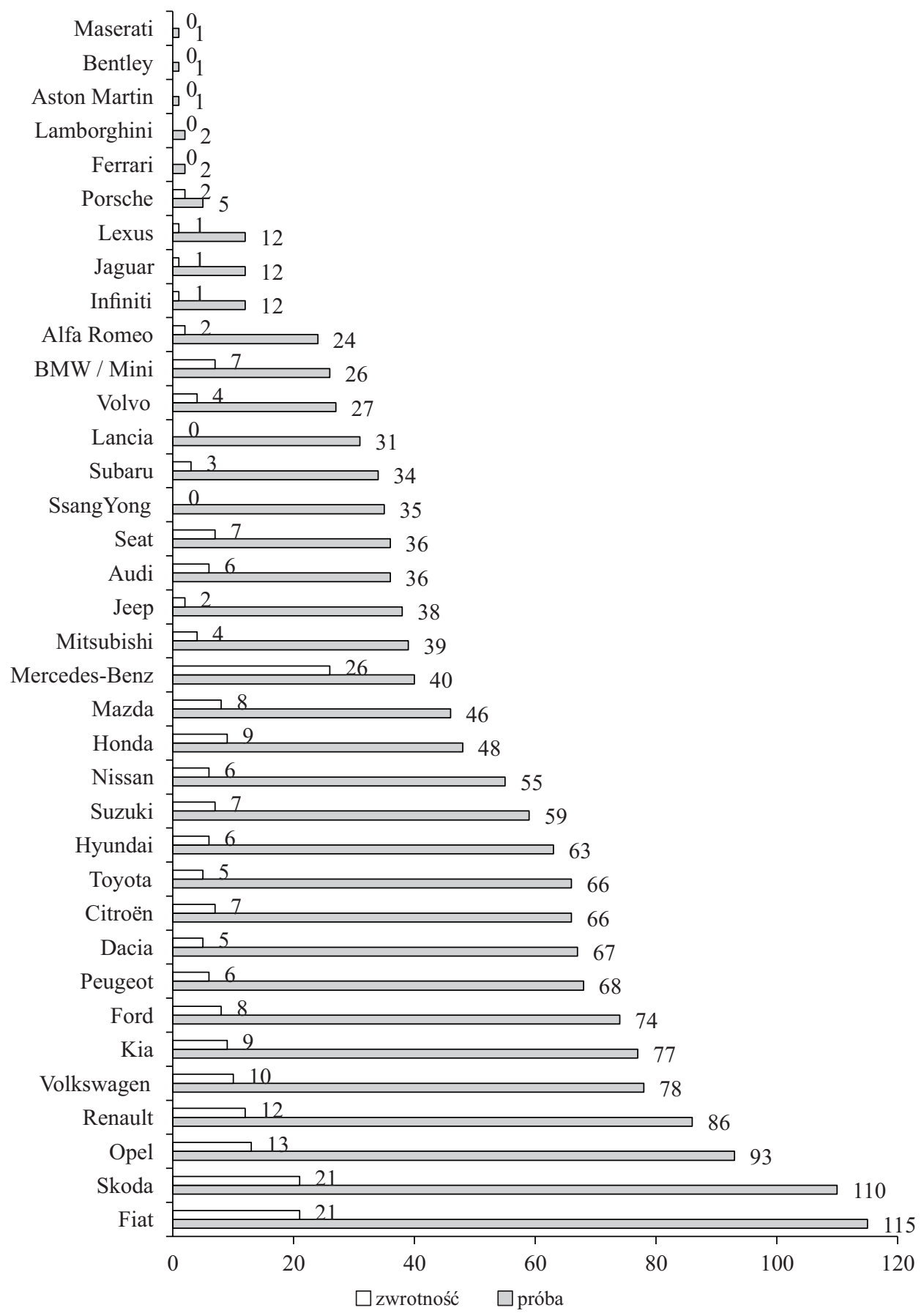

Wykres 4. Badane salony sprzedaży i serwisu samochodów osobowych w Polsce według autoryzacji marek producenckich 
Tabela 3. Struktura respondentów, którzy wzięli udział w badaniu ankietowym

\begin{tabular}{|r|l|c|l|}
\hline Lp. & \multicolumn{1}{|c|}{$\begin{array}{c}\text { Stanowisko osoby } \\
\text { wypełniającej ankietę }\end{array}$} & $\begin{array}{c}\text { Liczba } \\
\text { wypelnionych ankiet }\end{array}$ & $\begin{array}{c}\text { Grupa respondentów } \\
\text { (liczebność) }\end{array}$ \\
\hline 1 & Dyrektor & 115 & \\
2 & Dyrektor zarządzający & 25 & \\
3 & Współwłaściciel & 18 & \\
4 & Szef & 10 & \\
5 & Właściciel & 5 & Kierownictwo \\
6 & Dyrektor organizacyjny & 3 & (193) \\
7 & Prezes & 2 & \\
8 & Zarząd & 2 & \\
9 & Kadra zarządzająca & 2 & \\
10 & Dyrektor serwisu & 2 & \\
11 & Szef sprzedaży & 1 & \\
12 & Menedżer zarządzający & 1 & \\
13 & Dyrektor jednostki & 13 & \\
14 & Pełnomocnik zarządu & 7 & Służby jakości \\
\hline 15 & Pełnomocnik ds. SZJ & 1 & \\
16 & Lider jakości & 1 & \\
17 & Pełnomocnik ds. jakości & 1 & \\
18 & Specjalista ds. jakości & 1 & \\
19 & Specjalista ds. metod i systemów & 1 & \\
20 & Kierownik recepcji & (26) \\
21 & Pracownik administracyjny & Specjalista ds. marketingu & \\
22 & Spu & \\
\hline
\end{tabular}

wniosek, że np. „pełnomocnik ds. SZJ” ma prawdopodobnie taki sam zakres działań do osoby zajmującej stanowisko „pełnomocnika ds. jakości”. Jednocześnie jest to prawdopodobnie odmienny zakres, w szczególności w tematyce zarządzania jakością, wobec „pracownika administracyjnego” czy „specjalisty ds. marketingu". Kwestia nazewnictwa stanowiska i zakresu rzeczywistych obowiązków pojawia się również w działalności gospodarczej i w przypadku ankietyzacji jest to zagadnienie niepewności, kto fizycznie wypełniał ankietę, jakie wpisał stanowisko, czy jest ono zgodne z zajmowanym oraz czy jest adekwatne do wykonywanych służbowo zadań. W przypadku ostatnich czterech stanowisk (wskazanych w tabeli nr 3) pracownicy realizują ten sam zakres działań z obszaru zarządzania jakością. Wiedza autora niniejszej pracy wynika z funkcjonowania danych lokalizacji i znajomości tych osób (które dodatkowo brały udział w badaniu pilotażowym). Również nazwa stanowiska „dyrektor serwisu" mogłaby sugerować, że pracownicy danego pionu organizacyjnego 
wypełnili ankietę za całą lokalizację, aczkolwiek analiza szczegółowa wskazała, że byli to reprezentanci dwóch lokalizacji o wyłącznie serwisowym zakresie działalności.

Drugie ograniczenie dotyczy kwestii nazewnictwa stanowisk zaszeregowanych do grupy „Kierownictwo” (np. dotyczących stanowiska „właściciel” oraz „współwłaściciel”) w kontekście udziału tych osób w bieżącym funkcjonowaniu danej lokalizacji. Bez analizy szczegółowej, w formie wywiadów bezpośrednich, nie jest możliwa ocena, czy dana osoba uczestniczy na bieżąco w operacyjnej działalności, czy też występuje $\mathrm{w}$ roli właściciela bez angażowania się w codzienne aktywności gospodarcze. Autor niniejszej monografii spotkał się w swojej praktyce zawodowej z różnymi zależnościami w tym obszarze. Niewiadoma co do rzeczywistego udziału wskazanych osób w działaniach i skali wpływu na kształt poszczególnych działań może stanowić dualistyczne ograniczenie badań. Po pierwsze, może to rzutować na wyniki badania poprzez udzielanie odpowiedzi, które nie oddają w pełni rzeczywistego charakteru działań. $\mathrm{W}$ przypadku małego zaangażowania i małego natężenia w bieżące gospodarcze aktywności może to rzutować na odpowiedzi oparte m.in. na ogólnych wyobrażeniach ${ }^{66}$, np. „całościowej zyskowności biznesu”. Po drugie, właściciele lub kierownictwo organizacji, jako osoby zarządzające, mogą mieć różne podejście do samooceny bądź dzielenia się informacją o wynikach działań. W najprostszym ujęciu dotyczy to zagadnień ukazywania jak najlepszych wyników celem utrzymania i (lub) wzmocnienia swojej pozycji w ramach organizacji.

Wskazane powyżej zagadnienia stanowią zasadniczo tło każdego badania ankietowego i problematyka z tym związana jest niwelowana statystyczną obróbką danych. Dodatkowo różnicowano wyniki badania ankietowego m.in. według grup respondentów dla zidentyfikowania ewentualnych różnic w wynikach badania.

Mając na uwadze zasygnalizowane zagadnienia dotyczące stanowisk służbowych ujętych w metryczce ankiety, zgrupowano respondentów w dwóch obszarach: „Kierownictwo” oraz „Służby jakości”.

Wszyscy respondenci zaklasyfikowani do grupy „Służby jakości” reprezentują organizacje, które posiadają certyfikowany system zarządzania jakościąa ${ }^{67}$.

${ }^{66}$ Wyobrażenia na temat biznesu są narażone na iluzje, a najbardziej rozpowszechnioną z nich jest tzw. efekt aureoli. Przejawia się on w skłonności do oceny cech indywidualnych na podstawie ogólnego wrażenia. Umysł tworzy i podtrzymuje całościowy i niesprzeczny wewnętrznie obraz rzeczywistości, ograniczając dysonans poznawczy. Efekt aureoli powoduje „słabe miejsce” oceny rzeczywistości, co ogranicza jakość uzyskiwanych danych i jasność spojrzenia na czynniki wpływające na rezultaty i efektywność działalności firm [Krzakiewicz 2014, s. 159].

${ }^{67}$ Certyfikowany system zarządzania jakością, zgodny z wymaganiami z normy ISO 9001, nie stanowi zakresu przedmiotowego niniejszej pracy. Jednak nie jest możliwe uniknięcie zagadnień normalizacyjnych w analizie zarządzania jakością, a jednocześnie ma to wymiar praktyczny z uwagi na możliwość wdrożenia certyfikowanego systemu zarządzania jakością. 


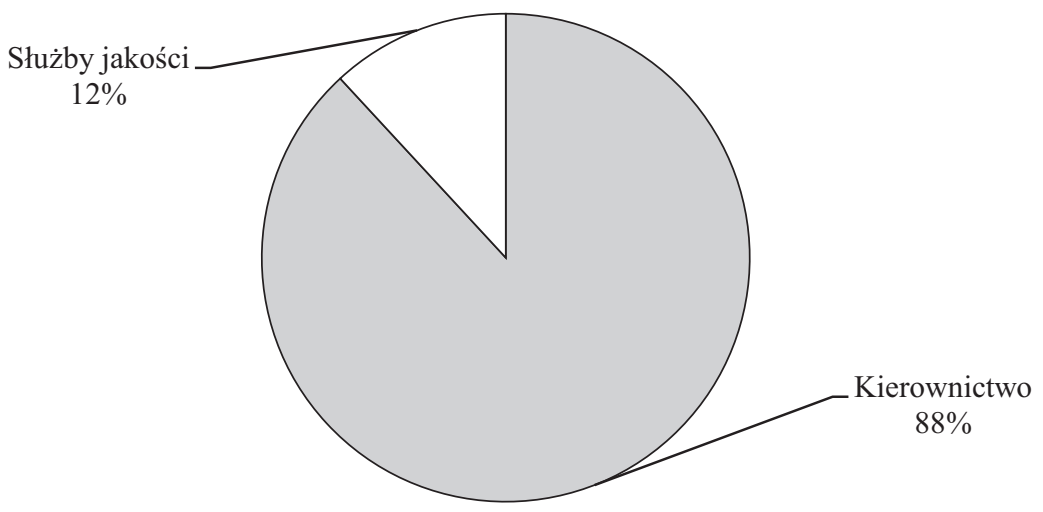

\section{Wykres 5. Badane organizacje w podziale według grup respondentów}

W grupie respondentów „Kierownictwo”, liczącej 193 lokalizacje, 17 autoryzowanych salonów sprzedaży i serwisu samochodów osobowych w Polsce posiada ,certyfikat ISO 9001”.

Analizując lokalizacje, które wzięły udział w badaniu według liczby zatrudnionych pracowników, zauważono prawie 98-procentowy udział dwóch grup salonów sprzedaży i serwisu samochodów osobowych, co zostało zaprezentowane na wykresie 6.

W największej grupie pod względem liczby zatrudnionych pracowników (26-100 osób) znajduje się 148 badanych lokalizacji, z czego 93 to jedyne lokalizacje danego dealera, a pozostałe to 37 lokalizacji wskazanych jako centrale

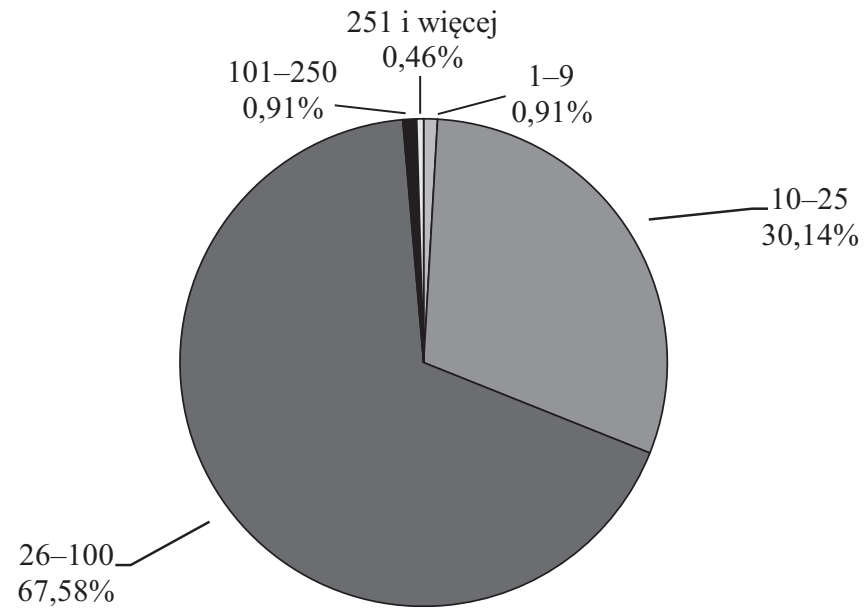

Wykres 6. Struktura badanych organizacji pod względem liczby zatrudnionych pracowników 
oraz 18 oddziałów. W grupie lokalizacji zatrudniających pomiędzy 10 a 25 osób znajdują się jedynie oddziały, w liczbie 66.

Po względem okresu prowadzenia działalności przeważającą grupę (141 na 219) stanowią lokalizacje funkcjonujące na rynku ponad 10 lat.

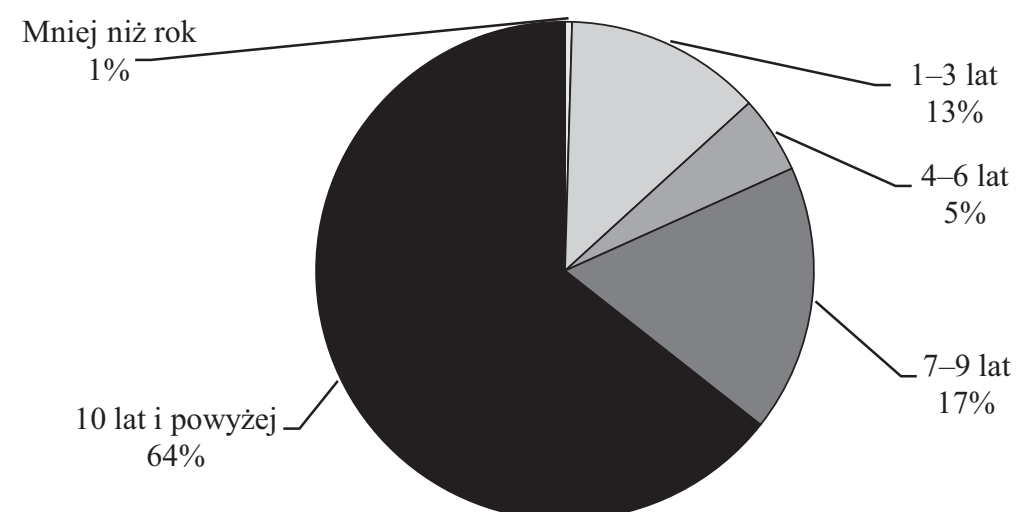

\section{Wykres 7. Struktura badanych organizacji pod względem okresu prowadzenia dzialalności w danej lokalizacji}

Respondenci, którzy wzięli udział w badaniu, reprezentowali lokalizacje, które w zdecydowanej większości (81\%) funkcjonują na rynku ponad 7 lat, co zdaniem autora pozytywnie wpływa na wyniki badania ankietowego z uwagi na długookresowe doświadczenia z zakresu zarządzania jakością w poszczególnych badanych lokalizacjach ${ }^{68}$.

Analizując zwrotność ankiet wypełnionych przez respondentów, można wskazać, że ankietowane organizacje reprezentowały (lokalizacyjnie) wszystkie województwa w Polsce. Również wśród analizowanych wyników znajdują się odpowiedzi reprezentantów zdecydowanej większości autoryzowanych salonów sprzedaży i serwisu poszczególnych marek pojazdów. Charakterystyka respondentów, względem próby badawczej, na płaszczyźnie terytorialnej oraz według marek samochodów pozwala, zdaniem autora, na dalsze analizy z uwagi na dopuszczalny błąd badania ${ }^{69}$ oraz niezidentyfikowanie istotnych różnić ilościowych pomiędzy potencjalnymi (próba badawcza) a rzeczywistymi respondentami (zwrotność ankiet).

${ }^{68}$ Aczkolwiek można by do rozważań o respondentach dołożyć kolejne, dotyczące okresu zatrudnienia na danym stanowisku i wówczas można by badać ewentualny dysonans pomiędzy okresem zatrudnienia a czasem funkcjonowania lokalizacji.

${ }^{69}$ Przy poziomie istotności alfa $=10 \%$ maksymalny dopuszczalny błąd badania wynosi $5 \%$. 


\section{Zarządzanie jakością w badanych organizacjach}

\subsection{Ważność głównych wewnętrznych czynników zarządzania jakością}

Kwestionariusz ankiety zawierał w pierwszej części ogólne pytanie o ustosunkowanie się respondentów do kwestii wpływu poszczególnych wewnętrznych czynników na rezultaty zarządzania jakością. Respondenci udzielali odpowiedzi w odniesieniu do ośmiu głównych wewnętrznych czynników zarządzania jakością zidentyfikowanych w wyniku analiz teoretycznych.

Tabela 4. Glówne wewnętrzne czynniki zarządzania jakością - ważność w badanych lokalizacjach

\begin{tabular}{|l|c|}
\hline \multicolumn{1}{|c|}{$\begin{array}{c}\text { Główne wewnętrzne czynniki zarządzania jakością } \\
\text { (kolejność } \boldsymbol{i} \text { oznaczenie jak } \boldsymbol{w} \text { I czesści ankiety) }\end{array}$} & $\begin{array}{c}\text { Średnia ważność } \\
\text { w ocenie respon- } \\
\text { dentów }\end{array}$ \\
\hline $\begin{array}{l}\text { I.1. Przywództwo i zaangażowanie najwyższego kierownictwa w jakośćc } \\
\text { pozytywnie wpływa na rezultaty zarządzania jakością }\end{array}$ & 6,26 \\
\hline $\begin{array}{l}\text { I.2. Planowanie strategiczne i operacyjne pozytywnie wpływa na rezultaty } \\
\text { zarządzania jakością }\end{array}$ & 6,00 \\
\hline $\begin{array}{l}\text { I.3. Orientacja na klienta pozytywnie wpływa na rezultaty zarządzania } \\
\text { jakością }\end{array}$ & 6,26 \\
\hline $\begin{array}{l}\text { I.4. Zarządzanie na podstawie faktów pozytywnie wpływa na rezultaty } \\
\text { zarządzania jakością }\end{array}$ & 5,56 \\
\hline $\begin{array}{l}\text { I.5. Zarządzanie zasobami ludzkimi pozytywnie wpływa na rezultaty zarzą- } \\
\text { dzania jakością }\end{array}$ & 6,10 \\
\hline $\begin{array}{l}\text { I.6. Zaangażowanie pracowników pozytywnie wpływa na rezultaty zarzą- } \\
\text { dzania jakością }\end{array}$ & 6,52 \\
\hline $\begin{array}{l}\text { I.7. Zarządzanie procesowe pozytywnie wpływa na rezultaty zarządzania } \\
\text { jakością }\end{array}$ & 5,46 \\
\hline $\begin{array}{l}\text { I.8. Ciągłe doskonalenie pozytywnie wpływa na rezultaty zarządzania } \\
\text { jakością }\end{array}$ & 5,49 \\
\hline
\end{tabular}

Respondenci w badaniu ankietowym najwyżej ocenili „Zaangażowanie pracowników” (średnia 6,52), a najniżej „Zarządzanie procesowe” (wartość 5,46). Ta najniższa wartość znajduje się „W połowie” pomiędzy 5 „raczej tak”, a 6 „tak” w ocenie pozytywnego wpływu danego wewnętrznego czynnika na rezultaty zarządzania jakością. Uszeregowanie ważności głównych czynników wewnętrznych (przy zachowaniu pierwotnej numeracji jak w kwestionariuszu ankietowym), od najniższej oceny istotności ${ }^{70}$, zobrazowano na wykresie 8 .

${ }^{70} \mathrm{~W}$ opisie wyników badania empirycznego dla „ważności” poszczególnych badanych elementów używane jest zamiennie słowo „istotność”, które ma odrębne znaczenie w analizach statystycznych. 


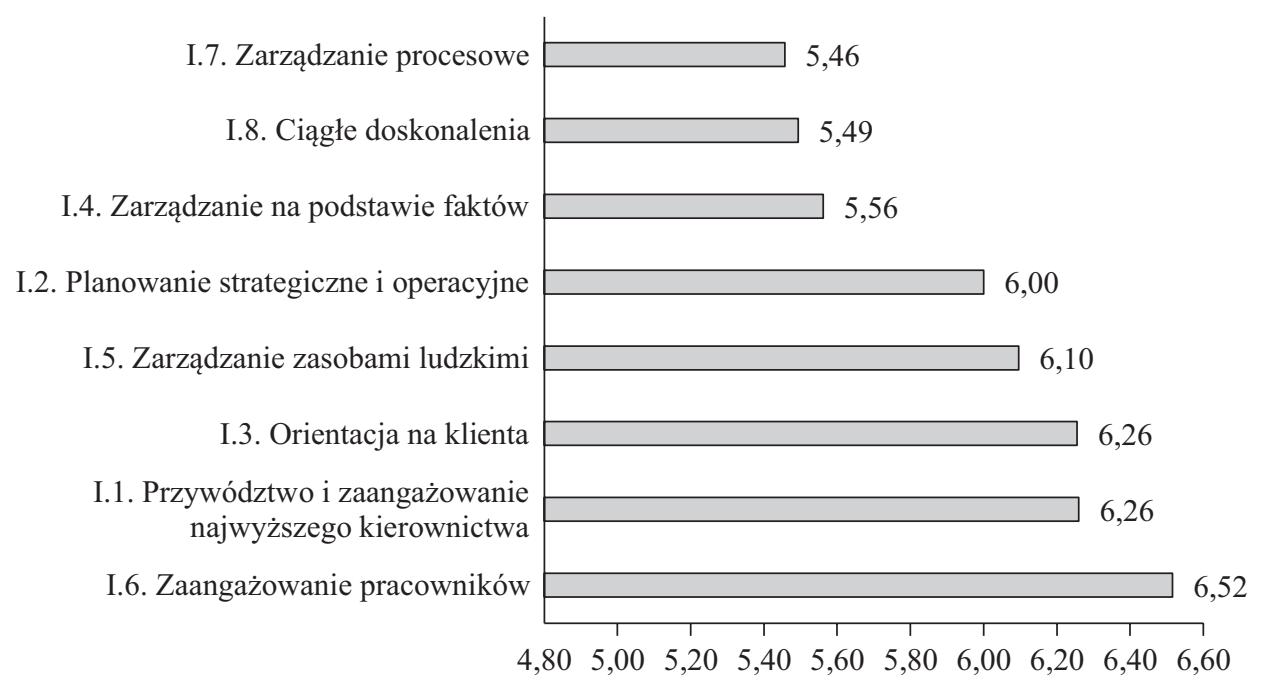

\section{Wykres 8. Ocena wpływu głównych czynników wewnętrznych na rezultaty zarządzania jakością - według rosnącej istotności}

W literaturze z obszaru zarządzania jakością jako krytyczny czynnik sukcesu wskazywane jest „Zaangażowanie najwyższego kierownictwa”. W prezentacji wyników przeprowadzonego badania tenże główny wewnętrzny czynnik zarządzania jakością został oceniony jako drugi pod względem ważności w opinii respondentów, aczkolwiek różnice pomiędzy wartością wskazań dla wszystkich umieszczonych w kwestionariuszu głównych wewnętrznych czynników zarządzania jakością są stosunkowo niewielkie.

Porównanie ważności głównych wewnętrznych czynników zarządzania jakością w zależności od stanowiska respondenta zostało zaprezentowane na wykresie 9.

Analiza średniej ważności w ocenie wpływu głównych wewnętrznych czynników na rezultaty zarządzania jakością wskazuje, że niezależnie od stanowiska służbowego respondenta najwyżej został oceniony ten sam czynnik: „Zaangażowanie pracowników". Podobnie jest w sytuacji analizowania czynnika, który został najniżej oceniony przez respondentów we wpływie na rezultaty podejmowanych działań w obszarze zarządzania jakością - „Zarządzania procesowego”. Generalnie wśród respondentów zaliczonych do grupy „Kierownictwo” oceny są wyższe dla każdego czynnika w organizacjach posiadających certyfikowany system zarządzania jakością. Z kolei analizując różnice $\mathrm{w}$ organizacjach posiadających certyfikowany system zarządzania jakością w zależności od przynależności respondenta do danej grupy, to „Służby jakości” oceniają wyżej od „Kierownictwa” pięć czynników. Są to: „Zarządzanie na podstawie faktów” (różnica bezwzględna 0,33), „Zarządzanie zasobami ludzkimi” $(0,15)$, „Zaangażowanie 


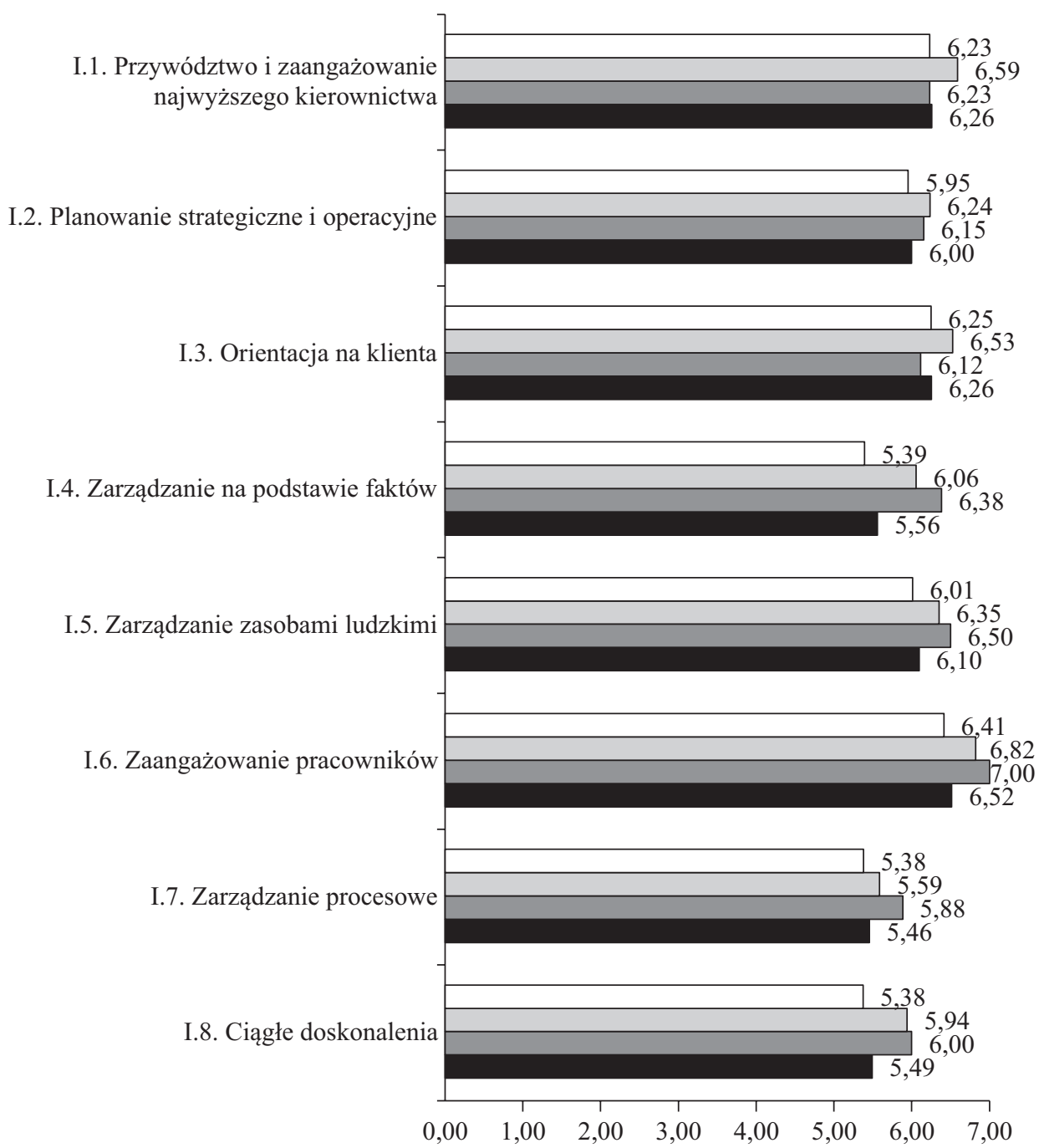

$\square$ kierownictwo (bez SZJ) $\square$ kierownictwo (z SZJ) $\square$ służby jakości $\square$ ogólna ważność

\section{Wykres 9. Ocena wpływu głównych wewnętrznych czynników na rezultaty zarządzania jakością, w zależności od grupy respondentów}

pracowników” $(0,18)$, „Zarządzanie procesowe” $(0,30)$, „Ciągłe doskonalenie” $(0,06)$. Odwrotne różnicowanie wyników zostało zidentyfikowane dla trzech czynników: „Przywództwo i zaangażowanie najwyższego kierownictwa” $(0,36)$, „Planowanie strategiczne i operacyjne” $(0,08)$, „Orientacja na klienta” $(0,41)$.

Największa różnica pomiędzy dwiema grupami respondentów w ocenie wpływu wewnętrznych czynników na rezultaty zarządzania jakością dotyczy „Orientacji na klienta”. Kierownictwo salonów sprzedaży i serwisu samochodów 
osobowych, które dokonały certyfikacji swojego systemu zarządzania jakością, wyżej (różnica bezwzględna 0,41) oceniają ten czynnik $(6,53)$, niż „Służby jakości” $(6,12)$. Podobna sytuacja (różnica 0,36$)$ występuje w ocenie pozytywnego wpływu czynnika „Przywództwo i zaangażowanie najwyższego kierownictwa" na rezultaty zarządzania jakością.

Dwa wewnętrzne czynniki zarządzania jakością zostały wyżej ocenione przez „Służby jakości” niż „Kierownictwo” z lokalizacji posiadających „certyfikat ISO 9001”. Dotyczy to „Zarządzania na podstawie faktów” (różnica 0,33) oraz „Zarządzania procesowego" $(0,30)$.

W grupie 219 autoryzowanych salonów sprzedaży i serwisu samochodów osobowych w Polsce $81 \%$ prowadzi działalność w poszczególnych lokalizacjach ponad 7 lat.

Tabela 5. Ważność głównych wewnętrznych czynników zarządzania jakością według czasookresu prowadzenia działalności w badanych lokalizacjach

\begin{tabular}{|l|c|c|}
\hline \multicolumn{1}{|c|}{$\begin{array}{c}\text { Glówny wewnętrzny czynnik zarządzania jakością } \\
\text { (oznaczenie jak } \boldsymbol{w} \text { I części ankiety) }\end{array}$} & Do 6 lat & Od 7 lat \\
\hline I.6. Zaangażowanie pracowników & 6,60 & 6,50 \\
\hline I.1. Przywództwo i zaangażowanie najwyższego kierownictwa w jakość & 6,50 & 6,21 \\
\hline I.3. Orientacja na klienta & 6,43 & 6,22 \\
\hline I.5. Zarządzanie zasobami ludzkimi & 6,40 & 6,03 \\
\hline I.2. Planowanie strategiczne i operacyjne & 6,30 & 5,93 \\
\hline I.4. Zarządzanie na podstawie faktów & 5,90 & 5,49 \\
\hline I.8. Ciągłe doskonalenie & 5,88 & 5,41 \\
\hline I.7. Zarządzanie procesowe & 5,75 & 5,39 \\
\hline
\end{tabular}

Dane w tabeli 5 zostały pogrupowane w kolejności malejącej według ważności głównych wewnętrznych czynników zarządzania jakością, dla grupy organizacji prowadzących działalność gospodarczą w danej lokalizacji do 6 lat. Zasadniczo, poza zbliżonymi wartościami średniej dla „Przywództwa i zaangażowania najwyższego kierownictwa w jakość” (I.1) oraz „Orientacji na klienta” (I.3), kolejność głównych wewnętrznych czynników zarządzania jakością według ważności jest do siebie podobna w obydwu grupach, co jest widoczne w ujęciu graficznym (wykres 10).

Najbardziej zauważalne $\mathrm{w}$ analizie powyższych danych są niższe oceny przyznane wszystkim głównym wewnętrznym czynnikom zarządzania jakością przez respondentów z lokalizacji dłużej funkcjonujących na rynku. Można przypuszczać, że kultura jakości upowszechnia się w organizacji wraz z upływem czasu i może właśnie wpływ poszczególnych wewnętrznych czynników na rezultaty zarządzania jakością jest coraz mniej zauważalny (z uwagi na naturalne 
I.8. Ciągłe doskonalenie

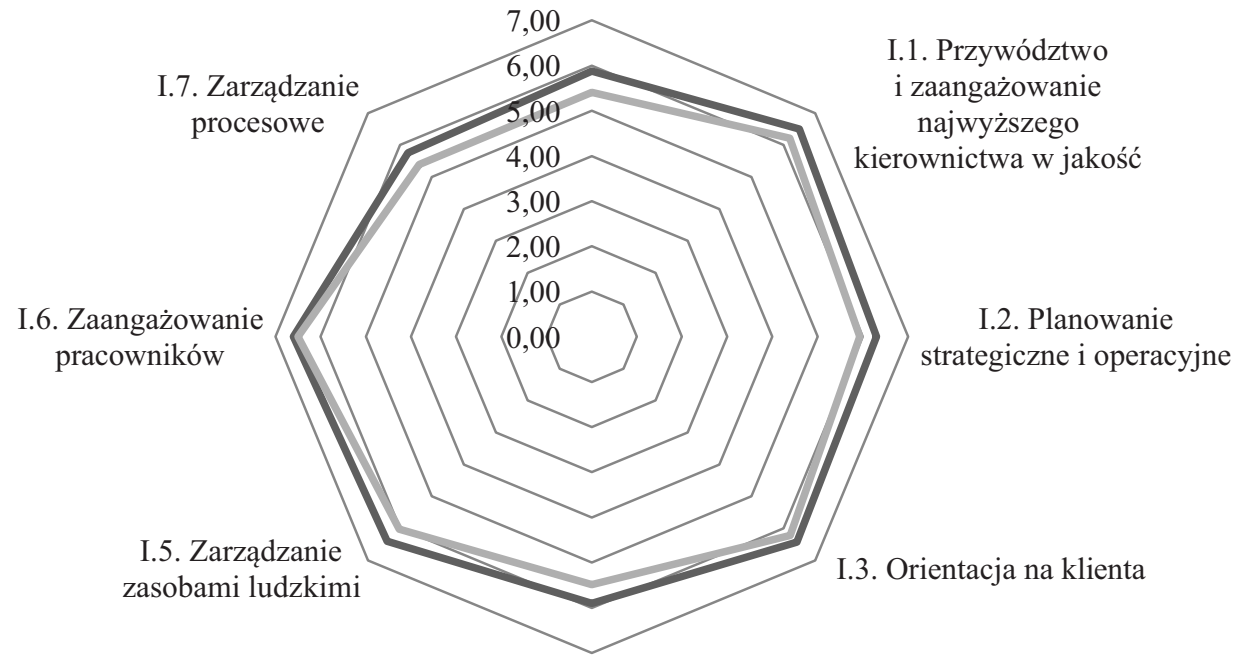

I.4. Zarządzanie na podstawie faktów

$\longrightarrow$ do 6 lat $\longrightarrow$ od lat

Wykres 10. Ocena ważności głównych czynników wewnętrznych wpływających na rezultaty zarządzania jakością, w podziale na dwa okresy funkcjonowania lokalizacji

uwzględnianie tych organizacyjnych zagadnień w prowadzeniu działalności gospodarczej) lub bardziej uświadomiony (w wyniku rosnących doświadczeń pracowników). Tematyka kultury jakości w każdej organizacji stanowi materię złożoną. Pozostając w nurcie rozważań różnicujących ważność głównych wewnętrznych czynników zarządzania jakością w zależności od okresu prowadzenia działalności, warto zwrócić uwagę na kwestie szczegółowe z obszaru planowania jakości, orientacji na klienta oraz pracowników. Ważność dla wybranych elementów konstytuujących główne wewnętrzne czynniki zarządzania jakością została ujęta w tabeli 6 .

Tylko jeden z przywołanych elementów konstytuujących główne wewnętrzne czynniki zarządzania jakością został wyżej oceniony w lokalizacjach dłużej prowadzących działalność.

W teoretycznej części monografii ukazano, że znormalizowane systemy zarządzania mają ściślej określone ramy niż ogólnie podejmowane działania w obszarze zarządzania jakością. W tym kontekście przeanalizowano ogólną ważność głównych wewnętrznych czynników zarządzania jakością według posiadania „certyfikatu ISO 9001”, co przedstawiono w tabeli 7. 
Tabela 6. Ważność elementów konstytuujących główne wewnętrzne czynniki według czasookresu prowadzenia dzialalności w badanych lokalizacjach

\begin{tabular}{|c|c|c|}
\hline $\begin{array}{c}\text { Aspekty zarządzania jakością } \\
\text { (oznaczenie jak } \boldsymbol{w} \text { II części ankiety) }\end{array}$ & Do 6 lat & Od 7 lat \\
\hline $\begin{array}{c}\text { II.1.4. Najwyższe kierownictwo formalnie definiuje cele jakościowe } \\
\text { i rozlicza z ich realizacji }\end{array}$ & 5,95 & 5,55 \\
\hline II.2.7. Jakość stanowi priorytet w planowaniu celów & 5,30 & 4,93 \\
\hline $\begin{array}{c}\text { II.3.1. W działaniach najwyższego kierownictwa priorytetem są wyma- } \\
\text { gania i oczekiwania klientów }\end{array}$ & 6,18 & 6,06 \\
\hline $\begin{array}{c}\text { II.5.4. Elementy jakościowe uwzględniane są w premiowaniu pracow- } \\
\text { ników }\end{array}$ & 5,05 & 4,84 \\
\hline $\begin{array}{c}\text { II..5.10. Skuteczność naszych selekcji i rekrutacji można określić sfor- } \\
\text { mułowaniem „właściwy człowiek na właściwym miejscu” }\end{array}$ & 4,78 & 4,75 \\
\hline $\begin{array}{c}\text { II.8.3. Organizacja przyjmuje ciągłe doskonalenie działań jako długo- } \\
\text { okresową strategię doskonalenia jakości }\end{array}$ & 4,80 & 5,05 \\
\hline
\end{tabular}

Tabela 7. Ważność głównych wewnętrznych czynników zarządzania jakością w zależności od funkcjonowania certyfikowanego systemu zarządzania jakością

\begin{tabular}{|c|c|c|c|}
\hline $\begin{array}{l}\text { Główny wewnętrzny } \\
\text { czynnik zarządzania jakością }\end{array}$ & $\begin{array}{l}\text { Ogólna waż- } \\
\text { ność (219) }\end{array}$ & $\begin{array}{c}\text { Organizacje } \\
\text { bez SZJ } \\
(43)\end{array}$ & $\begin{array}{c}\text { Organizacje } \\
\text { z certyfikowa- } \\
\text { nym } \mathrm{SZJ}(176)\end{array}$ \\
\hline I.6. Zaangażowanie pracowników & 6,52 & 6,41 & 6,93 \\
\hline $\begin{array}{l}\text { I.1. Przywództwo i zaangażowanie najwyż- } \\
\text { szego kierownictwa }\end{array}$ & 6,26 & 6,23 & 6,37 \\
\hline I.3. Orientacja na klienta & 6,26 & 6,25 & 6,28 \\
\hline I.5. Zarządzanie zasobami ludzkimi & 6,10 & 6,01 & 6,44 \\
\hline I.2. Planowanie strategiczne i operacyjne & 6,00 & 5,95 & 6,19 \\
\hline I.4. Zarządzanie na podstawie faktów & 5,56 & 5,39 & 6,26 \\
\hline I.8. Ciągłe doskonalenia & 5,49 & 5,38 & 5,98 \\
\hline I.7. Zarządzanie procesowe & 5,46 & 5,38 & 5,77 \\
\hline
\end{tabular}

Respondenci z lokalizacji, w których funkcjonuje certyfikowany system zarządzania jakością, wyżej ocenili wpływ głównych wewnętrznych czynników na rezultaty zarządzania jakością.

Dla ogólnego zobrazowania różnic w ocenie ważności głównych wewnętrznych czynników zarządzania jakością, w zależności od (nie)posiadania „certyfikatu ISO 9001", naniesiono dane dla dwóch grup na wykresie 11. Zachowano kolejność czynników według ogólnej malejącej ważności i oznaczono jak w I części ankiety.

Czynnik „Orientacja na klienta” (I.3) został oceniony przez respondentów na tym samym poziomie, niezależnie od spełniania wymagań normatywnych zawartych w normie ISO 9001. Wydaje się to naturalnym wynikiem badania 


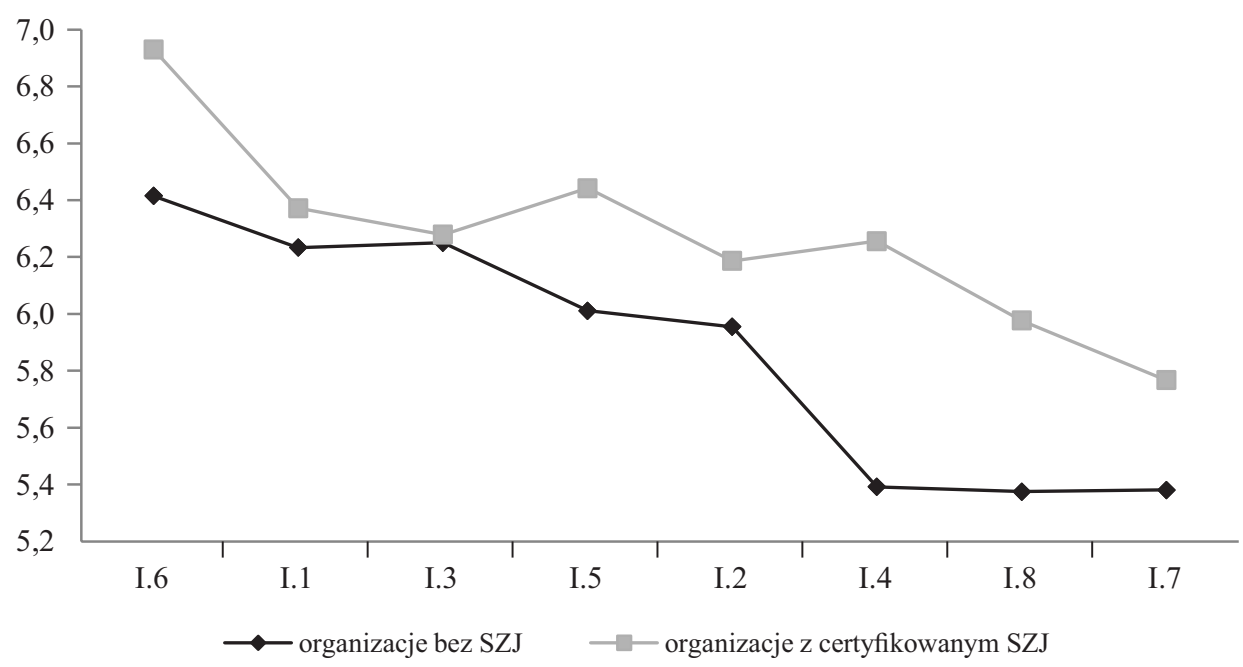

Wykres 11. Ważność głównych wewnętrznych czynników zarządzania jakością w zależności od funkcjonowania certyfikowanego systemu zarządzania jakością

z uwagi na rolę klientów w działalności każdej komercyjnej organizacji. Wymagania i oczekiwania klientów stanowią dane wejściowe dla prowadzonej działalności i wynikowo to klienci wpływają na rezultaty podejmowanych działań. Jednak wpływ jest właśnie „wynikowy”, ponieważ to, czy nabywcy danych wyrobów i usług pozostają klientami danej organizacji, zależy właśnie od wewnętrznych działań podejmowanych w każdej organizacji. Największa różnica ważności dla ukazanych powyżej wewnętrznych czynników występuje natomiast dla czynnika „Zarządzanie na podstawie faktów” (I.4, różnica bezwzględna 0,86$)$. Kolejna różnica dotyczy oceny ważności wewnętrznego czynnika „Ciągłe doskonalenie” (I.8, różnica 0,6 ).

Wdrożenie i certyfikacja systemu zarządzania jakością wymaga spełnienia normatywnych wymagań, co się przekłada na podejmowanie działań w sposób uporządkowany i jest widoczne w przedstawionych ocenach respondentów. Dla porównania ważności wewnętrznych czynników zarządzania jakością w zależności od dwóch kryteriów: czasu prowadzenia działalności gospodarczej w danej lokalizacji oraz posiadania „certyfikatu ISO 9001” został sporządzony wykres 12 .

Główny wewnętrzny czynnik zarządzania jakością „Orientacja na klienta” (I.3) został oceniony najniżej (oznaczenie „A” na wykresie 12) w lokalizacjach posiadających „,ertyfikat ISO 9001” i funkcjonujących na rynku do 6 lat, aczkolwiek ważność tego czynnika jest każdorazowo powyżej poziomu „tak” we wpływie na rezultaty zarządzania jakością. Ważność wewnętrznego czynnika zarządzania jakością „Zarządzanie na podstawie faktów” (I.4) we wpływie na 


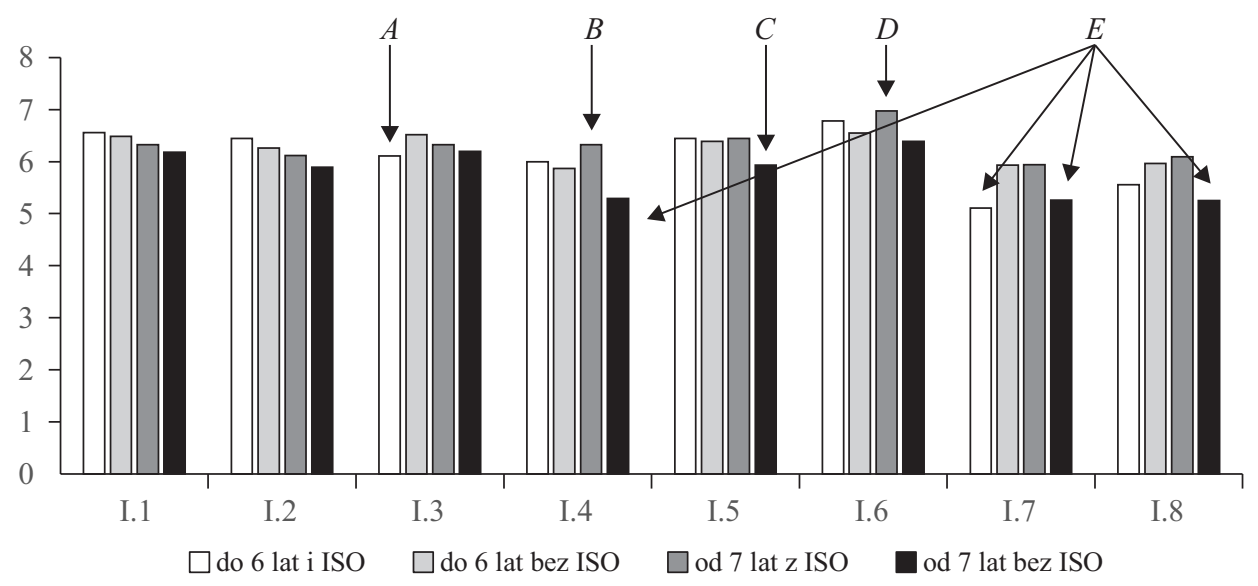

Wykres 12. Ważność głównych wewnętrznych czynników zarządzania jakością w zależności od okresu prowadzenia działalności gospodarczej oraz funkcjonowania certyfikowanego ,systemu ISO 9001" w badanych lokalizacjach

rezultaty najbardziej jest zauważalna (oznaczenie „B”) w organizacjach funkcjonujących na rynku ponad 7 lat $\mathrm{w}$ ramach certyfikowanego systemu zarządzania jakością. Ważność „Zarządzania zasobami ludzkimi” (I.5) maleje według opinii respondentów reprezentujących lokalizacje funkcjonujące na rynku ponad 7 lat i niedziałające w ramach certyfikowanego systemu zarządzania jakością (oznaczenie „C”). Najwyższa ważność „Zaangażowania pracowników” (I.6) w oddziaływaniu na rezultaty zarządzania jakością (oznaczenie „D”) została już w niniejszym rozdziale zasygnalizowana. Najniższy „słupek” na wykresie 12 (oznaczenie „E”) oznacza, że najniżej została oceniona ważność „Zarządzania procesowego" (I.7) w lokalizacjach posiadających „certyfikat ISO 9001” w lokalizacjach działających do 6 lat. Pozostałe trzy wskazania dotyczą salonów sprzedaży i serwisu samochodów osobowych, które prowadzą działalność gospodarczą w poszczególnych lokalizacjach w Polsce powyżej 7 lat bez spełniania wymagań z normy ISO 9001. Są to trzy główne wewnętrzne czynniki (ocenione powyżej „raczej tak” we wpływie na rezultaty zarządzania jakością): „Zarządzanie na podstawie faktów” (I.4), „Zarządzanie procesowe” (I.7), „Ciągłe doskonalenie" (I.8).

Reasumując część rozważań dotyczących ogólnej (uśrednionej) ważności poszczególnych głównych wewnętrznych czynników zarządzania jakością, należy podkreślić, że w ocenie respondentów najważniejszym głównym wewnętrznym czynnikiem zarządzania jakością pozytywnie wpływającym na rezultaty zarządzania jakością jest „Zaangażowanie pracowników” (średnia 6,52). W ramach analiz związanych z ogólną ważnością tego czynnika można wskazać na dwa zagadnienia: 
1. Respondenci zaklasyfikowani do grupy „Służby jakości” oceniają czynnik „Zaangażowanie pracowników” maksymalnie wysoko (7,00 jako jedyne takie wskazanie w ważności głównych czynników według różnych kryteriów), a „Kierownictwo” z organizacji posiadających certyfikowany system zarządzania jakością - na poziomie 6,41 .

2. $\mathrm{W}$ ocenie respondentów $\mathrm{z}$ organizacji prowadzących do 6 lat działalność w danej lokalizacji ważność tego czynnika wynosi 6,60 , a dla organizacji dłużej prowadzących działalność istotność kształtuje się na poziomie 6,50. W analizie ważności tego wewnętrznego czynnika zarządzania jakością została zidentyfikowana najniższa różnica (stosunkowo niewielka) ważności dla wszystkich ośmiu wewnętrznych czynników, w zależności od czasu prowadzenia działalności w danej lokalizacji.

Respondenci swoimi odpowiedziami wskazali na ważność „Przywództwa i zaangażowania najwyższego kierownictwa w jakość" na poziomie 6,52 , co uplasowało tenże czynnik na drugiej pozycji w rankingu malejącej istotności. Analizując ważność tego czynnika wyłącznie w organizacjach posiadających certyfikowany system zarządzania jakością, warto zauważyć, że „Kierownicy” przypisali mu o 0,36 większą istotność niż „Służby jakości”.

$\mathrm{Na}$ trzeciej pozycji pod względem średniej ważności respondenci umiejscowili czynnik wewnętrzny „Orientacja na klienta”, z ważnością wynoszącą 6,26. Podobnie jak dla wcześniejszego czynnika, również i tutaj można wskazać, że „Kierownicy” z organizacji posiadających „certyfikat ISO 9001” przypisali temu czynnikowi większą wartość niż „Służby jakości” (o wartość 0,41 ).

Wewnętrzny czynnik „Zarządzanie zasobami ludzkimi” (ważność 6,10) został oceniony najwyżej przez „Służby jakości”, na poziomie 6,50. Grupa respondentów nazwana „Kierownictwo” oceniła tenże wewnętrzny czynnik zarządzania jakością niżej - ważność 6,35 (w lokalizacjach z „certyfikatem ISO 9001”) oraz 6,01 (w lokalizacjach bez certyfikowanego systemu zarządzania jakością).

„Planowanie strategiczne i operacyjne” w swoim pozytywnym wpływie na rezultaty zarządzania jakością zostało ocenione przez respondentów na poziomie 6,00. „Kierownicy” z lokalizacji posiadających „certyfikat ISO 9001” nieznacznie wyżej $(0,08)$ oceniają istotność tego czynnika od „Służb jakości”. Jednocześnie szczegółowe analizy elementów konstytuujących tenże czynnik wskazują na istnienie największych (w całym badaniu ankietowym) bezwzględnych różnic $\mathrm{w}$ ich ważności, według różnych kryteriów. Lokalizacje funkcjonujące na rynku do 6 lat wskazują na wyższe znaczenie (o 0,90) „szczegółowego rozpisywania celów na zadania dla poszczególnych działów organizacyjnych" niż działające dłużej. Istnieją trzy różnice ważności powyżej wartości bezwzględnej „1”, ukazujące wyższe oceny elementów konstytuujących poszczególne główne wewnętrzne czynniki zarządzania jakością przez respondentów z lokalizacji dłużej działających na rynku („od 7 lat” względem „,do 6 lat”). Te wyższe oceny 
dotyczą trzech elementów składowych z obszaru „podejścia opartego na ryzyku":

- dla zidentyfikowanych zagrożeń w realizacji celów są tworzone prewencyjne plany zarządzania ryzykiem mające zminimalizować prawdopodobieństwo zaistnienia zagrożeń (element II.2.8) - różnica bezwzględna 1,45;

- dla zidentyfikowanych szans realizacji celów są tworzone plany zarządzania ryzykiem mające maksymalizować prawdopodobieństwo wykorzystania szans (II.2.10) - różnica bezwzględna 1,21;

- dla zidentyfikowanych zagrożeń w realizacji celów są tworzone plany na wypadek rzeczywistego zaistnienia zagrożenia mające zminimalizować skutki sytuacji kryzysowej (II.2.11) - różnica bezwzględna 1,11.

„Zarządzanie na podstawie faktów” zostało ocenione przez respondentów jako pierwszy wewnętrzny czynnik poniżej „tak” w ocenie wpływu na rezultaty zarządzania jakością (ważność na poziomie 5,56). Respondenci z lokalizacji funkcjonujących powyżej 7 lat oceniają ważność tego czynnika niżej od pozostałych (wartość bezwzględna 0,41). W ramach różnicowania wyników oceny ważności w grupie respondentów „Kierownicy” według certyfikowanego systemu zarządzania jakością została zidentyfikowana maksymalna różnica dla wszystkich ośmiu głównych wewnętrznych czynników. „Kierownicy” z lokalizacji posiadających certyfikowany system zarządzania jakością oceniają wyżej od „Kierowników” z lokalizacji nieposiadających „certyfikatu ISO 9001” wskazany wewnętrzny czynnik (różnica bezwzględna 0,67). Jednocześnie „Kierownicy” z lokalizacji z „certyfikatem ISO 9001” niżej oceniają tenże czynnik od „Służb jakości” (o 0,33$)$.

Kolejny wewnętrzny czynnik zarządzania jakością "Ciągłe doskonalenie” został oceniony przez respondentów na poziomie 5,49. Na podobnym poziomie oceniają ważność tego czynnika „Służby jakości” $(6,00)$ oraz „Kierownicy” z lokalizacji z certyfikowanym systemem zarządzania jakością $(5,94)$, a „Kierownicy” z lokalizacji bez „certyfikatu ISO 9001” - na poziomie 5,38. Pozytywny wpływ „Ciągłego doskonalenia” na rezultaty zarządzania jakością bardziej jest widoczny w lokalizacjach funkcjonujących na rynku do 6 lat (ważność 5,88 ), których ocena jest o 0,41 wyższa niż respondentów z lokalizacji działających powyżej 7 lat. Jednocześnie element szczegółowy „Organizacja przyjmuje ciągłe doskonalenie działań jako długookresową strategię doskonalenia jakości” (II.8.3) wyżej oceniają respondenci z lokalizacji działających na rynku powyżej 7 lat (ważność 5,08) niż lokalizacji prowadzących działalność 6 lat (średnia ważność 4,80). Różnice bezwzględne pomiędzy poszczególnymi ocenami są stosunkowo niewielkie, jednak można przypuszczać, że zauważalność pozytywnego wpływu doskonalenia projakościowych działań w organizacji rośnie w czasie z uwagi na upowszechnianie się kultury jakości. Jednocześnie organizacje „młodsze” silniej się koncentrują na bieżących działaniach 
doskonalących, przypuszczalnie z uwagi na potrzebę utrzymania się na rynku i dążenie do zapewnienia sobie stabilnej pozycji na rynku.

Czynnik wewnętrzny „Zarządzanie procesowe” został oceniony najniżej ze wszystkich (poziom ważności 5,46). „Kierownicy” z lokalizacji nieposiadających certyfikowanego systemu zarządzania jakością wyżej ocenili ten czynnik o 0,21 od „Kierowników” z lokalizacji z „certyfikatem ISO 9001”. „Służby jakości” wyżej oceniają tenże czynnik od „Kierowników” zarówno z lokalizacji posiadających „certyfikat ISO 9001” (o 0,30$)$, jak i lokalizacji bez certyfikowanego systemu zarządzania jakością (o 0,09$)$. Zarządzanie procesowe jest związane m.in. z organizacją pracy i określeniem zależności pomiędzy różnymi zasobami i działaniami organizacji. W przypadku próby badawczej wewnętrzne procedury postępowania, jak również kwestie np. infrastrukturalne, są uregulowane umową autoryzacyjną pomiędzy danym dealerem a przedstawicielem producenta samochodów. Umowa taka wskazuje m.in. na konieczność standaryzacji działań i infrastruktury w poszczególnych obszarach. Zatem procesowe podejmowanie działań biznesowych w analizowanych podmiotach stanowi codzienność funkcjonowania w strukturze sieciowej autoryzowanych salonów sprzedaży i serwisu samochodów osobowych i tym prawdopodobnie można thumaczyć najniższą zauważalność wpływu podejścia procesowego na sukces projakościowego zarządzania $\mathrm{w}$ organizacji.

Ogólna ważność głównych wewnętrznych czynników zarządzania jakością na podstawie odpowiedzi respondentów wskazuje na pozytywny ich wpływ na rezultaty zarządzania jakością. Ważność poszczególnych głównych wewnętrznych czynników zarządzania jakością, według średnich ze wskazań respondentów, znajduje się w wyższych przedziałach skali udzielanych odpowiedzi. Jest to stwierdzenie natury ogólnej, co uzasadnia konieczność przeprowadzenia dalszych analiz.

\subsection{Ocena rezultatów zarządzania jakością}

Ocenianie jest nieodzownym elementem naszej egzystencji, występującym powszechnie, choć nie zawsze uświadamianym. Każde ocenianie jest dokonywane z określonego punktu widzenia, określonej perspektywy i ze względu na pewne właściwości (cechy) przedmiotu oceny, czyli z zastosowaniem określonych kryteriów [Lichtarski 2015, s. 119]. Kryteria to cechy leżące jednocześnie w zbiorze skutków ocenianego rozwiązania (podlegających zmianom pod jego wpływem) oraz w zbiorze jego istotnych celów, czyli cech tworzących wspólną część wymienionych zbiorów [Lichtarski 2015, s. 120]. Pomiędzy zagadnieniami poruszanymi $\mathrm{w}$ pracy można wskazać na piramidę zależności [Waśniewski 2016, s. 165]: 
- krytyczne czynniki sukcesu - na czym należy się skupić, aby urzeczywistnić wizję, która w zakresie mojej pracy dotyczy orientacji na jakość w działaniach organizacyjnych ujmowanej pod nazwą projakościowe zarządzanie w organizacji;

- kluczowe mierniki dokonań - jakie są miary charakteryzujące sukcesu, które w niniejszej pracy odnoszą się do rezultatów projakościowego zarządzania w organizacji;

- kluczowe działania - jakie działania przybliżą nas do osiągnięcia celów, co w pracy nawiązuje do elementów konstytuujących poszczególne wewnętrzne czynniki sukcesu w aspekcie jakości oraz ryzyka.

Respondenci, odpowiadając na pytania umieszczone w trzeciej części kwestionariusza ankietowego, oceniali wpływ zarządzania jakością na rezultaty tychże działań w swoich lokalizacjach. Rezultaty zostały podzielone na trzy grupy (które nie zostały wydzielone w samym kwestionariuszu ankietowym): rezultaty ogólne, niefinansowe oraz finansowe. Rezultaty ogólne zawierały cztery zdania dotyczące osiągania ogólnych wyników. W kolejnych dwóch grupach rezultaty zostały ujęte w zdaniach wskazujących na pozytywny wpływ zarządzania jakością na uzyskiwanie rezultatów w organizacji, a wyniki ujęto w tabeli 8 .

Na siedemnaście rezultatów zarządzania jakością ujętych w kwestionariuszu ankietowym respondenci nie ocenili żadnego rezultatu powyżej oceny 6,00 , w skali siedmiostopniowej. Respondenci wskazali, że w jedenastu przypadkach zarządzanie jakością wpływa pozytywnie na wyniki organizacji w sposób pomiędzy „raczej tak” a „tak” (średnia ważność pomiędzy 5 a 6). Cztery rezultaty, w opinii respondentów, znajdują się powyżej „nie mam zdania”, a ocena „,raczej nie" przypisana została do dwóch rezultatów.

Przedstawiciele autoryzowanych salonów sprzedaży i serwisu samochodów osobowych w Polsce najniżej ocenili wpływ zarządzania jakością na minimalizację czasu obsługi klientów (III.11, średnia ważność 3,46). Porównywalnie nisko $(3,63)$ respondenci ocenili, że działania z obszaru zarządzania jakością nie wpływają na minimalizację kosztów działalności (III.16). W ocenie kolejnych dwóch rezultatów respondenci „nie mają zdania”, czy zarządzanie jakością wpływa pozytywnie na ich osiąganie. Dotyczy to minimalizacji fluktuacji pracowników (III.6, ważność 4,08) oraz zmniejszenia reklamacji dotyczących wyrobów (III.12, ważność 4,40). Ostatnie wskazanie można powiązać z zakresem działalności realizowanej w organizacjach stanowiących zakres podmiotowy badania. Autoryzowane salony sprzedaży i serwisu samochodów osobowych nie są producentem samochodów oraz części zamiennych lub akcesoriów, zatem reklamacje dotyczące wyrobów zazwyczaj mają swoje źródła u zewnętrznych podmiotów strony zasileniowej organizacji. Aczkolwiek można zwrócić uwagę na kwestie zabezpieczania nowych pojazdów przygotowanych do przekazania 
Tabela 8. Średnia ważność rezultatów zarządzania jakością w ocenie respondentów

\begin{tabular}{|c|c|c|}
\hline $\begin{array}{c}\text { Grupa rezulta- } \\
\text { tów zarządzania } \\
\text { jakością }\end{array}$ & $\begin{array}{c}\text { Rezultaty zarządzania jakością } \\
\text { (oznaczenie jak w III części ankiety) }\end{array}$ & $\begin{array}{l}\text { Średnia } \\
\text { ważność }\end{array}$ \\
\hline \multirow{4}{*}{ Ogólne } & III.1. Klienci są usatysfakcjonowani naszymi wyrobami & 5,86 \\
\hline & III.2. Klienci są usatysfakcjonowani naszymi usługami & 5,93 \\
\hline & III.3. Osiągamy zaplanowane cele jakościowe & 5,33 \\
\hline & III.4. Osiągamy zaplanowane rezultaty finansowe & 5,14 \\
\hline \multirow{11}{*}{ Niefinansowe } & $\begin{array}{l}\text { III.5. Zarządzanie jakością pozytywnie wpływa na zwięk- } \\
\text { szenie zaangażowania pracowników }\end{array}$ & 5,16 \\
\hline & $\begin{array}{l}\text { III.6. Zarządzanie jakością pozytywnie wpływa na minima- } \\
\text { lizację fluktuacji pracowników }\end{array}$ & 4,08 \\
\hline & $\begin{array}{l}\text { III.7. Zarządzanie jakością pozytywnie wpływa na zwięk- } \\
\text { szenie współpracy pomiędzy działami w organizacji }\end{array}$ & 4,55 \\
\hline & $\begin{array}{l}\text { III.8. Zarządzanie jakością pozytywnie wpływa na pozyska- } \\
\text { nie nowych klientów }\end{array}$ & 5,15 \\
\hline & $\begin{array}{l}\text { III.9. Zarządzanie jakością pozytywnie wpływa na utrzyma- } \\
\text { nie obecnych klientów }\end{array}$ & 5,37 \\
\hline & $\begin{array}{l}\text { III.10. Zarządzanie jakością pozytywnie wpływa na dosko- } \\
\text { nalenie naszych działań organizacyjnych }\end{array}$ & 5,22 \\
\hline & $\begin{array}{l}\text { III.11. Zarządzanie jakością wpływa na minimalizację czasu } \\
\text { obsługi klientów }\end{array}$ & 3,46 \\
\hline & $\begin{array}{l}\text { III.12. Zarządzanie jakością wpływa na zmniejszenie rekla- } \\
\text { macji dotyczących wyrobów }\end{array}$ & 4,40 \\
\hline & $\begin{array}{l}\text { III.13. Zarządzanie jakością wpływa na zmniejszenie rekla- } \\
\text { macji na świadczone usługi }\end{array}$ & 5,26 \\
\hline & $\begin{array}{l}\text { III.14. Zarządzanie jakością wpływa na zmniejszenie rekla- } \\
\text { macji dotyczących procesu obsługi klientów }\end{array}$ & 5,35 \\
\hline & $\begin{array}{l}\text { III.15. Zarządzanie jakością wpływa na zmniejszenie nie- } \\
\text { zgodności wewnętrznych }\end{array}$ & 5,31 \\
\hline \multirow{2}{*}{ Finansowe } & $\begin{array}{l}\text { III.16. Zarządzanie jakością wpływa na minimalizację kosz- } \\
\text { tów działalności }\end{array}$ & 3,63 \\
\hline & $\begin{array}{l}\text { III.17. Zarządzanie jakością wpływa na maksymalizację } \\
\text { przychodów ze sprzedaży }\end{array}$ & 4,59 \\
\hline
\end{tabular}

klientom na terenie danej lokalizacji czy też magazynowania i zabezpieczania części zamiennych, co w przypadku nieodpowiednich działań może skutkować zgłoszeniami reklamacyjnymi klientów. Kolejne dwa rezultaty zostały ocenione bliżej potwierdzenia, że „raczej” zarządzanie jakością pozytywnie wpływa na ich uzyskiwanie: zwiększenie współpracy pomiędzy działami (III.7, ważność 4,55) oraz maksymalizację przychodów ze sprzedaży (III.17, ważność 4,59). Kolejnych dziewięć rezultatów (na wykresie 12) znajduje się powyżej oceny „raczej tak” we wpływie zarządzania jakością na ich osiąganie. Respondenci 
jedynie w dwóch przypadkach wskazali najbardziej zdecydowany wpływ zarządzania jakością na uzyskiwanie rezultatów organizacyjnych. Obydwa wskazania dotyczą rezultatów zarządzania jakością z grupy ogólnych: usatysfakcjonowania klientów z wyrobów (III.1, ważność 5,86) i usług (III.2, ważność 5,93). Na ocenę klientów dotyczącą samego pojazdu wpływ ma w największym stopniu producent samochodów. Rezultat ten (III.1) należy uznać za uzależniony właśnie od działań mających miejsce poza badanymi organizacjami. Natomiast na zadowolenie klientów z usług (III.2) mają już zdecydowany wpływ działania organizacyjne podejmowane wewnątrz autoryzowanych salonów sprzedaży i serwisu samochodów osobowych.

Wskazując grupowo ważność rezultatów (zakładając ich równe wagi), można zauważyć, że rezultaty „ogólne” zostały ocenione przez respondentów najwyżej (średnia ważność 5,57), natomiast „,finansowe” - najniżej $(4,11)$ przy pośredniej ważności rezultatów niefinansowych (istotność na poziomie 4,85).

Poszczególne grupy rezultatów zarządzania jakością nie były jednorodne pod względem liczebności. W ogólnym spojrzeniu na rezultaty badania empirycznego, traktując rezultaty równoważnie, najwyżej zostały ocenione ogólne rezultaty zarządzania jakością (średnia 5,57), w dalszej kolejności rezultaty niefinansowe $(4,85)$. Najniżej został oceniony w badaniu pozytywny wpływ zarządzania jakością na wyniki organizacji w aspekcie finansowym $(4,11)$, co nawiązuje do fakultatywnej oceny efektywności ${ }^{71}$ znormalizowanego systemu zarządzania jakością. Ocena rezultatów zarządzania jakością została zaprezentowana na wykresie 13, ze wskazaniem ogólnej ważności oraz podziałem na ważność wśród respondentów z organizacji posiadających „certyfikat ISO 9001” oraz takich, w których certyfikowany system zarządzania jakością nie funkcjonuje.

Największa różnica w ocenie rezultatów zarządzania jakością pomiędzy respondentami reprezentującymi organizacje posiadające i niemające „,ertyfikatu ISO 9001" występuje w ocenie ważności wpływu zarządzania jakością na minimalizację czasu obsługi klientów (rezultat III.11). Organizacje, w których certyfikowano system zarządzania jakością, wyżej oceniają ten rezultat od lokalizacji nieposiadających „certyfikatu ISO 9001” (różnica bezwzględna 1,54). Podobnie jest oceniany wpływ zarządzania jakością na minimalizację kosztów działalności (III.16, różnica bezwzględna 1,18). Takie różnice w ocenie tych rezultatów są prawdopodobnie związane z koniecznością spełniania wymagań normatywnych certyfikowanego systemu zarządzania jakością. Podejmowane działania organizacyjne $w$ ramach implementacji i funkcjonowania znormalizowanego systemu zarządzania jakością wpływają zatem na optymalizację procesu obsługi klientów. Następnym w kolejności rezultatem zarządzania jakością wyżej ocenianym (różnica bezwzględna 0,71 ) w organizacjach prowadzących

\footnotetext{
${ }^{71} \mathrm{~W}$ ocenie efektywności systemowego zarządzania jakością można skorzystać z wytycznych zawartych w normie ISO 10014.
} 


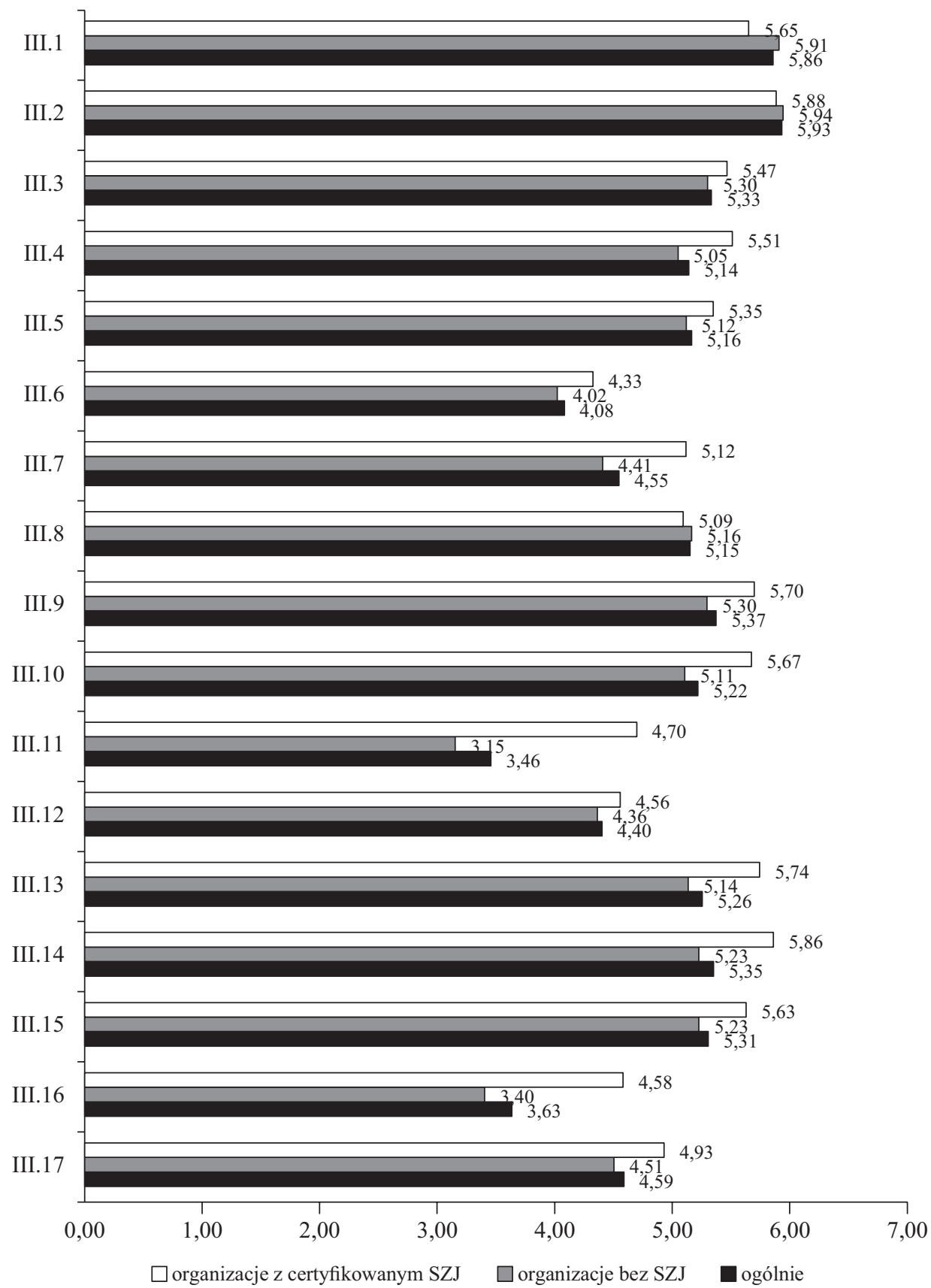

Wykres 13. Średnia ważność rezultatów zarządzania jakością w organizacji porównanie względem posiadania certyfikowanego systemu zarządzania jakością 
działania $\mathrm{w}$ ramach znormalizowanego systemu zarządzania jakością niż bez certyfikowanego systemu zarządzania jakością jest „zwiększenie współpracy pomiędzy działami” (III.7), co nawiązuje do wymagań normatywnych związanych z podejściem procesowym oraz systemowym.

Trzy rezultaty zarządzania jakością zostały wyżej ocenione przez respondentów z organizacji nieposiadających „certyfikatu ISO 9001” niż organizacji, w których spełniono wymagania normatywne z adekwatnej normy:

1. Klienci są usatysfakcjonowani naszymi wyrobami (III.1) - różnica bezwzględna 0,26 .

2. Zarządzanie jakością pozytywnie wpływa na pozyskanie nowych klientów (III.8) - różnica bezwzględna 0,07.

3. Klienci są usatysfakcjonowani naszymi usługami (III.2) - różnica bezwzględna 0,06 .

Na podstawie powyższych wyników można wskazać, że w badanych organizacjach zauważalny jest pozytywny wpływ zarządzania jakością na rezultaty dotyczące klientów.

W odniesieniu do ogólnych rezultatów zarządzania jakością respondenci w największym stopniu są przekonani, że klienci są usatysfakcjonowani usługami danej organizacji (III.2, średnia 5,93 dla wszystkich organizacji). Usatysfakcjonowanie klientów z wyrobów (III.1) znajduje się na drugim miejscu pod względem ważności $(5,86)$, jako rezultat osiągany działaniami z zakresu zarządzania jakością.

W ramach ogólnych rezultatów zarządzania jakością zauważalna jest niższa ocena wpływu tych działań na rezultaty organizacji w aspekcie satysfakcji z wyrobów w lokalizacjach posiadających certyfikowany system zarządzania jakością. Można oczywiście zwrócić uwagę, że wyniki i analiza dotyczą sfery pozytywnego wpływu zarządzania jakością na rezultaty w danym obszarze działań organizacyjnych. Poszukując jednak przyczyn takich wyników, można wskazać, że aby doskonalić działania, konieczna jest wiedza o wynikach w danym momencie. Wymagania normatywne w ramach certyfikowanego systemu zarządzania jakością wymuszają konieczność monitorowania procesów oraz badania satysfakcji klientów, mając zatem takie dane, można udzielić obiektywnej odpowiedzi o doskonaleniu. Należy jednak pamiętać, że analiza dotyczy odpowiedzi respondentów z grupy autoryzowanych salonów sprzedaży i serwisu samochodów osobowych. Oznacza to, że niezależnie od posiadania certyfikowanego systemu zarządzania jakością, poszczególne lokalizacje spełniają szereg wymagań autoryzacyjnych, które dotyczą również i sfery zarządzania jakością.

W ramach niefinansowych rezultatów zarządzania jakością ogólna ważność dla jedenastu zmiennych została przedstawiona w tabeli 9.

We wskazanej grupie rezultatem najwyżej ocenionym przez respondentów był pozytywny „wpływ zarządzania jakością na utrzymanie obecnych klientów”. 
Tabela 9. Niefinansowe rezultaty zarządzania jakością - ważność w ocenie respondentów

\begin{tabular}{|c|c|}
\hline $\begin{array}{c}\text { Rezultaty zarządzania jakością } \\
\text { (numeracja zgodna z przyjęta w III części kwestionariusza ankietowego) }\end{array}$ & $\begin{array}{l}\text { Średnia } \\
\text { ważność }\end{array}$ \\
\hline $\begin{array}{l}\text { III.5. Zarządzanie jakością pozytywnie wpływa na zwiększenie zaangażowania } \\
\text { pracowników }\end{array}$ & 5,16 \\
\hline $\begin{array}{l}\text { III.6. Zarządzanie jakością pozytywnie wpływa na minimalizację fluktuacji pracow- } \\
\text { ników }\end{array}$ & 4,08 \\
\hline $\begin{array}{l}\text { III.7. Zarządzanie jakością pozytywnie wpływa na zwiększenie współpracy pomię- } \\
\text { dzy działami w organizacji }\end{array}$ & 4,55 \\
\hline III.8. Zarządzanie jakością pozytywnie wpływa na pozyskanie nowych klientów & 5,15 \\
\hline III.9. Zarządzanie jakością pozytywnie wpływa na utrzymanie obecnych klientów & 5,37 \\
\hline $\begin{array}{l}\text { III.10. Zarządzanie jakością pozytywnie wpływa na doskonalenie naszych działań } \\
\text { organizacyjnych }\end{array}$ & 5,22 \\
\hline III.11. Zarządzanie jakością wpływa na minimalizację czasu obsługi klientów & 3,46 \\
\hline $\begin{array}{l}\text { III.12. Zarządzanie jakością wpływa na zmniejszenie reklamacji dotyczących wyro- } \\
\text { bów }\end{array}$ & 4,40 \\
\hline $\begin{array}{l}\text { III.13. Zarządzanie jakością wpływa na zmniejszenie reklamacji na świadczone } \\
\text { usługi }\end{array}$ & 5,26 \\
\hline $\begin{array}{l}\text { III.14. Zarządzanie jakością wpływa na zmniejszenie reklamacji dotyczących proce- } \\
\text { su obsługi klientów }\end{array}$ & 5,35 \\
\hline III.15. Zarządzanie jakością wpływa na zmniejszenie niezgodności wewnętrznych & 5,31 \\
\hline
\end{tabular}

Kwestia wpływu zarządzania jakością na pozyskanie nowych klientów została oceniona przez respondentów na podobnym poziomie (obydwa powyżej wartości 5 „tak”). Wokół wartości „tak” we wpływie zarządzania jakością na rezultaty osiągane w organizacji respondenci umiejscowili „Zwiększenie zaangażowania pracowników” oraz „Zwiększenie współpracy pomiędzy działami w organizacji”.

Zarządzanie jakością w organizacji wpływa pozytywnie na podejście pracowników do realizacji działań, które końcowo wpływają na klientów. Jednocześnie w opinii respondentów zarządzanie jakością w najmniejszym stopniu wpływa na minimalizację czasu obsługi klientów, co stanowi jednocześnie najmniej ważny rezultat spośród siedemnastu ocenianych w badaniu ankietowym. W wynikach badania ankietowego jest zauważalne, że projakościowe zarządzanie $\mathrm{w}$ autoryzowanych salonach sprzedaży i serwisu samochodów osobowych w Polsce pozytywnie oddziałuje na klientów, co w porównaniu z negatywnym spojrzeniem na minimalizację czasu obsługi może wzbudzać wątpliwości. Klienci chcą być obsługiwani szybko, a wymagania autoryzacyjne, jak również normatywne w przypadku wdrożenia systemu zarządzania jakością, wymagają dokumentowania działań, co może właśnie stać w sprzeczności z minimalizacją czasu obsługi klientów. Jednak brak minimalizacji czasu obsługi nie prowadzi do utraty klientów, respondenci wskazują na wysoki pozytywny wpływ 
projakościowego zarządzania $\mathrm{w}$ organizacji na utrzymanie obecnych i również pozyskanie nowych klientów. Wymagania autoryzacyjne w ramach poszczególnych sieci motoryzacyjnych dotyczą m.in. dokumentowania historii kontaktów z klientami w bazach danych - nie wpływa to na minimalizację czasu obsługi klientów, ale buduje zaufanie klientów do danej lokalizacji.

Ostatnią grupę rezultatów projakościowego zarządzania w organizacji tworzą dwa - ukazujące pozytywny wpływ zarządzania jakością na finansowe aspekty działalności organizacji:

1. Zarządzanie jakością wpływa na minimalizację kosztów działalności (III.16) - średnia ważność 3,63.

2. Zarządzanie jakością wpływa na maksymalizację przychodów ze sprzedaży (III.17) - ważność 4,59.

$\mathrm{Na}$ siedemnaście rezultatów zarządzania jakością pięć zostało ocenionych wyżej w organizacjach dłużej funkcjonujących na rynku. Największa różnica ważności (wartość bezwzględna 0,47) dotyczy „Wpływu zarząazania jakością na minimalizację czasu obsługi klientów", a zatem rezultatu ocenionego najniżej ze wszystkich (średnia ważność 3,46). Organizacje działające do 6 lat oceniają ten rezultat na poziomie 3,08 , a respondenci $z$ organizacji działających dłużej ocenili ważność tego rezultatu na poziomie 3,54. Wyższa ważność rezultatu zarządzania jakością w lokalizacjach działających do 6 lat (ważność 5,05) niż dłużej działających (różnica bezwzględna 0,79 ) dotyczy „Wpływu zarządzania jakością na zmniejszenie reklamacji dotyczących wyrobów".

Analizując dwa ogólnie najważniejsze, według wskazań respondentów, rezultaty projakościowego zarządzania w organizacji, można stwierdzić, że:

1. Rezultat: „Klienci są usatysfakcjonowani naszymi usługami” (III.2) jest oceniany jedynie o 0,05 wyżej $\mathrm{w}$ organizacjach krócej prowadzących działalność gospodarczą w danej lokalizacji.

2. Rezultat: „Klienci są usatysfakcjonowani naszymi wyrobami” (II.1) jest oceniany jedynie o 0,13 niżej w organizacjach krócej prowadzących działalność gospodarczą w danej lokalizacji.

Zmiany w czasie ważności grupowej rezultatów zarządzania jakością prezentują się następująco:

\begin{tabular}{|c|c|}
\hline \multicolumn{2}{|c|}{ Ogólne $5,61 / \underline{5,56} /(0,05)$} \\
\hline Niefinansowe $5,06 / \underline{4,80} /(0,26)$ & Finansowe $3,96 / \underline{4,15} /(0,19)$ \\
\hline
\end{tabular}

kursywa - ważność grupy rezultatów w lokalizacjach działających do 6 lat podkreślenie - ważność grupy rezultatów w lokalizacjach działających powyżej 7 lat (...) - w nawiasie podana została bezwzględna różnica ważności

Rysunek 2. Grupy rezultatów zarządzania jakością - ważność według respondentów $\mathbf{w}$ ujęciu czasowym 
Wyniki badania ankietowego wskazują na pozytywny wpływ zarządzania jakością na uzyskiwane $\mathrm{w}$ organizacji rezultaty zarządzania jakością w poszczególnych grupach. Analizy szczegółowe według województw, marek samochodów oraz rodzaju lokalizacji (centrala, oddział) nie ukazały istotnych odchyleń w prezentowanych wynikach badania. Różnice bezwzględne ważności w czasie są stosunkowo niewielkie, aczkolwiek zauważalny jest wzrost ważności finansowych rezultatów zarządzania jakością przy spadku ważności pozostałych dwóch grup. W interpretacji takich wyników można się odnieść do kwestii podejmowania działań organizacyjnych w obszarze zarządzania jakością, w tym systemowego podejścia. Inwestowanie w znormalizowane systemy zarządzania to inwestycje rentujące się [Lisiecka 2017, s. 12]. Orientacja na jakość w krótkim okresie może być postrzegana jako zwiększająca koszty, ale w długim czasie wpływa na maksymalizację przychodów ze sprzedaży oraz minimalizację kosztów działalności. Nawiązuje to do powszechnego sformułowania, że ,jakość się opłaca”.

Reasumując rozważania dotyczące wpływu zarządzania jakością na uzyskiwane w organizacji rezultaty, na podstawie ogólnych wskazań respondentów, warto zauważyć, że:

1. Wszystkie rezultaty zarządzania jakością zostały przez respondentów ocenione poniżej wartości „„” (,tak”). Tylko ważność dwóch rezultatów zarządzania jakością, z grupy ogólnych, można ,zaokrąglić” do tej wartości:

- „Klienci są usatysfakcjonowani naszymi wyrobami” - ważność 5,93;

- „Klienci są usatysfakcjonowani naszymi usługami” - ważność 5,86.

2. Dwa rezultaty zarządzania jakością w organizacji zostały ocenione przez przedstawicieli autoryzowanych salonów sprzedaży i serwisu samochodów osobowych w Polsce poniżej poziomu „4":

- najniżej spośród 17 rezultatów ujętych w kwestionariuszu ankietowym respondenci ocenili rezultat $\mathrm{z}$ grupy niefinansowej - na poziomie 3,46; oznacza to, że projakościowe zarządzanie w organizacji „raczej nie” wpływa pozytywnie na minimalizację czasu obsługi klientów;

- respondenci zasadniczo „nie mają zdania” co do pozytywnego wpływu zarządzania jakością na „minimalizację kosztów działalności” (jeden z dwóch rezultatów finansowych).

3. Respondenci, pomimo niskiej oceny przyznanej minimalizacji kosztów działalności, stosunkowo wyżej (aczkolwiek nie można powiedzieć, że wysoko, bo po zaokrągleniu w górę „raczej tak”) ocenili drugi rezultat z grupy finansowych - „Pozytywny wpływ zarządzania jakością na maksymalizację przychodów ze sprzedaży" (średnia ważność na poziomie 4,59).

4. Analizując wyniki grupowej ważności rezultatów projakościowego zarządzania w organizacji, warto wskazać, że:

- rezultaty finansowe zarządzania jakością zostały ocenione najniżej, ale jednocześnie (jako jedyna grupa) ich ważność jest zauważalna w więk- 
szym stopniu wraz z dłuższym okresem prowadzenia działalności gospodarczej;

- pozostałe dwie grupy rezultatów (ogólne, niefinansowe) są oceniane niżej wraz z upływem czasu funkcjonowania poszczególnych lokalizacji na rynku.

5. Ważność pozostałych piętnastu rezultatów zarządzania jakością jest wyższa w lokalizacjach, w których funkcjonuje certyfikowany system zarządzania jakością.

Przy zastosowaniu tej samej siedmiostopniowej skali punktacji średnie ważności rezultatów projakościowego zarządzania $\mathrm{w}$ organizacji zostały ocenione przez respondentów na niższym poziomie niż główne wewnętrzne czynniki zarządzania jakością. Można to thumaczyć dwojako. Po pierwsze, zarządzanie jakością jest obszarem występującym w każdej organizacji i mającym wpływ na wynik końcowy (produkt - wyrób i usługę). Tym samym zarządzanie jakością jest traktowane jako podstawowy i naturalny obszar działań organizacji, co się przekłada na oceny respondentów bez specjalnego akcentowania ważności tych rezultatów. Z drugiej strony można przypuszczać, że respondenci świadomie pomijają pozytywny wpływ zarządzania jakością na wskazane rezultaty osiągane w organizacji z uwagi na oddziaływanie innych podsystemów na całościowe wyniki organizacji. W jednym i drugim przypadku warto, zdaniem autora, posiadać informacje o czynnikach projakościowego zarządzania, które - kształtowane poprzez wewnętrzne decyzje w organizacji - wpływają na osiąganie bieżących rezultatów oraz długookresowych efektów.

\subsection{Ważność elementów konstytuujących główne wewnętrzne czynniki zarządzania jakością w organizacji}

Ważność poszczególnych elementów konstytuujących główne wewnętrzne czynniki zarządzania jakością $\mathrm{w}$ organizacji zostały zaprezentowane w niniejszym punkcie pracy w dwóch aspektach - jakości oraz ryzyka. Warto podkreślić, że są to aspekty uwzględniane łącznie w podejmowaniu decyzji w każdej organizacji, aczkolwiek ich wyróżnienie stanowi wypełnienie zidentyfikowanej luki badawczej oraz podkreślenie znaczenia poszczególnych elementów i możliwości koncentracji na nich celem oddziaływania na sukces projakościowego zarządzania w organizacji.

Pierwszy główny wewnętrzny czynnik zarządzania jakością „Przywództwo i zaangażowanie najwyższego kierownictwa w jakość" został scharakteryzowany łącznie trzynastoma stwierdzeniami. Pierwszych sześć elementów dotyczy aspektu jakości, a kolejne siedem odnosi się do aspektu ryzyka. 
I.1.1. Najwyższe kierownictwo kładzie nacisk na zagadnienia jakościowe

I.1.2. Najwyższe kierownictwo w celach jakościowych uwzględnia trendy rynkowe

I.1.3. Najwyższe kierownictwo demonstruje swoje zaangażowanie w jakość

I.1.4. Najwyższe kierownictwo formalnie definiuje cele jakościowe i rozlicza $\mathrm{z}$ ich realizacji

I.1.5. Najwyższe kierownictwo stworzyło, udokumentowało i zakomunikowało Politykę Jakości

I.1.6. Najwyższe kierownictwo przeznacza wystarczające zasoby na rzecz doskonalenia jakości

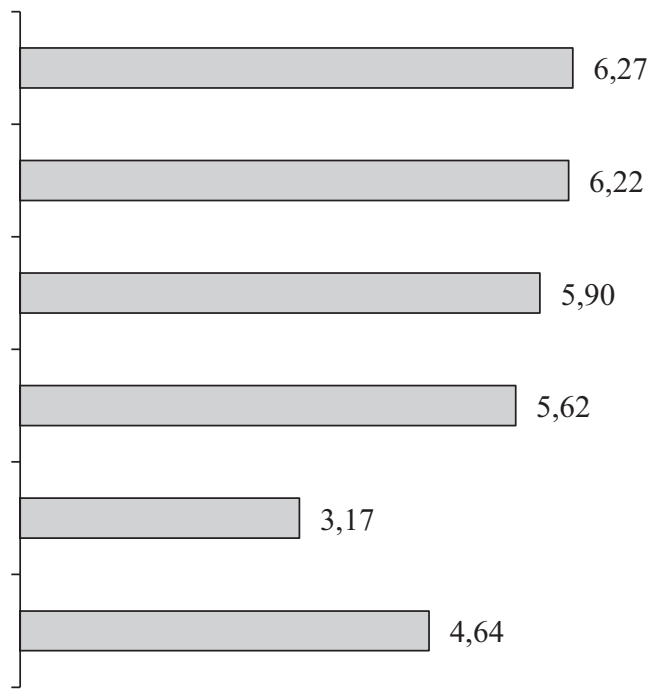

\section{Wykres 14. Ważność elementów składowych głównego wewnętrznego czynnika „Przywództwo i zaangażowanie najwyższego kierownictwa w jakość” - aspekt jakości}

Najbardziej zauważalna na wykresie 14 jest niska ocena ważności dla piątego elementu szczegółowego charakteryzującego główny wewnętrzny czynnik (średnia ważność 3,17). Wśród respondentów, reprezentujących 219 organizacji w 43 lokalizacjach (ponad 19\%), funkcjonuje certyfikowany system zarządzania jakością. Oznacza to, że ponad $80 \%$ badanych lokalizacji nie posiada „certyfikatu ISO 9001”, zatem ocena ważności tego elementu wynika z braku konieczności spełniania odpowiednich wymagań normatywnych. Jednocześnie największe różnice $\mathrm{w}$ ocenie poszczególnych składowych w całym badaniu empirycznym występują właśnie w ramach pierwszego głównego wewnętrznego czynnika zarządzania jakością i dokładnie dla elementu dotyczącego polityki jakości. W organizacjach nieposiadających certyfikowanego systemu zarządzania jakością jest to wartość 2,47 oraz 6,02 w lokalizacjach, które posiadają „certyfikat ISO 9001”. Z kolei różnica odwrotna, wskazująca na wyższą ocenę danego elementu $\mathrm{w}$ organizacjach posiadających certyfikowany system zarządzania jakością, dotyczy uwzględniania przez najwyższe kierownictwo trendów rynkowych w definiowaniu celów dotyczących jakości (wartość 6,4 względem średniej 5,5, różnica bezwzględna to 0,9 ). Podobnie pierwszy element uszczegóławiający (,najwyższe kierownictwo kładzie nacisk na zagadnienia jakościowe") w analizowanym głównym wewnętrznym czynniku projakościowego zarządzania w organizacji został wyżej oceniony w organizacjach, które nie mogą się pochwalić posiadaniem „certyfikatu ISO 9001” (różnica bezwzględna $0,74)$. 
I.1.7. Najwyższe kierownictwo identyfikuje zagrożenia wpływające na realizację zidentyfikowanych celów jakościowych

I.1.8. Najwyższe kierownictwo identyfikuje szanse wpływające na maksymalizację osiąganych efektów jakościowych

I.1.9. Najwyższe kierownictwo identyfikuje potencjalne skutki dla zagrożeń wpływających na realizację celów jakościowych

I.1.10. Najwyższe kierownictwo identyfikuje potencjalne skutki dla szans dotyczących maksymalizacji efektów jakościowych

I.1.11. Najwyższe kierownictwo określa prawdopodobieństwo wystąpienia zagrożeń i szans związanych z realizacją celów dotyczących jakości

I.1.12. Najwyższe kierownictwo identyfikuje zagrożenia i (lub) szanse w obszarze zarządzania jakością w sposób udokumentowany

I.1.13. Najwyższe kierownictwo zidentyfikowało kluczowe wyroby i usługi, które chronimy i dążymy do realizacji nawet w sytuacjach kryzysowych (jak np. brak prądu, choroby pracowników)

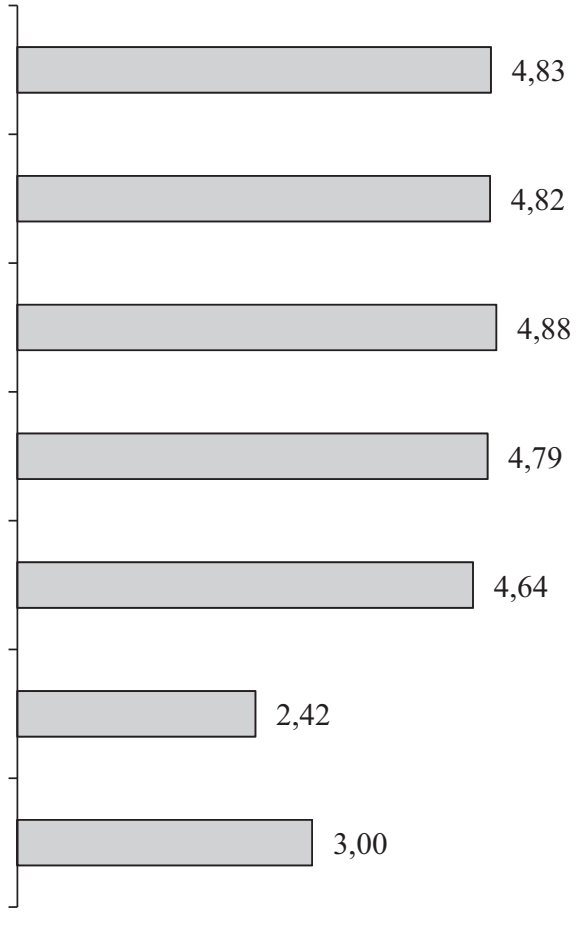

\section{Wykres 15. Ważność elementów składowych głównego wewnętrznego czynnika „Przywództwo i zaangażowanie najwyższego kierownictwa w jakość” - aspekt ryzyka}

Dwa ostatnie elementy składowe czynnika „Przywództwo i zaangażowanie najwyższego kierownictwa w jakość" zostały przez respondentów ocenione stosunkowo nisko. Odnosząc odpowiedzi do zastosowanej skali, oznacza to, że elementy te nie są stosowane w badanych lokalizacjach. Nawet w organizacjach posiadających certyfikowany system zarządzania jakością wartości średnie oscylują wokół „nie mam zdania”. Respondenci z 21 lokalizacji udzielili zdecydowanej odpowiedzi (,zdecydowanie tak”) odnośnie do elementu „Najwyższe kierownictwo identyfikuje zagrożenia i (lub) szanse w obszarze zarządzania jakością w sposób udokumentowany" (I.1.12). W tej grupie dwanaście organizacji posiadało „certyfikat ISO 9001” i w czterech przypadkach odpowiedzi udzielili przedstawiciele „Służb jakości”. Analizując szczegółowo ważność tych dwóch ostatnich elementów w aspekcie ryzyka, według wielkości zatrudnienia czy czasu funkcjonowania lokalizacji na rynku, wyniki są podobne i ich ważność jest każdorazowo najmniejsza. Istotą tego elementu uszczegóławiającego (I.1.12) jest dokumentowanie działań, które w ogólnym ujęciu zostały wskazane w poprzedzających zmiennych tego czynnika. Respondenci ocenili ważność tych elementów (I.1.7-11) bliżej „raczej tak” niż „nie mam zdania”, w perspektywie 
podejmowania tych działań w badanych lokalizacjach. $\mathrm{Z}$ jednej strony można zatem uznać, że najwyższe kierownictwo uwzględnia ,intuicyjnie” podejście oparte na ryzyku w ramach zarządzania jakością, aczkolwiek w sposób mało zdecydowany, a jednocześnie nieudokumentowany. Natomiast ostatni element (I.1.13) został nisko oceniony, co ukazuje brak podejmowania w badanych organizacjach działań z obszaru ciągłości działania, czego przyczyny należałoby indywidualnie identyfikować w poszczególnych organizacjach.

Drugi główny wewnętrzny czynnik zarządzania jakością został zatytułowany „Planowanie strategiczne i operacyjne” i opisany trzynastoma stwierdzeniami, z podziałem na siedem elementów ,jakościowych” oraz sześć „ryzykownych”.

II.2.1. Cele jakościowe planowane są na poszczególnych poziomach w organizacji

II.2.2. Cele jakościowe są mierzalne i jasno sprecyzowane

II.2.3. Nasze cele jakościowe w pełni dopasowane są do specyfiki i zakresu naszej działalności

II.2.4. Cele dotyczące jakości komunikowane są wszystkim pracownikom

II.2.5. Cele są szczegółowo rozpisywane na zadania dla poszczególnych działów organizacyjnych

II.2.6. Każdy z pracowników ma wyznaczone zadania dla realizacji zidentyfikowanych celów jakości

II.2.7. Jakość stanowi priorytet w planowaniu celów

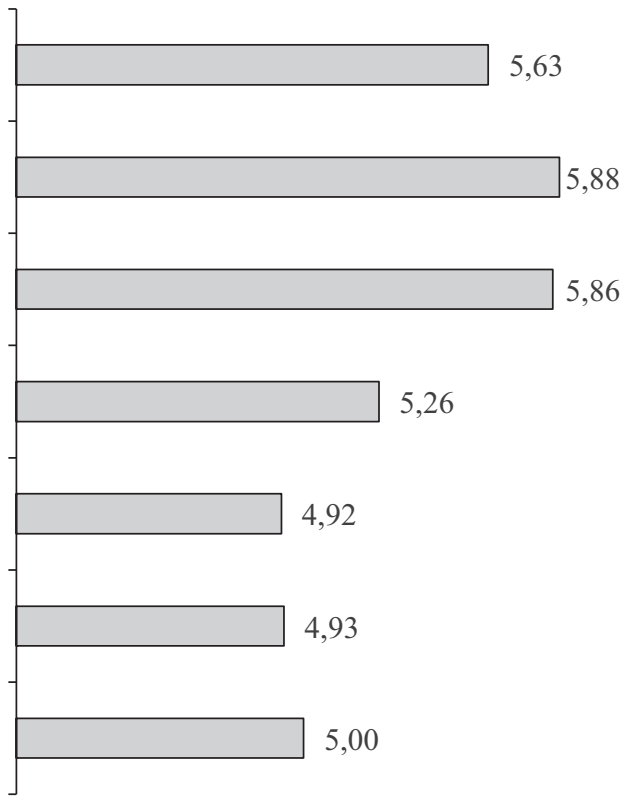

Wykres 16. Ważność elementów składowych głównego wewnętrznego czynnika „Planowanie strategiczne i operacyjne" - aspekt jakości

Respondenci w ramach jakościowego aspektu głównego wewnętrznego czynnika „Planowanie strategiczne i operacyjne” za najważniejszy uznali obszar planowania celów jakościowych zarówno pod względem ich mierzalności, jak i dopasowania do specyfiki działalności oraz w mniejszym stopniu - ich planowania na poszczególnych poziomach $\mathrm{w}$ organizacji. $\mathrm{W}$ badanej grupie organizacji plany sprzedażowe oraz związane z parametrami pracy serwisu (m.in. sprzedaż roboczogodzin, części zamiennych, pakietów serwisowych) jest kwestią umowną pomiędzy poszczególnymi lokalizacjami a podmiotem przyznającym autoryzację. Takie stosunkowo wysokie wyniki ważności tych elementów nie są zatem 
zaskakujące. Natomiast stosunkowo nisko zostały ocenione kwestie kaskadowości planowania, a konkretnie rozpisywania celów na zadania zarówno na płaszczyźnie organizacyjnej (w poszczególnych działach), jak i stanowisk. Odnosząc wyniki ważności tych elementów (II.2.5-6) do zastosowanej skali badawczej, można zauważyć, że „raczej” te działania mają miejsce w badanych organizacjach, aczkolwiek w mniej zdecydowany sposób od pozostałych elementów, w ramach analizowanego głównego wewnętrznego czynnika projakościowego zarządzania $\mathrm{w}$ organizacji. W praktyce funkcjonowania autoryzowanych salonów sprzedaży i serwisu samochodów osobowych w Polsce można zauważyć, że cele organizacyjne są rozpisywane na poszczególne obszary organizacyjne oraz na role pracowników. Jednak zadania pozostają często kwestią poszczególnych pracowników, a sposób ich ustalania, jak również dokumentowania, często wynika z indywidualnych wymagań służbowych bezpośredniego przełożonego. Autor niniejszej monografii skłania się jednak do stwierdzenia, że w większości przypadków zadania służące realizacji celów pozostają w gestii danego pracownika.

W ramach drugiego głównego wewnętrznego czynnika zarządzania jakością respondenci oceniali również elementy w aspekcie ryzyka, a wyniki oceny zostały zaprezentowane na wykresie 17.

II.2.8. Dla zidentyfikowanych zagrożeń w realizacji celów tworzone są prewencyjne plany zarządzania ryzykiem, mające zminimalizować prawdopodobieństwo zaistnienia zagrożeń

II.2.9. Powyższe plany są dokumentowane oraz komunikowane wewnętrznie w organizacji

II.2.10. Dla zidentyfikowanych szans realizacji celów tworzone są plany zarządzania ryzykiem mające maksymalizować prawdopodobieństwo wykorzystania szans

II.2.11. Dla zidentyfikowanych zagrożeń w realizacji celów tworzone są plany na wypadek rzeczywistego zaistnienia zagrożenia, mające zminimalizować skutki sytuacji kryzysowej

II.2.12. Powyższe plany są dokumentowane oraz komunikowane wewnętrznie w organizacji

II.2.13. Okresowo realizowane są ćwiczenia/testowanie planów na wypadek sytuacji awaryjnych

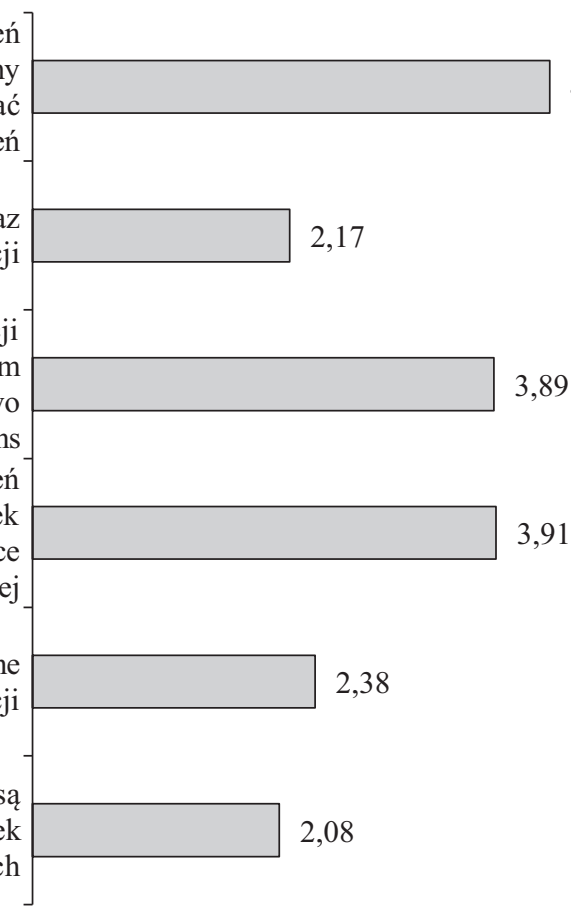

Wykres 17. Ważność elementów składowych głównego wewnętrznego czynnika „Planowanie strategiczne i operacyjne" - aspekt ryzyka 
W ramach elementów ujętych na wykresie 17 można zwrócić uwagę na niezdecydowaną ocenę respondentów $\mathrm{w}$ odniesieniu do tworzenia prewencyjnych planów w obszarze minimalizacji zagrożeń (II.2.8), maksymalizacji wykorzystania szans (II.2.10) oraz planów na wypadek sytuacji kryzysowej (II.2.11). Jednocześnie, podobnie jak w ocenie elementów konstytuujących pierwszy główny wewnętrzny czynnik zarządzania jakością, dokumentowanie wskazanych kwestii jest już oceniane zdecydowanie niżej (blisko odpowiedzi „nie”). W ramach drugiego analizowanego głównego wewnętrznego czynnika projakościowego zarządzania w organizacji występuje potrzeba uwzględniania, według wskazań respondentów, zagadnień w aspekcie ryzyka, jednak w sposób nieudokumentowany.

Kolejnym uwzględnionym w badaniu ankietowym głównym wewnętrznym czynnikiem zarządzania jakością była „Orientacja na klienta”, gdzie wśród 12 elementów konstytuujących dany czynnik pierwszych dziewięć dotyczyło dotychczasowego aspektu jakości.

II.3.1. W działaniach najwyższego kierownictwa priorytetem są wymagania i oczekiwania klientów

II.3.2. W działaniach każdego pracownika priorytetem są wymagania i oczekiwania klientów

II.3.3. Aktywnie poszukujemy informacji zwrotnych od klientów

II.3.4. Istnieje sformalizowany system identyfikacji potrzeb i oczekiwań klientów

II.3.5. Wymagania klientów i informacje zwrotne są uwzględniane w procesie doskonalenia jakości

II.3.6. Istnieje procedura przyjmowania uwag i reklamacji ze strony klientów

II.3.7. W procesie obsługi klienta uwzględniane są dane $\mathrm{z}$ okresowych analiz rynku oraz konkurencji

II.3.8. Istnieją udokumentowane procedury obsługi klientów

II.3.9. Identyfikujemy tematy rynkowe mające wpływ na obsługę klientów

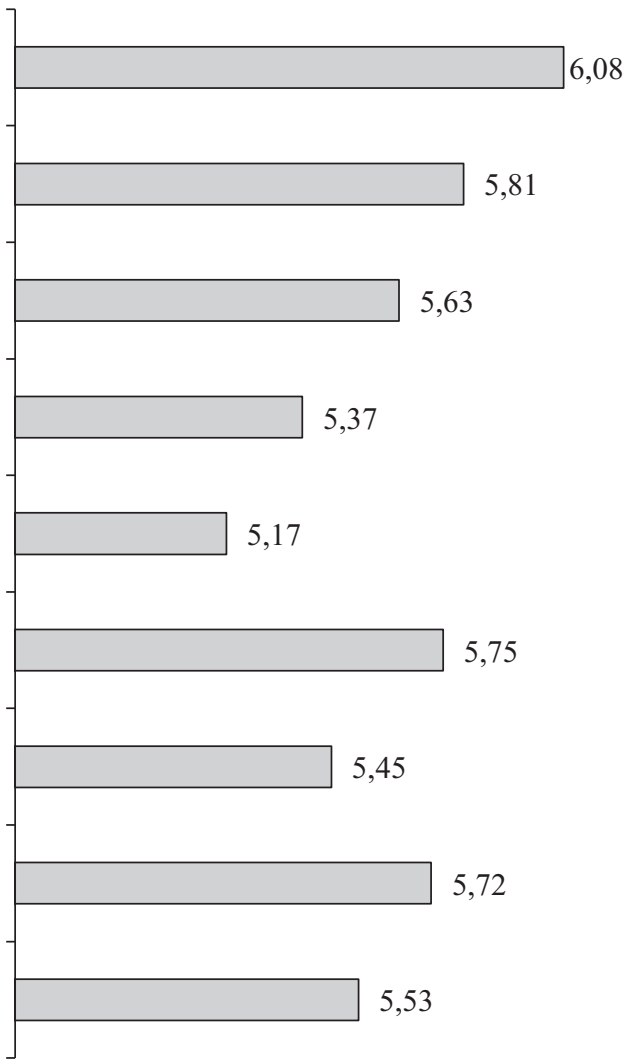

Wykres 18. Ważność elementów składowych głównego wewnętrznego czynnika „Orientacja na klienta" - aspekt jakości 
Ważność sześciu elementów wskazanych na wykresie 18 oscyluje wokół wartości „tak” w odniesieniu do podejmowania danych działań w badanych organizacjach. Dla trzech pozostałych elementów wskazania respondentów są o mniejszej ważności („raczej tak”) względem podejmowania danych działań w badanych autoryzowanych salonach sprzedaży i serwisu samochodów osobowych w Polsce. Stosunkowo wysokie oceny ważności dla poszczególnych elementów uszczegóławiających główny wewnętrzny czynnik „Orientacja na klienta” oddają istotę ukierunkowania działań na rzecz identyfikacji potrzeb i oczekiwań klientów oraz realizacji działań w kierunku osiągania ich satysfakcji. Wyniki oceny ważności elementów składowych opisywanego wewnętrznego czynnika, z punktu widzenia wyodrębnionego ryzyka, zostały zaprezentowane na wykresie 19.

II.3.10. Jesteśmy świadomi potrzeby identyfikacji i postępowania z ryzykiem w obszarze obsługi klientów

II.3.11. Klienci stanowią źródło największych zagrożeń w działalności

II.3.12. Wszystkie dane dotyczące obsługi klientów uzupełniane są w systemie komputerowym

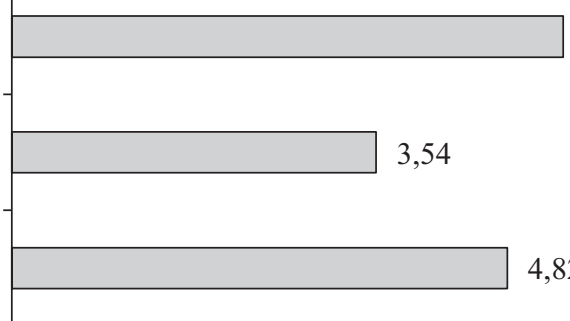

Wykres 19. Ważność elementów składowych glównego wewnętrznego czynnika „Orientacja na klienta" - aspekt ryzyka

Rola klientów w działalności każdej organizacji jest niezaprzeczalna z uwagi na strumień finansowy płynący od klientów oraz ich wpływ na długookresowe funkcjonowanie podmiotów gospodarczych na rynku. To sprawia, że znaczenia nabierają kwestie identyfikacji zagrożeń mogących negatywnie wpłynąć na obsługę klientów, który to element został najwyżej przez badanych respondentów oceniony w analizowanej grupie elementów. Klienci stanowią podstawę działań, spadek ich liczby oraz zamówień może stanowić zagrożenie mogące przekształcić się $\mathrm{w}$ duże ryzyko. Ten aspekt $\mathrm{w}$ działalności organizacji jest zauważalny w najwyższej ocenie potrzeby identyfikacji i postępowania z ryzykiem w obszarze obsługi klientów.

„Zarządzanie na podstawie faktów” stanowi kolejny zidentyfikowany w wyniku analizy teoretycznej, główny wewnętrzny czynnik projakościowego zarządzania w organizacji. Czynnik ten w pierwszej części został zoperacjonalizowany poprzez sześć stwierdzeń, które w większości badanych organizacji (67\%) „raczej” występują w prowadzonej działalności gospodarczej, co zostało przedstawione na wykresie 20. 
II.4.1. Okresowo organizowane są spotkania dotyczące analizy danych jakościowych

II.4.2. Okresowo przeprowadzane są wewnętrzne audyty jakościowe

II.4.3. Okresowo przeprowadzane są zewnętrzne audyty jakościowe

II.4.4. Organizowane są doraźne spotkania w celu rozwiązywania problemów jakościowych w poszczególnych działach

II.4.5. Organizowane są okresowe międzydziałowe spotkania na rzecz doskonalenia jakości

II.4.6. Dane jakościowe uwzględniane są w podejmowaniu decyzji na wszystkich szczeblach organizacyjnych

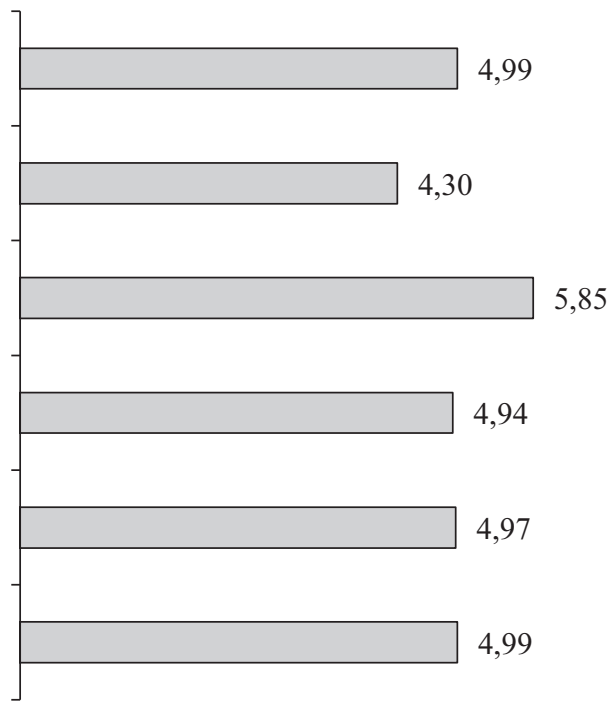

Wykres 20. Ważność elementów składowych głównego wewnętrznego czynnika „Zarządzanie na podstawie faktów” - aspekt jakości

Analizując średnią ważność poszczególnych elementów widoczny jest „brak zdania" w ogólnej ocenie respondentów względem okresowo przeprowadzanych wewnętrznych audytów jakościowych. Jest to powiązane $\mathrm{z}$ próbą badawczą, w której $20 \%$ organizacji posiada certyfikowany system zarządzania jakością, w ramach którego okresowo realizowane są audyty wewnętrzne. Najwyżej w analizowanej grupie elementów ocenione zostało przez respondentów „Okresowe przeprowadzanie zewnętrznych audytów jakościowych”, co wynika $\mathrm{z}$ audytów realizowanych przez (bądź na zlecenie) podmiotu przyznającego autoryzację.

II.4.7. Ograniczamy podejmowanie decyzji przy niepełnym posiadaniu danych

II.4.8. Przy podejmowaniu decyzji identyfikujemy zagrożenia dla sukcesu podejmowanych działań

II.4.9. Przy podejmowaniu działań rozważamy szanse ich realizacji

II.4.10. Zagrożenia i szanse związane z podejmowaniem decyzji są dokumentowane

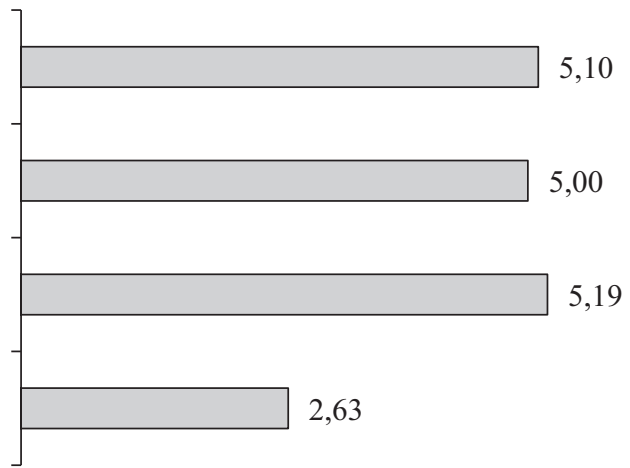

Wykres 21. Ważność elementów składowych głównego wewnętrznego czynnika „Zarządzanie na podstawie faktów” - aspekt ryzyka 
W ramach obszaru wyodrębnionych elementów ryzyka nisko ocenione zostało dokumentowanie zagrożeń i szans związanych z podejmowaniem różnorodnych decyzji.

Analizując dane uwidocznione na wykresie 21, można zauważyć konsekwentne (w stosunku do elementów konstytuujących wcześniejsze główne wewnętrzne czynniki projakościowego zarządzania w organizacji) ocenianie przez respondentów dwóch zauważalnych płaszczyzn w aspekcie ryzyka. Wyżej oceniane są przez respondentów elementy wskazujące na podejmowanie różnorodnych działań, lecz nie są one dokumentowane.

W ramach głównego wewnętrznego czynnika zarządzania jakością „Zarządzanie zasobami ludzkimi" respondenci najniżej ocenili kwestie swobodnego wypowiadania się pracowników o osiąganych wynikach organizacji, co zostało zobrazowane na wykresie 22 .

II.5.1. Organizacja motywuje pracowników do działania i realizacji zdefiniowanych celów jakości

II.5.2. Najwyższe kierownictwo organizacji zachęca i motywuje do pracy zespołowej

II.5.3. Okresowo pracownicy biorą udział w szkoleniach z zakresu zarządzania jakością

II.5.4. Elementy jakościowe uwzględniane są w premiowaniu pracowników

II.5.5. Pracownicy swobodnie pozwalają sobie na wypowiadanie się o ich spojrzeniu, uwagach krytycznych i informacji zwrotnych nt. osiąganych wyników przez organizację

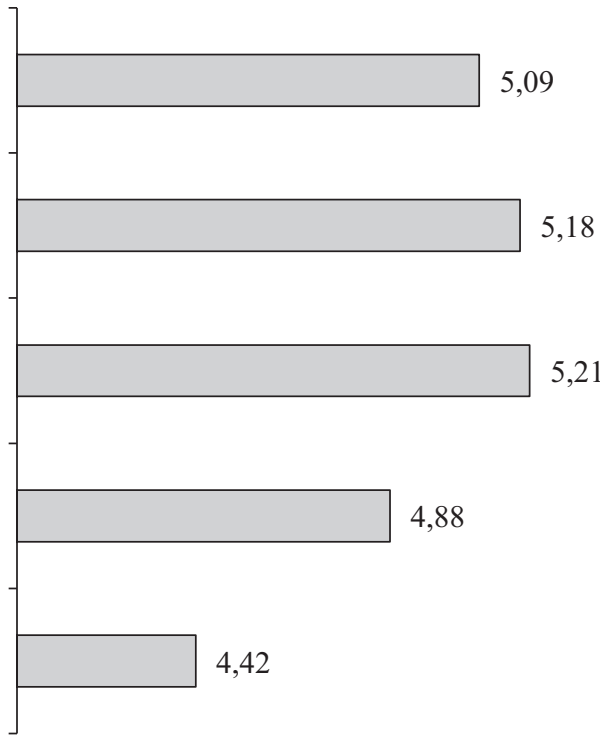

Wykres 22. Ważność elementów składowych głównego wewnętrznego czynnika „Zarządzanie zasobami ludzkimi” - aspekt jakości

Kwestia udziału pracowników w szkoleniach z zakresu zarządzania jakością została oceniona najwyżej w analizowanej grupie elementów. Różnica ważności tego elementu $\mathrm{w}$ ocenie respondentów $\mathrm{z}$ organizacji posiadających certyfikowany system zarządzania jakością $(5,33)$ względem niemających „,certyfikatu ISO 9001" $(5,19)$ jest stosunkowo niewielka, wartość bezwzględna wynosi bowiem 0,14 . To wskazuje, że ukierunkowanie zarządzania jakością $\mathrm{w}$ autoryzowanych salonach sprzedaży i serwisu samochodów osobowych w Polsce jest niezależne od normatywnego podejścia do tych kwestii. 
II.5.6. Elementem w rozliczaniu pracowników jest zapobieganie zagrożeniom $\mathrm{w}$ realizacji celów

II.5.7. Elementem w rozliczaniu pracowników jest wykorzystywanie szans dla zwiększenia osiąganych efektów

II.5.8. Pracownicy mają odpowiednie kompetencje do zarządzania ryzykiem w obszarach swoich obowiązków

II.5.9. Świadomość jakościowa potencjalnych pracowników stanowi ważne kryterium w procesie rekrutacji

II.5.10. Skuteczność naszych selekcji i rekrutacji można określić sformułowaniem „właściwy człowiek na właściwym miejscu”

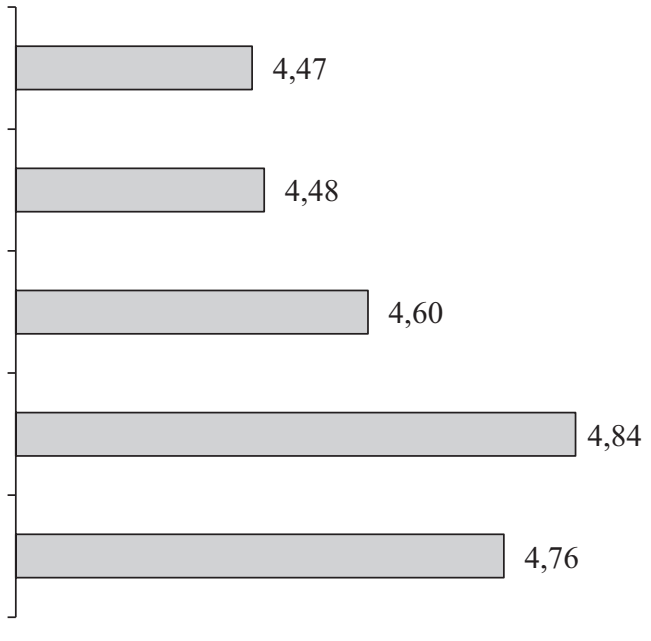

Wykres 23. Ważność elementów składowych głównego wewnętrznego czynnika „Zarządzanie zasobami ludzkimi” - aspekt ryzyka

Elementy $\mathrm{w}$ aspekcie ryzyka wchodzące w skład czynnika "Zarządzanie zasobami ludzkimi" zostały przez respondentów ocenione poniżej odpowiedzi „tak” co do ich stosowania w organizacji. Respondenci deklarują, że w procesie rekrutacji pracowników uwzględniana jest świadomość jakościowa kandydatów, ale jednocześnie najniżej oceniają kwestie rozliczania pracowników z zapobiegania zagrożeniom $\mathrm{w}$ realizacji celów. Takie podejście można interpretować $\mathrm{w}$ ten sposób, że z założenia jakość procesów i produktów jest ważna w funkcjonowaniu organizacji. Uwzględnianie zagadnień jakościowych jest naturalnym działaniem w organizacji i tym samym brak jest koncentracji na niej na etapie oceny, co nawiązuje do kwestii odpowiedzialności każdego pracownika. Można tutaj zauważyć, że twórcza postawa pracowników oraz działania doskonalące są zasadniczo pobudzane przez sytuacyjne uwarunkowania, przy założeniu posiadania przez personel odpowiedniego wykształcenia, doświadczenia i honorowania preferowanego systemu wartości [Lisiecka 2012a, s. 149].

Najwyżej przez respondentów został oceniony główny wewnętrzny czynnik zarządzania jakością „Zaangażowanie pracowników”, z ważnością na poziomie 6,52. W ramach analizy ważności elementów opisujących tenże czynnik w aspekcie jakości najwyżej ocenione zostały zagadnienia współpracy pomiędzy pracownikami, ujęte na wykresie 24.

Respondenci nie do końca są przekonani o istnieniu skutecznej komunikacji w organizacji w kwestii grupowego rozwiązywania problemów jakościowych. Jednocześnie dokładnie taka sama średnia ważność tego elementu została przyznana przez respondentów reprezentujących organizacje posiadające certyfikowany system zarządzania jakością, jak i pozostałe. W obszarze elementów 


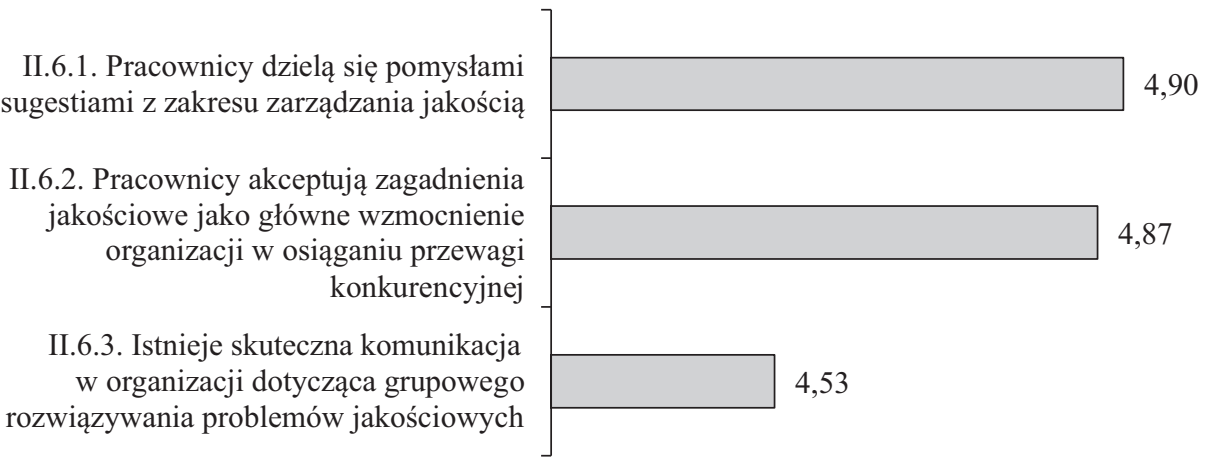

\section{Wykres 24. Ważność elementów składowych glównego wewnętrznego czynnika „Zaangażowanie pracowników” - aspekt jakości}

w aspekcie ryzyka najniżej oceniono dzielenie się przez pracowników z kierownictwem swoimi spostrzeżeniami dotyczącymi zagrożeń i szans związanych z realizacją celów jakościowych.

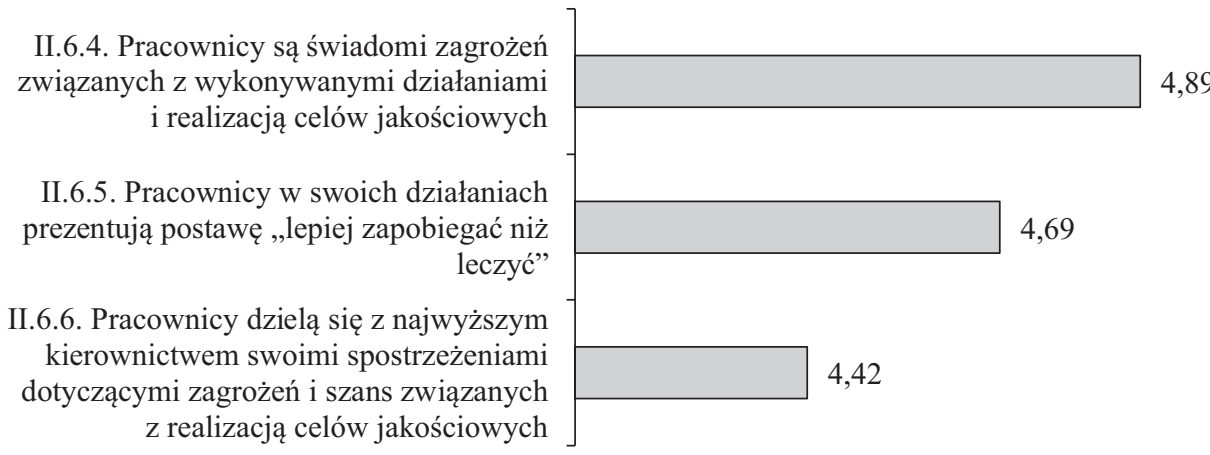

Wykres 25. Ważność elementów składowych głównego wewnętrznego czynnika „Zaangażowanie pracowników” - aspekt ryzyka

Główny wewnętrzny czynnik „Zarządzanie procesowe” został przez respondentów oceniony najniżej ze wszystkich ośmiu umieszczonych w kwestionariuszu ankietowym. Aczkolwiek ważność na poziomie 5,46 wskazuje na średnią ocenę pomiędzy „raczej tak” a „tak” w pozytywnym wpływie zarządzania procesowego na rezultaty projakościowego zarządzania w organizacji.

Najniżej, z ,jakościowych" elementów składowych analizowanego wewnętrznego czynnika zostały ocenione zagadnienia dotyczące dostawców i podwykonawców. Takie wyniki wydają się naturalne z perspektywy przyjętego zakresu podmiotowego badań. Autoryzowane salony sprzedaży i serwisu samochodów osobowych w Polsce stanowią ogniwo w dystrybucji danej producenckiej marki samochodowej, zatem dostawcą pojazdów jest jednocześnie podmiot 
II.7.1. W organizacji zostały zidentyfikowane procesy obejmujące całą działalność organizacji

II.7.2. Działania w poszczególnych procesach zostały opisane w formie ,procedur”

II.7.3. Istniejące w organizacji procedury postępowania uwzględniają aspekty jakościowe

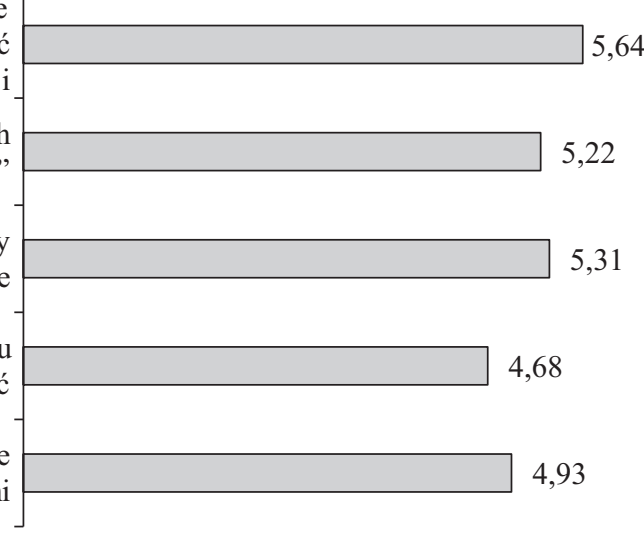

II.7.4. Pierwszorzędnym kryterium doboru dostawców/podwykonawców jest jakość

II.7.5. Budujemy długookresową współpracę ze stałymi dostawcami

Wykres 26. Ważność elementów składowych głównego wewnętrznego czynnika „Zarządzanie procesowe” - aspekt jakości

przyznający autoryzację. Pojedyncze lokalizacje mają więc zawężony wybór co do obszarów poszukiwania dostawców i podwykonawców, najczęściej lokalnie i w odniesieniu do pobocznych procesów, np. utrzymania infrastruktury.

Podejście procesowe zobowiązuje do zidentyfikowania i zarządzania procesami, co prowadzi do optymalizacji relacji występujących pomiędzy nimi. Zobowiązuje to do postępowania w sposób logiczny, tworzenia ciągu następujących po sobie czynności, co warunkuje wytworzenie produktu kompleksowo spełniającego wymagania klienta i dostarcza mu oczekiwaną wartość [Łukasiński 2016b, s. 19-20]. Dla wzmocnienia wpływu zarządzania procesowego na rezultaty zarządzania jakością należy zwrócić uwagę na ważność elementów składowych tego czynnika w aspekcie ryzyka, co ujęte zostało na wykresie 27.

Zarządzanie procesowe grupuje działania realizowane w organizacji. Konieczne jest przypisanie właścicieli do procesów. Ten element został najwyżej oceniony w analizowanej „ryzykownej” grupie elementów, zarówno przez respondentów z organizacji z certyfikowanym systemem zarządzania jakością, jak

II.7.6. Procesy mają przypisanych właścicieli, którzy są odpowiedzialni za zarządzanie ryzykiem tych procesów

II.7.7. Zarządzanie ryzykiem jest częścią zarządzania każdym procesem

II.7.8. Reklamacji do dostawców jest stosunkowo niewiele

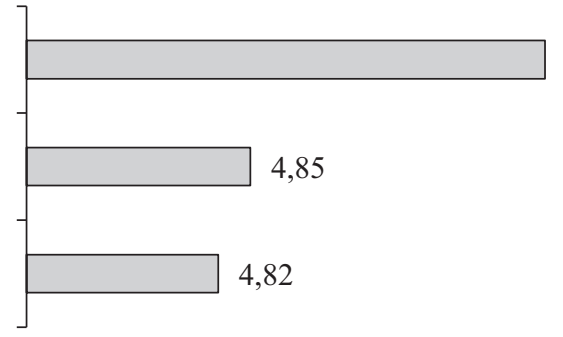

Wykres 27. Ważność elementów składowych głównego wewnętrznego czynnika „Zarządzanie procesowe" - aspekt ryzyka 
i pozostałych, nieposiadających „certyfikatu ISO 9001”. Jednocześnie kwestia reklamacji do dostawców jest rozpatrywana w aspekcie ryzyka, czyli szans i zagrożeń dotyczących tej sfery funkcjonowania organizacji. Jednocześnie kwestia liczby ewentualnych reklamacji wskazuje na sposób współpracy pomiędzy daną lokalizacją a podmiotami zewnętrznymi, co znajduje się w procesach zakupowych organizacji.

Procesy zarządzania ryzykiem powinny przenikać całe przedsiębiorstwo i być kluczowe dla ich funkcjonowania oraz rozwoju [Lisiecka 2012b, s. 569]. Uwzględnienie ryzyka w podejściu procesowym wpływa na „Ciągłe doskonalenie”, stanowiąc kolejny główny wewnętrzny czynnik projakościowego zarządzania w organizacji.

W wynikach oceny ankietowej elementów składowych danego czynnika w aspekcie jakości zauważalne jest (wykres 28) nawiązanie do roli klientów w działalności organizacji.

Zwiększanie zadowolenia klientów stanowi priorytet w planowaniu i realizacji działań doskonalących. Najniższą ocenę respondentów uzyskał element

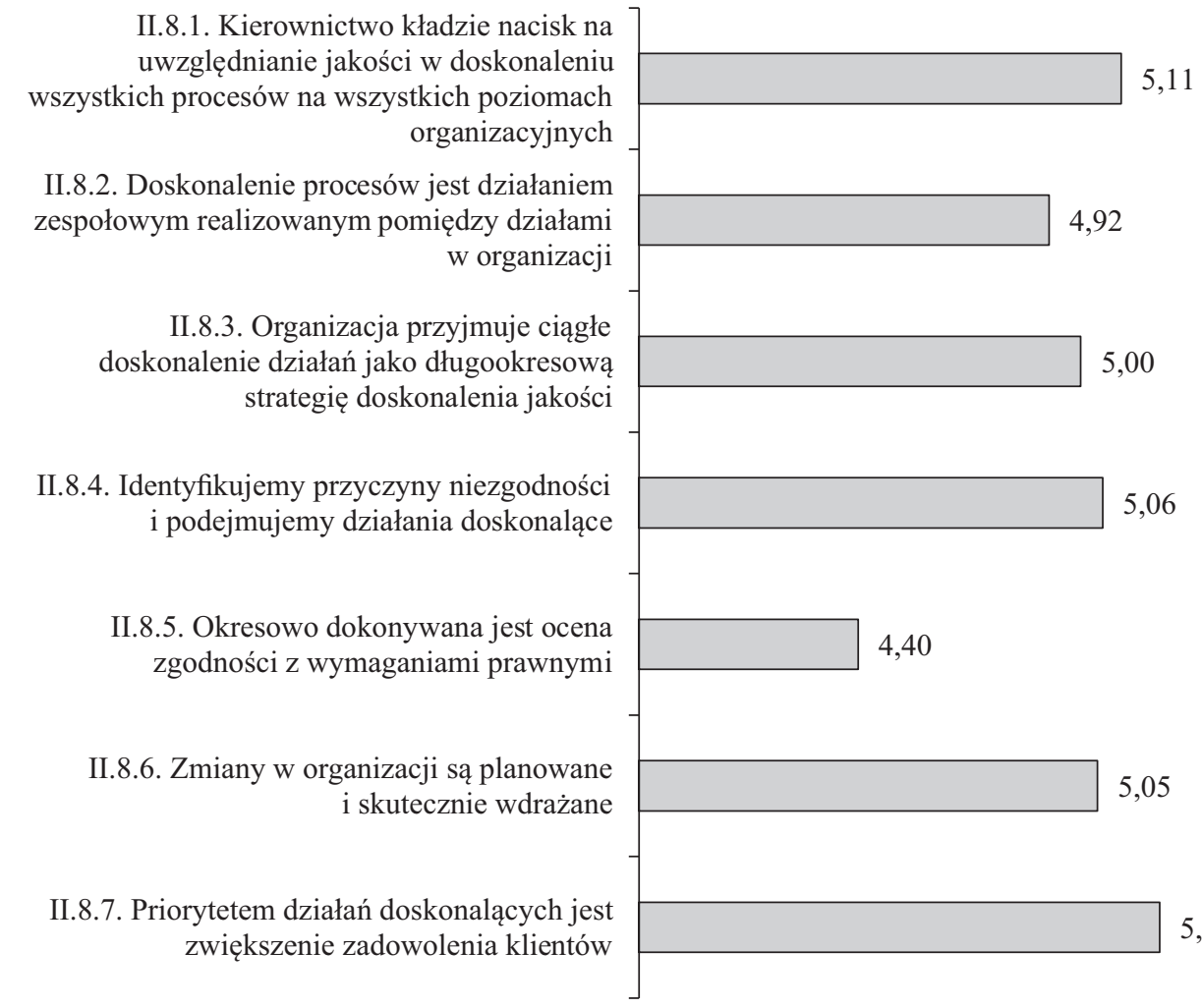

Wykres 28. Ważność elementów składowych glównego wewnętrznego czynnika "Ciągle doskonalenie" - aspekt jakości 
wskazujący na przeprowadzanie okresowej oceny zgodności z wymaganiami prawnymi, i to niezależnie od stanowiska zajmowanego przez respondenta. Również kwestia posiadania certyfikowanego systemu zarządzania jakością nie zmienia istotnie ważności tego elementu. Takie wyniki można wiązać albo z brakiem wymagań normatywnych dotyczących okresowej oceny zgodności, albo dwoma możliwymi przyczynami braku takich działań. Respondenci mogą być świadomi bieżącego stosowania się do przepisów prawnych bądź mogą być przeświadczeni o braku potrzeby takich działań z uwagi na domniemywanie zgodności.

II.8.8. Priorytetem w doskonaleniu są działania zapobiegawcze (ukierunkowanych na przyczyny potencjalnych niezgodności)

II.8.9. Priorytetem w doskonaleniu są korekty (naprawa niezgodności)

II.8.10. Priorytetem w doskonaleniu są działania korygujące (ukierunkowane na przyczyny zaistniałych niezgodności)

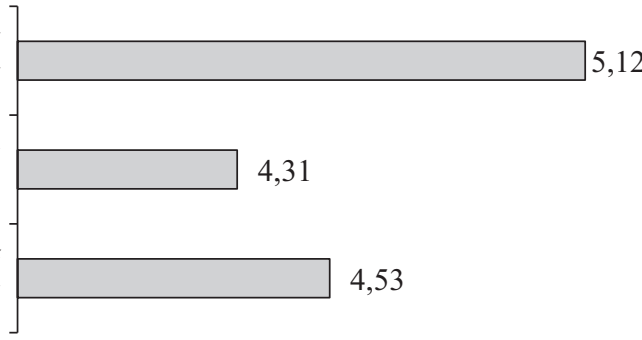

\section{Wykres 29. Ważność elementów składowych glównego wewnętrznego czynnika "Ciągłe doskonalenie" - aspekt ryzyka}

Charakter elementów uszczegóławiających „Ciągłe doskonalenie” w aspekcie ryzyka wskazuje na działania również jakościowe, zasadniczo podejmowane w organizacjach każdego dnia. Przyporządkowanie powyższych elementów do obszaru podejścia opartego na ryzyku jest uznaniowe dla pokazania ukierunkowania działań doskonalących. Wskazane elementy i zasadniczo możliwość tworzenia przez nie zbioru wspólnego dla aspektu jakości i ryzyka w projakościowym zarządzaniu w organizacji obrazują hasło, że podejście oparte na ryzyku występuje we wszystkich działaniach. W zależności od podejścia do jakości w organizacji będą to zagadnienia uwzględniane w poszczególnych obszarach bądź - w przypadku wysokiej kultury jakości w organizacji - po prostu będą realizowane w ukierunkowaniu na osiąganie celów, bez konieczności ich grupowania czy precyzowania charakteru organizacyjnego.

Zestawienie odpowiedzi respondentów w odniesieniu do dwóch grup elementów konstytuujących poszczególne główne wewnętrzne czynniki zarządzania jakością ukazane na wykresie 30 wskazuje na wyższą ważność elementów w aspekcie jakości niż ryzyka ${ }^{72}$.

Elementy konstytuujące główne wewnętrzne czynniki zarządzania jakością w aspekcie jakości mają w poszczególnych czynnikach wyższą ważność od elementów składowych w aspekcie ryzyka. Największa bezwzględna różnica

\footnotetext{
${ }^{72}$ Przy założeniu równych wag dla wszystkich elementów.
} 
I.1. Przywództwo i zaangażowanie najwyższego kierownictwa

I.2. Planowanie strategiczne i operacyjne

I.3. Orientacja na klienta

I.4. Zarządzanie na podstawie faktów

I.5. Zarządzanie zasobami ludzkimi

I.6. Zaangażowanie pracowników

I.7. Zarządzanie procesowe

I.8. Ciągłe doskonalenia
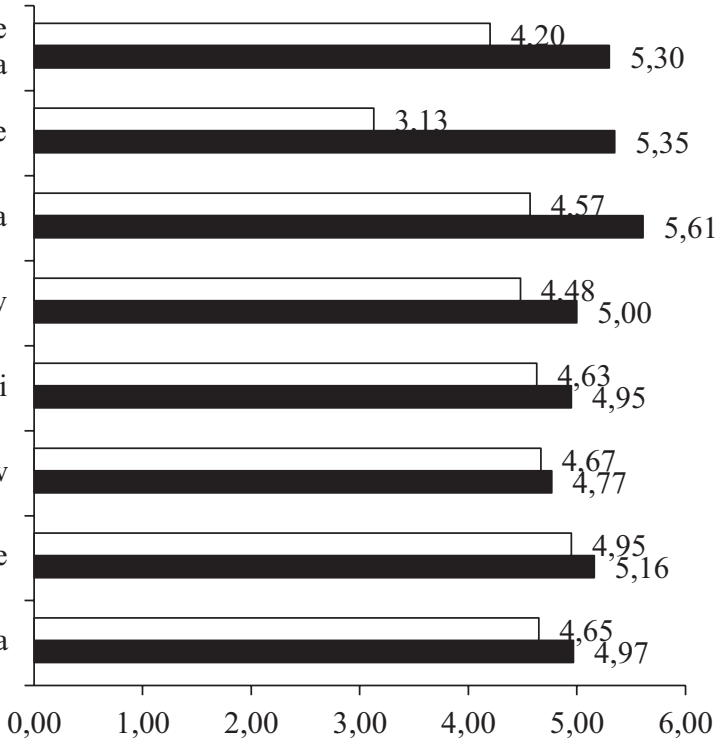

$\square$ aspekt ryzyka

aspekt jakości

Wykres 30. Ocena ważności elementów konstytuujących poszczególne główne wewnętrzne czynniki zarządzania jakością - porównanie dla aspektu jakości i ryzyka

$(2,22)$ dotyczy wewnętrznego czynnika „Planowanie strategiczne i operacyjne”. Kolejne dwa znajdują się niżej o połowę wskazanej różnicy: „Przywództwo i zaangażowanie najwyższego kierownictwa” $(1,10)$ oraz „Orientacja na klienta" $(1,04)$. Najmniejsza różnica $(0,10)$ dotyczy ważności dwóch grup elementów składowych dla wewnętrznego czynnika ,Zaangażowanie pracowników", który to czynnik został ogólnie wskazany przez respondentów jako najważniejszy.

Ważność głównych wewnętrznych czynników projakościowego zarządzania w organizacji oraz elementów konstytuujących poszczególne czynniki hierarchizuje analizowane zmienne. Z perspektywy praktycznej, oprócz wskazanej przez respondentów ważności, istotne jest zidentyfikowanie zależności pomiędzy głównymi wewnętrznymi czynnikami projakościowego zarządzania w organizacji a rezultatami podejmowanych aktywności. Analizy relacyjne pomiędzy wskazanymi zagadnieniami przedstawione zostały w kolejnym punkcie niniejszego opracowania. 


\subsection{Współzmienność pomiędzy głównymi wewnętrznymi czynnikami oraz rezultatami zarządzania jakością}

W niniejszym punkcie pracy zostały przedstawione wyniki analizy korelacji na dwóch płaszczyznach. Pierwsza płaszczyzna dotyczy relacji zachodzących pomiędzy poszczególnymi głównymi wewnętrznymi czynnikami zarządzania jakością. Drugi obszar analiz jest związany z wzajemną współzmiennością pomiędzy głównymi wewnętrznymi czynnikami a rezultatami zarządzania jakością.

Analiza korelacji umożliwia identyfikację wzajemnego powiązania pomiędzy zmiennymi zarówno co do kierunku, jak i siły. Ważnym elementem w ocenie danych statystycznych i ich merytorycznej interpretacji jest kwestia kierunku powiązania, który jest obustronny. Oznacza to, że dodatnia wartość współczynnika Pearsona wiąże wzrost ważności jednej zmiennej ze wzrostem wartości drugiej bądź spadkiem drugiej zmiennej dla ujemnej wartości tego współczynnika. Jednak wyniki analizy korelacji nie dostarczają informacji o kierunku przyczynowo-skutkowym zależności, co pozostaje kwestią merytoryczną w analizie wyników dla danego obszaru badawczego.

Analiza korelacji pomiędzy poszczególnymi głównymi wewnętrznymi czynnikami zarządzania jakością wskazuje na wysoką istotność statystyczną obustronnej relacji (na poziomie poniżej $0,01^{73}$ ). Współzmienność pomiędzy ośmioma głównymi wewnętrznymi czynnikami zarządzania jakością jest wyłącznie dodatnia, zatem wzrostowi znaczenia danego czynnika nie towarzyszy spadek średniej ważności innych. Cztery relacje pomiędzy głównymi wewnętrznymi czynnikami zarządzania jakością są bardzo wysokie (współczynnik korelacji Pearsona znajduje się w przedziale wartości $0,7-0,9$ ). Sześć relacji jest określanych jako wysokie współzmienności (wartość współczynnika z przedziału $0,5-0,7$ ), a kolejnych osiem jako przeciętne (wartość współczynnika z przedziału $0,3-0,5)$ i finalnie osiem jako słabe $(0,1-0,3)$.

Zależności korelacyjne pomiędzy głównymi wewnętrznymi czynnikami zarządzania jakością zostały przedstawione na rysunku 3. Współzmienność bardzo wysoka została zaznaczona pogrubioną strzałką.

Najsilniejsze związki korelacyjne występują w dwóch relacjach, dla których współczynnik korelacji Pearsona znajduje się ponad poziomem 0,8. Główny wewnętrzny czynnik zarządzania jakością "Zarządzanie na podstawie faktów” jest obustronnie zależny z „Ciągłym doskonaleniem”. Również „Przywództwo

${ }^{73}$ Dwie relacje pomiędzy głównymi wewnętrznymi czynnikami zarządzania jakością są istotne statystycznie, ale na niższym poziomie:

- 0,001 dla obustronnej relacji pomiędzy „3. Orientacja na klienta” i „4. Zarządzanie na podstawie faktów",

- 0,010 dla obustronnej relacji pomiędzy „6. Zaangażowanie pracowników” i „8. Ciągłe doskonalenie". 


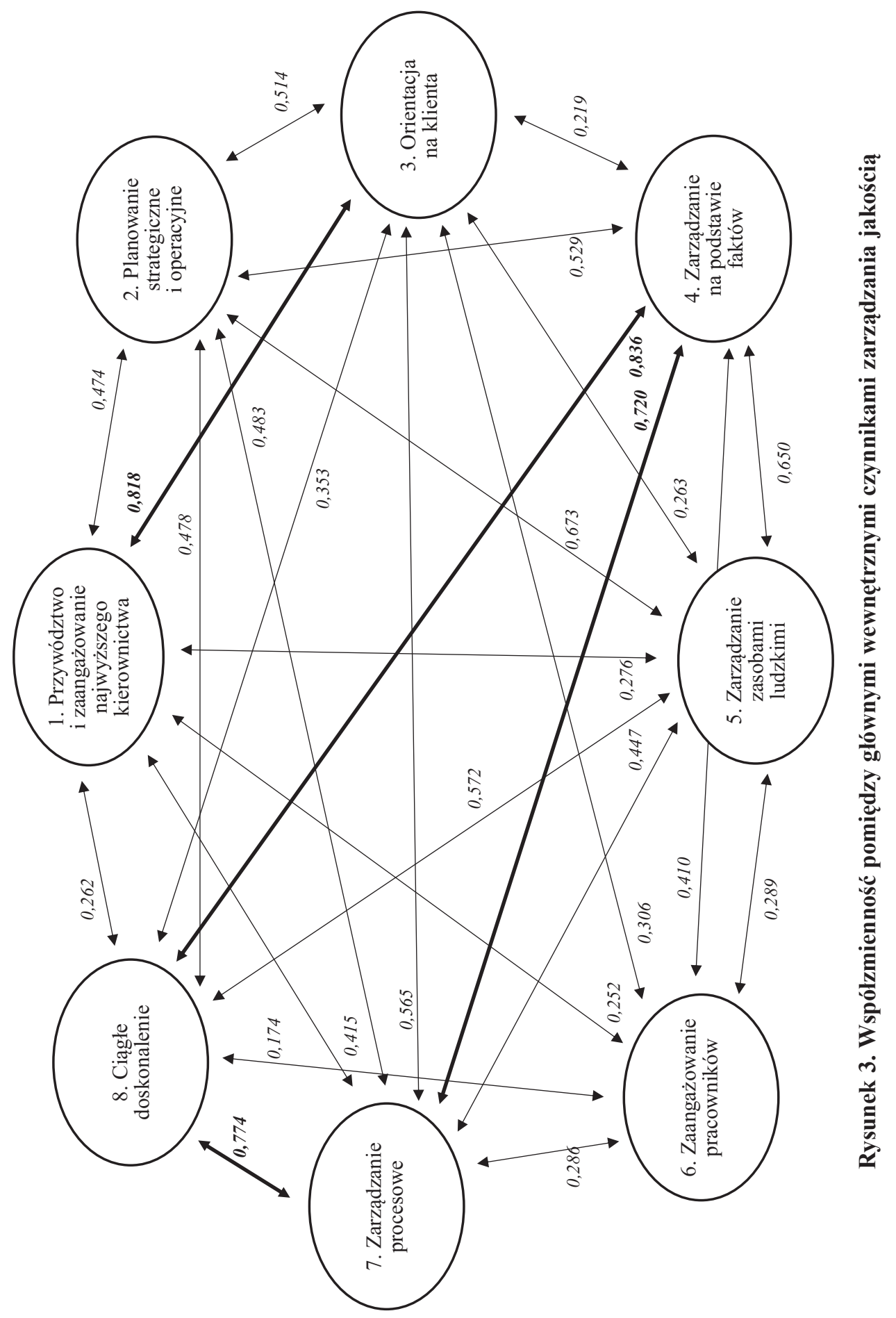


i zaangażowanie najwyższego kierownictwa” jest współzależne z „Orientacją na klienta”.

Zagłębiając się w analizie współzmienności w poszczególne główne wewnętrzne czynniki zarządzania jakością, można wskazać na elementy konstytuujące najsilniej skorelowane z poszczególnymi czynnikami.

Główny wewnętrzny czynnik zarządzania jakością „Przywództwo i zaangażowanie najwyższego kierownictwa" jest dodatnio w największym stopniu $(0,634)$ skorelowany z trzecim ,jakościowym” elementem składowym „Najwyższe kierownictwo demonstruje swoje zaangażowanie w jakość”. Największa ujemna współzmienność $(-0,270)$ występuje dla 13 . elementu konstytuującego tenże czynnik, wskazującego na „Identyfikację przez najwyższe kierownictwo kluczowych wyrobów i usług, które chronimy i dążymy do realizacji nawet w sytuacjach kryzysowych", co jest związane z podejściem opartym na ryzyku.

Dla wewnętrznego czynnika „Planowanie strategiczne i operacyjne” istnieją wyłącznie dodatnie zależności korelacyjne z elementami konstytuującymi tenże czynnik. Trzy wysokie współzmienności występują dla trzech jakościowych elementów konstytuujących:

- cele jakościowe są planowane na poszczególnych poziomach w organizacji $(0,760)$,

- cele jakościowe są mierzalne i jasno sprecyzowane $(0,742)$,

- nasze cele jakościowe są w pełni dopasowane do specyfiki i zakresu naszej działalności $(0,701)$.

Trzeci główny wewnętrzny czynnik zarządzania jakością „Orientacja na klienta” jest dodatnio, wysoko $(0,640)$ skorelowany z ,jakościowym” elementem konstytuującym „Identyfikacji tematów rynkowych mających wpływ na obsługę klientów". Z kolei odwrotna zależność korelacyjna występuje dla drugiego „jakościowego" elementu konstytuującego tenże wewnętrzny czynnik. Wzrost ważności dla uwzględniania wymagań i oczekiwań klientów w działaniach każdego pracownika (drugi element ,jakościowy”) oznacza słaby $(-0,157)$ spadek ważności „Orientacji na klienta”.

Korelacje pomiędzy elementami składowymi czwartego głównego wewnętrznego czynnika zarządzania jakością „Zarządzanie na podstawie faktów” a nim samym są wyłącznie dodatnie. Najwyższa wartość $(0,625)$ wskazuje na wysoką współzmienność z piątym elementem jakościowym „Organizowane są okresowe międzydziałowe spotkania na rzecz doskonalenia jakości” (aspekt jakości).

Kolejny wewnętrzny czynnik zarządzania jakością „Zarządzanie zasobami ludzkimi" jest wyłącznie dodatnio skorelowany z elementami szczegółowymi go opisującymi. Współzmienność dla jakościowego elementu „Pracownicy swobodnie pozwalają sobie na wypowiadanie się o swoim spojrzeniu, uwagach krytycznych i informacjach zwrotnych nt. osiąganych wyników przez organizację" a głównego czynnika wynosi 0,550 . 
Istnieje tylko jedna dodatnia współzmienność pomiędzy elementami konstytuującymi a samym głównym wewnętrznym czynnikiem „Zaangażowanie pracowników" dotycząca elementu z obszaru podejścia opartego na ryzyku „Pracownicy w swoich działaniach prezentują postawę: lepiej zapobiegać niż leczyć" (dla relacji statystycznej na poziomie 0,05 i słaba na poziomie 0,165 ). Maksymalna ujemna $(-0,304)$ współzmienność występuje dla elementu ,jakościowego" „Istnieje skuteczna komunikacja w organizacji dotycząca grupowego rozwiązywania problemów jakościowych".

Siódmy główny wewnętrzny czynnik projakościowego zarządzania w organizacji „Zarządzanie procesowe” jest wyłącznie dodatnio skorelowany z elementami składowymi. Najwyższa współzmienność $(0,448)$ istnieje z elementem analizowanym $\mathrm{w}$ aspekcie ryzyka „Zarządzanie ryzykiem jest częścią zarządzania każdym procesem".

Pomiędzy głównym wewnętrznym czynnikiem zarządzania jakością „Ciągłe doskonalenie" a jego elementami składowymi występują wyłącznie dodatnie korelacje. Najwyższa $(0,583)$ dotyczy elementu ,jakościowego” „Kierownictwo kładzie nacisk na uwzględnianie jakości w doskonaleniu wszystkich procesów na wszystkich poziomach organizacyjnych".

Drugi obszar analiz korelacji dotyczy współzmienności pomiędzy głównymi wewnętrznymi czynnikami a rezultatami projakościowego zarządzania w organizacji. Statystyczne wyniki korelacji zostały przedstawione w tabeli 10 dla danych istotnych statystycznie. W tabeli usunięte zostały dane dla istotności powyżej 0,05 jako nieistotne statystycznie.

Współzmienności pomiędzy głównymi wewnętrznymi czynnikami projakościowego zarządzania w organizacji a rezultatami zarządzania jakością (istotne na poziomie 0,01 oraz wysoką współzmiennością - współczynnik Pearsona do 0,7 ) zostały przedstawione graficznie na rysunku 4. Pogrubioną strzałką zostały przedstawione najsilniejsze zależności korelacyjne, dla współczynnika powyżej 0,6.

Każdy z dwóch wewnętrznych czynników: „Przywództwo i zaangażowanie najwyższego kierownictwa” (I.1) oraz „Orientacja na klienta” (I.3) są wysoko skorelowane z sześcioma rezultatami. Pięć rezultatów zarządzania jakością pojawia się dla obu wskazanych wewnętrznych czynników oraz osobno, po jednym rezultacie dla każdego z nich.

W dalszej kolejności, pozostając tylko w obszarze wysokich statystycznych zależności (do 0,7 dla korelacji Pearsona), można wskazać na czynnik „Zarządzanie procesowe" (I.7), którego wzrost znaczenia oznacza wzrost średniej ważności czterech rezultatów ukazujących wpływ zarządzania jakością na wyniki organizacji, jako całości:

- III.7. Zwiększenie współpracy pomiędzy działaniami,

- III.9. Utrzymanie obecnych klientów,

- III.10. Doskonalenie działań organizacyjnych, 


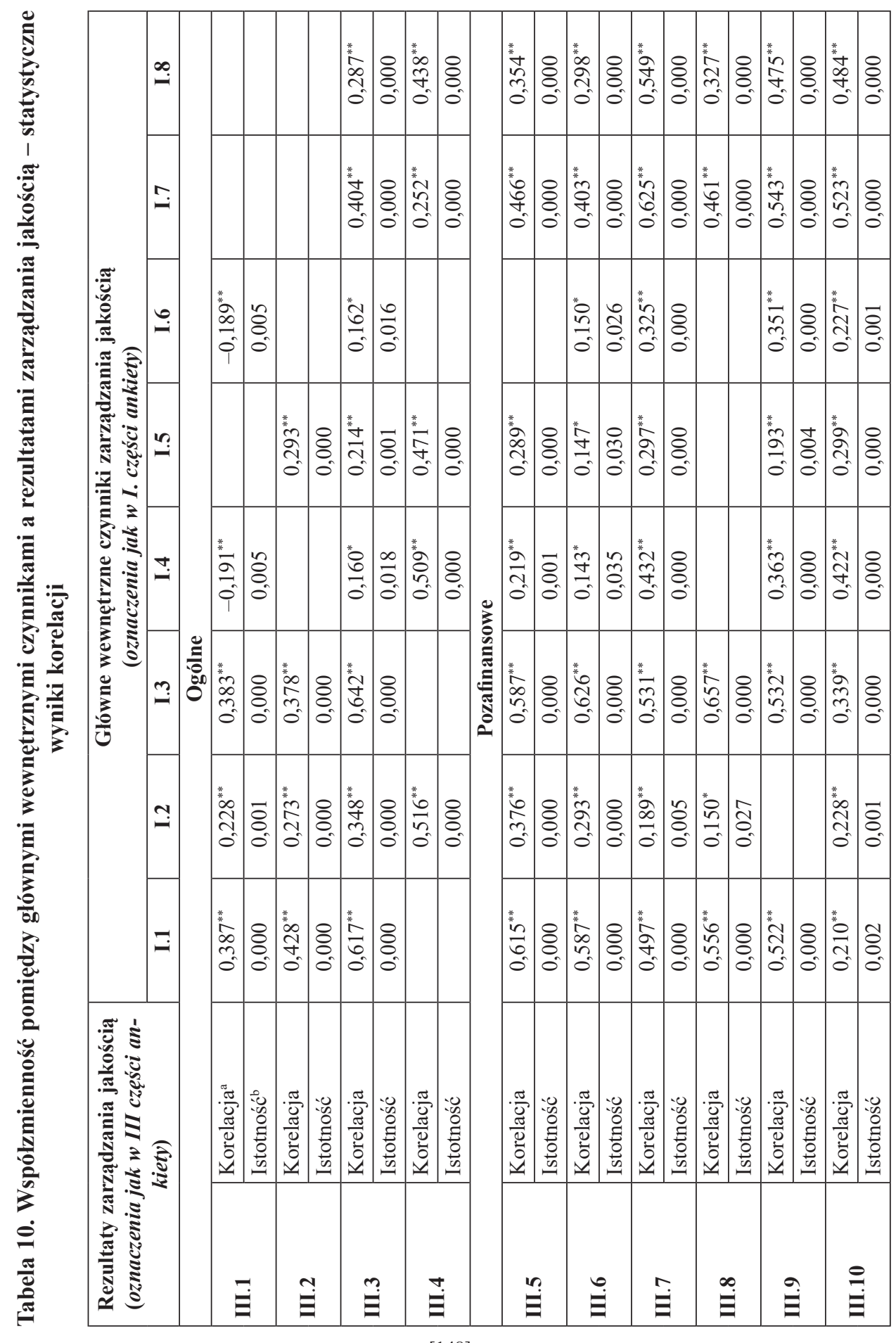

[148] 


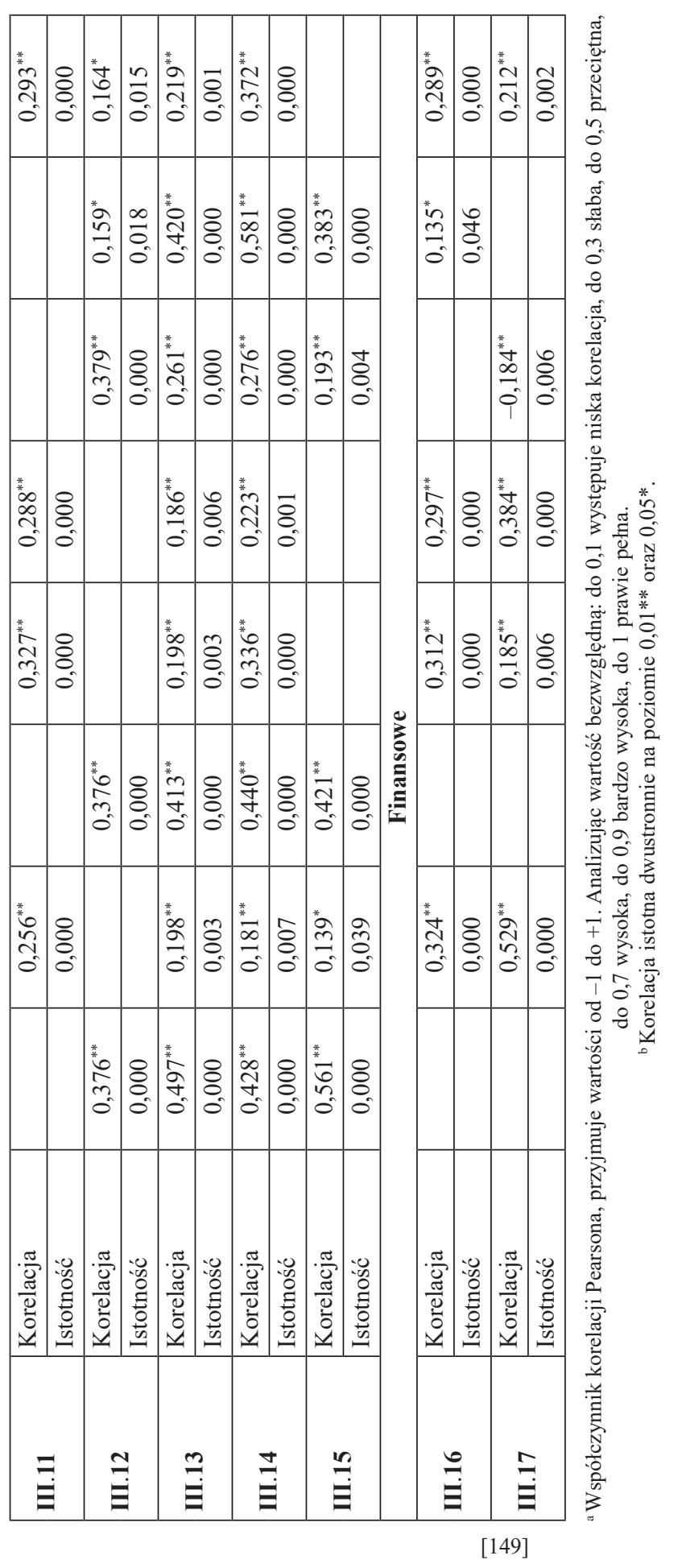




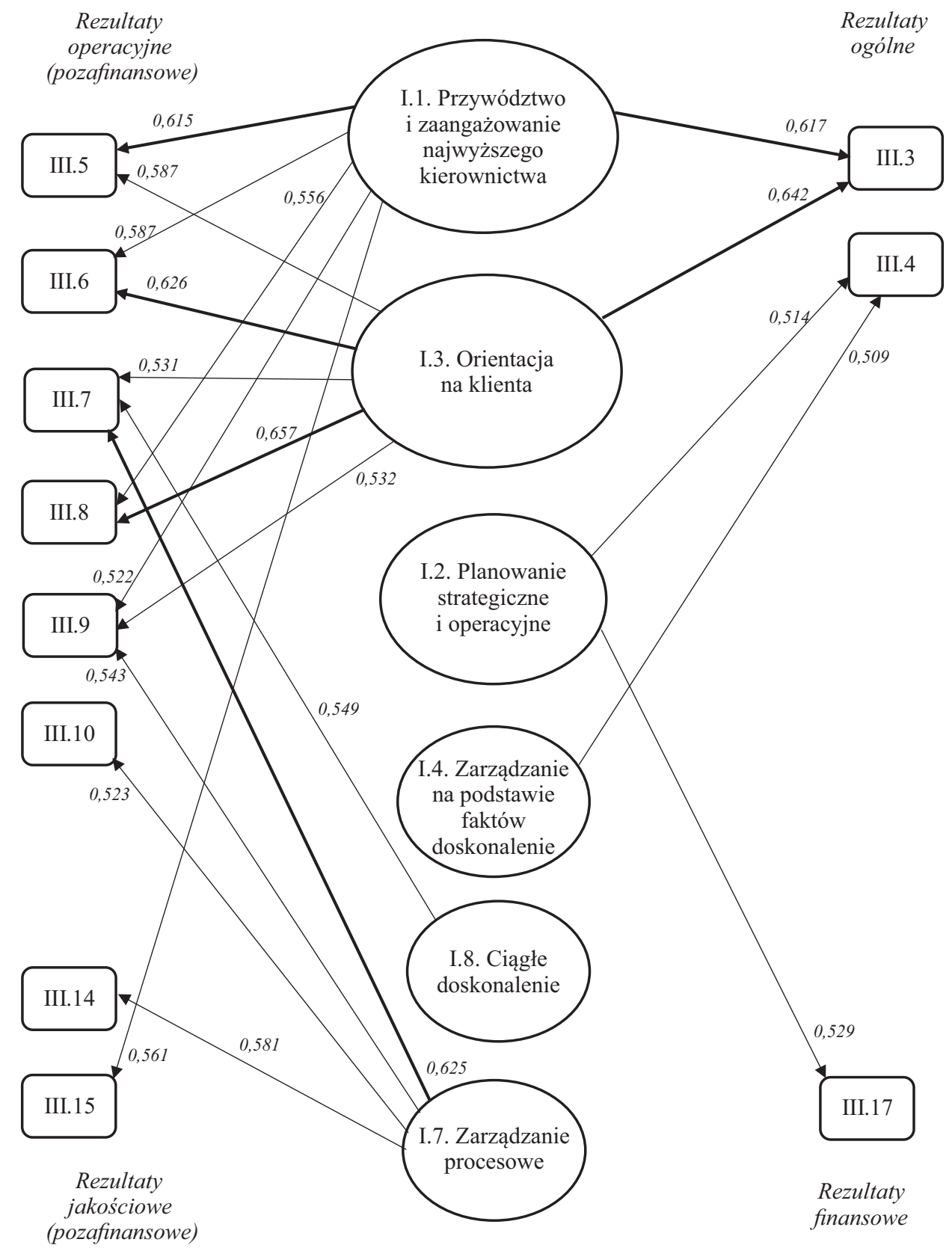

Rysunek 4. Wysoka wspólzmienność dla statystycznie istotnych korelacji pomiędzy głównymi wewnętrznymi czynnikami a rezultatami zarządzania jakością 
Tabela 11. Wysoka współzmienność pomiędzy głównymi wewnętrznymi czynnikami a rezultatami zarządzania jakością

\begin{tabular}{|c|c|c|}
\hline \multirow{2}{*}{$\begin{array}{c}\text { Główny wewnętrzny } \\
\text { czynnik zarządzania } \\
\text { jakością }\end{array}$} & \multicolumn{2}{|c|}{ Rezultaty zarządzania jakością } \\
\hline & odrębny wpływ & wspólny wplyw \\
\hline $\begin{array}{l}\text { I.1. Przywództwo } \\
\text { i zaangażowanie } \\
\text { najwyższego kie- } \\
\text { rownictwa }\end{array}$ & $\begin{array}{l}\text { III.15. Zmniejszenie } \\
\text { niezgodności we- } \\
\text { wnętrznych }\end{array}$ & $\begin{array}{l}\text { III.3. Osiąganie zaplanowanych celów } \\
\text { jakościowych } \\
\text { III.5. Zwiększenie zaangażowania pra- } \\
\text { cowników }\end{array}$ \\
\hline $\begin{array}{l}\text { I.3. Orientacja na } \\
\text { klienta }\end{array}$ & $\begin{array}{l}\text { III.7. Zwiększenie współ- } \\
\text { pracy pomiędzy } \\
\text { działami }\end{array}$ & $\begin{array}{l}\text { III.6. Minimalizacja fluktuacji pracow- } \\
\text { ników } \\
\text { III.8. Pozyskanie nowych klientów } \\
\text { III.9. Utrzymanie obecnych klientów }\end{array}$ \\
\hline
\end{tabular}

- III. 14. Zmniejszenie reklamacji dotyczących procesu obsługi klientów.

Według skorelowania z liczbą rezultatów w sposób wysoki należy wskazać na czynnik „Planowanie strategiczne i operacyjne” (I.2), którego wzrost ważności oznacza wzrost ważności dwóch rezultatów: osiąganie zaplanowanych rezultatów finansowych (III.4) oraz maksymalizację przychodów ze sprzedaży (III.17).

Z kolei dwa czynniki są wysoko skorelowane z pojedynczymi rezultatami:

1. Główny wewnętrzny czynnik projakościowego zarządzania w organizacji „Zarządzanie na podstawie faktów” (I.4) jest wysoko dodatnio skorelowany z rezultatem „Osiągania zaplanowanych rezultatów finansowych” (III.4).

2. Wzrost ważności czynnika „Ciągłe doskonalenie” (I.8) oznacza również wzrost, w wysokim stopniu, „Zwiększenia współpracy pomiędzy działami w organizacji” (III.7).

W obszarze zależności korelacyjnych o tym samym kierunku i wysokiej współzmienności wg wskaźnika korelacji Pearsona można wskazać na ujęcie tych zagadnień od strony rezultatów zarządzania jakością.

Dla dwóch rezultatów zarządzania jakością występuje współzmienność $\mathrm{z}$ trzema głównymi czynnikami projakościowego zarządzania w organizacji:

1. „Zwiększenie współpracy pomiędzy działami w organizacji” (III.7) jest wysoko skorelowane z trzema głównymi czynnikami zarządzania jakością: „Orientacja na klienta” (I.3), „Zarządzanie procesowe” (I.7) oraz „Ciągłe doskonalenie" (I.8).

2. „Utrzymanie obecnych klientów” (III.9) jest wysoko współzmienne z głównymi wewnętrznymi czynnikami zarządzania jakością: z „Przywództwem i zaangażowaniem najwyższego kierownictwa” (I.1), „Orientacją na klienta” (I.3) oraz „Zarządzaniem procesowym (I.7). 
Dla dwóch głównych czynników zarządzania jakością w organizacji nie zostały zidentyfikowane żadne wysokie zależności obustronne z rezultatami zarządzania jakością: „Zarządzanie zasobami ludzkimi” (I.5) i „Zaangażowanie pracowników” (I.6). Główny wewnętrzny czynnik zarządzania jakością „Zarządzanie zasobami ludzkimi” (I.5) jest skorelowany w najwyższym stopniu z „Osiąganiem zaplanowanych rezultatów finansowych” (III.4), aczkolwiek jest to przeciętna współzmienność (na poziomie 0,471). Najwyższa wartość współzmienności dla czynnika „Zaangażowanie pracowników” wynosi 0,379 i dotyczy rezultatu zarządzania jakością w obszarze zmniejszania reklamacji dotyczących wyrobów (III.12). Na zbliżonych poziomach współzmienność odnosi się jeszcze do dwóch efektów zarządzania jakością, dotyczących zwiększenia współpracy pomiędzy działami w organizacji (III.7) oraz utrzymania obecnych klientów (III.9).

Z powyższego opisu wynika, że trzy główne wewnętrzne czynniki projakościowego zarządzania $\mathrm{w}$ organizacji są obustronnie skorelowane $\mathrm{z}$ największą liczbą rezultatów zarządzania jakością: „Przywództwo i zaangażowanie najwyższego kierownictwa”, „Orientacja na klienta”, „Zarządzanie procesowe”.

$\mathrm{W}$ analizie danych $\mathrm{z}$ badania ankietowego zidentyfikowano trzy ujemne obustronne relacje. Dwie dotyczą odwrotnych zmian ważności rezultatu usatysfakcjonowania klientów z wyrobów (III.1) w zależności od zmiany czynników: „Zarządzanie na podstawie faktów” (I.4) oraz „Zaangażowanie pracowników” (I.6). Obydwie współzmienności są jednak na słabym poziomie (współczynnik korelacji Pearsona poniżej wartości 0,2). Również słaba współzmienność występuje pomiędzy wewnętrznym czynnikiem "Zaangażowanie pracowników” (I.6), a maksymalizacją przychodów ze sprzedaży (III.17).

W ramach podsumowania tej części rozważań w tabeli 12 przedstawiono ilościowe zestawienie opisanych współzależności.

Dane zawarte w tabeli mają charakter poglądowy, wskazujący na udział istotnych statystycznie relacji w ogólnej ich maksymalnej liczbie. Relacje pomiędzy

Tabela 12. Współzmienność pomiędzy głównymi wewnętrznymi czynnikami a rezultatami zarządzania jakością - ilościowe zestawienie zależności

\begin{tabular}{|l|c|c|c|}
\hline $\begin{array}{c}\text { Grupa rezultatów } \\
\text { zarządzania jakością }\end{array}$ & $\begin{array}{c}\text { Maksymalna moż- } \\
\text { liwa liczba relacji }\end{array}$ & $\begin{array}{c}\text { Liczba relacji istot- } \\
\text { nych statystycznie } \\
\text { (procent ogółu) }\end{array}$ & $\begin{array}{c}\text { Wysoka współ- } \\
\text { zmienność } \\
\text { (procent istot- } \\
\text { nych statystycznie) }\end{array}$ \\
\hline Ogólne & 32 & $22(69 \%)$ & $4(18 \%)$ \\
\hline Pozafinansowe & 88 & $73(83 \%)$ & $15(20 \%)$ \\
\hline Finansowe & 16 & $10(63 \%)$ & $1(10 \%)$ \\
\hline Podsumowanie & 136 & $105(77 \%)$ & $20(19 \%)$ \\
\hline
\end{tabular}


wskazanymi zmiennymi są współzmienne. Oznacza to, że wyniki korelacyjne ukazują kierunek współzmienności oraz siłę relacji. Współzmienność nie określa jednokierunkowo relacji przyczyno-skutkowych. Dla identyfikacji takiej zależności konieczna jest merytoryczna analiza zmiennych. Teoretycznie zatem można by wskazać, że to rezultaty działań wpływają na analizowany czynnik, co oznaczałoby relację odwrotną niż założona od samego początku prowadzonych teoretycznych analiz. Takie zagrożenie, zdaniem autora tej monografii, nie występuje (patrz wyniki analizy teoretycznej przedstawione w drugim rozdziale monografii).

\section{Eksploracyjna analiza czynnikowa aspektów zarządzania jakością}

W celu zbadania wzajemnych relacji zachodzących pomiędzy zmiennymi umieszczonymi w kwestionariuszu ankietowym została zastosowana eksploracyjna analiza czynnikowa. W wyniku analizy czynnikowej wyodrębniono grupę czynników niedostępnych bezpośredniej obserwacji [Gatnar i Walesiak 2012, s. 318]. Jej zastosowanie umożliwia zidentyfikowanie ukrytych uwarunkowań i wyjaśnienie ich występowania. Eksploracyjna ${ }^{74}$ analiza czynnikowa została zastosowana zarówno $\mathrm{w}$ odniesieniu do obszaru zidentyfikowanych w literaturze elementów konstytuujących główne wewnętrzne czynniki zarządzania jakością, jak i rezultatów zarządzania jakością. Zastosowanie analizy czynnikowej pozwoliło na sprowadzenie dużej liczby badanych zmiennych do zbiorów grup wzajemnie niezależnych (nieskorelowanych) czynników (w metodzie nazywanych składowymi). Ograniczanie liczby kluczowych czynników sukcesu, czyli ich priorytetyzacja, jest dobrą praktyką w wyborze kluczowych czynników spośród wielu zidentyfikowanych, a statystyczną metodą ich priorytetyzacji jest właśnie eksploracyjna analiza czynnikowa [Niemiec 2016, s. 70-71]. W efekcie zastosowania tej metody możliwe jest skoncentrowanie dalszych analiz na

${ }^{74}$ Eksploracyjna analiza czynnikowa została zastosowana w celu identyfikacji zależności dla zmiennych ujętych w dwóch obszarach - elementów konstytuujących główne wewnętrzne czynniki zarządzania jakością oraz rezultatów zarządzania jakością tworzących cztery grupy. Wybór alternatywnej analizy czynnikowej (konfirmacyjnej) mógłby mieć miejsce w przypadku ukierunkowania pracy na potwierdzenie w badaniu ankietowym wcześniej określonego modelu zależności pomiędzy czynnikami i rezultatami zarządzania jakością a poszczególnymi pytaniami w kwestionariuszu. Jednak nie tylko cel badań uzasadnia zastosowanie eksploracyjnej analizy czynnikowej, lecz również struktura elementów składowych konstytuujących poszczególne wewnętrzne czynniki. Wzbogacenie dotychczasowych analiz o aspekt ryzyka stanowi, zdaniem autora, nowość wobec dotychczasowych badań i publikacji. 
istotnych zagadnieniach, z perspektywy relacji zachodzących w organizacjach, i tym samym wpływa to na upraktycznienie formułowanych wniosków z badań.

$\mathrm{W}$ tym miejscu poruszone zostaną zagadnienia terminologiczne, konieczne, zdaniem autora, dla wprowadzenia porządku w dalszych analizach i komentarzach. W analizowanym obszarze badawczym zastosowanie mają słowa: czynniki, składowe, elementy, grupy, główne czynniki, które można odnieść zarówno do wyników analizy teoretycznej, jak i wyników badania ankietowego poddanych obróbce statystycznej.

Na zakończenie treści ujętych $\mathrm{w}$ drugim rozdziale niniejszej monografii podkreślono, że różnorodność pojęć na płaszczyźnie teoretycznej zarządzania jakością w organizacji i czynników wpływających na różne aspekty w tym obszarze działań organizacji ma wspólny mianownik - cel zarządzania jakością, jakim jest realizacja działań na rzecz zapewnienia odpowiednej i powtarzalnej jakości. Wskazane zostało, że wewnętrzne czynniki zarządzania jakością dotyczą obszarów działań w organizacji, które mogą się odnosić do różnych aktywności. Zasadniczo te zbiory można nazwać głównymi wewnętrznymi czynnikami zarządzania jakością, ponieważ zawierają w sobie zakresy określone jako elementy składowe. Z kolei elementy składowe konstytuujące główne wewnętrzne czynniki zarządzania jakością mogą mieć dwojaką naturę - dotyczącą jakościowego (tradycyjnego) ich ujęcia (tzw. aspekt jakości) bądź uwzględniającą podejście oparte na ryzyku (tzw. aspekt ryzyka). Działania organizacyjne realizowane w ramach elementów konstytuujących główne wewnętrzne czynniki projakościowego zarządzania $\mathrm{w}$ organizacji prowadzą finalnie do osiągania wyników gospodarczych. Te wyniki (zwane również rezultatami, efektami) zarządzania jakością w organizacji zostały zidentyfikowane w części literaturowej opracowania poprzez określenie wpływu projakościowego zarządzania na rezultaty uzyskiwane $\mathrm{w}$ organizacji.

W ramach zastosowania eksploracyjnej analizy czynnikowej jako metody statystycznej następuje poszukiwanie przyczyn zmienności, która jest generowana przez czynniki wspólne, które nie są bezpośrednio obserwowane, lecz są to wielkości abstrakcyjne. Celem tej statystycznej analizy jest wykrycie tych abstrakcyjnych czynników (nazywanych w metodzie „składowymi”), co prowadzi do redukcji wymiaru przestrzeni zmiennych. Oznacza to, że te „składowe" są kombinacją pierwotnych atrybutów zbioru danych. W odniesieniu do zagadnień teoretycznych ujętych w badaniu ankietowym „składowe” to elementy w zbiorach nazwanych „głównymi wewnętrznymi czynnikami zarządzania jakością” oraz „grupami rezultatów zarządzania jakością”. Natomiast słowo „składowe” było używane dotychczas jako element bądź element składowy dla elementów konstytuujących główne czynniki zarządzania jakością. Stąd właśnie konieczność uściślenia stosowanej terminologii, a naświetlenie płaszczyzn tego obszaru analizy zostało zobrazowane na rysunku 5 . W poziomie zostały ujęte 
poszczególne płaszczyzny (uszczegółowienia) analiz, a pionom przyporządkowano obszar działań (czynniki zarządzania jakością) oraz efektów (rezultaty zarządzania jakością). Liczebność poszczególnych kategorii zidentyfikowanych $\mathrm{w}$ teoretycznej analizie przedstawiono w nawiasach.

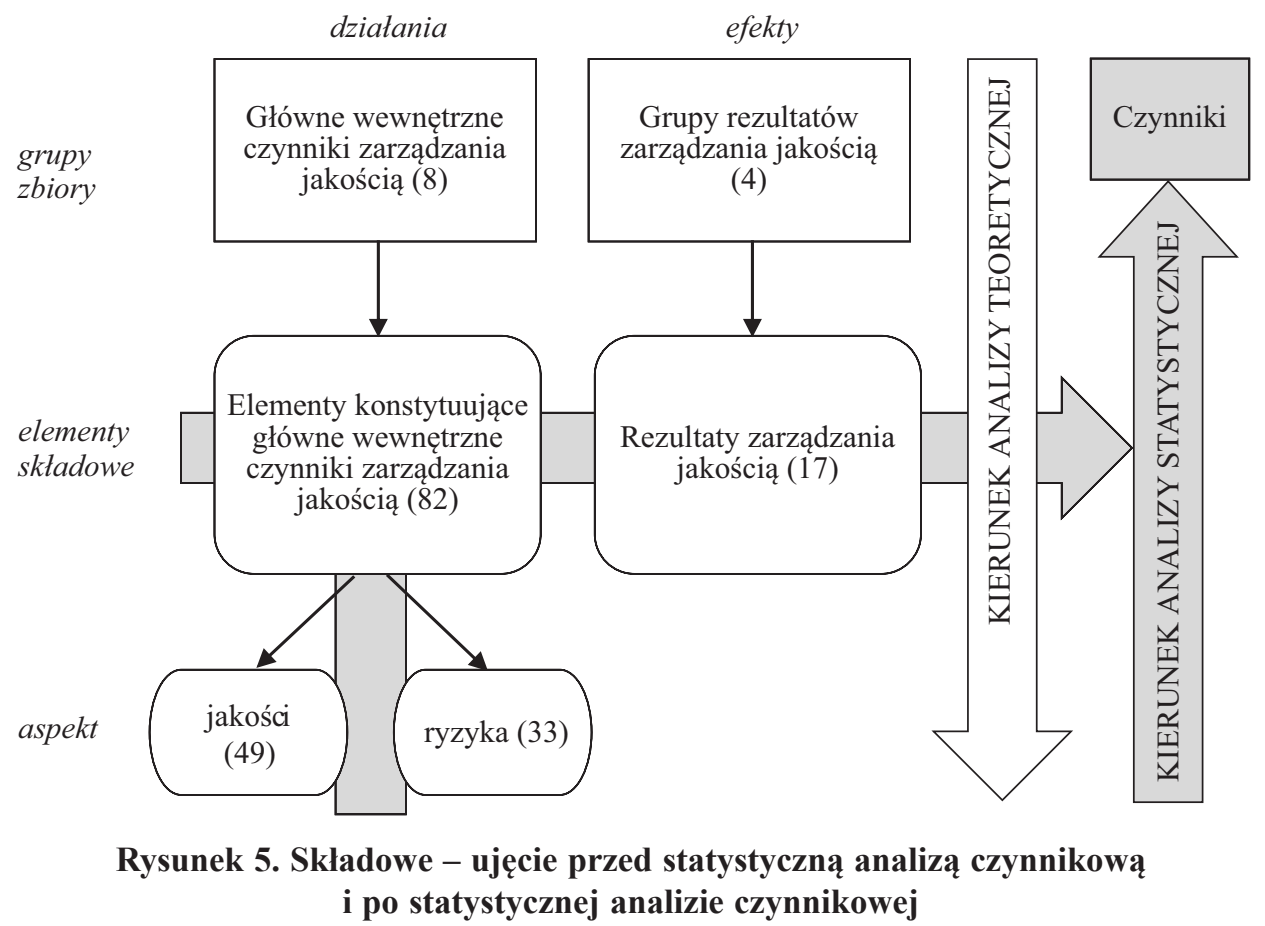

W eksploracyjnej analizie czynnikowej na podstawie odpowiedzi respondentów oceniających ważność pierwotnie pogrupowanych elementów wyodrębniane są „składowe”. Punktem wyjścia w analizie czynnikowej są zatem elementy zidentyfikowanych wcześniej grup. Te grupy w analizie czynnikowej nazywane są właśnie „składowymi”. Następuje zatem odwrotne wyodrębnienie grup niż w analizie teoretycznej, co mają obrazować dwie pionowe strzałki (szare obrazują analizę statystyczną). W wyniku przeprowadzenia analizy czynnikowej następuje inne (niż pierwotne na bazie analizy literatury) pogrupowanie tych elementów w zbiory (tzw. składowe, ukryte zbiory, abstrakcyjne czynniki), które wyjaśniają zmienność $\mathrm{w}$ analizowanym obszarze zarządzania jakością. Wyodrębnione „składowe" mają swoją interpretację merytoryczną (z uwagi na zgrupowanie różnorodnych elementów), zachowując jednocześnie znaczną część informacji zawartych w zmiennych pierwotnych. Konieczna jest jednak dalsza analiza w celu wychwycenia charakteru poszczególnych nowych czynników dotyczących w niniejszej pracy projakościowego zarządzania w organizacji. 
Ostatecznie przyjęto do dalszych prac następujące terminy:

1. Wewnętrzne czynniki zarządzania jakością - na określenie składowych zidentyfikowanych w wyniku analizy czynnikowej, gdzie pierwotnie w wyniku analizy literatury przedmiotu te zbiory nazwane były „głównymi wewnętrznymi czynnikami zarządzania jakością".

2. Rezultaty zarządzania jakością na określenie składowych zidentyfikowanych w wyniku analizy czynnikowej, gdzie pierwotnie w wyniku analizy literatury przedmiotu te zbiory nazywane były grupami rezultatów zarządzania jakością.

Wyodrębnienie składowych w eksploracyjnej analizie czynnikowej rozpoczęto od oceny istotności statystycznej macierzy korelacji, przeprowadzając test sferyczności Barletta. Następnie dokonano oceny adekwatności macierzy korelacji za pomocą współczynnika Kaisera-Mayera-Olkina (KMO).

Tabela 13. Informacje na temat testu sferyczności Barletta i wspólczynnika KMO dla elementów konstytuujących glówne wewnętrzne czynniki zarządzania jakością

\begin{tabular}{|l|l|c|}
\hline \multicolumn{2}{|l|}{ Miara adekwatności doboru próby KMO } & 0,841 \\
\hline \multirow{4}{*}{ Test sferyczności Barletta } & przybliżone chi-kwadrat & 44001,456 \\
\cline { 2 - 3 } & df (stopnie swobody) & 3321 \\
\cline { 2 - 3 } & istotność (p-value) & 0,000 \\
\hline
\end{tabular}

Tabela 14. Informacje na temat testu sferyczności Barletta i wspólczynnika KMO dla rezultatów zarządzania jakością

\begin{tabular}{|l|l|c|}
\hline \multicolumn{2}{|l|}{ Miara adekwatności doboru próby KMO } & 0,774 \\
\hline \multirow{3}{*}{ Test sferyczności Barletta } & przybliżone chi-kwadrat & 3501,992 \\
\cline { 2 - 3 } & df (stopnie swobody) & 136 \\
\cline { 2 - 3 } & istotność ( $p$-value) & 0,000 \\
\hline
\end{tabular}

Dla obydwu analizowanych grup danych otrzymano bardzo niską istotność (wartość p-value po zaokrągleniu do trzech miejsc po przecinku), co wskazuje na istnienie statystycznej zależności w analizowanych zbiorach zmiennych. Stopień adekwatności, określony miarą KMO, ukształtował się w obydwu analizach powyżej wartości 0,5 . Takie wyniki pozwalają na odrzucenie hipotezy zerowej, że macierz korelacji jest równa macierzy jednostkowej; to zaś oznacza, że przeprowadzenie analizy czynnikowej jest zasadne z perspektywy przyjętych celów pracy. 


\subsection{Identyfikacja wewnętrznych czynników zarządzania jakością}

Do ustalenia liczby składowych (abstrakcyjnych czynników) wykorzystano kryterium Kaisera, wskazujące na pozostawienie czynników o wartościach własnych większych od jedności. Wartości dla sumy rotacji kwadratów ładunków przedstawione zostały w tabeli 15 .

Tabela 15. Wartości własne oraz wariancja wyjaśniania w analizie czynnikowej dla elementów konstytuujących główne wewnętrzne czynniki zarządzania jakością

\begin{tabular}{|c|c|c|c|}
\hline \multirow{2}{*}{ Składowa } & \multicolumn{3}{|c|}{ Sumy kwadratów ladunków po rotacji } \\
\cline { 2 - 4 } & ogólem & procent wariancji & procent skumulowany \\
\hline 1 & 26,126 & 31,860 & 31,860 \\
\hline 2 & 9,252 & 11,283 & 43,144 \\
\hline 3 & 8,273 & 10,089 & 53,233 \\
\hline 4 & 6,414 & 7,822 & 61,055 \\
\hline 5 & 5,574 & 6,798 & 67,853 \\
\hline 6 & 5,018 & 6,119 & 73,972 \\
\hline 7 & 3,770 & 4,598 & 78,569 \\
\hline 8 & 2,702 & 3,295 & 81,865 \\
\hline 9 & 1,939 & 2,365 & 84,230 \\
\hline 10 & 1,784 & 2,176 & 86,405 \\
\hline 11 & 1,529 & 1,864 & 88,270 \\
\hline
\end{tabular}

W kwestii prowadzenia dalszych analiz konieczne jest dokonanie wyboru liczby składowych. W tym celu zastosowano kryterium osypiska Cattela, skoncentrowane na poszukiwaniu miejsca, w którym następuje łagodny spadek wartości własnych, czyli miejsca nazywanego „osypisko czynnikowe”.

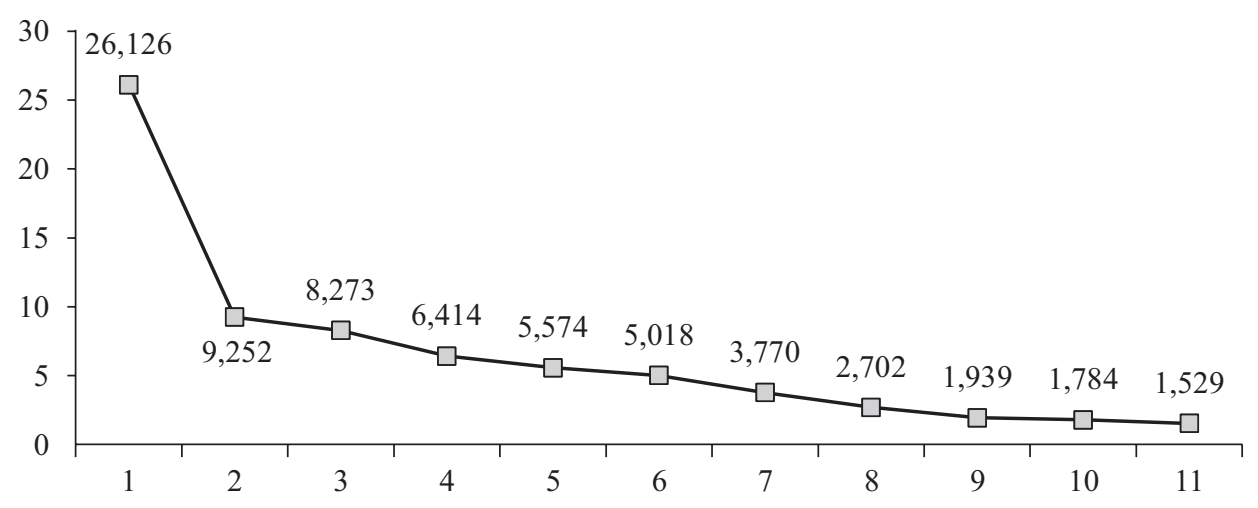

Wykres 31. Wykres osypiska dla wewnętrznych czynników zarządzania jakością 
Można zauważyć, że w zasadzie zjawisko „osypiska” zaczyna się już po pierwszej składowej, jednak wynika to z optyki uwarunkowanej składową obejmująca stosunkowo dużą liczbę pierwotnych elementów. Konieczna jest analiza skoncentrowana na macierzy rotowanych składowych oraz wartości ładunków czynnikowych. Wartość całkowita wyjaśnionej wariancji zaczyna bardziej maleć za ósmą składową, dlatego też wstępnie postanowiono do dalszych analiz przyjąć osiem składowych zidentyfikowanych w analizie czynnikowej. W metodzie analizy czynnikowej kolejne składowe są coraz mniej licznymi zbiorami. Ósma składowa zawiera dwa pierwotne elementy. Dla kolejnych składowych znajdowały się elementy o ładunkach czynnikowych powyżej 0,3 (maksymalnie cztery), lecz te ładunki były mniejsze od innych, wskazujących na lepszą przystawalność danego elementu do wcześniejszych składowych. Dlatego ostatecznie przyjęto do dalszych analiz osiem składowych wyodrębnionych $\mathrm{w}$ analizie czynnikowej. Tym samym w wyborze ośmiu składowych nie pominięto wpływu żadnego pytania zadanego w drugiej części ankiety, czyli wszystkie pierwotne elementy składowe głównych wewnętrznych czynników projakościowego zarządzania w organizacji zostały uwzględnione w nowych zbiorach.

Składowa nr 1 jest najliczniejszą grupą, zawierającą w sobie 38 literaturowych, pierwotnych elementów konstytuujących główne czynniki wewnętrzne zarządzania jakością. Łącznie jest to 38 elementów, które w 24 przypadkach odnoszą się do aspektu jakości oraz w 14 przypadkach odnoszą się do aspektu ryzyka. Analizując szczegółowo pierwotne elementy zgrupowane w ramach składowej $\mathrm{nr}$ 1, warto zauważyć, że dużo elementów pochodzi z pierwszego teoretycznego głównego wewnętrznego czynnika zarządzania jakością „Przywództwo i zaangażowanie najwyższego kierownictwa" oraz wszystkie dotyczą „Zarządzania procesowego”. W ramach analizowanej składowej znajdują się elementy pochodzące ze wszystkich grup zidentyfikowanych teoretycznie jako główne wewnętrzne czynniki projakościowego zarządzania w organizacji. Liczba oraz zakres tych elementów w ramach jednej, szerokiej składowej wskazuje na zagadnienia ogólnego podejścia do jakości w organizacji.

W ramach składowej $\mathrm{nr} 2$ zauważalne są dwa obszary zgrupowania pierwotnych elementów konstytuujących główne wewnętrzne czynniki zarządzania jakością. Pierwszy dotyczy klientów, drugi jest związany z pracownikami.

W ramach składowej nr 3 zauważalny jest udział siedmiu „ryzykownych” elementów konstytuujących dotychczasowe główne wewnętrzne czynniki zarządzania jakością, z ich ukierunkowaniem na prewencyjny charakter działań w ramach „Podejścia opartego na ryzyku”.

Składowa $\mathrm{nr} 4$ zawiera siedem na osiem elementów związanych dotychczas z teoretycznym głównym czynnikiem zarządzania jakością „Orientacja na klienta”. Jeden element dotyczy dotychczasowego głównego wewnętrznego czynnika 


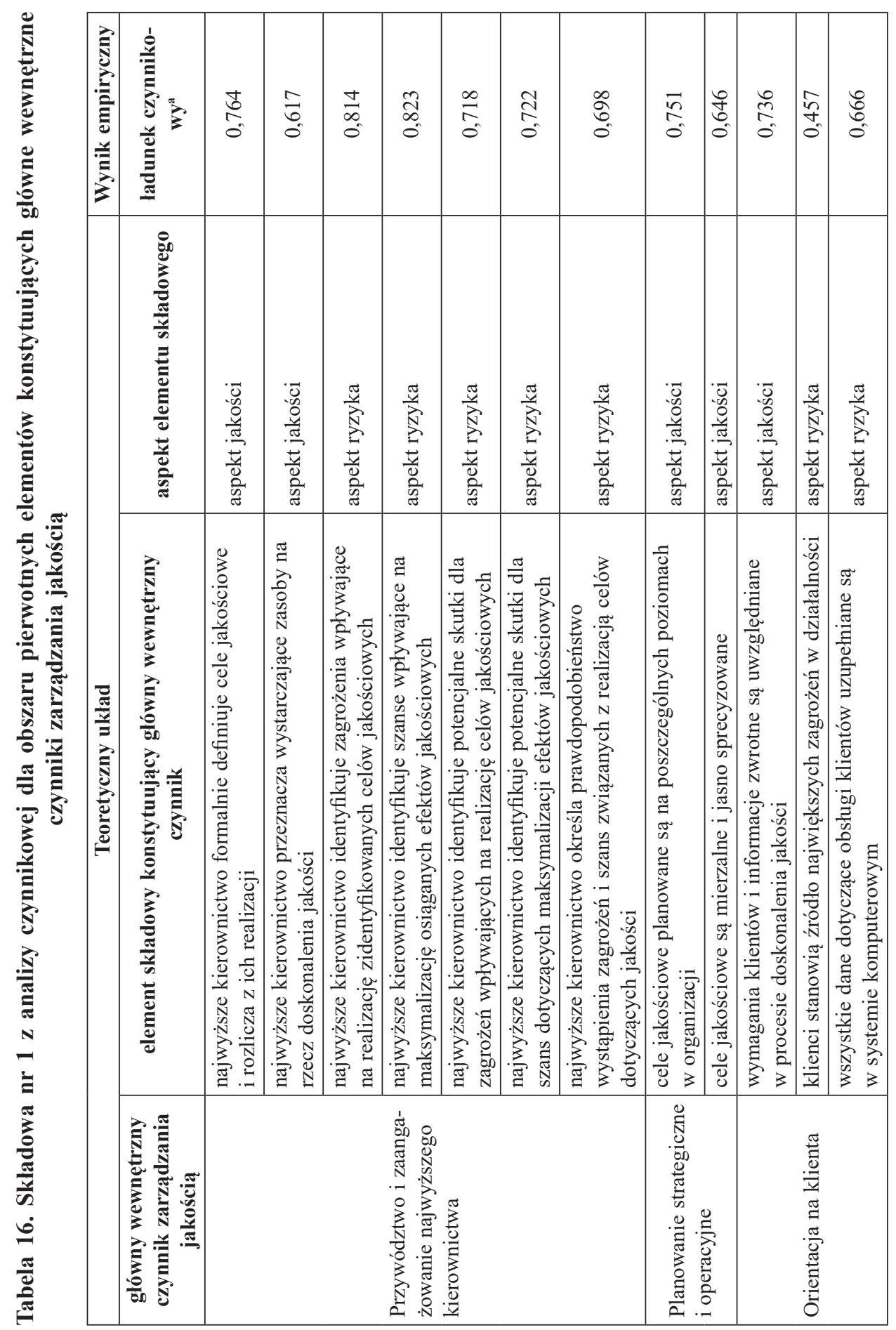

[159] 


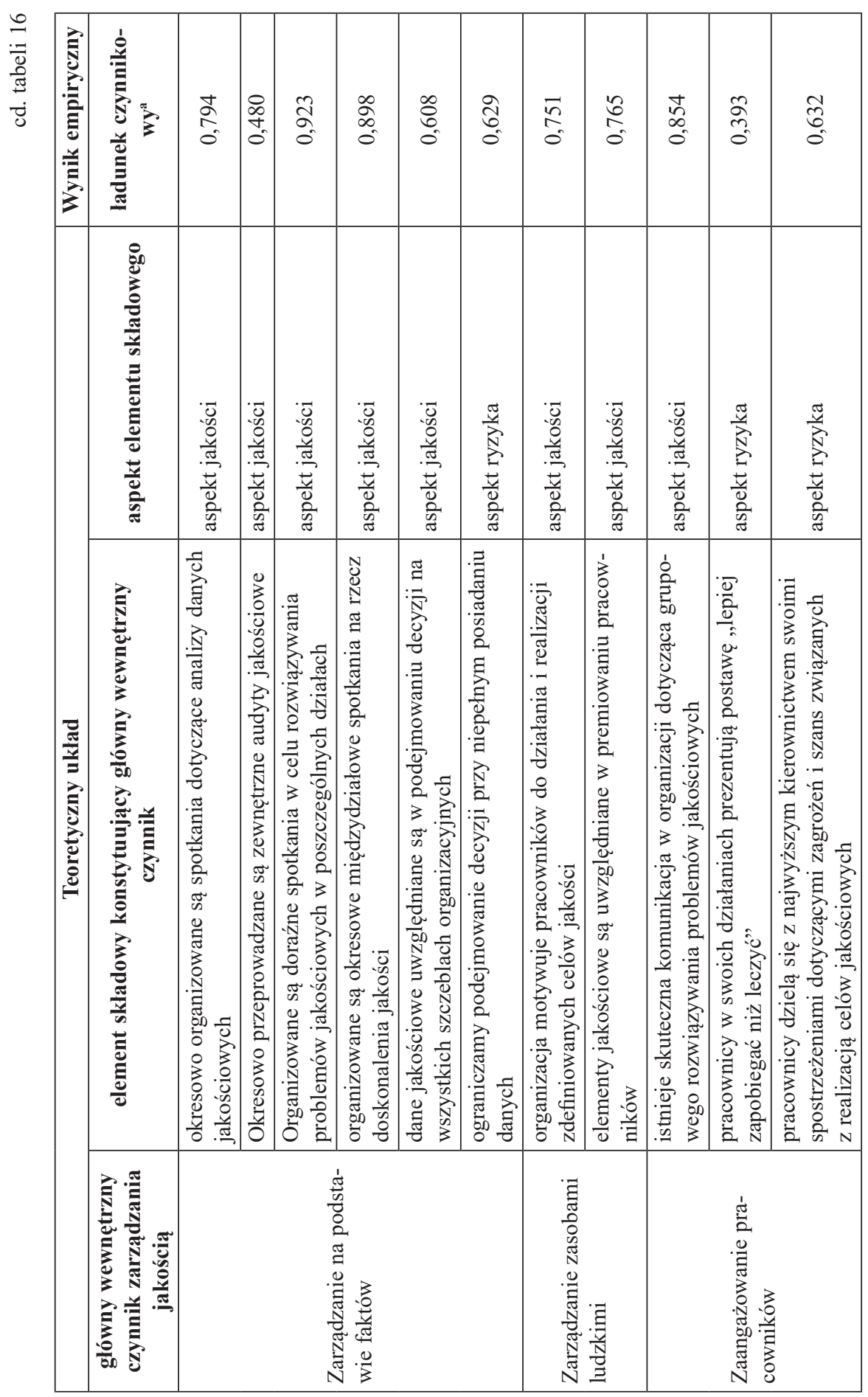

[160] 


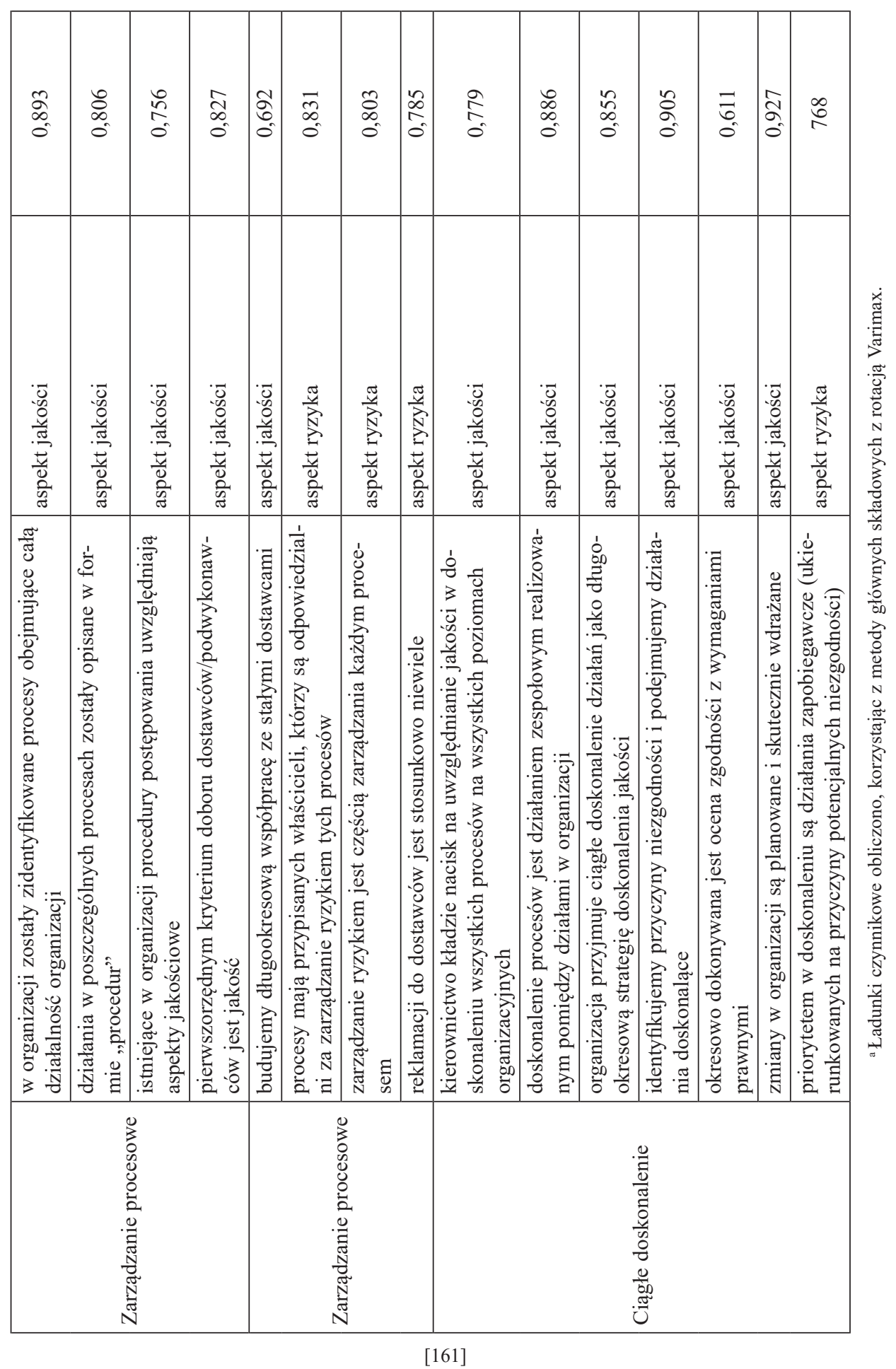




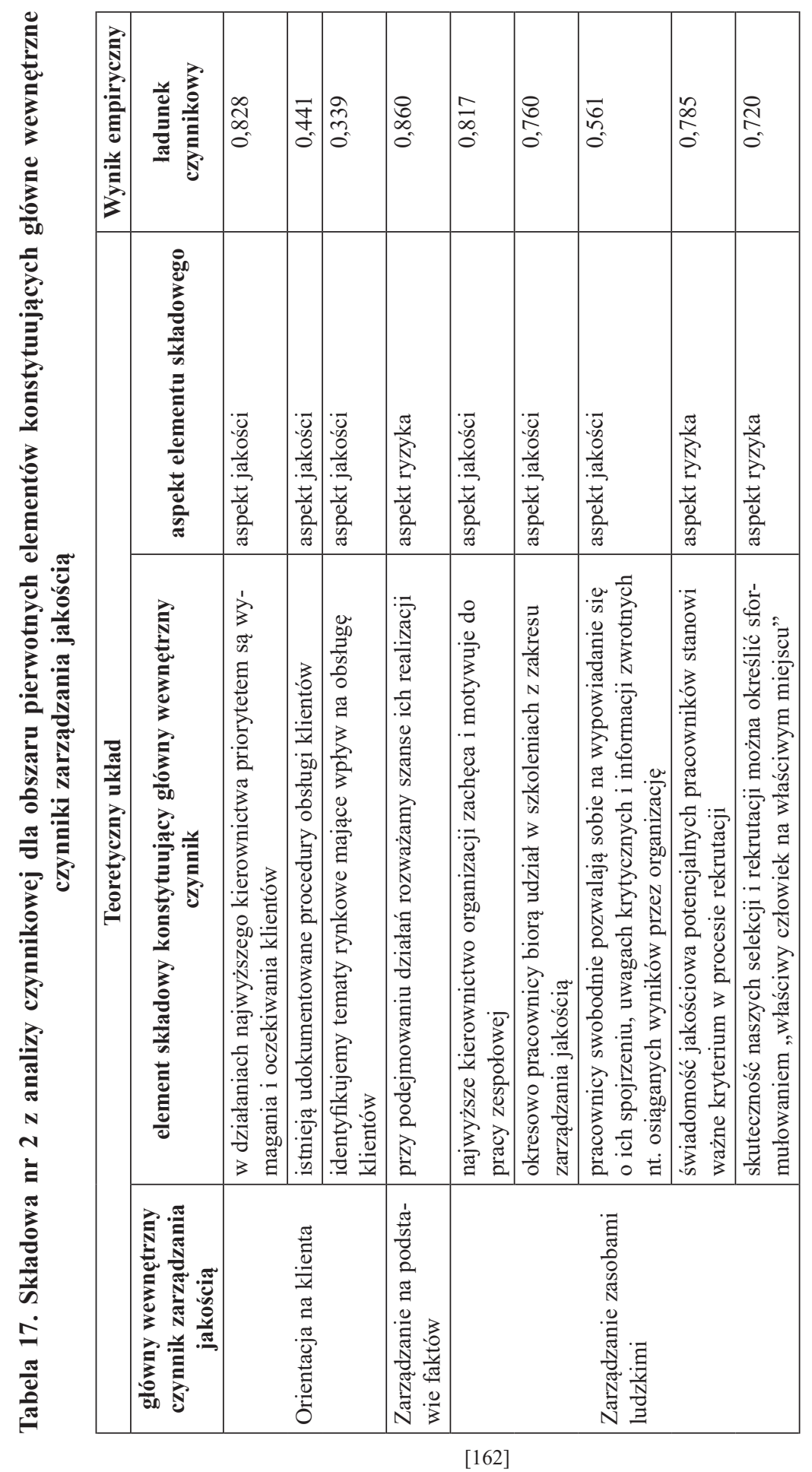




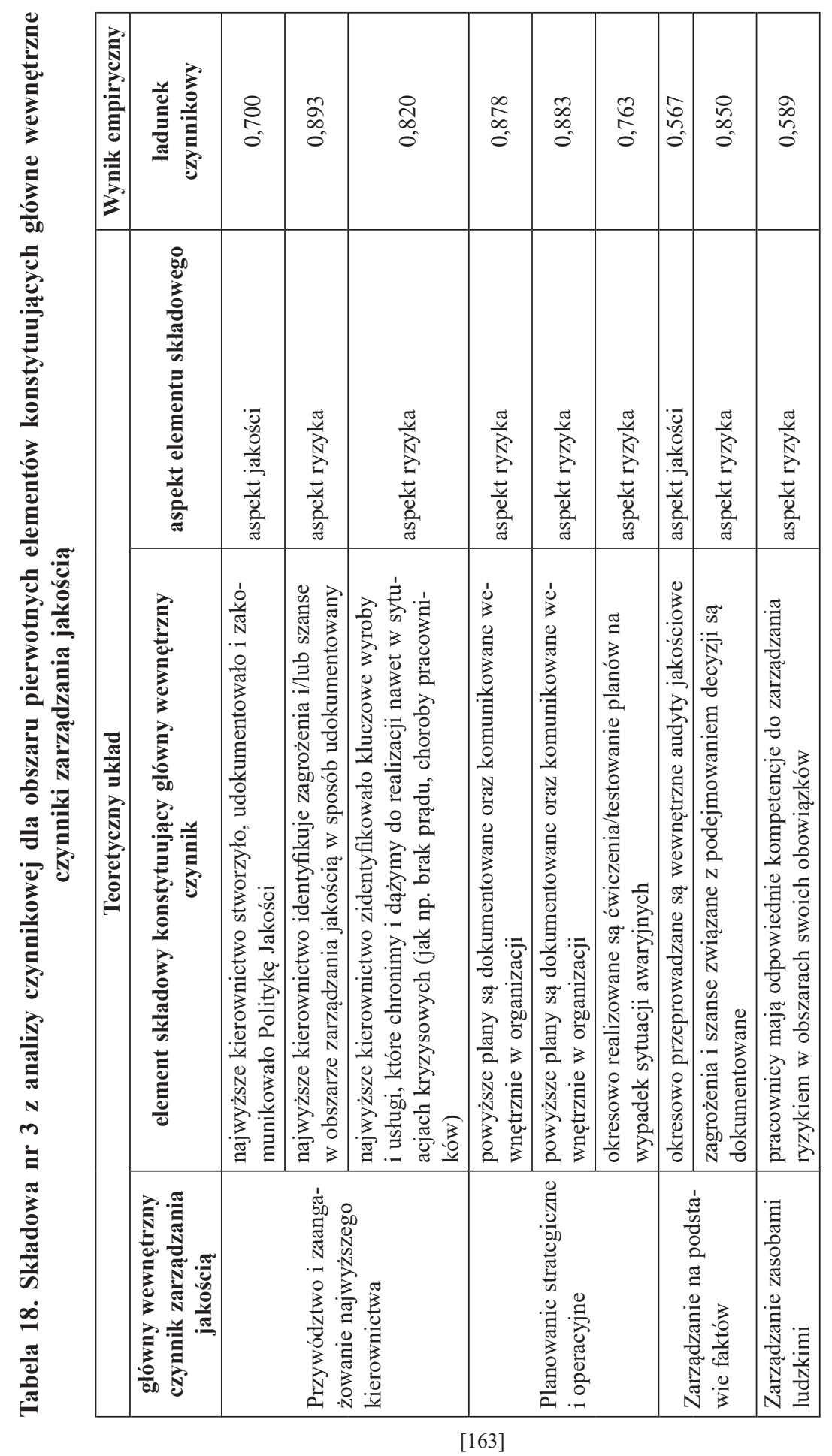




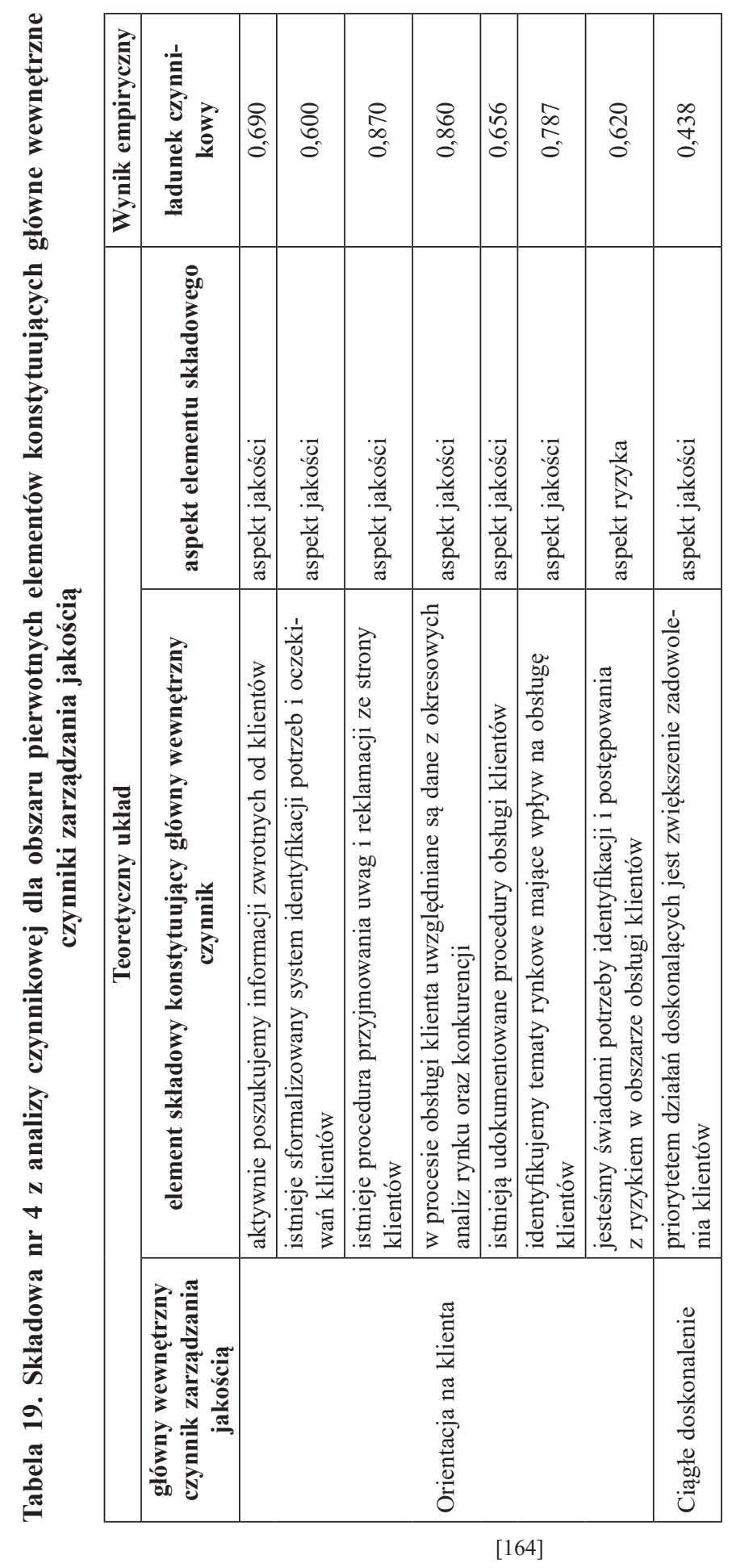




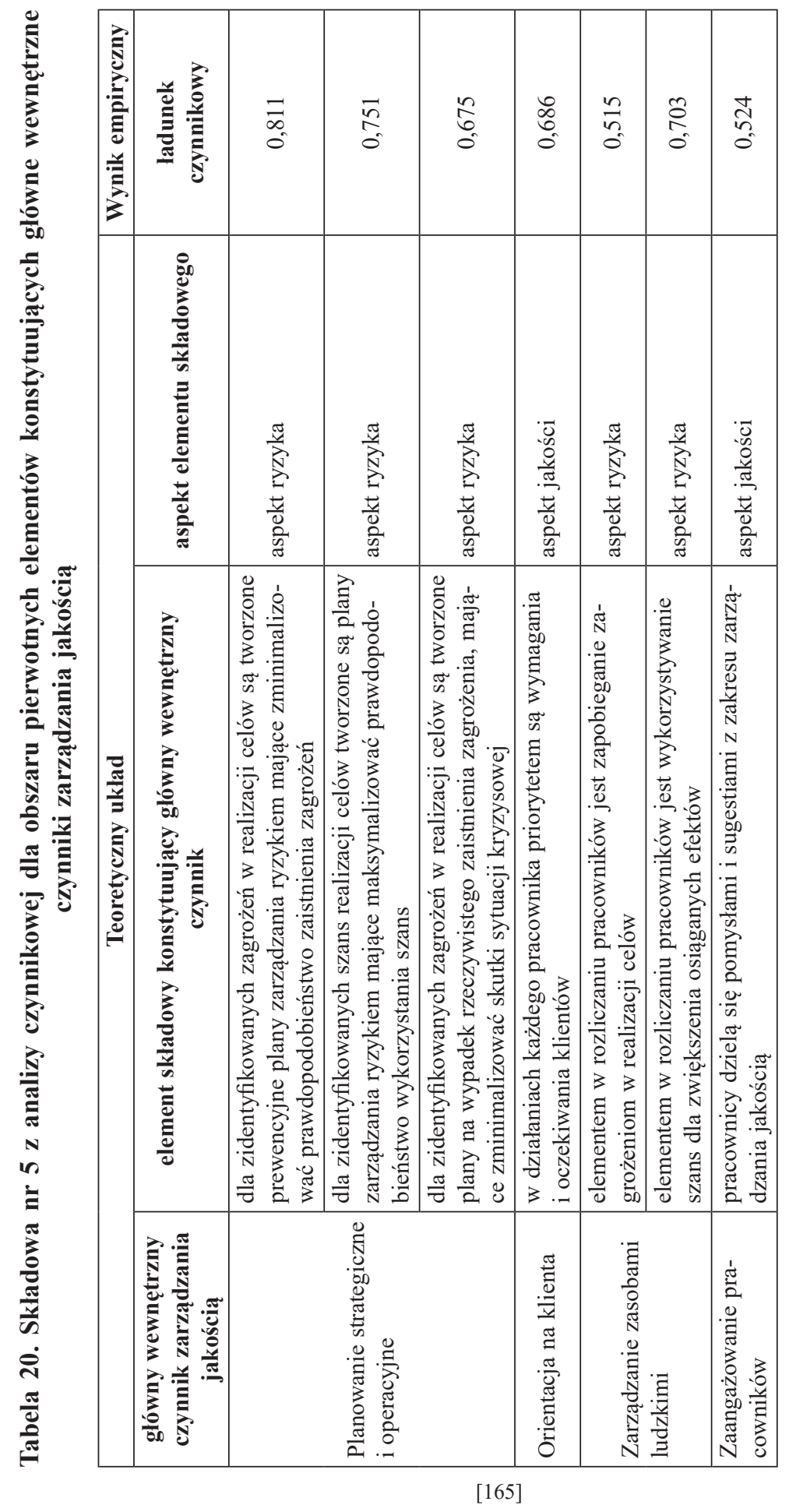




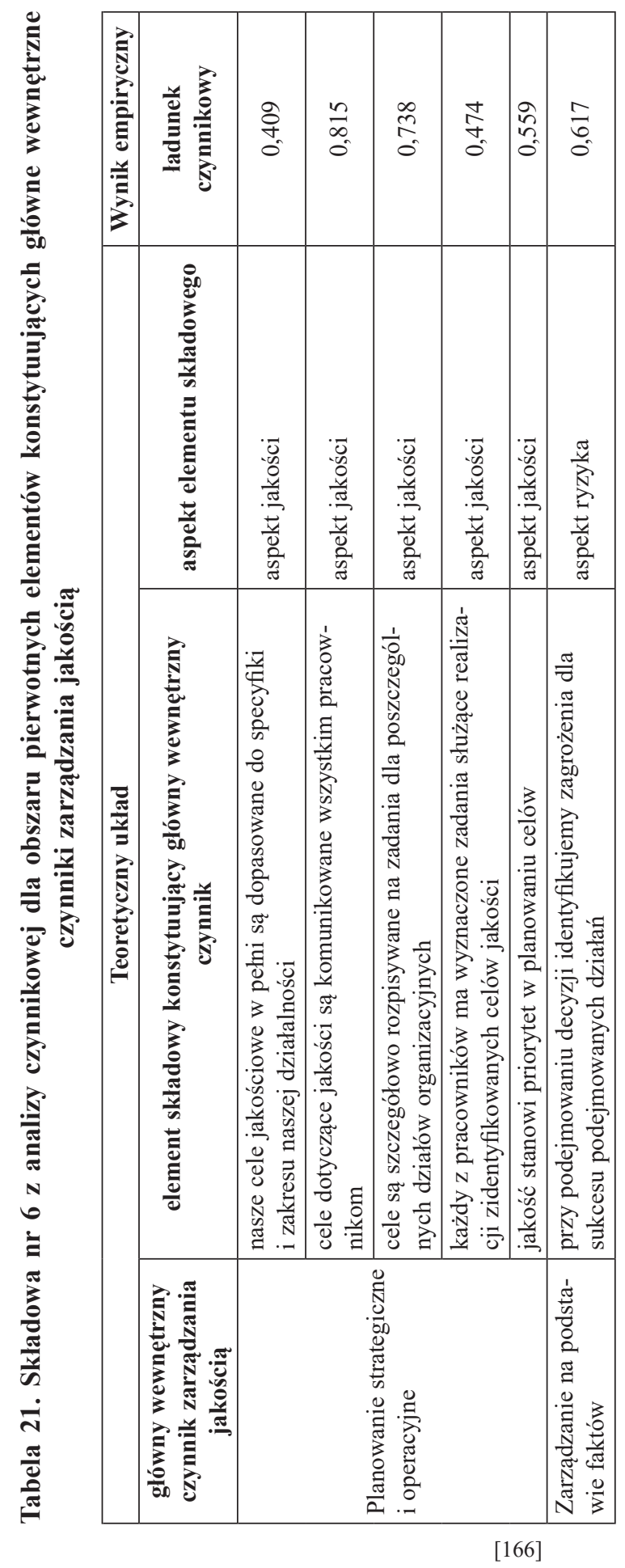




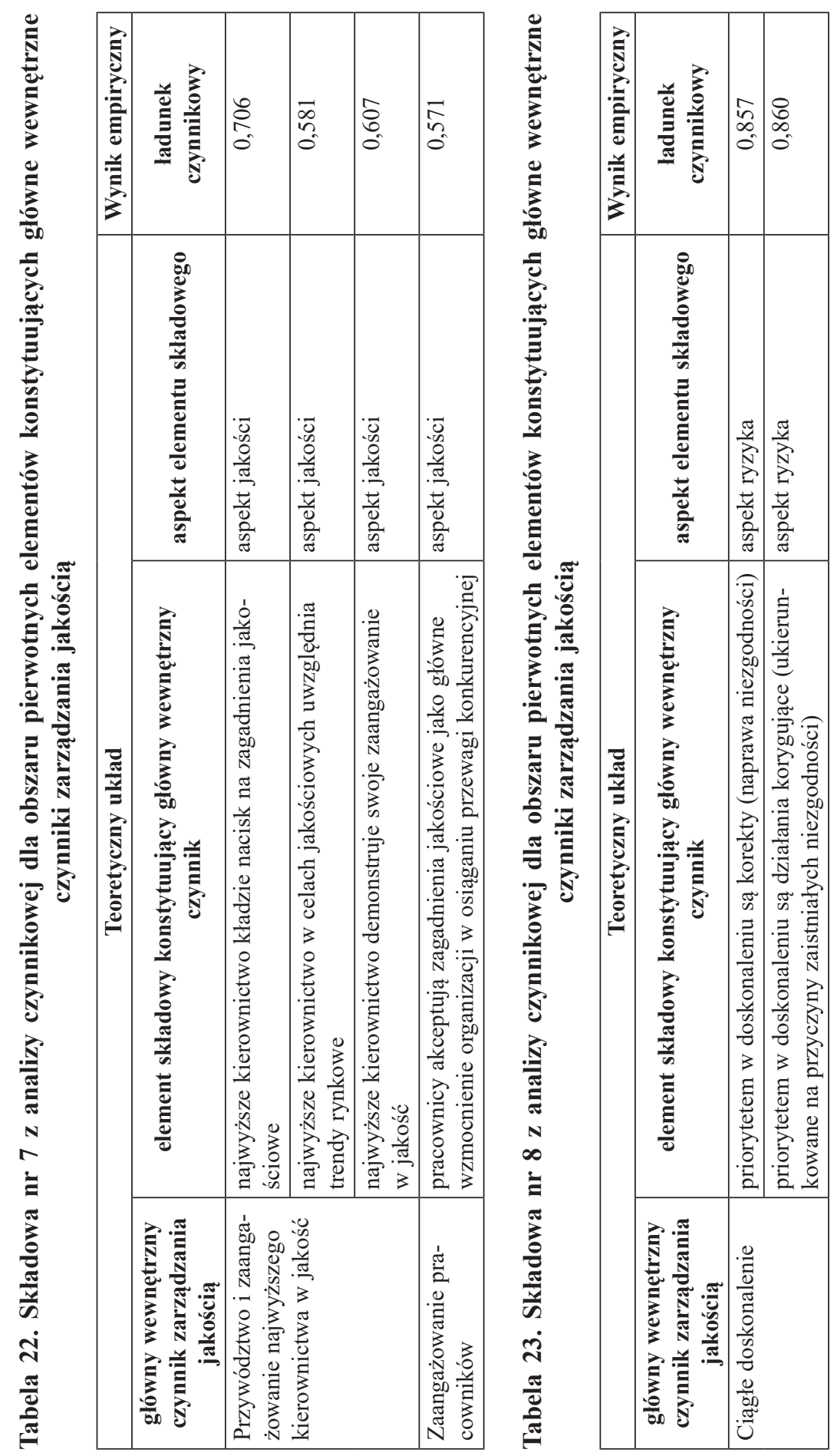

[167] 
zarządzania jakością „Ciągłe doskonalenie” i element ten nawiązuje w swojej treści do działań ukierunkowanych na zwiększenie zadowolenia klienta.

Składowa nr 5 zrzesza dotychczasowe składowe elementy z obszaru identyfikacji i podejmowania działań organizacyjnych na rzecz maksymalizacji szans i minimalizacji zagrożeń w podejściu do jakości.

W wyniku przeprowadzonej analizy czynnikowej w ramach składowej $\mathrm{nr} 6$ ujęte zostały pierwotne elementy konstytuujące główny wewnętrzny czynnik zarządzania jakością „Planowanie strategiczne i operacyjne”. Jeden dodatkowy element dotyczy identyfikowania zagrożeń dla sukcesu podejmowanych działań.

W ramach składowej nr 7 zauważalne są elementy wyłącznie ,jakościowe", pochodzące $z$ dwóch najwyżej ocenionych przez respondentów głównych wewnętrznych czynników zarządzania jakością, a dotyczące kwestii uwzględniania jakości jako ważnego aspektu funkcjonowania organizacji na rynku.

Składowa nr 8, jako ostatnia wyodrębniona w statystycznej analizie czynnikowej, zawiera najmniej pierwotnych elementów przypisywanych do głównych wewnętrznych czynników zarządzania jakością. Obydwa są związane z obszarem ciągłego doskonalenia w spojrzeniu na aktywności organizacyjne w aspekcie ryzyka.

Składowe zidentyfikowane w wyniku eksploracyjnej analizy czynnikowej, zgodnie ze wskazanymi na początku wyjaśnieniami terminologicznymi, stanowią po prostu czynniki zarządzania jakością. Ponieważ te nowe abstrakcyjne zbiory zawierają $\mathrm{w}$ sobie dotychczasowe elementy konstytuujące wewnętrzne czynniki zarządzania jakością, to i te nowe składowe można uznać za wewnętrzne czynniki projakościowego zarządzania w organizacji. Konieczne jest jednak nadanie im nazw, które w jak najpełniejszy sposób wskazywałyby na charakter zawartości, czyli dotychczasowych elementów, tworzących po analizie czynnikowej nowy układ rzeczywistości badawczej. W tabeli 24 wskazano, wraz

Tabela 24. Wewnętrzne czynniki zarządzania jakością - pierwotne elementy w składowych po eksploracyjnej analizie czynnikowej

\begin{tabular}{|c|l|c|c|}
\hline Skladowa & $\begin{array}{c}\text { Nazwa wewnętrznego czynnika za- } \\
\text { rządzania jakością }\end{array}$ & $\begin{array}{c}\text { Lączna liczba } \\
\text { elementów }^{\mathbf{1}}\end{array}$ & $\begin{array}{c}\text { Relacja elementów } \\
\text { (aspekt jakości / } \\
\text { aspekt ryzyka) }\end{array}$ \\
\hline 1 & Przywództwo i kultura jakości & 38 & $24 / 14$ \\
\hline 2 & Dualizm jakości „klienci-pracownicy” & 9 & $6 / 3$ \\
\hline 3 & Podejście prewencyjne do jakości & 9 & $2 / 7$ \\
\hline 4 & Orientacja na klienta & 8 & $7 / 1$ \\
\hline 5 & Szanse i zagrożenia jakości & 7 & $2 / 5$ \\
\hline 6 & Planowanie jakości & 6 & $5 / 1$ \\
\hline 7 & Priorytetyzacja jakości & 4 & $4 / 0$ \\
\hline 8 & Podejście reakcyjne do jakości & 2 & $0 / 2$ \\
\hline
\end{tabular}


z ilościową charakterystyką, zmienne wchodzące w skład ośmiu wewnętrznych czynników zarządzania jakością.

W ramach szczegółowego analizowania czynników zidentyfikowanych w analizie czynnikowej zostały obliczone wartości średnich odchyleń ważności według trzech kryteriów: posiadania certyfikowanego systemu zarządzania jakością, okresu prowadzenia działalności przez badane podmioty w poszczególnych lokalizacjach oraz liczby zatrudnionych pracowników.

W analizowanej grupie 219 autoryzowanych salonów sprzedaży i serwisu samochodów osobowych w Polsce w 43 lokalizacjach funkcjonuje certyfikowany system zarządzania jakością (20\%) wobec 176 (80\%), które nie posiadają „certyfikatu ISO 9001”.

Tabela 25. Wewnętrzne czynniki zarządzania jakością - średnie odchylenie ważności w zależności od funkcjonowania certyfikowanego systemu zarządzania jakością

\begin{tabular}{|c|c|c|c|c|c|}
\hline \multirow[t]{2}{*}{$\begin{array}{c}\text { Wewnętrzne } \\
\text { czynniki zarzą- } \\
\text { dzania jakością }\end{array}$} & „ISO” & $\begin{array}{l}\text { „Bez } \\
\text { ISO" }\end{array}$ & $\begin{array}{c}\text { Test Levene'a } \\
\text { jednorodności } \\
\text { wariancji }\end{array}$ & \begin{tabular}{|} 
Test t równo- \\
ści średnich \\
(założono \\
równość wa- \\
riancji)
\end{tabular} & $\begin{array}{l}\text { Test t równo- } \\
\text { ści średnich } \\
\text { (nie zalożono } \\
\text { równości wa- } \\
\text { riancji) }\end{array}$ \\
\hline & średnia & średnia & istotność & $\begin{array}{c}\text { istotność dwu- } \\
\text { stronna }\end{array}$ & $\begin{array}{c}\text { istotność dwu- } \\
\text { stronna }\end{array}$ \\
\hline $\begin{array}{l}\text { Przywództwo } \\
\text { i kultura jakości }\end{array}$ & 0,34 & $-0,08$ & 0,19 & 0,012 & \\
\hline $\begin{array}{l}\text { Dualizm jakości } \\
\text { „klienci-pra- } \\
\text { cownicy” }\end{array}$ & $-0,08$ & 0,02 & 0,00 & & 0,670 \\
\hline $\begin{array}{l}\text { Podejście } \\
\text { prewencyjne do } \\
\text { jakości }\end{array}$ & 1,20 & $-0,29$ & 0,00 & & 0,000 \\
\hline $\begin{array}{l}\text { Orientacja na } \\
\text { klienta }\end{array}$ & 0,34 & $-0,08$ & 0,61 & 0,014 & \\
\hline $\begin{array}{l}\text { Szanse i zagro- } \\
\text { żenia jakości }\end{array}$ & $-0,15$ & 0,04 & 0,97 & 0,270 & \\
\hline $\begin{array}{l}\text { Planowanie } \\
\text { jakości }\end{array}$ & $-0,19$ & 0,05 & 0,00 & & 0,399 \\
\hline $\begin{array}{l}\text { Priorytetyzacja } \\
\text { jakości }\end{array}$ & $-0,32$ & 0,08 & 0,00 & & 0,094 \\
\hline $\begin{array}{l}\text { Podejście reak- } \\
\text { cyjne do jakości }\end{array}$ & $-0,31$ & 0,07 & 0,00 & & 0,151 \\
\hline
\end{tabular}

Wyniki analizy danych zawarte w tabeli 25 są istotne statystycznie dla trzech wewnętrznych czynników zarządzania jakością, co na tle pozostałych jest widoczne na wykresie 32. 


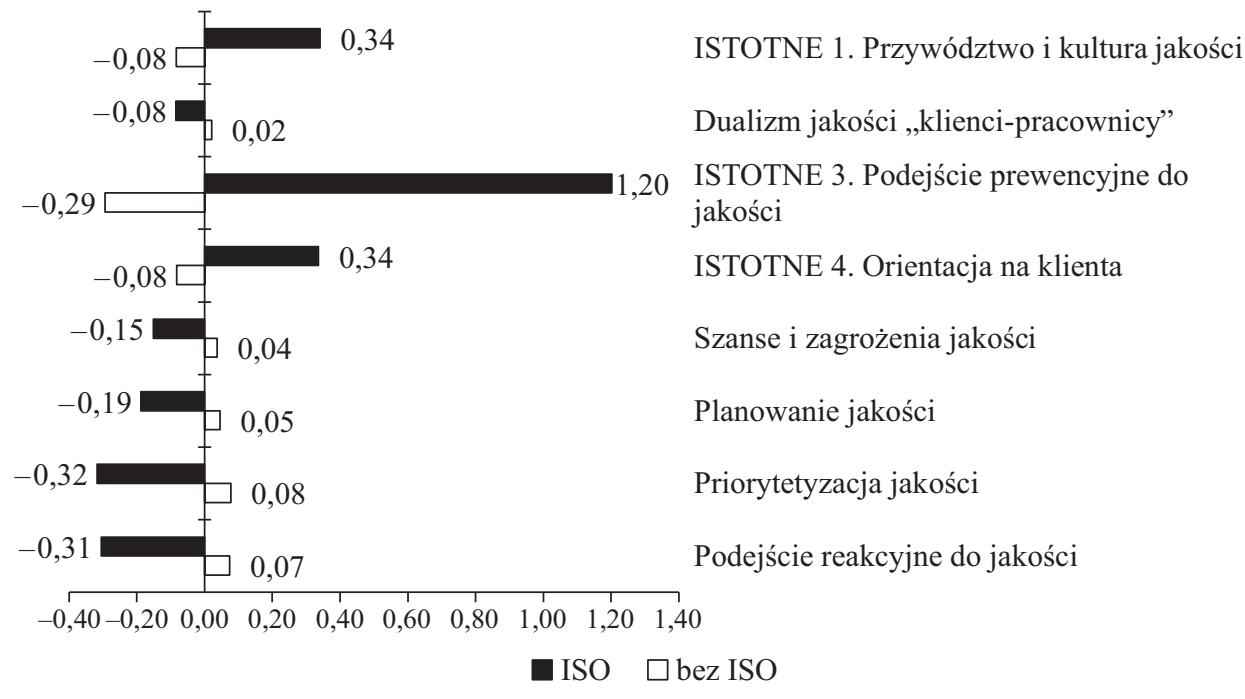

Wykres 32. Wewnętrzne czynniki zarządzania jakością - średnie odchylenie ważności w zależności od funkcjonowania certyfikowanego systemu zarządzania jakością (z wyróżnieniem danych istotnych statystycznie)

Analizując widoczne na wykresie różnice w odchyleniu średnich wartości dla poszczególnych wewnętrznych czynników zarządzania jakością, można zauważyć, że istotne statystycznie są te o największej bezwzględnej wartości. W największym stopniu wewnętrzny czynnik „Podejście prewencyjne do jakości” został wyżej oceniony przez respondentów w organizacjach posiadających certyfikowany system zarządzania jakością niż w jednostkach nieposiadających „certyfikatu ISO 9001”. Na porównywalnym poziomie względem różnic ważności pomiędzy dwiema analizowanymi grupami respondentów znajdują się dwa czynniki wewnętrzne: pozostające w sferze prewencji jakości - „Przywództwo i kultura jakości” oraz w ukierunkowaniu na zadowolenia klientów - „Orientacja na klienta".

Analizując zróżnicowanie ważności wewnętrznych czynników zarządzania jakością, przeprowadzono identyfikację odchyleń ich ważności w zależności od okresu prowadzenia działalności gospodarczej w poszczególnych lokalizacjach autoryzowanych salonów sprzedaży i serwisu samochodów osobowych w Polsce. Czterdzieści lokalizacji prowadzi działalność do 6 lat (18\%), a pozostałe $179(82 \%)$ - od siedmiu lat.

Dla przedstawionych (tabela 26) różnic ważności poszczególnych wewnętrznych czynników projakościowego zarządzania w organizacji, w zależności od czasu funkcjonowania poszczególnych lokalizacji objętych badaniem ankietowym, zależności statystycznie istotnie zidentyfikowano dla dwóch wewnętrznych czynników zarządzania jakością. 
Tabela 26. Wewnętrzne czynniki zarządzania jakością - średnie odchylenie ważności w zależności od okresu prowadzenia działalności

\begin{tabular}{|l|c|c|c|c|c|}
\hline \multicolumn{1}{|c|}{$\begin{array}{c}\text { Wewnętrzne } \\
\text { czynniki zarzą- } \\
\text { dzania jakością }\end{array}$} & do 6 lat & od 7 lat & $\begin{array}{c}\text { Test } \\
\text { Levene'a } \\
\text { jednorodno- } \\
\text { ści wariancji }\end{array}$ & $\begin{array}{c}\text { Test t równo- } \\
\text { ści średnich } \\
\text { (założono } \\
\text { równość wa- } \\
\text { riancji) }\end{array}$ & $\begin{array}{c}\text { Test t równo- } \\
\text { ści średnich } \\
\text { (nie założono } \\
\text { równości wa- } \\
\text { riancji) }\end{array}$ \\
\cline { 2 - 6 } & średnia & średnia & istotnośćc & $\begin{array}{c}\text { istotność } \\
\text { dwustronna }\end{array}$ & $\begin{array}{c}\text { istotnośćc } \\
\text { dwustronna }\end{array}$ \\
\hline $\begin{array}{l}\text { Przywództwo } \\
\text { i kultura jakości }\end{array}$ & 0,14 & $-0,03$ & 0,027 & 0,317 & \\
\hline $\begin{array}{l}\text { Dualizm jakości } \\
\text { „klienci-pra- } \\
\text { cownicy” }\end{array}$ & $-0,01$ & 0,00 & 0,036 & 0,953 & \\
\hline $\begin{array}{l}\text { Podejście } \\
\text { prewencyjne do } \\
\text { jakości }\end{array}$ & 0,04 & $-0,01$ & 0,936 & 0,807 & \\
\hline $\begin{array}{l}\text { Orientacja na } \\
\text { klienta }\end{array}$ & $-0,11$ & 0,02 & 0,635 & 0,440 & \\
\hline $\begin{array}{l}\text { Szanse i zagro- } \\
\text { żenia jakości }\end{array}$ & $-0,92$ & 0,20 & 0,000 & & $\mathbf{0 , 0 0 0}$ \\
\hline $\begin{array}{l}\text { Planowanie } \\
\text { jakości }\end{array}$ & 0,40 & $-0,09$ & 0,687 & $\mathbf{0 , 0 0 5}$ & \\
\hline $\begin{array}{l}\text { Priorytetyzacja } \\
\text { jakości }\end{array}$ & $-0,03$ & 0,01 & 0,746 & 0,832 & \\
\hline $\begin{array}{l}\text { Podejście reak- } \\
\text { cyjne do jakości }\end{array}$ & 0,22 & $-0,05$ & 0,321 & 0,130 & \\
\hline
\end{tabular}

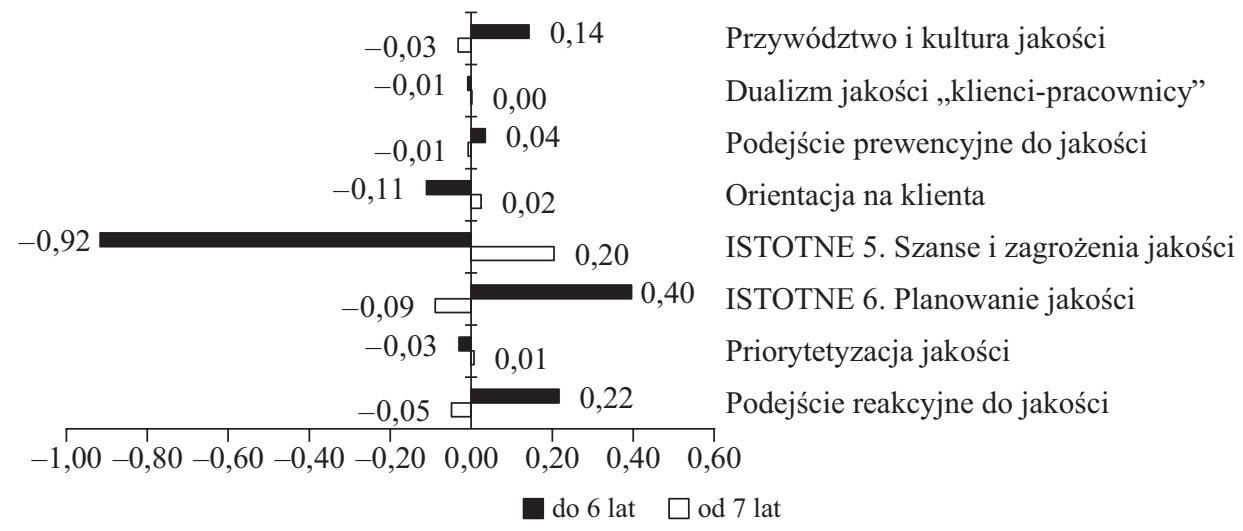

Wykres 33. Wewnętrzne czynniki zarządzania jakością - średnie odchylenie ważności w zależności od okresu prowadzenia działalności (z wyróżnieniem danych istotnych statystycznie) 
Zależności istotne statystycznie dotyczą najwyższych bezwzględnych różnic odchyleń dla dwóch czynników. Respondenci z lokalizacji krócej działających na rynku stosunkowo niższą ważność przyznają czynnikowi „Szanse i zagrożenia jakości”, ale czynnik „Planowanie jakości” oceniają już relatywnie wyżej niż respondenci z lokalizacji działających na rynku co najmniej od siedmiu lat.

Organizacje stanowiące próbę badawczą zatrudniają w 66 lokalizacjach (30\%) maksymalnie 25 osób, a w pozostałych 153 lokalizacjach liczebność pracowników wynosi minimalnie 26 pracowników (70\%). Wyniki różnicowania ważności wewnętrznych czynników zarządzania jakością w zależności od liczby zatrudnionych pracowników zostały przedstawione w tabeli 27 .

Tabela 27. Wewnętrzne czynniki zarządzania jakością - średnie odchylenie ważności w zależności od liczby zatrudnionych pracowników

\begin{tabular}{|c|c|c|c|c|c|}
\hline \multirow[t]{2}{*}{$\begin{array}{c}\text { Wewnętrzne } \\
\text { czynniki zarzą- } \\
\text { dzania jakością }\end{array}$} & Do 25 osób & Od 26 osób & $\begin{array}{c}\text { Test } \\
\text { Levene'a } \\
\text { jednorodno- } \\
\text { ści wariancji }\end{array}$ & $\begin{array}{l}\text { Test t równo- } \\
\text { ści średnich } \\
\text { (założono } \\
\text { równość wa- } \\
\text { riancji) }\end{array}$ & $\begin{array}{l}\text { Test t równo- } \\
\text { ści średnich } \\
\text { (nie założono } \\
\text { równości wa- } \\
\text { riancji) }\end{array}$ \\
\hline & średnia & średnia & istotność & $\begin{array}{c}\text { istotnośćc } \\
\text { dwustronna }\end{array}$ & $\begin{array}{c}\text { istotnośćc } \\
\text { dwustronna }\end{array}$ \\
\hline $\begin{array}{l}\text { Przywództwo } \\
\text { i kultura jakości }\end{array}$ & $-0,01$ & 0,00 & 0,76 & 0,96 & \\
\hline $\begin{array}{l}\text { Dualizm jakości } \\
\text { „klienci-pra- } \\
\text { cownicy” }\end{array}$ & 0,03 & $-0,01$ & 0,60 & 0,75 & \\
\hline $\begin{array}{l}\text { Podejście } \\
\text { prewencyjne do } \\
\text { jakości }\end{array}$ & 0,15 & $-0,07$ & 0,00 & & 0,17 \\
\hline $\begin{array}{l}\text { Orientacja na } \\
\text { klienta }\end{array}$ & 0,11 & $-0,05$ & 0,56 & 0,27 & \\
\hline $\begin{array}{l}\text { Szanse i zagro- } \\
\text { żenia jakości }\end{array}$ & 0,07 & $-0,03$ & 0,70 & 0,49 & \\
\hline $\begin{array}{l}\text { Planowanie } \\
\text { jakości }\end{array}$ & 0,00 & 0,00 & 0,07 & 1,00 & \\
\hline $\begin{array}{l}\text { Priorytetyzacja } \\
\text { jakości }\end{array}$ & $-0,37$ & 0,16 & 0,00 & & $\mathbf{0 , 0 0}$ \\
\hline $\begin{array}{l}\text { Podejście reak- } \\
\text { cyjne do jakości }\end{array}$ & $-0,02$ & 0,01 & 0,14 & 0,82 & \\
\hline
\end{tabular}

Tylko dla jednego wewnętrznego czynnika zarządzania jakością relacja jest istotna statystycznie, co na tle pozostałych czynników jest widoczne na wykresie 34.

Pierwotne 82 elementy konstytuujące osiem głównych wewnętrznych czynników projakościowego zarządzania $\mathrm{w}$ organizacji zostało w wyniku eksplo- 


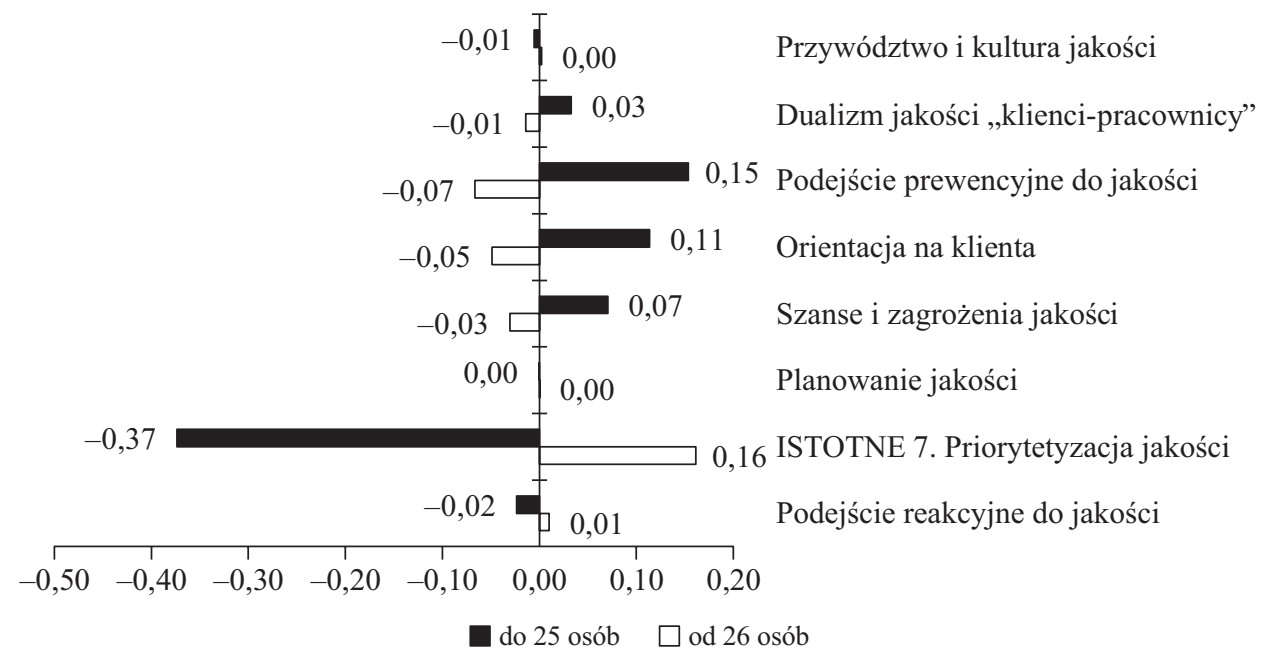

Wykres 34. Wewnętrzne czynniki zarządzania jakością - średnie odchylenie ważności w zależności od liczby zatrudnionych pracowników (z wyróżnieniem danych istotnych statystycznie)

racyjnej analizy czynnikowej zgrupowanych również w osiem wewnętrznych czynników zarządzania jakością. Pierwszy wewnętrzny czynnik zawiera w sobie aż 38 elementów opisujących danych czynnik. $Z$ uwagi na różnorodny charakter tych elementów, które tworzą ogólny klimat dla jakości w organizacji, czynnik ten został nazwany: „Przywództwo i kultura jakości”. Analiza zawartości kolejnych siedmiu zbiorów zidentyfikowanych w statystycznej analizie czynnikowej naprowadziła na nadanie nazw poszczególnym wewnętrznym czynnikom zarządzania jakością: „Dualizm jakości «klienci-pracownicy»”, „Podejście prewencyjne do jakości”, „Orientacja na klienta”, „Szanse i zagrożenia jakości”, „Planowanie jakości”, „Priorytetyzacja jakości”, „Podejście reakcyjne do jakości”.

Wewnętrzne czynniki zarządzania jakością oddziałują na osiągane w organizacji rezultaty, których grupowanie zostało przedstawione w kolejnym punkcie niniejszego rozdziału pracy.

\subsection{Grupowanie rezultatów projakościowego zarządzania w organizacji}

W wyniku zastosowania eksploracyjnej analizy czynnikowej, ukierunkowanej na minimalizację zmiennych opisujących badaną rzeczywistość, zgrupowano siedemnaście rezultatów ukazujących wpływ zarządzania jakością na rezultaty organizacji (z III części ankiety), otrzymując trzy składowe. 
Tabela 28. Wartości własne oraz wariancja wyjaśniania w analizie czynnikowej dla rezultatów zarządzaniu jakością

\begin{tabular}{|c|c|c|c|}
\hline \multirow{2}{*}{ Składowa } & \multicolumn{3}{|c|}{ Sumy kwadratów ladunków po rotacji } \\
\cline { 2 - 4 } & ogólem & procent wariancji & procent skumulowany \\
\hline 1 & 6,156 & 36,210 & 36,210 \\
\hline 2 & 3,438 & 20,220 & 56,430 \\
\hline 3 & 2,773 & 16,313 & 72,743 \\
\hline
\end{tabular}

$\mathrm{Na}$ podstawie analizy literatury przedmiotu przedstawionej $\mathrm{w}$ drugim rozdziale niniejszej monografii zidentyfikowano trzy grupy rezultatów zarządzania jakością: ogólne, niefinansowe i finansowe. Wyniki przeprowadzonej statystycznej eksploracyjnej analizy czynnikowej wyznaczyły pogrupowanie pierwotnych zmiennych (17 rezultatów zarządzania jakością) w trzy składowe, gdzie tylko dwa rezultaty zostały zaszeregowane do innych grup niż pierwotnie w wyniku analizy literatury przedmiotu. Dlatego grupom rezultatów projakościowego zarządzania w organizacji nadano nazwy jak w pierwotnych analizach.

W ramach szczegółowego analizowania rezultatów zarządzania jakością, zidentyfikowanych w analizie czynnikowej, obliczone zostały wartości średnich odchyleń ważności według trzech kryteriów (tych samych jak w analizie wewnętrznych czynników projakościowego zarządzania w organizacji): posiadania certyfikowanego systemu zarządzania jakością, okresu prowadzenia działalności przez badane podmioty w poszczególnych lokalizacjach oraz liczby zatrudnionych pracowników.

Wyniki analizy danych wskazujące na odchylenie ważności wszystkich trzech obszarów rezultatów zarządzania jakością są wartościami istotnymi statystycznie.

Respondenci z organizacji, w których funkcjonuje certyfikowany system zarządzania jakością, oceniają niżej od pozostałych uzyskiwanie rezultatów ogólnych. W ramach tej kategorii znajdują się trzy jednostkowe rezultaty, których

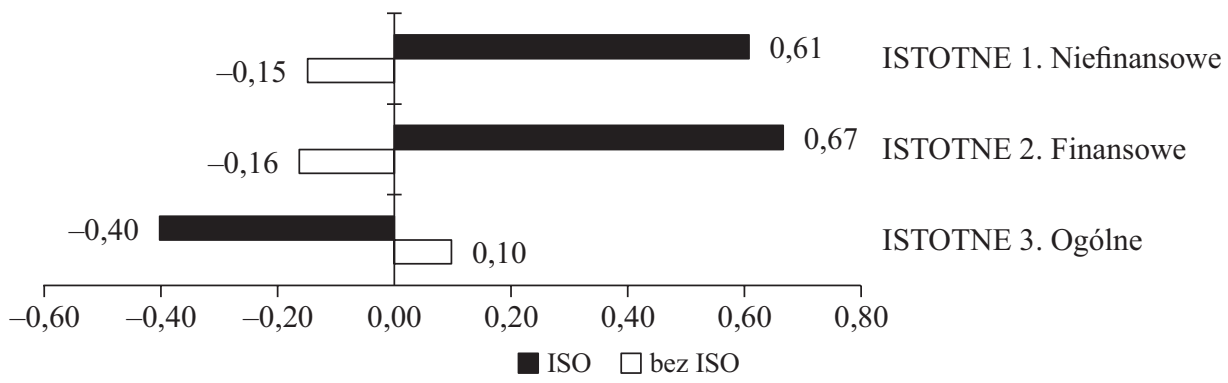

Wykres 35. Rezultaty zarządzania jakością - średnie odchylenie ważności w zależności od funkcjonowania certyfikowanego systemu zarządzania jakością (z wyróżnieniem danych istotnych statystycznie) 


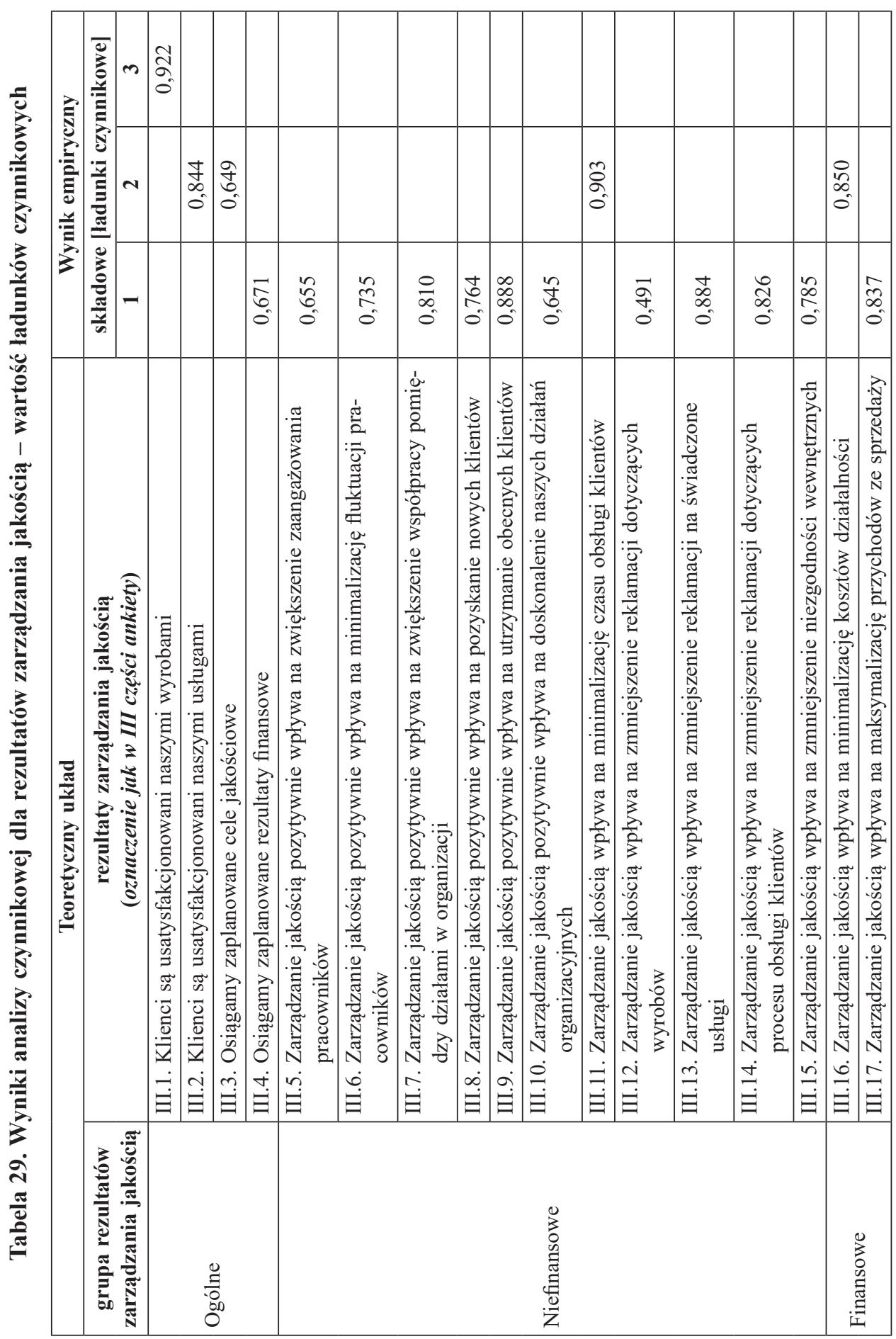

[175] 


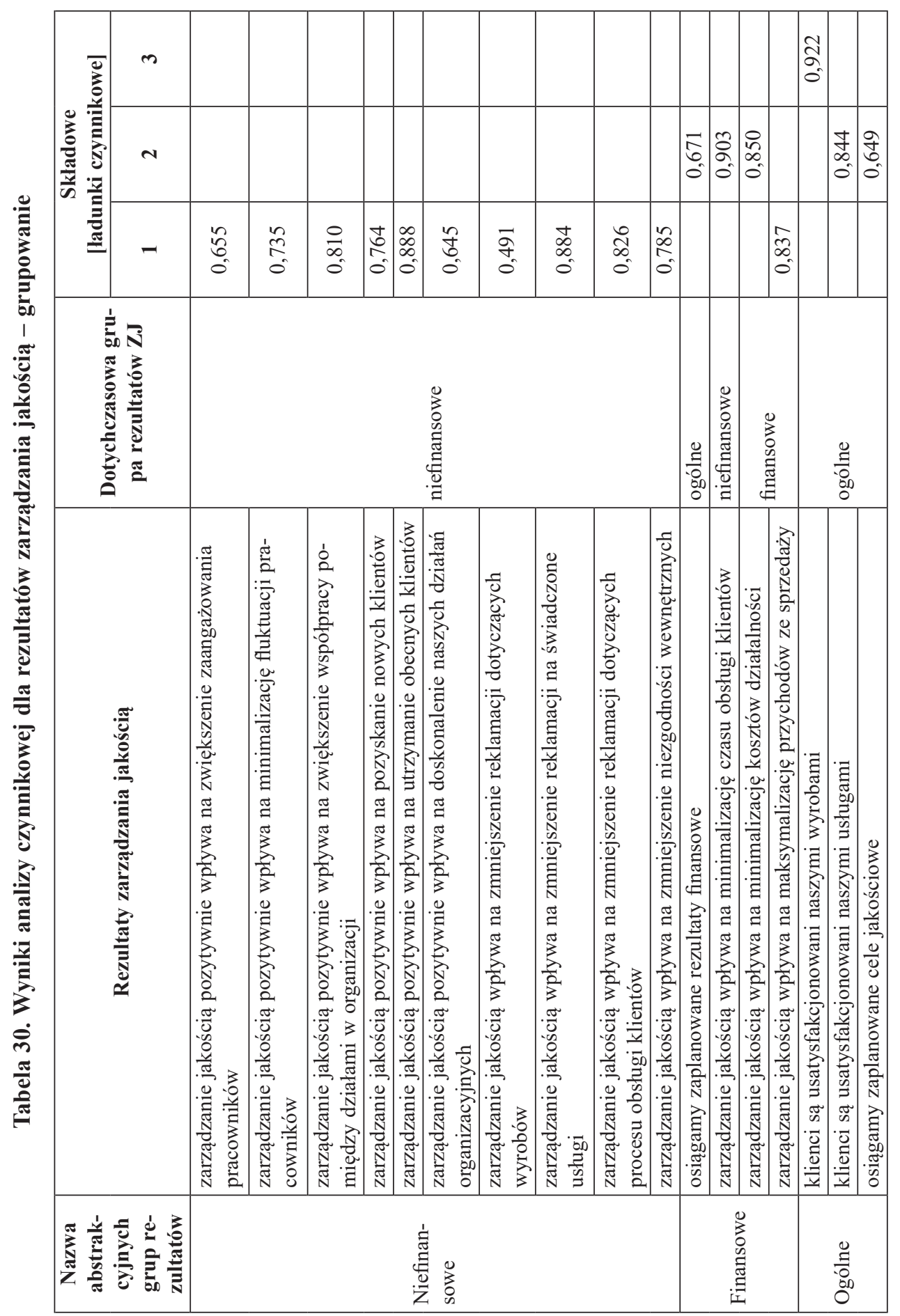

[176] 
indywidualna analiza ważności (wykres 13) wskazała, że organizacje posiadające „,ertyfikat ISO 9001” wyżej oceniają trzeci jednostkowy rezultat „Osiąganie zaplanowanych celów jakościowych”. Jednak w ocenie grupowej pozostałe dwa jednostkowe rezultaty przewyższają tę ocenę.

Tabela 31. Rezultaty zarządzania jakością - średnie odchylenie ważności w zależności od funkcjonowania certyfikowanego systemu zarządzania jakością

\begin{tabular}{|l|c|c|c|c|c|}
\hline \multirow{2}{*}{$\begin{array}{c}\text { Wewnętrzne } \\
\text { czynniki zarzą- } \\
\text { dzania jakością }\end{array}$} & $\begin{array}{c}\text {,ISO” } \\
{[\mathbf{2 0 \%}]}\end{array}$ & $\begin{array}{c}\text { „Bez ISO” } \\
{[\mathbf{8 0 \%}]}\end{array}$ & $\begin{array}{c}\text { Test } \\
\text { Levene'a } \\
\text { jednorodno- } \\
\text { ści wariancji }\end{array}$ & $\begin{array}{c}\text { Test t równo- } \\
\text { ści średnich } \\
\text { (założono } \\
\text { równość wa- } \\
\text { riancji) }\end{array}$ & $\begin{array}{c}\text { Test t równo- } \\
\text { ści średnich } \\
\text { (nie założono } \\
\text { równości wa- } \\
\text { riancji) }\end{array}$ \\
\cline { 2 - 6 } & średnia & średnia & istotność & $\begin{array}{c}\text { istotność } \\
\text { dwustronna }\end{array}$ & $\begin{array}{c}\text { istotność } \\
\text { dwustronna }\end{array}$ \\
\hline Niefinansowe & 0,61 & $-0,15$ & 0,000 & $\mathbf{0 , 0 0 0}$ & \\
\hline Finansowe & 0,67 & $-0,16$ & 0,001 & $\mathbf{0 , 0 0 0}$ & \\
\hline Ogólne & $-0,40$ & 0,10 & 0,000 & $\mathbf{0 , 0 0 3}$ & \\
\hline
\end{tabular}

Tabela 32. Rezultaty zarządzania jakością - średnie odchylenie ważności w zależności od okresu prowadzenia dzialalności

\begin{tabular}{|l|c|c|c|c|c|}
\hline $\begin{array}{c}\text { Wewnętrzne } \\
\text { czynniki zarzą- } \\
\text { dzania jakością }\end{array}$ & $\begin{array}{c}\text { Do 6 lat } \\
{[\mathbf{1 8 \%}]}\end{array}$ & $\begin{array}{c}\text { Od 7 lat } \\
{[\mathbf{8 2 \%}]}\end{array}$ & $\begin{array}{c}\text { Test } \\
\text { Levene'a } \\
\text { jednorodno- } \\
\text { ści wariancji }\end{array}$ & $\begin{array}{c}\text { Test t równo- } \\
\text { ści średnich } \\
\text { (założono } \\
\text { równość wa- } \\
\text { riancji) }\end{array}$ & $\begin{array}{c}\text { Test t równo- } \\
\text { ści średnich } \\
\text { (nie założono } \\
\text { równości wa- } \\
\text { riancji) }\end{array}$ \\
\cline { 2 - 6 } & średnia & średnia & istotność & $\begin{array}{c}\text { istotnośćc } \\
\text { dwustronna } \\
\text { dwustronna }\end{array}$ \\
\hline Niefinansowe & 0,39 & $-0,09$ & 0,890 & $\mathbf{0 , 0 0 6}$ & \\
\hline Finansowe & $-0,26$ & 0,06 & 0,026 & 0,074 & \\
\hline Ogólne & 0,09 & $-0,02$ & 0,326 & 0,516 & \\
\hline
\end{tabular}

W analizowaniu odchyleń ważności rezultatów zarządzania jakością według okresu prowadzenia działalności gospodarczej tylko dla jednego rezultatu dane są istotne statystycznie (wykres 36).

Autoryzowane salony sprzedaży i serwisu samochodów osobowych w Polsce funkcjonujące do sześciu lat wyżej oceniają pozytywny wpływ zarządzania jakością na uzyskiwanie niefinansowych rezultatów, niż podmioty prowadzące dłużej działalność gospodarczą. Taki wynik analizy pokrywa się z wynikami ogólnej ważności rezultatów zarządzania jakością przedstawionymi na rysunku 2.

Wyniki analizy zmiany ważności rezultatów zarządzania jakością w zależności od liczby zatrudnionych pracowników w poszczególnych badanych podmiotach nie są istotne statystycznie. 


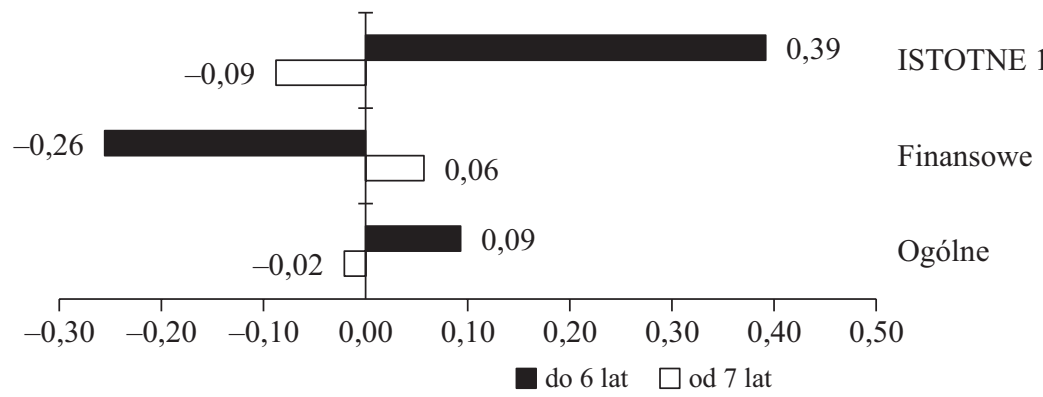

Wykres 36. Rezultaty zarządzania jakością - średnie odchylenie ważności w zależności od okresu prowadzenia działalności (z wyróżnieniem danych istotnych statystycznie)

Tabela 33. Rezultaty zarządzania jakością - średnie odchylenie ważności w zależności od liczby zatrudnionych pracowników

\begin{tabular}{|l|c|c|c|c|c|}
\hline $\begin{array}{c}\text { Wewnętrzne } \\
\text { czynniki zarzą- } \\
\text { dzania jakością }\end{array}$ & Do 25 [30\%] & Od 26 [70\%] & $\begin{array}{c}\text { Test } \\
\text { Levene'a } \\
\text { jednorodno- } \\
\text { ści wariancji }\end{array}$ & $\begin{array}{c}\text { Test t równo- } \\
\text { ści średnich } \\
\text { (założono } \\
\text { równość wa- } \\
\text { riancji) }\end{array}$ & $\begin{array}{c}\text { Test t równo- } \\
\text { ści średnich } \\
\text { (nie założono } \\
\text { równości wa- } \\
\text { riancji) }\end{array}$ \\
\cline { 2 - 7 } & średnia & średnia & istotność & $\begin{array}{c}\text { istotność } \\
\text { dwustronna }\end{array}$ & $\begin{array}{c}\text { istotność } \\
\text { dwustronna }\end{array}$ \\
\hline Niefinansowe & 0,07 & $-0,03$ & 0,901 & 0,485 & \\
\hline Finansowe & 0,15 & $-0,06$ & 0,892 & 0,157 & \\
\hline Ogólne & $-0,18$ & 0,08 & 0,011 & 0,084 & \\
\hline
\end{tabular}

$\mathrm{Na}$ podstawie analizy literatury przedmiotu zidentyfikowano trzy grupy rezultatów zarządzania jakością: ogólne, finansowe oraz niefinansowe. Eksploracyjna analiza czynnikowa zasadniczo nie zmieniła układu rezultatów zarządzania jakością. W wyniku jej zastosowania pozostały trzy grupy. Zatem siedemnaście pierwotnych rezultatów zarządzania jakością zgrupowano w trzech obszarach rezultatów: ogólnych, niefinansowych oraz finansowych. Pomiędzy grupami sprzed analizy i po analizie czynnikowej tylko dwa pojedyncze rezultaty zarządzania jakością zostały inaczej zaszeregowane:

- rezulatat „Osiągamy zaplanowane rezultaty finansowe” z grupy ogólnej został przesunięty do grupy finansowej,

- rezulatat „Zarządzanie jakością pozytywnie wpływa na minimalizację czasu obsługi klientów" został przeniesiony do grupy rezultatów finansowych z grupy rezultatów niefinansowych.

Kształtowanie zidentyfikowanych rezultatów poprzez działania wewnętrzne prowadzi do sukcesu zarządzania jakością w organizacji. Relacjom pomiędzy wewnętrznymi czynnikami a rezultatami zarządzania jakością został poświęcony kolejny punkt niniejszej monografii. 


\subsection{Oddziaływanie wewnętrznych czynników na rezultaty zarządzania jakością}

Współzmienność pomiędzy głównymi wewnętrznymi czynnikami zarządzania jakością a rezultatami zarządzania jakością przedstawiono już w niniejszym rozdziale w punkcie 2.3. Zaprezentowane wyniki analizy danych dotyczą korelacji pomiędzy elementami ujętymi wprost w kwestionariuszu ankietowym. Relacje przedstawione $\mathrm{w}$ niniejszym punkcie dotyczą współzależności pomiędzy wewnętrznymi czynnikami projakościowego zarządzania w organizacji a rezultatami tych działań zidentyfikowanymi w wyniku przeprowadzonej eksploracyjnej analizy czynnikowej.

Wyniki analizy współzmienności pomiędzy analizowanymi zmiennymi zostały przedstawione w tabeli 34, w której zostały umieszczone dane wyłącznie istotne statystycznie. Komórki z maksymalną dodatnią wartością współzmienności oraz wszystkie (dwie) ujemne zostały wyróżnione pogrubionymi krawędziami.

Tabela 34. Współzmienność pomiędzy wewnętrznymi czynnikami, a rezultatami zarządzania jakością - statystyczne wyniki korelacji

\begin{tabular}{|l|l|c|c|c|}
\hline \multirow{2}{*}{$\begin{array}{c}\text { Wewnętrzne czynniki } \\
\text { zarządzania jakością }\end{array}$} & \multirow{2}{*}{$\begin{array}{c}\text { Parametry } \\
\text { statystyczne }\end{array}$} & \multicolumn{3}{|c|}{ Rezultaty zarzadzania jakością } \\
\cline { 3 - 5 } & niefinansowe & finansowe & ogólne \\
\hline \multirow{2}{*}{ 1. Przywództwo i kultura jakości } & korelacja & $0,417^{* *}$ & $0,343^{* *}$ & $0,259^{* *}$ \\
\cline { 2 - 5 } & istotność & 0,000 & 0,000 & 0,000 \\
\hline \multirow{2}{*}{ 2. Dualizm jakości „klienci-pracownicy”” } & korelacja & $0,491^{* *}$ & $0,222^{* *}$ & $0,175^{* *}$ \\
\cline { 2 - 5 } & istotność & 0,000 & 0,001 & 0,009 \\
\hline \multirow{2}{*}{ 3. Podejście prewencyjne do jakości } & korelacja & & & $-0,422^{* *}$ \\
\cline { 2 - 5 } & istotność & & & 0,000 \\
\hline \multirow{2}{*}{ 4. Orientacja na klienta } & korelacja & $0,377^{* *}$ & $0,133^{*}$ & $0,150^{*}$ \\
\cline { 2 - 5 } & istotność & 0,000 & 0,049 & 0,026 \\
\hline \multirow{2}{*}{ 5. Szanse i zagrożenia jakości } & korelacja & $-0,203^{* *}$ & $0,434^{* *}$ & \\
\cline { 2 - 5 } & istotność & 0,003 & 0,000 & \\
\hline \multirow{2}{*}{ 6. Planowanie jakości } & korelacja & $0,300^{* *}$ & $0,291^{* *}$ & $0,335^{* *}$ \\
\cline { 2 - 5 } & istotność & 0,000 & 0,000 & 0,000 \\
\hline \multirow{2}{*}{ 7. Priorytetyzacja jakości } & korelacja & $0,163^{*}$ & & $0,166^{*}$ \\
\hline \multirow{2}{*}{ 8. Podejście reakcyjne do jakości } & istotność & 0,016 & & 0,014 \\
\hline & korelacja & $0,147^{*}$ & $0,386^{* *}$ & $0,354^{* *}$ \\
\cline { 2 - 5 } & istotność & 0,030 & 0,000 & 0,000 \\
\hline
\end{tabular}

${ }^{a}$ Współczynnik korelacji Pearsona, przyjmuje wartości od -1 do +1 . Analizując wartość bezwzględną: do 0,1 występuje niska korelacja, do 0,3 słaba, do 0,5 przeciętna, do 0,7 wysoka, do 0,9 bardzo wysoka, do 1 prawie pełna.

$\mathrm{b} * *$ Korelacja istotna dwustronnie na poziomie 0,01 .

* Korelacja istotna dwustronnie na poziomie 0,05 . 
Maksymalna bezwzględna wartość współczynnika korelacji Pearsona dla analizowanych w tabeli zmiennych wynosi 0,491 . Oznacza to, że maksymalna zidentyfikowana współzmienność pomiędzy wewnętrznymi czynnikami a rezultatami projakościowego zarządzania w organizacji jest przeciętna.

Relacje zostały przedstawione graficznie na rysunku 6, gdzie dla najwyższej współzmienności strzałka została pogrubiona, a w przypadku ujemnych jest przerywana.

Analizując przeciętną współzmienność wzrostową pomiędzy wewnętrznymi czynnikami zarządzania jakością a rezultatami zarządzania jakością, można wskazać na następujące zależności:

1. „Przywództwo i kultura jakości” wpływa zarówno na rezultaty niefinansowe, jak i finansowe.

2. „Dualizm jakości «klienci-pracownicy»” oddziałuje na niefinansowe rezultaty zarządzania jakością.

3. „Orientacja na klienta” jest współzmienna z niefinansowymi rezultatami zarządzania jakością.

4. „Szanse i zagrożenia jakości” oddziałują obustronnie z finansowymi rezultatami zarządzania jakością.

5. „Planowanie jakości”, jako jedyny czynnik, jest współzmienne z dwoma rezultatami zarządzania jakością - finansowymi oraz ogólnymi.

6. „Podejście reakcyjne do jakości” jest skorelowane z finansowymi rezultatami zarządzania jakością.

7. „Podejście reakcyjne do jakości” oddziałuje na ogólne rezultaty zarządzania jakością.

W ramach analizy korelacji zostały zidentyfikowane dwie ujemne współzmienności. Słaba współzmienność (na poziomie $-0,203$ ) dotyczy relacji pomiędzy wewnętrznym czynnikiem „Szanse i zagrożenia jakości’ względem niefinansowych rezultatów projakościowego zarządzania w organizacji. Natomiast przeciętna ujemna współzmienność (wartość - 0,422 ) dotyczy zależności pomiędzy wzrostem znaczenia „Podejścia prewencyjnego do jakości” a spadkiem ogólnych rezultatów zarządzania jakością. Dosyć dziwnym w interpretacji może się wydawać wpływ większego zaangażowania organizacji w działania prewencyjne w obszarze jakościowym względem spadku ważności rezultatu osiągania zaplanowanych celów jakościowych (III.3). Jest to przykład, który wskazuje, że eksploracyjna analiza czynnikowa uwidacznia ukryte statystyczne zależności, które wymagają merytorycznej analizy i interpretacji. W tym przypadku trudno jest znaleźć logiczne wytłumaczenie, że wzrostowi natężenia działań projakościowych towarzyszy niższa realizacja zaplanowanych celów jakościowych. W tym obszarze analizy można by zwrócić uwagę, że wyższa ważność podejścia prewencyjnego do jakości oznacza niższą ocenę ważności osiągania zaplanowanych rezultatów finansowych. Działania prewencyjne są podejmowane w organizacji 


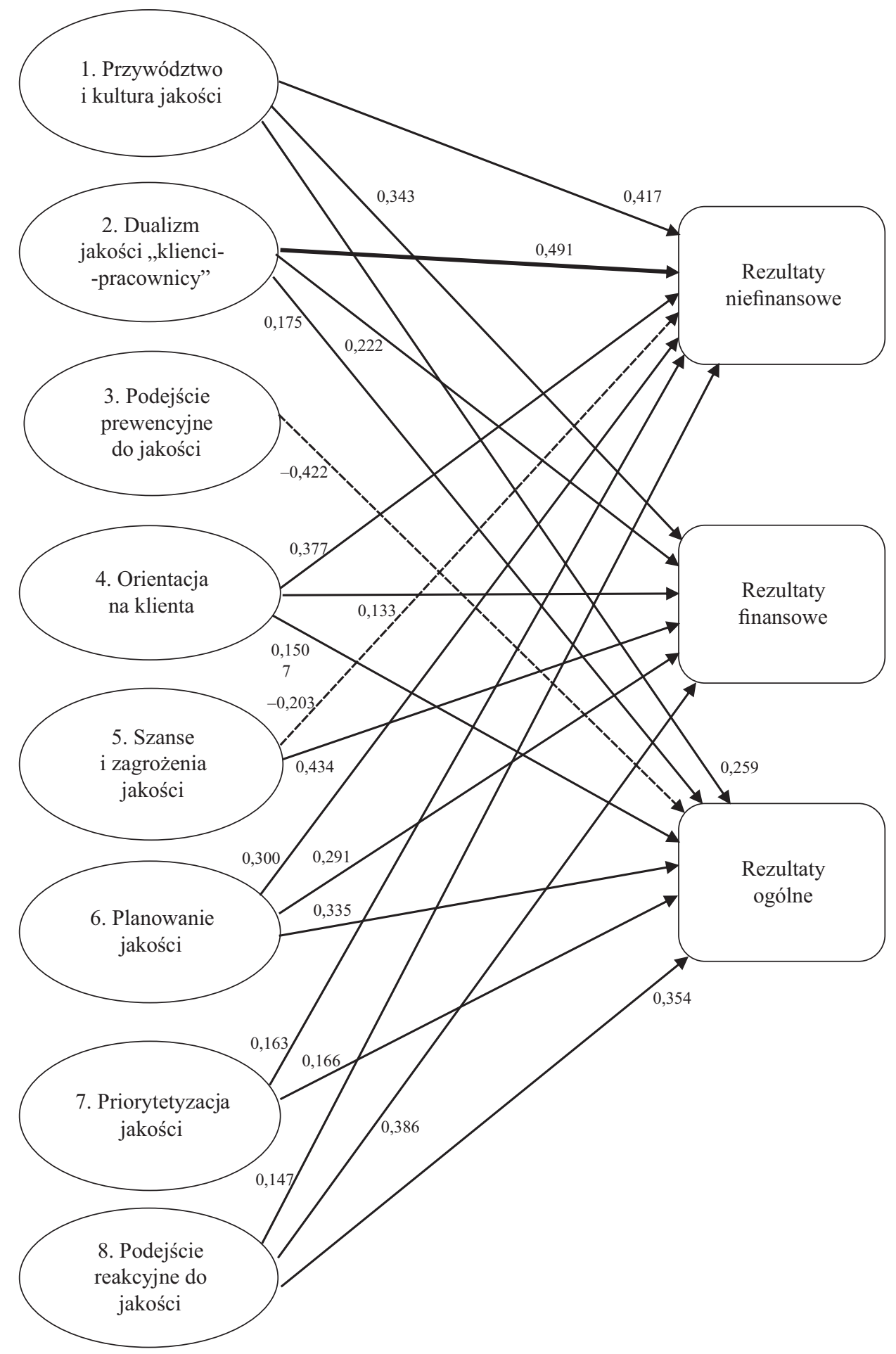

Rysunek 6. Wspótzmienność pomiędzy wewnętrznymi czynnikami a rezultatami zarządzania jakością 
każdego dnia i są na bieżąco dostosowywane do zmieniających się okoliczności gospodarowania. Można zatem przypuszczać, że bieżąca modyfikacja różnorodnych działań w ukierunkowaniu na zapewnienie odpowiedniej jakości efektu końcowego prowadzi do generowania dodatkowych kosztów, co wpływa na niższy od zaplanowanego wynik finansowy. Takie zagadnienia stanowią jednak ogólne przypuszczenie interpretacyjne zidentyfikowanych zależności. Analiza danych i zidentyfikowane zależności pozwalają na stworzenie obrazu statystycznych zależności na podstawie danych uzyskanych z badania ankietowego o danej charakterystyce podmiotowej, przedmiotowej, przestrzennej i czasowej.

Analizując powyższe korelacyjne relacje (przeciętne statystycznie) od strony rezultatów projakościowego zarządzania w organizacji, można zwrócić uwagę, że każdy rezultat jest współzmienny z trzema wewnętrznymi czynnikami zarządzania jakością. Natomiast jeden wewnętrzny czynnik zarządzania jakością „Szanse i zagrożenia jakości” jest współzmienny z dwoma rezultatami zarządzania jakością w organizacji.

Jest zauważalne, że zdecydowana większość wewnętrznych czynników zarządzania jakością nie jest skorelowana $\mathrm{z}$ więcej niż jednym rezultatem zarządzania jakością. Oznacza to, że koncentracja działań wewnątrzorganizacyjnych na danym czynniku pozwala w największym stopniu oddziaływać na rezultaty projakościowego zarządzania w organizacji w jednym obszarze. Działania zgrupowane w poszczególnych wewnętrznych czynnikach są realizowane w ramach zarządzania jakością stanowiącego część zarządzania organizacją. Nie sposób zatem analizować wyników badania w oderwaniu od interakcji zachodzących w całej organizacji, które są wielokierunkowe i o złożonym charakterze. Jednak zidentyfikowanie relacji ukazujących wpływ wewnętrznych czynników na rezultaty zarządzania jakością pozwala na wyłonienie spośród sieci powiązań najistotniejszych. Zidentyfikowane relacje wynikają $\mathrm{z}$ odpowiedzi respondentów uwzględniających czynniki umieszczone w kwestionariuszu ankietowym. Analizy związane z rzetelnością narzędzia badawczego wskazały na poprawność przyjętych składowych wyjaśniających w zdecydowanej większości zmienność obszaru badawczego. Jednak przedstawiane wyniki należy traktować jako wyłonienie relacji, które odnoszą się do przyjętego zakresu podmiotowego.

\section{Konkluzje badawcze}

W ramach statystycznej obróbki danych można wyróżnić dwie płaszczyzny w przeprowadzonych analizach i interpretacji wyników.

Pierwsza płaszczyzna dotyczy ogólnych danych odnoszących się wprost do czynników ujętych w kwestionariuszu ankietowym, których analizy dotyczyły 
ogólnej ważności głównych wewnętrznych czynników zarządzania jakością, składowych je konstytuujących oraz rezultatów projakościowego zarządzania $\mathrm{w}$ organizacji.

Druga płaszczyzna jest związana $\mathrm{z}$ analizą danych uzyskanych w ramach eksploracyjnej analizy czynnikowej. Składowe wyodrębnione w wyniku zastosowania tej statystycznej metody dotyczą zarówno wewnętrznych czynników, jak i rezultatów projakościowego zarządzania w organizacji.

W ramach pierwszej płaszczyzny analizy danych można wskazać na ramowe wnioski:

1. Respondenci ocenili, że wszystkie osiem głównych wewnętrznych czynników zarządzania jakością pozytywnie wpływa na rezultaty zarządzania jakością.

2. Jako najważniejszy główny wewnętrzny czynnik zarządzania jakością wskazane zostało „Zaangażowanie pracowników”.

3. W organizacjach posiadających certyfikowany, znormalizowany system zarządzania jakością pozytywny wpływ wewnętrznych czynników na rezultaty projakościowego zarządzania $\mathrm{w}$ organizacji jest oceniany na wyższym poziomie niż w autoryzowanych salonach sprzedaży i serwisu, które nie posiadają ,certyfikatu ISO 9001”.

4. Rezultaty zarządzania jakością ujęte w grupie „ogólne” zostały najwyżej ocenione przez respondentów.

5. Wraz ze wzrostem okresu prowadzenia działalności gospodarczej respondenci z autoryzowanych salonów sprzedaży i serwisu samochodów osobowych w Polsce coraz wyżej oceniają wpływ zarządzania jakością na rezultaty ze sfery finansowej.

6. Z potencjalnych 28 zależności korelacyjnych pomiędzy głównymi wewnętrznymi czynnikami zarządzania jakością 26 zostało zidentyfikowanych jako istotne statystycznie.

7. Spośród powyższych 26 relacji 24 zidentyfikowane zostały na poziomie istotności statystycznej poniżej 0,01 , a dwie poniżej 0,05 .

8. Cztery najsilniejsze zależności korelacyjne (współczynniki Pearsona powyżej 0,7$)$ pomiędzy głównymi wewnętrznymi czynnikami zarządzania jakością dotyczą współzmienności pomiędzy:

- „Ciągłym doskonaleniem” a „Zarządzaniem na podstawie faktów”,

- „Przywództwem i zaangażowaniem najwyższego kierownictwa” a „Orientacją na klienta",

- „Zarządzaniem na podstawie faktów” a „Ciągłym doskonaleniem”,

- „Zarządzaniem procesowym” a „Zarządzaniem na podstawie faktów”.

9. Nieistotne statystycznie okazały się dwie współzmienności pomiędzy następującymi głównymi wewnętrznymi czynnikami zarządzania jakością: 
- „Przywództwo i zaangażowanie najwyższego kierownictwa” a „Zarządzanie na podstawie faktów”,

- „Planowanie strategiczne i operacyjne” a „Zaangażowanie pracowników".

10. Dla maksymalnej liczby 136 zależności korelacyjnych pomiędzy ośmioma głównymi wewnętrznymi czynnikami zarządzania jakością a siedemnastoma rezultatami zarządzania jakością $\mathrm{w}$ organizacji zidentyfikowano 105 (wyłącznie dodatnich współzmienności) współzmienności istotnych statystycznie (10 na poziomie istotności poniżej 0,05 , a 95 na poziomie 0,01 ).

11. Sześć najsilniejszych zależności korelacyjnych (współczynniki Pearsona powyżej 0,6 ) pomiędzy głównymi wewnętrznymi czynnikami zarządzania jakością a rezultatami zarządzania jakością dotyczy:

- „Przywództwa i zaangażowania najwyższego kierownictwa” a „Osiągania zaplanowanych celów" jakościowych",

- „Przywództwa i zaangażowania najwyższego kierownictwa” a „Pozytywnego wpływu zarządzania jakością na zwiększenie zaangażowania pracowników",

- „Orientacji na klienta” a „Osiągania zaplanowanych celów” jakościowych",

- „Orientacji na klienta” a „Pozytywnego wpływu zarządzania jakością na minimalizację fluktuacji pracowników”,

- „Orientacji na klienta” a „Pozytywnego wpływu zarządzania jakością na pozyskanie nowych klientów",

- „Zarządzania procesowego” a „Pozytywnego wpływu zarządzania jakością na zwiększenie współpracy pomiędzy działami w organizacji”.

W ramach drugiej płaszczyzny analizy danych można wskazać na ramowe wnioski:

1. W ramach przeprowadzonej eksploracyjnej analizy czynnikowej zidentyfikowano składowe:

- osiem wewnętrznych czynników zarządzania jakością (stanowiących zbiory zawierające $\mathrm{w}$ sobie wszystkie pierwotne elementy konstytuujące literaturowe główne wewnętrze czynniki zarządzania jakością),

- trzy rezultaty zarządzania jakością (stanowiące zbiory zawierające w sobie wszystkie siedemnaście pierwotnych rezultatów zarządzania jakością).

2. Jako najistotniejszy wewnętrzny czynnik zarządzania jakością został zidentyfikowany obszar zawierający 38 pierwotnych elementów opisujących czynniki. Obszar ten, z uwagi na charakter elementów konstytuujących, nazwany został „Przywództwo i kultura jakości” i wyjaśnia prawie 32\% zmienności analizowanego obszaru.

3. Osiem wewnętrznych czynników projakościowego zarządzania w organizacji wyjaśnia prawie $82 \%$ zmienności analizowanego obszaru. 
4. W trzech wewnętrznych czynnikach zarządzania jakością $\mathrm{w}$ organizacji przeważają elementy składowe z obszaru podejścia opartego na ryzyku: „Podejście prewencyjne do jakości”, „Szanse i zagrożenia jakości”, „Podejście reakcyjne do jakości".

5. Wynikiem zastosowania eksploracyjnej analizy czynnikowej w obszarze rezultatów zarządzania jakością było zidentyfikowanie trzech grup rezultatów: ogólnych, niefinansowych, finansowych.

6. Trzy grupy rezultatów zarządzania jakością wyjaśniają prawie $73 \%$ zmienności analizowanego obszaru.

7. Trzy najsilniejsze zidentyfikowane zależności korelacyjne pomiędzy wewnętrznymi czynnikami zarządzania jakością a rezultatami zarządzania jakością dotyczą (współczynniki Pearsona powyżej 0,4):

- dodatniej współzmienności pomiędzy „Dualizmem jakości «klienci-pracownicy»" a niefinansowymi rezultatami zarządzania jakością,

- dodatniej zależności korelacyjnej pomiędzy „Przywództwem i kulturą jakości” a niefinansowymi rezultatami zarządzania jakością,

- ujemnej współzmienności pomiędzy „Podejściem prewencyjnym do jakości” a ogólnymi rezultatami zarządzania jakością.

8. Jeden wewnętrzny czynnik projakościowego zarządzania $\mathrm{w}$ organizacji „Szanse i zagrożenia jakości” jest współzmienny z dwoma rezultatami zarządzania jakością, raz w sposób dodatni, a raz ujemnie. Wzrost znaczenia tego wewnętrznego czynnika oznacza malejące (słabo) rezultaty niefinansowe, a jednocześnie wzrost (przeciętny) rezultatów finansowych. Większość (5 na 7) elementów konstytuujących tenże wewnętrzny czynnik zarządzania jakością dotyczy aspektu ryzyka. Charakter tych elementów wskazuje na minimalizację zagrożeń oraz maksymalizację szans i stąd też przyjęta nazwa danego wewnętrznego czynnika. Można przypuszczać, że takie wyniki statystycznej obróbki danych ukazują niewidzialne wprost relacje, które właśnie w wyniku analizy ujawniają istotę i ważność podejmowania różnorodnych działań wewnątrzorganizacyjnych. Działania ukierunkowane na minimalizację zagrożeń oraz maksymalizację szans generują aktywności, które wymagają czasu i koncentracji kosztem podejmowania innych działań. Operacyjnie zatem można by wskazać na „stratę czasu”, ale ostatecznie te działania pozytywnie wpływają na rezultaty finansowe.

Zawartość niniejszego rozdziału pracy jest związana z analizą danych uzyskanych w badaniu ankietowym wśród autoryzowanych salonów sprzedaży i serwisu samochodów osobowych w Polsce. Zagadnienia opisane w niniejszym rozdziale pozwoliły, zdaniem autora, na zrealizowanie empirycznych celów pracy:

1. Oceniono ważność elementów konstytuujących poszczególne wewnętrzne czynniki projakościowego zarządzania $\mathrm{w}$ organizacji oraz relacje pomiędzy tymi elementami. 
2. Oceniono ważność wewnętrznych czynników zarządzania jakością w organizacji oraz zależności zachodzących pomiędzy nimi.

3. Oceniono ważność oraz zhierarchizowano rezultaty projakościowego zarządzania w organizacji.

4. Zidentyfikowano relacje i oceniono oddziaływania pomiędzy wewnętrznymi czynnikami a rezultatami projakościowego zarządzania w organizacji.

Zagadnienia przedstawione $\mathrm{w}$ niniejszym rozdziale monografii stanowią podstawę do analiz i wniosków zaprezentowanych w V rozdziale monografii, a ukierunkowanych na weryfikację hipotez badawczych. 


\section{Rozdział V \\ KLUCZOWE ZAGADNIENIA W OSIĄGANIU SUKCESU W ZARZĄDZANIU JAKOŚCIĄ}

Treść niniejszego rozdziału została skoncentrowana na poszukiwaniu uwarunkowań dla uzyskanych wyników ankietowych oraz zestawieniu najważniejszych efektów badawczych w celu wskazania kluczowych zagadnień w osiąganiu sukcesu w projakościowym zarządzaniu w organizacji.

\section{Analiza skupień w zarządzaniu jakością}

W celu zidentyfikowania homogenicznych grup obiektów autoryzowanych salonów sprzedaży i serwisu samochodów osobowych zastosowano statystyczną analizę skupień. Kryterium w statystycznej identyfikacji skupień stanowiły pytania ujęte w kwestionariuszu ankietowym. Na podstawie podobieństw w odpowiedziach udzielanych przez respondentów zidentyfikowano pięć skupień. Następnie zidentyfikowane grupy poddano analizom w celu identyfikacji cech pozwalających scharakteryzować poszczególne zbiory, aby w praktycznym ujęciu zwrócić uwagę na zagadnienia wpływające na sukces projakościowego zarządzania w organizacji.

Analizując udział badanych lokalizacji w poszczególnych skupieniach według marek obsługiwanych samochodów, nie jest możliwe jednoznaczne zidentyfikowanie wyróżniającej się marki ani co do udziału w jednym skupieniu, ani co do powtarzalności w różnych z nich. Szczegółowe analizy danych, oddzielnie w ramach każdego skupienia, nie pozwoliły na zidentyfikowanie marek samochodów jako kryterium przynależności do poszczególnych skupień. Analizy szczegółowe skoncentrowano na: markach samochodów (premium, wolumenowych), przynależności do danego koncernu motoryzacyjnego, ilościowych rankingach sprzedaży. Również analiza skupień według lokalizacji autoryzowanych salonów sprzedaży i serwisu samochodów osobowych w poszczególnych 
województwach w Polsce nie pozwoliła na zidentyfikowanie wyróżniających się regionów pod względem wartości danych.

Tabela 35. Charakterystyka skupień według marek samochodów i zlokalizowania podmiotów

\begin{tabular}{|c|c|c|c|}
\hline Skupienie & $\begin{array}{c}\text { Liczebność } \\
\text { lokalizacji }\end{array}$ & $\begin{array}{c}\text { Udział marek } \\
\text { [liczba w skupieniu / } \\
\text { procent ogółu marek] }\end{array}$ & $\begin{array}{c}\text { Udzial województw } \\
\text { [liczba w skupieniu / } \\
\text { procent ogółu województw] }\end{array}$ \\
\hline 1 & 101 & $22 / 61 \%$ & $16 / 100 \%$ \\
\hline 2 & 54 & $11 / 31 \%$ & $15 / 94 \%$ \\
\hline 3 & 29 & $7 / 19 \%$ & $9 / 56 \%$ \\
\hline 4 & 22 & $4 / 11 \%$ & $12 / 84 \%$ \\
\hline 5 & 13 & $4 / 11 \%$ & $7 / 44 \%$ \\
\hline
\end{tabular}

Na podstawie danych zawartych w tabeli 35 można przypuszczać, że ani uwarunkowania lokalizacyjne, ani autoryzacja danej marki, przyznawana poszczególnym salonom sprzedaży i serwisu samochodów osobowych w Polsce, nie decyduje o przynależności do danego skupienia jako jednorodnej grupy. Oznacza to, że ani autoryzacja, ani lokalizacja badanych podmiotów nie decydują o ważności poszczególnych wewnętrznych czynników zarządzania jakością w organizacji i relacjach do rezultatów podejmowanych działań.

Dalsze analizy zostały skoncentrowane na różnicowaniu ważności poszczególnych wewnętrznych czynników zarządzania jakością w podmiotach ujętych w poszczególnych skupieniach.

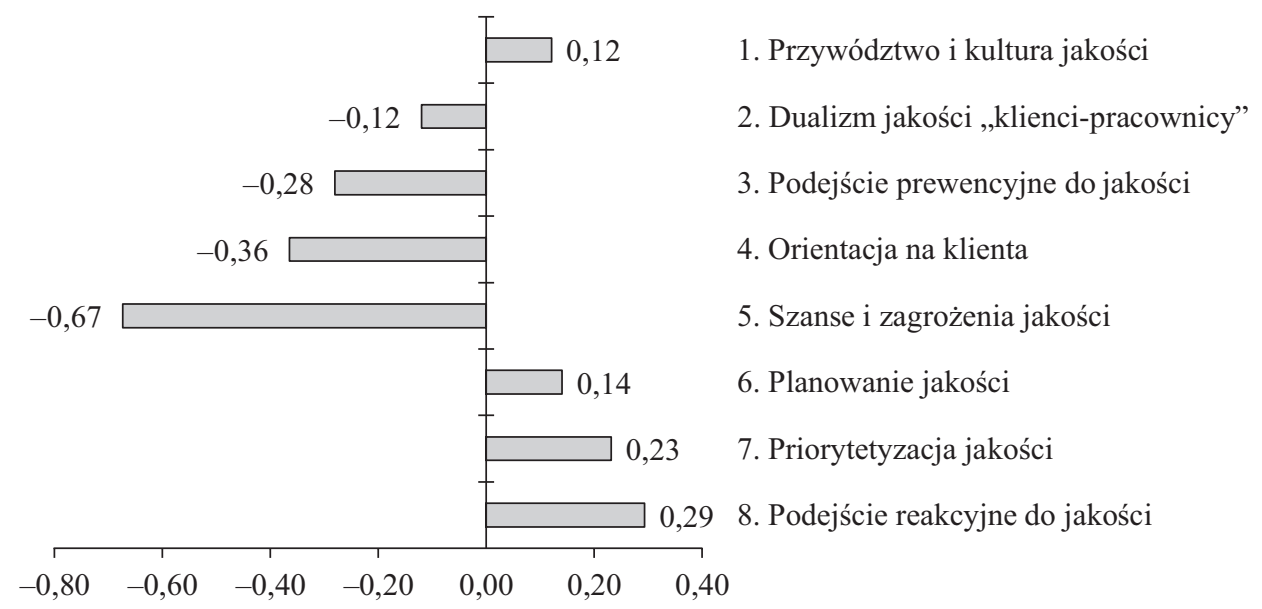

Wykres 37. Wewnętrzne czynniki zarządzania jakością - średnie odchylenie ważności w pierwszym skupieniu 
Respondenci zgrupowani w pierwszym statystycznym skupieniu wyżej od średniej zestandaryzowanej ważności wewnętrznych czynników projakościowego zarządzania w organizacji oceniają „Przywództwo i kulturę jakości”. Czynnik ten grupuje największą liczbę pierwotnych elementów składowych i nadaje ogólny klimat działaniom z zakresu zarządzania jakością. Zauważalne jest również wyższe ocenianie przez podmioty tego skupienia ważności wewnętrznych czynników dotyczących planowania jakości i uwzględnienia jej jako priorytetu w prowadzonej działalności. Jednoczesne wyższe ocenianie podejścia reakcyjnego do jakości można interpretować tak, że po etapie planowania nie ma w organizacji koncentracji na kliencie, ani prewencyjnym podejściu do jakości powiązanym również z identyfikacją szans i zagrożeń. To może wskazywać na charakter podmiotów, które planują i działają bez atmosfery podejścia opartego na ryzyku, dokonując jedynie korekt i działań korygujących po wystąpieniu niezgodności.

W drugim statystycznym skupieniu znajdują się autoryzowane salony sprzedaży i serwisu samochodów osobowych w Polsce, które tylko jeden wewnętrzny czynnik zarządzania jakością oceniają niewiele niżej od średniej ważności dla wszystkich.

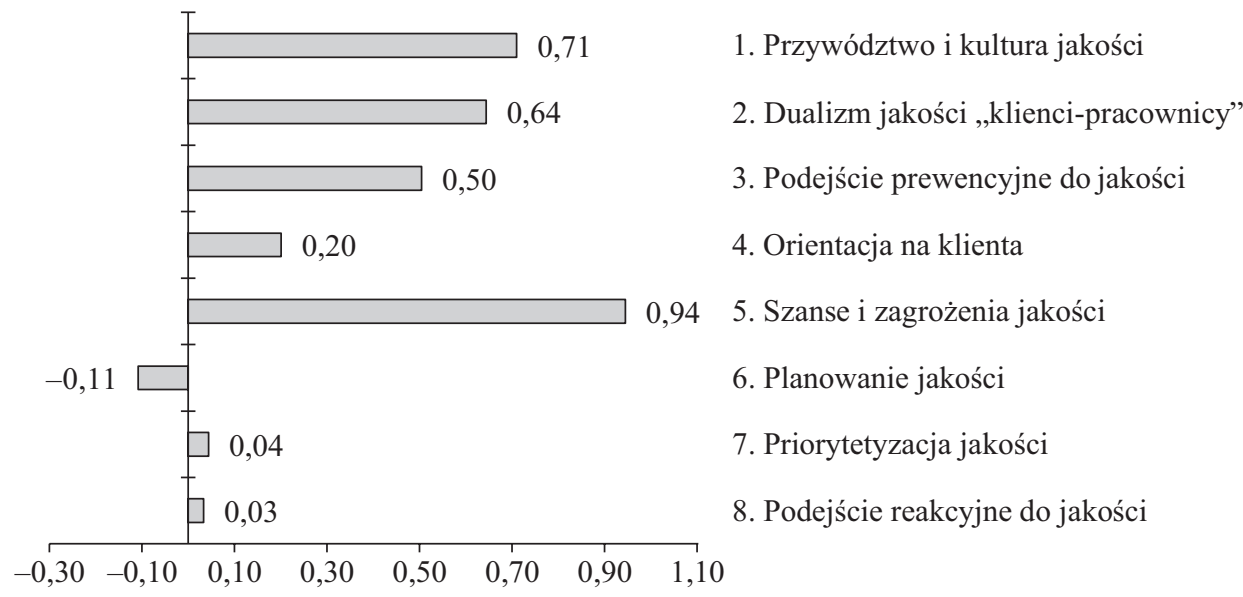

Wykres 38. Wewnętrzne czynniki zarządzania jakością - średnie odchylenie ważności w drugim skupieniu

Podmioty z drugiego skupienia w mniejszym stopniu od średniej ważności oceniają wpływ planowania na rezultaty zarządzania jakością, jednak zdecydowanie bardziej koncentrują się w swoich działaniach na szansach i zagrożeniach związanych z prowadzonymi działaniami. Również wyżej od średniej ważności oceniają działania prewencyjne i orientację na klienta. Całościowo te zagadnienia łączą się z postrzeganą istotnością przywództwa i kultury jakości. Taki 
rozkład zmian w ważności poszczególnych wewnętrznych czynników zarządzania jakością może wskazywać na koncentrację podmiotów tego skupienia na podejściu opartym na ryzyku w ukierunkowaniu na spełnianie potrzeb i oczekiwań klientów.

W trzecim statystycznym skupieniu zauważalne jest nadawanie przez respondentów przeciwstawnych ocen dwóm wewnętrznym czynnikom projakościowego zarządzania $\mathrm{w}$ organizacji, które obszarowo są ze sobą powiązane. „Orientacja na klienta” jest zdecydowanie wyżej oceniana od ogólnej ważności tego czynnika w badaniu empirycznym (najwyższa dodatnia wartość w analizowanych skupieniach). Natomiast powiązanie orientacji na klienta z kwestiami pracowników jest w podmiotach zaklasyfikowanych do analizowanego skupienia zdecydowanie mniej istotne w porównaniu do średniego poziomu ważności analizowanych wewnętrznych czynników zarządzania jakością w organizacji.

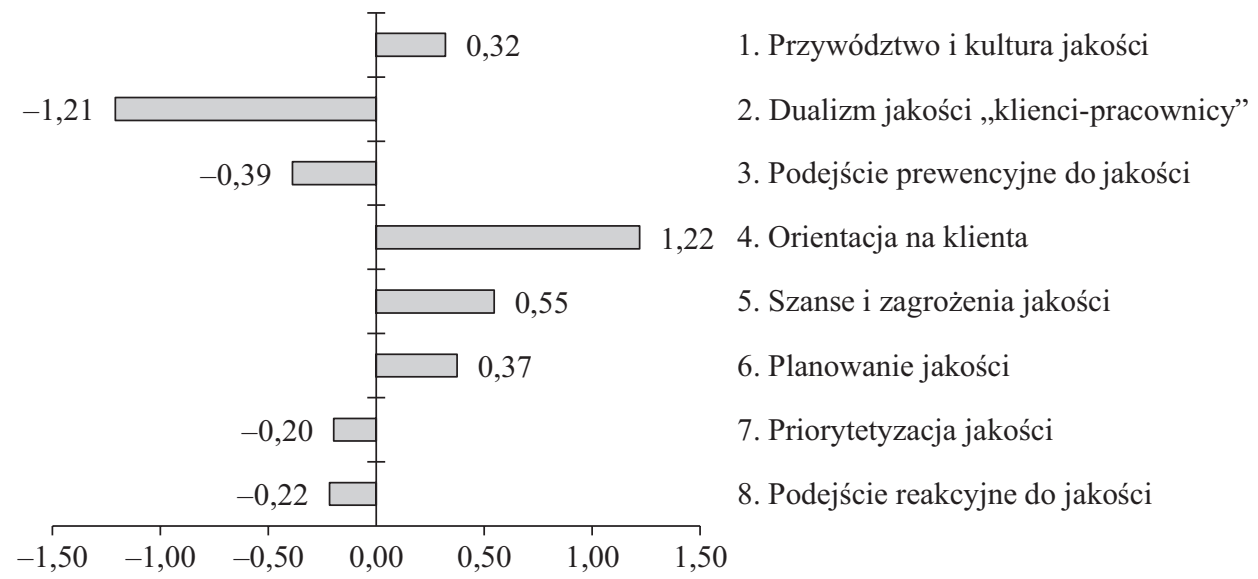

Wykres 39. Wewnętrzne czynniki zarządzania jakością - średnie odchylenie ważności w trzecim skupieniu

Powyższe wyniki można interpretować w ten sposób, że w organizacjach tego skupienia panuje pozytywne podejście do jakości. Jednak podejście prewencyjne i priorytetyzacja jakości jest niżej oceniana. Zupełnie przeciwstawnie respondenci z tego skupienia oceniają dwa inne czynniki. Zdecydowanie wyżej wskazują na pozytywny wpływ „Orientacji na klienta” na sukces zarządzania jakością w organizacji. Jednocześnie na podobnym poziomie, ale niżej od średniej w badaniu oceniają dualistyczny wpływ zależności „klienci-pracownicy”. Takie wyniki mogą sugerować „fasadowe podejście do jakości”, że zewnętrznie organizacja stara się pokazać, że klienci są najważniejsi, ale jednocześnie pracownicy nie koncentrują się na tych działaniach w organizacji. 
W czwartym skupieniu występuje sytuacja odwrotna wobec drugiej grupy analizowanych organizacji. Tylko jeden wewnętrzny czynnik zarządzania jakością związany z klientami i pracownikami został wyżej oceniony od średniej ważności tego czynnika.

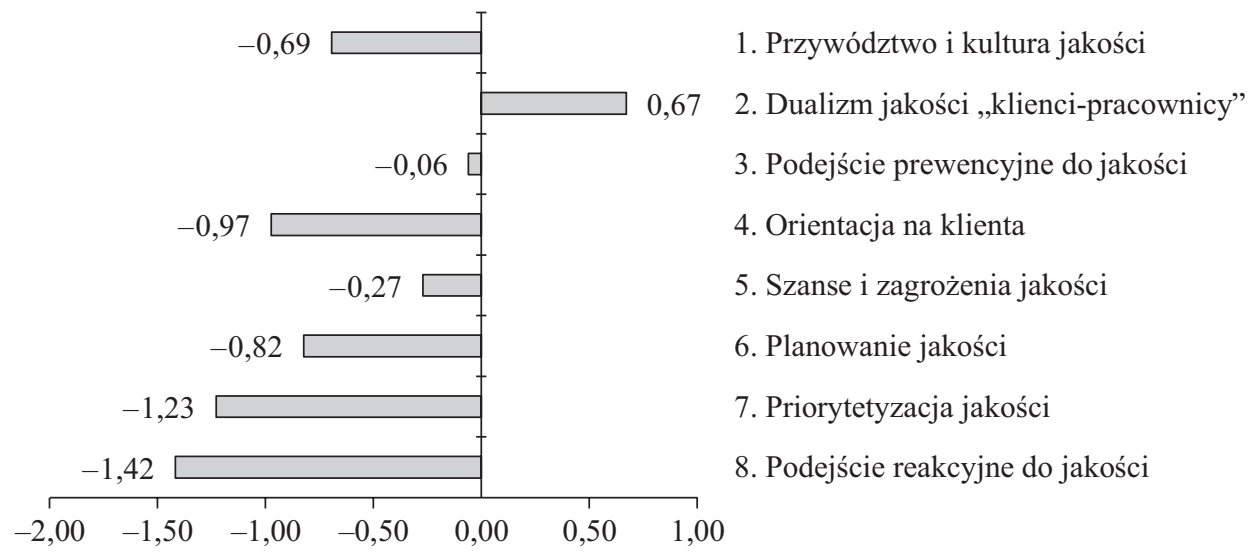

Wykres 40. Wewnętrzne czynniki zarządzania jakością - średnie odchylenie ważności w czwartym skupieniu

Respondenci z autoryzowanych salonów sprzedaży i serwisu samochodów osobowych w Polsce zaklasyfikowanych do czwartego statystycznego skupienia aż siedem na osiem wewnętrznych czynników zarządzania jakością oceniają relatywnie znacznie niżej od ich średnich wartości. Takie wyniki mogą sugerować, że pracownicy koncentrują się na działaniach jakościowych na rzecz klientów, przy jednoczesnych niższych ocenach dla pozostałych obszarów. Choć „Orientacja na klienta” jest oceniana zdecydowanie niżej, sama jakość nie stanowi priorytetu w działaniach, przy jednocześnie niskiej ocenie „Przywództwa i kultury jakości”, co jest zauważalne na wykresie 41.

W ostatnim zidentyfikowanym statystycznym skupieniu na uwagę zasługuje zdecydowanie niższa ważność wewnętrznego czynnika „Przywództwo i kultura jakości”.

Wyniki zmian ważności wewnętrznych czynników zarządzania jakością w ostatniej grupie tworzącej statystyczne skupienie przysparzają trudność w merytorycznej ich interpretacji. Zagadnieniem, które mogłoby wpłynąć na wyjaśnienie zdecydowanie niższej oceny „Przywództwa i kultury jakości”, jest kwestia respondentów. Stanowiskowa analiza respondentów nie wskazała jednak na żadną zależność, bowiem siedmiu reprezentantów zaklasyfikowanych zostało do „Służb jakości”, a pozostałych sześciu do „Kierownictwa”. Również analizy $\mathrm{w}$ zależności od funkcjonowania certyfikowanego systemu zarządzania jakością nie umożliwiły wyjaśnienia zdecydowanie niższej wartości oceny 


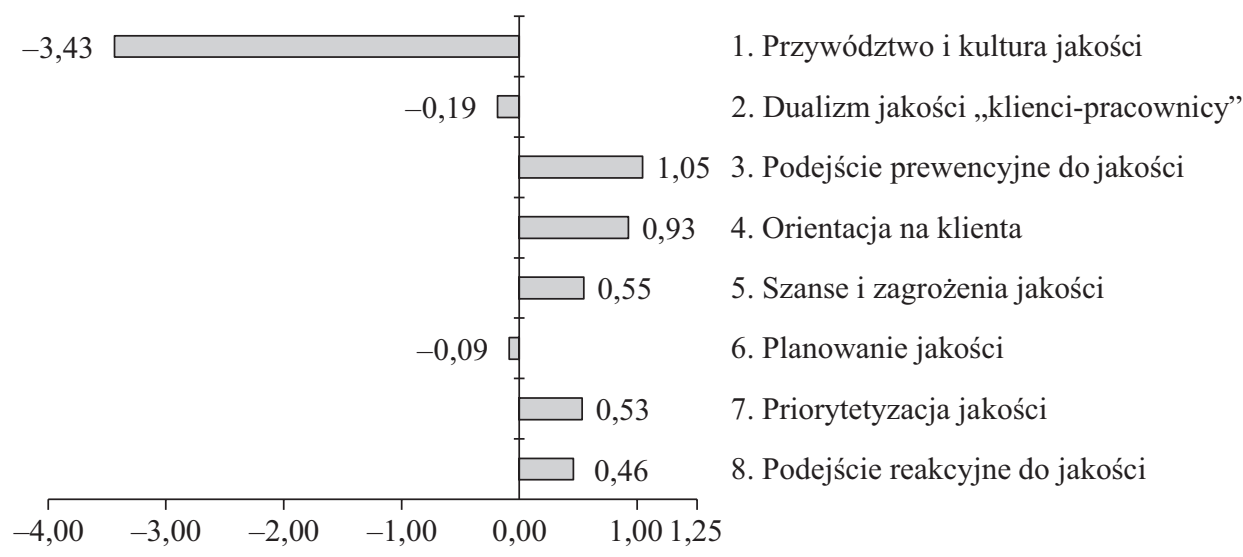

Wykres 41. Wewnętrzne czynniki zarządzania jakością - średnie odchylenie ważności w piątym skupieniu

pierwszego wewnętrznego czynnika zarządzania jakością w analizowanej grupie podmiotów.

Próbując scharakteryzować poszczególne skupienia autoryzowanych salonów sprzedaży i serwisu samochodów osobowych w Polsce, można zbiorczo spojrzeć na skrajne odchylenia ważności poszczególnych czynników projakościowego zarządzania w organizacji od średniej ich ważności, co zostało przedstawione w tabeli 36 .

Tabela 36. Minimalne i maksymalne odchylenia ważności wewnętrznych czynników zarządzania jakością w poszczególnych skupieniach

\begin{tabular}{|c|c|c|}
\hline $\begin{array}{c}\text { Skupienie } \\
\text { (numer) }\end{array}$ & $\begin{array}{c}\text { Odchylenie „,na minus” } \\
\text { (wewnętrzny czynnik zarzadzania ja- } \\
\text { kościa) }\end{array}$ & $\begin{array}{c}\text { Odchylenie „,na plus” } \\
\text { (wewnętrzny czynnik zarzadzania ja- } \\
\text { kościa) }\end{array}$ \\
\hline 1 & $\begin{array}{l}-0,67 \\
\text { 5. Szanse i zagrożenia jakości }\end{array}$ & $\begin{array}{l}+0,29 \\
8 . \text { Podejście reakcyjne do jakości }\end{array}$ \\
\hline 2 & $\begin{array}{l}-0,11 \\
\text { 6. Planowanie jakości }\end{array}$ & $\begin{array}{l}+0,94 \\
\text { 5. Szanse i zagrożenia jakości }\end{array}$ \\
\hline 3 & $\begin{array}{l}\text {-1,21 } \\
\text { 2. Dualizm jakości „klienci-pracownicy” }\end{array}$ & $\begin{array}{l}+1,22 \\
\text { 3. Orientacja na klienta }\end{array}$ \\
\hline 4 & $\begin{array}{l}-1,42 \\
\text { 8. Podejście reakcyjne do jakości }\end{array}$ & $\begin{array}{l}+0,67 \\
\text { 2. Dualizm jakości „klienci-pracownicy” }\end{array}$ \\
\hline 5 & $\begin{array}{l}-3,43 \\
\text { 1. Przywództwo i kultura jakości }\end{array}$ & $\begin{array}{l}+1,05 \\
\text { 4. Podejście prewencyjne do jakości }\end{array}$ \\
\hline
\end{tabular}

W ramach dalszych badań analizowano poszczególne skupienia według: respondentów, posiadania „certyfikatu ISO 9001”, liczby zatrudnionych, rodzaju lokalizacji (centrala, oddział), czasu prowadzenia działalności. Nie zidentyfiko- 
wano żadnych jednoznacznych kryteriów, które wyjaśniałyby przynależność poszczególnych podmiotów do poszczególnych skupień.

W ramach dalszej analizy zidentyfikowanych skupień zostały przeanalizowane odchylenia odpowiedzi respondentów w ramach oceny poszczególnych rezultatów projakościowego zarządzania $\mathrm{w}$ organizacji. Zestawienie ilościowe odchyleń, wraz ze wskazaniem maksymalnych odchyleń w wyższym oraz niższym od średniej ważności ocenianiu rezultatów, zostało ujęte w tabeli 37.

Tabela 37. Skupienia a ocena rezultatów zarządzania jakością

\begin{tabular}{|c|c|c|}
\hline $\begin{array}{l}\text { Skupienie } \\
\text { (liczba od- } \\
\text { chyleń) }\end{array}$ & $\begin{array}{c}\text { Odchylenia „na minus” } \\
\text { (rezultat zarzadzania jakościa) }\end{array}$ & $\begin{array}{c}\text { Odchylenia ,na plus” } \\
\text { (rezultat zarządzania jakościa) }\end{array}$ \\
\hline $\begin{array}{l}1 \\
12 \text { minus } \\
5 \text { plus }\end{array}$ & $\begin{array}{l}-0,64 \\
\text { III.7. Zwiększenie współpracy pomię- } \\
\text { dzy działaniami w organizacji }\end{array}$ & $\begin{array}{l}+0,45 \\
\text { III.17. Maksymalizacja przychodów ze } \\
\text { sprzedaży }\end{array}$ \\
\hline $\begin{array}{l}2 \\
2 \text { minus } \\
15 \text { plus }\end{array}$ & $\begin{array}{l}-0,11 \\
\text { III.1. Klienci są usatysfakcjonowani } \\
\text { z naszymi wyrobami }\end{array}$ & $\begin{array}{l}+0,95 \\
\text { III.7. Zwiększenie współpracy pomię- } \\
\text { dzy działaniami w organizacji }\end{array}$ \\
\hline $\begin{array}{l}3 \text { minus } \\
14 \text { plus }\end{array}$ & $\begin{array}{l}-0,70 \\
\text { III.11. Minimalizacja czasu obsługi } \\
\text { klientów }\end{array}$ & $\begin{array}{l}+1,23 \\
\text { III.8. Pozyskanie nowych klientów }\end{array}$ \\
\hline $\begin{array}{l}4 \\
17 \text { minus } \\
0 \text { plus }\end{array}$ & $\begin{array}{l}-1,76 \\
\text { III.3. Osiąganie zaplanowanych celów } \\
\text { jakościowych }\end{array}$ & - \\
\hline $\begin{array}{l}5 \\
5 \text { minus } \\
12 \text { plus }\end{array}$ & $\begin{array}{l}-2,75 \\
\text { III.4. Osiągamy zaplanowane rezultaty } \\
\text { finansowe }\end{array}$ & $\begin{array}{l}+1,63 \\
\text { III.15. Zmniejszenie niezgodności } \\
\text { wewnętrznych }\end{array}$ \\
\hline
\end{tabular}

Szarym tłem wyróżniono komórki zawierające maksymalne i minimalne odchylenia w ważności rezultatów. Wyraźnie niżej od pozostałych oceniany jest wynik projakościowego zarządzania w organizacji dotyczący osiągania zaplanowanych rezultatów finansowych. Dotyczy to respondentów zgrupowanych w piątym skupieniu, w którym również zidentyfikowano najniższe odchylenie w ocenie ważności czynników wewnętrznych - dla „Przywództwa i kultury jakości”. Zestawiając te dane, można zauważyć, że respondenci, którzy zdecydowanie niżej oceniają kwestie przywództwa najwyższego kierownictwa, również nisko oceniają osiąganie zaplanowanych rezultatów finansowych. Przedstawiając odwrotnie zidentyfikowaną zależność można wskazać, że wyższej ocenie przywództwa towarzyszy wyższa ocena osiągania sukcesu projakościowego zarządzania w organizacji w sferze finansowej.

W skupieniu trzecim znajdują się podmioty reprezentowane przez respondentów, którzy zdecydowanie wyżej (od średniej ważności) ocenili „Pozyskanie 
nowych klientów" jako rezultat zarządzania jakością. Jednocześnie w tymże skupieniu występuje największe dodatnie odchylenie w ważności wewnętrznych czynników zarządzania jakością - „Orientacji na klienta”. Można zatem przyjąć, że wyniki badania potwierdzają, że koncentracja działań na klientach wpływa pozytywnie na pozyskanie nowych klientów.

Poszczególne skupienia przywoływane zostały w porządku malejącym według ich podmiotowej liczebności. Trudność w charakteryzacji poszczególnych skupień jest związana z brakiem jednoznacznych uwarunkowań wskazujących i jednocześnie uzasadniających przynależność poszczególnych badanych lokalizacji do poszczególnych skupień. Dlatego też autor niniejszej pracy zdecydował o pozostawieniu skupień bez ich nazywania, bowiem przy wskazanych uwarunkowaniach tytuły bazowałyby na niewielkich odchyleniach i samą nazwą mogłyby sugerować większą odmienność od rzeczywistej. $\mathrm{Z}$ drugiej strony powstaje pytanie, na ile pewne dane kryterialne dotyczące skupien miałyby praktyczny wymiar. Dla przykładu informacja, że pracownicy salonów sprzedaży i serwisu samochodów osobowych danej marki wyżej od średnich wartości oceniają wszystkie wewnętrzne czynniki oraz rezultaty projakościowego zarządzania $\mathrm{w}$ organizacji, nie wpłynęłaby na chęć zmiany u innych podmiotów autoryzacji. Jednak takie wyniki oznaczałyby, że prawdopodobnie przewaga jakościowa $\mathrm{w}$ tych lokalizacjach jest związana $\mathrm{z}$ wymaganiami autoryzacyjnymi, jak również - na wcześniejszym etapie - z jakością samego pojazdu i kwestią jego wytwarzania. Jednak są to jedynie dywagacje natury ogólnej, natomiast wniosek płynący ze szczegółowej analizy danych dotyczącej skupień badanych podmiotów wydaje się jeden, zasadniczy. O ważności i relacjach pomiędzy wewnętrznymi czynnikami a rezultatami zarządzania jakością decydują działania wewnętrzne w organizacji (ujęte jako elementy konstytuujące wewnętrzne czynniki zarządzania jakością), a nie kwestie lokalizacji, autoryzacji danej marki, wielkości organizacji mierzonej liczbą pracowników, posiadania certyfikowanego systemu zarządzania jakością, czasu funkcjonowania na rynku, rodzaju lokalizacji w strukturze danej organizacji. Oczywiście wszystkie wskazane elementy, jako zagadnienia immanentnie dotyczące każdej działalności gospodarczej, oddziałują na postawy pracowników i podejmowane działania wewnątrzorganizacyjne. Jednak $\mathrm{w}$ analizach przeprowadzonych $\mathrm{w}$ ramach niniejszej pracy nie zidentyfikowano jednoznacznych uwarunkowań podmiotowych dla osiągania sukcesu projakościowego zarządzania w organizacji poza samym ich podejmowaniem. Należy zatem przyjąć, że ważność wewnętrznych czynników zarządzania jakością we wpływie na rezultaty zarządzania jakością jest regulowana wewnątrzorganizacyjnymi działaniami i koncentracją na poszczególnych elementach konstytuujących główne wewnętrzne czynniki zarządzania jakością w organizacji. 


\section{Optymalizacja zarządzania jakością w organizacji}

Optymalizacja jest związana z poszukiwaniem najlepszych rozwiązań. Ocena, czy dane rozwiązanie jest najlepsze, wynika z zastosowania indywidualnych kryteriów w danej organizacji przez pryzmat zaplanowanych celów, kosztów podejmowanych działań i uzyskiwanych korzyści końcowych.

Z przeprowadzonych badań i analiz wynika, że istnieją różnorodne relacje pomiędzy zagadnieniami poruszanymi $\mathrm{w}$ niniejszej pracy. $\mathrm{W}$ celu pozyskania użytecznej informacji o hierarchizacji i relacjach pomiędzy wewnętrznymi czynnikami zarządzania jakością oraz ich oddziaływaniu na rezultaty konieczne jest wyłonienie najstotniejszych powiązań. W tym celu została przyjęta następująca ścieżka analityczna, której efekty ukazano graficznie na rysunkach 7-14:

- przyjęcie po kolei ośmiu głównych wewnętrznych czynników zarządzania jakością jako podstawy do identyfikacji zależności (górna część środkowej kolumny na każdym rysunku);

- wskazanie najwyżej współzmiennego korelacyjnie głównego wewnętrznego czynnika zarządzania jakością (dolna część środkowej kolumny);

- wskazanie najwyżej współzmiennych elementów konstytuujących dany wewnętrzny czynnik zarządzania jakością (kolumna po lewej stronie); założeniem było wskazanie maksymalnej korelacji dodatniej i ujemnej (strzałka przerywana) bądź tylko jednej w przypadku wyłącznie jednostronnych relacji lub większej ich liczby w przypadku zbliżonych wartości współczynnika Pearsona (którego wartość została podana przy strzałkach); dodatkowo zaznaczono charakter elementu: (J) ,jakościowy” lub (R) „ryzykowny”;

- wskazanie, do której składowej (w wyniku eksploracyjnej analizy czynnikowej) zostały przyporządkowane elementy konstytuujące wewnętrzne czynniki zarządzania jakością (strzałka przerywana z kreskami i dwiema kropkami);

- wskazanie dla głównych wewnętrznych czynników najsilniejszych korelacji z rezultatami zarządzania jakością (prawa kolumna na rysunkach).

Powyższe zagadnienia zostały przedstawione na kolejnych ośmiu rysunkach.

Podsumowując osiem przedstawionych rysunków należy zauważyć, że prezentują one w syntetyczny sposób najważniejsze relacje spośród opisanych w IV rozdziale niniejszej monografii. Elementy konstytuujące poszczególne główne wewnętrzne czynniki projakościowego zarządzania w organizacji zostały zaszeregowane do sześciu z ośmiu składowych (wewnętrznych czynników zidentyfikowanych w eksploracyjnej analizie czynnikowej). Najwięcej, bo aż osiem elementów znalazło się $\mathrm{w}$ ramach pierwszego wewnętrznego czynnika „Przywództwo i kultura jakości”. Dwa elementy zostały zaszeregowane do czynnika nazwanego „Dualizm jakości «klienci-pracownicy»”. Po jednym 


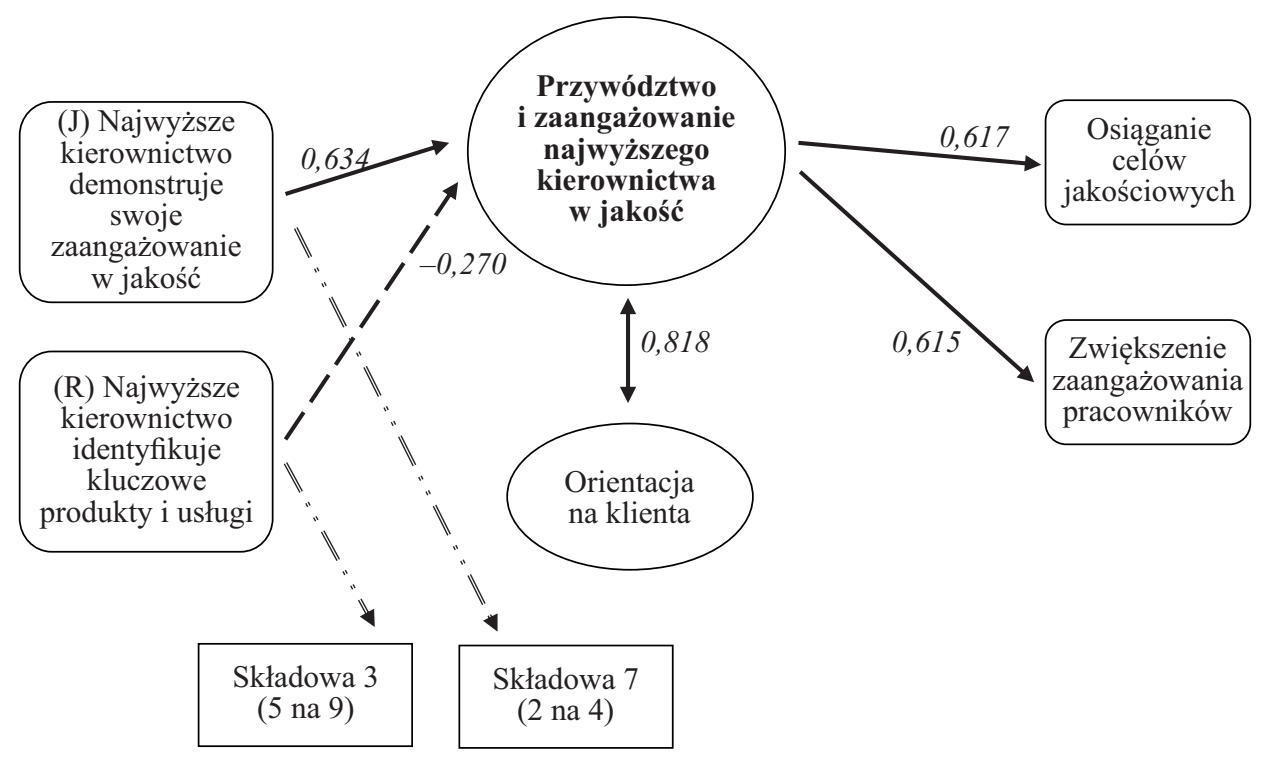

Rysunek 7. Przywództwo i zaangażowanie najwyższego kierownictwa priorytetowe relacje

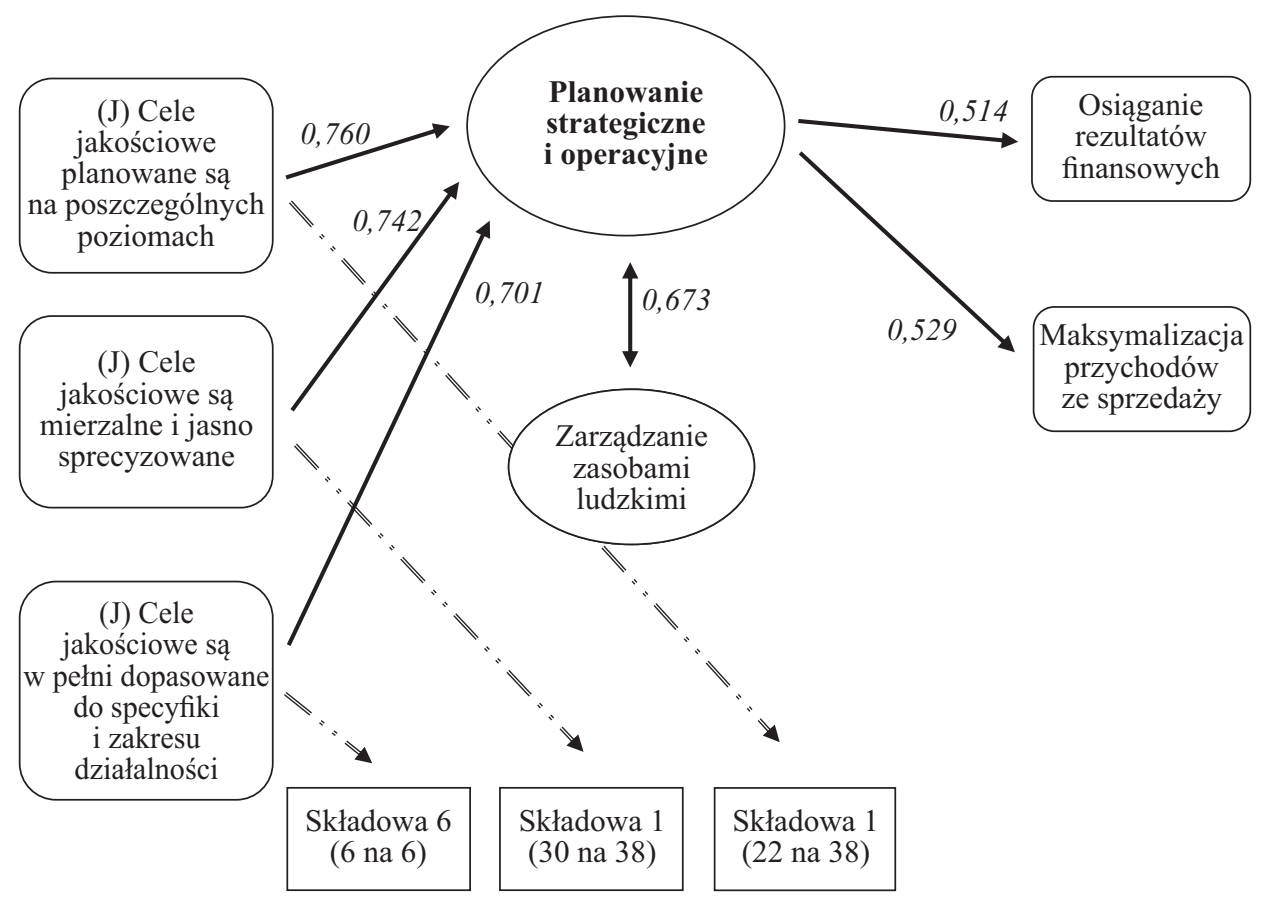

Rysunek 8. Planowanie strategiczne i operacyjne - priorytetowe relacje 


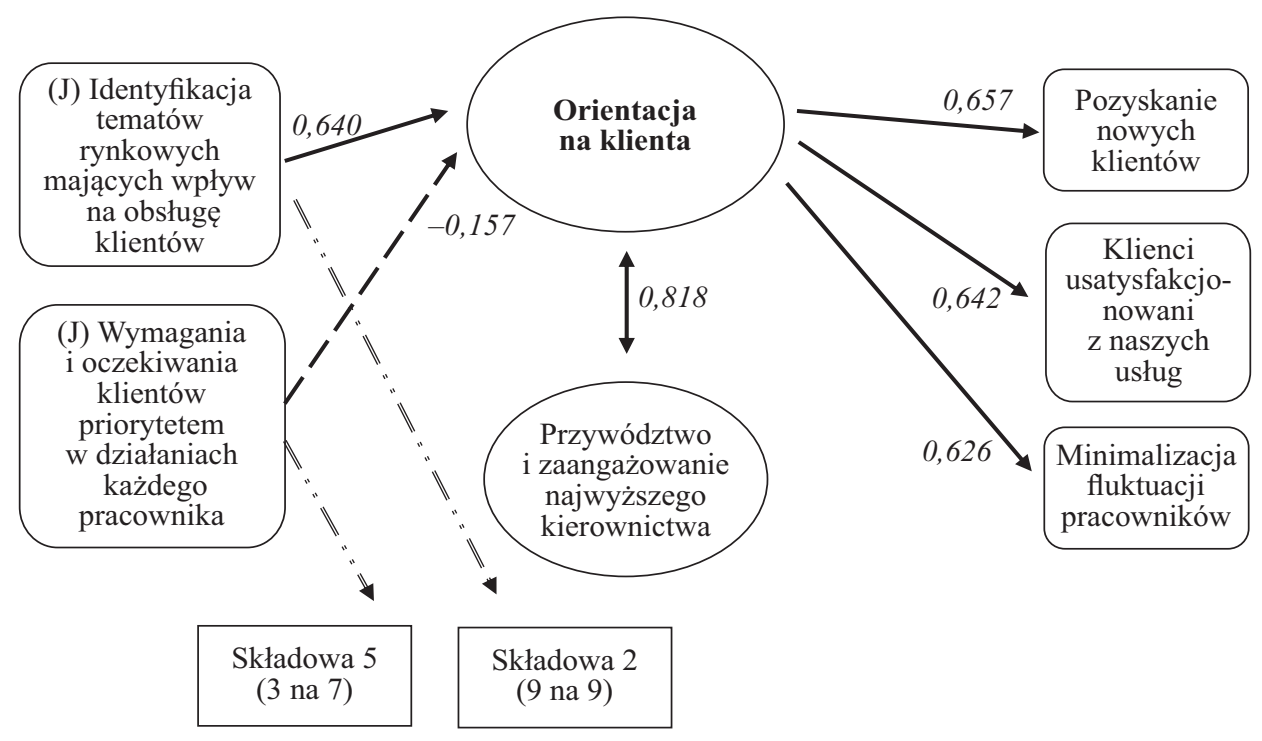

Rysunek 9. Orientacja na klienta - priorytetowe relacje

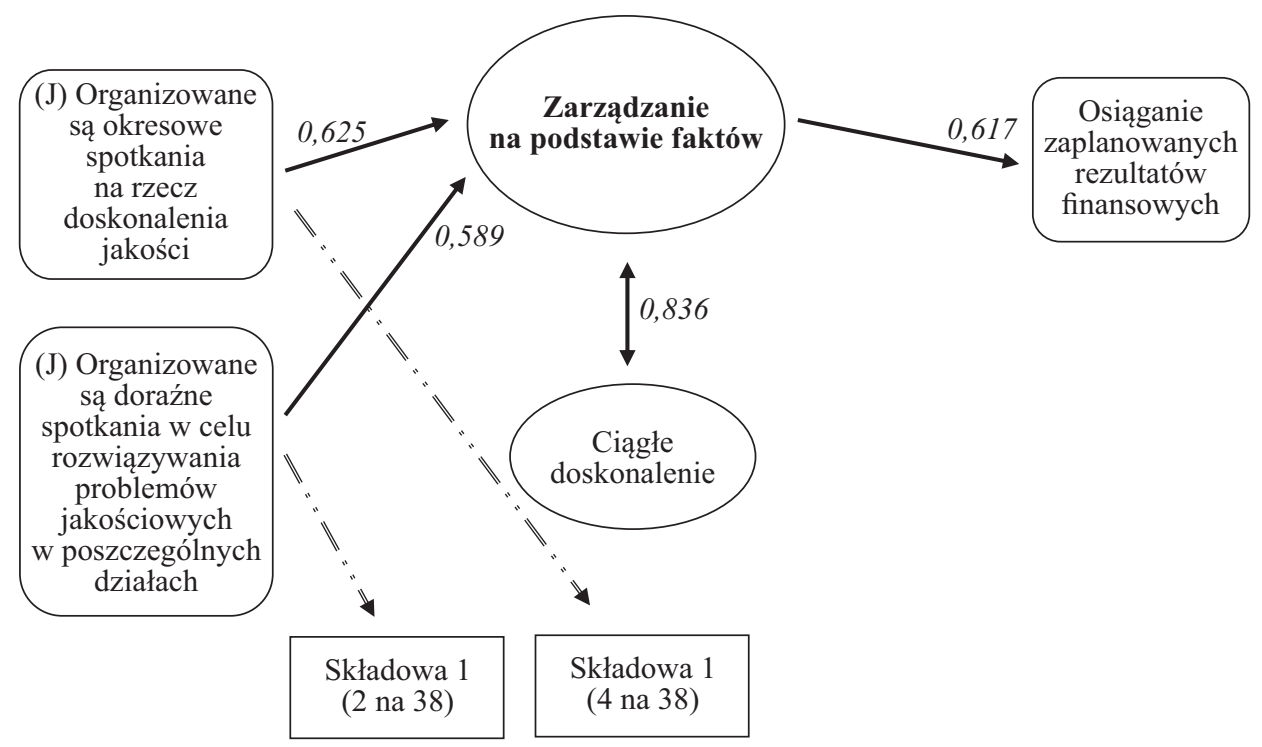

Rysunek 10. Zarządzanie na podstawie faktów - priorytetowe relacje

elemencie trafiło do wewnętrznych czynników: „Podejście prewencyjne do jakości”, „Szanse i zagrożenia jakości”, „Planowanie jakości”, „Priorytetyzacja jakości”. W tym zestawieniu nie ma dwóch wewnętrznych czynników: „Orientacji na klienta” oraz „Podejścia reakcyjnego do jakości”. 


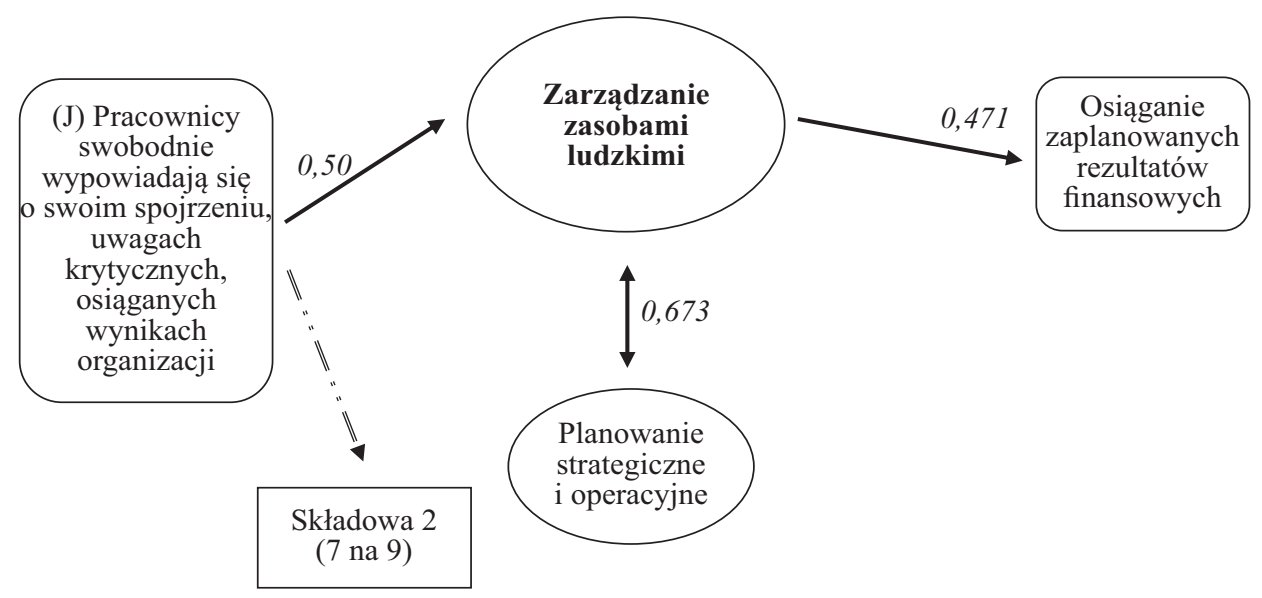

Rysunek 11. Zarządzanie zasobami ludzkimi - priorytetowe relacje

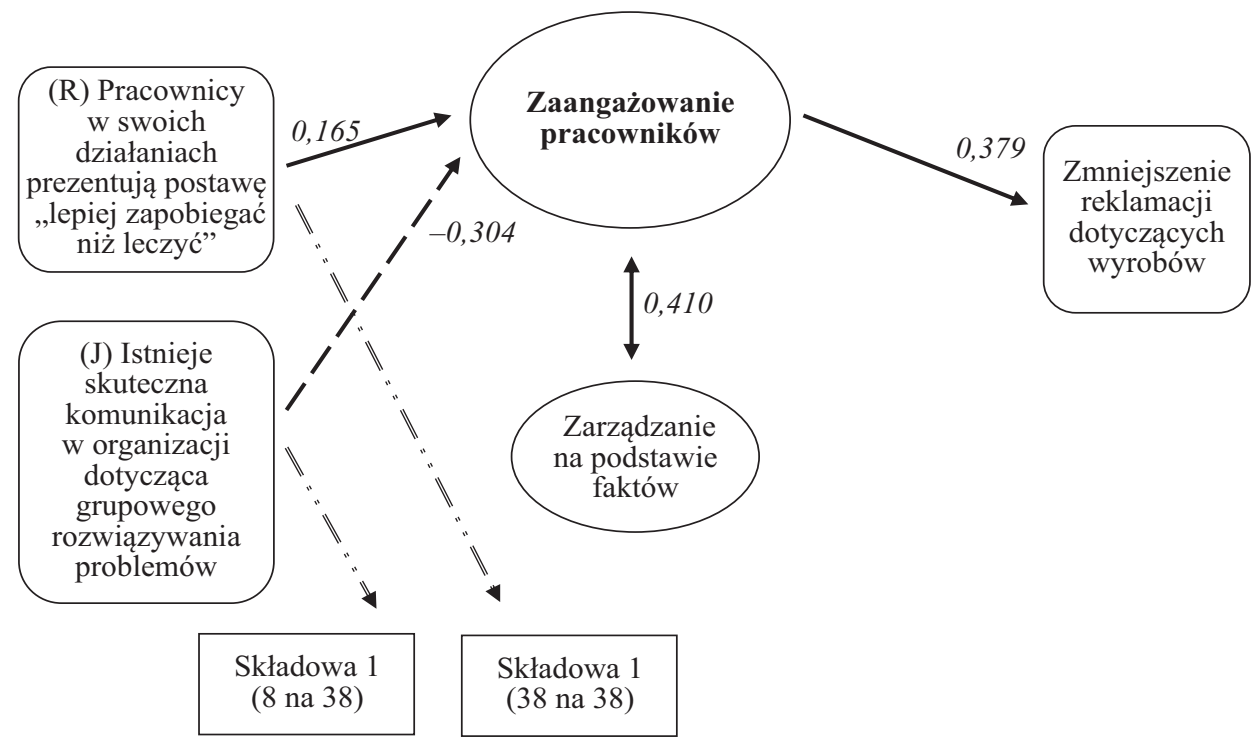

Rysunek 12. Zaangażowanie pracowników - priorytetowe relacje

Kontynuacją w wyłanianiu najważniejszych relacji dla analizowanych zmiennych jest spojrzenie na wewnętrzne czynniki zidentyfikowane w eksploracyjnej analizie czynnikowej. Te czynniki od poprzednich różni ich wyłonienie na bazie analiz statystycznych i ukrytych zależności pomiędzy zmiennymi. Można zatem uznać, że relacje ukazane na rysunkach nr 7-14 są bardziej oczywiste dla decydentów, natomiast zestawienie ich z wyłonionymi statystycznie może ukazać relacje nieuświadomione, które jednak w znaczny sposób wpływają na sukces 


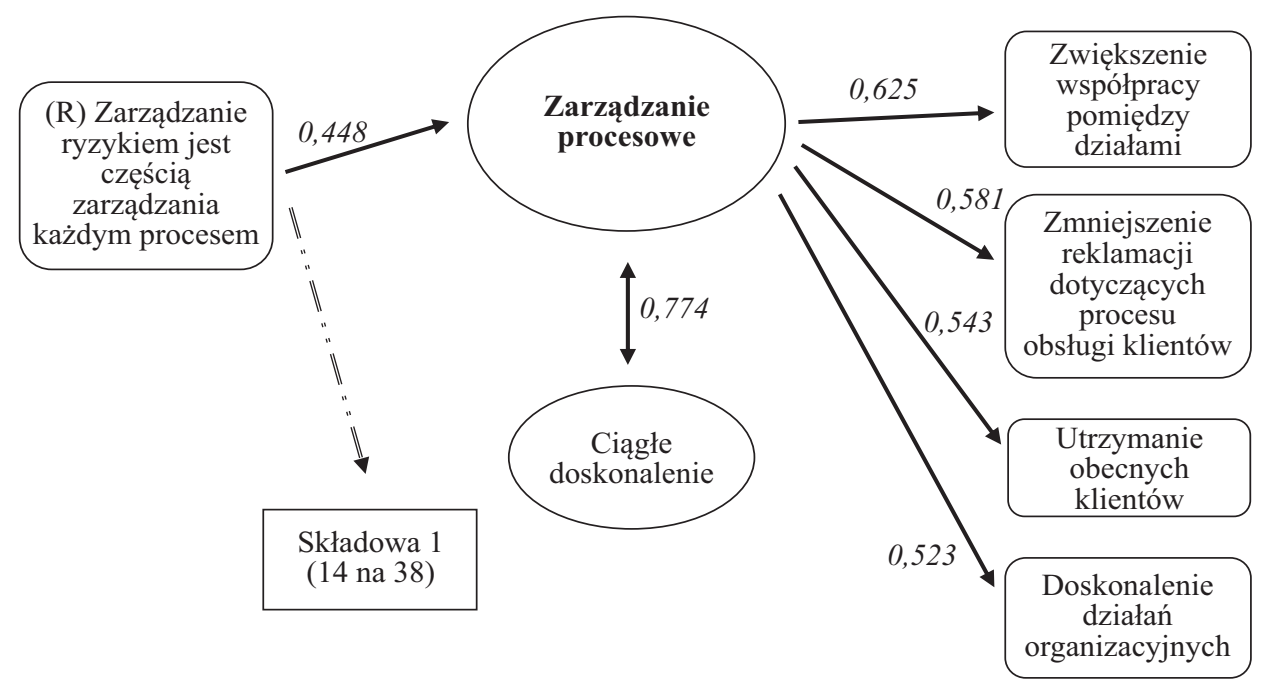

Rysunek 13. Zarządzanie procesowe - priorytetowe relacje

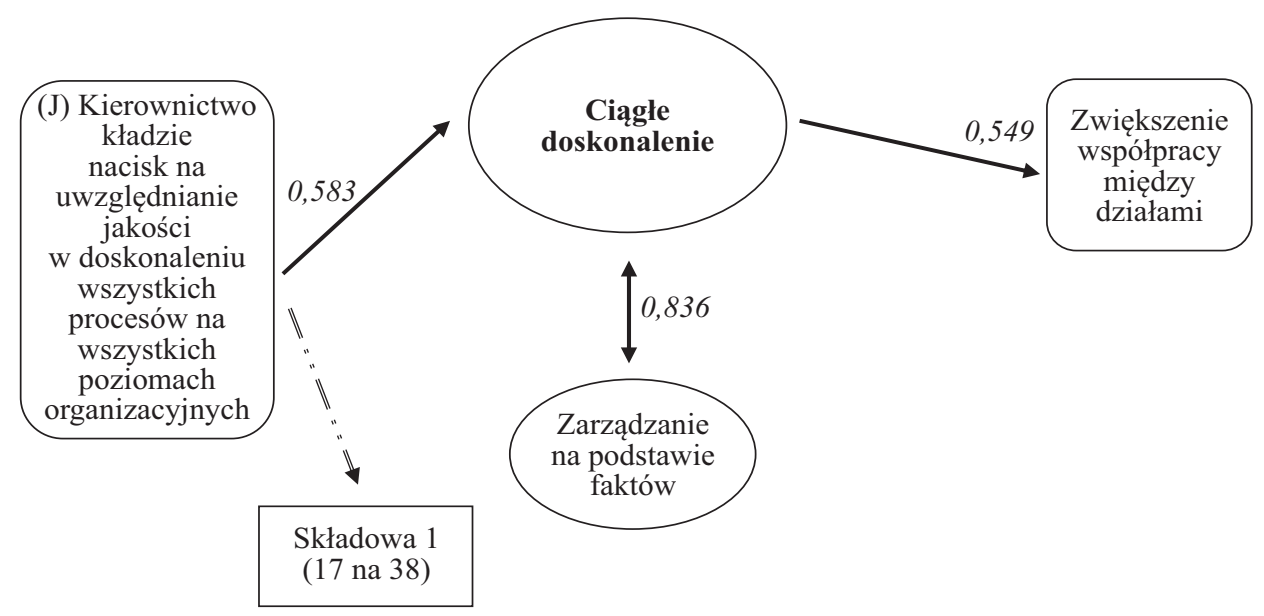

Rysunek 14. Ciągłe doskonalenie - priorytetowe relacje

projakościowego zarządzania w organizacji. Przywołując elementy zgrupowane w poszczególnych wewnętrznych czynnikach zarządzania jakością, skoncentrowano się na najwyższych wartościach ładunków czynnikowych. W tym celu została przyjęta następująca ścieżka analityczna, której efekty ukazano graficznie na rysunkach $15-22$ :

- przyjęcie po kolei ośmiu wewnętrznych czynników zarządzania jakością jako podstawy do identyfikacji zależności (środkowa kolumna na każdym rysunku); 
- wskazanie najważniejszych (według ładunków czynnikowych) elementów konstytuujących dany wewnętrzny czynnik zarządzania jakością (kolumna po lewej stronie);

- wskazanie dla wewnętrznych czynników najsilniejszych korelacji z rezultatami zarządzania jakością (prawa kolumna na rysunkach).

Powyższe zagadnienia zostały przedstawione na kolejnych ośmiu rysunkach. W ramach czynnika „Przywództwo i kultura jakości” trzy elementy (na 38) mają ładunki czynnikowe powyżej wartości 0,9 :

1. Zmiany w organizacji są planowane i skutecznie wdrażane (obszar jakościowy, pierwotnie uwzględniony w ramach „Ciągłego doskonalenia”).

2. Organizowane są doraźne spotkania w celu rozwiązywania problemów jakościowych w poszczególnych działach (obszar jakościowy, „Zarządzanie na podstawie faktów").

3. Identyfikujemy przyczyny niezgodności i podejmujemy działania doskonalące (obszar jakościowy, „Ciągłe doskonalenie”).

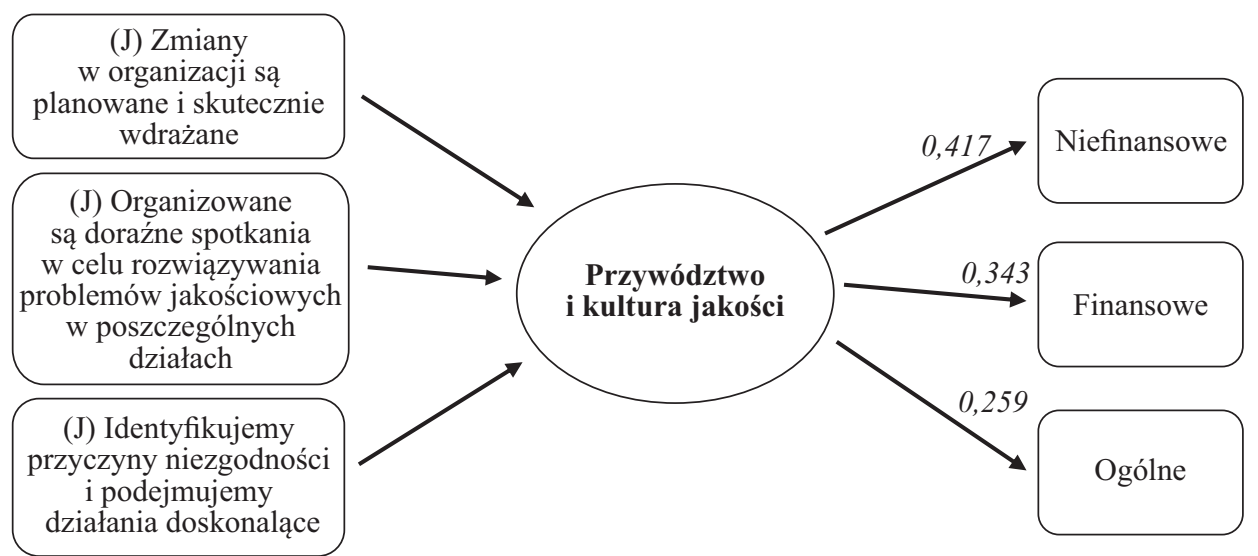

Rysunek 15. Przywództwo i kultura jakości - priorytetowe relacje

„Dualizm jakości «klienci-pracownicy»" to czynnik, w którym dla dwóch elementów (na dziewięć) ładunki czynnikowe znajdują się powyżej wartości 0,8 : 1. Przy podejmowaniu działań rozważamy szanse ich realizacji (obszar ryzykowny, „Zarządzanie na podstawie faktów”).

2. W działaniach najwyższego kierownictwa priorytetem są wymagania i oczekiwania klientów (obszar jakościowy, „Orientacja na klienta”).

Trzecim wewnętrznym czynnikiem jest „Podejście prewencyjne do jakości”, skorelowane tylko z jednym rezultatem zarządzania jakością, i to ujemnie.

W ramach powyższego wewnętrznego czynnika aż pięć elementów na dziewięć ma ładunki czynnikowe powyżej poziomu 0,8 . Wszystkie te elementy mają naturę „ryzykowną” i pochodzą z następujących pierwotnych głównych 


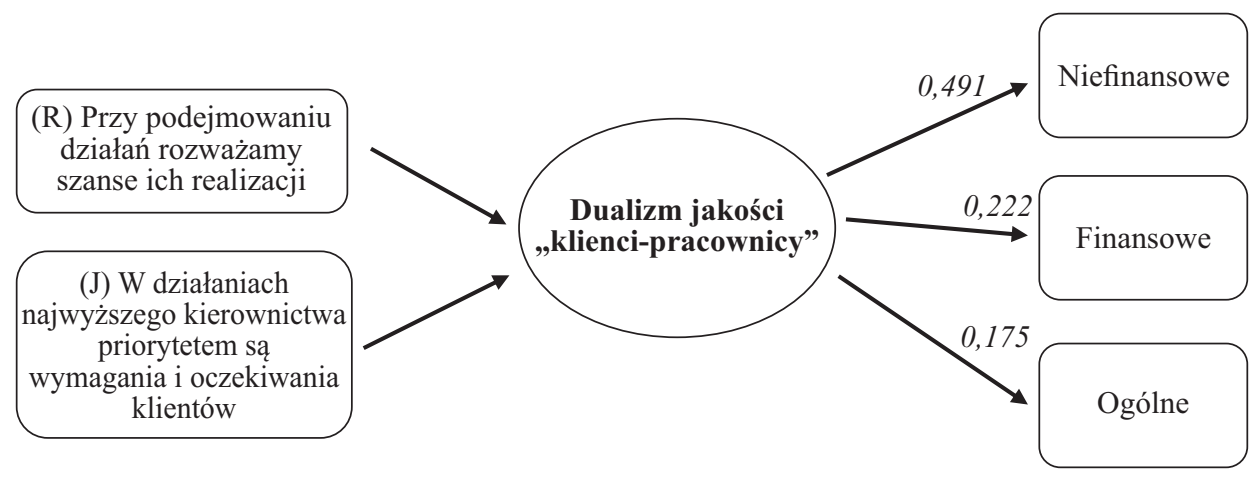

Rysunek 16. Dualizm jakości „klienci-pracownicy” - priorytetowe relacje
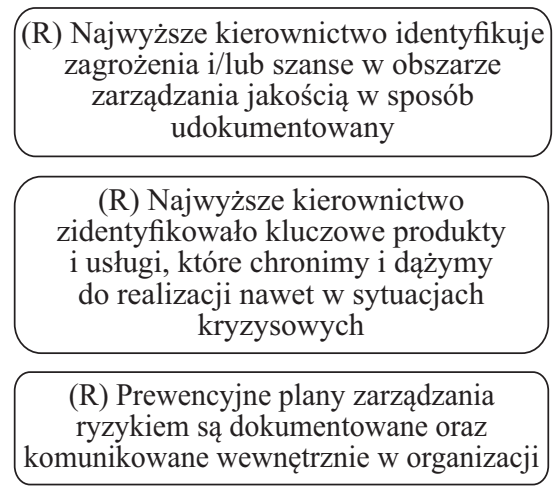

(R) Zagrożenia i szanse związane z podejmowaniem decyzji są dokumentowane

(R) Plany na wypadek rzeczywistego zaistnienia zagrożenia są dokumentowane

\section{Rysunek 17. Podejście prewencyjne do jakości - priorytetowe relacje}

wewnętrznych czynników zarządzania jakością: „Przywództwo i zaangażowanie najwyższego kierownictwa” (2), „Planowanie strategiczne i operacyjne” (2), „Zarządzanie na podstawie faktów” (1).

Czwarty zbiór zidentyfikowany w eksploracyjnej analizie czynnikowej nazwany został „Orientacja na klienta”. Na osiem elementów w nim zawartych dla dwóch najwyższe ładunki czynnikowe znajdują się powyżej poziomu 0,8. Obydwa elementy mają naturę jakościową i pierwotnie zostały uwzględnione w głównym wewnętrznym czynniku zarządzania jakością o tym samym tytule. 


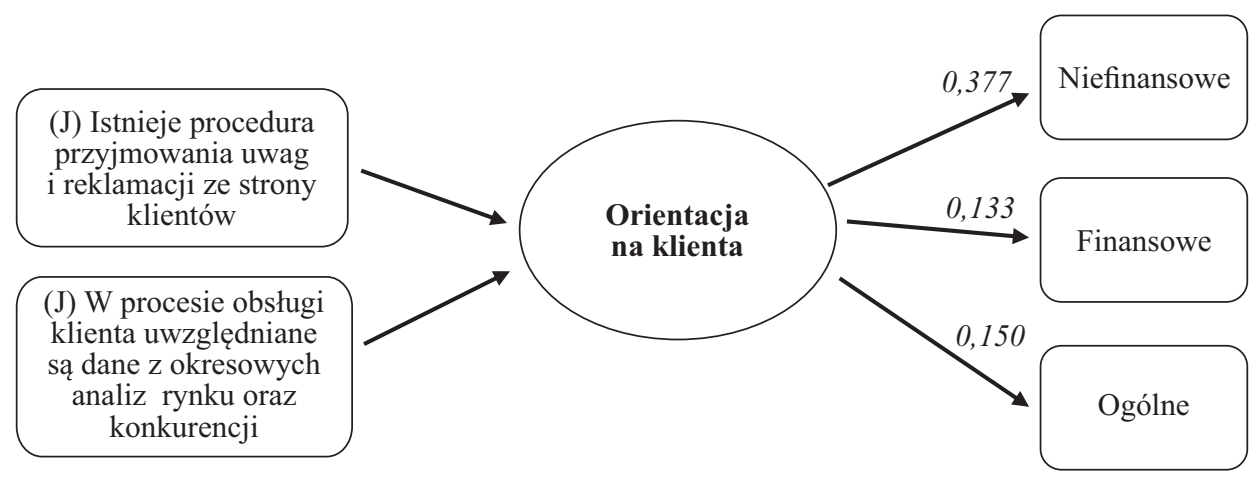

\section{Rysunek 18. Orientacja na klienta - priorytetowe relacje}

W ramach czynnika „Szanse i zagrożenia jakości” jeden element na siedem jest najistotniejszy, pierwotnie zaklasyfikowany do „Planowania strategicznego i operacyjnego".

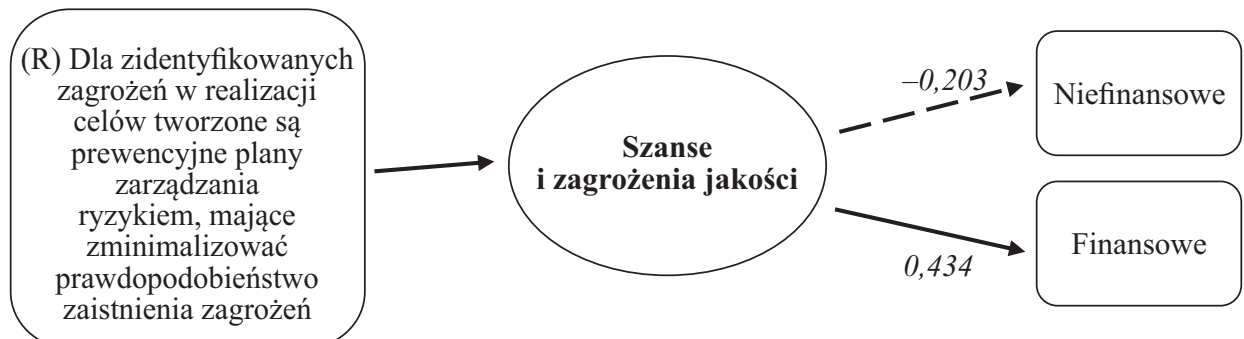

Rysunek 19. Szanse i zagrożenia jakości - priorytetowe relacje

„Planowanie jakości” stanowi kolejny wewnętrzny czynnik zarządzania jakością, w którym jeden (na sześć) element w aspekcie jakości jest najważniejszy i pochodzi z pierwotnego zbioru „Planowanie strategiczne i operacyjne”.

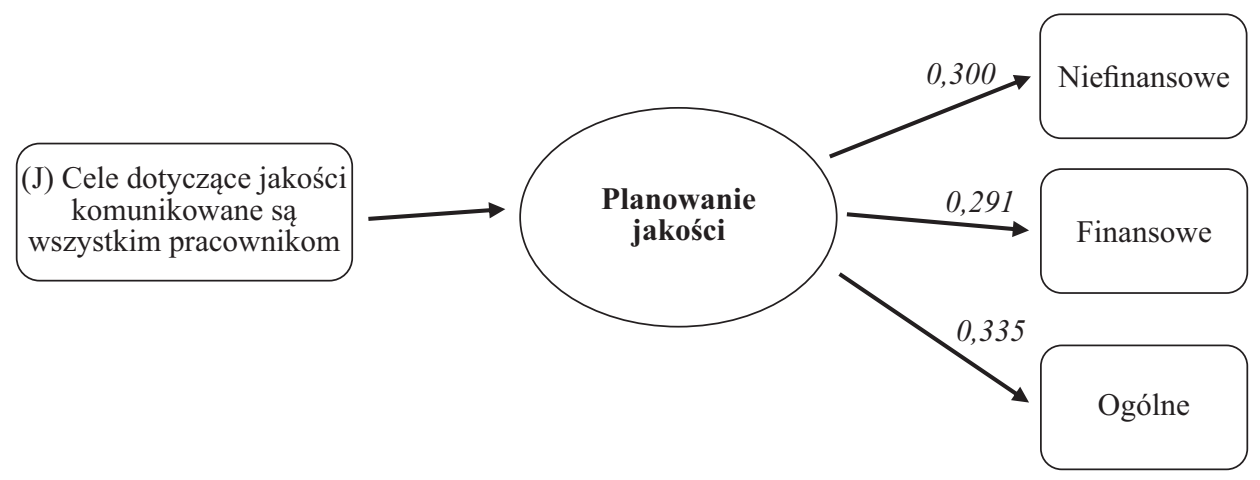

Rysunek 20. Planowanie jakości - priorytetowe relacje 


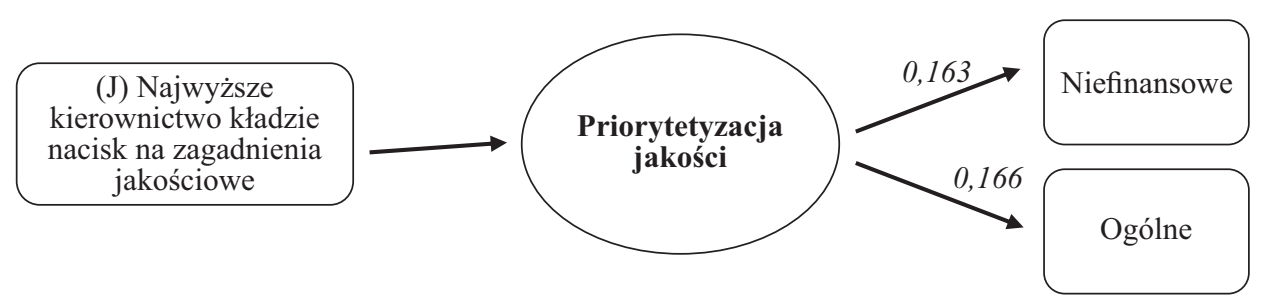

Rysunek 21. Priorytetyzacja jakości - priorytetowe relacje

W ramach czynnika „Priorytetyzacja jakości” jeden najwyższy ładunek czynnikowy znajduje się powyżej poziomu 0,7 i dotyczy aspektu jakości z pierwszej grupy „Przywództwo i zaangażowanie najwyższego kierownictwa w jakość”.

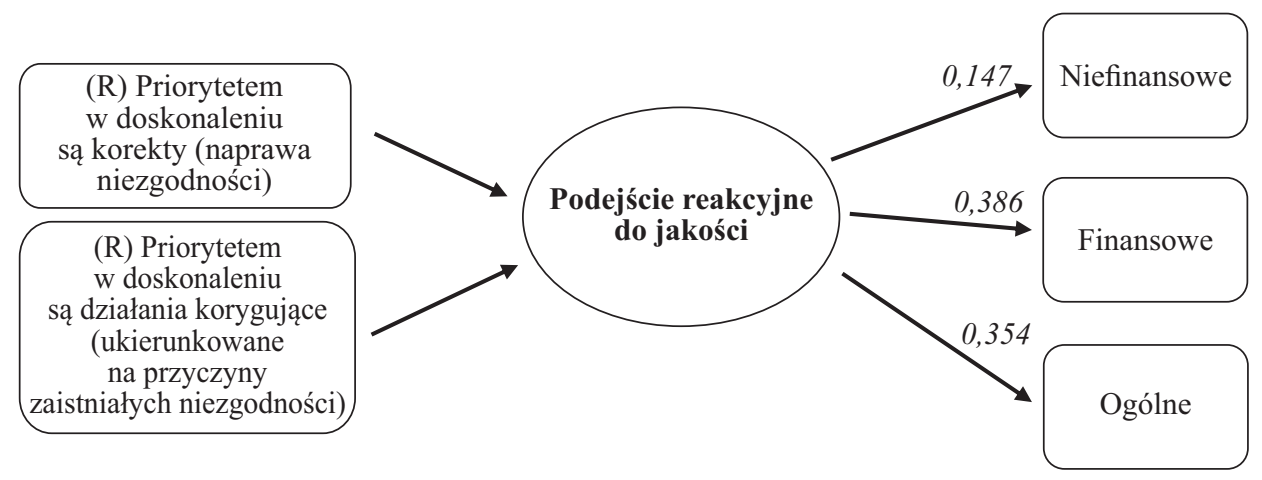

Rysunek 22. Podejście reakcyjne do jakości - priorytetowe relacje

Ostatni wewnętrzny czynnik projakościowego zarządzania w organizacji „Podejście reakcyjne do jakości” zawiera w sobie tylko dwa elementy uszczegóławiające tenże czynnik, obydwa z ładunkami czynnikowymi powyżej 0,8. Jednocześnie obydwa elementy nawiązują swoim charakterem do aspektu ryzyka i pochodzą z pierwotnej grupy zatytułowanej „Ciągłe doskonalenie”.

Przedstawione powyżej najsilniejsze relacje pomiędzy różnymi zmiennymi pozwalają, zdaniem autora, na dokonanie podsumowań ukierunkowanych na weryfikację trzech hipotez badawczych w kolejnych podpunktach niniejszego rozdziału.

\subsection{Krytyczne wewnętrzne czynniki zarządzania jakością}

Za najważniejszy główny wewnętrzny czynnik projakościowego zarządzania w organizacji respondenci uznali „Zaangażowanie pracowników”, ze średnią ważnością 6,52 w pozytywnym wpływie na rezultaty zarządzania jakością. 
W bezpośrednich odpowiedziach respondentów ważność tego czynnika jest zawsze najwyższa, niezależnie od stanowiska osoby wypełniającej ankietę. Jednocześnie jest to jedyny główny wewnętrzny czynnik, który w sprofilowanych analizach szczegółowych został oceniony na maksymalnym 7-stopniowym poziomie (według pracowników „Służb jakości”). To jednoznacznie wskazuje na przekonanie respondentów o wysokim pozytywnym wpływie zaangażowania pracowników na rezultaty projakościowego zarządzania w organizacji badanej grupy autoryzowanych salonów sprzedaży i serwisu samochodów osobowych w Polsce. Zaangażowanie pracowników jest dodatnio skorelowane z głównym wewnętrznym czynnikiem „Zarządzanie na podstawie faktów” (rysunek 12). Wzrost wartości jednego z tych czynników oznacza wzrost wartości drugiego z nich. W praktyce wiele zagadnień wpływa na zaangażowanie pracowników w realizowanie zadań służbowych. W badaniu empirycznym została zidentyfikowana zależność, że jedną z nich jest kwestia opierania się na danych podczas podejmowania decyzji. Wyznaczanie celów i zadań w sposób sformalizowany, a następnie bieżąca informacja o stanie realizacji celów pozwala pracownikom na „spokojne działania”, z uwagi na obiektywne kryteria oceny ich służbowych aktywności. W dalszej kolejności wzrostowi istotności „Zaangażowania pracowników” towarzyszy wzrost ważności „Orientacji na klienta” (rysunek 3). Klienci stanowią podstawę funkcjonowania organizacji, a wymagania autoryzacyjne w badanej grupie podmiotów zobowiązują do dokumentowania różnorodnych aktywności wobec klientów. Bieżące uzupełnianie informacji i operacyjne bazowanie na danych wpływają na możliwości analityczne i tym samym umożliwiają tworzenie rankingów pomiędzy pracownikami, które przekładają się na ich wyniki finansowe. Powiązanie zagadnień planowania i realizacji z systemem motywacyjnym, zarówno finansowym, jak i pozafinansowym, wpływa pozytywnie na zaangażowanie pracowników, co skutkuje m.in. „Zmniejszeniem reklamacji dotyczących wyrobów", jako najsilniejszym rezultatem zarządzania jakością, na który wpływa analizowany wewnętrzny czynnik (rysunek 12). Choć należy zwrócić uwagę, że zaangażowani pracownicy sprawiają, że działania realizowane w każdej organizacji pozytywnie wpływają na osiąganie zaplanowanych celów dotyczących jakości.

$\mathrm{Na}$ tym samym poziomie ważności respondenci ocenili wpływ dwóch głównych wewnętrznych czynników na rezultaty zarządzania jakością w organizacji - „Przywództwo i zaangażowanie najwyższego kierownictwa w jakość” oraz „Orientacja na klienta”. Jednocześnie pomiędzy tymi dwoma głównymi wewnętrznymi czynnikami zarządzania jakością występuje silna współzmienna relacja, gdzie wzrost ważności jednego z nich o „1” powoduje wzrost średniej ważności drugiego o „,0,818”. Organizacyjny klimat dla działań wobec klientów wynika bezpośrednio z działań podejmowanych przez kierownictwo na najwyższym poziomie organizacyjnym. Jednocześnie w myśl potocznej zasady, że 
„przykład idzie z góry”, to właśnie działania podejmowane na rzecz klientów będą wynikiem bezpośredniego podejścia do tych zagadnień przez pracowników. Pracownicy mogą być bowiem bardzo zaangażowani w podejmowanie działań ukierunkowanych na pozyskanie nowych klientów oraz utrzymanie obecnych, jednak bez zaangażowania najwyższego kierownictwa takie działania w dłuższym okresie mogą wpływać na fluktuację kadr i implikować niższe oceny klientów. Potwierdzeniem tych zależności jest zidentyfikowany w badaniu wpływ analizowanego głównego wewnętrznego czynnika na rezultaty zarządzania jakością, gdzie najważniejsze dwa to (rysunek 7): osiąganie celów jakościowych oraz zwiększenie zaangażowania pracowników. Zaangażowanie pracowników zostało wskazane jako najważniejszy główny wewnętrzny czynnik zarządzania jakością, a jednocześnie zwiększenie tego zaangażowania jest bezpośrednim efektem zaangażowania najwyższego kierownictwa. Kwestia zaangażowania najwyższego kierownictwa jest jednocześnie tematem bardzo trudnym do zbadania, zagadnieniem newralgicznym na płaszczyźnie psychologii zarządzania. Z przeprowadzonych badań ankietowych wynika, że „Kierownictwo” oceniło pozytywny wpływ „Przywództwa i zaangażowania najwyższego kierownictwa" na rezultaty projakościowego zarządzania w organizacji wyżej od „Służb jakości” (druga najwyższa różnica w ocenie). Analizując te dane z perspektywy „Służb jakości”, można wskazać, że ich ocena zaangażowania przełożonych jest niższa niż „samoocena” przełożonych. Na ile są to kwestie zbieżne z rzeczywistym podejściem, a na ile odzwierciedlają subiektywne odczucia respondentów, jest tematem złożonym w praktyce funkcjonowania różnorodnych organizacji na całym świecie.

Ważność „Orientacji na klienta”, podobnie jak powyżej opisanego wewnętrznego czynnika zarządzania jakością, jest wyższa w ocenie „Kierownictwa” niż „Służb jakości”. Jednocześnie jest to największa różnica ważności wyników ocen pomiędzy tymi dwoma grupami respondentów. Z kolei poziom ważności „Orientacji na klienta” jest niezależny od funkcjonowania w organizacji certyfikowanego systemu zarządzania jakością. Najsilniejsza współzmienność z innym wewnętrznym czynnikiem została wskazana dla opisanego w powyższym akapicie „Przywództwa i zaangażowania najwyższego kierownictwa w jakość”. Jednocześnie zauważalne jest powiązanie obszarowe nie tylko obydwu czynników, ale również wpływu na rezultaty zarządzania jakością. „Orientacja na klienta" wpływa na zbliżonym (wysokim) poziomie na trzy rezultaty zarządzania jakością (rysunek 9). Dwa dotyczą bezpośrednio klientów - pozyskania nowych oraz satysfakcji obecnych ze świadczonych usług. Natomiast trzecim rezultatem działań z obszaru orientacji na klienta jest minimalizacja fluktuacji pracowników zasygnalizowanej przy analizie w poprzednim akapicie. Zauważalne są zatem relacje pomiędzy zaangażowaniem pracowników i kierownictwa w ukierunkowaniu na klientów. 
„Zarządzanie zasobami ludzkimi” jako kolejny, w ogólnej ważności, główny wewnętrzny czynnik zarządzania jakością w organizacji został najwyżej oceniony przez „Służby jakości”. Jest silnie współzmienny z „Planowaniem strategicznym i operacyjnym”. Można wskazać, że kwestie zarządzania kadrami są obszarowo powiązane z zaangażowaniem pracowników i kwestią planowania działań w tym obszarze. Jednocześnie jest to związane z zarządzaniem na podstawie faktów. Wynikowo działania z obszaru zarządzania zasobami ludzkimi wpływają na „Osiąganie zaplanowanych rezultatów finansowych” (rysunek 11).

„Planowanie strategiczne i operacyjne”, skorelowane z powyższym wewnętrznym czynnikiem, respondenci ocenili na piątej pozycji w pozytywnym wpływie na rezultaty zarządzania jakością. Jednocześnie spośród różnorodnych zależności korelacyjnych pomiędzy głównymi wewnętrznymi czynnikami zarządzania jakością (rysunek 3) najniższa jego współzmienność z pozostałymi czynnikami wewnętrznymi kształtuje się na poziomie 0,474 . Wskazuje to na ważność „Planowania strategicznego i operacyjnego” w relacjach z poszczególnymi obszarami $\mathrm{w}$ organizacji określonymi poszczególnymi wewnętrznymi czynnikami zarządzania jakością. Jedynie pomiędzy wskazanym głównym wewnętrznym czynnikiem a „Zaangażowaniem pracowników” nie występuje współzmienność istotna statystycznie. Planowanie to proces wyznaczania celów, które stanowią podstawę do podejmowanych w organizacji działań. Brak wskazanej zależności można by zatem tłumaczyć, że planowanie i cele stanowią bazę do podejmowanych działań, a na osiąganie zaplanowanych celów wpływ mają inne różnorodne zagadnienia. Wynikowo natomiast zagadnienia „Planowania strategicznego i operacyjnego" wpływają na rezultaty (rysunek 8) ze sfery finansowej. Analizując poziomy planowania w działalności autoryzowanych salonów sprzedaży i serwisu samochodów osobowych, warto zwrócić uwagę na coroczne umowy celowe zawierane pomiędzy salonami sprzedaży i serwisu pojazdów z przedstawicielem producenta samochodów. Umowy te określają cele m.in. w dwóch płaszczyznach: ilościowej (np. liczba sprzedanych pojazdów, części, roboczogodzin) i jakościowej (np. wyniki badania satysfakcji klientów). W perspektywie roku kalendarzowego można wskazać, że taka umowa celowa odnosi się do wszystkich trzech poziomów planowania. W ujęciu strategicznym dotyczy to całości planu w okresie dwunastu miesięcy. W perspektywie taktycznej jest to związane z kwartałem, co najczęściej służy rozliczeniom planów sprzedażowych z przedstawicielem producenta (otrzymywaniem tzw. bonusów). Na poziomie operacyjnym są planowane i następnie w ramach każdego miesiąca rozliczane plany poszczególnych pracowników.

„Zarządzanie na podstawie faktów” jest najsilniej skorelowane $\mathrm{z}$ „Ciągłym doskonaleniem" (rysunek 10). Taka relacja nawiązuje do konieczności posiadania danych jako obiektywnej podstawy do podejmowania decyzji w obszarze działań doskonalących. Czynnik ten nie jest współzmienny jedynie 
z „Przywództwem i zaangażowaniem najwyższego kierownictwa”, co jest zastanawiające, ponieważ bazowanie na podstawie faktów powinno stanowić jeden z elementów przywództwa. Choć należy również zauważyć, że przywództwo to nie tylko kwestie obiektywizmu względem danych, ale i umiejętności tworzenia ogólnego klimatu jakościowego w organizacji. Jednocześnie szczegółowe analizy danych ważności wewnętrznego czynnika „Zarządzanie na podstawie faktów" wskazały na najwyższe różnice w ważności w trzech płaszczyznach tych analiz:

1. „Służby jakości” wyżej oceniły pozytywny wpływ „Zarządzania na podstawie faktów” na rezultaty zarządzania jakością od „Kierownictwa” z organizacji posiadających certyfikowany system zarządzania jakością (różnica bezwzględna 0,33 ).

2. Respondenci z grupy „Kierownictwo” z organizacji z „certyfikatem ISO 9001 " wyżej ocenili pozytywny wpływ tego czynnika na rezultaty zarządzania jakością od „Kierownictwa” bez certyfikowanego systemu zarządzania jakością (różnica bezwzględna 0,61 ).

3. Autoryzowane salony sprzedaży i serwisu samochodów osobowych w Polsce posiadające certyfikowany system zarządzania jakością wyżej oceniły ważność tego czynnika względem lokalizacji bez „certyfikatu ISO 9001” (różnica bezwzględna 0,86 ).

„Ciągłe doskonalenie” jest skorelowane ze wskazanym już powyżej „Zarządzaniem na podstawie faktów”, a jednocześnie wpływa najsilniej na „Zwiększenie współpracy między działami” (rysunek 14). Ważność tego wewnętrznego czynnika jest wyższa w lokalizacjach krócej funkcjonujących na rynku. Różnica bezwzględna wynosi 0,41 pomiędzy tymi funkcjonującymi do sześciu lat, a organizacjami działającymi na rynku co najmniej od siedmiu lat.

„Zarządzanie procesowe” jest wewnętrznym czynnikiem najniżej ocenionym w badaniu ankietowym w pozytywnym wpływie na rezultaty projakościowego zarządzania w organizacji, niezależnie od stanowiska respondenta. Czynnik ten jest skorelowany ze wskazanym już „Ciągłym doskonaleniem”, gdzie wzrost ważności jednego z nich o „1” powoduje wzrost ważności drugiego o „0,774”.

Wskazanych osiem głównych wewnętrznych czynników zarządzania jakością stanowi wykaz zidentyfikowany na podstawie analizy literatury przedmiotu. W wyniku przeprowadzonej eksploracyjnej analizy czynnikowej został zidentyfikowany zestaw ośmiu wewnętrznych czynników zarządzania jakością. Zestawienie porównawcze nazw wewnętrznych czynników zarządzania w ujęciu teoretycznym oraz empirycznym zostało przedstawione w tabeli 38 .

W pierwszej połowie każdej z grup wewnętrznych czynników zarządzania jakością znajdują się zbiory wskazujące na zagadnienia zaangażowania najwyższego kierownictwa, ich przywództwa, znaczenia kultury jakości, zaangażowania pracowników oraz orientacji na klienta. To zestawienie podsumowuje 
Tabela 38. Wewnętrzne czynniki zarządzania jakością - zestawienie konstrukcji teoretycznej i empirycznej

\begin{tabular}{|l|l|}
\hline \multicolumn{1}{|c|}{$\begin{array}{c}\text { Glówne wewnętrzne } \\
\text { czynniki zarządzania jakością } \\
\text { (teoretyczna konstrukcja) }\end{array}$} & \multicolumn{1}{c|}{$\begin{array}{c}\text { Wewnętrzne } \\
\text { czynniki zarządzania jakością } \\
\text { (empiryczna konstrukcja) }\end{array}$} \\
\hline 1. Zaangażowanie pracowników & 1. Przywództwo i kultura jakości \\
\hline $\begin{array}{l}\text { 2. Przywództwo i zaangażowanie najwyższego } \\
\text { kierownictwa w jakość }\end{array}$ & 2. Dualizm jakości ,klienci-pracownicy” \\
\hline 3. Orientacja na klienta & 3. Podejście prewencyjne do jakości \\
\hline 4. Zarządzanie zasobami ludzkimi & 4. Orientacja na klienta \\
\hline 5. Planowanie strategiczne i operacyjne & 5. Szanse i zagrożenia jakości \\
\hline 6. Zarządzanie na podstawie faktów & 6. Planowanie jakości \\
\hline 7. Ciągłe doskonalenie & 7. Priorytetyzacja jakości \\
\hline 8. Zarządzanie procesowe & 8. Podejście reakcyjne do jakości \\
\hline
\end{tabular}

dotychczasowe analizy wskazujące na istotność relacji pomiędzy zaangażowaniem pracowników i orientacją na klienta w pozytywnym wpływie na rezultaty projakościowego zarządzania $\mathrm{w}$ organizacji. Przedstawione analizy szczegółowe, kategoryzujące wyniki badawcze według różnorodnych kryteriów szczegółowych, nie zakłócają stwierdzenia, że orientacja na klientach w działalności organizacji i zaangażowania wszystkich pracowników w działania projakościowe na rzecz satysfakcji klientów stanowią kluczowe wewnętrzne czynniki zarządzania jakością. W analizie skupień zostało zidentyfikowane, że w analizowanej grupie organizacji o ważności i relacjach pomiędzy wewnętrznymi czynnikami a rezultatami zarządzania jakością decydują działania wewnętrzne w organizacji (ujęte jako elementy konstytuujące wewnętrzne czynniki projakościowego zarządzania w organizacji), a nie kwestie lokalizacji, autoryzacji danej marki, wielkości organizacji mierzonej liczbą pracowników, posiadania certyfikowanego systemu zarządzania jakością, czasu funkcjonowania na rynku, rodzaju lokalizacji w strukturze danej organizacji.

Przedstawione wyniki badań oraz wnioski z analiz pozwalają na pozytywną weryfikację pierwszej hipotezy badawczej. Można zatem stwierdzić, że: Zaangażowanie kierownictwa i pracowników w jakość oraz orientacja na klientów stanowia najważniejsze wewnętrzne czynniki sukcesu projakościowego zarzadzania $w$ organizacji.

W każdej organizacji funkcjonuje indywidualna wewnętrzna kultura, która nie zawsze jest efektem celowego i świadomego działania kadry kierowniczej i jest zbiorem różnorodnych postaw ludzkich, które tworzą charakterystyczną pajęczynę dla każdej organizacji. W ramach kultury organizacji istnieje kultura jakości, która jest elementem całościowego zbioru postaw i podejść do różnorodnych działań gospodarczych. Istotą kultury jakości jest właściwe oddziaływanie 
na postawy i zachowania ludzi, którzy potrafią sprawić, że nawet kiepski operacyjny system będzie działał, a dobry upadnie [Lisiecka i Czyż-Gwiazda 2014, s. 31-32].

Siła i natężenie działań w ramach kultury organizacyjnej, na które składają się różnorodne wewnętrzne czynniki, są decydujące w osiąganiu sukcesu projakościowego w zarządzaniu w organizacji. Ważność ogólnego klimatu dla podejmowanych działań z zakresu zarządzania jakością w organizacji potwierdzają wyniki przeprowadzonego badania empirycznego.

\subsection{Priorytetowe elementy konstytuujące wewnętrzne czynniki zarządzania jakością}

Zagłębiając się w diagnozie zależności budujących sukces projakościowego zarządzania $\mathrm{w}$ organizacji, należy dokonać analizy elementów tworzących poszczególne zbiory, nazwane wewnętrznymi czynnikami zarządzania jakością.

Zestawienie odpowiedzi respondentów w odniesieniu do dwóch grup elementów konstytuujących poszczególne główne wewnętrzne czynniki zarządzania jakością (wykres 30) pozwoliło zidentyfikować wyższą średnią ważność elementów rozpatrywanych $\mathrm{w}$ aspekcie jakości względem ryzyka. Elementy konstytuujące główne wewnętrzne czynniki zarządzania jakością z obszaru jakościowego mają w poszczególnych grupach wyższą ważność od elementów składowych dotyczących podejścia opartego na ryzyku. Największa bezwzględna różnica $(2,22)$ dotyczy wewnętrznego czynnika „Planowanie strategiczne i operacyjne”. Kolejne dwa znajdują się niżej o połowę wskazanej różnicy: „Przywództwo i zaangażowanie najwyższego kierownictwa” $(1,10)$ oraz „Orientacja na klienta" $(1,04)$. Najmniejsza różnica $(0,10)$ dotyczy ważności dwóch grup elementów składowych dla wewnętrznego czynnika „Zaangażowanie pracowników”, który to czynnik został ogólnie wskazany przez respondentów jako najważniejszy.

W ramach rozpatrywanego aspektu ryzyka można dokonać szczegółowej analizy poszczególnych elementów na podstawie przedstawionych wyżej rysunków.

Analiza ogólnej średniej ważności poszczególnych elementów konstytuujących główne wewnętrzne czynniki zarządzania jakością w aspekcie ryzyka hierarchizuje istotność poszczególnych podzbiorów. Aktywności odnoszące się do zarządzania ryzykiem zostały przez respondentów najwyżej ocenione (średnia ważność 4,71) i jest to wskazanie bliżej „tak” co do ich zastosowania w badanych organizacjach. Zdecydowanie niżej znajdują się zagadnienia z obszaru zarządzania ciągłością działania (średnia ważność 3,00). Najniżej (średnia ważność 2,88 ) są pozycjonowane zagadnienia wskazujące na dokumentowanie działań z obszaru ryzyka. 
Powyższe zagadnienia zostały przedstawione w sposób ogólny, wprost na podstawie średniej ważności opinii respondentów. Konieczne jest podsumowanie bardziej szczegółowe. Dwa elementy konstytuujące główne wewnętrzne czynniki zarządzania jakością (skorelowane z tymi czynnikami), wskazane na rysunku 7 oraz 10, zostały jednocześnie zidentyfikowane jako ważne elementy tworzące wewnętrzne czynniki zarządzania jakością po eksploracyjnej analizie czynnikowej.

Pierwszy element z obszaru ryzyka „Najwyższe kierownictwo identyfikuje kluczowe wyroby i usługi” był istotnie współzmienny (ujemnie) z ważnością głównego wewnętrznego czynnika „Przywództwo i zaangażowanie najwyższego kierownictwa w jakość” (rysunek 7). Ważność wskazanego elementu jest również wysoka w ramach wewnętrznego czynnika „Podejście prewencyjne do jakości” (rysunek 17). Należy jednak od razu zauważyć, że przywołany element razem z czterema innymi, również $\mathrm{z}$ obszaru ryzykownego, w największym stopniu wyjaśniają zmienność wewnętrznego czynnika „Podejście prewencyjne do jakości”, który oddziałuje na ogólne rezultaty projakościowego zarządzania w organizacji, również ujemnie. Takie wyniki wskazują na przekonanie respondentów o zdecydowanie mniejszym znaczeniu aktywności dotyczących podejścia opartego na ryzyku od działań jakościowych. Dostrzegalna jest relacja w wynikach badania empirycznego, że wzrostowi działań z obszaru ryzyka towarzyszy ocena uzyskiwania mniejszych rezultatów z kategorii projakościowego zarządzania w organizacji. Można tutaj nawiązać do podsumowania z ostatnich stron czwartego rozdziału monografii, gdzie skomentowana została współzmienność „Szans i zagrożeń jakości”, dwojaka względem rezultatów. „Działania ukierunkowane na minimalizację zagrożeń oraz maksymalizację szans generują aktywności, które wymagają czasu i koncentracji kosztem podejmowania innych działań. Operacyjnie zatem można by wskazać na „stratę czasu", ale ostatecznie te działania pozytywnie wpływają na rezultaty finansowe".

Drugi element z obszaru jakościowego dotyczy organizowania doraźnych spotkań w celu rozwiązywania problemów jakościowych w poszczególnych działach. Jest to element współzmienny z głównym wewnętrznym czynnikiem zarządzania jakością „Zarządzanie na podstawie faktów” (rysunek 10). W wyniku eksploracyjnej analizy czynnikowej wskazany element zasilił najważniejszy zbiór nazwany „Przywództwo i kultura jakości” (rysunek 15).

Analizując najważniejsze elementy konstytuujące wewnętrzne czynniki projakościowego zarządzania $\mathrm{w}$ organizacji (po eksploracyjnej analizie czynnikowej, ukazane na rysunkach 15-22), warto zwrócić uwagę, na pierwotne ich zaszeregowanie do głównych wewnętrznych czynników zarządzania jakością: „Planowanie strategiczne i operacyjne” (4), „Przywództwo i zaangażowanie najwyższego kierownictwa w jakość" (3), „Zarządzanie na podstawie faktów” (3), „Ciągłe doskonalenie” (3), „Orientacja na klienta” (1), „Zaangażowanie 
pracowników” (0), „Zarządzanie zasobami ludzkimi” (0), „Zarządzanie procesowe" (0). Ujmując te zidentyfikowane i przedstawione na rysunkach 7-22 zależności, można wskazać na ilościowy podział elementów konstytuujących wewnętrzne czynniki zarządzania jakością, w aspekcie jakości oraz ryzyka.

\section{Tabela 39. Relacje pomiędzy aspektami jakości i ryzyka w czynnikach projakościowego zarządzania $\mathrm{w}$ organizacji}

\begin{tabular}{|c|c|}
\hline $\begin{array}{c}\text { Glówne wewnętrzne } \\
\text { czynniki zarządzania jakością } \\
\text { (teoretyczna konstrukcja) }\end{array}$ & $\begin{array}{c}\text { Wewnętrzne } \\
\text { czynniki zarządzania jakością } \\
\text { (empiryczna konstrukcja) }\end{array}$ \\
\hline \multicolumn{2}{|c|}{ aspekt jakości/aspekt ryzyka } \\
\hline $\begin{array}{l}\text { Zaangażowanie pracowników } \\
(1 / 1)\end{array}$ & $\begin{array}{l}\text { Przywództwo i kultura jakości } \\
(3 / 0)\end{array}$ \\
\hline $\begin{array}{l}\text { Przywództwo i zaangażowanie najwyższego } \\
\text { kierownictwa w jakość } \\
(1 / 1)\end{array}$ & $\begin{array}{l}\text { Dualizm jakości „klienci-pracownicy” } \\
(1 / 1)\end{array}$ \\
\hline $\begin{array}{l}\text { Orientacja na klienta } \\
(2 / 0)\end{array}$ & $\begin{array}{l}\text { Podejście prewencyjne do jakości } \\
(0 / 5)\end{array}$ \\
\hline $\begin{array}{l}\text { Zarządzanie zasobami ludzkimi } \\
(1 / 0)\end{array}$ & $\begin{array}{l}\text { Orientacja na klienta } \\
(2 / 0)\end{array}$ \\
\hline $\begin{array}{l}\text { Planowanie strategiczne i operacyjne } \\
(3 / 0)\end{array}$ & $\begin{array}{l}\text { Szanse i zagrożenia jakości } \\
(0 / 1)\end{array}$ \\
\hline $\begin{array}{l}\text { Zarządzanie na podstawie faktów } \\
(2 / 0)\end{array}$ & $\begin{array}{l}\text { Planowanie jakości } \\
(1 / 0)\end{array}$ \\
\hline $\begin{array}{l}\text { Ciągłe doskonalenie } \\
(1 / 0)\end{array}$ & $\begin{array}{l}\text { Priorytetyzacja jakości } \\
(1 / 0)\end{array}$ \\
\hline $\begin{array}{l}\text { Zarządzanie procesowe } \\
(0 / 1)\end{array}$ & $\begin{array}{l}\text { Podejście reakcyjne do jakości } \\
(0 / 2)\end{array}$ \\
\hline$(11 / 3)$ & $(8 / 9)$ \\
\hline
\end{tabular}

W wyniku eksploracyjnej analizy czynnikowej zostały zidentyfikowane najważniejsze elementy konstytuujące wewnętrzne czynniki projakościowego zarządzania w organizacji. Analizując wyłącznie ilościowe ich podsumowanie z konstrukcji empirycznej (8/9), należałoby wskazać, że elementy w aspekcie ryzyka (9) są ważniejsze od jakościowych (8) we wpływie na rezultaty zarządzania jakością. Jednak konieczne jest szczegółowe spojrzenie na kierunek ich oddziaływania. Pięć na dziewięć najważniejszych elementów z obszaru ryzyka tworzy czynnik „Podejście prewencyjne do jakości”, który jest ujemnie skorelowany wyłącznie z ogólnymi rezultatami zarządzania jakością. Również jedyny ryzykowny element $\mathrm{w}$ przywołanym już wewnętrznym czynniku „Szanse i zagrożenia jakości" wpływa ujemnie na niefinansowe, a dodatnio na finansowe rezultaty zarządzania jakością. Takie wyniki dotyczące siły współzmienności 
wskazują na duże znaczenie aspektu ryzyka w podejmowaniu działań projakościowych w organizacji. Jednak analiza kierunku oddziaływania wskazuje na negatywny ich wpływ na sukces projakościowego zarządzania w analizowanej grupie organizacji. Jest to z zauważalne nie tylko w obszarze ukrytych relacji zidentyfikowanych $\mathrm{w}$ ramach zastosowania statystycznej eksploracyjnej analizy czynnikowej. Również bezpośrednie wyniki badania ważności poszczególnych głównych wewnętrznych czynników projakościowego zarządzania w organizacji ukazują ujemny wpływ dwóch elementów ryzykownych na ważność tych czynników. Dotyczy to „Przywództwa i zaangażowania najwyższego kierownictwa w jakość” oraz „Zaangażowania pracowników”. Takie wyniki, zdaniem autora, potwierdzają ważność aspektu ryzyka w funkcjonowaniu organizacji i wpływie na rezultaty projakościowego zarządzania w organizacji. Jednocześnie wyniki ukazują niskie zainteresowanie $\mathrm{w}$ analizowanych organizacjach tymi zagadnieniami. Mała koncentracja działań na aktywnościach $\mathrm{z}$ obszaru podejścia opartego na ryzyku, przy jednoczesnym ich dużym wpływie na rezultaty zarządzania jakością w organizacji, jednoznacznie wskazuje, zdaniem autora, na potrzebę koncentracji działań na aspektach ryzyka. Koncentracja na nich pozwoli na wzmocnienie pozytywnego wpływu wewnętrznych czynników na sukces projakościowego zarządzania w organizacji.

Wyniki badań i analiz przedstawione w niniejszym punkcie wskazują na najważniejsze zależności pomiędzy dwoma aspektami elementów konstytuujących wewnętrzne czynniki projakościowego zarządzania w organizacji. Aktywności z obszaru podejścia opartego na ryzyku mają duży wpływ na rezultaty zarządzania jakością, aczkolwiek elementy jakościowe w większym stopniu pozytywnie wpływają na sukces zarządzania jakością w organizacji. Jednocześnie należy podkreślić, że aktywności dotyczące podejścia opartego na ryzyku nie są celem samym w sobie, ale narzędziem do osiągnięcia celów danej organizacji [Kumpiałowska 2011, s. 11]. Podejmowanie działań z obszaru podejścia opartego na ryzyku powinno zatem wspomóc uzyskiwanie rezultatów w ramach zarządzania jakością. Jak można zauważyć w wynikach przeprowadzonych badań i analiz, najwyższe kierownictwo uwzględnia aspekty ryzyka $\mathrm{w}$ ramach projakościowego zarządzania w organizacji, aczkolwiek w sposób mało zdecydowany (według ogólnej ważności bliżej „tak” w stosowaniu, ale generalnie w skali pomiędzy „tak” a „nie mam zdania”), a jednocześnie nieudokumentowany. Nawiązuje to do opinii sformułowanych w pierwszych dwóch rozdziałach niniejszej pracy, że działania z obszaru podejścia opartego na ryzyku są uwzględniane $\mathrm{w}$ organizacji w sposób bieżący (intuicyjny), aczkolwiek nieudokumentowany, a wyniki badania empirycznego wskazują na konieczność koncentracji działań na zagadnieniach podejścia opartego na ryzyku w celu oddziaływania na rezultaty zarządzania jakością i osiągania sukcesu w działaniach organizacyjnych. 
Przedstawione wyniki badań oraz wnioski z analiz pozwalają, zdaniem autora, na pozytywną weryfikację drugiej hipotezy badawczej. Można zatem stwierdzić, że: Elementy konstytuujace wewnętrzne czynniki zarządzania jakościa $w$ aspekcie ryzyka maja mniejsze znaczenie $w$ oddzialywaniu na sukces zarzadzania jakościa niż elementy $w$ aspekcie jakości.

Oddziaływanie wobec zdarzeń krytycznych jako przejawów ryzyka może się odnosić do przyczyn tych zdarzeń (prewencja jako postępowanie ex ante), co określa się zapewnianiem bezpieczeństwa operacyjnego, jak również do skutków (terapia jako postępowanie ex post), co dotyczy zapewniania ciągłości działania [Zawiła-Niedźwiecki 2013, s. 85]. Problematyka zarządzania jakością wpisuje się w pierwszy nurt, jako systemowe podejście do zapobiegania zagrożeniom w ukierunkowaniu na realizację zaplanowanych celów i w tym kontekście warto, zdaniem autora, podejmować działania w zakresie wewnętrznych czynników implikujących sukces projakościowego zarządzania w organizacji.

\subsection{Newralgiczne relacje między wewnętrznymi czynnikami i rezultatami zarządzania jakością}

Działania ukierunkowane na weryfikację ostatniej hipotezy badawczej stanowią rozszerzenie i uzupełnienie zagadnień przedstawionych w dwóch poprzedzających podpunktach pracy. Przedstawiciele autoryzowanych salonów sprzedaży i serwisu samochodów osobowych w Polsce najniżej ocenili wpływ projakościowego zarządzania w organizacji na minimalizację czasu obsługi klientów (średnia ważność 3,46 ), a najwyżej rezultat z grupy ogólnych: usatysfakcjonowania klientów z usług (ważność 5,93). Wraz ze wzrostem okresu prowadzenia działalności gospodarczej respondenci z autoryzowanych salonów sprzedaży i serwisu samochodów osobowych w Polsce coraz wyżej oceniają wpływ zarządzania jakością na rezultaty ze sfery finansowej, a pozostałe grupy rezultatów oceniane są niżej (rysunek 2) wraz ze wzrostem okresu funkcjonowania na rynku.

W ramach głównych wewnętrznych czynników zarządzania jakością zidentyfikowano wyłącznie dodatnie współzmienności pomiędzy nimi a pojedynczymi rezultatami zarządzania jakością w organizacji. Zagadnienia te zostały szczegółowo opisane w IV rozdziale monografii i syntetycznie podsumowane na ostatnich stronach tegoż rozdziału. Te poszczególne rezultaty zarządzania jakością zostały umiejscowione w grupach rezultatów również zidentyfikowanych na podstawie analizy literatury przedmiotu.

Najsilniejsze oddziaływania pomiędzy głównymi wewnętrznymi czynnikami a rezultatami zarządzania jakością w organizacji (konstrukcja teoretyczna) zestawiono ze wszystkimi relacjami zachodzącymi pomiędzy analizowanymi czynnikami i rezultatami dla konstrukcji empirycznej. 
Tabela 40. Najsilniejsze ${ }^{a}$ oddziaływanie czynników na rezultaty zarządzania jakością

\begin{tabular}{|c|c|c|}
\hline $\begin{array}{c}\text { Glówne wewnętrzne } \\
\text { czynniki zarządzania jakością } \\
(\text { teoretyczna konstrukcja })\end{array}$ & $\begin{array}{c}\text { Rezultaty } \\
\text { zarządzania } \\
\text { jakością }\end{array}$ & $\begin{array}{c}\text { Wewnętrzne } \\
\text { czynniki zarządzania jakością } \\
(\text { empiryczna konstrukcja })\end{array}$ \\
\hline $\begin{array}{l}\text { - Orientacja na klienta: } 0,657 ; 0,626 \\
\text { - Zarządzanie procesowe: } 0,625 \\
\text { - Przywództwo i zaangażowanie naj- } \\
\text { wyższego kierownictwa w jakość: } \\
\text { 0,615 } \\
\text { - Zarządzanie procesowe: } 0,581 \\
\text { - Ciągłe doskonalenie: } 0,549 \\
\text { - Zarządzanie procesowe: } 0,543 \\
0,523\end{array}$ & niefinansowe & $\begin{aligned} & \text { - } \text { Dualizm jakości „klienci-pracowni- } \\
& \text { cy”: } 0,491 \\
& \text { - Przywództwo i kultura jakości: } \\
& 0,417 \\
& \text { - } \text { Orientacja na klienta: } 0,377 \\
& \text { - Planowanie jakości: } 0,300 \\
& \text { - } \\
& \text { - Pzanse i zagrożenia jakości: }=0,203 \\
& \text { - Priorytetyzacja jakości: } 0,163 \\
& \text { - Podejście reakcyjne do jakości: } \\
& 0,147\end{aligned}$ \\
\hline $\begin{aligned} \text { - } & \text { Orientacja na klienta: } 0,642 \\
\text { - Przywództwo i zaangażowanie naj- } & \text { wyższego kierownictwa w jakość: } \\
& 0,617 \\
\text { - } & \text { Zarządzanie na podstawie faktów: } \\
& 0,617 \\
\text { - } & \text { Planowanie strategiczne i operacyj- } \\
& \text { ne: } 0,514\end{aligned}$ & ogólne & 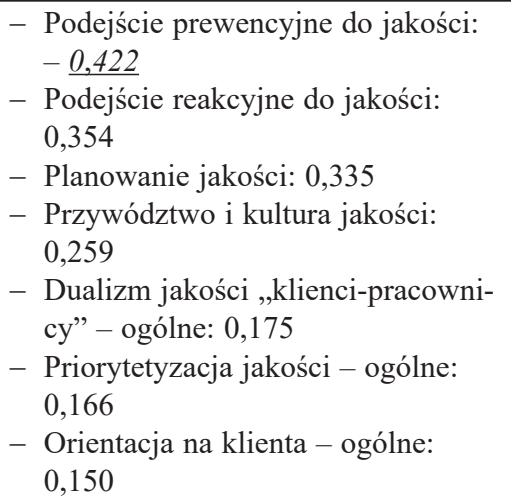 \\
\hline $\begin{array}{l}\text { - Planowanie strategiczne i operacyj- } \\
\text { ne: } 0,529\end{array}$ & finansowe & $\begin{array}{l}\text { - Szanse i zagrożenia jakości: } 0,434 \\
\text { - Podejście reakcyjne do jakości: } \\
\text { 0,386 } \\
\text { - Przywództwo i kultura jakości: } \\
\text { 0,343 } \\
\text { - Planowanie jakości: } 0,291 \\
\text { - Dualizm jakości „klienci-pracowni- } \\
\text { cy”: } 0,222 \\
\text { - Orientacja na klienta: } 0,133\end{array}$ \\
\hline
\end{tabular}

${ }^{a}$ Dla konstrukcji teoretycznej przedstawiono współzmienność wysoką, według współczynnika korelacji Pearsona (pomiędzy 0,5 a 0,7). Bazą dla tych relacji stanowiły zależności pomiędzy poszczególnymi elementami konstytuującymi główne wewnętrzne czynniki zarządzania jakością, dlatego przy niektórych czynnikach znajduje się więcej niż jedna wartość.

Dla konstrukcji empirycznej przedstawiono wszystkie zależności korelacyjne.

Dla każdej konstrukcji przedstawiono zależności malejąco, według współczynnika korelacji Pearsona.

Analizując wysokie współzmienności w obszarze teoretycznej konstrukcji zmiennych, można wskazać na relacje wyłącznie dodatnie: osiem dla wpływu głównych wewnętrznych czynników zarządzania jakością na grupę niefinansowych rezultatów zarządzania jakością, cztery na ogólne wyniki i jeden 
na finansowy obszar. Na osiąganie zaplanowanych rezultatów finansowych w znacznym stopniu oddziałują trzy główne wewnętrzne czynniki projakościowego zarządzania w organizacji: „Planowanie strategiczne i operacyjne”, „Zarządzanie na podstawie faktów”, „Zarządzanie zasobami ludzkimi”. Analizując współzmienność dla konstruktów empirycznych, występują relacje dwukierunkowe pomiędzy wewnętrznymi czynnikami a rezultatami zarządzania jakością w organizacji: siedem dla niefinansowych (w tym jeden ujemny), siedem dla ogólnych (w tym jeden ujemny), sześć dla finansowych. Analizując łącznie zależności przedstawione $\mathrm{w}$ powyższej tabeli dla konstrukcji teoretycznej oraz empirycznej, można wskazać na piętnaście relacji względem finansowego obszaru rezultatów zarządzania jakością, jedenaście w obszarze ogólnych wyników oraz siedem w sferze finansowej.

Przedstawione wyniki badań oraz wnioski $\mathrm{z}$ analiz pozwalają, zdaniem autora, na pozytywną weryfikację trzeciej hipotezy badawczej. Można zatem stwierdzić, że: Wewnętrzne czynniki zarządzania jakościa w największym stopniu wpływaja na niefinansowe mierniki sukcesu projakościowego zarzadzania w organizacji.

Dwie najczęściej wymieniane w literaturze przedmiotu podstawowe zasady - filary, na których opiera się zarządzanie jakością, to [Grudowski i in. 2016, s. 19]: zapobieganie problemom oraz zarządzanie ryzykiem. Zapobieganie ma na celu jak najszybsze wykrycie niezgodności i minimalizację kosztów związanych z jej usunięciem w przypadku przejścia do kolejnej fazy w działaniach organizacyjnych. Jednocześnie znajomość problematyki zarządzania ryzykiem znacznie ułatwia podniesienie skuteczności działań prewencyjnych i poprawę ogólnej efektywności organizacji [Grudowski i in. 2016, s. 19]. Końcowo wszystkie działania sprowadzają się zatem do oceny w sferze finansowej, również projakościowe zarządzanie w organizacji, którego coraz większy wpływ na efekty finansowe jest zauważalny w miarę upływu czasu.

Na podstawie wyników przeprowadzonej analizy skupień stwierdzono, że wyższej ocenie przywództwa towarzyszy wyższa ocena w osiąganiu sukcesu projakościowego zarządzania w organizacji w sferze finansowej. Koncentracja działań w obszarze „Przywództwa i kultury jakości” ma zatem wpływ na pozostałe wewnętrzne czynniki zarządzania jakością oraz przełożenie na osiąganie efektów finansowych. W badanej grupie autoryzowanych salonów sprzedaży i serwisu samochodów osobowych w Polsce nie zidentyfikowano jednoznacznych uwarunkowań podmiotowych dla osiągania sukcesu działań z zakresu zarządzania jakością, poza samym ich podejmowaniem. Ważność wewnętrznych czynników we wpływie na rezultaty projakościowego zarządzania $\mathrm{w}$ organizacji jest regulowana wewnątrzorganizacyjnymi działaniami i koncentracją czynnościową na poszczególnych elementach konstytuujących główne wewnętrzne czynniki zarządzania jakością. 
Weryfikacja trzech hipotez badawczych potwierdziła istnienie założonych relacji w obszarze badawczym. Można wskazać, że:

1. Zaangażowanie kierownictwa i pracowników w jakość oraz orientacja na klientów stanowią najważniejsze wewnętrzne czynniki sukcesu projakościowego zarządzania w organizacji. Dodatkowo można wskazać, że uzyskane wyniki badawcze pozwalają potwierdzić powyższe sformułowanie, niezależnie od uwarunkowań organizacyjnych dotyczących okresu i miejsca prowadzenia działalności, wielkości zatrudnienia oraz funkcjonowania znormalizowanego systemu zarządzania jakością.

2. Elementy konstytuujące wewnętrzne czynniki zarządzania w aspekcie jakości mają większe znaczenie w oddziaływaniu na sukces zarządzania jakością niż elementy w aspekcie ryzyka. Jednocześnie uzyskane wyniki badania empirycznego wskazują, że wykorzystywanie koncepcji podejścia opartego na ryzyku w projakościowym zarządzaniu w organizacji ma miejsce w sposób nieudokumentowany.

3. Zarządzanie jakością $\mathrm{w}$ organizacji stanowi zbiór działań ukierunkowanych na osiąganie celów jakości. Wewnętrzne czynniki zarządzania jakością $\mathrm{w}$ największym stopniu wpływają na niefinansowe rezultaty stanowiące jeden $\mathrm{z}$ mierników sukcesu projakościowego zarządzania $\mathrm{w}$ organizacji. Wszystkie działania organizacyjne wpływają na wyniki finansowe, w tym i aktywności podejmowane $\mathrm{w}$ ramach projakościowego zarządzania w organizacji są zauważalne w czasie.

Elementy konstytuujące wewnętrzne czynniki zarządzania jakością są uwzględniane w bieżących działaniach każdej organizacji w różny sposób - pośrednio $\mathrm{w}$ ramach bieżącego zarządzania oraz bezpośrednio $\mathrm{w}$ ramach koncentracji działań na wybranych zagadnieniach. Kształtowanie elementów konstytuujących wewnętrzne czynniki decyzjami wewnątrzorganizacyjnymi pozwala oddziaływać w pożądany sposób na sukces projakościowego zarządzania w organizacji. 


\section{Zakończenie}

Z jakością jest jak z tlenem. Organizm potrzebuje tlenu, by żyć. Organizacja potrzebuje klientów i koncentracji na jakości, by funkcjonować na rynku. Dlatego $\mathrm{z}$ funkcjonowaniem organizacji jest jak z funkcjonowaniem organizmu. W organizmie funkcjonują różnorodne układy, od których zależy prawidłowe działanie całości. W organizacji podsystemy tworzą system zarządzania organizacją, wspomagając realizowanie celów. Jeden z takich podsystemów dotyczy zarządzania jakością, który jest jak układ nerwowy człowieka. W ramach zarządzania jakością w organizacji odbierane są bodźce z jej otoczenia, analizowane i przetwarzane względem uwarunkowań wewnętrznych, i podejmowane są działania dostosowawcze. Układ nerwowy stymuluje prace całego organizmu i optymalizuje wykorzystanie zasobów. Aby jednak organizm funkcjonował, potrzebuje wartości odżywczych, które rozprowadza krew. Tym płynnym łącznikiem pomiędzy jakościowymi elementami organizacji jest kultura jakości, istniejąca każdego dnia, a objawiająca się w momentach sytuacji kryzysowych. Tak samo jak krew, która jest niewidzialna do momentu skaleczenia. Jeżeli pewne układy w organizmie nie funkcjonują prawidłowo, następuje koncentracja na nich i leczenie. $\mathrm{W}$ ramach projakościowego zarządzania $\mathrm{w}$ organizacji uruchamiane są działania doskonalące. Niezależnie od stanu organizmu, bez tlenu i krwi człowiek nie przeżyje. Tak jak organizacja nie utrzyma się na rynku bez jakości i kultury jakości.

\section{Wnioski końcowe}

Treść niniejszej monografii została skoncentrowana na identyfikacji i ocenie ważności wewnętrznych czynników oraz ich oddziaływania na sukces projakościowego zarządzania w organizacji. Przyjęte w pracy cele, zakresy, koncepcja badań zostały ukierunkowane na wypełnienie zidentyfikowanej luki badawczej. Problem badawczy został zdefiniowany w formie pytania: Jakimi wewnętrznymi czynnikami można wpływać na sukces projakościowego zarządzania w organizacji? Tematyka rozprawy, zdaniem autora, jest istotna zarówno w perspektywie teoretycznej, jak i praktycznej. Obydwu powyższym sferom zostały przypisane cele badawcze, które zostały osiągnięte. Realizacja celów polegała na:

- kwerendzie literatury przedmiotu ukierunkowanej na zidentyfikowanie głównych wewnętrznych czynników projakościowego zarządzania w organizacji;

- określeniu obszarów wpływu zarządzania jakością na rezultaty osiągane w organizacji, poprzez identyfikację grup efektów zarządzania jakością; 
- zidentyfikowaniu elementów konstytuujących główne wewnętrzne czynniki zarządzania jakością w aspekcie jakości;

- uzupełnieniu elementów konstytuujących główne wewnętrzne czynniki projakościowego zarządzania w organizacji o elementy w aspekcie ryzyka;

- opracowaniu kwestionariusza ankietowego wykorzystanego w badaniu ankietowym celem pozyskania informacji badawczych od respondentów z autoryzowanych salonów sprzedaży i serwisu samochodów osobowych w Polsce;

- ocenie ważności głównych wewnętrznych czynników zarządzania jakością w badanych organizacjach oraz zależności zachodzących pomiędzy nimi;

- ocenie ważności elementów konstytuujących poszczególne główne wewnętrzne czynniki projakościowego zarządzania w organizacji oraz relacji pomiędzy tymi elementami;

- ocenie ważności oraz hierarchizacji rezultatów zarządzania jakością stanowiących miary sukcesu projakościowego zarządzania w organizacji;

- identyfikacji relacji i ocenie oddziaływania pomiędzy głównymi wewnętrznymi czynnikami a poszczególnymi rezultatami zarządzania jakością w organizacji;

- ukazaniu wewnętrznych czynników zarządzania jakością w ramach eksploracyjnej analizy czynnikowej;

- określeniu liczby ukrytych składowych w ramach rezultatów zarządzania jakością poprzez zastosowanie eksploracyjnej analizy czynnikowej;

- analizie korelacji pomiędzy wyłonionymi wewnętrznymi czynnikami a rezultatami projakościowego zarządzania w organizacji;

- analizie skupień dla oceny podobieństw grup analizowanych organizacji;

- opisie najsilniejszych współzmienności pomiędzy analizowanymi zagadnieniami.

W celu weryfikacji postawionych hipotez badawczych badanie empiryczne zostało przeprowadzone jako pośrednie badanie sondażowe $\mathrm{z}$ wykorzystaniem metody badań ankietowych, w formie ankiety internetowej. Na podstawie przeprowadzonych badań i analiz pozytywnie zweryfikowano hipotezy badawcze oraz sformułowano syntetyczne wnioski.

\section{Synteza wyników badawczych dla praktyki zarządzania}

Przeprowadzone $\mathrm{w}$ ramach niniejszej pracy badania i analizy (w szczególności eksploracyjna analiza czynnikowa) pozwoliły zidentyfikować trzy grupy rezultatów projakościowego zarządzania $\mathrm{w}$ organizacji. W tych poszczególnych zbiorach zostały zidentyfikowane najważniejsze pojedyncze rezultaty zarządzania jakością: 
1. Ogólne:

- osiąganie celów jakościowych,

- satysfakcja klientów.

2. Niefinansowe:

- zwiększenie zaangażowania pracowników,

- minimalizacja fluktuacji pracowników,

- zwiększanie współpracy pomiędzy działami,

- doskonalenie działań organizacyjnych,

- zmniejszanie reklamacji dotyczących wyrobów,

- zmniejszanie reklamacji dotyczących procesu obsługi klientów,

- pozyskanie nowych klientów,

- utrzymanie obecnych klientów.

3. Finansowe:

- osiąganie zaplanowanych rezultatów finansowych,

- maksymalizacja przychodów ze sprzedaży.

Rezultaty zarządzania jakością $\mathrm{w}$ organizacji są naprzemienne, bowiem niefinansowe efekty działań wpływają ostatecznie na finansowe, a jednocześnie ogólne, które dotyczą zarówno sfery finansowej, jak i niefinansowej. Interakcje pomiędzy wewnętrznymi czynnikami a rezultatami projakościowego zarządzania $\mathrm{w}$ organizacji są wielokierunkowe. Wiedza o ważności wewnątrzorganizacyjnych czynników wpływających na rezultaty działań z zakresu zarządzania jakością, w zestawieniu działań tradycyjnie podejmowanych (aspekt jakości) z podejściem opartym na ryzyku (aspekt ryzyka), umożliwia organizacjom optymalizację działań ukierunkowanych na osiąganie sukcesu projakościowego zarządzania w organizacji. Konieczna jest jednak każdorazowo interpretacja wyników badawczych i aplikacja działan dopasowanych do indywidualizmu każdej organizacji.

$\mathrm{Na}$ osiąganie celów jakościowych i zaangażowanie pracowników wpływ ma „Przywództwo i zaangażowanie najwyższego kierownictwa w jakość”, głównie poprzez „demonstrowanie zaangażowania w jakość”. Jednocześnie w ramach „Priorytetyzacji jakości” ważnym jakościowym elementem wpływającym na osiągane rezultaty projakościowego zarządzania w organizacji jest kwestia „kładzenia nacisku na zagadnienia jakościowe przez najwyższe kierownictwo”. W ramach panującej w organizacji kultury jakości orientacja najwyższego kierownictwa na jakość może być różnorodna. Najważniejsze wyniki badawcze również w różny sposób można dopasowywać do specyfiki każdej organizacji. Konieczna jest bowiem interpretacja zależności i podejmowanie odpowiednio dopasowanych działań. Dlatego powstaje pytanie o różnicowanie aktywności najwyższego kierownictwa w kontekście „demonstrowania” swojego zaangażowania oraz „kładzenia nacisku” na tematy jakościowe. $\mathrm{Z}$ perspektywy najwyższego kierownictwa można bowiem „kłaść nacisk” na jakość poprzez 
instruowanie swoich podwładnych o ważności tych zagadnień w pozyskiwaniu i utrzymywaniu klientów. Jednocześnie „demonstrowanie” zaangażowania w jakość może być pasywne i aktywne. W tym pierwszym podejściu będzie to właśnie wyłącznie słowne „kładzenie nacisku” dotyczące realizowania obowiązków służbowych. W podejściu aktywnym „demonstrowanie” pośrednio i automatycznie będzie wynikać z podejmowania przez najwyższe kierownictwo działań operacyjnych dotyczących jakości, klientów i pracowników. Są to zagadnienia szerokie, związane ze stylami zarządzania, a w ramach projakościowego zarządzania w organizacji wpisujące się w kulturę jakości, która jako wynik historii organizacji na rynku może być uwarunkowana różnorodnymi zagadnieniami, w tym charakterem interesariuszy.

Pierwotnym zagadnieniem dla skuteczności podejmowanych działań w ramach projakościowego zarządzania w organizacji jest kwestia „Planowania strategicznego i operacyjnego". Na podstawie wyników badania empirycznego można wskazać, że działania $\mathrm{z}$ obszaru planowania w zarządzaniu jakością implikują rezultaty ze sfery finansowej, a operacyjnie - maksymalizację przychodów ze sprzedaży. Choć oczywiście należy pamiętać, że na finansowe rezultaty projakościowego zarządzania $\mathrm{w}$ organizacji wpływ mają również inne podsystemy zarządzania, interakcje pomiędzy działaniami z ich zakresów oraz przepisy prawne i zmienność sytuacji rynkowych. Niemniej jednak planowanie w sposób istotny wpływa na rezultaty poprzez jasne precyzowanie mierzalnych celów jakościowych, które są dopasowane do możliwości organizacyjnych. W ramach eksploracyjnej analizy czynnikowej została zidentyfikowana zależność dla wewnętrznego czynnika projakościowe zarządzanie w organizacji „Planowanie jakości”, gdzie ważność tego czynnika w sposób istotny zależy od komunikowania celów jakościowych wszystkim pracownikom. W połączeniu z wysoką ważnością kaskadowania celów na poszczególne, coraz niższe poziomy w schemacie struktury organizacyjnej można skonkludować, że planowanie i tworzenie celów uwzględniających powyższe zagadnienia jest bardzo istotnym elementem wpływającym na obiektywizm i przejrzystość podejmowanych aktywności gospodarczych.

W fazie realizacji działań ukierunkowanych na osiągnięcie zaplanowanych celów jakości konieczne jest wykonywanie zadań w sposób usystematyzowany, co jest związane z podejściem procesowym. Bieżące aktywności gospodarcze, realizowane w ramach procesów, wpływają na „doskonalenie działań organizacyjnych”, „utrzymanie obecnych klientów”, „zmniejszenie reklamacji dotyczących procesu obsługi klientów”, „Zwiększenie współpracy pomiędzy działami”. Zarządzanie procesowe wpływa zatem na szereg rezultatów projakościowego zarządzania $\mathrm{w}$ organizacji, pomimo niskiej ważności $\mathrm{w}$ ocenie respondentów tego głównego wewnętrznego czynnika zarządzania jakością. Jednocześnie w wynikach badawczych zauważalna jest świadomość respondentów dotycząca 
potrzeby zarządzania ryzykiem procesów organizacyjnych. Podejście procesowe jest zagadnieniem naturalnym w działalności każdej organizacji, ponieważ codzienne aktywności tworzą właśnie tematyczne zbiory. Działania podejmowane w ramach tych zbiorów wpływają na efekty działalności gospodarczej.

Zasygnalizowana powyżej kwestia zarządzania ryzykiem procesów organizacyjnych jest istotna i sprowadza się do zagadnień zarówno prewencyjnych, jak i reakcyjnych. „Podejście prewencyjne do jakości” zostało w badaniu ankietowym zidentyfikowane jako negatywnie wpływające na ogólne rezultaty projakościowego zarządzania w organizacji. Najważniejsze elementy konstytuujące tenże wewnętrzny czynnik zarządzania jakością pochodzą jedynie z płaszczyzny „podejścia opartego na ryzyku”. Na wewnętrzny czynnik „Podejście prewencyjne do jakości" składają się działania podejmowane przez najwyższe kierownictwo w obszarze: ,identyfikacji zagrożeń i (lub) szans w obszarze zarządzania jakością”, ,identyfikacji kluczowych wyrobów i usług wymagających ochrony w sytuacjach kryzysowych”, „dokumentowania prewencyjnych i reakcyjnych planów zarządzania ryzykiem". Wskazane aktywności zostały uznane w niniejszej pracy za istotne w działalności każdej organizacji, w perspektywie niezakłóconej realizacji działań biznesowych. Na negatywne oddziaływanie wymienionych aktywności z obszaru podejścia opartego na ryzyku na ogólne rezultaty zarządzania jakością $\mathrm{w}$ organizacji można spojrzeć $\mathrm{z}$ dwóch perspektyw. Można wnioskować, że rzeczywiście takie podejście negatywnie oddziałuje na rezultaty podejmowanych działań, a ogólniej można stwierdzić, że zagadnienia zarządzania ryzykiem nie wspomagają realizacji zaplanowanych celów. To jednak przeczyłoby idei zarządzania ryzykiem (wspomaganiu w osiąganiu zaplanowanych celów) oraz wnioskom płynącym z różnorodnych badań i obserwacji rzeczywistości gospodarczej. Na uzyskane wyniki badania empirycznego należy zatem spojrzeć z perspektywy grupy badanych podmiotów, w których wskazane działania prawdopodobnie nie są podejmowane. Rzadkie podejmowanie działań $\mathrm{i}$ ich negatywny wpływ na rezultaty projakościowego zarządzania w organizacji potwierdza właśnie konieczność podejmowania aktywności dotyczących aspektu ryzyka w sposób świadomy. Uwzględnianie takiego podejścia w działalności organizacji i wewnątrzorganizacyjne kształtowanie poszczególnych czynników pozwoli zmaksymalizować osiągane rezultaty zarządzania jakością w organizacji, co się przekłada na sukces organizacji na rynku.

Podsumowując badawcze wyniki pracy w aspekcie ryzyka, warto zwrócić uwagę na wyłonienie w eksploracyjnej analizie czynnikowej dwóch składowych, którym nadano nazwy: „Podejście reakcyjne do jakości” oraz „Szanse i zagrożenia jakości”. W „Podejściu reakcyjnym do jakości” dwa elementy konstytuujące zostały zidentyfikowane jako najważniejsze: zagadnienia uwzględniania działań korekcyjnych oraz korygujących jako priorytetowe w działaniach organizacyjnych z zakresu zarządzania jakością. Jedank elementy te w niewielkim stopniu 
wpływają na wszystkie trzy sfery rezultatów projakościowego zarządzania w organizacji. Z kolei jeden element $\mathrm{w}$ aspekcie ryzyka w sposób istotny tworzy wewnętrzny czynnik projakościowego zarządzania w organizacji - „Szanse i zagrożenia jakości”, i dotyczy tworzenia prewencyjnych planów zarządzania ryzykiem dla zidentyfikowanych zagrożeń w realizacji celów. Całościowo czynnik „Szanse i zagrożenia jakości” wpływa negatywnie na niefinansowe rezultaty projakościowego zarządzania $\mathrm{w}$ organizacji zarządzania jakością, a pozytywnie na sferę finansową.

Przywołane powyżej „Zarządzanie procesowe” łączy się istotnie z wewnątrzorganizacyjnym czynnikiem „Ciągłe doskonalenie” jako procesem nieustannego dopasowywania wewnętrznych warunków gospodarowania do zmieniających się okoliczności. Na skuteczność działań na tym etapie zarządzania jakością $\mathrm{w}$ organizacji oddziałuje istotnie postawa kierownictwa odzwierciedlona w „kładzeniu nacisku na uwzględnianie jakości w doskonaleniu wszystkich procesów na wszystkich poziomach organizacyjnych". Takie podejście najwyższego kierownictwa w opinii respondentów implikuje zwiększenie współpracy pomiędzy działami w organizacji. Przejawem tej współpracy jest kwestia „organizowania okresowych spotkań na rzecz doskonalenia jakości” oraz „doraźnych spotkań w celu rozwiązywania problemów jakościowych". Te dwa jakościowe elementy konstytuują główny wewnętrzny projakościowego zarządzania w organizacji „Zarządzanie na podstawie faktów” i wpływają ostatecznie na „osiąganie zaplanowanych rezultatów finansowych”. Kwestia organizowania „doraźnych spotkań w celu rozwiązywania problemów jakościowych” w istotny sposób wpływa na najważniejszy (po eksploracyjnej analizie czynnikowej) wewnętrzny czynnik zarządzania jakością w organizacji - „Przywództwo i kultura jakości”. Tenże czynnik łączy się w logiczny sposób z kolejnymi dwoma istotnymi jakościowymi zagadnieniami. Najwyższe kierownictwo tworzy klimat dla ,identyfikacji przyczyn niezgodności i podejmowania działań doskonalących" i jednocześnie „zmiany w organizacji są planowane i skutecznie wdrażane”. Klimat jakości tworzony przez najwyższe kierownictwo jest jak powietrze przenikające przez poszczególne poziomy struktury organizacyjnej, niewidzialne, lecz niezbędne do funkcjonowania. Równowaga pomiędzy podejściem prewencyjnym a reakcyjnym wynika z bieżącej sytuacji rynkowej i podejścia do jakości reprezentowanego przez najwyższe kierownictwo.

Niezależnie od wewnętrznego klimatu jakościowego każda organizacja potrzebuje klientów. Zbiór działań organizacyjnych umiejscowionych w ramach „Orientacji na klienta” w sposób logiczny wpływa na pozyskiwanie nowych klientów oraz usatysfakcjonowanie obecnych świadczonymi usługami i oferowanymi wyrobami. Jako najważniejsze elementy konstytuujące „Orientację na klienta” można wskazać „identyfikację tematów rynkowych mających wpływ na obsługę klientów”, „uwzględnianie danych z okresowych analiz rynku oraz 
konkurencji”, jak również „istnienie procedury przyjmowania uwag i reklamacji ze strony klientów". Bieżące działania organizacyjne ukierunkowane na klientów wymagają uwzględniania wiedzy o ogólnej sytuacji rynkowej.

Zorientowanie działań organizacyjnych na klientów jest nierozerwalnie związane z pracownikami każdej organizacji, bowiem obowiązki służbowe przez nich podejmowane są właśnie ukierunkowane na efekt końcowy - produkt (wyrób i (lub) usługę) podlegający ocenie przez klientów. W ramach eksploracyjnej analizy czynnikowej został zidentyfikowany wewnętrzny czynnik projakościowego zarządzania w organizacji dotyczący dualizmu jakości „klienci-pracownicy", skupiający w sobie elementy dotyczące właśnie zarówno pracowników, jak i klientów. Ten wewnętrzny czynnik oddziałuje na wszystkie rezultaty zarządzania jakością $\mathrm{w}$ organizacji, a najsilniej na te ze sfery niefinansowej. Wśród dwóch najważniejszych elementów konstytuujących tenże wewnętrzny czynnik zarządzania jakością w organizacji jeden dotyczący aspektu jakości, a drugi ryzyka.

Za najważniejszy główny wewnętrzny czynnik projakościowego zarządzania w organizacji pozytywnie wpływający na rezultaty działań w tym obszarze zarządzania uznane zostało w opinii respondentów „Zaangażowanie pracowników”. Jednocześnie najsilniej pozytywnie wpływającym elementem konstytuującym tenże czynnik jest postawa pracowników „lepiej zapobiegać niż leczyć". Podkreśla to znaczenie podejścia prewencyjnego w osiąganiu sukcesu projakościowego zarządzania $\mathrm{w}$ organizacji. Jednocześnie na ważność wskazanego głównego wewnętrznego czynnika zarządzania jakością w organizacji negatywnie wpływa ,istnienie skutecznej komunikacji w organizacji dotyczącej grupowego rozwiązywania problemów”. Taki empiryczny wynik, podobnie jak przy analizie „Podejścia prewencyjnego do jakości”, stanowi rezultat badawczy uzyskany w danym zakresie podmiotowym. Rzeczywista wysoka ważność tych zagadnień w kontekście osiągania pożądanych rezultatów projakościowego zarządzania $\mathrm{w}$ organizacji wynika $\mathrm{z}$ dużej istotności powiązanych tematycznie elementów - „organizowania okresowych spotkań na rzecz doskonalenia jakości” oraz „doraźnych spotkań w celu rozwiązywania problemów jakościowych”. Główny wewnętrzny czynnik zarządzania jakością „Zaangażowanie pracowników” jest najwyżej skorelowany z „Zarządzaniem na podstawie faktów”. Dane odgrywają istotną rolę $\mathrm{w}$ działaniu organizacji i ich posiadanie oraz bieżący do nich dostęp pozytywnie wpływa na zaangażowanie pracowników, m.in. poprzez obiektywizm w działaniach organizacyjnych. W wynikach badania ankietowego zauważalne jest, że zaangażowanie pracowników pozytywnie wpływa na osiąganie zaplanowanych celów dotyczących jakości, jako jeden z ogólnych rezultatów zarządzania jakością w organizacji.

$\mathrm{Na}$ „osiąganie zaplanowanych rezultatów finansowych” pozytywnie wpływa wewnętrzny czynnik „Zarządzanie zasobami ludzkimi”. Jednocześnie naj- 
ważniejszym elementem tworzącym tenże czynnik jest kwestia, że „pracownicy swobodnie wypowiadają się o swoim spojrzeniu, uwagach krytycznych, osiąganych wynikach organizacji”. Ten element wiąże się logicznie z kolejnymi, już wskazanymi. Po pierwsze, z ważnością zagadnień planowania mierzalnych celów na poszczególnych poziomach organizacyjnych oraz ich komunikowania w organizacji, a po drugie z organizowaniem okresowych i doraźnych spotkań dotyczących zagadnień jakościowych.

Dostrzegalna jest relacja w wynikach badania empirycznego, że wzrostowi działań z zakresu podejścia opartego na ryzyku towarzyszy ocena uzyskiwania mniejszych ogólnych rezultatów zarządzania jakością w organizacji. Można tutaj nawiązać do podsumowania $\mathrm{z}$ ostatnich stron czwartego rozdziału monografii, gdzie została skomentowana współzmienność „Szans i zagrożeń jakości”, ambiwalentna względem rezultatów osiąganych w organizacji. „Działania ukierunkowane na minimalizację zagrożeń oraz maksymalizację szans" generują aktywności, które wymagają czasu i koncentracji kosztem podejmowania innych działań. Operacyjnie zatem można by wskazać na „stratę czasu”, ale ostatecznie te działania pozytywnie wpływają na rezultaty finansowe. Również wyniki badania dla ważności poszczególnych głównych wewnętrznych czynników projakościowego zarządzania w organizacji ukazują ujemny wpływ dwóch elementów w aspekcie ryzyka na ważność danych wewnętrznych czynników. Dotyczy to „Przywództwa i zaangażowania najwyższego kierownictwa w jakość” oraz „Zaangażowania pracowników”. Takie wyniki, zdaniem autora, potwierdzają właśnie ważność uwzględniania aspektów ryzyka w funkcjonowaniu organizacji i wpływie na sukces projakościowego zarządzania $\mathrm{w}$ organizacji. Jednocześnie wyniki przeprowadzonych badań i analiz ukazują niskie zainteresowanie w badanych podmiotach tymi zagadnieniami. Małe natężenie działań w aspekcie ryzyka, przy jednoczesnym ich dużym wpływie na rezultaty zarządzania jakością, wskazuje, zdaniem autora, jednoznacznie na potrzebę koncentracji aktywności na elementach z obszaru podejścia opartego na ryzyku w celu minimalizowania zagrożeń i maksymalizowania szans w projakościowym zarządzaniu w organizacji.

\section{Przedmiotowo-podmiotowe konkluzje końcowe}

Zidentyfikowane zależności pomiędzy wewnętrznymi czynnikami a rezultatami zarządzania jakością w organizacji można umieścić na czterech poziomach. Elementy te kaskadowo ukazują podejście do podejmowania działań organizacyjnych ukierunkowanych na sukces projakościowego zarządzania $\mathrm{w}$ organizacji: przywództwo, klienci, pracownicy oraz działania wewnętrzne. Działania wewnętrzne zależą od zaangażowania pracowników, co jest efektem klimatu 
jakości stworzonego przez najwyższe kierownictwo, uwzględniającego orientację na klientów.

Na zidentyfikowane najważniejsze wyniki badawcze można spojrzeć z perspektywy przedmiotowej. Kierunek dla podejmowanych w organizacjach działań wyznaczają zidentyfikowane cele dotyczące jakości. Cele te powinny być mierzalne i dopasowane do specyfiki organizacji, co wpływa na ich obiektywne postrzeganie. Ważnym zagadnieniem jest kwestia zakomunikowania celów jakościowych wszystkim pracownikom, co ma istotne znaczenie dla ich zaangażowania w realizację działań. Jednocześnie zaangażowanie najwyższego kierownictwa w zagadnienia zarządzania jakością implikuje zwiększenie współpracy pomiędzy działami w organizacji. Przejawem tej współpracy jest m.in. kwestia „organizowania okresowych spotkań na rzecz doskonalenia jakości” oraz „doraźnych spotkań w celu rozwiązywania problemów jakościowych”. W ramach prowadzenia bieżących działań operacyjnych konieczne jest zarządzanie ryzykiem procesów, co dotyczy identyfikacji szans i zagrożeń dla jakości procesów i produktów. Podejście oparte na ryzyku może wzmocnić uzyskiwanie zaplanowanych celów i osiąganie rezultatów organizacji poprzez np. dokumentowanie odpowiednich planów. Sporządzanie pisemnych planów samo $\mathrm{w}$ sobie stanowi przejaw podejścia opartego na ryzyku, z uwagi na formalne zapisywanie działań i możliwość korzystania z nich podczas podejmowania działań prewencyjnych oraz aktywności reakcyjnych, w sytuacji zagrożeń realizacyjnych dla ustalonych celów jakości. Dodatkowo sporządzanie udokumentowanych planów jest poprzedzone działaniami analitycznymi, a poruszanie kwestii zagrożeń występujących $\mathrm{w}$ danej działalności gospodarczej przypomina pracownikom o możliwych scenariuszach. W ramach "Ciągłego doskonalenia” konieczne jest zwrócenie uwagi na przyczyny pojawiających się niezgodności i podejmowanie działań korygujących ukierunkowanych na eliminację negatywnych zdarzeń w przyszłości. A wszystko jest realizowane nie tylko w odpowiednim klimacie jakościowym, ale również zgodnie z ukierunkowaniem rynkowym. W ramach „Orientacji na klienta” konieczne jest bowiem identyfikowanie aktualnych tematów rynkowych oraz uwzględnianie wymagań i oczekiwań klientów w planowanych i podejmowanych działaniach. Jednak kwestia poziomu uwzględniania wymagań i oczekiwań klientów w realizowanych działaniach powinna być określona szczegółowo w ramach celów dotyczących jakości oraz ogólnie w ramach kultury jakości. Wyniki przeprowadzonego badania empirycznego wykazały, że uwzględnianie informacji płynących od klientów przez pracowników może odmiennie wpływać na rezultaty zarządzania jakością niż ich uwzględnianie przez najwyższe kierownictwo. Konieczne jest zatem ustalenie klimatu jakościowego na styku organizacji względem klientów, aby zoptymalizować wymagania jakościowe (np. ustanowione w ramach kryteriów badania jakości obsługi w formie testów tajemniczego klienta) względem 
ilościowych (np. zaplanowane cele sprzedażowe). Z perspektywy zakresu podmiotowego opracowania dokonano próby interpretacji wyników badawczych w zależności od obszarów prowadzonej działalności przez autoryzowane salony sprzedaży i serwisu samochodów osobowych w Polsce. Stan każdej organizacji jest wynikiem działań historycznych, każda ma swoje zasoby, działa w określonym otoczeniu, przy różnorodnych relacjach $\mathrm{z}$ interesariuszami i co najważniejsze - przy różnej charakterystyce grupy docelowej i pojedynczych klientów. Dlatego każdorazowo przy podejmowaniu działań organizacyjnych konieczne jest uwzględnianie zmieniającego się otoczenia i optymalizacja podejmowanych decyzji w danym czasie.

W aspekcie praktycznych implikacji wyników badawczych można zwrócić uwagę na trzy płaszczyzny: ogólną, sferę sprzedaży nowych samochodów oraz obszar serwisowania pojazdów. Każdy z tych obszarów funkcjonuje w ramach jednej organizacji ukierunkowanej na klientów, którzy w swoich wyborach i decyzjach zakupowych kierują się różnorodnymi zagadnieniami, w tym czynnikami jakości. Przedstawiciele autoryzowanych salonów sprzedaży i serwisu samochodów osobowych w Polsce wskazali podczas badań jakościowych (wywiadów bezpośrednich) na trzy istotne hasła: czas, cena i zgodność. Wszystkie trzy atrybuty wyrobów i usług dotyczą wymagań i oczekiwań klientów. Klienci chcieliby jak najszybciej, w jak najniższej cenie i zgodnie właśnie ze swoimi wymaganiami i oczekiwaniami kupić samochód lub zrealizować wizytę serwisową (czynności przeglądowe bądź weryfikację usterki i naprawę). Oczywiście kwestia ceny jest adekwatna do zakresu uzgodnionych działań serwisowych oraz w części handlowej modelu i wyposażenia pojazdu, a globalnie jest związana z polityką cenową w ramach sieci sprzedaży i obsługi posprzedażnej danej marki samochodów. Powyższe zagadnienia są powiązane z czynnikami jakości, które mogą być różnorodne i tym samym odpowiadające im działania podejmowane $\mathrm{w}$ ramach wewnętrznych czynników zarządzania jakością w organizacji będą zindywidualizowane. Warto jednocześnie zauważyć, że w przypadku sieci autoryzowanych salonów sprzedaży i serwisu samochodów osobowych w Polsce czynniki jakości w dużej mierze są uwzględniane na poziomie podmiotu przyznającego autoryzację $\mathrm{w}$ ramach wymagań autoryzacyjnych. Dodatkowo pod kątem tych wymagań często są tworzone wewnętrzne dokumenty przedstawiające zasady funkcjonowania procesów oraz szczegółowe procedury ukierunkowane na zapewnienie powtarzalnej jakości w poszczególnych punktach odwiedzanych przez klientów.

Szczegółowe powiązanie zaprezentowanych wyników badawczych z praktycznymi działaniami jest kwestią indywidualną $w$ poszczególnych autoryzowanych salonach sprzedaży i serwisu samochodów osobowych w Polsce. Próba ogólnego powiązania empirycznych wyników z praktyką dnia codziennego jest związana z ogólnym klimatem dla jakości i szczegółowymi zasadami 
międzydziałowej współpracy. Najwyższe kierownictwo powinno podejmować działania demonstrowania istotnego znaczenia jakości w funkcjonowaniu całej organizacji poprzez np. organizowanie okresowych spotkań na rzecz doskonalenia jakości. Takie spotkania wpływają na skuteczność zarządzania procesowego na poziomie zarówno najwyższego kierownictwa, jak i pracowników operacyjnych, których bieżące działania oraz współpraca budują całościowy efekt. Podejście zespalające działania poszczególnych działów organizacyjnych powinno pozytywnie wpływać na wyniki jakościowo-ilościowe całej organizacji. Jednocześnie będzie to przyczynek do niwelowania wskazywanej przez ekspertów w badaniu jakościowym bariery w bieżących działaniach - alienacji serwisu od sprzedaży i odwrotnie, co w założeniu organizacji jako jednego podmiotu z jedną księgowością wydaje się co najmniej zadziwiające. Autor zidentyfikował w swoich praktycznych działaniach $\mathrm{w}$ organizacjach $\mathrm{z}$ zakresu podmiotowego pracy, że odmienny charakter działań w tychże działach oraz związany z tym inny charakter planowanych celów może wpływać negatywnie na międzydziałową współpracę. Kwestia przełamywania tych barier jest związana z kulturą jakości. Najwyższe kierownictwo, z racji zarządzania organizacją jako całością i ukierunkowania działań na jeden wynik, powinno wyznaczać kierunki wewnętrznej współpracy. Jednym z nich może być bieżąca wymiana informacji pomiędzy doradcami handlowymi oraz doradcami serwisowymi. Doradcy handlowi mogą analizować grafik wizyt serwisowych pod kątem posiadanych przez klientów modeli pojazdów, zbliżającego się terminu zakończenia finansowania i innych parametrów. Wynikiem takiej analizy może być przygotowanie spotkania z klientem celem np. przedstawienia możliwości wymiany modelu samochodu na nowszy, przedstawienia możliwości finansowania pojazdu czy też odkupu od klienta obecnego pojazdu, w ramach rozliczenia przy zakupie nowego. Podejmowanie takich przykładowych działań oznacza, że klient, zamiast tracić czas w oczekiwaniu na zakończenie prac przy serwisowanym pojeździe, może go przeznaczyć na spotkanie z doradcą handlowym, co ostatecznie może pozytywnie wpłynąć na realizację celów po obu stronach podażowo-popytowego postępowania. Odwrotna relacja międzydziałowa może oznaczać, że doradcy serwisowi mogą uczestniczyć w spotkaniach doradców handlowych z potencjalnymi klientami. Ich rolą będzie wówczas podkreślenie korzyści zakupu pojazdu w danej lokalizacji związanych np. ze specjalną ofertą pakietów serwisowych, przedłużonymi gwarancjami czy wyznaczaniem opiekuna serwisowego i świadczeniem usługi door-to-door w ramach zapewnienia mobilności serwisowej. Rolą kierownictwa jest ustalanie zasad w obszarze współpracy międzydziałowej w kontekście czynnościowym (procedur postępowania) oraz wynikowym, dotyczącym bardzo istotnej kwestii, jaką jest wynagradzanie finansowe pracowników. Dla przykładu cele działu zajmującego się sprzedażą części zamiennych i akcesoriów mogą dotyczyć rotacji pozycji magazynowych, jak również wolumenu i wartości sprzedaży, przy czym 
sprzedaż akcesoriów może być powiązana ze sprzedażą samochodu. Wówczas klient chciałby otrzymać ze strony doradcy handlowego ofertę korzystniejszą cenowo niż odrębny zakup samych akcesoriów. To wpływa na odmienny poziom cenowy i tym samym kwestię premii w aspekcie jej ewentualnego podziału pomiędzy doradcę handlowego i doradcę ds. części i akcesoriów. W relacji tego obszaru do serwisu również występują dylematy w działaniach mające wpływ na postrzeganie zarządzania jakością $\mathrm{w}$ danej organizacji przez klientów - sprzedaż „biurkowa” i „serwisowa”. Pierwsza jest związana ze sprzedażą klientom wyłącznie części zamiennych, druga - z wiązaniem tej sprzedaży z montażem danej części w pojeździe klienta. Tutaj również mogą występować dylematy proceduralne co do międzydziałowych zasad działania, jak i efektów finansowych. Kolejne kwestie szczegółowe, rozważane i systematyzowane w ramach projakościowego zarządzania $\mathrm{w}$ organizacji, dotyczą procedur obsługi klientów. Zarówno w obszarze handlowym, jak i serwisowym istotną kwestią jest pierwszy kontakt $\mathrm{z}$ klientem oraz następnie jego utrzymanie. Z perspektywy klienta jest to związane z początkiem działań na linii organizacja-klient, zgodnie z powiedzeniem, że „pierwsze wrażenie można zrobić tylko raz”. Podtrzymywanie relacji z klientem jest kwestią istotną dla organizacji z perspektywy zamknięcia transakcji po pierwszym kontakcie oraz utrzymania klienta dla realizacji działań posprzedażowych. Zagadnienia te są regulowane procedurami wewnętrznymi, których stopień realizacji jest poddawany badaniom jakości obsługi w formie testów tajemniczego klienta. Wizyty tajemniczych klientów mają miejsce zarówno w obszarze sprzedaży, jak i serwisu i dopiero za pomocą takich badań możliwe jest dokonanie pełnej oceny realizacji procesów operacyjnych przez pryzmat zgodności z kryteriami oceny.

Powyższe dywagacje o szczegółowych działaniach dotyczących projakościowego zarządzania $\mathrm{w}$ organizacji $\mathrm{w}$ autoryzowanych salonach sprzedaży i serwisu samochodów osobowych w Polsce odnoszą się do realizacji celów ilościowych poprzez podejście jakościowe. Należy jednak pamiętać, że to finansowy rezultat stanowi kompleksowy wynik oceny efektów podejmowanych działań. W tym kontekście pozytywny wynik finansowy organizacji może usypiać czujność kierownictwa w obszarze jakościowym w myśl potocznego sformułowania ,ilość kosztem jakości”. W momencie gorszej koniunktury na rynku motoryzacyjnym działania organizacyjne będą skoncentrowane na poszukiwaniu nowych klientów oraz utrzymaniu obecnych. Ci jednak, pamiętając słabsze podejście jakościowe z przeszłości, mogą podejmować decyzje o wyborze organizacji konkurencyjnych. Aby uniknąć takich sytuacji, konieczne jest podejmowanie projakościowych działań w organizacji przy uwzględnieniu aspektu ryzyka w sposób usystematyzowany, a nie akcyjny i uzależniony wyłącznie od celów ilościowych w krótkim okresie. Rolą kierownictwa jest uwzględnianie długookresowego podejścia prewencyjnego w działaniach jakościowych. 
Zasygnalizowane działania operacyjne są związane z minimalizacją zagrożeń (np. procedowanie zgodnie z zasadami danej sieci motoryzacyjnej, organizowanie bieżących prewencyjnych spotkań) oraz maksymalizacją szans (np. pakietowa sprzedaż akcesoriów, okresowe promocyjne akcje serwisowe). Zagadnienia te nie zawsze są rozumiane w organizacji jako „podejście oparte na ryzyku", raczej są realizowane w ramach bieżącej działalności gospodarczej. Koncentrując się w działaniach organizacyjnych na aspekcie ryzyka, różnorodne działania można przypisać do wskazanego podejścia, bowiem elementy zarządzania ryzykiem są wkomponowane w codzienne działania gospodarcze, a wyniki przeprowadzonych badań i analiz wskazują na potrzebę świadomego podejścia do tych zagadnień i ich dokumentowania na rzecz maksymalizacji sukcesu projakościowego zarządzania w organizacji.

W każdej organizacji są identyfikowane różnorodne zagrożenia i szanse oddziałujące na realizację zaplanowanych celów dotyczących jakości. Implementacja znormalizowanego systemu zarządzania jakością umożliwia systemowe zorganizowanie działań $\mathrm{w}$ tym zakresie. Podstawę takiego systemu stanowią wymagania zawarte w normie ISO 9001. Wyniki badania empirycznego jednoznacznie wskazały, że respondenci z organizacji posiadających certyfikowany system zarządzania jakością wyżej oceniają wpływ wewnętrznych czynników na rezultaty projakościowego zarządzania $\mathrm{w}$ organizacji. Wymagania normatywne dla systemowego zarządzania jakością uwzględniają zagadnienia „podejścia opartego na ryzyku" w sposób elastyczny, bez narzucania konkretnych metod zarządzania ryzykiem. Tematyka podejścia i zorganizowania tego aspektu systemu zarządzania jakością jest pozostawiona organizacji wdrażającej taki znormalizowanych system. Zakres działań dotyczących „podejścia opartego na ryzyku" jest uzależniony od wielu uwarunkowań, a przy projektowaniu, budowie i wdrażaniu takiego systemu warto uwzględniać wyniki badań opisanych w niniejszej monografii, z uwagi na optymalizację projakościowych działań w organizacji. W ramach wdrożenia systemu zarządzania jakością należy zwrócić uwagę na kwestię wewnętrznych czynników wpływających na sukces zarządzania jakością, które można powiązać m.in. z wymaganiami autoryzacyjnymi, kryteriami w testach tajemniczego klienta, wynikami audytów standardów importerskich, jak również z cyklem PDCA i zasadami zarządzania jakością wskazanymi w wymaganiach normatywnych. Znormalizowany system zarządzania jakością w organizacji tworzy ramy dla podejmowanych działań i prawdopodobnie niezależnie od motywów jego wdrożenia konieczność spełniania wymagań i okresowych audytów zewnętrznych pozytywnie wpływa na rezultaty zarządzania jakością w organizacji, czego analizy i badania mogłyby stanowić temat odrębnej monografii.

Reasumując można stwierdzić, że projakościowe zarządzanie $\mathrm{w}$ organizacji było, jest i będzie zawsze aktualne $\mathrm{z}$ uwagi na organizacyjny charakter działań 
w ukierunkowaniu na odpowiednią i powtarzalną jakość końcowych produktów (wyrobów i usług). Zarządzanie jakością implikuje pozyskiwanie i utrzymywanie klientów, co ma przełożenie na generowanie przychodów i długookresowe funkcjonowanie organizacji na rynku. Jednocześnie poszukiwanie informacji o wewnętrznych czynnikach wpływających na sukces tych działań jest nieustanne z uwagi na zmieniające się okoliczności gospodarowania.

\section{Ograniczenia i kierunki przyszłych badań}

Zaprezentowane w niniejszej monografii wyniki badań i analiz dotyczące wewnętrznych czynników projakościowego zarządzania w organizacji nie zawierają odpowiedzi na wszystkie pytania w tym obszarze badawczym. Treść monografii stanowi efekt empirycznej oceny przyjętej teoretycznej konstrukcji, na wybranej grupie organizacji, $w$ danym zakresie czasowym i terytorialnym. $\mathrm{Z}$ tego wynikają ograniczenia przeprowadzonych badań, które dotyczą:

1. Zakresu podmiotowego. $\mathrm{W}$ organizacjach $\mathrm{z}$ różnych branż te same zmienne mogą tworzyć odmienne zbiory i w różny sposób zachodzić na siebie we wzajemnych relacjach. Kwestia hierarchizacji wewnętrznych czynników projakościowego zarządzania $\mathrm{w}$ organizacji jest zatem związana $\mathrm{z}$ charakterystyką każdej organizacji i jej uwarunkowaniami oraz okolicznościami gospodarowania w danym czasie.

2. Przyjętych zmiennych $\mathrm{w}$ badaniu ankietowym. Kwerenda literatury była ukierunkowana na stworzenie jak najpełniejszej listy zmiennych umieszczonych w kwestionariuszu ankietowym. Wyniki eksploracyjnej analizy czynnikowej wskazały na wysokie wartości wyjaśniania zmienności w badanych obszarach wewnętrznych czynników i rezultatów zarządzania jakością w organizacji. Zawsze jednak pozostaje sfera niezbadana, część rzeczywistości gospodarczej wpływająca w poszczególnych organizacjach na sukces projakościowego zarządzania w organizacji w sposób indywidualny.

3. Przyjętej metody badawczej. Ankietyzacja jako metoda pośrednia pozwala na ocenę zagadnień realizowanych $\mathrm{w}$ organizacjach rozproszonych terytorialnie. Metody sondażowe bezpośrednie mogłyby umożliwić pozyskanie bardziej szczegółowych informacji odnośnie do działań z zakresu zarządzania jakością podejmowanych $\mathrm{w}$ poszczególnych organizacjach, np. w perspektywie poziomów planowania i realizowania działań w ukierunkowaniu na sukces zarządzania jakością w organizacji.

Zmieniające się okoliczności gospodarowania sprawiają, że wewnętrznych czynników zarządzania jakością i ich hierarchizacji nie można traktować jako zbioru statycznego. Ważność wewnętrznych czynników oraz ich oddziaływania na rezultaty zarządzania jakością wynikają zarówno ze zmieniających się 
okoliczności gospodarowania danej organizacji, jak i uwarunkowań dla poszczególnych zakresów podmiotowych. Dlatego też wskazane ograniczenia przeprowadzonego badania mogą stanowić punkt odniesienia dla projektowania kolejnych badań. W ramach danego zakresu podmiotowego można wskazać na rozszerzenie analizowanych zagadnień o kwestie autoryzacji przyznawanej poszczególnym salonom sprzedaży i serwisu samochodów osobowych w Polsce. Wymagania autoryzacyjne odnoszą się do różnych obszarów zarządzania jakością, a w niniejszej pracy zostały celowo pominięte z uwagi na objęcie badaniem podmiotów posiadających autoryzacje różnych marek, co oznacza ich zróżnicowanie. Próba badania odmienności tych wymagań i ich wpływu na rezultaty projakościowego zarządzania w organizacji mogłaby umożliwić uzyskanie szczegółowych danych przy zastosowaniu metody wywiadu bezpośredniego lub analiz szczegółowych wymagań autoryzacyjnych względem wymagań normatywnych dla systemu zarządzania jakością.

W dalszej kolejności można wskazać na kierunki przyszłych badań, rozszerzających zagadnienia podjęte $\mathrm{w}$ niniejszej monografii:

1. Rozszerzenie zakresu merytorycznego obszaru badawczego. W tym kontekście można zwrócić uwagę na relacje pomiędzy czynnikami wewnętrznymi a zewnętrznymi wpływającymi na różne aspekty projakościowego zarządzania w organizacji. Jednocześnie można by rozbudować kwestie podejścia opartego na ryzyku w zarządzaniu jakością o stosowane w organizacjach narzędzia zarządzania ryzykiem czy też kategorie rozpatrywanego ryzyka.

2. Realizowanie badań porównawczych. Uwzględniając zastosowane narzędzie badawcze z przyjętymi zmiennymi lub nową konstrukcję badawczą, można by dokonać badań porównawczych pomiędzy różnymi grupami podmiotów lub zmiany podejścia tych samych organizacji do badanych zagadnień w czasie. Można by tutaj również uwzględnić w planowaniu badań i późniejszym różnicowaniu empirycznych wyników kwestie rozdzielenia i sprofilowania rynku b2b i b2c.

Zidentyfikowane $\mathrm{w}$ badaniu empirycznym relacje pomiędzy wewnętrznymi czynnikami a rezultatami projakościowego zarządzania w organizacji dotyczą wycinka rzeczywistości gospodarczej. Zaprezentowane wyniki należy potraktować jako przyczynek do dalszych badań podejmowanych z perspektywy użyteczności pożądanych efektów w danym czasie i zakresach.

Wyodrębniając w wynikach przeprowadzonych badań i analiz dwie sfery zarządzania jakością - prewencyjną oraz reakcyjną - zidentyfikowane wewnętrzne czynniki zarządzania jakością w organizacji można przyrównać do medykamentów o różnorodnych elementach składowych. W zależności od dolegliwości i pożądanych efektów dobieramy suplementy diety lub lekarstwa. Dla normalnego funkcjonowania i budowania odporności korzystamy z suplementów diety. W przypadku stanów zapalnych korzystamy z lekarstw. Analogicznie 
w organizacji podejmowane są działania w ramach zarządzania jakością. Podczas bieżących działań gospodarczych realizowane są działania prewencyjne, które są jak suplementy diety, mają wspomagać aktywności i prowadzić płynnie do realizacji zaplanowanych celów. Natomiast gdy organizacja traci balans, $\mathrm{z}$ uwagi na zmiany wewnętrzne bądź bodźce płynące $\mathrm{z}$ otoczenia, konieczna jest aplikacja lekarstwa, czyli wzmocnione działania na wybranych elementach składowych na rzecz uzyskania danego celu. Należy jednak pamiętać, że zażywanie lekarstw niesie ze sobą potencjalne skutki uboczne. Koncentracja działań na wybranych czynnikach projakościowego zarządzania w organizacji może zakłócić interakcje pomiędzy całą ich grupą, a ukierunkowanie aktywności wyłącznie na dany cel może oznaczać obniżenie skuteczności w pozostałych obszarach. Dlatego konieczne jest zbalansowane podejście podczas kształtowania wewnętrznych czynników, uwzględniające różnorodne elementy i powiązania organizacyjne na rzecz wynikowego sukcesu projakościowego zarządzania w organizacji. 


\section{Literatura}

Aba, E.K., Badar, M.A., Hayden, M.A., 2016, Impact of ISO 9001 certification on firms financial operating performance, International Journal of Quality \& Reliability Management, vol. 33, no. 1.

Abdi, H., 2003, Factor rotations in factor analyses, w: Lewis-Beck, M., Bryman, A., Futing, T. (Eds.), Encyclopedia of Social Sciences Research Methods, Thousand Oaks (CA): Sage.

Aczel, A.D., 2000, Statystyka w zarzadzaniu, Wydawnictwo Naukowe PWN, Warszawa. Anderberg, M.R., 1973, Cluster Analysis for Applications, Academic Press, New York. Apanowicz, J., 2003, Metodologia nauk, TNOIK, Toruń.

Baird, K., Jia Hu, K., Reeve, R., 2011, The relationships between organizational culture, total quality management practices and operational performance, International Journal of Operations \& Production Management, vol. 31, no. 7.

Balicki, A., 2013, Statystyczna analiza wielowymiarowa $i$ jej zastosowania spoteczno-ekonomiczne, Wydawnictwo Uniwersytetu Gdańskiego, Gdańsk.

Barczak, B., Bartusik, K., 2010, Kryzys w przedsiębiorstwie $w$ kontekście aktualnych uwarunkowań gospodarczych, w: Stabryła, S. (red.), Zarzadzanie w kryzysie, Mfiles Encyklopedia Zarządzania, Kraków.

Bezpieczna firma, 2010, wkładka do Harvard Business Review Polska, nr 7-9.

Bielecki, W.T., 2009, Zarzadzanie wiedza a zarzadzanie ryzykiem w firmie, w: Chmielarz. W., Turyna, J. (red.), Komputerowe systemy zarządzania, Wydawnictwo Naukowe Wydziału Zarządzania Uniwersytetu Warszawskiego, Warszawa.

Bieńkowska, B., 2004, Lokalne uwarunkowania rozwoju przedsiębiorczości, w: Brdulak, J., Kulikowski, M. (red.), Przedsiębiorczość stymulatorem rozwoju gospodarczego, Wydawnictwo Instytut Wiedzy, Warszawa.

Bizon-Górecka, J., 2002, Koncepcja dokumentowanego systemu zarządzania ryzykiem w przedsiębiorstwie, w: Bizon-Górecka, J. (red.), Ryzyko. Zarządzanie ryzykiem $w$ przedsiębiorstwie. Strategie zarzadzania ryzykiem $w$ przedsiębiorstwie - ryzyka wewnętrzne $i$ w otoczeniu organizacji, Towarzystwo Naukowe Organizacji i Kierownictwa, Bydgoszcz.

Black, S.A., Porter, L.J., 1996, Identification of the critical factors of TQM, Decision Science, vol., 27 no. 1.

Borawiecki, R. (red.), 2014, Zarzadzanie przedsiębiorstwem $w$ warunkach globalizacji - szanse i zagrożenia, Fundacja Uniwersytetu Ekonomicznego w Krakowie, Kraków.

Borys, T., Rogala, P. (red.), 2011, Doskonalenie sformalizowanych systemów zarządzania, Difin, Warszawa.

Borys, T., Sudoł, S., 1992, Jakość wyrobów. Strategia i sterowanie w przedsiębiorstwie przemysłowym, Akademia Ekonomiczna w Krakowie, Kraków.

Bou-Llusar, J.C., Escrig-Tena, B., Roca-Puig, V., Beltran-Martin, I., 2009, An empirical assessment of the EFQM Excellence Model: Evaluation as a TQM framework relative to the MBNQA Model, Journal of Operations Management, vol. 27, no 1. 
Boulter, L., Bendell, T., Dahlgaard, J., 2013, Total quality beyond North America. A comparative analysis of the performance of European excellence award winners, International Journal of Operations \& Production Management, vol. 33, no. 2.

Brajer-Marczak, R., 2015, Doskonalenie zarządzania jakościa procesów i produktów w organizacjach, Wydawnictwo Uniwersytetu Ekonomicznego we Wrocławiu, Wrocław.

Branża motoryzacyjna, 2017, Raport Kwartalny, Edycja Q1/2017, PZPM i KPMG, Warszawa.

BS 25999-1, 2006, Business continuity management. Code of practice, British Standards Institution.

BS 25999-2, 2007, Business continuity management. Specification, British Standards Institution.

Bugdol, M., 2015, Znaczenie stereotypów w ocenie jakości usług, Problemy Jakości, nr 6.

Calvo-Mora, A., Picón, A., Ruiz, C., Cauzo, L., 2013, The relationships between softhard TQM factors and key business results, International Journal of Operations \& Production Management, vol. 34, no. 1.

Cândido, C.J., Coelho, L.M., Peixinho, R.M., 2016, The financial impact of a withdrawn ISO 9001 certificate, International Journal of Operations \&Production Management, vol. 36, no. 1.

Chin, K.S., Pun, K.F., Xu, Y., Chan, J.S.F., 2002, An AHP based study of critical factors for TQM implementation in Shanghai manufacturing industries, Technovation, vol. 22, no. 11.

Churchill, G.A., 2002, Badania marketingowe. Podstawy metodologiczne, Wydawnictwo Naukowe PWN, Warszawa.

Conti, T., 2010, Systems thinking in quality management, The TQM Journal, vol. 22, no. 4.

Cyfert, S., Dyduch, W., Latusek-Jurczak, D., Niemczyk, J., Sopińska, A., 2014, Subdyscypliny $w$ naukach o zarzadzaniu - logika wyodrębnienia, identyfikacja modelu koncepcyjnego oraz zawartość tematyczna, Organizacja i Kierowanie, nr 1 (161).

Cyfert, S., Krzakiewicz, K., 2010, Kryzysy jako determinanta ewolucji organizacji zorientowanej na procesy, w: Stabryła, S. (red.), Zarządzanie w kryzysie, Mfiles Encyklopedia Zarządzania, Kraków.

Denton, P.D., Maatgi, M.K., 2016, The development of a work environment framework for ISO 9000 standard success, International Journal of Quality \& Reliability Management, vol. 33, no. 2.

Desai, D.A., Antony, J., Patel, M.B., 2012, An assessment of the critical success factors for Six Sigma implementation in Indian industries, International Journal of Productivity and Performance Management, vol. 61, no. 4.

Dick, G.P., 2009, Exploring performance attribution: The case of quality management standards adoption and business performance, International Journal of Productivity and Performance Management, vol. 58, no. 4.

Drucker, P.F., 2000, Zarzadzanie w XXI wieku, Muza, Warszawa.

Dubisz, S. (red.), 2008, Uniwersalny słownik języka polskiego PWN, Wydawnictwo Naukowe PWN, Warszawa. 
Ebrahimi, M., Sadeghi, M., 2013, Quality management and performance: An annotated review, International Journal of Production Research, vol. 51, no. 18.

Elliott, D., Swartz, E., Herbane, B., 2010, 2nd ed., Business continuity management. A crisis management approach, Routlege.

Everitt, B.S., Landau, S., Leese, M., 1993, Cluster analysis, Edward Arnold, London.

Falkner, E.M., Hiebl, M.R., 2015, Risk management in SMEs: a systematic review of available evidence, The Journal of Risk Finance, vol. 16, no. 2.

Fatemi, S.M., Wei, C.C., Moayeryfard, H., 2016, CSFs for total quality management (TQM) in service organizations: review, International Journal of Academic Research in Business and Social Sciences, vol. 6, no. 1.

Ferguson, G.A., Takane, Y., 2009, Analiza statystyczna w psychologii i pedagogice, Wydawnictwo Naukowe PWN, Warszawa.

Field, A., 2005, Discovering statistics using SPSS, Sage, London.

Finstad, K., 2010, Response interpolation and scale sensitivity: evidence against5-point scales, Journal of Usabilities Studies, vol. 5, no. 3.

Fotopoulos, C.V., Psomas, E.L., 2010, The structural relationships between TQM factors and organizational performance, The TQM Journal, vol. 22, no. 5.

Gambi, L.D.N., Boer, H., Gerolamo, M.C., Jørgensen, F., Carpinetti, L.C.R., 2015, The relationship between organizational culture and quality techniques, and its impact on operational performance, International Journal of Operations \& Production Management, vol. 35 , no. 10 .

Garbarski, L., 2016, Sukces marketingowy produktu w percepcji konsumentów, Studia Ekonomiczne. Zeszyty Naukowe Uniwersytetu Ekonomicznego w Katowicach, nr 262.

Gatnar, E., Walesiak, M., 2004, Metody statystycznej analizy wielowymiarowej w badaniach marketingowych, Wydawnictwo Akademii Ekonomicznej we Wrocławiu, Wrocław.

Gierszewska, G., Romanowska, M., 2017, Analiza strategiczna przedsiębiorstwa, Polskie Wydawnictwo Ekonomiczne, Warszawa.

Godziszewski, B., Haffner, M., Stankiewicz, M.J., Sudoł, S., 2011, Przedsiębiorstwo. Teoria i praktyka zarzadzania, PWE, Warszawa.

Gołąb, P., 2009, Zarzadzanie ryzykiem ciagłości działania w firmach ubezpieczeniowych, Wiadomości Ubezpieczeniowe, $\mathrm{nr} 1$.

Grabowska, M., Drygas, M., 2010, Determinanty sukcesu przedsiębiorstw, Konferencja Innowacje w Zarządzaniu i Inżynierii Produkcji, Zakopane 2010, http://www.ptzp. org.pl/s80/Konferencja_KZZ_Zakopane_2010_Artykuly.

Grajewski, P., 2016, Organizacja procesowa, Polskie Wydawnictwo Ekonomiczne, Warszawa.

Griffin, R.W., 2013, Podstawy zarządzania organizacjami, Wydawnictwo Naukowe PWN, Warszawa.

Grönroos, Ch., 2000, Service Management and Marketing, John Wiley \& Sons.

Grudowski, P., Szpakowska, M.J., Brodnicka, E., Marjańska, E., Celmerowski, Z., 2016, Wybrane aspekty zarządzania jakościa i towaroznawstwa żywności: systemy, metody, narzędzia, Difin, Warszawa. 
Grzesiak, S., 1996, Efektywność funkcjonowania przedsiębiorstw - aspekty prakseologiczne i ekonomiczne, w: Przedsiębiorstwo na rynku, t. 1: Gospodarka polska w procesie transformacji systemowej, Wydawnictwo Uniwersytetu Szczecińskiego, Szczecin.

Habrzyk, A., 2013, Raport badania w internecie, Wydawca Interaktywne.com.

Hadyniak, B., Monkiewicz, J. (red.), 2010, Ubezpieczenia w zarzadzaniu ryzykiem przedsiębiorstwa, Wydawnictwo Poltext, Warszawa.

Hair, J.F., Black, W.C., Babin, B.J., Anderson, R.E., 2009, Multivariate data analysis, PrenticeHall, Upper Saddle River, NJ.

Hassan, M., Mukhtar, A., Qureshi, S.U., Sharif, S., 2012, Impact of TQM practices on firm's performance of Pakistan's manufacturing organizations, International Journal of Academic Research in Business and Social Sciences, vol. 2, no. 10.

Hawrysz, L., 2014a, Kluczowe czynniki sukcesu przy implementacji systemu zarzadzania jakością, Zarządzanie. Teoria i Praktyka, Wyższa Szkoła Menedżerska w Warszawie, nr 2 (10).

Hawrysz, L., 2014b, Niematerialne czynniki konstytuujące systemy zarzadzania oparte na jakości w organizacjach sektora publicznego, Difin, Warszawa.

Hawrysz, L., 2015, Determinanty jakości w kontekście skuteczności na przykładzie organizacji sektora publicznego, Ekonomika i Organizacja Przedsiębiorstwa, nr 4.

Hietschold, N., Reinhardt, R., Gurtner, S., 2014, Measuring critical success factors of TQM implementation successfully - a systematic literature review, International Journal of Production Research, vol. 52, no. 21.

Hiles, A., 2011, Developing and implementing the written plan, 3th ed., The Definitive Handbook of Business Continuity Management.

Huq, Z., 2005, Managing change: a barrier to TQM implementation in service industries, Managing Service Quality, vol. 15, no. 5.

Hys, K., 2015, Dyfuzja systemu zarządzania jakościa i koncepcji społecznej odpowiedzialności organizacji, Politechnika Opolska, Opole.

IBRM Samar, 2017, http://www.samar.pl/__/3/3.a/91706/Najlepszy-wynik-od-lat-.html, [dostęp: 28.02.2017].

IEC/ISO 31010, 2009, Risk management - Risk assessment techniques, International Organization for Standardization, Geneva.

Ignatczyk, W., Chromińska, M., 2004 Statystyka: teoria i zastosowanie, Wydawnictwo Wyższej Szkoły Bankowej, Poznań.

Ismyrlis, V., Moschidis, O., 2015, The effects of ISO 9001 certification on the performance of Greek companies, The TQM Journal, vol. 27, no. 1.

Ismyrlis, V., Moschidis, O., Tsiotras, G., 2015, Critical success factors examined in ISO 9001:2008-certified Greek companies using multidimensional statistics, International Journal of Quality \& Reliability Management, vol. 32, no. 2.

ISO 22300, 2012, Societal Security - Terminology, International Organization for Standardization, Geneva.

ISO 22301, 2012, Societal Security - Business continuity management systems - Requirements, International Organization for Standardization, Geneva.

ISO 31000, 2009, Risk management - Principles and guidelines, International Organization for Standardization, Geneva. 
ISO 9000, 2015, Quality management systems - Fundamentals and vocabulary, International Organization for Standardization, Geneva.

ISO 9001, 2015, Quality management systems - Requirements, International Organization for Standardization, Geneva.

ISO 9004, 2009, Managing for the sustained success of an organizaction - a quality management approach, International Organization for Standardization, Geneva.

ISO Survey of Management System Standard Certifications 2016, International Organization for Standardization, wyd. 09-2017.

ISO/TC 176/SC2/N1284, Risk-based thinking in ISO 9001:2015, www.iso.org/tc176/ sc02/public [dostęp: 14.10.2016].

ISO/TR 31004, 2013, Risk management - Guidance for the implementation of ISO 31000, International Organization for Standardization, Geneva.

Jaeger, M., Adair, D., 2016, Perception of TQM benefits, practices and obstacles, The TQM Journal, vol. 28, no. 2.

Jagoda, H., Lichtarski, J. (red.), 2010, Kierunki i dylematy rozwoju nauki i praktyki zarządzania przedsiębiorstwem, Wydawnictwo Uniwersytetu Ekonomicznego we Wrocławiu, Wrocław.

Jagoda, H., Lichtarski., J., Nowosielski, S., 2013, Nowe kierunki w zarzadzaniu przedsiębiorstwem - wiodace orientacje, Wydawnictwo Uniwersytetu Ekonomicznego we Wrocławiu, Wrocław.

Jajuga, K., 2007, Zarzadzanie ryzykiem, Wydawnictwo Naukowe PWN, Warszawa.

Jakubiec, M., 2013, Zarządzanie jakościa jako czynnik rozwoju wyrobów medycznych, w: Zeszyty Naukowe Politechniki Łódzkiej, nr 1153, seria Organizacja i Zarządzanie, nr 54, Wydawnictwo Politechniki Łódzkiej, Łódź.

Jakubiec, M., 2017, Projakościowe zarządzanie przedsiębiorstwem, Difin, Warszawa.

Jedynak, P., 2007, Ocena znormalizowanych systemów zarzadzania. Instrumenty $i$ uwarunkowania wartości, Wydawnictwo Uniwersytetu Jagiellońskiego, Kraków.

Jedynak, P., 2013, Business continuity management - the perspective of management science, International Journal of Contemporary Management, vol. 12, no. 4.

Kaczmarczyk, S., 2007, Zastosowania badań marketingowych: zarzadzanie marketingowe i otoczenie przedsiębiorstwa, Polskie Wydawnictwo Ekonomiczne, Warszawa.

Kaczmarczyk, S., 2011, Badania marketingowe. Podstawy metodyczne, Polskie Wydawnictwo Ekonomiczne, Warszawa.

Kaczmarek, T.T., 2010, Zarządzanie ryzykiem. Ujęcie interdyscyplinarne, Difin, Warszawa.

Kaczmarek, T.T., Ćwiek, G., 2009, Ryzyko kryzysu a ciagłość działania. Business Continuity Management, Difin, Warszawa.

Kafetzopoulos, D.P., Psomas, E.L., Gotzamani, K.D, 2015, The impact of quality management systems on the performance of manufacturing firms, International Journal of Quality \& Reliability Management, vol. 32, no. 4.

Kałowski, A., 2015, Czynniki sukcesu organizacji współczesnych przedsiębiorstw, Marketing i Rynek, nr 5.

Kaniewska-Sęba, A., Leszczyński, G., Pilarczyk, B., 2006, Badania marketingowe na rynku business-to-business, Oficyna Ekonomiczna, Oddział Polskich Wydawnictw Profesjonalnych, Kraków. 
Karaszewski, R., Skrzypczyńska, K., 2013, Zarządzanie jakościa, Towarzystwo Naukowe Organizacji i Kierownictwa. Stowarzyszenie Wyższej Użyteczności „Dom Organizatora", Toruń.

Karkoszka, T., 2013, Ryzyko w spetnieniu wymagań jakościowych, środowiskowych oraz bezpieczeństwa pracy, Wydawnictwo Naukowe „Śląsk”, Katowice.

Karuppusami, G., Gandhinathan, R., 2006, Pareto analysis of critical success factors of total quality management. A literature review and analysis, The TQM Magazine, vol. 18 , no. 4.

Kharub, M., Sharma, R.K., 2016, Investigating the role of CSF's for successful implementation of quality management practices in MSMEs, International Journal of System Assurance Engineering and Management, vol. 7, no. 1.

Klimczak, W., 2014, Zarzadzanie ryzykiem czy działania zapobiegawcze w systemie zarzązania?, Problemy Jakości, r. 46, nr 2.

Kline, P., 1994, An easy guide to factor analysis, Routledge, London \& New York.

Konarzewska-Gubała, E., Barcewicz, M. (red.), 2013, Zarządzanie przez jakość: koncepcje, metody, studia przypadków, Wydawnictwo Uniwersytetu Ekonomicznego we Wrocławiu, Wrocław.

Kosieradzka, A., Zawiła-Niedźwiecki, J. (red.), 2016, Zaawansowana metodyka oceny ryzyka w publicznym zarządzaniu kryzysowym, edu-Libri, Kraków - Legionowo.

Kotler, P., Keller, K.L., 2012, Marketing, Rebis, Poznań.

Koźmiński, A.K., Piotrowski, W. (red.), 2005, Zarzadzanie. Teoria i praktyka, Wydawnictwo Naukowe PWN, Warszawa.

Krzakiewicz, K., 2008, Zarządzanie antykryzysowe w organizacji, Wydawnictwo Akademii Ekonomicznej w Poznaniu, Poznań.

Krzakiewicz, K., 2014, Efekt aureoli i badanie czynników sukcesu organizacji, w: Bełz, G., Kacała, J. (red), Zmiana warunkiem sukcesu. Doskonałość w kształtowaniu konkurencyjności przedsiębiorstw, Prace Naukowe Uniwersytetu Ekonomicznego we Wrocławiu, nr 359, Wydawnictwo Uniwersytetu Ekonomicznego we Wrocławiu, Wrocław.

Krzyżanowski, L., 1994, Podstawy nauk o organizacji i zarzadzaniu, PWN, Warszawa.

Kumpiałowska, A. (red.), 2011, Skuteczne zarzadzanie ryzykiem a kontrola zarzadcza w sektorze publicznym, Wydawnictwo C.H. Beck, Warszawa.

Kutlu, C.A., Kadaifci, C., 2014, Analyzing critical success factors of total quality management by using fuzzy cognitive mapping, Journal of Enterprise Information Management, vol. 27, no. 5 .

Lettieri, E., Masella, C., Radaelli, G., 2009, Disaster management: findings from a systematic review, Disaster Prevention and Management: An International Journal, vol. 18, no. 2 .

Lichtarski, J., 2015, Praktyczny wymiar nauk o zarządzaniu, Polskie Wydawnictwo Ekonomiczne, Warszawa.

Ligarski, M.J., 2010, Podejście systemowe do zarządzania jakościa w organizacji, Wydawnictwo Politechniki Śląskiej, Gliwice.

Lindström, J., 2012, A model to explain a business contingency process, Disaster Prevention and Management: An International Journal, vol. 21, no. 2.

Lisiecka, K., 2012a, Doskonalenie zarządzania jakościa produktów subsystemem jakości zarządzania organizacja, w: Sikora, T., Giemza, M. (red.), Praktyka zarządzania 
jakościa XXI wieku, Uniwersytet Ekonomiczny w Krakowie, Wydawnictwo Naukowe PTT Z, Kraków.

Lisiecka, K., 2012b, Zarządzanie ryzykiem - determinanta jakości zarządzania przedsiębiorstwem, Zarządzanie i Finanse, r. 10, nr 3, cz. 1.

Lisiecka, K., 2017, Jakość imperatywem myślenia i działania, Problemy Jakości, nr 5.

Lisiecka, K., Czyż-Gwiazda E., 2014, Zarządzanie jakościa działań w organizacji modele i metody doskonalenia, Uniwersystet Ekonomiczny w Katowicach, Katowice.

Łańcucki, J., 2002, Jakość usług, Problemy Jakości, nr 34.

Łańcucki, J., 2006, Podstawy kompleksowego zarządzania jakościa TQM, Wydawnictwo Akademii Ekonomicznej w Poznaniu, Poznań.

Łańcucki, J. (red.), 2010, Znormalizowane systemy zarządzania, Wydawnictwo Uniwersytetu Ekonomicznego w Poznaniu, Poznań.

Łańcucki, J., 2013, Aspekty regulacyjne zarządzania ryzykiem w sektorze ubezpieczeń, Prawo Asekuracyjne, nr 2(75).

Łukasiński, W., 2013, Proces kształtowania projakościowego zarządzania organizacja, Zeszyty Naukowe Uniwersytetu Ekonomicznego w Krakowie, nr 915.

Łukasiński, W., 2016a, Dojrzałość organizacji zarządzanej projakościowo, Polskie Wydawnictwo Ekonomiczne, Warszawa.

Łukasiński, W., 2016b, Podejście procesowe a jakość funkcjonowania organizacji, Problemy Jakości, nr 7-8.

Maatta, O.H., 2009, Certification an integral part of risk management strategy, ISO Management Systems, no. 3-4.

Majewska-Opiełka, I., 2007, Sukces firmy, Gdańskie Wydawnictwo Psychologiczne, Gdańsk.

Malarska, A., 2005, Statystyczna analiza danych z programem SPSS, SPSS Polska, Kraków.

Marczak, M., 2014 Podmiotowe czynniki ryzyka $w$ zarzadzaniu organizacjami, Studia i Prace Kolegium Zarządzania i Finansów, SGH, z. 136.

Mendes, L., Lourenço, L., 2014, Factors that hinder quality improvement programs implementation in SME, Journal of Small Business and Enterprise Development, vol. 21 , no. 4 .

Mensah, J.O., Copuroglu, G., Fening, F.A., 2012, The status of total quality management (TQM) in Ghana. A comparison with selected quality awards winners from Turkey, International Journal of Quality \& Reliability Management, vol. 29, no. 8.

Miara, A., 2016, Czynniki determinujące wdrożenie systemu zarządzania jakościa w przedsiębiorstwach z branży spożywczej na tle pozostatych branż, Towaroznawcze Problemy Jakości, nr 1.

Misztal, A., 2015, Kryteria brzegowe implementacji systemów zarządzania jakościa w przedsiębiorstwach branży motoryzacyjnej, Wydawnictwo Politechniki Poznańskiej, Poznań.

Mitkow, S., Leszczyńska, A., 2016, Istota tworzenia Planów Ciagłości Działania w przedsiębiorstwie, Problemy Jakości, r. 48, nr 7-8.

Monkiewicz, J., 2010, Przedsiębiorstwo jako podmiot ryzyka - rozwój koncepcji zarzadzania ryzykiem, w: Monkiewicz, J., Gąsiorkiewicz, L. (red.), Zarządzanie ryzykiem działalności organizacji, Wydawnictwo C.H. Beck, Warszawa. 
Monkiewicz, J., Gąsiorkiewicz, L. (red.), 2010, Zarządzanie ryzykiem działalności organizacji, Wydawnictwo C.H. Beck, Warszawa.

Mosadeghrad, A.M., 2014, Why TQM programmes fail? A pathology approach, The TQM Journal, vol. 26, no. 2 .

Musgrave, B., Woodman, P., 2013, Weathering the storm-the 2013 business continuity management survey, Chartered Management Institute, London.

Niedzielski, E., 2016, Różne oblicza sukcesu przedsiębiorstw, w: Czubasiewicz, H., Grajewski, P., Waśniewski, J., Perspektywy spojrzenia na czynniki sukcesu organizacji XXI wieku, Wydział Zarządzania Uniwersytetu Gdańskiego, Gdańsk.

Niemiec, A., 2015, Możliwość zastosowania analizy istotności-osiagnięć w identyfikacji $i$ ewaluacji zestawu kluczowych mierników dokonań (KPIs), Zeszyty Naukowe Uniwersytetu Szczecińskiego, nr 873 Finanse, Rynki Finansowe, Ubezpieczenia, nr 77.

Niemiec, A. (red.), 2016, System pomiaru dokonań $w$ przedsiębiorstwach, CeDeWu, Warszawa.

Nieżurawski, L., Duarte, N., Nieżurawska, J., 2016, Determinanty sukcesu przedsiębiorstwa (studium przypadku wybranych przedsiębiorstw), Research Papers of the Wrocław University of Economics/Prace Naukowe Uniwersytetu Ekonomicznego we Wrocławiu, nr 420.

Nowosielski, S. (red.), 2008, Procesy i projekty logistyczne, Wydawnictwo Uniwersytetu Ekonomicznego we Wrocławiu, Wrocław.

Oakland, J., 1995, Total quality management - text with cases, 2nd ed., ButterworthHeinemann Professional Publishing, Oxford.

Pełka, M., Pełka, J., 2000, Co wdrażać: normy serii ISO 9000 czy TQM?, Problemy Jakości, nr 8 (32).

Pilch, T., Bauman, T., 2001, Zasady badań pedagogicznych, Wydawnictwo Akademickie Żak, Warszawa.

PN-EN ISO 10014, 2008, Zarzadzanie jakościa - wytyczne do osiagania korzyści finansowych i ekonomicznych, Polski Komitet Normalizacyjny, Warszawa.

PN-EN ISO 9000:2015-10, Systemy zarzadzania jakościa. Podstawy i terminologia, Polski Komitet Normalizacyjny, Warszawa.

PN-EN ISO 9001:2015-10, Systemy zarządzania jakością. Wymagania, Polski Komitet Normalizacyjny, Warszawa.

PN-EN ISO 9004, 2010, Zarzadzanie ukierunkowane na trwaty sukces organizacji Podejście wykorzystujące zarządzanie jakościa, Polski Komitet Normalizacyjny, Warszawa.

PN-ISO 31000, 2012, Zarzadzanie ryzykiem. Zasady i wytyczne, Polski Komitet Normalizacyjny, Warszawa.

Podolec, B., Zając, K., 1978, Ekonometryczne metody ustalania rejonów konsumpcji, PWE, Warszawa.

Prajogo, D.I., McDermott, C.M., 2005, The relationship between total quality management practices and organizational culture, International Journal of Operation and Production Management, vol. 25, no. 11.

Psomas, E.L., Jaca, C., 2016, The impact of total quality management on service company performance: evidence from Spain, International Journal of Quality \& Reliability Management, vol. 33, no. 3. 
Psomas, E.L., Kafetzopoulos, D.P., 2014, Performance measures of ISO 9001 certified and non-certified manufacturing companies, Benchmarking: An International Journal, vol. 21, no. 5.

Psomas, E.L., Pantouvakis, A., Kafetzopoulos, D.P., 2013, The impact of ISO 9001 effectiveness on the performance of service companies, Managing Service Quality: An International Journal, vol. 23, no. 2.

Risk Intelligent view of reputation. An outside-in perspective, 2011, Deloitte, Risk Intelligence Science, no. 22.

Rockart, J.F., 1979, Chief executives define their own data needs, Harvard Business Review, vol. 57, no. 2.

Rogala, P., 2010, Zasady zarzadzania jakościa-ISO czy EFQM?, Problemy Jakości, r. 42, nr 10.

Rogala, P., 2012, Tożsamość zarządzania jakościa wybrane zagadnienia, Zarządzanie i Finanse, r. 10, nr 3, cz. 1.

Rogala, P., 2016, Identification of barriers to improving quality management systems, The TQM Journal, vol. 28, no. 1.

Rogoziński, K., 2016, Zarządzanie organizacja usługowa, Difin, Warszawa.

Ronnback, A., Witell, L., 2008, A review of empirical investigations comparing quality initiatives in manufacturing and service organizations, Managing Service Quality, vol. 18 , no. 6 .

Rószkiewicz, M., 2012, Metody ilościowe w badaniach marketingowych, Wydawnictwo Naukowe PWN, Warszawa.

Salaheldin, S.I., 2009, Critical success factors for TQM implementation and their impact on performance of SMEs, International Journal of Productivity and Performance Management, vol. 58, no. 3.

Sampaio, P., Saraiva, P., Guimarães Rodrigues, A., 2011, ISO 9001 certification forecasting models, International Journal of Quality \& Reliability Management, vol. 28, no. 1 .

Saraph, J.V., Benson, P.G., Schroeder, R.G., 1989, An instrument for measuring the critical factors of quality management, Decision Sciences, vol. 20, no. 4.

Shahin, A., 2011, An investigation on the influence of total quality management on $\mathrm{fi-}$ nancial performance the case of Boutan industrial corporation, International Journal of Business and Social Science, vol. 2, no. 15.

Sikora, T., Giemza, M. (red.), 2012, Praktyka zarządzania jakościa XXI wieku, Uniwersytet Ekonomiczny w Krakowie, Wydawnictwo Naukowe PTTŻ, Kraków.

Sila, I., Ebrahimpour, M., 2002, An investigation of the total quality management survey based research published between 1989 and 2000, International Journal of Quality \& Reliability Management, vol. 19, no. 7.

Singh, R.K., 2011, Analyzing the interaction of factors for success of total quality management in SMEs, Asian Journal on Quality, vol. 12, no. 1.

Skrzypek, E., 2012, Efektywność ekonomiczna jako ważny czynnik sukcesu organizacji, Prace Naukowe Uniwersytetu Ekonomicznego we Wrocławiu, nr 262, Wrocław.

Skrzypek, E. (red.), 2014, Jakość jako czynnik sukcesu w nowej gospodarce, Uniwersytet Marii Curie-Skłodowskiej, Lublin.

Sobczyk, M., 2002, Statystyka, Wydawnictwo Naukowe PWN, Warszawa. 
Stabryła, S. (red.), 2010, Zarządzanie w kryzysie, w: Encyklopedia zarządzania, Kraków.

Stabryła, S. (red.), 2015, Metodologia projektowania systemów organizacyjnych przedsiębiorstwa, Wydawnictwo C.H. Beck, Warszawa.

Staniec, I., 2011, Uwarunkowania skuteczności zarządzania ryzykiem $w$ organizacjach, Wydawnictwo Politechniki Łódzkiej, Łódź.

Staniec, I., 2014, Współczesne koncepcje zarządzania ryzykiem, Marketing i Rynek, nr 5.

Staniec, I., Zawiła-Niedźwiecki, J. (red.), 2015, Ryzyko operacyjne w naukach o zarzadzaniu, Wydawnictwo C.H. Beck, Warszawa.

Starosta, A., 2014, Przyczyny kryzysu w przedsiębiorstwach-ujęcie teoretyczne i empiryczne, Marketing i Rynek, nr 5.

Szczepańska, K., 2013, Doskonalenie zarządzania jakością: podstawy, ocena, perspektywy, Oficyna Wydawnicza Politechniki Warszawskiej, Warszawa.

Szczepańska, K., Bugdol, M. (red.), 2016, Podstawy zarządzania procesami, Difin, Warszawa.

Szkoda, J., 2012, Systemy zarządzania jakościa w organizacjach, Instytut Transportu Samochodowego, Warszawa.

Talib, F., Rahman, Z., 2010, Critical success factors of TQM in service organizations: a Proposed Model, Services Marketing Quarterly, vol. 31, no. 3.

Talib, F., Rahman, Z., 2015, Identification and prioritization of barriers to total quality management implementation in service industry, The TQM Journal, vol. 27, no. 5.

Talib, F., Rahman, Z., Qureshi, M.N., 2011a, Analysis of interaction among the barriers to totalquality management implementation using interpretive structural modeling approach, Benchmarking: AnInternational Journal, vol. 18, no. 4.

Talib, F., Rahman, Z., Qureshi, M.N., 2011b, A study of total quality management and supply chainmanagement practices, International Journal of Productivity and Performance Management, vol. 60, no. 3.

Talib, F., Rahman, Z., Qureshi, M.N., 2013, An empirical investigation of relationship between total quality management practices and quality performance in Indian service companies, International Journal of Quality \& Reliability Management, vol. 30, no. 3 .

Tarí, J.J., 2005, Components of successful total quality management, The TQM Magazine, vol. 17, no. 2.

Teixeira, H.N., Lopes, I., Sousa, S., 2015, Prioritizing quality problems in SMEs: a methodology, The TQM Journal, vol. 27, no. 1.

Thompson, B., 2004, Exploratory and confirmatory factor analysis: understanding concepts and applications, American Psychological Association, Washington, DC.

Tickle, M., Mann, R., Adebanjo, D., 2016, Deploying business excellence - success factors for high performance, International Journal of Quality \& Reliability Management, vol. 33, no. 2 .

Tritos, L., Pei-Lee, T., Dotun, A., 2013, Revisiting quality management and performance, Industrial Management \& Data Systems, vol. 113, no. 7.

Turban, E., McLean, E., Wetherbe, J., 1999, Information technology for management: making connections for strategic advantage, John Wiley \& Sons, Hoboken, NJ. 
Urbaniak, M., 2010a, Kierunki doskonalenia systemów zarządzania jakością, Wydawnictwo Uniwersytetu Łódzkiego, Łódź.

Urbaniak, M., 2010b, Perspektywy rozwoju systemowego zarządzania jakościa, w: Lachniewicz, S., Nogalski, B. (red.), Osiagnięcia i perspektywy nauk o zarządzaniu, Oficyna Wolters Kluwer Business, Warszawa.

Urbaniak, M., 2013a, Certyfikacja systemów zarządzania jakościa, środowiskiem oraz bezpieczeństwem produktów a kryzys gospodarczy, w: Kaczmarek, B., Biliński, W. (red.), Przedsiębiorczość polskich menedżerów w warunkach kryzysu, Wydawnictwo Uniwersytetu Łódzkiego, Łódź.

Urbaniak, M., 2013b, Uwarunkowania zwiąane z doskonaleniem systemów zarządzania, Prace Naukowe Uniwersytetu Ekonomicznego we Wrocławiu, vol. 301, nr 1.

Urbaniak, M., 2016, Wykorzystanie koncepcji zarzadzania ryzykiem w doskonaleniu systemów jakości, Problemy Jakości, nr 6.

Urbanowska-Sojkin, E., 2013a, Ryzyko w wyborach strategicznych w przedsiębiorstwach, Polskie Wydawnictwo Ekonomiczne, Warszawa.

Urbanowska-Sojkin, E., 2013b, Zasobowy kontekst sukcesu przedsiębiorstwa, Zarządzanie i Finanse, r. 11, nr 4, cz. 1.

Urbanowska-Sojkin, E., 2014, Zarządzanie ryzykiem wobec wyzwań z otoczenia, Prace Naukowe Uniwersytetu Ekonomicznego we Wrocławiu, nr 366.

Valmohammadi, C., 2011, The impact of TQM implementation on the organizational performance of Iranian manufacturing SMEs, The TQM Journal, vol. 23, no. 5.

Walas-Trębacz, J., Borek, M., 2015, Przygotowanie się przedsiębiorstw do podejmowania skutecznych strategii zarządzania kryzysowego, Marketing i Rynek, nr 5.

Wasilewski, L., 1999, Rozważania o jakości, Warszawa.

Waśniewski, P., 2016, Kluczowe czynniki sukcesu jako podstawa pomiaru dokonań, Finanse, Rynki Finansowe, Ubezpieczenia, nr 2 (80), cz. 1.

Weckenmann, A., Akkasoglu, G., Werner, T., 2015, Quality management - history and trends, The TQM Journal, vol. 27, no. 3.

Wielicki, T., 2000, Ewolucyjny model doskonalenia firmy XXI wieku: od ISO i TQM do organizacji inteligentnej, w: Grudzewski W.M., Hejduk I.K. (red.), Przedsiębiorstwo przyszłości, Difin, Warszawa.

Wieteska, G., 2011, Zarządzanie ryzykiem w łańcuchu dostaw na rynku B2B, Difin, Warszawa.

Wilkinson, A., 1992, The other side of quality: 'soft'issues and the human resource dimension, Total Quality Management, vol. 3, no. 3.

Williams, R., Bertsch, B., Dale, B., Van Der Wiele, T., Van Iwaarden, J., Smith, M., Visser, R., 2006, Quality and risk management: what are the key issues?, The TQM Magazine, vol. 18, no. 1.

Wolniak, R., 2011, Parametryzacja kryteriów oceny poziomu dojrzałości systemu zarzadzania jakością, Wydawnictwo Politechniki Śląskiej, Gliwice.

Wu, S.I., Chen, J.H., 2011, Comparison between manufacturing companies that are ISO certified and those that are not certified using performance measurement model, Total Quality Management \& Business Excellence, vol. 22, no. 8.

Yusof, S.R.M., Aspinwall, E., 2000, Total quality management implementation frameworks: comparison and review, Total Quality Management, vol. 11, no. 3. 
Zairi, M., Alsughayir, A.A., 2011, The adoption of excellence models through cultural and social adaptations: An empirical study of critical success factors and a proposed model, Total Quality Management \& Business Excellence, vol. 22. no. 6.

Zapłata, S., 2009, Zarządzanie jakościa w przedsiębiorstwie. Ocena i uwarunkowania skuteczności, Wolters Kluwer, Warszawa.

Zapłata, S., 2012, Zarządzanie ryzykiem, ciagłość działania, znormalizowane systemy zarzadzania - praktyczne zastosowanie teorii, w: Zarzadzanie ryzykiem - 2. Ryzyko $w$ działaniach biznesowych, praktyczne podejście, Polskie Forum ISO 9000, Ciechocinek 15-17 października 2012.

Zapłata, S., 2016a, Miejsce systemowego zarządzania jakością w zarządzaniu ryzykiem $w$ organizacji, Studia Oeconomica Posnaniensia, vol. 4, no. 12.

Zapłata, S., 2016b, Zarządzanie ryzykiem jakości. Aspekty teoretyczno-praktyczne na przykładzie branży motoryzacyjnej, Zarzadzanie ryzykiem-5. Zmiany $w$ normach o co tu chodzi?, materiały seminarium, Szczyrk, 27-29 stycznia 2016, Polskie Forum ISO 9000.

Zapłata, S., Kaźmierczak, M., 2011, Ryzyko, ciagłość biznesu, odpowiedzialność społeczna. Nowoczesne koncepcje zarządzania. Ocena i uwarunkowania, Wolters Kluwer, Warszawa.

Zawiła-Niedźwiecki, J., 2013, Zarządzanie ryzykiem operacyjnym w zapewnianiu ciagłości działania organizacji, Wydawnictwo edu-Libri, Kraków, Warszawa.

Zimon, D., Sikora, T., 2012, Ocena funkcjonowania systemu zarzadzania jakościa $w$ matych i średnich organizacjach handlowych, Handel Wewnętrzny, nr 2. 


\section{SPIS TABEL}

\section{SPIS TABEL}

1. Czynniki sukcesu zarządzania jakością - analiza literatury anglojęzycznej ........ 54

2. Ramowy harmonogram prac badawczych ...................................................... 88

3. Struktura respondentów, którzy wzięli udział w badaniu ankietowym.................. 106

4. Główne wewnętrzne czynniki zarządzania jakością - ważność w badanych lokalizacjach

5. Ważność głównych wewnętrznych czynników zarządzania jakością według czasookresu prowadzenia działalności w badanych lokalizacjach ....

6. Ważność elementów konstytuujących główne wewnętrzne czynniki według czasookresu prowadzenia działalności w badanych lokalizacjach ....

7. Ważność głównych wewnętrznych czynników zarządzania jakością W zależności od funkcjonowania certyfikowanego systemu zarządzania jakością 115

8. Średnia ważność rezultatów zarządzania jakością w ocenie respondentów

9. Niefinansowe rezultaty zarządzania jakością - ważność w ocenie respondentów

10. Współzmienność pomiędzy głównymi wewnętrznymi czynnikami a rezultatami zarządzania jakością - statystyczne wyniki korelacji.

11. Wysoka współzmienność pomiędzy głównymi wewnętrznymi czynnikami a rezultatami zarządzania jakością.

12. Współzmienność pomiędzy głównymi wewnętrznymi czynnikami a rezultatami zarządzania jakością - ilościowe zestawienie zależności....

13. Informacje na temat testu sferyczności Barletta i współczynnika KMO dla elementów konstytuujących główne wewnętrzne czynniki zarządzania jakością. 156

14. Informacje na temat testu sferyczności Barletta i współczynnika KMO dla rezultatów zarządzania jakością

15. Wartości własne oraz wariancja wyjaśniania w analizie czynnikowej - dla elementów konstytuujących główne wewnętrzne czynniki zarządzania jakością. 157

16. Składowa $\mathrm{nr} 1 \mathrm{z}$ analizy czynnikowej dla obszaru pierwotnych elementów konstytuujących główne wewnętrzne czynniki zarządzania jakością

17. Składowa $\mathrm{nr} 2 \mathrm{z}$ analizy czynnikowej dla obszaru pierwotnych elementów konstytuujących główne wewnętrzne czynniki zarządzania jakością

18. Składowa nr 3 z analizy czynnikowej dla obszaru pierwotnych elementów konstytuujących główne wewnętrzne czynniki zarządzania jakością

19. Składowa $\mathrm{nr} 4 \mathrm{z}$ analizy czynnikowej dla obszaru pierwotnych elementów konstytuujących główne wewnętrzne czynniki zarządzania jakością 
20. Składowa nr 5 z analizy czynnikowej dla obszaru pierwotnych elementów konstytuujących główne wewnętrzne czynniki zarządzania jakością ....

21. Składowa nr 6 z analizy czynnikowej dla obszaru pierwotnych elementów konstytuujących główne wewnętrzne czynniki zarządzania jakością

22. Składowa $\mathrm{nr} 7 \mathrm{z}$ analizy czynnikowej dla obszaru pierwotnych elementów konstytuujących główne wewnętrzne czynniki zarządzania jakością

23. Składowa $\mathrm{nr} 8 \mathrm{z}$ analizy czynnikowej dla obszaru pierwotnych elementów konstytuujących główne wewnętrzne czynniki zarządzania jakością

24. Wewnętrzne czynniki zarządzania jakością - pierwotne elementy w składowych po eksploracyjnej analizie czynnikowej.

25. Wewnętrzne czynniki zarządzania jakością - średnie odchylenie ważności W zależności od funkcjonowania certyfikowanego systemu zarządzania jakością 169

26. Wewnętrzne czynniki zarządzania jakością - średnie odchylenie ważności w zależności od okresu prowadzenia działalności.

27. Wewnętrzne czynniki zarządzania jakością - średnie odchylenie ważności w zależności od liczby zatrudnionych pracowników.

28. Wartości własne oraz wariancja wyjaśniania w analizie czynnikowej - dla rezultatów zarządzaniu jakością

29. Wyniki analizy czynnikowej dla rezultatów zarządzania jakością - wartość ładunków czynnikowych

30. Wyniki analizy czynnikowej dla rezultatów zarządzania jakością - grupowanie. 176

31. Rezultaty zarządzania jakością - średnie odchylenie ważności w zależności od funkcjonowania certyfikowanego systemu zarządzania jakością 177

32. Rezultaty zarządzania jakością - średnie odchylenie ważności w zależności od okresu prowadzenia działalności.

33. Rezultaty zarządzania jakością - średnie odchylenie ważności w zależności od liczby zatrudnionych pracowników.

34. Współzmienność pomiędzy wewnętrznymi czynnikami, a rezultatami zarządzania jakością - statystyczne wyniki korelacji

35. Charakterystyka skupień według marek samochodów i zlokalizowania podmiotów

36. Minimalne i maksymalne odchylenia ważności wewnętrznych czynników zarządzania jakością w poszczególnych skupieniach

37. Skupienia a ocena rezultatów zarządzania jakością.

38. Wewnętrzne czynniki zarządzania jakością - zestawienie konstrukcji teoretycznej i empirycznej.

39. Relacje pomiędzy aspektami jakości i ryzyka w czynnikach projakościowego zarządzania w organizacji.

40. Najsilniejsze ${ }^{\mathrm{a}}$ oddziaływanie czynników na rezultaty zarządzania jakością..... 


\section{SPIS RYSUNKÓW}

1. Organizacyjne poziomy w zarządzaniu ryzykiem

2. Grupy rezultatów zarządzania jakością - ważność według respondentów w ujęciu czasowym

3. Współzmienność pomiędzy głównymi wewnętrznymi czynnikami zarządzania jakością

4. Wysoka współzmienność dla statystycznie istotnych korelacji pomiędzy głównymi wewnętrznymi czynnikami a rezultatami zarządzania jakością.

5. Składowe - ujęcie przed statystyczną analizą czynnikową i po statystycznej analizie czynnikowej

6. Współzmienność pomiędzy wewnętrznymi czynnikami a rezultatami zarządzania jakością

7. Przywództwo i zaangażowanie najwyższego kierownictwa - priorytetowe relacje.

8. Planowanie strategiczne i operacyjne - priorytetowe relacje ................................. 196

9. Orientacja na klienta - priorytetowe relacje …................................................... 197

10. Zarządzanie na podstawie faktów - priorytetowe relacje.................................... 197

11. Zarządzanie zasobami ludzkimi - priorytetowe relacje....................................... 198

12. Zaangażowanie pracowników - priorytetowe relacje ............................................ 198

13. Zarządzanie procesowe - priorytetowe relacje ..................................................... 199

14. Ciągłe doskonalenie - priorytetowe relacje ......................................................... 199

15. Przywództwo i kultura jakości - priorytetowe relacje .......................................200

16. Dualizm jakości „klienci-pracownicy” - priorytetowe relacje ..............................201

17. Podejście prewencyjne do jakości - priorytetowe relacje .....................................201

18. Orientacja na klienta - priorytetowe relacje ........................................................ 202

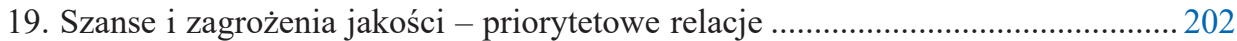

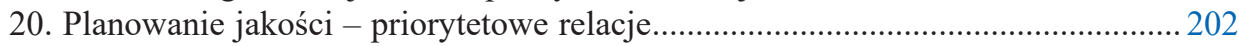

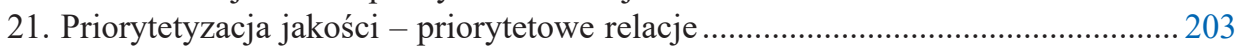

22. Podejście reakcyjne do jakości - priorytetowe relacje .......................................... 203 


\section{SPIS WYKRESÓW}

1. Lokalizacje autoryzowanych salonów sprzedaży i serwisu samochodów osobowych w Polsce - ujęcie terytorialne

2. Autoryzowane salony sprzedaży i serwisu samochodów osobowych w Polsce ujęcie według marek pojazdów

3. Badane autoryzowane salony sprzedaży i serwisu samochodów osobowych w Polsce w podziale na województwa.

4. Badane salony sprzedaży i serwisu samochodów osobowych w Polsce według autoryzacji marek producenckich

5. Badane organizacje w podziale według grup respondentów ................................. 108

6. Struktura badanych organizacji pod względem liczby zatrudnionych pracowników....

7. Struktura badanych organizacji pod względem okresu prowadzenia działalności w danej lokalizacji

8. Ocena wpływu głównych czynników wewnętrznych na rezultaty zarządzania jakością - według rosnącej istotności

9. Ocena wpływu głównych wewnętrznych czynników na rezultaty zarządzania jakością, w zależności od grupy respondentów

10. Ocena ważności głównych czynników wewnętrznych wpływających na rezultaty zarządzania jakością, w podziale na dwa okresy funkcjonowania lokalizacji

11. Ważność głównych wewnętrznych czynników zarządzania jakością w zależności od funkcjonowania certyfikowanego systemu zarządzania jakością .....

12. Ważność głównych wewnętrznych czynników zarządzania jakością w zależności od okresu prowadzenia działalności gospodarczej oraz funkcjonowania certyfikowanego „systemu ISO 9001” w badanych lokalizacjach.

13. Średnia ważność rezultatów zarządzania jakością w organizacji - porównanie względem posiadania certyfikowanego systemu zarządzania jakością

14. Ważność elementów składowych głównego wewnętrznego czynnika „Przywództwo i zaangażowanie najwyższego kierownictwa w jakość” - aspekt jakości

15. Ważność elementów składowych głównego wewnętrznego czynnika „Przywództwo i zaangażowanie najwyższego kierownictwa w jakość” - aspekt ryzyka.

16. Ważność elementów składowych głównego wewnętrznego czynnika „Planowanie strategiczne i operacyjne” - aspekt jakości 
17. Ważność elementów składowych głównego wewnętrznego czynnika

„Planowanie strategiczne i operacyjne” - aspekt ryzyka

18. Ważność elementów składowych głównego wewnętrznego czynnika „Orientacja na klienta” - aspekt jakości

19. Ważność elementów składowych głównego wewnętrznego czynnika „Orientacja na klienta” - aspekt ryzyka.

20. Ważność elementów składowych głównego wewnętrznego czynnika „Zarządzanie na podstawie faktów” - aspekt jakości.....

21. Ważność elementów składowych głównego wewnętrznego czynnika „Zarządzanie na podstawie faktów” - aspekt ryzyka

22. Ważność elementów składowych głównego wewnętrznego czynnika „Zarządzanie zasobami ludzkimi” - aspekt jakości.

23. Ważność elementów składowych głównego wewnętrznego czynnika „Zarządzanie zasobami ludzkimi” - aspekt ryzyka

24. Ważność elementów składowych głównego wewnętrznego czynnika „Zaangażowanie pracowników” - aspekt jakości.

25. Ważność elementów składowych głównego wewnętrznego czynnika „Zaangażowanie pracowników” - aspekt ryzyka ....

26. Ważność elementów składowych głównego wewnętrznego czynnika „Zarządzanie procesowe" - aspekt jakości

27. Ważność elementów składowych głównego wewnętrznego czynnika „Zarządzanie procesowe" - aspekt ryzyka

28. Ważność elementów składowych głównego wewnętrznego czynnika „Ciągłe doskonalenie" - aspekt jakości

29. Ważność elementów składowych głównego wewnętrznego czynnika „Ciągłe doskonalenie" - aspekt ryzyka.

30. Ocena ważności elementów konstytuujących poszczególne główne wewnętrzne czynniki zarządzania jakością - porównanie dla aspektu jakości i ryzyka.

31. osypiska dla wewnętrznych czynników zarządzania jakością.

32. Wewnętrzne czynniki zarządzania jakością - średnie odchylenie ważności w zależności od funkcjonowania certyfikowanego systemu zarządzania jakością (z wyróżnieniem danych istotnych statystycznie).

33. Wewnętrzne czynniki zarządzania jakością - średnie odchylenie ważności w zależności od okresu prowadzenia działalności (z wyróżnieniem danych istotnych statystycznie)

34. Wewnętrzne czynniki zarządzania jakością - średnie odchylenie ważności w zależności od liczby zatrudnionych pracowników (z wyróżnieniem danych istotnych statystycznie)

35. Rezultaty zarządzania jakością - średnie odchylenie ważności

w zależności od funkcjonowania certyfikowanego systemu zarządzania jakością

(z wyróżnieniem danych istotnych statystycznie)

36. Rezultaty zarządzania jakością - średnie odchylenie ważności w zależności od okresu prowadzenia działalności (z wyróżnieniem danych istotnych statystycznie) 
37. Wewnętrzne czynniki zarządzania jakością - średnie odchylenie ważności w pierwszym skupieniu

38. Wewnętrzne czynniki zarządzania jakością - średnie odchylenie ważności w drugim skupieniu

39. Wewnętrzne czynniki zarządzania jakością - średnie odchylenie ważności w trzecim skupieniu.

40. Wewnętrzne czynniki zarządzania jakością - średnie odchylenie ważności w czwartym skupieniu

41. Wewnętrzne czynniki zarządzania jakością - średnie odchylenie ważności w piątym skupieniu. 